\title{
CIÊNCIAS SOCIAIS HOJE: ANTROPOLOGIA
}

\section{Orgs.}

Igor José de René Machado Soraya Fleischer Deise Lucy Oliveira Montardo Julie Cavignac 


\section{Comissão Editorial}

Editora-chefe

Marcia Consolim (Universidade Federal de São Paulo)

Editora assistente

Raissa Wihby Ventura (Universidade Estadual de Campinas)

Editoria de área

Antropologia

Deise Lucy Oliveira Montardo (Universidade Federal do Amazonas) Igor José de Renó Machado (Universidade Federal de Sáo Carlos) Julie Cavignac (Universidade Federal do Rio Grande do Norte)

Soraya Fleischer (Universidade de Brasília)

Ciência Política

Adriano Codato (Universidade Federal do Paraná)

Mariana Batista (Universidade Federal do Pernambuco)

Ricardo Fabrino Mendonça (Universidade Federal de Minas Gerais)

Sociologia

André Botelho (Universidade Federal do Rio de Janeiro)

Eliana dos Reis (Universidade Federal Maranhão)

Luiz Cláudio Lourenço (Universidade Federal da Bahia)

Marcelo Carvalho Rosa (Universidade de Brasília)

Produção Editorial: Zeppelini Publishers (www.zeppelini.com.br)

Arte da capa: Marco Giannotti - Sem título (quarentena) - 170 X $150 \mathrm{~cm}$ - 2020 - Óleo sobre tela Preparação da capa: Maiane Bittencourt

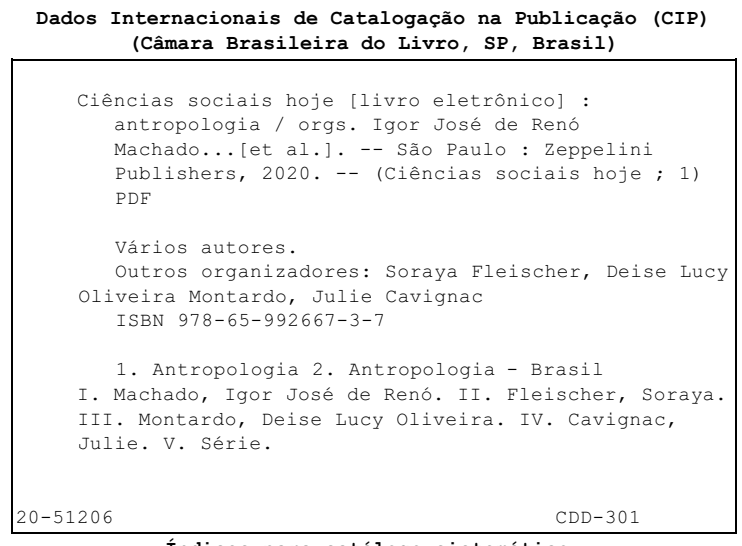




\section{Sumário}

Apresentação

Equipe Editorial

Introdução

Igor José de Renó Machado, Soraya Fleischer, Deise Lucy Oliveira Montardo, Julie Cavignac

Tem um corpo nessa alma: encruzilhadas da antropologia da performance no Brasil.

Luciana Hartmann, Esther Jean Langdon

Para além da ciência e do anthropos: deslocamentos da antropologia da

ciência e da tecnologia no Brasil.

Fabiola Rohden, Marko Monteiro

O encontro das antropologias do meio ambiente e dos desastres no Brasil. 79

May Waddington Telles Ribeiro

Migrações e deslocamentos: balanço bibliográfico da produção antropológica brasileira entre 1940 e 2018. 103

Bela Feldman-Bianco, Liliana Sanjurjo, Douglas Mansur da Silva

O ensino de Antropologia e a formação de antropólogos no Brasil hoje:

de tema primordial a campo (possível) de pesquisa (antropológica) 160

Guillermo Vega Sanabria, Luiz Fernando Dias Duarte

Movimentos sociais contemporâneos: um balanço da produção de teses e dissertações em antropologia (2008-2018). 191

Paula Alegria, Lucas Bulgarelli, Rosana Pinheiro-Machado

Interconectividades: antropologia \& museus, um campo em movimento

Antônio Mota, Isabela Tamaso

Antropologia da saúde: entre práticas, saberes e políticas

Sônia Weidner Maluf, Érica Quinaglia Silva, Marcos Aurélio da Silva

A produção antropológica em gênero e sexualidades no Brasil na última década (2008-2018).

Mónica Franch, Silvana Nascimento

Balanços bibliográficos e ciclos randômicos: o caso dos futebois na Antropologia brasileira. .321

Luis Henrique de Toledo

Das áreas culturais às redes de relações. Os sistemas regionais ameríndios em análise 352

Felipe Vander Velden, Pedro Lolli

Antropologia e a questão das drogas: um século de embates políticos e teóricos . 408

Ygor Diego Delgado Alves, Pedro Paulo Gomes Pereira 


\section{Apresentação}

Os balanços bibliográficos têm o papel fundamental de informar e orientar pesquisas em todas as áreas do conhecimento, motivo pelo qual nos mobilizamos para publicar a coleção Ciências Sociais Hoje. Os três volumes que compóem a coleção - Antropologia, Ciência Política e Sociologia — são o resultado do trabalho de muitas pessoas e este espaço é dedicado a agradecê-las. Em primeiro lugar, a quem primeiro teve a ideia desse projeto, Carlos Costa Ribeiro (IESP-UERJ), então editor da área de Sociologia da Revista Brasileira de Informação Bibliográfica em Ciências Sociais (BIB), em meados de 2017. A ideia de publicar na revista artigos que comporiam os balanços bibliográficos da Associação Nacional de Pesquisa e Pós-Graduação em Ciências Sociais (Anpocs) foi muito bem recebida pela Equipe Editorial da BIB e, desde então, passamos a enfrentar as etapas seguintes. A primeira questão era decidir como escolher os(as) organizadores(as) de cada volume e preferimos que cada área tivesse autonomia para indicá-los(as) segundo critérios próprios. Assim, na área de Antropologia decidiu-se que os próprios editores seriam os(as) organizadores(as) do volume, enquanto nas áreas de Ciência Política e de Sociologia os(as) editores(as) preferiram escolher organizadores(as) externos(as). Em todos os casos, buscamos reunir pesquisadores(as) oriundos(as) de diversas regióes do país e de especialidades distintas — além de atentar para a diversidade de gênero e raça. A segunda questão foi decidir como seriam escolhidos os temas de cada capítulo e os(as) autores(as) responsáveis. Essa etapa foi muito complexa e envolveu debates importantes entre os(as) organizadores(as) — que tam- bém tiveram total autonomia - a respeito da posição das especialidades tradicionais em relação às emergentes a fim de chegar a um ponto de equilíbrio entre os capítulos. As introduçôes dos volumes relatam como se deu esse processo em cada uma das áreas, mas é importante enfatizar que, a despeito das tensôes e dos imprevistos envolvidos nessa estratégia, o processo foi marcado por intenso engajamento de todos(as) os(as) organizadores(as) — sempre orientados(as) pelo critério da legitimidade dos tópicos e do reconhecimento dos(as) autores(as). No que diz respeito à escolha dos(as) autores(as), decidiu-se realizar chamada pública e convites a especialistas, a fim de garantir a ampla participação da comunidade acadêmica. Em relação ao tipo de balanço, revisão narrativa ou sistemática da literatura, optou-se por deixar à livre escolha dos autores, uma vez que tais preferências articulam-se às perguntas, às hipóteses e ao corpus selecionado. Chegamos, assim, a um total de 36 capítulos (12 por volume) e 83 autores(as) — uma vez que muitos dos capítulos foram escritos em coautoria. O resultado demonstra que houve, de fato, pluralidade de posiçóes e espaço para negociaçôes, ainda que isso não signifique que os balanços sejam o espelho da diversidade e da complexidade do campo das Ciências Sociais atual. Como decidimos que os textos seriam primeiramente publicados como artigos na $\mathrm{BIB}$, era necessário indicar pareceristas segundo as normas da revista - dois pareceres duplo-cego - para todos os 36 artigos. Isso significou que 72 pareceristas estiveram envolvidos no processo de avaliação dos capítulos, a quem agradecemos o cuidado e a presteza no atendimento de 
nossas demandas. Assim, considerando-se os(as) editores da BIB, os(as) organizadores(as), os(as) autores(as) e os(as) pareceristas(as), envolvemos nada menos do que 177 pesquisadores neste projeto - um número expressivo e, esperamos, bastante representativo das áreas e especialidades no campo das Ciências Sociais. Aproveitamos este espaço para também agradecer aos autores o empenho com que trabalharam a fim de atualizar os debates e propor uma leitura qualificada de um vasto volume de textos - que constituem, em seu conjunto, um importante registro da evolução das Ciências Sociais na última década. Nesse período, também organizamos alguns eventos para divulgar o projeto e/ou discutir os textos dos(as) auto- res(as) - um fórum na Anpocs (2018), uma mesa redonda também na Anpocs (2019) e um colóquio no IESP - UERJ (2019), neste caso para discutir especificamente os textos da área de sociologia. Ou seja, foi um trabalho que envolveu outras instituiçôes e, em particular, a secretaria da Anpocs e a direção da Anpocs - a gestão atual e a anterior —, a quem agradecemos imensamente o apoio. Finalmente, seria importante registrar que, segundo nossa experiência, a qualidade da produção acadêmica é correlata à diversidade de vozes e ao profissionalismo dos(as) pesquisadores e que, nesse quesito, estáo todos(as) de parabéns. 
Vemo-nos no lado oculto da lua ou a multiplicação dos "agoras".

\section{Introdução}

Como se faz um livro de revisões bibliográficas? Essa é uma questão aparentemente simples, mas por trás da resposta está toda uma parafernália de escolhas, posicionamentos, decisóes e atos mais ou menos arbitrários. Parece simples, já que basta reunir temas relevantes, solicitar as resenhas e depois publicá-las. Mas quais são os temas relevantes? Qual é o marco temporal que deve ser coberto? Quem são as pessoas em melhor posição, interessadas e disponíveis para realizar as revisóes? A concordância em realizar a tarefa será cumprida no prazo editorial? Quem escolher para ler e avaliar o texto, quais são as pareceristas que conhecem o tema e conseguem dialogar com o recorte bibliográfico dos textos?

Este livro é uma história da seleção dos temas, das autoras e de tudo o que acontece entre o planejamento e a prática: como autoras têm os textos recusados, o quanto incorporam dos pareceres, como outras deixam de entregar e como é preciso construir novos convites, correçóes e mudanças de rumo a todo momento ao longo do caminho. A maior parte do resultado é diferente do planejado. Talvez não seja comum expor o processo de produçáo de um livro: talvez seja melhor dar a entender que tudo é o resultado de um planejamento perfeito, autoevidente na sua realização final, e apenas introduzir o tema como se tudo estivesse correspondendo aos processos de decisão iniciais, provavelmente tidos como assépticos.

As introduçôes podem ser purificaçôes de um processo muito complexo. Não desejamos inventar essa perspectiva aqui: vamos contar os meandros da construção de um híbrido (Latour, 1994). Vamos contar que as decisões não foram consensuais, que a escolha por autoras e autores não foi simples e que o processo de produçáo foi mais ou menos caótico. E que, apesar de tudo, o resultado foi muito interessante, talvez justamente pelas tensôes que a produção gerou. O livro é resultado dessas confusóes. E geralmente assim é feita a ciência.

\section{Temas e autorias}

No começo éramos quatro editoras de área a decidir pelos temas. A decisão passou por reuniôes ampliadas com a participação

\footnotetext{
'Universidade Federal de São Carlos - São Carlos (SP), Brasil. E-mail: igor@ufscar.br

"Iniversidade de Brasília - Brasília (DF), Brasil. E-mail: soraya@unb.br

IIIUniversidade Federal do Amazonas - Manaus (AM), Brasil. E-mail: deiselucy@gmail.com

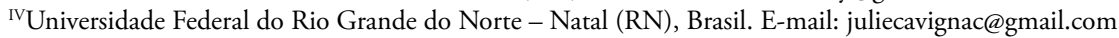


de ainda mais pessoas. Embora o livro seja produzido no seio da Associaçáo Nacional de Pós-Graduação e Pesquisa em Ciências Sociais (ANPOCS), as reuniôes para o volume de antropologia aconteceram virtualmente, por e-mail e por aplicativo de comunicação por celular, bem como presencialmente nas reunióes da International Union of Anthropological and Ethnological Sciences (IUAES) (Florianópolis, 2018), da Associação Brasileira de Antropologia (ABA) (Brasília, 2018) e da Reunião de Antropologia do Mercosul (RAM) (Porto Alegre, 2019). Com a participação de dirigentes da ANPO$\mathrm{CS}$ e da $\mathrm{ABA}$, e considerando que esse volume da antropologia compóe a coleção da Revista Brasileira de Informação Bibliográfica em Ciências Sociais (BIB/ANPOCS) com os da sociologia e da ciência política, essas reunióes definiram o conjunto de temas a serem explorados (retratar os temas pungentes do momento), a quantidade padronizada de textos (12), o período histórico resenhado (2010-2019) e os prazos gerais (publicação em fins de 2020). Seguimos alguns critérios básicos: encontrar uma variação de temas em relação às coletâneas anteriores (Micelli, 1999; Martins e Duarte, 2010) e, além do leque temático, buscar também autoras diferentes das que já haviam publicado nesses livros anteriores, revelando a renovação geracional e institucional. Essas coletâneas foram também organizadas pela ANPOCS, e o presente livro é uma terceira versão com o mesmo objetivo, um mapeamento da produçáo relevante em certos temas da antropologia contemporânea na última década.

Buscamos organizar a coletânea de forma distinta das duas anteriores. O primeiro dos volumes, que cobriu a última década do século passado, trazia apenas cinco textos, assinados por nomes já consagrados à época na antropologia brasileira e concentrados em quatro instituiçôes: Universidade de São Paulo (USP), Universidade do Estado do Rio de Janeiro (UERJ), Museu Nacional e Universidade de Brasília (UnB). Mas são, no final das contas, instituiçóes de apenas três estados (SP, RJ e DF). A segunda versão, que se ocupou da primeira década do novo século, optou por uma dispersão um pouco maior: temos quatro estados e o DF representados (SC, RS, SP e RJ), mas sem representações das regióes Nordeste, Norte e Centro-Oeste (além do DF). A segunda coletânea também recorreu a muitos big names e poucos nomes de geraçóes mais novas.

Para a nossa coletânea, propositalmente quisemos fazer um recorte mais representativo das várias instituiçóes de ensino de antropologia no Brasil, considerando também a grande expansão que ela viveu em tempos recentes, até mesmo em termos de interiorização ao redor do país (Simião; Feldman-Bianco, 2018). O projeto original derivado dessas reuniōes entre as editoras previa a participaçáo de pesquisadores de nove estados diferentes, contemplando todas as regióes do país. Veremos que essa conta se alterou no processo de produção do livro.

Se precisávamos de uma distribuição de instituiçôes, pensamos também em variar as autoras e os autores e não repetir nenhum deles de ediçóes anteriores. Decidimos também assumir a expansão recente, buscando representantes de várias geraçôes, gênero, raça e etnia de antropólogas. Buscamos aqui dispersar a produçáo pelo país e realizar uma multiplicação autoral, ao menos no projeto inicial. Isso porque a vida interfere nos planos, como sempre.

Dos convites enviados, tivemos dois contratempos primeiros: dois textos apresentados, apesar de excelentes, não foram considerados revisóes bibliográficas. $\mathrm{E}$ os autores não se dispuseram a produzir novos 
textos, que foi a condição colocada pelos pareceres. Vale refletir sobre a definição do gênero revisão bibliográfica, o que cabe nela, se há um conjunto de ingredientes que não pode faltar, se há um consenso sobre esse tipo de texto entre as três áreas das ciências sociais, se consideramos numa revisão as trajetórias e as socializaçóes que envolvem outras formas narrativas para recordar fatos, sistematizar histórias, recontar resumos. Precisamos também de mais reflexão sobre o lugar que os chamados marco teórico e revisáo bibliográfica têm ocupado nos processos de formação na antropologia. Como consequência concreta da reflexão sobre o estatuto da revisão bibliográfica em nossa área, pensamos se e como a discussão bibliográfica tem aparecido nas dissertaçóes e teses, se mais ou menos concentrada em um único capítulo ou acionada à medida que interpelada pelo material empírico, por exemplo. Estamos apontando para questóes epistemológicas que a antropologia parece trazer. A recusa por parte desses dois autores e os formatos escolhidos pelas autoras da presente coletânea (como discutiremos na próxima seção) abrem debates importantes nesse sentido.

Esses dois autores eram responsáveis por dois temas fundamentais a nosso ver: políticas indígenas e populaçóes quilombolas. Com o tempo curto, tentamos de todas as formas manter os temas e a representatividade, mas novamente as pessoas escolhidas e convidadas aceitaram para depois desistir (a cada novo convite, o tempo ia ficando mais curto para a produção dos textos, considerando-se que o prazo final se mantinha inalterado). Ao fim e ao cabo, para dar conta da exigência editorial de 12 textos, as editoras foram em busca de textos, mas as áreas deslizaram para o possível, no prazo que se esgotava. Ainda conseguimos manter quase to- dos critérios de centralidade, novidade e não repetição temática das coletâneas anteriores.

Outro fator de embaralhamento dos nossos planos iniciais é a questão da coautoria. Muitas das autoras foram convidadas individualmente, mas, ao aceitarem a incumbência, solicitaram a permissão para recorrer a colegas com quem vinham trabalhando naquele tema. Como a natureza da produção de um balanço bibliográfico é extensa, aceitamos sem qualquer restrição a organização de times de trabalho. Essa marca coautoral talvez indique uma característica da produção mais recente na área, mais inclinada ao trabalho em equipes maiores, estimuladas a publicar com estudantes e orientandas, por exemplo. Assim, temos 25 autoras, quando inicialmente pensávamos em apenas 12. A distribuição regional desse conjunto também escapou ao controle, levando a outro quadro - por um lado, mais plural e, por outro lado, também um pouco concentrado.

Mais plural porque temos a participação de 18 instituiçóes diferentes, representantes de todas as regióes brasileiras (11 estados e uma autora brasileira que atualmente trabalha no exterior), e, ao mesmo tempo, também mais concentrado porque, entre as 25 autoras, 10 são provenientes de instituiçôes paulistas. Em contrapartida, em comparação com as coletâneas anteriores, temos mais universidades de porte médio e de cidades que não as capitais de estado. Assim, a imprevisibilidade do processo gerou ganhos e perdas. Algumas autoras mudaram de instituição durante o processo, algumas desistiram do nosso convite, outras ainda trouxeram colaboradoras de lugares variados. Há ainda outros cortes a pensar: a distribuição de gênero é equilibrada: mais da metade das autoras é composta de mulheres.

Grandes temas presentes nas outras coletâneas também estão propositalmente 
ausentes aqui: família, identidade nacional, Estado, economia, imagem, antropologia urbana, raça, história da antropologia, religião, criminalidade. Raça também era um tema muito explorado nas ediçóes anteriores, e decidimos por um texto mais específico nessa temática, sobre quilombos, que acabou não sendo considerado uma resenha (e por isso não foi publicado). Correndo contra o tempo, e embora tenhamos dirigido mais alguns convites, infelizmente náo conseguimos uma resenhista para o tema no curto prazo que nos restava. No caso da etnologia, tínhamos a mesma intençáo de solicitar um texto focalizado na questáo das políticas indígenas, tema muito importante que precisava de um reforço de revisão, e vimos acontecer o mesmo processo. Não conseguimos um texto sobre esse tema, mas sim sobre outra temática mais específica no seio da etnologia (a questão das áreas culturais/etnográficas). Alguns temas na presente coletânea são variaçóes de temas das antigas coletâneas, indicando as transformaçóes de certas concentraçóes de trabalhos, colocados agora em novos ordenamentos. Alguns temas que apareceram, por exemplo, na segunda coletânea têm na presente coletânea os seguintes correlatos deslizantes:

- festas e patrimônios : museus;

- território e ecologia : desastres e meio ambiente;

- gênero : gênero e sexualidade;

- saúde e sofrimento : saúde;

- ciência : ciência e tecnologia;

- esporte : futebol.

Esses deslizamentos acontecem em dois sentidos: o da fragmentaçáo do tema anterior em focos mais específicos (gênero para gênero e sexualidade; ciência para ciência e tecnologia; de esportes para futebol); o da concentração temática, em movimento in- verso, como na passagem de um tema mais específico, como saúde e sofrimento, para um mais amplo, saúde. Há também desdobramentos e reposicionamentos nos campos temáticos. O tema território e ecologia reposiciona-se como desastres e meio ambiente, marcando outra visada sobre questóes similares; o tema festas e patrimônios desdobra-se em uma revisão exclusiva sobre museus, em geral associados à questáo do patrimônio. Ante o tema que propusemos inicialmente, algumas autoras sugeriram desdobramentos, recortes ou mesmo ampliaçóes. Por isso, certos temas ganharam um segundo tópico, funcionando como díade; outros temas foram explicados com subtítulos, por exemplo. Concordamos com esses entendimentos e (re)interpretaçóes do campo que elas, especialistas, nos apresentaram. Assim, todos esses textos resultam em enquadramentos diferentes, deslizantes em relação àquelas temáticas da coletânea anterior, indicando as mudanças que a antropologia tem proposto na última década.

Outros temas aparecem pela primeira vez nesta coletânea: drogas, performance, movimentos sociais, ensino de antropologia e migraçôes. Ou talvez, mesmo que já contassem com produção e representantes desde os primórdios da antropologia no país, pode ser que ainda padecessem de algum desenvolvimento na área, como Sanabria e Duarte nos mostram ser o caso do tema do ensino, por exemplo. $\mathrm{O}$ único tema presente tout court nas três coletâneas é o da etnologia. Neste livro, isso se deu mais pelo acaso, como vimos anteriormente.

Temos convicçáo de que todos os temas citados aqui mereceriam um lugar num conjunto mais completo sobre a produção antropológica contemporânea. Mas isso não seria possível num livro apenas. Assim, fizemos escolhas e, ao mesmo tempo, escolhas 
foram feitas à nossa revelia. Mas tanto umas como outras revelam também um pouco das feiçốes da antropologia brasileira: o fato de termos textos mais à mão da temática de etnologia e futebol para cobrir as ausências do projeto original nos diz algo sobre o vigor dessas áreas. Então o acaso não é exatamente um acaso: é um retrato das figuraçôes políticas e relacionais do campo da antropologia tal qual ele se organiza atualmente. As escolhas planejadas são também um retrato dessas mesmas figuraçôes, mesmo que os planos tentem conscientemente produzir distribuiçáo de temas e pessoas: no fim, falamos com base em redes de relaçóes, amizades, posicionamentos intelectuais e lugares num contexto mais abrangente das políticas institucionais da área.

\section{Abordagens}

As 12 recensōes bibliográficas aqui apresentadas são organizadas de formas idiossincráticas. Não há consenso aparente sobre o que são ou devem ser esses textos de revisóes bibliográficas, ou estados da arte. E essa é uma questão relevante: as diferentes concepçôes de recensóes podem tanto dizer algo sobre as atuais percepçôes do campo de conhecimento quanto reproduzirem estruturas de poder inconscientes. Qual é a fronteira entre considerar um texto apresentado na forma de recensão como não satisfatório ou aproveitável? Algumas respostas a essa pergunta remontam ao formato dado para a revisão ou ao conjunto de obras trabalhadas pelas resenhistas: se tais e tais autores e autoras ou grupos de autores e autoras não estão presentes, pode-se considerar aquela resenha como insatisfatória. Mas isso carrega um grande perigo de censura intelectual, claro: pode uma parecerista determinar quais autoras são fundamentais se o texto apresentado organi- zava outro cenário (no qual essas autoras não são tão relevantes)?

Isso é só um dos problemas que avaliar resenhas nos traz: o perigo do reforço de certas estruturas de poder, que intervêm nas leituras dos campos intelectuais. E considerando que as autoras estabelecem para si perspectivas pessoais sobre a organização de suas próprias recensôes, é um confronto sujo de perspectivas que entra em ação na produção das revisóes. Sujo porque não está dado a partir de consensos negociados: a tentativa de autoras de remodelar campos, de propor outras perspectivas pode encontrar muitas dificuldades e, ao mesmo tempo, ser fundamental para sacudir, desempoeirar, rever o rumo de um tema da área. E entre as quatro editoras desse livro, como é também o caso dos outros livros da coleção da ANPOCS ou outras coletâneas de modo geral, não há exatamente um consenso sobre como devem ser as resenhas. Além das organizadoras de uma publicação, há o conjunto de pareceristas e as regras específicas do periódico em questão que precisam ser levados em conta. Assim, o caminho para a produção desse tipo de livro é necessariamente complexo e caótico: um confronto de perspectivas estruturais (sobre o que deve ser uma recensão), perspectivas de autoridade intelectual (que autoras e/ou grupos devem aparecer em certos temas) e mesmo de perspectivas sobre quais sáo os espaços para a criação autoral num texto de estado da arte. A presença do dissenso, portanto, náo necessariamente é algo negativo ou evitável, mas intrínseco e revelador sobre as formas de autopercepção da área. É, em alguma medida, produtivo.

Como já afirmamos, dois dos textos apresentados originalmente não foram considerados recensôes. E um deles foi recusado nos pareceres por ser "intimista" demais, ou seja, muito focado na perspectiva de vida da 
autora. Isso causou um ruído na produção do livro, uma vez que não concordávamos todas com essa perspectiva, mas, como um corpo editorial, somos mais ou menos prisioneiras dos pareceres e da condução da editoração de cada um dos textos pelas editoras de área e pela editoria geral. Esse embate de muitas perspectivas num terreno pantanoso é responsável, contudo, por um resultado final surpreendente: é um retrato efetivo de concepções diferentes, de tensões sobre o que consideramos conhecimento válido e sobre o que deve ser uma recensão. Os textos que compóem esse volume apresentam estilos diferentes, formas distintas de pensar e organizar a sistematização do conhecimento em revisōes bibliográficas. Sua diversidade é, para nós, uma riqueza científica em si e uma riqueza a respeito da antropologia brasileira, mais especificamente.

Isso tudo serve para explicar por que os textos aqui reunidos seguem direções múltiplas. Não há um formato definido e regulado de resenha que tenha sido orientado por nós e seguido por elas, e o resultado é uma apresentação das várias formas de pensar o conhecimento: a multiplicidade aqui é um ganho acadêmico e representa ela própria a possibilidade de ser resenhada. É isso que podemos fazer aqui, não tanto resumir as resenhas (o que parece ser pouco produtivo), mas produzir uma recensão das recensões. Ao mesmo tempo que descrevemos os bastidores de nosso trabalho, oferecemos um panorama crítico do corpo de textos que reflete, até mesmo, o estado da arte da área.

\section{Visão geral}

Temos ao menos três estilos de revisão bibliográfica apresentados: um estilo tradicional, um reinventado e ainda um propositivo. As resenhas tradicionais propóem-se a olhar exclusivamente para trás: dado tal tema, como ele se forma e como podemos explicar suas características atuais olhando para suas configuraçóes temporais. $\mathrm{O}$ exemplo mais relevante desse estilo é o texto de Feldman-Bianco, Sanjurjo e Silva sobre migraçôes. Ao abarcarem um período de 70 anos, analisam as principais temáticas e perspectivas teóricas que informaram o campo das migraçóes desde os anos 1950 até o momento presente. Assim, ao chegar no momento presente, temos a clara sensação de entender o que se passou e por que determinadas questôes aparecem como relevantes hoje em dia. É uma historiografia do conhecimento para explicar o presente. Consideramos que Motta e Tamaso; Alegria, Bulgarelli e Pinheiro-Machado; Waddington; Sanabria e Duarte são textos do mesmo estilo tradicional de balanço bibliográfico.

Nesse tipo de exercício, o momento atual é o nexo de explicação e, como em qualquer trabalho historiográfico, isso pode conduzir a uma reconstrução que deixa de lado muito do que não é relevante para explicar o agora (mas foi significativo para explicar outros agoras, agoras anteriores). $\mathrm{Ou}$ seja, nenhuma construção do campo de conhecimento sobre um tema é definitiva em si, pois nesse estilo sempre respondemos ao olhar presente, com seus desafios enfrentados e suas perguntas feitas no presente. Assim, o movimento das resenhas ao longo do tempo pode também nos dizer muito sobre os diferentes agoras das configuraçóes do campo de conhecimento.

Isso pode nos levar a uma ponte com o segundo estilo, que chamamos de reinvenção: o texto de Toledo sobre o futebol é um exemplo dessa perspectiva. E ela deriva talvez da escolha do autor de produzir uma resenha exclusivamente de outras resenhas, ou seja, de tentar identificar aqueles dife- 
rentes agoras que organizaram a imaginação do campo acadêmico do futebol ao longo do tempo. Essa comparação de diferentes ordens de condensação do conhecimento permitiu ao autor uma perspectiva radical: o entendimento da recensão como um instrumento temporário, móvel e radicalmente metafórico em um sentido wagneriano (Wagner 1975). Como invençóes momentâneas de realidades intelectuais, esses campos criados emergem e submergem nas recensóes futuras, que os reinventam trazendo outras questóes, outros conjuntos bibliográficos, outras desestabilizaçóes. O resultado dessa perspectiva é tão fluido que permite ao autor introduzir um exemplo etnográfico para metaforizar suas próprias perspectivas em relação aos campos de conhecimento construídos sobre os futebóis. Aqui a fronteira entre recensão e não recensão (vamos inventar este segundo termo) é tão desestabilizada que, no limite, muitos podem considerar que o texto não é uma revisão bibliográfica. Mas decidimos, não consensualmente, que seria uma perspectiva interessante para pensar a produção do conhecimento em antropologia nos dias atuais.

O foco nas recensóes anteriores como instrumento da análise (Toledo) ou como parte da estratégia (Franch e Nascimento; Maluf, Silva e Silva; Monteiro e Rohden) é produtivo, mas também tem suas desvantagens, pois, ao focar o olhar em seleçôes do campo que já foram realizados no passado, as recensóes presentes acabam por chancelar possíveis esquecimentos que essas recensóes passadas realizaram. Embora seja um instrumento analítico poderoso para produzir um retrato dinâmico da produção, também pode significar uma revisão bibliográfica a respeito dos não silenciados dos campos de pesquisa. Assumindo que qualquer recensão produz luz (os textos citados) e sombras (textos deixados de lado por vários motivos), uma recensão de recensóes reproduz compulsoriamente algumas sombras do passado. Nesse sentido, a reconstrução do movimento do campo é, necessariamente, o movimento dos citados. Retomar e fazer novamente o trabalho já feito por outros pode, como no caso da recensão de Feldman-Bianco, Sanjurjo e Silva e Alves e Pereira, trazer à luz textos perdidos em recensóes passadas, por exemplo.

Em contrapartida, o texto de Velden e Lolli corre para outro caminho, que chamamos de propositivo. Aqui a funçáo da recensão não é historiográfica nem metafórica: é relativa a uma proposição colocada desde o início. Uma proposta de renovar o pensamento sobre o tema que se discute. Ou seja, os autores defendem uma nova forma de pensar o que tradicionalmente e por tanto tempo foi chamado de áreas culturais ou áreas etnográficas e, para justificar a proposição, articulam uma apresentação do campo e de vários trabalhos que juntos justificam a proposição (nesse caso, por uma perspectiva sistêmica dos conjuntos de relaçóes entre povos indígenas: não mais áreas culturais, mas sistemas de relação). Ou seja, a produção da resenha inventa uma nova realidade intelectual: o texto é voltado ao futuro e não ao passado. Há uma deliberada reorganização das fontes bibliográficas, segundo outros parâmetros teóricos, sugerindo que, a partir daí, sigamos uma nova forma de pensarmos as obras, as contribuições, as ideias. Há uma proposta conceitual por excelência.

Um texto propositivo é uma forma de ver o cenário atual e pensar que ele, apesar de tudo, não dá conta do que se imagina serem as realidades sobre as quais se pensa. Assim o ponto é identificar que alternativas representariam o novo real (ou nova forma de se ver o que sempre esteve lá). A manipulação do 
conhecimento, nesse caso, está atrelada desde o começo à proposição. Assim, a vantagem analítica desse estilo é exatamente a sua potencial fraqueza: o que justifica uma nova abordagem pode não corresponder ao cenário do campo analisado. Certa pré-seleçáo em razáo da perspectiva analítica propositiva pode criar sombras mais facilmente, justamente pelos recortes adotados. Pode ser provisória a sua utilidade, mas ainda assim útil para apontar cenários futuros aperfeiçoados.

Os três estilos têm olhares diferentes, direçóes diferentes a sistematizar a própria reflexão. Coordenadas díspares, produzindo recensôes diferentes entre si, seja na estrutura, seja na forma de inventar as realidades intelectuais agrupadas em distintos conjuntos. Cada estilo traz suas vantagens e também desvantagens, que são medidas pelas autoras ao pensar a reflexão sobre o campo, introduzindo no trabalho uma grande dose de arbitrariedade. Isso, do nosso ponto de vista, enriquece o trabalho como um todo, pois, além de um conjunto de recensóes, temos também um conjunto variado de estilos, estratégias e maneiras de pensar os campos. Há ainda muitas outras formas de pensar os trabalhos bibliográficos, claro. Além das ideias do que é uma recensão, as formas de mobilizar o conhecimento para sustentá-las também variam imensamente. Neste volume, temos várias formas de sistematização das bases de dados utilizadas para sustentar os textos.

As autoras podem focar principalmente em artigos, livros e capítulos de livro como o material que sustenta as argumentaçóes. É o caso de Maluf, Silva e Silva; Hartmann e Langdon; Monteiro e Rohden; Alves e Pereira neste volume. $\mathrm{Ou}$, ainda, as histórias construídas remetem menos às publicaçôes e mais às práticas de construçáo do conhecimento - os encontros em reunióes científicas (principalmente ABA, RAM e Reunião Equatorial de Antropologia - REA) onde os grupos criam e sistematizam certos temas e perspectivas. Os textos de Duarte e Sanabria, Motta e Tamaso e Waddington, por exemplo, tomam este caminho: preocupam-se em ilustrar a condensação dos temas com base nas práticas de interação acadêmica que acontecem em eventos, encontros, trânsitos. Fazem recurso também a muitos livros, coletâneas, artigos e capítulos de livros, mas esses todos estáo, de certa forma, circunscritos pela história da constituição dos grupos de pesquisa. Como Motta e Tamaso mostram, especialmente, muitas coletâneas (em livros ou, como dossiês, em periódicos) derivam desses encontros científicos, revelando quem toma a dianteira para organizar os grupos de pesquisa, os grupos de trabalho, as iniciativas editoriais e de financiamento para que livros sejam produzidos e divulgados.

Há ainda outras formas de recorte. Alegria, Bulgarelli e Pinheiro-Machado, por exemplo, escolheram uma estratégia alternativa: focam exclusivamente as teses e dissertaçôes publicadas em vários lugares do país nos últimos 10 anos, criando um mapa da produçáo do conhecimento sobre movimentos sociais nos programas de pós-graduaçáo em antropologia ao redor do país. É um mapa constituído com outras coordenadas, mais afeito à revelação de grupos de pesqui$\mathrm{sa}^{1}$ que de pesquisadoras em si, bem como tentando já captar as novíssimas configuraçôes dos movimentos sociais antes que consigam finalmente deixar os repositórios das bibliotecas e chegar às publicaçōes oficiais:

1 Embora náo seja esse o objetivo do texto, mas sim o de revelar novas e jovens autoras. 
apresenta-se um panorama diferente daqueles baseados exclusivamente nos artigos e livros, por exemplo. Hartmann e Langdon, pela própria natureza do tema (performance), adicionam dados de outros tipos de produção, que não meramente a escrita: filmes, documentários, fotografias, eventos e performances variadas são também material para pensar o campo.

Franch e Nascimento, Maluf, Silva e Silva e Monteiro e Rohden fazem uma mescla de algumas das estratégias citadas: produzem uma análise de outras recensóes, dos grupos de trabalho em congressos da área e de artigos em revistas especializadas no tema. Feldman-Bianco, Sanjurjo e Silva também analisam artigos, livros e capítulos de livro somados a outras recensóes sobre o tema. Mesmo a estratégia de análise de artigos pode ser modulada por outras variáveis, como Monteiro e Rohden o fizeram: decidiram por um corte temporal (2010-2018) e por status dos periódicos (Qualis A1) e mais algumas coletâneas significativas nesse período, além de considerar também a produção derivada de encontros científicos.

Uma questão importante é também a relação que as autoras estabelecem com o próprio campo a ser analisado. Quando a temática é transversal a muitos temas, como é o caso da ciência, na resenha de Monteiro e Rohden, o texto é ele próprio uma ferramenta de construçáo de uma unidade no campo (uma invenção wagneriana, portanto). Isso permite uma oscilação entre expor a transversalidade do campo (e certa fragmentação) e, ao mesmo tempo, referir-se a ele como uma entidade em si: o mesmo objeto aparece fragmentado e inteiro ao longo do texto. Isso reflete uma posição das autoras, que falam de dentro do campo, como porta-vozes de uma área que busca se consolidar.
Outras autoras, em áreas já consolidadas, como é o caso dos estudos migratórios e etnológicos, por exemplo, falam não como porta-vozes do campo, mas como críticos externos, ou seja, a recensão é também uma crítica a certas posiçóes e perspectivas. Nesse sentido, o trabalho náo inventa um campo, mas traz uma nova perspectiva desse campo, depois de estabelecidas as críticas que o fizeram menos interessante. A resenha opera entáo como uma reconstrutora do campo com base em perspectivas e críticas específicas: separando análises que são mais ou menos importantes para o formato do que seria um campo mais crítico atualmente. A profundidade histórica do campo em questão permite às autoras certa exterioridade na escrita. Processo que, ao final, resulta em uma nova interioridade, pois a reconstrução vai limpando o terreno até que o resultado é uma nova configuração na qual as autoras identificam sua presença como interna ao campo.

Assim, exterioridade e interioridade são formas de analisarmos as resenhas: qual o posicionamento das autoras e o que resulta delas. Esses tipos de posicionamento ou de posicionalidades são móveis e dinâmicos, produzindo múltiplos posicionamentos ao longo dos textos. Elas podem acontecer simultaneamente, como no texto de Motta e Tamaso: ao mesmo tempo que se colocam como internos a um campo geral de patrimônio, passam a destacar a especificidade da questáo museológica, para então se colocarem numa perspectiva exterior ao tema do patrimônio para constituir o campo da antropologia dos museus como um universo já autônomo: passam ao papel de porta-vozes do novo campo (falando de um ponto geral interno, portanto e, ao mesmo tempo, externo ao tema do patrimônio).

Todas essas técnicas de arrebanhamento de textos para construir um campo também 
implicam cruzamentos interessantes: certos temas compóem diversos conjuntos. $\mathrm{O}$ caso da intersecção entre o campo da antropologia dos desastres, no texto de Waddington, e o campo da ciência e da tecnologia, no texto de Monteiro e Rohden, são exemplos: a mesma discussão sobre os desastres ambientais alimenta algo da invenção dos dois campos. A intersecção entre antropologia da saúde e antropologia da ciência é também evidente, assim como saúde e gênero (e sexualidade); saúde e drogas; movimentos sociais e gênero e sexualidades; performance e museus; ensino e ciência; futebol e performance, e as resenhas sobre os temas aqui cobrem áreas em comum nessas confluências.

Assim temos vários níveis de multiplicidade: tanto na forma mesmo como se estrutura a sistematização da bibliografia como nas estratégias de coleta e análise de dados. As várias autoras neste livro usam livremente de várias das perspectivas que elencamos, montando seus próprios modelos de análise, muitas vezes resultado também das próprias injunções do campo estudado. Ou seja, talvez a forma como o campo se organiza também favoreça este ou aquele modelo de recensão e análise de dados.

\section{Conclusão}

Este é um livro de recensões múltiplas, variadas pela autoria, pelo formato, pelas estratégias de sistematização de dados e pelos objetivos. Nem todas olham na mesma direçáo e quase nenhuma das autoras se limitou pelas nossas diretivas como editoras (em termos de escopo temporal, tamanho de artigos e mesmo definição do que são recensôes). Essa desobediência sistemática é uma virtude inalienável deste livro e talvez mesmo da área de antropologia. Até mesmo o não enquadramento no que se considera correntemente como revisão bibliográfica, segundo o corpo de pareceristas, e que resultou na recusa de dois textos, fala-nos sobre as relaçôes que organizam a academia e suas publicaçóes, no perfil de texto e de autoria que deve ser incluído e excluído. A desobediência desafia-nos a pensar sobre a natureza das recensões e das avaliaçôes das recensões e, portanto, sobre a natureza das relaçôes de poder e dominação acadêmicas que estão sempre embutidas nessas atividades, caso não as tragamos à luz. Trazê-las à vista, como procuramos fazer nessa introdução, é tornar evidente o processo híbrido (ou sujo, como dissemos anteriormente) de construção desses modelos, e não apenas os esconder sob um produto final purificado e perfeitamente acadêmico.

Esses projetos embutem de antemão uma estratificação acadêmica, entre as autoras, os grupos de pesquisa, as universidades, os nomes que são e os que não são citados, aceitos, publicados e, à medida que a roda editorial gira, os que serão mais uma vez citados etc. E também entre as pesquisadoras que aparecem como parte de grupos de produção de conhecimento e as que ficam alijadas dessa narrativa, até mesmo historicamente, como mostram as resenhas. Como toda narrativa, essas trazem também seus escondidos, separados e ignorados. Nossa mensagem é que tentamos a pluralidade. A escolha inicial de tentar fugir de temas muito explorados já nos trouxe mais perto desse objetivo. O espalhamento das autoras por várias instituiçôes e regiôes também ajudou. A aceitaçâo de uma variedade significativa de estilos de recensão e de coautoria também é favorável a essa meta.

Assim, tentamos combater os efeitos hierarquizantes das recensôes dos ditos temas mais importantes pela estratégia da multiplicidade e da variação tanto de temas, insti- 
tuiçôes e autoras como de estilos, tamanhos e formatos de recensóes. $\mathrm{O}$ quadro formal contém ainda limitaçóes de nosso tempo, como ademais qualquer projeto como este traria. Mas, ao menos, o realizamos com base em uma consciência e intenção de minimizar esses efeitos que podemos chamar, na falta de melhor nome, de coloniais. Eis assim que tratamos nesta introdução de expor os processos híbridos que levaram ao resultado final evitando a tentação da purificação dos resultados finais. Que essas escolhas, perdas e provocaçôes vivenciadas ao longo da produção desta coletânea inspirem a produçáo das próximas coletâneas, para que sejam capazes de sempre renovar o rumo e continuar incentivando a pluralidade, até mesmo ao ponderar sobre os bastidores editoriais.

\section{Bibliografia}

LATOUR, B. Jamais fomos modernos. Rio de Janeiro: Editora 34, 1994.

MARTINS, C. B.; DUARTE, L. F. D. Horizontes das ciências sociais: antropologia. São Paulo: ANPOCS/Bacarolla, 2010.

MICELLI, S. O que ler na ciência social brasileira (1970-1985). Antropologia. São Paulo: Sumaré, 1999. v. 1.

SIMIÃO, D. S.; FELDMAN-BIANCO, B. O campo da antropologia no Brasil: retrospectiva, alcances e desafios. Rio de Janeiro: Aba Ediçôes, 2018.

WAGNER, R. The invention of culture. Chicago: University of Chicago Press, 1975. 
Tem um corpo nessa alma: encruzilhadas da antropologia da performance no Brasil

\author{
Luciana Hartmann ${ }^{1}$ \\ Esther Jean Langdon ${ }^{\text {II }}$
}

\section{Abrindo caminhos}

Neste artigo procuraremos oferecer um panorama sobre a produção das últimas duas décadas na intersecção, ou encruzilhada, entre antropologia e performance no Brasil. Adotamos o termo "encruzilhada" inspiradas em Leda Maria Martins (1997) ${ }^{1}$, que a define como

um princípio de construção retórica e metafísica, um operador semântico pulsionado de significância, ostensivamente disseminado nas manifestaçóes culturais e religiosas brasileiras de predominância nagô e naquelas matizadas pelos saberes bantos. O termo encruzilhada, utilizado como operador conceitual, oferece-nos a possibilidade de interpretação do trânsito sistêmico e epistêmico que emergem dos processos inter e transculturais, nos quais se confrontam e dialogam, nem sempre amistosamente, registros, concepçóes e sistemas simbólicos diferenciados e diversos (Martins, 1997, p. 28).

Acreditamos que a encruzilhada, nesse sentido, carrega uma potência semântica que pode ser produtiva para pensar o campo da antropologia da performance no país. E antes de começar, pedimos licença ao dono do corpo, senhor das encruzilhadas, dos caminhos, das portas e patrono da comunicação, Exú, para apresentar o levantamento feito a seguir ${ }^{2}$.

$\mathrm{Na}$ encruzilhada (lugar de cruzamentos, influências, divergências, cisóes, fusóes, rupturas, multiplicidades) entre Antropologia e formas expressivas em performance, danças, cantos, músicas, narrativas, jogos, brincadeiras, procissões, dramatizações, festas e festivais, manifestaçóes sociais e políticas, rituais de vida e de morte recebem especial atenção, não apenas pelas interpretaçóes ou pelas leituras do social que possibilitam, mas, sobretudo, pelos aspectos simbólicos, expressivos,

1 Leda Maria Martins é importante referência na pesquisa do teatro negro no Brasil e dos congados. Realizou dois pós-doutorados em estudos da performance, na New York University, e tem travado importantes diálogos com os pesquisadores da antropologia da performance no Brasil.

2 Agradecemos à colega Renata Lima e Silva a generosa leitura do artigo e a devida referência e reverência a Exu. Agradecemos também a Taís Ferreira as contribuiçôes ao texto.

'Universidade de Brasília - Brasília (DF), Brasil. E-mail: luhartm71@gmail.com

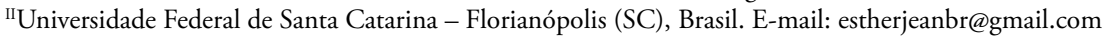


poéticos, estéticos, políticos e reflexivos que evocam e que produzem. Considerando que se trata de um campo interdisciplinar, que tem tido franco crescimento e despertado forte interesse dos pesquisadores brasileiros nas últimas décadas, não é possível abarcar a totalidade de suas produçôes, tampouco de seus autores. Procuraremos, no entanto, apontar as tendências e as contribuiçóes que permitam aos leitores e às leitoras encontrar caminhos que os(as) conduzam a outros textos que, porventura, não se encontrem em nosso artigo.

Se sobrevoarmos nossa "floresta de símbolos"3, olhando por cima das copas das árvores, vamos encontrar outras encruzilhadas, da própria antropologia da performance com outros campos, bastante próximos, com os quais desenvolve férteis diálogos. Entendemos, portanto, que devemos dirigir (limitar) nosso olhar para o cruzamento que a antropologia da performance vem travando com os estudos da música, das artes cênicas, do teatro, da arte e do audiovisual dentro e fora da própria antropologia, que partilham perspectivas, referenciais teóricos, metodológicos e dialogam com sujeitos e grupos sociais comuns. Consideramos que há vários aspectos, no que se refere a campo empírico e conceitos agenciados - reflexividade, ruído, margem, liminaridade, subversão, polifonia, experiência, corporalidade, movimento, transformação, negociação, contextualização, entre outros -, que se tangenciam sob a perspectiva de performance, o que permite estabelecer certa "identidade" entre elas. Acreditamos - e procuraremos desenvolver nosso argumento nesse sentido - que grande parte dessa identidade passa pela abordagem dos corpos (humanos e náo humanos, de an- tropólogos e de seus interlocutores), por sua expressividade gráfica, sonora, gestual, visual - em performance.

Atualmente, a antropologia da performance no Brasil pode ser considerada um campo consolidado, apesar de sua diversidade interna, e é melhor abordada como um "programa de pesquisa". Conceito desenvolvido pelo filósofo da ciência Imre Lakatos (1970), o programa de pesquisa pressupóe que uma comunidade científica partilhe de um conjunto comum de teorias, métodos e técnica. Conforme Escobar (2004, p. 31), um programa de pesquisa desenvolve-se como uma perspectiva emergente e significativamente coesa que alimenta uma série de investigaçôes, reunióes, publicaçóes e outras atividades em torno de um conjunto de conceitos compartilhados. É um programa de escopo multi ou interdisciplinar, e os problemas de pesquisa, teorias, conceitos, métodos e estratégias são negociados entre os pesquisadores dos campos associados de conhecimento, constituindo redes que se estendem além dos tradicionais limites disciplinares, uma vez que os pesquisadores encontram outras áreas que trabalham com os mesmos objetivos, questóes e temas. Novas questóes de pesquisa, que poderiam ser tomadas como temas marginais ou irrelevantes para os fundamentos e as prioridades de uma disciplina, estimulam a criação de outras relaçôes, fora dos limites disciplinares e das estruturas de poder estabelecidos que orientam a produção de conhecimento.

$\mathrm{O}$ que podemos perceber, e que procuraremos demonstrar ao longo do artigo, é que a antropologia da performance se debruça sobre aspectos expressivos, artísticos produzidos em sociedade, sem tratá-los me-

3 Fazemos aqui alusão ao título do livro clássico de Victor Turner (2005b), uma das principais referências dos estudos da performance em antropologia. 
ramente como "objetos", mas também como maneiras de estar no mundo, que tanto expressam e refletem quanto provocam novas experiências (Bauman, 1986; Turner, 1988). Nesse sentido, o campo em questáo afasta-se cada vez mais das ideias de ciência ou de arte strictu sensu, insinuando-se em passos coreografados, filmados, cantados em direção à criação artística. Dawsey et al. (2013, p. 29) também constatam a "mistura de gêneros" ${ }^{4}$ que caracteriza a antropologia da performance, cujos trabalhos "articulam diversas formas expressivas, como o mito, o rito, o filme etnográfico e o cinema de ficção". Ligaremos, assim, a ideia de programa de pesquisa da antropologia da performance no Brasil à perspectiva de um programa da performance antropológica brasileira, que pressupóe o questionamento e o atravessamento das fronteiras tradicionais disciplinares, de saberes e do fazer científico.

O campo antropológico brasileiro vem passando por diversas transformaçóes que, como defenderemos ao longo do texto, tanto impactam como também foram impactadas por algumas propostas diretamente ligadas à antropologia da performance. Em capítulo publicado recentemente no livro O Campo da Antropologia no Brasil (2018), Lia Zanotta Machado analisa o que intitula de dupla vocação do desenvolvimento da antropologia no Brasil:

1) prioridade da constituiçáo de estudos sobre as minorias presentes na diversidade social e cultural da nação brasileira e defesa pública, diante do poder de Estado, dos direitos dessas minorias; e 2) constituição e desenvolvimento da pesquisa de qualidade na pós-graduação (Machado, 2018, p. 285).
A essas vocaçóes, a autora soma uma terceira, um itinerário ou, ainda, uma provocação política: a internacionalização realização de pesquisas em outros países, publicações em revistas internacionais e reconhecimento de nossa produção. Se adotarmos sua perspectiva, no caso das pesquisas no campo da antropologia da performance, poderíamos avançar um pouco mais em sua avaliação e afirmar:

- não fazemos pesquisa sobre minorias, mas com pessoas e grupos sociais, alguns dos quais se autodenominam "minorias", e estes também têm produzido reflexóes sobre suas próprias experiências, frequentemente de forma artística, performática. As pesquisas realizadas na antropologia da performance vêm sendo feitas em coparticipação e, muitas vezes, em coautoria com nossos interlocutores, pelo forte diálogo estabelecido com esses e pela divulgação dos resultados em formatos náo necessariamente acadêmicos - como veremos detalhados a seguir -, tais como vídeos, performances e instalações;

- de fato, grande parte das pesquisas no campo em questão se dá na pós-graduação, embora também sejam notórias as parcerias com artistas sem, necessariamente, formação acadêmica;

- já no caso dos processos de internacionalização da produção no campo da antropologia da performance, esses parecem percorrer outros circuitos, menos acadêmicos e mais artísticos, reforçando a tendência de produção antropológica em outros formatos, ou seja, menos pela escrita, em periódicos científicos, e mais em festivais de cinema e vídeo do-

4 Os autores referem-se aqui ao artigo de Clifford Geertz (2000) "Mistura de gêneros: a reconfiguração do pensamento social". 
cumentário e etnográfico, mostras, exposiçóes, entre outros. Destaca-se, por exemplo, o No Performance's Land, um evento organizado em 2011, em Lisboa, Portugal, em uma parceria entre os antropólogos portugueses Paulo Raposo e Teresa Fradique (Instituto Universitário de Lisboa - ISCTE-IUL) e os brasileiros John Dawsey (Universidade de São Paulo - USP) e Vânia Cardoso (Universidade Federal de Santa Catarina - UFSC). $\mathrm{O}$ evento contou com a participação de artistas e pesquisadores de diversos países, combinando conferências e performances, e posteriormente deu origem ao livro A Terra do Não-Lugar: diálogos entre antropologia e performance (Raposo et al., 2013). Recentemente (2019), Raposo organizou o Corpos Dissidentes/ Cidades Rebeldes: Arte(s), Antropologia(s) e Ativismo(s), um evento que reforçou os vínculos entre membros do Centro em Rede de Investigação em Antropologia (CRIA) do ISCTE - Lisboa, do Grupo de Pesquisa em Oralidade e Performance (GESTO) da UFSC e do Núcleo de Performance e Drama (NAPEDRA) da USP.

Embora não fuja às vocaçóes mencionadas por Machado (2018), em razão da natureza subversiva e temporária da performance, esse campo repleto de encruzilhadas possivelmente as desestabilize, em um "efeito sismológico" (Dawsey, 2016) que causa fissuras por meio das quais o campo deixe escapar certezas e possa se contaminar por outros campos, corpos, movimentos e teorias:
$\mathrm{Na}$ formação de um campo é preciso estar atento aos movimentos que ressoam com os sons e ruídos de processos criativos. Em foco, os deslocamentos capazes de subverter palcos, implodir tempos e $\mathrm{f}(\mathrm{r})$ iccionar corpos e personas. $\mathrm{O}$ corpo tem razóes que a cultura desconhece. Primazia do sensível. Na busca por sentidos do mundo, a antropologia da performance se altera e se transforma numa antropologia em performance (Dawsey, 2016, p. 10).

Para tratar das nossas antropologias em performance, faremos um panorama histórico das pesquisas que vêm sendo desenvolvidas no país, atentando aos corpos e personas que as compóem.

\section{Encruzilhadas históricas e conceituais}

No Brasil, o programa de pesquisa da antropologia da performance vem sendo desenvolvido desde meados da década de 1990, relacionado aos estudos do ritual (Cavalcanti, 2013; Cavalcanti; Sinder; Lage, 2013; Dawsey, 2005; 2016; Langdon, 1996; 2007; Langdon; Pereira, 2012; Langdon; Wiik, 2008; Silva, 2005). Seu crescimento foi impulsionado em grande parte pelo retorno de pesquisadores de seus estágios de formação no exterior e pode ser constatado no surgimento de núcleos de pesquisa em universidades e na frequência, como veremos a seguir, de grupos de trabalho (GTs) em congressos de ciências sociais voltados para a discussão da relação entre performan$c e$, arte, identidade e sociedade. Todo esse movimento, a nossa "virada performativa",

5 Para mais informaçôes sobre o assim chamado performative turn na antropologia, ver Conquergood (1989). Para Dawsey (2016): "A 'virada performativa', que ocorre em um conjunto amplo e variado de disciplinas, envolve uma mudança paradigmática. Questionando o texto-centrismo e a primazia das análises de estruturas sociais e simbólicas em diversos campos, pesquisadores voltam suas atençốes para a ação humana e para o modo como os sentidos do corpo são mobilizados na significação do mundo". 
tem como forte característica a interdisciplinaridade, possivelmente alimentada pelas especificidades dos objetos em questão e de seus respectivos interlocutores. Esse campo interdisciplinar - e por vezes indisciplinado - parte de preocupaçóes com a produção de ação simbólica e da prática expressiva e tem enfoque nos atores e no que eles estão produzindo e criando. No Brasil, esse programa de pesquisa combina uma multiplicidade de vozes e tradiçóes acadêmicas e performativas. Se, por um lado, as tradiçôes acadêmicas que nos servem de referência frequentemente têm sua origem no exterior (assumindo aqui contornos e características bem brasileiros), por outro lado, as tradiçóes performáticas que inspiram nossos estudos são majoritariamente locais e específicas.

Interessadas em identificar as abordagens teórico-metodológicas da noção de performance nos estudos antropológicos brasileiros, realizamos, entre 2005 e 2006, uma pesquisa apoiada pelo Conselho Nacional de Desenvolvimento Científico e Tecnológico $(\mathrm{CNPq})$ na qual tentamos identificar as várias linhas em desenvolvimento relacionado com o cruzamento de performance com antropologia ${ }^{6}$. Realizamos levantamento sobre publicaçóes, grupos de pesquisa e eventos. Também fizemos entrevistas com alguns dos principais nomes dos estudos da performance no país naquele momento, tais como Regina Muller, John Dawsey e Maria Laura Viveiros de Castro Cavalcanti, Mariza Peirano e Gabriel Alvarez, da antropologia;
Zéca Ligièro e Armindo Bião, das artes cênicas; Antônio Herculano, da história; e João Gabriel Teixeira, da sociologia.

A pesquisa indicou ainda a necessidade de desenvolvimento de um diálogo mais teórico e analítico no Brasil, já que grande parte das pesquisas se detinha na descrição das manifestações expressivas "sob as lentes da performance", utilizando ferramentas analíticas frequentemente baseadas nos autores citados para compreender os eventos analisados. Naquele momento, percebíamos uma ênfase em apresentações de estudos de caso, nas quais os usos dos termos "performativo" e "performance" apresentavam conotaçóes bastante variadas. Longe de representar um simples dissenso, essa variedade de usos e compreensóes dos termos reflete, por um lado, a plasticidade destes, e por outro, talvez, a falta de conceitos antropológicos locais que dessem conta das poéticas e das políticas dos fenômenos expressivos. Também constatamos algumas reaçóes contrárias à disseminação do conceito de performance no país e ao consequente crescimento do campo ${ }^{7}$.

Verificamos ainda que há uma diversidade de conceitos que vêm sendo utilizados nesse campo interdisciplinar. Para compreendermos as principais linhagens teóricas agenciadas pelos pesquisadores brasileiros, é importante compreender melhor as origens desse campo de estudos no exterior. $O$ conceito de performance surgiu nas interfaces - ou, podemos retomar aqui, encruzilhadas - entre os estudos de sociedades

6 Auxílio de Pesquisa CNPq Edital CNPq 032/2004 "Antropologia da Performance - os marcos teórico-metodológicos nos estudos de performance”. Processo 402785/2004-5. Esther Jean Langdon Bolsa de Produtividade 301969/2007-8 1/03/2008-28/02/2011 Performance: Aspectos Teóricos, Estéticos e Políticos.

7 Por exemplo, ainda no âmbito do referido projeto, visando estimular um olhar analítico sobre o conceito, organizamos uma mesa-redonda, na Reunião Brasileira de Antropologia de 2006, com a participação de Jean Langdon, John Dawsey, Maria Laura Viveiros de Castro Cavalcanti e Mariza Peirano. Esta, que trabalha com a noçâo de performatividade de Tambiah (Peirano, 2001), questionou fortemente o valor e o emprego do conceito performance (Peirano, 2006). 
complexas e os estudos sobre ritual, teatro e linguagem como comunicação. Milton Singer (1972) introduziu o termo "performance cultural" como uma proposta conceitual e metodológica para o estudo das sociedades complexas, partindo de um estudo de caso na Índia (Camargo, 2013). Performances culturais são gêneros performativos não limitados ao teatro ou a concertos, reconhecidos no mundo ocidental, pois também incluem ritos, rezas, cerimônias, festivais, casamentos etc. São eventos artísticos e culturais marcados por um limite temporal, uma sequência de atividades, um programa de atividades organizado, um conjunto de atores ou performers, plateia, local específico e motivação para a performance. Performances podem ser observadas em uma experiência direita e única e, ainda mais importante, são compostas de "mídia cultural", o que Singer (1972, p. 71) descreve como meios de comunicação que incluem não só a linguagem falada, mas meios não linguísticos, tais como cantos, dança, interpretaçóes performativas, artes gráficas e plásticas. Ampliando a noção de rito para "performance cultural", o autor pretendeu compreender a complexidade das sociedades por meio da observação dos eventos que seus próprios grupos sociais produzem e expressam.

Enfatizando a performance como prática e realização criativa, Dell Hymes (1975) faz a seguinte sistematização:

- A performance realiza, concretiza, faz passar algo que eu reconheço, da virtualidade à atualidade;

- A performance situa-se em um contexto ao mesmo tempo cultural e situacional. Nesse contexto, ela aparece como uma "emergência";

- A performance é uma conduta na qual o sujeito assume, aberta e funcionalmente, a responsabilidade e é um compor- tamento que pode ser repetitivo sem ser redundante, semelhantemente ao que Schechner (1988) define como "comportamento restaurado";

- A performance modifica o conhecimento. Ela não é simplesmente um meio de comunicação. Comunicando, ela os marca.

Já o conceito de performance de Richard Bauman, proposto na década de 1970, parte das abordagens de Singer e de Dell Hymes, mas avança, enfocando especificamente a interação entre os atores na construção dos eventos e suas implicações poéticas e políticas (Bauman, 1977). Formado em estudos de folclore, sociolinguística e antropologia, ele define esse conceito-método nas linhas de Singer por meio da definição dos elementos que compóem uma performance: keying (ou enquadramento), display (ou demonstração), competência e avaliação. Porém, sua abordagem prioriza os aspectos estéticos, poéticos e políticos (relacionados ao poder) das performances e ressalta a experiência em relevo e a qualidade emergente destas (Bauman, 1975; 1992; 1977; 2000; Langdon, 1996). $\mathrm{Na}$ parceria que desenvolve com Charles Briggs (Bauman; Briggs, 1990; 2003; 2006; Briggs; Bauman, 1992), percebe-se que há maior ênfase na criatividade e na inovação que ocorre durante os eventos de performance e menos em seus aspectos normativos. Procuram olhar como as culturas constroem e produzem seus gêneros particulares de performance nos seus contextos específicos. De acordo com Langdon (1999), quando a cultura passa a ser considerada como dinâmica e emergente, na junção do campo da interação simbólica (Goffman, 1983) com a antropologia simbólica e com a etnografia da fala, surgem os estudos da performance em antropologia. 
Complexificando a proposta de Bauman, Schieffelin (1985) reforça que as análises de performance chamam atenção para o temporário, o emergente, a poética, a negociação de expectativas e a sensação de estranhamento do cotidiano. Já Tambiah (1985), outra referência importante no Brasil, em sua discussão sobre a abordagem performativa do rito, faz a distinção entre a análise cultural e a análise formal, distinção que se aproxima da que fazemos entre o conteúdo semântico e a experiência estimulada pelos mecanismos poéticos da performance. Tambiah também teve influência no cruzamento entre política e rito, introduzido no Brasil por sua aluna Mariza Peirano, por meio de seu projeto de análise política de ritos, que inaugurou uma série de etnografias de eventos performativos (Peirano, 2001) ${ }^{8}$.

Por sua vez, a abordagem dramatúrgica de Victor Turner (1982; 1988; 2005a), incrementada em sua parceria com o diretor de teatro Richard Schechner e fundador dos Peformance Studies da Tish School of Art em Nova York, possivelmente tenha sido a que causou - e ainda causa - maior impacto na antropologia simbólica e, subsequentemente, nas pesquisas sobre performance no Brasil (Cavalcanti, 2012; 2013; Cavalcanti; Sinder; Lage, 2013; Dawsey, 1997; 2000; 2005; 2013; 2016; Dawsey, 2018; Mül- ler, 2005) $)^{9}$. Nos últimos anos de sua vida, Turner desloca sua preocupação dos ritos nas sociedades tribais para temas como performance, experiência e subjetividade nas sociedades complexas ${ }^{10}$. Partindo da noçáo de performances culturais de Singer, ele enfoca os espaços liminoides ${ }^{11}$ de performances e suas relaçôes com a sociedade e o Estado: as rupturas e descontinuidades, o imprevisto ou indeterminado, a marginalidade, a polifonia de vozes, a subversão, a subjetividade e a transformaçáo contínua. Assim como Turner, Schechner $(1985 ; 1993)$ também enxerga a performance como um entrelaçamento entre elementos do ritual e do teatro. Inspirado nas distintas fases do processo, Turner $(1974 ; 1981)$ define os dramas sociais como situaçóes de "desordem" que se iniciam com uma ruptura/quebra da normalidade, seguida pelas fases de crise, reparação e reintegração. Quando os interesses dos grupos e/ou indivíduos que partilham valores e histórias comuns se encontram em oposição, ocorre uma quebra no ritmo das relaçôes cotidianas e o drama social consiste no processo de vivência e resolução desse conflito. De acordo com Turner, há relação de reciprocidade entre os dramas sociais de um grupo e as suas performances culturais. Já Schechner (1985) recorre ao símbolo do infinito (infinity-loop model) para pensar as

8 Apesar de, como notamos previamente, Peirano criticar a adequação de "performance" como conceito. Suas pesquisas e as de seus alunos, nessa coletânea sobre performances rituais-políticas no Brasil, compartilham abordagens, conceitos e autores comuns à antropologia de performance (Austin, Goffman, Gumperz, Jakobson, Tambiah, Silverstein).

9 Uma causa provável para essa influência é o fato de que as obras de Turner já eram conhecidas no Brasil na década de 1970, com a primeira tradução de O Processo Ritual publicada em 1974. No entanto, as últimas obras de Turner, nas quais ele desenvolve mais claramente a relação com estudos da performance, só foram publicadas recentemente: Dramas, campos e metáforas, em 2008, e Do ritual ao teatro, em 2015. Já a primeira tradução de um artigo de Bauman e Briggs só foi publicada em 2005 (Bauman; Briggs, 2006). Até o momento, nenhuma obra completa desses autores foi publicada no país. O mesmo ocorre com as obras de Schechner: de toda sua vasta obra, estáo disponíveis apenas alguns artigos traduzidos recentemente e uma coletânea (Schechner, 2012b).

10 Para maior aprofundamento no diálogo da antropologia simbólica com a antropologia da experiência, ver Dawsey (2005) e Langdon (2007).

11 Liminoide seria o equivalente, na performance, ao período liminar, no ritual (ver Turner, 2015). 
interações contínuas entre dramas estéticos e "dramas sociais"12.

\section{Origens e desenvolvimento do campo no Brasil: criando nossas próprias encruzilhadas}

Com base na análise das entrevistas realizadas no âmbito da pesquisa mencionada e da já vasta bibliografia produzida pelos antropólogos brasileiros no campo da antropologia da performance, podemos constatar, em linhas gerais, dois caminhos que se encontram: um traçado por Turner e Schechner, e o outro, por Bauman e Briggs.

A vertente Turner-Schechner foi introduzida mais fortemente no país a partir de 1995, com a realização, em Brasília, do I Seminário Nacional Performáticos, Performance e Sociedade, organizado pelo sociólogo João Gabriel Teixeira, que havia voltado de um pós-doutorado com Schechner, em Nova York. Inspirado pelos performance studies, Teixeira e os membros do Laboratório Transdisciplinar de Estudos sobre a performance (TRANSE) reuniram em três dias um conjunto de artistas, performers, atores, pesquisadores e professores de vários campos, incluindo artes cênicas, sociologia e antropologia, em uma programação que combinava mesas-redondas com performances (Teixeira, 1996). Esse seminário foi um marcador importante do programa de pesquisa sobre performance como campo interdisciplinar que estava surgindo no país. Nesse evento, participaram nomes que contribuíram na construção e na consolidação dos estudos da performance no Brasil, tais como Armindo Bião (Teatro - Universidade Federal da Bahia - UFBA), Bia Medeiros (Artes Visuais - Universidade de Brasília - UnB), Jean Langdon (Antropologia - UFSC), Renato Cohen (Teatro - USP), Regina Muller (Dança - Universidade Estadual de Campinas Unicamp), Rita Gusmão (Teatro - Universidade Federal de Minas Gerais - UFMG), entre outros ${ }^{13}$. A performance antropológica brasileira no campo da antropologia da performance começa, com esse evento, a desenvolver marcadores fortemente ligados ao diálogo entre o fazer artístico - em alguns casos, por parte dos próprios antropólogos - e o estudo deste.

Já a vertente Bauman-Briggs, ligada a uma abordagem performática da linguagem, foi introduzida sobretudo pelos trabalhos de Esther Jean Langdon e de seus orientandos, ainda nos anos 1990 na UFSC, sobre xamanismo, ritual e arte (Langdon, 1996; 1997; 1999). Longe de serem excludentes em sua perspectiva conceitual, o grupo tem passado por transformaçóes nos últimos 20 anos, com a fundação formal do GESTO e a inclusão de pesquisadores de outras tradiçóes analíticas e interesses. O português Paulo Raposo, por exemplo, mencionado anteriormente, vem dando importantes contribuiçóes para as atividades desse grupo e, hoje, perspectivas dessa vertente dialogam e se combinam criativamente nas pesquisas brasileiras.

Como consequência daquele primeiro evento, em menos de dez anos já se podia contabilizar um número considerável de

12 O livro Performance: uma introdução crítica, de Marvin Carlson, publicado no Brasil em 2010, traz uma relevante revisão das principais teorias da performance, em diversos campos artísticos e/ou científicos.

13 Em 1997, ocorreu o II Seminário Nacional sobre Performance, Performáticos e Sociedade, na UFBA, em conjunto com o III Colóquio Internacional de Etnocenologia (ver Teixeira; Gusmão, 2000). Para mais informaçōes sobre as relações entre os estudos da performance e a etnocenologia, ver Bião (2011). 
grupos e núcleos de estudos de performance, tais como o NAPEDRA, criado em 2001, na USP, com a experiência de John Dawsey com Richard Schechner, e o já mencionado GESTO, criado em 2004 na UFSC, mais ligado à segunda vertente, bem como diversos outros, tanto na área do teatro - tais como o Núcleo de Estudos das Performances Afroameríndias (NEPAA - Universidade Federal do Estado do Rio de Janeiro - UNIRIO) e o Grupo Interdisciplinar de Pesquisa e Extensão em Contemporaneidade, Imaginário e Teatralidade (GIPE-CIT) da UFBA - quanto na antropologia, como o Núcleo de Estudos de Arte, Ritual e Performance (NUARP) da Universidade Federal do Paraná (UFPR). Mais recentemente, encontramos a Rede de Pesquisa em Performances Culturais, da Universidade Federal de Goiás (UFG); o Grupo de Estudos em Educação, Teatro e Performance (GETEPE), da Universidade Federal do Rio Grande do Sul (UFRGS), o FATUMBI: Núcleo de Performance, Memória e Religiosidades, da Universidade Estadual do Maranhão (UEMA), entre outros. Para esses grupos convergem pesquisadores que desenvolvem pesquisas sobre e com performances que cruzam a perspectiva antropológica com os campos artísticos e literários.

Os dois grupos de pesquisa alojados em programas de pós-graduação em Antropologia foram responsáveis por diversos eventos, enfatizando a interdisciplinaridade e a realização de performances, por parte de pesquisadores, interlocutores e convidados durante sua programação. Entre esses eventos, podemos citar as quatro ediçóes do Colóquio Antropologias em Performance, organiza- das pelo GESTO, em 2009'14, 2012, 2015 e 2018; o I Encontro Nacional de Antropologia da Performance (ENAP), realizado em 2010; e o Encontro Internacional de Antropologia da Performance (EIAP), de 2011, os dois últimos organizados pelo NAPEDRA ${ }^{15}$. Reforçando nosso argumento em relação às principais filiações teóricas dos respectivos grupos (sem excluir seus frequentes diálogos e trocas), devemos mencionar que a edição de 2009 do Colóquio Antropologias em Performance contou com a presença de Richard Bauman, em sua primeira vinda ao país, e que em 2012, Richard Schechner fez uma visita de dez dias ao NAPEDRA. Esses eventos, além de possibilitarem estabelecer diálogos e parcerias entre grupos e pesquisadores brasileiros, também têm promovido trocas diretas com pesquisadores de fora do país, cujo alcance é notoriamente ampliado com a tradução de algumas de suas obras (Bauman; Briggs, 2006; Bauman, 2009; 2014; Brandstetter, 2011; Fischman, 2009; Gómez-Peña, 2013; Schechner, 2011a; 2011b, 2012a, 2012b; 2013; 2014; Taylor, 2013a; 2013b), bem como com publicaçôes de entrevistas e artigos deles (ver Abreu, 2018; Dawsey, 2011; 2018; Raposo, 2010; 2013; 2014; 2015; 2016).

Nesse contexto, outro ponto que merece destaque foi a criação, em 2012, do Programa de Pós-Graduação Interdisciplinar em Performances Culturais, na UFG, o primeiro com essa característica na América do Sul. Congregando pesquisadores das áreas das artes cênicas e da antropologia, entre outras, esse PPG vem se salientando no cenário nacional pela produção de um corpus de pesquisas, de caráter artístico e/ou etnográfico, sobre

$14 \mathrm{O}$ evento contava com performances e trabalhos acadêmicos; estes foram publicados em um dossiê especial da Ilha - Revista de Antropologia, em 2009 (Cardoso, 2009).

15 Em 2013, o NAPEDRA publicou uma importante coletânea de textos apresentados nesses eventos (Dawsey et al., 2013; Ferreira; Muller, 2010). 
performances culturais brasileiras (Camargo, 2017; Camargo; Reinato; Capel, 2011; Camargo; Cunha; Correia, 2015; Camargo et al., 2019; Correia; Camargo, 2016). Seus Seminários Internacionais de Performances Culturais vêm promovendo significativas colaboraçôes e debates entre diferentes pesquisadores brasileiros e estrangeiros.

\section{A encruzilhada em número e fatos: a consolidação do campo no país}

Visando compreender como a relação entre antropologia e performance vem se constituindo e dialogando no quadro da produção antropológica brasileira, lançamos um questionamento: o que tem levado ao grande crescimento do interesse das pesquisas antropológicas brasileiras pelos estudos da performance, em suas variadas perspectivas (teóricas e metodológicas; como objeto de estudo e produção de conhecimento)? A pergunta possibilita muitas respostas. Talvez a mais simplista relacionaria a profusão de pesquisas às características festivas, expressivas e performativas fartamente presentes de norte a sul do Brasil. A arte, a festa, a dança, a narrativa - entre outras - despertam interesse porque seriam formas de $O$ que $f a z$ o Brasil, Brasil. São expressóes da experiência brasileira ${ }^{16}$ que refletem a multiplicidade dos modos de ser nesse país do tamanho de um continente e com diversidade sem igual na América Latina. Outra resposta enxergaria na concretude e na multiplicidade das performances estudadas uma possibilidade de conhecer as tensões, as fricçôes e as ambiguidades históricas e as provocaçôes, as críticas e as reflexóes que permitem uma leitura mais acurada das intensas transformaçóes políticas e sociais vividas no país nas últimas décadas. Há ainda uma terceira possibilidade de resposta - esta, talvez, a que mais faça sentido, pois complementa as anteriores: a antropologia da performance permite que antropólogos e antropólogas não apenas conheçam o que seus interlocutores pensam, $o$ que fazem e como fazem, mas também reposiciona, nessa relaçáo de troca, a própria prática antropológica. Nessa perspectiva, o debate desloca o próprio lugar do antropólogo, de "tradutor" de experiências, para mediador e criador, aquele que promove e participa de encontros performáticos, nos quais os sujeitos da pesquisa falam, cantam, dançam, contam com suas próprias palavras e com seus próprios corpos. Aqui entram em debate outros formatos de registro, produção e divulgação que não se limitam à escrita, e daí o frequente uso de recursos de áudio, fotografia, desenho e vídeo - e, mais recentemente, também de performances em tempo presente - nas pesquisas antropológicas sobre e com formas artísticas/expressivas.

Levantadas essas hipóteses, lançamos uma segunda questão: quais são as evidências do crescimento do programa de performance no Brasil? Procuramos responder a ela com o levantamento de alguns dados importantes. Comecemos pelo número de teses e dissertaçôes defendidas no Brasil desde o ano 2000, disponíveis no Banco de Teses da Coordenação de Aperfeiçoamento de Pessoal

16 Roberto Da Matta (1979), autor da frase evocada, sugere, em grande medida por meio da relação estabelecida com Victor Turner, que o domínio do ritual é a "região privilegiada para se penetrar no coração cultural de uma sociedade". Foi por meio de manifestaçôes expressivas como o carnaval, as paradas militares e as interaçóes sociais que ele explorou a cultura brasileira. A convite de Da Matta, Turner passa uma curta temporada no Brasil, em 1979. Sobre o legado de Turner à antropologia brasileira, ver Cavalcanti, Sinder e Lage (2013). 
de Nível Superior (CAPES) ${ }^{17}$. Utilizando as palavras-chave que encontramos na encruzilhada entre performance e antropologia, buscamos as teses identificadas com o campo. $\mathrm{Na}$ antropologia da arte, foram encontradas 60 referências; na antropologia da música, 15; na etnomusicologia, 539 (aqui, um dado importante é que grande parte dessas referências é defendida em programas na área de música); na antropologia da performance, especificamente, 52; na antropologia visual, 161; e, na antropologia da dança, 11. Com esses parâmetros, foram encontradas 838 teses e dissertações - algumas aparecendo como resultado em mais de uma busca. É um número significativo, sobretudo se considerarmos que, com o termo geral "antropologia", constam 8.938 referências. Em números aproximados, portanto, chega-se a quase $10 \%$ da produção total da área.

Já na consulta ao Diretório de Grupos de Pesquisa do $\mathrm{CNPq}$, verifica-se, na grande área da antropologia, atualmente, existem 42 grupos cadastrados com a palavra-chave "performance". Se ampliarmos a busca para aquelas áreas que, como têm demonstrado nossas pesquisas, frequentemente partilham de encruzilhadas com a antropologia da performance, encontramos: 14 grupos cadastrados com a palavra-chave "antropologia da arte" e $84 \mathrm{com}$ o termo "arte"; 21 grupos com o termo "música" e 12 com "etnomusicologia"; 25 com o termo "dança", 28 com a palavra-chave "antropologia visual" e 51 registros com o termo "imagem". Nota-se aqui que os grupos também estão cadastrados com mais de uma palavra-chave e que, por esse motivo, podem constar de mais de um dos resultados encontrados. Considerando que o total de grupos de pesquisa registrados na área de antropologia é de 531 (entre todos os certificados e náo atualizados, os resultados listados anteriormente permitem inferir, portanto, que uma parcela considerável desses grupos tem dado ênfase às pesquisas com e sobre performance, em suas múltiplas linguagens e acepçôes).

Outro dado que permite demonstrar com bastante clareza a relevância das pesquisas antropológicas na encruzilhada entre performance e antropologia no Brasil é a quantidade de atividades organizadas nas Reunióes Brasileiras de Antropologia (RBAs) e da Associação Nacional de Pós-Graduação e Pesquisa em Ciências Sociais (Anpocs) desde o ano 2000. Somente nas RBAs, identificamos mais de 45 GTs ou Fóruns de Pesquisa (FP), cerca de 20 mesas-redondas, além de diversas sessões de comunicaçôes coordenadas, oficinas e de programação especial com intervençóes performáticas. Como mencionado anteriormente, para além das atividades organizadas nessas associaçóes, constata-se também a realização de eventos específicos que aprofundam a relação entre antropologia e os estudos da performance no Brasil.

Verifica-se o aprofundamento do debate entre performance e antropologia no país também a partir da criação e da publicação de periódicos específicos, que têm aumentado significativamente nos últimos anos. $\mathrm{Na}$ convergência dos estudos entre arte, performance e imagem temos a pioneira Sexta-Feira, cuja primeira edição foi lançada em 1997 e que explorou distintos estilos de linguagem escrita e visual. Podemos encontrar ainda a PROA - Revista de Antropologia e Arte, editada pelo Instituto de Filosofia e Ciências Humanas (IFCH)-Unicamp desde 2009, os Cadernos de Arte e Antropologia (CAA), editados pela UFBA desde 2012, e a GIS - Gesto, Imagem e Som - Revista de Antropologia, publicada pela USP desde 2016.

17 Todas as buscas foram feitas com a palavra-chave entre aspas, com filtro nos anos de 2000 a 2018. 
Diversos periódicos da área de antropologia também têm publicado dossiês que refletem o interesse no aprofundamento do debate sobre as manifestaçóes artísticas. Entre esses, salientamos os dossiês publicados pela revista Horizontes Antropológicos, da UFRGS, como "Cultura Oral e Narrativas" (1999), "Antropologia da Performance" (2005) e Antropologia e Arte (2008). Para 2019, está prevista a publicação de um dossiê sobre Arte e Cidade. A Ilha-Revista de Antropologia, da UFSC, também já publicou dois dossiês intitulados "Antropologias em Performance", em 2009 e em 2011, respectivamente, fruto dos trabalhos apresentados nos colóquios de mesmo nome, já mencionados. A Antropolitica, da UFF, publicou, em 2012, um dossiê sobre antropologia da dança, e a Revista de Antropologia, da USP, publicou um dossiê sobre antropologia da performance, em 2013, resultado dos trabalhos apresentados no Encontro Internacional de Antropologia da Performance (EIAP). A Sociedade e Estado, da UnB, publicou, em 2014, um dossiê sobre estudos da performance. No mesmo ano, foi publicado o dossiê "Dança e Culturas Populares", na ACENO Revista de Antropologia do Centro-Oeste. O dossiê intitulado "Música e Festa" foi publicado na Anthropológicas, em 2015. Já a Vibrant publicou, em 2017, o dossiê "Ritual and Performance”. Finalmente, pode-se mencionar ainda as apresentaçóes de Renata de Sá Gonçalves e Patrícia Silva Osório aos dossiês "Antropologia da Dança" (2012) e "Dança e Culturas Populares" (2014), que debatem a relação entre dança e sociedade, e que procuram situar o histórico dessas referidas pesquisas, no Brasil e no exterior, traçando um panorama das recentes produçóes brasileiras. Dialogando fortemente com a antropologia da performance, o livro de Marianna Monteiro (2011) e os quatro volumes de antropologia da dança, organizados por Giselle Camargo (2013; 2015a; 2015b; 2018), e os artigos de Heloísa Gravina $(2005 ; 2009$; 2012) também são uma importante referência nesse campo.

Também em diálogo com a antropologia da performance, encontramos na antropologia visual o artigo "Antropologia da Imagem no Brasil: experiências fundacionais para a construção de uma comunidade interpretativa”, de Cornelia Eckert e Ana Luiza Carvalho da Rocha, publicado em 2016, que enfoca as experiências com o ensino e a pesquisa antropológica com e através das imagens em diferentes instâncias acadêmicas e não acadêmicas correlacionadas, tais como: as pesquisas realizadas nos Programas de Pós-Graduação e Núcleos de Pesquisa, a realização de eventos, festivais e mostras de filmes e vídeos etnográficos, a publicação de periódicos científicos e premiaçóes na área.

\section{Para onde conduzem nossas encruzilhadas?}

Atualmente, como resultado da profusão do campo, várias coletâneas, livros e artigos têm sido produzidos, demonstrando a variedade de abordagens do conceito de performance no país, frequentemente com críticas, revisões, ampliações e novas perspectivas sobre os referenciais estrangeiros anteriormente citados.

Vejamos agora como alguns dos protagonistas brasileiros na antropologia de performance têm se servido do conceito como objeto de estudo, categoria analítica, proposta metodológica e possibilidade epistemológica, forma de organização, expressão, criação e, também, transformação de experiências.

John Dawsey, por exemplo, propóe uma análise de mão dupla com base na antropo- 
logia da performance desenvolvida por Victor Turner: se esta é sugestiva para analisar o que chama de "teatro dos boias-frias", também o teatro de canaviais e carrocerias de caminhóes é sugestivo para repensar questôes que emergem nas interfaces entre performance e antropologia (Dawsey, 2005, p. 16). Desafiando a ideia de que, assim como rituais, os dramas sociais configuram momentos extraordinários, de quebra do cotidiano, Dawsey propóe um olhar "às margens das margens":

se o conceito de "drama social" privilegia um conhecimento que se adquire nos momentos extraordinários do cotidiano, o teatro, ou melhor dizendo, o metateatro dos "bóias-frias" pode provocar o efeito inverso. Ilumina-se nesses palcos o lado cotidiano do extraordinário. (Dawsey, 2005, p. 30).

Em uma perspectiva semelhante, pensando a performance também enquanto desordem inserida no dia a dia, a partir das erupçóes do "povo da rua" (malandros, pombas-gira etc.), no cotidiano e na paisagem, Vânia Zikán Cardoso problematiza a abordagem de Bauman e Briggs, e questiona: se a performance é momento privilegiado de reflexão, como podemos pensar a dimensão performática, logo reflexiva, do cotidiano?

A ênfase teórica e etnográfica no enquadramento das performances acentua sua distinção em relação ao cotidiano em termos de uma dimensão reflexiva, de uma percepção acentuada que marca a performance e que leva à avaliação e ao comentário (Bauman e Briggs, 1990: 73). Se por um lado essa caracterizaçáo abre caminho para pensarmos a performance como um momento privilegiado de crítica ao social (ibid.), por outro lado ela leva à articulação de um exterior à performance então caracterizado como o lugar do 'não-reflexivo'. Se o cotidiano é esse exterior, ele aqui se torna naturalizado enquanto suposto fluxo ordinário do social (Cardoso, 2006).

Explorando a relação ou os "pontos de contato entre teatro e antropologia" propostos e posteriormente "revisitados" por Richard Schechner (2013), encontramos, por exemplo, as pesquisas de Rubens Alves da Silva e de Luciana Lyra. O primeiro evoca os seis pontos de contato como possibilidade metodológica a seguir na análise do fenômeno das congadas de Minas Gerais (Silva, 2005, p. 63). Já Luciana Lyra (2010) busca traçar o que chama de "pontes e pontos de contato" entre o cavalo-marinho, manifestação tradicional de Pernambuco, e a arte da performance. A novidade aqui é que a autora aborda ambos como performances culturais e procura sistematizar os elementos que permitiriam sua aproximação do ponto de vista analítico. Em outro trabalho desenvolvido na mesma regiáo, com pescadeiras de ostras do mangue, Lyra (2013) apresenta um novo conceito, o de artetnografia, a partir do qual enfatiza a relação entre os diferentes sujeitos que se encontram em uma pesquisa: "não se traduz apenas em olhar, escutar, escrever, atuar a partir do outro. É, acima de tudo, uma trama entre o ator e este outro, uma trama sempre performática por ter o corpo como topos da experiência de afetos no exercício das relações" (Lyra, 2013, p. 408).

Ao questionar também a própria performance em campo, Francirosy Ferreira (2013), que faz uma "antropologia da performance islâmica", pergunta-se: antropólogos também constroem personagens? Recorrendo à obra de Michael Taussig, outra importante referência do campo, que considera que o conhecimento é corporal, sensorial, por uma compreensão que se dá por meio dos 
corpos (mimeses), a autora afirma: "Estou certa de que o aprendizado do pesquisador é, sobretudo, corporal. Nesse sentido, é preciso 'desconstruir' o corpo para 'adaptá-lo' ao ambiente de pesquisa. Cada campo nos possibilita diferentes entradas e diferentes percepçôes" (Ferreira, 2013, p. 291).

Procurando estabelecer um diálogo entre as diferentes vertentes da antropologia da performance (a perspectiva linguística e a perspectiva dramatúrgica), Luciana Hartmann (2005) propõe a análise das performances narrativas de contadores de "causos" da região de fronteira entre Brasil, Argentina e Uruguai com base em duas abordagens: da performance como espetáculo e da performance como desempenho. A primeira configura-se como um momento extracotidiano, com clara demarcação de início e fim, utiliza a linguagem poética e envolve grande engajamento corporal e vocal do narrador; já a segunda participa do fluxo do cotidiano e revela aspectos semelhantes à primeira, porém de forma menos evidente, pois a ênfase é colocada na expressão de determinadas experiências vividas pelo narrador, embora os aspectos poéticos e reflexivos também se façam presentes. Assim como Esther Jean Langdon, Vânia Z. Cardoso e Danilo P. Ramos (entre outros), Hartmann (2011a), em suas pesquisas, tem se dedicado a enfrentar o desafio de textualizar as inflexóes verbais, vocais e corporais dos narradores, preservando os elementos contextuais dos eventos narrativos em questão.

No artigo "Conflitos de pressupostos na Antropologia da Arte: Relaçôes entre pessoas, coisas e imagens", publicado em 2017, Pedro Cesarino aponta os diversos dilemas conceituais presentes no debate do campo, entre os quais aqueles referentes à própria categoria "arte" e dois de seus pressupostos fundamentais: a noção de objeto e a noçâo de sujeito criador. No cerne desses dilemas, voltamos a um tema caro à antropologia da tradução pressuposta na produçáo de conhecimento etnográfico: como compreender as diversas formas de produção de sentido? $\mathrm{O}$ autor aponta para a produçáo de uma zona de complexidade, motivada por formas distintas de expressão: pela imagem, pela palavra ou pela materialidade. Segundo ele, "é isso que produzirá efeitos em um campo de reflexáo que, talvez, não seja mais propriamente nosso ou dos outros, mas sim constituído pela conexão entre distintas capacidades" (Cesarino, 2017, p. 13).

Essa "conexão entre distintas capacidades" pode ser percebida claramente tanto em processos quanto em alguns produtos de pesquisas antropológicas que envolvem o campo da arte. O Projeto Vídeo nas Aldeias, que desde 1986 se dedica à formação de cineastas indígenas, de 40 etnias brasileiras, bem como à produção e à divulgação de seus filmes e ao apoio à luta por seus direitos culturais e territoriais, atualmente conta com mais de 8 mil horas de imagens em seu acervo e é um bom exemplo disso ${ }^{18}$. A última edição da GIS - Gesto, Imagem e Som, da USP (v. 3, n. 18, 2018), também aborda essa "conexão entre distintas capacidades" em seu dossiê "Olhares cruzados", que discute experiências audiovisuais colaborativas realizadas em área indígena, entre cineastas indígenas e antropólogos que relacionam protagonismo indígena, produção compartilhada, arte, antropologia e política. Esses são apenas alguns exemplos, entre muitos outros que poderíamos mencionar. Em comum, pode-se perceber o engajamento desses antropólogos em debates que envolvem seus próprios corpos e performances no encontro antropológico.

18 Informaçóes sobre o projeto podem ser acessadas em: <http://videonasaldeias.org.br/>. Acesso em: 13 fev. 2019. 
Também é possível constatar que no campo da etnologia e dos estudos com povos indígenas há proeminência dessas produçôes compartilhadas, e é essa reflexão que pôe ênfase nas condiçôes e na viabilidade da tradução. $\mathrm{O}$ enfoque performativo permite examinar como as identidades indígenas são expostas por meio das artes performáticas e dos eventos rituais e políticos, com a utilização de multimídias. Exemplos importantes são o uso de novas tecnologias para a recriaçấo de tradiçôes e expressôes da identidade para a sociedade mais ampla (Gallois; Carelli, 1995a; 1995b; Gallois, 2000; 2007; 2014). As pesquisas examinando a identidade indígena e suas apresentaçóes públicas por meio das artes performáticas também têm aumentado na última década, enfocando as performances indígenas e sua relação com movimentos de afirmação étnica, etnogênesis, situações conflituosas e políticas públicas (Langdon; Wiik, 2008; Langdon, 2016a; 2016b; Santos, 2014; Macedo, 2011; Andrade, 2002; Grünewald, 2005; Hanna; Langdon; Vanclay, 2016; Neves, 2005). Já Edgar Teodoro da Cunha (2013), ao pesquisar o ritual fúnebre bororo, enfatiza a "mistura de gêneros" já mencionada, trabalhando na interseção entre os estudos da performance e o filme etnográfico e defendendo as possibilidades heurísticas do uso da imagem para análise do ritual. Partindo da premissa de que o filme se constrói com base em um discurso híbrido e que é fruto da troca de olhares e projetos, o autor aborda, a partir das diferentes performances realizadas pelos autores (incluindo o antropólogo), o caráter reflexivo dessa relação.
Nos últimos 20 anos, as reflexões nas etnografias e discussóes sobre festas, xamanismo e a produçáo ritual como comunicação com o mundo não humano e invisível deram continuidade às discussóes sobre arte relacionada ao corpo, à percepçáo e ao conhecimento. Nessa perspectiva, a arte indígena é uma arte performativa multissensorial que constrói mundos, articulaçóes e opera transformaçóes nas relações entre corpos, artefatos, música e seres humanos e não humanos (Barcelos Neto, 2009; 2011; 2016; Lagrou, 2009; 2018; Langdon, 2015; Montardo, 2009; 2010a; 2010b; 2010c; 2018; Wauja et al., 2016).

No tema da tradução da poética, o enfoque tem se deslocado da problemática norte-americana de como traduzir fielmente os mecanismos poéticos da arte verbal (Langdon, 1997; 1999) para outras questóes trazidas pelo movimento ontológico-perspectivista e as interfaces entre a linguística, a etnologia e os estudos literários (Cesarino, 2012; 2017; 2018; Ramos, 2018; Ramos; Epps, 2018). As poesias ameríndias representam outros regimes de pensamento, e o problema de tradução (ou retradução) é menos de entender as características formais reconhecidas pelo conceito ocidental de poética e mais de reconhecer a múltipla posicionalidade e polifonia das suas poéticas (Langdon, 2017a; 2018a; 2018b; Macedo, 2012; Schuler Zea, 2008; 2012; 2016; Stallaert; Schuler Zea, 2012) ${ }^{19}$. As artes performativas indígenas são reconhecidas como formas de memória e conhecimento (Fausto; Franchetto, 2008; Fausto; Franchetto; Montagnani, 2011; 2013; Gallois, 2012; Vieira, 2008) pertinentes para sua luta pela garantia

19 Além dessa discussão mais acadêmica, os povos indígenas estão realizando seu próprio movimento de descolonizaçâo por meio da pesquisa, da traduçáo e do registro de suas traduçôes orais (Andrello, 2010; Maxakali; Rosse, 2012). Essas publicações, além de registrarem o patrimônio imaterial do grupo, frequentemente são utilizadas em projetos de educaçấo indígena locais. 
de direitos nas políticas públicas brasileiras (Langdon, 2017b; 2018c).

Outro aspecto importante, que emerge do campo, é a perspectiva crítica da linguagem e da vida social, que trata da relação entre a linguagem e as representaçôes dos outros (os "nativos"). Enquanto essa relação pode ser analisada no discurso das comunidades pesquisadas, também deve ser a base para uma reflexão crítica sobre a poética e a política da escrita etnográfica (Bauman; Briggs, 2003; Cardoso, 2007a; 2007b; 2017; Cardoso; Head, 2013a; 2013b; 2015; Hartmann, 2005; 2009; 2014; Langdon, 1999; 2013).

Há que se notar também o crescimento, no âmbito das culturas urbanas e de periferia, de pesquisas e de seus respectivos resultados por meio de partilhas concretas, que se utilizam de meios expressivos (performances), audiovisuais (vídeos, filmes, hipertextos), paisagens sonoras e/ou experimentos em etnoficção (Castro, 2012; Devos, 2014; Devos; Vedana, 2010; Devos; Vedana; Barbosa, 2016; Ferraz, 2008; Head; Gravina, 2012; Hikiji, 2010; Hikiji; Caffé, 2014; Boudreault-Fournier; Caiuby Novaes; Hikiji, 2016; Silva, R. A., 2008; Vedana, 2010; 2011; 2018; Oliveira, 2007; Monte-Mor, 1995).

De todos os elementos elencados anteriormente, o que se pode depreender, em uma mirada a "olho nu", é que há um inegável investimento dos(as) antropólogos(as) brasileiro(as) e das respectivas instituiçóes aos quais estão ligados(as) em pesquisas sobre e com performance e seus respectivos autores/ criadores. Em uma mirada mais microscópica, é possível perceber um engajamento desses(as) mesmos(as) antropólogos(as) em estreitar, adensar e enriquecer as relaçóes que estabelecem com seus interlocutores por meio da arte, em processos que frequentemente passam a ser de cocriação. Ou seja, os "produtos" de nossas pesquisas são resul- tados de processos assumidamente coletivos e colaborativos. As táo proclamadas "vozes" de nossos interlocutores surgem com seus timbres, tons e cores próprias. Deixamos de ser mediadores e assumimos nosso papel, dependendo do contexto, de espectadores ou de cocriadores.

Verifica-se, portanto, com base no panorama exposto anteriormente, que a antropologia da performance tem explorado, inovado e avançado em relação aos métodos e às técnicas de pesquisa utilizados. Se, a princípio, o desenvolvimento teórico do campo parece não seguir o mesmo ritmo, talvez devamos fazer um exercício de abertura epistemológica que permitiria perceber que, aqui, o método também se transforma em teoria - ou mais ainda: ele é a teoria. Nesse sentido, podemos pensar que a própria etnografia, "enquanto forma de imersão e partilha, enquanto método de transformação e de vivência liminar, que permite quer a assimilação de novos pontos de vista, quer a experimentação de novos modelos e padrões estéticos" (Campos; Zoettl, 2012, p. 7), provocaria essa ênfase e expansão do campo em termos metodológicos. $\mathrm{Na}$ esteira dessa expansão, a etnografia passa a ser experimentada por artistas e a arte experimentada por antropólogos, em trabalhos que envolvem entrevistas ficcionais, etnopoesia, etnobiografia, fotoensaios, paisagens sonoras, plataformas multimídias, instalações, mockmentaries (falsos documentários), entre outros. Reconhecendo esse quadro, os editores do primeiro número dos CAA, Ricardo Campos e Peter Zoettl (2012), citados anteriormente, defendem que a linguagem estética seria central para o diálogo cultural:

A assunção da multissensorialidade é algo que devemos privilegiar em termos epistemológicos, reforçando a ideia de que o conhecimento não é uma mera construção 
racional e distanciada. Assumir a multissensorialidade é, igualmente, estar mais próximo da experiência estética, é assumir o corpo enquanto mediador de significados (Campos; Zoettl, 2012, p. 6).

Os processos artísticos podem proporcionar, portanto, formas alternativas, inovadoras, críticas e contra-hegemônicas de questionar os mecanismos de produção de conhecimento. Um exemplo disso pode ser encontrado na peça de teatro Raptada pelo Raio, escrita pelo antropólogo Pedro Cesarino com base em sua tese de doutorado, sobre narrativas do povo Marubo $^{20}$. Acreditamos que as pesquisas que póem em relação - ou em f(r)icção, como aposta John Dawsey (2009) - a antropologia e a performance estejam contribuindo, sobretudo nas últimas duas décadas, para o avanço não apenas do debate, mas também de açóes concretas nesse sentido. De alguma forma, percebemos que, cada vez mais, as pesquisas em antropologia da performance brasileiras estão buscando estabelecer outras formas de produção de conhecimento, mais horizontais, mais corporais, mais dialógicas e, mesmo que não necessariamente assim denominadas, mais descolonizadoras.

No Brasil, pioneiras nessa forma de abordagem da performance foram as propostas dos já mencionados João Gabriel Teixeira e Regina Muller. Privilegiando a concepção de performance enquanto linguagem artística, como manifestação cultural e a ideia de performance no quotidiano, o núcleo de pesquisa liderado por Teixeira (TRANSE) realizou diversos experimentos metodológicos, dentro e fora da sala de aula, na UnB. Entre esses experimentos, ressaltam-se oito montagens teatrais realizadas no fim dos anos 1980 (Tei- xeira, 1998), os espetáculos Danação Malandra, de 1997, e Mulheres Brasílicas, de 2000, e os experimentos performáticos realizados com estudantes de sociologia e arte, intitulados Corpos em Obras, em 2008, e A Sociologia Dança, em 2009. Em todos esses experimentos, a reflexão sobre a literatura sociológica deveria ocorrer a partir do corpo, promovendo um produto artístico a ser apresentado ao público universitário (Teixeira, 2006, 2013).

Já Regina Muller, artista e antropóloga, realizou pesquisa entre os Assurini do Alto Xingu e encontrou no conceito de "inscrição", de Geertz, uma possibilidade de interpretação da dança nos rituais do grupo (MULLER, 2000; 2008; 2013a; 2013b; 2013c). A autora vê na fixação do sentido, proposta por Geertz, a chave para a transição da escrita como discurso para a ação como discurso, com base em sua contextualização histórico-social. No entanto, Muller não se limita apenas a essa forma de análise, fazendo uma relação entre sua experiência entre os Assurini e a experiência como visiting scholar com Schechner, em Nova York, em 2001. A autora considera que é a performance, entre as linguagens das artes cênicas, a que mais se aproxima da experiência ritual nas sociedades indígenas. Ela conta, em artigo de 2005, como usou essa experiência para apresentar, no Congresso de Americanistas realizado em Santiago do Chile, em 2004, ao invés de uma comunicação oral, uma performance na qual, inspirada na dança das mulheres Assurini e nas mulheres novaiorquinas, usou somente colares, pulseiras e uma calça íntima, além de unhas vermelhas muitos longas e sandálias havaianas (Muller, 2005).

Essas iniciativas reverberaram e inspiraram muitos antropólogos e antropólogas.

20 Entrevista com o autor e maiores informaçôes sobre a peça podem ser consultadas em: <http://p.php.uol.com.br/ tropico/html/textos/3093,1.shl>. Acesso em: $1^{\circ}$ mar. 2019. 
Em 2010, por exemplo, no Encontro Nacional de Antropologia da Performance (ENAP - USP), foram reservados momentos para performances coletivas, tais como $O$ Levantamento do Mastro: Terra, Céu, Tupanaroca e Aruanda no Festejo do Sem Fim. Em 2015, no III Colóquio Antropologias em Performance (UFSC), os participantes foram convidados a integrar as Intervençóes de coisas que nos fazem falar/calar. Nos GTs de congressos, são cada vez mais comuns apresentaçóes performáticas por parte dos pesquisadores. $\mathrm{Ou}$ seja, pesquisar performance pode ser também, como já propunham Edith Turner e Victor Turner (1982), performatizar a própria pesquisa antropológica.

Esses são alguns exemplos de como pesquisadores brasileiros agenciam diferentes acepçóes do conceito de performance em suas pesquisas e como, em diálogo com interlocutores, colegas (sobretudo do meio artístico) e com a bibliografia estrangeira, produzem propostas críticas e originais ${ }^{21}$. Entre essas propostas, salientam-se as interlocuçóes com os campos da música, da dança, das artes visuais, do audiovisual e do teatro proporcionadas pela chave conceitual "performance".

Em linhas gerais, podemos perceber no país que as encruzilhadas da antropologia da performance possibilitam caminhos relacionados à perspectiva linguística, baseada em etnografias da fala, e à perspectiva dramatúrgica, baseada em análises das relaçóes cultura-sociedade-performance, com todas as variaçóes possíveis. Em alguma medida, todas as pesquisas investem inicialmente nos problemas metodológicos e analíticos relacionados a como conhecer, registrar e comunicar, na interação, a complexidade do caráter expres- sivo, poético, multissensorial e intenso das experiências em questão. Consideradas como performances, essas experiências são examinadas criticamente como arenas reflexivas, nas quais os sujeitos se servem de recursos estilísticos heterogêneos, contextualizando os significados e evidenciando as ideologias. Os estudos da performance possibilitam o exame de variadas expressóes culturais como eventos que tanto podem ser de reforço e reinvenção das tradiçóes quanto de crise, renovação e mudança frente um mundo pós-colonial e globalizado. Por meio do conceito - e, muitas vezes, da prática - de performance, expressóes sociais e negociaçôes de poder podem ser reconhecidas e analisadas por seus aspectos estéticos, multissensoriais, dialógicos $\mathrm{e}$ contextualizados.

\section{Considerações finais: caminhos abertos pelas encruzilhadas}

Como procuramos demonstrar ao longo deste artigo, os estudos da performance fazem uma contribuição para a antropologia em diversos âmbitos. No desenvolvimento da antropologia dialógica, por exemplo, tem se ocupado em como captar, em textos fixos, os mecanismos poéticos das performances orais (Langdon, 1999; Hartmann, 2011a; Ramos, 2018), bem como no desenvolvimento de uma reflexão crítica sobre o papel do antropólogo nos eventos performáticos (Cardoso, 2007a; Dawsey, 1997; 2000; 2013; Hikiji, 2010). O paradigma da performance reconhece que o(a) antropólogo(a) em campo está imerso(a) na política da interação comunicativa e, assim, demanda constante

21 Langdon e Pereira (2012), por exemplo, utilizaram o conceito de performance como orientação metodológica para alunos de graduação, trabalho que resultou em uma coletânea de artigos útil em disciplinas de metodologia de cursos de antropologia. 
reflexão sobre como nos posicionamos, seja na relação com nossos colaboradores, seja na representaçáo de suas falas, textos, gestos, sons, e na escrita geral dos textos etnográficos. Não é fortuito o fato de que muitos pesquisadores que se dedicam à antropologia da performance tenham formaçôes interdisciplinares (muitos são músicos, bailarinos, artistas visuais, cineastas, atores etc.), como também, no exercício antropológico, frequentemente coloquem em evidência essa interdisciplinaridade, produzindo resultados de pesquisa em formatos que explicitam, convocam e exaltam as qualidades poéticas das manifestaçóes investigadas.

Constatamos, portanto, que a antropologia da performance permite examinar criticamente os eventos sociais como arenas reflexivas, nas quais competem recursos estilísticos heterogêneos, significados contextualizados e ideologias conflitantes. Caracterizados por sua dialogicidade, contextualização e intertextualidade, esses eventos são analisados como manifestações e negociaçôes de poder. Performances são também formas de protesto e expressão de identidade (Hartmann, 2002; 2011a; 2011b; Silva, R. A., 2016; 2010; Silva, R. de C. O., 2008; Hartmann; Fischman, 2007). Questôes como a reinvenção das tradiçôes aparecem, nesse sentido, relacionadas à subjetividade, ao contexto, à práxis e à globalização (Cavalcanti, 2015; 2018a; 2018b; Carvalho, 2011; Hartmann, 2002; 2011a; 2011b; 2012; 2013; 2017; Rios et al., 2015; Silva, R. A., 2008; 2010; Tamaso, 2017; Teixeira; Gusmão, 2000; Teixeira; Vianna, 2012; Teixeira; Garcia; Gusmão, 2004). Performances são atos de comunicaçáo nos quais o modo de expressar é táo ou mais importante do que o conteúdo da mensagem.

Verificamos que há uma diversidade de conceitos que vêm sendo utilizados nesse campo interdisciplinar e que os teóricos mais influentes no Brasil são Victor Turner (1982; 1988), em associação com Richard Schechner (1988; 1993; 2002), e sua abordagem que vai da análise dos ritos para os estudos de performance (com a definição das noçóes de liminaridade e drama social); Walter Benjamin (1985) e a noção de experiência; John Austin (1990) e os atos de fala; Stanley Tambiah $(1985$; 1996) e a abordagem performativa dos ritos; Dell Hymes, Richard Bauman e Charles Briggs com a etnografia da fala e a arte verbal; Paul Zumthor (1993; 1997; 2000) e a performance na literatura oral; Diana Taylor (2013a; 2013b) e as noçóes de arquivo e repertório, além da recorrência a teóricos do teatro, tais como Antonin Artaud, Jerzy Grotowski, Patrice Pavis, Josétte Feral e Marvin Carlson.

John Dawsey (2016) escava os acervos teóricos do campo e, sensível aos sons dissonantes e às muitas $f(r)$ icçóes entre rostos e máscaras sociais, constata:

A performance é capaz de produzir um efeito sismológico em relação ao tempo. Imagens do passado irrompem no presente, em momentos de perigo, subvertendo um palco da história concebido como uma sequência de cenas que culmina num presente naturalizado (Dawsey, 2016, p. 5).

Esse efeito sismológico da performan$c e$, de acordo com ele, não apenas modifica as relaçóes que se dáo no espaço, mas também altera as temporalidades entre elas. Partindo dessa ideia, podemos pensar o que esse efeito sismológico pode causar às encruzilhadas aqui em questão: talvez caminhos que se bifurquem possam se encontrar, talvez os corpos de antropólogos(as) e de seus(suas) interlocutores(as) deparem com movimentos poéticos e políticos comuns. Se as encru- 
zilhadas, como nos lembra Vânia Cardoso (2007a), são lugar do "povo da rua", onde se entrecruzam não apenas múltiplas liminaridades, mas também a dimensão ritual, elas são também espaços potenciais de cruzamento entre antropologia e performance. Das encruzilhadas, esses "entre" caminhos, podem emergir formas antropológicas que tanto informam sobre os grupos sociais que lhes atravessam, quanto comunicam, de maneira estética, expressiva, polifônica e multissensorial, sobre seus atores - incluídos aí os próprios antropólogos. $\mathrm{Na}$ antropologia da performance, os corpos, seus movimentos e significados são uma importante chave para organizar, expressar, manifestar e, quiçá, transformar as experiências e os saberes que se cruzam no fazer antropológico.

\section{BIBLIOGRAFIA}

ABREU, C. de C. Caveiras da Performance, a ossada de uma filiaçấo comum: John Dawsey entrevista Richard Schechner. GIS - Gesto, imagem, som, v. 3, n.1, p. 302-308, 2018.

ANDRADE, U. M. Um grande atrator: toré e articulação (inter) étnica entre os Tumbalalá do sertão baiano. Cadernos de Campo, v. 10, n. 10, p. 79-92, 2002. https://doi.org/10.11606/issn.2316-9133.v10i10p79-92

ANDRELLO, G. Falas, objetos e corpos: autores indígenas no alto rio Negro. Revista Brasileira de Ciências Sociais, v. 25, n. 73, p. 5-26, 2010. http://dx.doi.org/10.1590/S0102-69092010000200001

AUSTIN, J. L. Quando dizer é fazer. Tradução de Danilo Marcondes de Souza Filho. Porto Alegre: Artes Médicas, 1990.

BARCELOS NETO, A. A serpente de corpo repleto de cançóes: um tema amazônico sobre a arte do trançado. Revista de Antropologia, v. 54, n. 2, p. 981-1012, 2011. https://doi.org/10.11606/2179-0892.ra.2011.39653

BARCELOS NETO, A. The (de)animalization of objects: food offerings and the subjectivization of masks and flutes among the Wauja of Southern Amazonia. In: SANTOS-GRANERO, F. (org.). The Occult Life of Things: Amazonian Theories of Materiality and Personhood. Tucson: University of Arizona Press, 2009. p. 128-153.

BARCELOS NETO, A. Wauja snake-basket: myth and the conceptual imagination of material culture in Amazonia. Mundo Amazónico, v. 7, n. 1-2, p. 115-136, 2016. https://doi.org/10.15446/ma.v7.55701

BAUMAN, R. A Poética do Mercado Público: Gritos de Vendedores no México e em Cuba. Ilha - Revista de Antropologia, v. 11, n. 1-2, p. 17-39, 2009. https://doi.org/10.5007/2175-8034.2009v11n1-2p17

BAUMAN, R. Fundamentos da performance. Sociedade e Estado, v. 29, n. 3, p. 727-746, 2014. http://dx.doi. org/10.1590/S0102-69922014000300004

BAUMAN, R. Language, identity, performance. Pragmatics, v. 10, n. 1, p. 1-5, 2000. http://doi.org/10.1075/ prag.10.1.01bau

BAUMAN, R. Performance. In: BAUMAN, R. (org). Folklore, Cultural Performances, and Popular Entertainments. Nova York: Oxford University Press, 1992. p. 41-49.

BAUMAN, R. Story, Performance and Event: contextual studies of oral narrative. Cambridge: Cambridge University Press, 1986.

BAUMAN, R. Verbal Art as Performance. Rowley: Newbury House Publishers, 1977. 
BAUMAN, R. Verbal art as performance. American Anthropologist, v. 77, n. 2, p. 290-311, 1975. https://doi. org/10.1525/aa.1975.77.2.02a00030

BAUMAN, R.; BRIGGS, C. L. Poética e Performance como Perspectiva Crítica da Linguagem e Vida Social. Ilha Revista de Antropologia, v. 8, n. 1-2, p. 185-229, 2006. https://doi.org/10.5007/\%25x

BAUMAN, R.; BRIGGS, C. L. Poetics and performance as critical perspectives on language and social life. Annual Review of Anthropology, v. 19, p. 59-88, 1990. https://doi.org/10.1146/annurev.an.19.100190.000423

BAUMAN, R.; BRIGGS, C. L. Voices of modernity: language ideologies and the politics of inequality. Nova York: Cambridge University Press, 2003.

BENJAMIN, W. Magia e técnica, arte e política. São Paulo: Brasiliense, 1985. (Obras escolhidas).

BIÃO, A. J. A Presença do Corpo em Cena nos Estudos da Performance e na Etnocenologia. Revista Brasileira de Estudos da Presença, v. 1, n. 2, p. 346-359, 2011. http://dx.doi.org/10.1590/2237-266022804

BOUDREAULT-FOURNIER, A.; CAIUBY NOVAES, S.; HIKIJI, R. S. G. Fabricar o Funk em Cidade Tiradentes, São Paulo: performance em etnoficção. Cultures-Kairós, v. 7, p. 1-22, 2016.

BRANDSTETTER, G. Entrelaçamentos culturais em dança. Ilha - Revista de Antropologia, v. 13, n. 1-2, p. 2140, 2011. https://doi.org/10.5007/2175-8034.2011v13n1-2p21

BRIGGS, C. L.; BAUMAN, R. Genre, intertextuality and social power. Journal of Linguistic Anthropology, v. 2, n. 2, p. 131-172, 1992.

CAMARGO, G. G. A. Antropologia da Dança I. Florianópolis: Insular, 2013.

CAMARGO, G. G. A. Antropologia da Dança II. Florianópolis: Insular , 2015a.

CAMARGO, G. G. A. Antropologia da Dança III. Florianópolis: Insular , 2015b.

CAMARGO, G. G. A. Antropologia da Dança IV. Florianópolis: Insular , 2018.

CAMARGO, R. C. de. Performances culturais: abordagens interdisciplinares. Goiânia: Ed. UFG, 2017.

CAMARGO, R. C. de; CUNHA, F. P.; CORREIA, P. P. (orgs.). Performances da Cultura: Ensaios e Diálogos. Goiânia: Sesc/Fapeg/Kelps, 2015.

CAMARGO, R. C. de; REINATO, E.; CAPEL, H. (orgs.). Performances Culturais: a História Invade a Cena. São Paulo: Hucitec/PUC Goiás, 2011.

CAMARGO, R. C. de et al. (orgs.). Performances Culturais: Abordagens Interdisciplinares. Goiânia: Ed. Universidade Federal de Goiás, 2019.

CAMPOS, R.; ZOETTL, P. Arte e Antropologia? Para uma espécie de introdução... Cadernos de Arte e Antropologia, v. 1, n. 1, p. 5-8, 2012.

CARDOSO, V. Z. Antropologias em Performance. Ilha - Revista de Antropologia, v. 11, n. 1-2, p. 9-16, 2009.

CARDOSO, V. Z. Danger of words: risk and (mis)comprehension in consultations with the spirits of the povo da rua. Vibrant, v. 14, n. 1, p. 45-60, 2017. http://dx.doi.org/10.1590/1809-43412017v14n1p045

CARDOSO, V. Z. Narrar o mundo: Estórias do "povo da rua" e a narraçáo do imprevisível. Mana, v. 13, n. 2, p. 317-345, 2007a. http://dx.doi.org/10.1590/S0104-93132007000200002

CARDOSO, V. Z. O Espírito da Performance. Ilha — Revista de Antropologia, v. 9, p. 197-213, 2007b. https://doi. $\operatorname{org} / 10.5007 / \% 25 \mathrm{x}$ 
CARDOSO, V. Z. Presenças Inesperadas: A Performance nas Brechas do Cotidiano. In: REUNIÃO BRASILEIRA DE ANTROPOLOGIA, 25., 2006, Goiânia. Anais [...]. 2006.

CARDOSO, V. Z.; HEAD, S. Encenaçôes da descrença: a performance dos espíritos e a presentificação do real. Revista de Antropologia, v. 56, n. 2, p. 257-289, 2013a. https://doi.org/10.11606/2179-0892.ra.2013.82469

CARDOSO, V. Z.; HEAD, S. Girando entre gestos: interrupçáo como fonte do fluir. Karpa: Journal of Theatricalities and Visual Culture, v. 6, p. 1-12, 2013b.

CARDOSO, V. Z.; HEAD, S. Matérias nebulosas: coisas que acontecem em uma festa de exu. Religião \& Sociedade, v. 35, n. 1, p. 164-192, 2015. http://dx.doi.org/10.1590/0100-85872015v35n1cap08

CARLSON, M. Performance: uma introdução crítica. Belo Horizonte: Ed. da UFMG, 2010.

CARVALHO, L. G. de. A graça de contar: um pai Francisco no bumba meu boi do Maranhão. Rio de Janeiro: Aeroplano, 2011.

CASTRO, R. de A. Ser em cena, flor ao vento: etnografia de olhares híbridos. Brasília: Editora da UnB, 2012.

CAVALCANTI, M. L. V. de C. Bumba-Meu Boi, Boi Bumbá: a inventividade das tradiçōes populares. Política \& Trabalho, n. 49, p. 23-39, 2018a. http://dx.doi.org/10.22478/ufpb.1517-5901.2018v1n49.40926

CAVALCANTI, M. L. V. de C. Carnaval, ritual e arte. Rio de Janeiro: 7 Letras, 2015.

CAVALCANTI, M. L. V. de C. Drama, ritual e performance em Victor Turner. Sociologia \& Antropologia, v. 3, n. 6, p. 411-440, 2013. http://dx.doi.org/10.1590/2238-38752013v363

CAVALCANTI, M. L. V. de C. Luzes e sombras no dia social. O símbolo ritual em Victor Turner. Horizontes Antropológicos, v. 18, n. 37, p. 103-131, 2012. http://dx.doi.org/10.1590/S0104-71832012000100005

CAVALCANTI, M. L. V. de C. O ritual e a brincadeira: rivalidade e afeição no bumbá de Parintins, Amazonas. Mana, v. 24, n. 1, p. 9-38, 2018b. http://dx.doi.org/10.1590/1678-49442018v24n1p009

CAVALCANTI, M. L. V. de C.; SINDER, V.; LAGE, G. Victor Turner e a Antropologia no Brasil. Duas visóes. Entrevistas com Roberto DaMatta e Yvonne Maggie. Sociologia \& Antropologia, v. 3, n. 6, p. 339-378, 2013. http://dx.doi.org/10.1590/2238-38752013v361

CESARINO, P. N. A escrita e os corpos desenhados: transformaçōes do conhecimento xamanístico entre os Marubo. Revista de Antropologia, v. 55, n. 1, p. 75-137, 2012. https://doi.org/10.11606/2179-0892.ra.2012.47583

CESARINO, P. N. Conflitos de Pressupostos na Antropologia da Arte: Relações entre pessoas, coisas e imagens. Revista Brasileira de Ciências Sociais, v. 32, n. 93, p. 1-17, 2017. http://dx.doi.org/10.17666/329306/2017

CESARINO, P. N. Eventos ou textos? A pessoa múltipla e o problema da tradução das artes verbais amazônicas. In: DAHER, A. (org.). Oral por escrito. Chapecó: Argos/Ed. da UFRJ, 2018.

CESARINO, P. N. Texto integral do espetáculo teatral Raptada pelo Raio. Revista Noz - Caderno Livre. Sáo Paulo: Programa de Fomento ao Teatro da Prefeitura de São Paulo/Cooperativa Paulista de Teatro, 2011.

CONQUERGOOD, D. Poetics, play, process, and power: the performative turn in anthropology. Text and Performance Quaterly, v. 9, n. 1, p. 82-88, 1989. https://doi.org/10.1080/10462938909365914

CORREIA, P. P.; CAMARGO, R. C. de (orgs.). Corpo, Estética, Diferença e outras performances nômades. São Paulo: Paulinas, 2016.

CUNHA, E. T. da. Ritual, performance e imagens entre os bororo do Mato Grosso. In: DAWSEY, J. C. et al. (orgs.). Antropologia e performance: ensaios Napedra. São Paulo: Terceiro Nome, 2013. p. 261-278. 
DA MATTA, R. Carnavais, Malandros e Heróis: para uma sociologia do Dilema Brasileira. Rio de Janeiro: Zahar, 1979.

DAWSEY, J. C. Antropologia em performance: entrevista com Richard Schechner. GIS — Gesto, Imagem, Som, v. 3, n. 1, p. 379-439, 2018.

DAWSEY, J. C. Caindo na cana com Marilyn Monroe: tempo, espaço e Bóias-Frias. Revista de Antropologia, v. 40, n. 1, p. 183-225, 1997. http://dx.doi.org/10.1590/S0034-77011997000100007

DAWSEY, J. C. Corpo, máscara e f(r)icção: a "fábula das três raças" no Buraco dos Capetas. Ilha — Revista de Antropologia, v. 11, n. 1-2, p. 41-62, 2009. https://doi.org/10.5007/2175-8034.2009v11n1-2p41

DAWSEY, J. C. De que riem os boias-frias? Diários de antropologia e teatro. São Paulo: Terceiro Nome, 2013.

DAWSEY, J. C. Nossa Senhora Aparecida e a Mulher Lobisomem: Benjamin, Brecht e o Teatro Dramático na Antropologia. Ilha — Revista de Antropologia, v. 2, n. 1, p. 85-103, 2000.

DAWSEY, J. C. Schechner, teatro e antropologia. Cadernos de Campo (USP. 1991), v. 20, p. 207-213, 2011.

DAWSEY, J. C. Sismologia da performance: palcos, tempos, f(r)icçôes. Cultures-Kairós, v. 7, p. 1-20, 2016.

DAWSEY, J. C. Victor Turner e Antropologia da experiência. Cadernos de Campo, v. 13, n. 13, p. 163-176, 2005. https://doi.org/10.11606/issn.2316-9133.v13i13p163-176

DAWSEY, J. C. et al. (orgs.). Antropologia e performance: ensaios Napedra. São Paulo: Terceiro Nome , 2013.

DEVOS, R. V. Arte e agência em documentários etnográficos. Antropologia em Primeira Mão, v. 143, p. 1-20, 2014.

DEVOS, R. V.; VEDANA, V. Do audiovisual à hipermídia. Antropologia em Primeira Mão, v. 120, p. 1-34, 2010.

DEVOS, R. V.; VEDANA, V.; BARBOSA, G. C. Paisagens como panorama e ritmos audiovisuais: percepção ambiental na pesca da Tainha. GIS — Gesto, Imagem e Som, v. 1, n. 1, p. 41-58, 2016. https://doi. org/10.11606/issn.2525-3123.gis.2016.116350

ECKERT, C.; ROCHA, A. L. C. da. Antropologia da Imagem no Brasil: experiências fundacionais para a construção de uma comunidade interpretativa. Iluminuras, v. 17, n. 41, p. 277-297, 2016. https://doi. org/10.22456/1984-1191.64571

ESCOBAR, A. The Latin American Modernity/Coloniality Research Program: Worlds and Knowledges Otherwise. Cuadernos del CEDLA, v. 16, p. 31-67, 2004.

FAUSTO, C. B.; FRANCHETTO, B. Tisakisü: Tradição e Novas Tecnologias da Memória (Kuikuro, Alta Xingu). Rio: Museu do Índio-FUNAI, 2008.

FAUSTO, C.; FRANCHETTO, B.; MONTAGNANI, T. Las Formas de la memoria: Arte verbal y música entre los kuikuros del Alto Xingú. Cuadernos Intercambio, v. 10, n. 12, p. 49-75, 2013.

FAUSTO, C. B.; FRANCHETTO, B.; MONTAGNANI, T. Les formes de la mémoire. Art verbal et musique chez les Kuikuro du Haut-Xingu. L'Homme, v. 197, p. 41-69, 2011.

FERRAZ, A. L. M. C. Mulheres, trabalho e redes sociais: Uma experiência etnográfica de produçáo de performances para o vídeo. Ciências \& Cognição, v. 13, n. 1, p. 142-151, 2008.

FERREIRA, F. C. B. Pesquisadoras e suas magias. In: DAWSEY, J. C. et al. (orgs.). Antropologia e performance: ensaios Napedra. São Paulo: Terceiro Nome, 2013. p. 279-292.

FERREIRA, F.; MULLER, R. P. (orgs.). Performance: Arte e Antropologia. São Paulo: Hucitec, 2010. 
FISCHMAN, F. Performance, escritura y oralidad en la socialización profesional de los abogados argentinos. Ilha Revista de Antropologia, v. 11, n. 1-2, p. 63-84, 2009. https://doi.org/10.5007/2175-8034.2009v11n1-2p63

GALLOIS, D. T. Alguns pontos de vista acerca da formaçáo de pesquisadores indígenas no Brasil. Nuevo MundoMundos Nuevos, v. 4, p. 1-15, 2014.

GALLOIS, D. T. Donos, detentores e usuários da arte gráfica kusiwa. Revista de Antropologia, v. 55, n. 1, p. 19-39, 2012. https://doi.org/10.11606/2179-0892.ra.2012.46956

GALLOIS, D. T. Gêneses waiápi, entre diversos e diferentes. Revista de Antropologia, v. 50, n. 1, p. 45-83, 2007. https://doi.org/10.1590/S0034-77012007000100002

GALLOIS, D. T. Intercâmbio de imagens e reconstruçóes culturais. Sinopses, v. II, n. 5, p. 82-84, 2000.

GALLOIS, D. T.; CARELLI, V. Diálogo Entre Povos Indígenas: A Experiência de Dois Encontros Mediados Pelo Vídeo. Revista de Antropologia, v. 38, n. 1, p. 205-258, 1995a. https://doi.org/10.11606/2179-0892. ra. 1995.111448

GALLOIS, D. T.; CARELLI, V. Vídeo e Diálogo Cultural. Horizontes Antropológicos, v. 2, p. 49-57, 1995 b.

GEERTZ, C. Mistura de gêneros: a reconfiguração do pensamento social. In: GEERTZ, C. O Saber Local. 3. ed. Petrópolis: Vozes, 2000. p. 33-56.

GOFFMAN, E. The Interaction Order. American Sociological Review, v. 48, n. 1, p. 1-17, 1983. https://doi. org/10.2307/2095141

GÓMEZ-PEÑA, G. Em defesa da arte da performance. In: DAWSEY, J. et al. (orgs.) Antropologia e Performance: ensaios NAPEDRA. São Paulo: Terceiro Nome, 2013. p. 441-466.

GONÇALVES, R.; OSÓRIO, P. Dança e Cultura Popular. Aceno, v. 1, n. 2, p. 12-24, 2014.

GRAVINA, H. C. Entre "artes" e "ciências": a performance como construção de conhecimento numa interface entre dança e antropologia social. Revista da Fundarte, v. 5, p. 9-12, 2005.

GRAVINA, H. C. Falar-fazer antropologia: uma experimentação etnográfica do corpo na capoeira Angola. Ilha Revista de Antropologia, v. 13, n. 1-2, p. 113-138, 2012. https://doi.org/10.5007/2175-8034.2011v13n1-2p113

GRAVINA, H. C. Le Monde de la Capoeira Angola vu de Marseille: corps, imaginaires et hiérarchies en jeu. Vibrant, v. 6, n. 1, p. 123-151, 2009.

GONÇALVES, R. S.; OSÓRIO, P. Dança e Cultura Popular. Aceno, v. 1, n. 2, p. 12-24, 2014.

GONÇALVES, R. S.; OSÓRIO, P. Apresentação. Antropolítica: Revista Contemporânea de Antropologia, n. 33, p. 13-23, 2012. https://doi.org/10.22409/antropolitica2012.0i33.a136

GRÜNEWALD, R. de A. (org.). Toré: regime encantado do índio do Nordeste. Recife: Massangana/FUNDAJ, 2005.

HANNA, P.; LANGDON, E. J.; VANCLAY, F. Indigenous Rights, Performativity and Protest. Land Use Policy, v. 50, p. 490-506, 2016. https://doi.org/10.1016/j.landusepol.2015.06.034

HARTMANN, L. Contando histórias com imagens. Doc On-Line — Revista Digital de Cinema Documentário, v. 6, n. 6, p. 55-70, 2009.

HARTMANN, L. Desafios da Diversidade em sala de aula: um estudo sobre performances narrativas de crianças imigrantes. Cadernos Cedes, v. 37, n. 101, p. 45-64, 2017. http://dx.doi.org/10.1590/cc010132622017168668 
HARTMANN, L. Gesto, palavra e memória: performances de contadores de causos. Florianópolis: Ed. da UFSC, 2011 a.

HARTMANN, L. Identidade, Ambigüidade, Conflito: performances narrativas como estratégia de análise da cultura de fronteira entre Argentina, Brasil e Uruguai. Revista de Investigaciones Folclóricas, Buenos Aires, v. 17, p. 114-122, 2002.

HARTMANN, L. "Just because they're lies doesn't mean they're not true": Learning and transmission of lies among storytellers. Compaso - Journal of Comparative Research in Anthropology and Sociology, v. 5, n. 2, p. 73-87, 2014.

HARTMANN, L. Medo e encantamento em narrativas orais contadas por crianças. Revista Cerrados, v. 22, n. 35, p. 49-69, 2013.

HARTMANN, L. "Não sendo mentira, são sempre verdade" — aprendizagem e transmissão da mentira entre contadores de causos. Ilha - Revista de Antropologia, v. 13, n. 1-2, p. 139-162, 2012. https://doi. org/10.5007/2175-8034.2011v13n1-2p139

HARTMANN, L. Performance e experiência nas narrativas orais da fronteira entre Argentina, Brasil e Uruguai. Horizontes Antropológicos, v. 11, n. 24, p. 125-153, 2005. http://dx.doi.org/10.1590/S010471832005000200007

HARTMANN, L. Performances culturais: expressōes de identidade nas festas da fronteira entre Brasil, Argentina e Uruguai. Etnográfica, v. 15, n. 2, p. 233-259, 2011 b.

HARTMANN, L.; FISCHMAN, F. (orgs.). Donos da palavra: autoria, performance e experiência em narrativas orais na América do Sul. Santa Maria: Ed. da UFSM, 2007.

HEAD, S.; GRAVINA, H. C. Blackness in Movement: Identifying with Capoeira Angola in and out of Brazil. African and Black Diaspora: An International Journal, v. 5, n. 2, p. 194-210, 2012. https://doi.org/10.1080/1 7528631.2012 .695221

HIKIJI, R. S. G. Video, Music and Shared Anthropology. Visual Anthropology, v. 23, n. 4, p. 330-343, 2010. https://doi.org/10.1080/08949468.2010.485009

HIKIJI, R. S. G.; CAFFÉ, C. A Arte e a Rua? Audiovisual Ethnography on the Outskirts of São Paulo. Alter/nativas — Latin American Cultural Studies Journal, n. 2, p. 1-15, 2014.

HYMES, D. Breakthrough into Performance. In: BEN-AMOS, D.; GOLDSTEIN, K. S. (orgs.). Folklore: Performance and Communication. Paris: Mouton, 1975. p. 11-74.

LAGROU, E. Anaconda-becoming: Huni Kuin image-songs, an Amerindian relational aesthetics. Horizontes Antropológicos, v. 24, n. 51, p. 17-49, 2018. http://dx.doi.org/10.1590/s0104-71832018000200002

LAGROU, E. Arte Indígena no Brasil. Belo Horizonte: C/ARTE, 2009.

LAKATOS, I. Falsification and the Methodology of Scientific Research Programmes. In: LAKATOS, I.; MUSGRAVE, A. (orgs.). Criticism and the Growth of Knowledge: Proceedings of the International Colloquium in the Philosophy of Science. London, 1965. Cambridge: Cambridge University Press , 1970. p. 91-196.

LANGDON, E. J. A fixação da narrativa: do mito para a poética da literatura oral. Horizontes Antropológicos, v. 5, n. 12, p. 13-36, 1999. http://dx.doi.org/10.1590/S0104-71831999000300002

LANGDON, E. J. A performance da diversidade: o xamanismo como modo performático. GIS — Gesto, Imagem e Som, v. 1, n. 1, p. 9-40, 2016a. https://doi.org/10.11606/issn.2525-3123.gis.2016.116460

LANGDON, E. J. "A Viagem à Casa das Onças": Narrativas sobre experiências extraordinárias. Revista de Antropologia, v. 56, n. 2, p. 183-212, 2013. https://doi.org/10.11606/2179-0892.ra.2013.82465 
LANGDON, E. J. Dialogicalidad, conflicto y memoria en etnohistoria siona. Boletín de Antropología, Medellín, v. 33, n. 55, p. 56-76, 2018a. http://doi.org/10.17533/udea.boan.v33n55a04

LANGDON, E. J. From Rau to Sacred Plants: Transfigurations of shamanic agency among the Siona Indians of Colombia. Social Compass, v. 64, n. 1, p. 343-359, 2017a. http://dx.doi.org/10.1177/0037768617713654

LANGDON, E. J. Indigenous Autonomy in Contemporary Colombia and Implications for the Return of Ethnographic Material. In: REUNIÃO DE ANTROPOLOGIA DA CIÊNCIA E TECNOLOGIA, 6., 2017. Anais [...]. 2017b. p. 21-37. Disponível em: <Disponível em: https://ocs.ige.unicamp.br/ojs/react/issue/ view/81>. Acesso em: 4 fev. 2019.

LANGDON, E. J. Mana e Substâncias Xamânicas: As reconfiguraçốes entre as Siona da Colômbia. Revista Campos, v. 19, n. 1, p. 113-135, 2018b. http://dx.doi.org/10.5380/cra.v19i1.64069

LANGDON, E. J. Oír y ver los espíritus: performances chamánicas y los sentidos entre los indígenas siona del Putumayo, Colombia. In: DE MORI, B.; LEWY, M.; GARCÍA, M. A. (orgs.). Sudamérica y sus Mundos audibles. Cosmologías y prácticas sonoras de los pueblos indígenas. Berlim: Iberoamerikanisches Institut / Gebr. Mann Verlag, 2015. (Estudios Indiana 8).

LANGDON, E. J. Performance e Preocupaçōes Pós-Modernas em Antropologia. In: TEIXEIRA, J. G. (org.). Performáticos, Performance e Sociedade. Brasília: Editora Universidade de Brasília, 1996. p. 23-29.

LANGDON, E. J. Performance e sua Diversidade como Paradigma Analítico: A Contribuição da Abordagem de Bauman e Briggs. Ilha. Revista de Antropologia, v. 8, n. 1-2, p. 163-183, 2006. https://doi.org/10.5007/\%25x

LANGDON, E. J. Textual interpretation in the Amazon. American Anthropologist, v. 99, n. 3, p. 628-629, 1997.

LANGDON, E. J. The Revitalization of Yajé Shamanism among the Siona: Strategies of Survival in Historical Context. Anthropology of Consciousness, v. 27, n. 2, p. 180-203, 2016b. https://doi.org/10.1111/anoc.12058

LANGDON, E. J. The Symbolic Efficacy of Rituals: From Ritual to Performance. Antropologia em Primeira Mão, v. 95, p. 1-39, 2007.

LANGDON, E. J. The Value of Narrative: Memory and Patrimony among the Siona. Revista del Museu de Antropologia, v. 11, Supl. Esp. 1, p. 91-100, 2018c. http://dx.doi.org/10.31048/1852.4826.v11.n0.21463

LANGDON, E. J.; PEREIRA, E. L. (orgs.). Rituais e performances: iniciaçôes em pesquisa de campo. Florianópolis: UFSC/Departamento de Antropologia, 2012.

LANGDON, E. J.; WIIK, F. B. Festa de Inauguração do Centro de Turismo e Lazer: uma Análise da Performance Identitária dos Laklánó (Xokleng) de Santa Catarina. Ilha — Revista de Antropologia, v. 10, p. 171-199, 2009.

LYRA, L. Da artetnografia à mitodologia e artes cênicas: a máscara-mangue em duas experiências performáticas. In: DAWSEY, J. C. et al. (orgs.). Antropologia e performance: ensaios Napedra. São Paulo: Terceiro Nome , 2013. p. 391-410.

LYRA, L. Pontes e pontos de contato: o cavalo-marinho e a arte da performance. In: FERREIRA, F.; MULLER, R. P. (orgs.). Performance: Arte e Antropologia. São Paulo: Hucitec, 2010. p. 254-279.

MACEDO, V. Dos cantos para o mundo: invisibilidade, figuraçôes da cultura e o se fazer ouvir nos corais guarani. Revista de Antropologia, v. 55, n. 1, p. 357-400, 2012. https://doi.org/10.11606/2179-0892.ra.2012.46969

MACEDO, V. Tracking Guarani songs: between villages, cities and worlds. Vibrant, v. 8, n. 1, p. 377-410, 2011. http://dx.doi.org/10.1590/S1809-43412011000100014 
MACHADO, L. Z. A Antropologia Brasileira um Triplo Itinerário? In: SIMIÃO, D. S.; FELDMAN-BIANCO, B. (orgs.). O campo da antropologia no Brasil: retrospectiva, alcances e desafios. Rio de Janeiro: Associação Brasileira de Antropologia, 2018.

MARTINS, L. M. Afrografias da Memória. São Paulo: Perspectiva; Belo Horizonte: Mazza Ediçôes, 1997.

MAXAKALI, T.; ROSSE, E. P. Kõmãyxop cantos xamânicos Maxakali. Rio de Janeiro: FUNAI, 2012. (com CD.)

MONTARDO, D. L. O. Através do Mbaraka: Música, Dança e Xamanismo Guarani. São Paulo: Editora da Universidade de São Paulo, 2009. (com CD)

MONTARDO, D. L. O. Através Caminhando, cantando e dançando com os pais criadores: o jeroky guarani visto como performance. Ilha. Revista de Antropologia, v. 11, n. 1-2, 131-144, 2010a. https://doi. org/10.5007/2175-8034.2009v11n1-2p131

MONTARDO, D. L. O. Através La música y la danza en la cosmología Guaraní. A Contratiempo: Revista de Música en la Cultura, n. 14, p. 1-8, 2010 b.

MONTARDO, D. L. O. Através Para uma Antropologia da Música na Amazônia. In: MONTARDO, D. L. O. Através Amazônia e Outros Temas. PPGAS. Manaus: EDUA, 2010c.

MONTARDO, D. L. O. Através Sons e Espacialidade, os Caminhos nos Cantos e Danças Guarani. Ilha — Revista de Antropologia, v. 20, n. 1, p. 145-162, 2018. https://doi.org/10.5007/2175-8034.2018v20n1p145

MONTE-MOR, P. Descrevendo culturas: etnografia e cinema no Brasil. Cadernos de Antropologia e Imagem no 1: antropologia e cinema, primeiros contatos. Rio de Janeiro: NAI/UERJ, 1995. p. 65-74.

MONTEIRO, M. Dança popular: espetáculo e devoção. São Paulo: Terceiro Nome , 2011.

MULLER, R. A. P. Arte gráfica Asuriní do Xingu: Corpo, mito e pensamento. In: SEVERI, C.; LAGROU, E. (orgs.). Quimeras em diálogo, grafismo e figuração na arte indígena. Rio de Janeiro: 7 Letras, 2013a. p. 163-180.

MULLER, R. A. P. Corpo e imagem em movimento: há uma alma neste corpo. Revista de Antropologia, v. 43, n. 2, p. 165-193, 2000. https://doi.org/10.1590/S0034-77012000000200008

MULLER, R. A. P. Mira Chica..: um estudo sobre arte da performance. In: DAWSEY, J. et al. (orgs.). Antropologia e Performance, ensaios Napedra. São Paulo: Terceiro Nome, 2013b. p. 361-371.

MULLER, R. A. P. Performance, corpo e ritual entre os Asurini do Xingu. In: RAPOSO, P. et al. (orgs.). A Terra do Não-lugar, diálogos entre antropologia e performance. Florianópolis: Ed. da UFSC , 2013c. p. 171-191.

MULLER, R. A. P. Ritual e performance nas artes indígenas. Revista do Museu de Arqueologia e Etnologia, v. 1, supl. 7, p. 69-75, 2008. https://doi.org/10.11606/issn.2594-5939.revmaesupl.2008.113496

MULLER, R. A. P. Ritual, Schechner e Performance. Horizontes Antropológicos, v. 1, n. 24, p. 67-85, 2005.

NEVES, R. de C. Dramas e Performance: O Processo de Reelaboração Étnica Xukuru nos Rituais, Festas e Conflitos. Tese (Doutorado em Antropologia Social) — Universidade Federal de Santa Catarina, Florianópolis, 2005.

OLIVEIRA, A. de P. Quando se canta o conflito: contribuiçôes para a análise de desafios cantados. Revista de Antropologia, v. 50, n. 1, p. 313-345, 2007. https://doi.org/10.1590/S0034-77012007000100008

PEIRANO, M. O dito e o feito: Ensaios de antropologia dos rituais. Rio de Janeiro: Relume Dumará, 2001.

PEIRANO, M. Temas ou Teorias? O estatuto das noçôes de ritual e de performance. Campos - Revista de Antropologia, v. 7, n. 2, p. 9-16, 2006. 
RAMOS, D. P. A caminho da Cidade das Onças: diálogos sobre sonhos no percurso para a Serra Grande-Metrópole dos Hupd'äh. Revista de Antropologia, v. 61, n. 1, p. 329-359, 2018. https://doi.org/10.11606/2179-0892. ra.2018.145528

RAMOS, D. P.; EPPS, P. Caminhos de sopro: discurso xamânico e percursos florestais. Mana, v. 24, n. 1, p. 161198, 2018. http://dx.doi.org/10.1590/1678-49442018v24n1p161

RAPOSO, P. A "Revolta das Barcas": sobre silenciamento performativo e imaterialidade do protesto na (in) visibilidade contemporânea das periferias urbanas. GIS — Gesto, Imagem e Som, v. 1, n. 1, p. 59-88, 2016. https://doi.org/10.11606/issn.2525-3123.gis.2016.116348

RAPOSO, P. "Artivismo": articulando dissidências, criando insurgências. Cadernos de Arte e Antropologia, v. 4, n. 2, p. 3-12, 2015.

RAPOSO, P. Diálogos antropológicos: da teatralidade à performance. In: FERREIRA, F.; MULLER, R. P. (orgs.). Performance: Arte e Antropologia. São Paulo: Hucitec , 2010. p. 19-49.

RAPOSO, P. Festa e performance em espaço público: tomar a rua! Ilha: Revista de Antropologia, v. 16, n. 2, p. 89114, 2014. https://doi.org/10.5007/2175-8034.2014v16n2p89

RAPOSO, P. No performance's land? Interrogaçôes contemporâneas para uma teoria da performance. In: RAPOSO, P. et al. (orgs.). A Terra do não-lugar: diálogos entre antropologia e performance. Santa Catarina, Brasil: EDUFSC, 2013. p. 10-16.

RAPOSO, P. et al. (orgs.). A Terra do não-lugar: diálogos entre antropologia e performance. Florianópolis: EDUFSC, 2013.

RIOS, S. et al. Toadas de Santos Reis em Inhumas - GO: tradição, circulação e criação individual. Goiânia: Faculdade de Ciências Sociais/UFG, 2015.

SANTOS, J. O. dos. Ritual, "Cultura” e Transformação: A Festa do Jacaré entre os Arara de Rondônia. In: CUNHA, M. C. da; CESARINO, P. N. (orgs.). Políticas Culturais e Povos Indígenas. São Paulo: Cultura Acadêmica, 2014. p. 135-163.

SCHECHNER, R. 11 de Setembro, Arte de Vanguarda? Tradução de Marcelo de Andrade Pereira e Martin Dahlström Heuser. Revista Brasileira de Estudos da Presença, v. 1, n. 2, p. 404-425, 2011a. http://dx.doi. org/10.1590/2237-266020986

SCHECHNER, R. A Vanguarda Conservadora. Tradução de Martin Dahlström Heuser. Revista Brasileira de Estudos da Presença, v. 2, n. 2, p. 573-600, 2012a. http://dx.doi.org/10.1590/2237-266020985

SCHECHNER, R. Between Theater and Anthropology. Filadélfia: The University of Pennsylvania Press, 1985.

SCHECHNER, R. Performance e Antropologia de Richard Schechner. Zeca Ligério (org.). Rio de Janeiro: Mauad, $2012 \mathrm{~b}$.

SCHECHNER, R. Performance Studies: an introduction. London: Routledge, 2002.

SCHECHNER, R. Performance Theory. Nova York e Londres: Routledge, 1988.

SCHECHNER, R. Podemos ser o (novo) Terceiro Mundo? Tradução de João Gabriel L. C. Teixeira. Sociedade e Estado, v. 29, n. 3, p. 711-726, 2014. http://dx.doi.org/10.1590/S0102-69922014000300003

SCHECHNER, R. Pontos de Contato entre o pensamento antropológico e teatral. Tradução de Ana Letícia de Fiori. Cadernos de Campo, v. 20, n. 20, p. 213-236, 2011b. https://doi.org/10.11606/issn.2316-9133. v20i20p213-236 
SCHECHNER, R. "Pontos de Contato" revisitados. In: DAWSEY, J. C. et al. (orgs.). Antropologia e Performance: ensaios NAPEDRA. São Paulo: Terceiro Nome , 2013. p. 37-65.

SCHECHNER, R. The Future of Ritual. Nova York e Londres: Routledge , 1993.

SCHIEFFELIN, E. Performance and the Cultural Construction of Reality. American Ethnologist, v. 12, n. 4, p. 707-724, 1985. https://doi.org/10.1525/ae.1985.12.4.02a00070

SCHULER ZEA, E. A inquietude do tradutor: notas sobre uma lógica das partes em La chute du ciel. Cadernos de Tradução, v. 2, n. 30, p. 171-184, 2012. https://doi.org/10.5007/2175-7968.2012v2n30p171

SCHULER ZEA, E. Tradução como iniciação. Cadernos de Tradução, v. 36, n. 3, p. 192, 2016.

SCHULER ZEA, E. Genitivo da Tradução. Boletim do Museu Paraense Emílio Goeldi, v. 3, n. 1, p. 65-77, 2008. http://dx.doi.org/10.1590/S1981-81222008000100006

SILVA, R. A. da. Entre "artes" e "ciências": a noção de performance no campo das ciências sociais. Horizontes Antropológicos, v. 11, n. 24, p. 35-65, 2005. http://dx.doi.org/10.1590/S0104-71832005000200003

SILVA, R. A. da. Entre o espetáculo musical e a tradição ritual: restauraçóes da memória do Rei Galanga. CulturesKairós, v. 1, p. 1-12, 2016.

SILVA, R. A. da. Negros católicos ou catolicismo negro? Um estudo sobre a construçáo de identidade negra no Congado mineiro. Belo Horizonte: Nandyala, 2010.

SILVA, R. A. da. Performance televisiva e montagens congadeiras no sertáo das Gerais. Teoria \& Sociedade, v. 15, n. 1, p. 178-196, 2008.

SILVA, R. de C. O. da. Superar no Movimento: Etnografia das Performances de Pirráias em Recife e Mais Além. Tese (Doutorado em Antropologia Social) — Universidade Federal de Santa Catarina, Florianópolis, 2008.

SINGER, M. When a Great Tradition Modernizes. Chicago: University of Chicago Press, 1972.

STALLAERT, C.; SCHULER ZEA, E. Deslocamentos: estudos no duplo campo de tradução e antropologia. Cadernos de Tradução, v. 2, p. 11-18, 2012.

TAMASO, I. Performances patrimoniais em Goiás: sobre Santos, Santas e Cristos. In: KULEMEYER, J. A.; CAMPOS, Y. D. S. (orgs.). El lado perverso del patrimonio cultural. San Salvador de Jujuy: Editorial de la Universidad Nacional de Jujuy, 2017. p. 278-292.

TAMBIAH, S. J. Culture, Thought, and Social Action: an Anthropological Perspective. Cambridge: Harvard University Press, 1985.

TAMBIAH, S. J. Leveling Crowds: Ethnonationalist conflicts and collective violence in South Asia. Berkeley: University of California Press, 1996.

TAYLOR, D. O Arquivo e o Repertório: performance e memória cultural nas Américas. Trad. Eliana M. de L. Reis. Belo Horizonte: Editora da UFMG, 2013a.

TAYLOR, D. Traduzindo performance. In: DAWSEY, J. et al. (orgs.). Antropologia e Performance: ensaios NAPEDRA. São Paulo: Terceiro Nome, 2013b. p. 9-16.

TEIXEIRA, J. G. L. C. A sociologia dança: um experimento em samba de gafieira. In: PEREIRA, M. A. (org.). Performance e Educação: desterritorializaçōes pedagógicas. Santa Maria: Ed. da UFSM , 2013. p. 251-264. 
TEIXEIRA, J. G. L. C. Análise dramatúrgica e teoria sociológica. Revista Brasileira de Ciências Sociais, v. 13, n. 37, p. 89-100, 1998. http://dx.doi.org/10.1590/S0102-69091998000200005

TEIXEIRA, J. G. L. C. Os estudos da performance e as metodologias experimentais em sociologia da arte. Sociedade em Estudos, v. 4, n. 7, p. 147-156, 2006. http://dx.doi.org/10.1590/S1678-53202006000100004

TEIXEIRA, J. G. L. C. Performáticos, performance e sociedade. Brasília: Ed. da UnB, 1996.

TEIXEIRA, J. G. L. C.; GARCIA, M. V. C; GUSMÃO, R. (orgs.). Patrimônio imagerial, performance cultural e (re) tradicionalização. Brasília: ICS-UnB, 2004.

TEIXEIRA, J. G. L. C.; GUSMÃO, R. Performance, cultura e sociedade. Brasília: Ed. da UnB , 2000.

TEIXEIRA, J. G. L. C.; VIANNA, L. C. R. (orgs.). As Artes Populares no Brasil Central performance e patrimônio. Brasília: Idade da Pedra, 2012.

TURNER, V. Dewey, Dilthey e Drama: Um ensaio em Antropologia da Experiência (primeira parte). From Anthropology of Experience. Tradução de Herbert Rodrigues. Cadernos de Campo, v. 13, n. 13, p. 177-185, 2005a. https://doi.org/10.11606/issn.2316-9133.v13i13p177-185

TURNER, V. Do Ritual ao Teatro: a seriedade humana de brincar. Trad. Michele Markowitz e Juliana Monteiro. Rio de Janeiro: Ed. UFRJ, 2015.

TURNER, V. Floresta de símbolos: aspectos do ritual Ndembu. Rio de Janeiro: EdUFF, 2005b.

TURNER, V. From Ritual to Theatre. New York: PAJ Press, 1982.

TURNER, V. O Processo Ritual. Petrópolis: Vozes , 1974.

TURNER, V. The Anthropology of Performance. Nova York: P. A. J. Publications, 1988.

TURNER, V. Social Dramas and Stories about Them. In: MITCHELL, W. J. T. (Org.). On Narrative. Chicago: University of Chicago Press, 1981.

TURNER, V.; TURNER, E. Performing Ethnography. The Drama Review, v. 26, n. 2, p. 33-50, 1982.

VEDANA, V. Diálogos entre a imagem visual e a imagem sonora: a experiência de escritura do sonoro nos documentários etnográficos. Ciberlegenda, v. 1, p. 29-42, 2011.

VEDANA, V. Escutar no Som: gravação e edição de etnografias sonoras a partir de um paradigma ecológico. Ilha Revista de Antropologia, v. 20, n. 1, p. 117-144, 2018. https://doi.org/10.5007/2175-8034.2018v20n1p117

VEDANA, V. Territórios sonoros e ambiências: etnografia sonora e antropologia urbana. Iluminuras, v. 11, n. 25, p. 10, 2010. https://doi.org/10.22456/1984-1191.15537

VIEIRA, J. G. Festas e brincadeiras: a vida cerimonial dos potiguaras. Ariús: Revista de Ciências Humanas e Artes, v. 14 , n. $1 / 2$, p. $40-50,2008$.

WAUJA, A. et al. Serpentes da transformação: desenhos da Amazônia indígena. PROA: Revista de Antropologia e Arte, v. 1, n. 6, p. 196-214, 2016.

ZUMTHOR, P. A Letra e a Voz: a "literatura” medieval. São Paulo: Companhia das Letras, 1993.

ZUMTHOR, P. Introdução à Poesia Oral. Campinas: Hucitec, 1997.

ZUMTHOR, P. Performance, Recepção, Leitura. São Paulo: Educ, 2000. 


\title{
Para além da ciência e do anthropos: deslocamentos da antropologia da ciência e da tecnologia no Brasil
}

\author{
Fabiola Rohden ${ }^{\mathrm{I}}$ \\ Marko Monteiro ${ }^{\text {II }}$
}

\section{Introdução}

A antropologia da ciência e da tecnologia (ACT) experimentou notável crescimento nos anos entre 2010 e 2018 , apontando desafios empíricos e teóricos de grande impacto para a disciplina, os quais, como se argumenta a seguir, trazem perguntas para aqueles elementos mais básicos da disciplina Antropologia tal como a conhecemos. Talvez por isso mesmo a ACT se mostre um campo tão vibrante nos últimos anos. Entre tais desafios, destacamos aqui a questáo da ciência e a do anthropos (ou do humano de forma geral, mas especialmente no que se refere ao humano enquanto objeto de estudo da ciência), que na ACT acabam por se tornar objetos de crítica e de reflexão fundamentais.

No que tange à ciência, deve-se ressaltar que o pensamento científico não é objeto recente da reflexão das ciências sociais ou de linhagens antropológicas dessas ciências - desde pelo menos As formas elementares da vida religiosa (Durkheim, 1996) ou o clássico Bruxaria, oráculos e magia entre os Azande (Evans-Pritchard, 2004) que as distinçóes (por vezes difíceis de estabelecer) entre pensamento mágico e racional-cientifico são parte do pensamento sobre a sociedade. Desde sempre, portanto, a antropologia e as ciências sociais se propóem à questão da ciência e mesmo da tecnologia, se pensarmos toda a tradição antropológica que se debruçou sobre cultura material, artefatos técnicos e circuitos de objetos como o clássico Kula, descrito por Malinowski (1984).

Sendo a ciência e a técnica problematizadas desde sempre, qual é então a razão de tão grande interesse pela $\mathrm{ACT}$ recentemente? A nosso ver, para começar a responder a essa pergunta, precisamos retomar problemas clássicos da disciplina. Tanto no que se refere ao fazer científico quanto no que diz respeito ao estudo do humano enquanto objeto específico e distinto do pensamento, vemos que a produçáo atual vem produzindo deslocamentos cada vez mais importantes nesses pilares das ciências sociais no geral e da antropologia particularmente. Isso fica visível, argumentamos, por meio da análise

\footnotetext{
IPrograma de Pós-Graduação em Antropologia Social, Universidade Federal do Rio Grande do Sul - Porto Alegre (RS), Brasil. E-mail: fabiola.rohden@gmail.com

IIDepartamento de Política Científica e Tecnológica, Universidade Estadual de Campinas - Campinas (SP), Brasil. E-mail: carambol@unicamp.br
} 
dos temas enfrentados pelas pesquisadoras e pelos pesquisadores engajados com esse campo, ou mesmo de outros campos, mas em diálogo com os avanços em torno da ciência e da tecnologia.

Tais temas, explorados aqui, incluem os seguintes eixos temáticos, que serão analisados em mais detalhes ao longo do artigo:

- conceitos e métodos da ACT;

- biomedicina e saúde;

- gêneros, sexualidades e tecnociências;

- humanos e não humanos;

- antropologia das técnicas;

- questóes ambientais e desenvolvimento.

Essa tipologia não se pretende de forma alguma exaustiva ou final, mas serve aqui de meio para navegar a grande amplitude e diversidade de temas e abordagens que encontramos ao buscar recuperar a produção da ACT brasileira dos últimos oito anos. Dessa forma, procuramos contribuir não apenas com uma breve revisão desses trabalhos, mas com uma tentativa inicial de melhor conceituar o lugar da ACT na antropologia brasileira como um todo e seu papel de crescente destaque no panorama atual.

$\mathrm{O}$ vigor da produção da ACT recente é perceptível nos artigos, livros e coletâneas, bem como nas teses e dissertaçóes defendidas e nos eventos científicos. Além disso, consolidam-se linhas, grupos de pesquisa e redes, como a própria Rede de Antropologia da Ciência e da Tecnologia (ReACT), que tem tido papel importante no crescimento dessa área de investigaçóes. Em análises atuais do campo antropológico no Brasil, a ACT surge como uma das novidades do período atual (Simóes, 2018), contudo não se trata de um campo novo, embora frequentemente receba o título de emergente. Como explicam Claudia Fonseca e Guilherme Sá (2011, p. 7): “Talvez porque as várias áreas e subáreas dis- ciplinares não se definem de forma tão nítida como antigamente e, assim, ostentam uma diversificação contínua e (para alguns observadores) inquietante".

É preciso dizer, em primeiro lugar, que esse campo tem suas raízes, e mesmo seus pertencimentos paralelos contemporaneamente, em vários outros campos da antropologia. Alguns desses outros subcampos da antropologia poderíamos chamar de mais tradicionais, como corpo e saúde, gênero, religião, etnologia, técnicas. Outros podem ser considerados mais recentes, como estudos de cibercultura, relaçôes multiespecíficas, discussôes sobre desenvolvimento e questôes ambientais contemporâneas, além da investigação antropológica sobre a própria ciência moderna (Latour, 1994) e das recentes discussóes teóricas sobre perspectivismo e ontologia (Jensen e Rödje, 2010; De Castro, 2018). Partilha-se, portanto, de muitas das bases da fundamentação antropológica tanto no que se refere às perspectivas teóricas quanto às orientações metodológicas, mas este artigo busca desenhar os contornos, sempre provisórios e inacabados, da constituição desse campo particular.

Quanto às abordagens teórico-metodológicas, destaca-se a ideia da ciência e tecnologia como produto de complexas redes de associações e articulações heterogêneas (Callon, 1987), de modo que se torna inconcebível a manutenção de proposiçôes analíticas calcadas em distinçôes como natural e cultural ou material e produzido (Latour e Woolgar, 1997; Law, 2009). A inspiraçáo vem não só da própria teoria antropológica, como também dos estudos sociais da ciência e da tecnologia (Martin, 1998; Fischer, 2007) e da crítica feminista da ciência (Haraway, 1989). Nesse último caso, a influência dos estudos antropológicos de gênero e a necessidade de reconhecer a situacionalidade 
do conhecimento científico, bem como a problematizaçáo da ideia de natureza contida nos pressupostos biológicos em torno da produção da diferença sexual e racial, já há muito fomentavam a análise crítica.

Em linhas mais gerais, não se pode conceber a atual ACT sem relacioná-la com avanços recentes nas discussóes dos estudos sobre ciência e tecnologia, que incluem uma atenção etnográfica aos processos da produção da "ciência em açáo" (Latour, 2000); ao estudo de performaçóes da materialidade nas práticas (Mol, 2002); além de campos de investigaçáo próximos, como o da Teoria-Ator-Rede (TAR), cujos conceitos estão presentes em boa parte da discussão da ACT, como ator-rede, redes sociotécnicas, coletivos, associações e controvérsias sociotécnicas (Callon, 1987; Latour, 2000; Law, 2009). Temos ainda as discussóes atuais envolvendo redes e híbridos (Strathern, 2014), atores-materiais-semióticos (Haraway, 2004), coprodução (Jasanoff, 2004), ontologias múltiplas (Mol, 2002), materialismo relacional (Law e Mol, 2002), cosmopolítica (Stengers, 2018) e realismo agencial (Barad, 2003), que se tornam fundamentais para dar conta do que é um campo da ACT. Embora não seja possível aprofundar essas discussóes aqui, é preciso frisar que inspiram muitos dos trabalhos considerados.

$\mathrm{Na}$ esfera dos empreendimentos etnográf$\cos$, podemos dizer que duas dimensões, evidentemente articuladas, ganham destaque. A primeira é a que se refere aos estudos acerca da produção do conhecimento técnico-científico, com relevo para as etnografias de labora- tório, análises da constituição de saberes disciplinares, investigaçóes sobre o papel de novos artefatos tecnológicos na produção científca. A segunda diz respeito mais diretamente aos impactos e às articulaçóes das ciências nos usos cotidianos ou na vida concreta das pessoas, o que pode ser traduzido em muitos contextos etnográficos distintos, como as implicaçôes normativas em vários âmbitos, as políticas públicas e tecnologias de governo, as transformaçôes corporais via recursos biomédicos, as novas tecnologias digitais etc.

\section{Mapeando os desafios teóricos e empíricos da antropologia da ciência e da tecnologia}

Ao apresentarmos esse mapeamento, gostaríamos de ressaltar as dificuldades enfrentadas e os limites e as restriçóes do trabalho realizado. Em primeiro lugar, nota-se o problema da definição das fronteiras de um campo que é bastante transversal, como apontamos. Para além disso, em termos pragmáticos, temos a restrição do que é possível agregar no espaço de um artigo e, do ponto de vista operacional, as dificuldades em dar conta de um levantamento mais amplo das publicaçóes do campo. Diante disso, considerando o período ente 2010 e 2018 , optamos pela combinação de diferentes estratégias: a análise de publicaçôes em periódicos científicos e coletâneas e o mapeamento das abordagens e temáticas presentes nos eventos científicos, além de informaçôes complementares relativas a disciplinas e trabalhos acadêmicos ${ }^{1}$.

1 Gostaríamos de mencionar que solicitamos a um conjunto de cerca de 40 pesquisadores/as do campo que nos enviassem sugestóes de referências bibliográficas ou de outra natureza. Aproveitamos para agradecer àqueles/as que se manifestaram e de alguma forma contribuíram para esse esforço de sistematizaçáo. De maneira especial, agradecemos a Jéssica Brandt, que colaborou na produção dos dados, e a Marina Nucci, o apoio. 
Uma das vertentes de investigação foram então os periódicos científicos classificados como Qualis A1 em antropologia publicados no Brasil, conforme divulgado pela Coordenação de Aperfeiçoamento de Pessoal de Nível Superior (CAPES) para o quadriênio 2013-2016. Essa é uma classificação restritiva, e importantes revistas foram deixadas de fora em função da falta de condiçóes de se fazer uma pesquisa mais abrangente. De qualquer forma, na medida em que optamos por considerar também as coletâneas e informaçóes relativas aos eventos, esperamos ter dado conta de produzir uma visão panorâmica em duas frentes:

- na publicação de investimentos de pesquisa possivelmente mais consolidados, divulgados nas revistas Qualis A1 e nas coletâneas de artigos;

- na produção emergente de conhecimento registrada nos anais dos congressos da área, apresentada mais brevemente ao final deste trabalho.

Buscamos, em suma, oferecer um panorama reflexivo sobre o que se produziu na ACT brasileira desde 2010, pensando nas temáticas e abordagens mais comuns e buscando explicitar para onde a atenção etnográfica desses trabalhos se voltou. Tentamos organizar esse mapeamento de acordo com o tipo de publicação e também em torno de temas específicos.

A seguir, explicitamos os procedimentos metodológicos utilizados nessa análise. $\mathrm{Na}$ sequência, apresentamos a produção publicada em periódicos e coletâneas e, por fim, acrescentamos informaçóes sobre eventos e campo acadêmico. Terminamos com algumas breves indicaçóes relativas às perspectivas que percebemos nesse cenário.

\section{Os periódicos}

Mediante um levantamento inicial para identificar quais dos periódicos Qualis A1 em antropologia continham artigos concernentes ao campo da ACT, a partir do ano de 2010, foi selecionado um conjunto mais restrito, composto de Mana, Horizontes Antropológicos, Vibrant, Revista Brasileira de Ciências Sociais, Revista Estudos Feministas e Cadernos Pagu. Essa lista não esgota os periódicos que publicaram artigos desse campo, mas auxilia-nos a perceber aquela produção mais visível, publicada em periódicos mais consolidados. Por meio de uma compilação de categorias fundamentadas no conhecimento prévio do campo e também no levantamento feito nos eventos científicos que, de alguma maneira, circunscrevem esse campo no Brasil, realizamos uma seleção dos artigos a serem considerados. A lista de categorias combina palavras-chave como ciência, tecnociência, tecnologia e sociotécnica juntamente com registros mais específicos, como técnica, (bio)medicalização, medicina, cibercultura, internet, gênero, animais, clima e ambiente.

Chegamos então a um corpus de 150 resumos. A etapa seguinte foi a leitura dos resumos e dos artigos para uma verificação mais qualificada acerca do seu possível enquadramento no campo da ACT. Utilizamos, então, como critérios a explicitação de uma perspectiva teórico-metodológica e bibliografia associadas à antropologia da ciência e aos estudos sociais da ciência e da tecnologia, conforme mencionado em linhas gerais na introdução deste artigo, e/ou consideração da produção de saberes e práticas científicas e tecnológicas enquanto objetos de investigação empírica. Isso nos levou à delicada tarefa de tentar distinguir campos 
absolutamente fronteiriços. Por exemplo, no universo dos estudos sobre (bio)medicina e saúde nos detivemos apenas nas pesquisas em que a produçáo do conhecimento biomédico enquanto artefato científico e tecnológico era tomada como central ${ }^{2}$.

É preciso também mencionar a presença da ACT nos dossiês temáticos apresentados em algumas revistas (especialmente Horizontes Antropológicos, Vibrant e Cadernos Pagu). Vale destacar, por exemplo, o número 35 (2011) da revista Horizontes Antropológicos, sobre "Ciência, poder e ética", organizado por Claudia Fonseca e Guilherme Sá, que sintetiza o desafio de produzir ACT a fim de "entender, entre outras coisas, como as pessoas forjam maneiras de agir, nomear e vir a conhecer um mundo em que os objetos 'híbridos' da ciência e da tecnologia ocupam uma centralidade cada vez maior" (Fonseca e Sá, 2011, p. 7). Esse volume contou com colaboraçóes internacionais, como de Donna Haraway (2011), e trouxe artigos versando sobre temas como interação humanos-animais, tecnologias biomédicas de diagnóstico, ensaios clínicos e saúde global, promoção de diagnósticos e medicamentos, hormônios, ancestralidade genética, além de discussôes teóricas.

Outros dossiês dignos de menção são o da revista Vibrant de 2012, "Anthropology, cooperation and development" (volume9, número 1), que ajuda a ilustrar as áreas fronteiriças cuja interseção com a ACT as torna relevantes para pensar o campo no país. Com diversos artigos sobre desenvolvimento, em- preendimentos extrativos e conflitos em torno de recursos naturais, os artigos abordam uma área de relevância crescente na antropologia e onde as perspectivas da ACT têm bastante força. Temas como conflitos cosmológicos entre povos indígenas (Wright, Kapfhammer e Wiik, 2012) e projetos de desenvolvimento, ou as relações entre saberes locais e regimes globais de propriedade intelectual (Radomsky e Leal, 2012), passando pela mirada etnográfica acerca de cooperação técnica (Cesarino, 2012), ajudam a mostrar a riqueza de uma produção atual que vai muito além da vida de laboratório.

\section{As coletâneas}

Nossa revisão identificou 10 coletâneas de artigos, organizadas no período 2010$2018^{3}$, cobrindo áreas tão diversas quanto antropologia das técnicas (Sautchuk, 2017); perspectivas antropológicas sobre práticas de governo e identificação (Fonseca e Machado, 2015); etnografias da chamada cibercultura (Segata e Rifiotis, 2016); trabalhos oriundos de discussóes realizadas em evento da ReACT (Fonseca et al., 2016a); e, de maneira mais numerosa, pesquisas em torno das denominadas "tecnologias da vida", cujo foco são as ciências e tecnologias ligadas ao corpo, à saúde e à medicina, ainda que com interfaces com outros temas (Premebida, 2011; Fonseca, Rohden e Machado, 2012; Santos, Gibbon e Beltrão, 2012; Mccallum e Rohden, 2015; Fonseca et al., 2016b; Segata e Rifiotis, 2018).

2 Cabe considerar que algumas áreas de fronteira, como biomedicina e saúde, relaçóes humanos-animais, gênero e sexualidade, foram consideradas de forma particular em cada caso, tendo em vista a realização de mapeamentos específicos por outros/as colegas para esta publicação.

3 É importante mencionar que durante esse período também uma série de importantes livros autorais foi publicada. Mais uma vez, por falta de condiçóes de darmos conta dessa grande produção, optamos por nos deter nas coletâneas que, sendo trabalhos coletivos, permitiriam o acesso a um conjunto maior de autores/as e temáticas. 
No que se refere à discussão e retomada da visibilidade de uma antropologia das técnicas calcada em uma tradição francesa e preocupada náo com tecnociência no sentido mais restrito, porém com formas de fazer e relacionar-se com artefatos os mais diversos, em contextos no geral distantes de centros urbanos e laboratórios, destaca-se o trabalho produzido e organizado por Carlos Sautchuk (2010). Outro campo de discussão outrora relativamente afastado dos debates mais visíveis na $\mathrm{ACT}$, mas que ganha grande centralidade com Claudia Fonseca e outros/ as colaboradores/as (Fonseca e Machado, 2015; Fonseca et al., 2016b), são as tecnologias de governo. Perícias, bases de dados policiais, biobancos forenses, vigilância e privacidade, entre outros temas, compóem um campo riquíssimo de discussão que cresce de modo consistente. Também a noção de cibercultura (em um quadro mais geral no qual se discutem as "políticas etnográficas") vem sendo proposta em diversos trabalhos por Theophilos Rifiotis e Jean Segata, dando espaço para produçóes colaborativas focadas tanto no estudo dos processos sociais mediados pelas tecnologias digitais quanto na interface com o campo das ciências da vida (Segata e Rifiotis, 2016; Segata, 2017).

Todavia, o campo de debates cuja relevância o torna incontornável são as ciências e tecnologias do corpo, medicina e governo da vida de modo geral. Desde a investigação da genômica e suas implicaçôes em pesquisas sobre saúde/doença e identidades, passando pela raça/etnia e pelas tecnologias de reprodução, além das formas de pensar o gênero e governar os corpos (particularmente os corpos femininos), chegando às formas de identificação, governo e vigilância de populaçôes (humanas e não humanas), medicina e definiçóes de vida e morte, os trabalhos agrupa- dos nessa temática vêm tendo impacto estruturante em como avança e se desenvolve a ACT no Brasil e no mundo (Rohden, 2012). Com linhagem feminista ou calcada na antropologia do corpo e da saúde, ou mesmo naqueles trabalhos que dialogam com estudos de raça e Estado, a riqueza e variedade desses trabalhos demonstram como os problemas da produção e reconstrução dos corpos e da vida são centrais para qualquer compreensão da ACT.

\section{Eixos temáticos em destaque}

\section{Conceitos e métodos da antropologia da ciência e da tecnologia}

Um dos temas que emergem da análise das revistas são as discussóes sobre o que são os métodos e conceitos centrais de uma ACT. Com o crescimento da ACT, muitos trabalhos começam a tratar de temas e conceitos que cada vez mais são considerados como um subcampo de grande relevância. Além dos artigos de apresentação dos dossiês, que trazem esforços de síntese e análise crítica das perspectivas teórico-conceituais em uso (Fonseca e Sá, 2011; Rohden, Russo e Roca, 2017), temos um conjunto de trabalhos que também investem nessa direção. Os artigos desta seção não oferecem uma visão acabada do que é a ACT, mas cabe mencioná-los pela tentativa que fazem de organizar um conjunto de perguntas específico.

Uma questão sempre presente nas discussões sobre ACT é o papel da etnografia. O método, táo definidor de um campo disciplinar próprio da antropologia, pode em um primeiro momento parecer uma base para se delimitar a ACT: quando antropólogos adotam seu método para investigar a tecnociência, estão então criando e dando forma 
a um novo tipo de antropologia (Latour e Woolgar, 1997), ao mesmo tempo em que oferecem visões renovadas sobre o fazer científico (Knorr-Cetina, 1983) e o "laboratório" (Knorr-Cetina, 1992). Em sua revisão acerca das abordagens etnográficas sobre ciência e tecnologia, Monteiro (2012) faz uma tentativa nesse sentido, traçando uma linhagem para a ACT que passa pelos estudos feministas da tecnociência, os chamados "estudos de laboratório" e os estudos sociais da ciência e da tecnologia (ESCT). Para o autor, mais do que o foco temático na tecnociência em si (um olhar para o "centro"), o que torna a ACT específica é o seu foco na tecnociência como "conquista prática". A abordagem das práticas e o questionamento de distinçóes ontológicas caras ao pensamento científico, como "natureza/cultura", abririam novos caminhos na interface entre a antropologia e os ESCT.

Ainda sobre a etnografia, Rifiotis (2016) mobiliza uma categoria importante na ACT brasileira de meados dos anos 2010 , a de cibercultura. Seu texto faz um mapeamento de como o autor percebe o desenvolvimento da etnografia do ciberespaço no Brasil desde os anos 1990. Segundo ele, se nos anos 1990 aconteciam certo deslumbramento com a mediação técnica e um investimento na distinção onlineloffline, na década seguinte se percebeu uma influência maior da noção de uma virada sociotécnica com influências de Latour e da TAR. O fazer etnográfico, por meio da mediação técnica ou em espaços "virtuais", perdeu espaço para debates em torno de redes heterogêneas e em função da incorporação de outras perspectivas mesmo nas investigaçóes sobre a cibercultura.
O questionamento de dualidades (onlineloff-line; natureza/cultura; moderno/ não moderno) é outra das marcas possíveis que identificam a ACT e ajudam a explicar tanto o interesse crescente nos seus debates e eventos quanto a riqueza da sua produção teórica. $\mathrm{O}$ dualismo natureza/cultura, assunto mais do que clássico na antropologia, é um dos temas mais abordados, direta ou indiretamente, pela ACT atual, ajudando a descentrar tanto o campo de questóes sobre ciência e tecnologia quanto a própria disciplina como um todo, que passa a cada vez mais fazer esse questionamento sobre suas próprias bases teórico-metodológicas (Latour, 2004; 2011).

$\mathrm{O}$ debate intenso em torno da TAR figura aqui como central, sendo fundamental para qualquer recuperação da ACT no Brasil. É difícil superestimar o impacto que as discussóes acerca de modernidade, agência e não humanos teve sobre os trabalhos hoje categorizados como ACT, o que talvez merecesse um debate à parte. Isso levou a certa predominância dessa visão nos trabalhos que encontramos nessa revisão, o que poderia sugerir homogeneidade teórica na ACT tal qual se configurou nesse período. Ainda que existam outras referências, há que se notar essa grande prevalência de autores/as associados/as à TAR e à chamada pós-TAR (ou pós-actor-network theory - pós-ANT) nas produçôes recentes da disciplina, algo que mereceria problematização mais aprofundada em trabalhos posteriores.

A interface entre etnografias da ciência e tecnologia e a TAR marca muitos trabalhos, de forma mais ou menos explícita. Um artigo que aborda uma tecnologia por

4 Essa categoria não se consolida dessa forma em trabalhos mais atuais, dando espaço cada vez mais à categoria mais geral de antropologia digital. 
esse ponto de vista é o artigo de Spiess e Mattedi (2010) que tenta etnografar a produção de uma rede heterogênea em torno de um processador de texto. Os autores propóem a etnografia de um softwa$r e$, argumentando que há poucos estudos como esse em comparação aos de hardware. $\mathrm{O}$ artigo propóe que o software pode ser pensado como rede heterogênea, afirmando que um software é mais do que um conjunto de comandos que fazem funcionar equipamentos eletrônicos.

O tema é também abordado por João Paulo Bachur (2016), ao discutir a ideia de uma antropologia simétrica e seus limites (Bachur, 2016). Para o autor, Latour não leva sua análise às últimas consequências, ao não radicalizar na sua proposta de superar a distinção entre palavras e coisas (Foucault, 1999) na discussão da realidade. Bachur (2016) aborda a ideia, para ele importante, do discurso como prática material, mas que em Latour não chegaria a se concretizar totalmente. Essa crítica vai na direção oposta às críticas usuais ao autor, que é muito questionado ao sugerir a agência dos não humanos como parte da sua explicação sociológica (que implica um questionamento radical às ciências sociais tradicionais). A presença dos não humanos é outra marca da produção da ACT atual, como se verá, ajudando a distingui-la interna ou externamente ante outros campos como antropologia interespecífica e até mesmo a arqueologia (Neumann, 2008).

\section{Biomedicina e saúde}

No cenário dos estudos sobre as ciências da vida de modo geral e envolvendo especialmente a produção do conhecimento (bio)médico e os processos referentes aos marcadores de saúde e doença, a ACT é profundamente marcada por suas raízes nos campos da antropologia da saúde e doença (e também de gênero e sexualidade) desenvolvidos no Brasil $^{5}$, reforçando a ideia da ACT como campo fronteiriço. Destacadamente no que diz respeito aos estudos que abrangem a produção do conhecimento científico (bio)médico, os trabalhos produzidos e orientados por Luiz Fernando Dias Duarte são uma referência fundamental. No que concerne aos investimentos mais recentes, podemos citar suas análises acerca da epigenética (em colaboração com Gláucia Silva) e da neurociência.

No artigo "Epigênese e epigenética: as muitas vidas do vitalismo ocidental", Silva e Duarte (2016) demonstram como tensóes entre perspectivas vitalistas e mecanicistas (ou entre epigenistas e pré-formacionistas) têm sido vetor estruturante nas ciências da vida, ao mesmo tempo em que os termos desse debate vão sendo renovados permanentemente, em razão de marcantes alteraçôes de sentido. Essas tensóes têm consequências também nas próprias ciências humanas, na medida em que reacendem a perene discussão acerca da relação entre natureza e cultura. Já em seu recente artigo sobre a relação entre ciências humanas e neurociências, Duarte

5 Sobre os estudos antropológicos sobre corpo e doença em relação aos saberes biológicos no campo científico da saúde, o artigo de Cynthia Sarti (2010) intitulado "Corpo e doença no trânsito de saberes" é uma referência importante. No que diz respeito ao eixo de reflexão e investigaçóes acerca de como a ciência constrói seu conhecimento (ou cultura epistêmica) tomando como foco o aprendizado em medicina, consultar o trabalho de Bonet (2015). Ainda nas fronteiras entre esses vários campos, podemos citar trabalhos como os de Pereira (2012a, 2012b) que discutem, considerando os marcos de uma antropologia simétrica e a grande questão da traduçấo, a relação entre conhecimentos indígenas e biomédicos. 
(2018) retoma essa discussão pelo viés da análise de proposiçóes de diversos "naturalismos”. Por meio da descrição de exposições realizadas no Museu do Amanhã (Rio de Janeiro), chama a atenção para "o cerebralismo radical das referências à condição humana e o caráter aleatório, assistemático e superficial da tentativa de demonstração da variedade e complexidade da experiência sociocultural da humanidade" (Duarte, 2018, p. 2). Nessa direção, o autor ressalta a importância dos estudos sociais sobre a ciência, especialmente desde uma perspectiva historicizante, na problematização da sacralidade atribuída ao conhecimento científico biomédico.

$\mathrm{Na}$ intenção de ilustrar a porosidade entre estudos sobre biomedicina e a ACT, podemos citar o dossiê "Saúde/doença, biossocialidades e cultura", organizado por Carlos G. Valle e Sahra Gibbon na revista Vibrant (2015). Embora trate de uma série de temas em saúde/doença, aos quais não podemos nos deter aqui, cabe registrar a confluência de trabalhos que de forma bastante diversa se centram na análise da produção e nos impactos do conhecimento científico.

Jean Segata (2015), por exemplo, por meio de uma etnografia em pet shops e clínicas veterinárias no Sul do Brasil, aborda as transformaçôes recentes nas práticas médico-veterinárias, destacando o surgimento de diagnósticos psiquiátricos em animais de estimação. As relaçôes humano-animal, bem como as formas de produção de conhecimento e transformaçóes nas biossocialidades e natureza, são consideradas pelo autor. Fabíola Rohden (2015), mediante uma análise antropológica das redes sociotécnicas, investiga a medicalização da sexualidade masculina no Brasil centrada na criação de uma nova farmacologia do sexo na passagem para o século XXI, com foco na disfunção erétil e na chamada andropausa. Naara Luna (2015), incorporando abordagens relativas aos direitos humanos e às biossocialidades, estuda as disputas públicas e a presença do discurso dos direitos humanos nos debates sobre o aborto e a pesquisa com células-tronco embrionárias. Já Juliana Macedo (2015) pesquisa as tensóes entre os campos médico e jurídico em torno das concepçóes de risco acionadas nas decisóes judiciais relativas à autorização do aborto de fetos com anomalias fetais incompatíveis com a vida.

Um assunto que vem sendo cada vez mais alvo de investigaçóes diz respeito à genética, em várias práticas possíveis. $\mathrm{O}$ artigo de Waleska Aureliano (2015) é um valioso exemplo de investigaçóes que alcançam as experiências concretas das pessoas na lida com o conhecimento biomédico "inovador" e suas consequências práticas no que concerne a diagnósticos, tratamentos e conformação de sociabilidades e expectativas de futuro. A autora analisa os significados que a noção de herança genética adquire para famílias cariocas afetadas por uma doença rara e hereditária, considerando como essas famílias lidavam com a doença antes e depois do conhecimento acerca dos riscos apresentados nas explicaçóes biomédicas.

Mobilizando um referencial teórico caro à antropologia e aos estudos sociais da ciência e tecnologia, Débora Allebrandt (2015) traz como tema mais geral a importância que o genoma e o próprio laboratório como ambiente capaz de produzi-lo ganham nas últimas décadas. De forma específica, problematiza como ciência e noçóes de herança e transmissão, além de um fascínio pelas raízes biogenéticas, fazem parte da busca das origens de pessoas adotadas no Brasil. Seus dados etnográficos permitem avançar na compreensão de como os conhecimentos 
científicos influenciam as concepções sobre família e parentesco.

O dossiê também conta com um artigo de Claudia Fonseca (2015) inspirado, segundo a autora, tanto nos estudos da ciência quanto na antropologia do parentesco. Com base no estudo do movimento político por reparaçáo encabeçado por filhos de pessoas compulsoriamente internadas por causa da hanseníase, Fonseca (2015) analisa como estruturas coletivas mediadas por diferentes tecnologias produzem formas de socialidade específicas. Para tanto, examina o que chama de "três tecnologias interconectadas" utilizadas pelos atores na configuração dessas conexôes familiares: narrativas orais, documentos escritos e o teste do ácido desoxirribonucleico (DNA).

A conexáo entre conhecimento científico, família e parentesco e direitos vai ser uma marca forte no trabalho de Fonseca também em outras publicaçóes. No artigo "Deslocando o gene: o DNA entre outras tecnologias de identificação familiar", publicado na revista Mana (Fonseca, 2016), o foco volta a ser o uso do teste de DNA em investigaçóes judiciais de paternidade, estudado pela autora desde o início dos anos 2000. Agora, no enquadramento de uma antropologia da ciência e na incorporação da perspectiva latouriana da TAR, propóe-se a problematizar a hipótese de uma "genetizaçáo" da vida social mostrando as complexidades envolvidas nas experiências cotidianas de uso das tecnologias.

Podemos sugerir que essa linha de reflexão, bem como a centralidade das etnografias, exemplarmente presentes no trabalho de Fonseca $(2015,2016)$, caracteriza boa parte das pesquisas feitas no campo da ACT no Brasil, especialmente no que se refere aos estudos envolvendo o campo das ciências $d a$ vida e seus impactos na vida das pessoas. Trata-se de uma apropriação crítica das inspiraçôes teórico-metodológicas da TAR, da ênfase nas associaçóes heterogêneas, dos coletivos, da ideia de coprodução, para citar apenas alguns marcos, profundamente subordinada à investigaçáo das experiências cotidianas (Rohden, 2012). Nessa direção, como bem mostra Fonseca (2016), é necessário trabalhar com uma noção ampliada de tecnologias e conhecimentos na medida em que, nas práticas concretas, diversas tecnociências envolvendo o campo biomédico ou jurídico, por exemplo, se constituem mutuamente.

As pesquisas envolvendo tecnologias ligadas à genômica, é válido lembrar, englobam outros campos de investigaçáo, para além de família e novas configuraçóes da doença. Tanto nesses temas citados quanto em outros que incluem desde processos de racialização e molecularização da saúde/ doença, passando por diferenças raciais e marcadores sociais da diferença (Fullwiley, 2007), além de uma variedade de dinâmicas "sociais" envolvendo os não humanos em escala molecular (Rheinberger, 2000; Rose, 2007), vemos temas caros e clássicos à antropologia sendo reconfigurados pela incorporação da tecnologia como uma preocupação analítica e empírica. A genética é um campo clássico de exploraçáo da ACT desde sempre, como mostram estudos clássicos sobre o DNA enquanto metáfora (Keller, 2009), ou a análise muito influente de Rabinow (1999) sobre biossocialidade. Nas pesquisas mais recentes, vemos um florescer pela óptica de uma diversidade crescente de perspectivas.

Um exemplo dessa diversidade são alguns estudos importantes sobre ancestralidade, genética e raça/etnia, como o de Gaspar Neto e Santos (2011). As tecnologias ligadas à genética molecular são um campo fértil de 
investigação na ACT há décadas, e sua relevância náo diminuiu no período recente. Pelo contrário, desdobram-se pesquisas sobre as diversas controvérsias em torno da racialização dos corpos em âmbito molecular, e reconstituem-se hierarquias e preconceitos em novos termos em torno da molecularizaçáo, como é debatido amplamente em anos recentes dentro e fora da antropologia (Keita et al., 2004; Fullwiley, 2007). O trabalho de Gaspar Neto e Santos (2011), que se insere em uma pesquisa maior envolvendo etnografias em três países da América Latina cujos resultados foram reunidos no livro Mestizo Genomics (Wade et al., 2014), merece ser apontado como um dos poucos compreensivos acerca dessa questáo do ponto de vista da ACT e dos ESCT.

Gaspar Neto e Santos (2011) fazem um estudo do material de divulgaçáo de testes genéticos de ancestralidade em três países: Estados Unidos, Inglaterra e Brasil. Em cada um deles, os significados e sentidos dessa tecnologia adquirem cores distintas. Os autores argumentam que os estudos de "biologização" evocados por Paul Rabinow (1999) e outros (Gibbon e Novas, 2007) na virada do século XX para o XXI passam a contar cada vez mais com exemplos etnográficos. Nos Estados Unidos, os testes permitem a reconexão dos negros norte-americanos com a ancestralidade africana, ao mesmo tempo fortalecendo laços com o continente e quebrando a categoria genérica de "africano-americano". O teste genético tem um caráter profundamente transformador da percepção de si das pessoas. $\mathrm{Na}$ Inglaterra, houve um movimento semelhante na publicidade: o estabelecimento de conexôes ancestrais com grupos étnico-raciais por meio de uma ancestralidade construída a posteriori com base em elementos moleculares. No Brasil, o foco encontrado pelo estudo foi concretizar as teorias de mistura genética tão influentes na antropologia e sociologia.

Ainda nos cenários dos estudos acerca das ciências da/na vida, outro eixo geral se refere a reflexóes concernentes à medicalização e à farmaceuticalização ${ }^{6}$ de condições humanas, pensadas no quadro de processos globais envolvendo redes variadas e complexas. Em dada direção, isso se traduz, por exemplo, na tentativa de entendimento da preeminência da lógica do aprimoramento individual (mediante recursos farmacológicos e cirúrgicos associados à otimização e ao desempenho), em contextos recentes, por vezes em conflito com a manutenção da saúde. Essa tensão tem requerido o aprofundamento de um debate teórico que problematize as novas formas de subjetivação centradas no investimento pessoal via transformaçóes corporais, nas quais os recursos biomédicos considerados inovadores se tornam centrais (Rohden, 2017). Particularmente, os estudos associados aos eixos de gênero e sexualidade têm caminhado nessa direção, como será explicitado mais adiante.

Em outra abordagem possível, os processos de farmaceuticalização são analisados tendo em vista a dinâmica de grandes intervençôes farmacêuticas pensadas à luz dos problemas envolvendo a saúde global. Nessa linha, João Biehl (2011) explora seus

6 Williams, Martin e Gabe (2011) ponderam que, enquanto a medicalização é a tradução de fatos não médicos em termos médicos, ampliando o campo de atuação da medicina, a farmaceuticalização se refere à "tradução ou transformação de condiçōes, recursos e capacidades humanas em oportunidade para intervenção farmacêutica" (Williams, Martin e Gabe, 2011, p. 711, tradução nossa). 
estudos etnográficos acerca da resposta terapêutica brasileira ao vírus da imunodeficiência humana/síndrome da imunodeficiência adquirida (HIV/AIDS) e suas repercussões nos âmbitos de governo, mercados, sistemas de saúde e vida pessoal, chamando a atenção para as singularidades dos contextos e das vidas concretas das pessoas.

\section{Gêneros, sexualidades e tecnociências}

A interface pujante entre o campo dos estudos em ciência e tecnologia e os estudos de gênero e sexualidade, como já mencionamos, está profundamente ancorada no projeto de crítica feminista da ciência que vem se constituindo de maneira sólida há bastante tempo (Bleier, 1984; Fausto-Sterling, 1985; Birke, 1986; Oudshoorn, 1994; Haraway, 1995, 2004). Esses estudos têm produzido uma análise crítica da produção científica moderna acerca das supostas bases naturais e imutáveis que determinariam sexo, gênero e sexualidade. De maneira especial, as ciências biomédicas têm sido profícuas em redesenhar variadas formas de "substancialização" da diferença, em contornos dualistas inspirados pela oposiçấo natureza/cultura (Rohden, 2008). No conjunto de artigos aqui analisados, essa interface revela-se na produçáo de dossiês em periódicos da área de antropologia, como o número 47 da Horizontes Antropológicos (2017), dedicada ao tema "Gênero e sexualidade, saberes e intervençóes", e mais particularmente na Revista Estudos Feministas e Cadernos Pagu, nas quais o cruzamento entre gênero e ciência tem ocupado espaço importante.

No caso da Cadernos Pagu, o dossiê publicado nos números 48 (2016) e 49 (2017) intitulado "Gênero em ciências: histórias e políticas no contexto ibero-americano" tem relevância peculiar, na medida em que se faz uma discussão específica acerca da consolidação desse campo ao longo dos últimos 10 anos. As organizadoras enfatizam a diversidade de temas e abordagens em curso, como a participação de mulheres nas ciências, gênero no discurso médico e na produção e promoção de medicamentos. Quanto às perspectivas adotadas, ressaltam a exigência de considerar como todas as ciências são necessariamente humanas e "as culturas científicas socialmente construídas, engendradas, localmente situadas, contingentes, com suas historicidades específicas" (Lopes e Sombrio, 2017, p. 1). Nota-se, nesses números, a predominância de análises provenientes de outros campos disciplinares que enfocam, sobretudo, a presença das mulheres e as diferenças de gênero na produção de conhecimento, programas e políticas científicas e em várias áreas tecnológicas. Essa linha de investimentos aparece também nos artigos que traçam panoramas acerca do campo de gênero, ciência e tecnologia no Brasil (Minella, 2013; Costa e Feltrin, 2016; Lima e Costa, 2016; Freitas e Luz, 2017). Contudo, como pretendemos ilustrar, não é particularmente nessa direção que se insere a produção mais singular $\mathrm{da}$ antropologia.

Gostaríamos de ressaltar o panorama analítico elaborado por Luzinete Minella na Cadernos Pagu (2013) a respeito da interseccionalidade, especialmente pensando no eixo de raça/etnia. A autora aponta que, no que se refere à manutençấo de assimetrias, os estudos têm salientado aspectos relacionados a gênero, geração e condição socioeconômica das mulheres, contudo verifica-se ausência do privilégio à dimensão de raça/etnia. É preciso mencionar que, no levantamento que realizamos, com poucas exceçóes, como no caso dos estudos sobre raça e genética, essa discussão ainda está pouco presente nos estudos da 
ACT, o que nos leva a destacar a importância de que seja cada vez mais incorporada a eles.

No que concerne a uma produção mais especificamente antropológica, nas interfaces entre gênero, ciência e tecnologia, observa-se um caráter particular. Trata-se da produção de uma abordagem que combina teoria antropológica, estudos feministas da ciência e estudos sociais da ciência e da tecnologia na análise etnográfica das chamadas ciências da vida por meio de suas interfaces com a dimensão do gênero e outros marcadores, especialmente a sexualidade. A área das biociências, de modo geral, encarnada em ramos como genética, medicina reprodutiva, medicina sexual, endocrinologia, neurociências, tem sido estudada tanto nas suas redes de produção quanto nos seus variados usos cotidianos nas vidas concretas das pessoas.

O dossiê publicado na Horizontes Antropológicos 47 (2017) traz um exemplo do conjunto de temáticas que têm caracterizado esse campo de estudos. As organizadoras enfocam nas conexóes entre os estudos de gênero e sexualidade e as interfaces entre ciências, tecnologias, sociedade e poder

tendo como foco as análises relativas às redes que envolvem desde a produção de conhecimentos até suas repercussões relacionadas a novas formas de entendimento do sujeito em diversos cenários contemporâneos, incluindo os recentes processos de (bio) medicalização em curso e o surgimento de distintas formas de (bio) sociabilidade e subjetividades (Rohden, Russo e Roca, 2017).
A "Apresentação" desse volume traz também uma proposta de síntese das abordagens teóricas que têm se destacado. $\mathrm{O}$ postulado do gênero como performado nas práticas, via inspiração em Judith Butler (1993), ganha aqui novos contornos, na medida em que é expandido para a produção e intervenções científicas. Ou seja, o gênero também se produz nas ciências, assim como as ciências coproduzem as normas e performances de gênero. Temos aí um caminho fecundo para muitas investigaçóes que, de modo especial, têm se dedicado não só à análise do conhecimento científico e seu caráter normativo, como também às suas interferências nas múltiplas práticas concretas das pessoas. No que diz respeito de forma singular às intervenções biomédicas, ganham relevo as proposiçôes teóricas que visam dar conta dos processos de materialização em cena e suas correlativas relacionalidades, como muitos trabalhos têm indicado (Rohden, Russo e Roca, 2017) 7 .

Por meio de investimentos etnográficos singulares e inovadores, as/os antropólogas/ os brasileiras/os têm se empenhado em uma incorporação crítica dessas inspirações teóricas e desenhado certos mapas do campo. Marina Nucci (2018), por exemplo, trabalha especificamente sobre a relação entre ciência, gênero e feminismo ao tomar como objeto de investigação o grupo de pesquisadoras da área de gênero e ciência conhecidas como "feministas biólogas" e a rede internacional interdisciplinar de "neurocientistas feministas” estabelecida em 2010 chamada Neuro-

7 Nessa linha podemos destacar as contribuiçóes de Donna Haraway (1995, 2004), Annemarie Mol (2002, 2013), Karen Barad (2003, 2007), Celia Roberts (2007), Myra Hird (2004, 2009), Amade M'Charek (2010), entre outras. 
Genderings $^{8}$. Nesse caso, o próprio grupo investigado incorpora as discussōes teóricas do campo de gênero e ciência, levando Nucci (2018) a ter de lidar com várias dimensões analíticas comprometidas com o debate em torno dos ideais de cientificidade e a crítica feminista.

No artigo "(Des)fazer corpo, (re)fazer teoria”, Paula S. Machado (2014) traça um balanço da produção acadêmica nas ciências humanas e sociais sobre intersexualidade e sua articulação com a produção latino-americana, no qual tem destaque a produção feminista ligada ao campo dos estudos da ciência. Particularmente, os investimentos da biomedicina em torno das origens da "diferença sexual" e de explicaçóes hormonais impactaram de modo contundente a percepção acerca da intersexualidade no mundo ocidental, em grande medida permeada por concepçóes patologizantes.

Essa atençáo acerca de como a produção biomédica tem sido insistente na delimitação da diferença entre os gêneros e nas prescriçóes sobre as sexualidades permitidas ou condenadas tem sido marca importante nessa linha da ACT. Além disso, as investigações em torno dos hormônios, e mais especialmente no que se refere à conformação de uma preeminência da lógica hormonal como metáfora de entendimento do humano (Oudshoorn, 1994; Roberts, 2007; Rohden, 2008), têm sido profícuas. O uso controverso de testosterona por mulheres cisgênero, de modo a não ultrapassar as barreiras que poderiam provocar algum tipo de "masculinização", mostra de forma contundente a preeminência de certos padróes de gênero e de sexualidade que regulam a utilização de recursos biomédicos e as novas formas de administração bioquímica de si (Rohden, 2017).

De forma particular, a insistência nessa lógica hormonal da diferença, bem como as percepçóes concretas acionadas pelas pessoas quanto à potência dos hormônios, para além do entendimento de contextos específicos, têm permitido um adensamento das discussões teóricas dos limites como natural/artificial ou biológico/social. Exemplo disso é a discussão feita no artigo "Os hormônios te salvam de tudo" (Rohden, 2018), em que se argumenta o caráter complexo e contínuo da produção de subjetividades e transformaçóes corporais com o uso de recursos biomédicos, nas quais as dimensões discursivas e materiais não podem ser pensadas separadamente. Por meio da noção de "realismo agencial" de Karen Barad (2003, 2007), é feita uma análise do próprio dispositivo do implante hormonal, considerando as interferências produzidas pelo tipo de materialidade empregada pelo artefato e pelos hormônios. A aparente invisibilidade do implante articula-se à ideia de que não se trata de um "remédio" associado a outras formas, como comprimidos orais ou injeçôes.

Essa vertente analítica é bem explorada no artigo de Daniela Manica e Marina Nucci (2017) que analisa o desenvolvimento $\mathrm{e}$ as controvérsias relativos aos implantes subcutâneos de hormônios no Brasil. Um dos pontos interessantes do trabalho é a explicitação da associação comumente feita entre esses implantes (cápsulas de silicone microporoso), acessíveis no mercado há algum tempo, e os chamados chips (placas de silício e titânio ativáveis por redes de dados digitais), que ainda não estão disponíveis. As autoras ressaltam, entre outros aspectos, as

8 Mais informaçôes disponíveis em: <https://neurogenderings.wordpress.com/>. Acesso em: 3 maio 2019. 
conexôes com o mercado da medicalização ligado a processos vitais, especialmente envolvendo gênero, sexualidade e reprodução. Sobretudo no que se refere à associação entre contracepção e tecnociência, os estudos de Manica (2011) têm explorado as complexidades da produçáo dos contraceptivos hormonais, também nas alteraçóes dos ciclos menstruais e proposição de supressão da menstruação, e sua pertinência para questionar as fronteiras entre natureza e cultura.

De certa forma, esses trabalhos têm explorado as conexóes entre a produção científica biomédica, diferentes níveis de circulaçáo de conhecimentos associados a essa produção (do mais acadêmico ao mais popular) e o estabelecimento de novos mercados e práticas de consumo, demarcados por normas de gênero, que se expressam também em corpos, comportamentos e modos de subjetivaçáo. Chama a atenção, particularmente, a inspiração no trabalho de Ludwig Fleck (2010) não só para pensar o enraizamento social do conhecimento científico e biomédico e sua articulação com as protoideias pré-científicas, como também para avaliar os trânsitos implicados nas passagens entre conhecimentos esotéricos (especializados e acadêmicos) e exotéricos (que dizem respeito a circuitos mais amplos de divulgação).

O caso das chamadas drogas prossexuais (medicamentos destinados a tratar problemas como disfunção erétil ou falta de desejo sexual), por exemplo, tem sido valioso para compreender a conformaçáo de certas masculinidades contemporâneas. No artigo "Homem com 'H': ideais de masculinidade (re)construídos no marketing farmacêutico", Faro et al. (2013) recorrem ao material publicitário relativo às drogas para tratamento da "disfunção erétil" para analisar os discursos do marketing farmacêutico. Concluem que as propagandas voltadas aos médicos veiculam novas concepçóes relacionadas a categorias nosológicas ao mesmo tempo em que reforçam noçôes tradicionais de gênero/ sexualidade. Segundo as autoras, "o 'novo homem' biomedicalizado, sexualmente potente, confiante e rígido é um produto híbrido corpo-tecnologia, na fronteira esfumaçada entre natureza e cultura" (Faro et al., 2013, p. 287).

Esse argumento coaduna-se com as investigaçóes feitas por Fabíola Rohden (2011, 2015) acerca da criação de uma nova farmacologia do sexo na passagem para o século XXI, com foco na disfunção erétil e na chamada andropausa, ou distúrbio androgênico do envelhecimento masculino. Mediante a análise da produção científica e da trajetória da construção dessas condiçôes como fenômenos de interesse público e mesmo de sua aceitação em associaçôes médicas e instâncias governamentais, aponta o surgimento de um processo inédito de medicalizaçấo do homem e da sexualidade masculina que nos anos recentes tem se apoiado na promoção do hormônio testosterona.

O trabalho de Faro e Russo (2017) segue em uma perspectiva paralela, ao focalizar a articulação entre pesquisa biomédica e indústria farmacêutica, por meio da análise de como o medicamento Intrinsa (um adesivo de testosterona destinado a aumentar o desejo sexual em mulheres) é apresentado em periódicos biomédicos. As autoras revelam as estratégias adotadas nos ensaios clínicos que permitiram a expansão do mercado potencial para o remédio, na medida em que a testosterona passou a ser associada também a tratamentos antienvelhecimento e à promoçấo do "bem-estar". Já o foco de Lucas Tramontano (2017) recai sobre como são apresentados os chamados hormônios sexuais 
em manuais de ciências básicas adotados no ensino de graduação em saúde no Brasil. De acordo com o autor, permanece "uma concepção dos hormônios sexuais como mensageiros químicos do gênero, num processo que confere características estereotípicas de masculinidade e feminilidade às próprias moléculas" (Tramontano, 2017, p. 163).

Esses processos de medicalização, farmaceuticalização e mesmo molecularização do gênero e da sexualidade, tão presentes nos casos envolvendo a promoção e o uso de testosterona, também se traduzem na ascensão de outro hormônio, a ocitocina. Fabíola Rohden e Fernanda V. Alzuguir (2016) demonstram como a ocitocina é um novo artefato tecnológico, capaz de capitanear, ao mesmo tempo, as explicaçóes acerca das supostas diferenças biológicas entre os sexos e as expectativas de aprimoramento individual. O foco de investigação foi a divulgação de descobertas científicas em torno desse hormônio em diferentes veículos de comunicação no Brasil, nos quais é frequentemente apresentado como o "hormônio do amor", traduzindo uma nova imagem bioquímica das relaçóes afetivo-sexuais. Importa ainda que as matérias estudadas se destacam por seu caráter de orientação pessoal, conformando o que se pode chamar de um campo de "autoajuda científica", no qual ciência, jornalismo, divulgação e autoajuda se misturam em diferentes veículos de comunicação. Esse trabalho apoia-se nas críticas que Nelly Oudshoorn $(1994,2004)$ tem feito aos estudos sociais da ciência em função de sua dificuldade em incluir a dimensão de gênero. Inspirada na concepção de Butler (1993) do gênero como repetição ritualizada de convenções, Oudshoorn (2004) sinaliza que as tecnologias são fundamentais nos processos de estabilização e desestabilização das con- vençôes de gênero, criando novas performances ou reforçando as já existentes.

\section{Humanos e não humanos}

A ACT vem abrindo ricos diálogos com perspectivas que poderíamos chamar de póshumanistas, no sentido de abordagens que descentram o humano, o anthropos, do foco conceitual da disciplina. Tal movimento não é banal e envolve tanto as críticas teóricas apontadas pela ACT quanto as recentes discussóes sobre as relaçóes entre humanos e animais, tão importantes em debates como os mobilizados na etnologia, entre outros (Vander Velden, 2012). Esse descentramento do humano também não é novo e pode ser traçado de forma direta desde os debates etnográficos de Strathern (1988), por exemplo, ou da crítica feminista (Haraway, 1991), algo que não aprofundaremos aqui.

Nos trabalhos levantados para este artigo, vemos uma preocupação que vai desde a exploração etnográfica dos animais na prática científica até consideraçôes sobre o papel dos não humanos em fenômenos de escala maior, envolvendo o governo dos corpos e dos saberes. Em todos eles, vemos a centralidade analítica e heurística desse descentramento do humano, desbravando caminhos para perguntas fundamentais sobre dinâmicas contemporâneas e ainda pouco exploradas pela comunidade antropológica.

A insistente questáo da agência dos não humanos, tão trabalhada e debatida na TAR, ganha contornos diversificados nos trabalhos atuais. Iara Souza (2017a; 2017b), por exemplo, ajuda a renovar tanto as investigaçôes sobre laboratórios quanto as pesquisas a respeito das relaçóes com animais nos seus trabalhos a propósito de animais de laboratório. Ao perguntar-se no tocante aos afetos existentes entre cientistas humanos e 
camundongos usados em seus experimentos (Souza, 2017a), por exemplo, traz à tona seu papel de "trabalhadores da ciência", quando participam de forma útil aos humanos, bem como nos momentos em que seus comportamentos demonstram resistência às práticas de experimentação. A ideia de trazer a categoria afeto para estudos de laboratório renova a perspectiva que trata da prática científica como mais do que pura objetividade e também coloca foco analítico nos animais enquanto agentes cruciais dessas práticas.

Em outro trabalho, seu olhar etnográfico trata da produção da comensurabilidade entre corpos humanos e não humanos, movimento tão central para possibilitar as verdades ali produzidas (Souza, 2017b). Tal comensurabilidade, como mostra sua etnografia, depende das diversas relaçóes estabelecidas entre humanos e náo humanos ao longo dos processos laboratoriais, muitas vezes marcadas por tensóes e resistências. O mesmo tópico é tratado por Marcos Castro Carvalho (2016), cujo olhar etnográfico também se volta para animais envolvidos em pesquisas biomédicas. Para o autor, o inusitado e a "não cooperação" dos roedores é por vezes elemento central na produção de fatos científicos, ampliando o escopo da investigação antropológica nesse tema.

O papel dos não humanos na produção de conhecimento científico é tema bastante consolidado, desde pelo menos os trabalhos de Guilherme Sá com primatas. Sá (2010), em sua pesquisa sobre a relação entre biólogos e muriquis em uma reserva ecológica, mostra como as discussóes acerca de como se dão as relaçóes entre os primatas está profundamente implicada nas ideias e imagens que se fazem em torno das sociedades humanas. As disputas em torno do olhar científico e das pessoas que moram na região trazem à tona elementos que vão ainda além da ciência stricto sensu: definir se o muriqui é pacífico ou náo era importante tanto para a primatologia quanto para pensar a realidade dos humanos naquele local.

O mote explorado por Sá (2010) de que o governo dos primatas é importante para a compreensáo do governo dos humanos é retomado por Jean Segata (2017) no seu estudo sobre o Aedes aegypti. Nesse artigo, parte de um dossiê maior a respeito de estudos animais, o autor conjuga diversos interesses: pensar o governo dos corpos e vidas humanos por intermédio de infraestruturas de monitoramento, governo dos animais e estratégias de controle do mosquito. Segata (2017) aqui retoma uma definição de cibercultura já citada, conceito que busca recolocar a ideia de cultura com base nas interfaces tecnológicas do presente, com foco especial em tecnologias digitais. $\mathrm{O}$ monitoramento tecnológico e as estratégias de controle do mosquito são analisados com cuidado etnográfico, mostrando como esses mapas e estratégias de governo intersectam mapas morais e relaçóes sociais de violência, dinâmicas urbanas ligadas à desigualdade e falta de acesso a infraestruturas básicas e dialogam com elas.

\section{Antropologia das técnicas}

Entre os temas clássicos da disciplina que dialogam diretamente com a ACT, talvez o que mais prontamente converse com esse campo seja o da antropologia das técnicas, objeto de revisão já realizada em momento anterior (Sautchuk, 2010). Sem pretender recuperar as origens dessa tradição, nem aprofundar demasiadamente esse tema, já alvo de revisões mais densas, merecem, no entanto, menção aqueles trabalhos que, aparecendo nesse levantamento mais recente, colocam em 
discussão conceitos e descriçôes etnográficos a respeito de técnicas, e náo necessariamente a tecnociência, muitas vezes associada ao campo da ACT propriamente dito.

Não é adequado, pensamos, reforçar esse contraste ou investir nele, como se tecnologia associada à ciência moderna ou ao capitalismo global fosse menos técnica, ou como se técnicas de pesca de ribeirinhos na Amazônia fossem menos complexas ou mais conectadas com saberes locais do que instrumentação de laboratório. Pelo contrário, trata-se de um campo de discussão essencialmente interligado. Como afirma Mura, em sua discussão etnográfica sobre o guarani-kaiowá do Mato Grosso do Sul (Mura, 2011, p. 98):

Em primeiro lugar, eu percebia que era relevante definir as relaçóes técnicas mais a partir das lógicas de uso do que daquelas de produção. Eram as necessidades de uso que regulavam e definiam se era melhor produzir ou adquirir um objeto, bem como definir sua distribuição e transformação. Em segundo lugar, seguindo a própria ontologia nativa, fui levado a considerar irrelevante a distinçáo entre "natural" e "cultural" nas concatenaçóes entre elementos do cosmo. Fatores de ordem política, mágica e simbólica podiam concatenar-se sem problemas com elementos químicos e físicos, numa lógica processual. Por sua vez, essa superação metodológica da contraposição entre natureza e cultura me levou a questionar a visão sistêmica que centrava parte significativa de sua epistemologia em torno dessa dicotomia, definindo primeiro o presumido sistema social, cultural, simbólico, semântico, etc. para, em um segundo momento, relacioná-lo, como uma totalidade, à realidade sensível do universo, e assim ordená-lo, conotá-lo, significá-lo, etc.
É importante dizer, no entanto, que o termo antropologia da técnica evoca tradiçôes teóricas e campos de investigação específicos, que convergem para perguntas, abordagens e descrições etnográficas com características próprias. Por conta disso, tratamos aqui desses trabalhos em seção separada, mas vale notar que, ainda que oriundos de tradiçóes distintas, esses trabalhos possuem em comum uma atençáo etnográfica atenta a modos de fazer e a artefatos em relaçáo com práticas, buscando análises que vão além de uma separação entre humano/não humano e muito adiante de encontrar os significados atribuídos a objetos. Assim como em toda a ACT, procura-se perceber processos dialógicos entre humanos e artefatos, a produção de corpos e artefatos por meio de técnicas específicas e uma apreensão da processualidade das técnicas com base na atenção para a prática.

Sautchuk e Sautchuk (2014), por exemplo, ao discutirem as particularidades de fazer etnografia sobre técnicas envolvendo tanto a pesca artesanal quanto a etnomusicologia, reafirmam a importância de acionar o "engajamento prático" como estratégia de pesquisa. Ou seja, apreender técnicas envolve também um engajamento particular do pesquisador com os processos e práticas de interesse, levando a dilemas metodológicos não tão diferentes daqueles de antropólogos interessados em etnografias virtuais, por exemplo. No caso de técnicas, aponta-se um dilema particular: como aproximar-se de fenômenos e práticas que se distanciam do verbal? Acostumados a engajamentos permeados de trocas verbais (como entrevistas), como estudamos o ato de pescar, por exemplo?

Uma estratégia mencionada é o uso de imagens. Ao discutir o valor que o uso de 
filmagens teve em seu trabalho etnográfico com técnicas de pesca, Sautchuk (2012) menciona a sua estratégia de mostrar as filmagens em público na Vila Sucuriju, no Amapá. Entre os moradores, havia emoção em comentar as técnicas videografadas e exibidas, discutir a relação dos pescadores com o peixe e comentar sobre a paisagem, especialmente para aqueles que não a conheciam. Segundo o autor, as imagens foram rapidamente incorporadas na economia simbólica local em torno da pesca, auxiliando assim seu próprio envolvimento etnográfico.

Além do engajamento teórico e metodológico com a antropologia visual e o cinema, pesquisadores também buscam inspiração na linguística e em estudos sobre cognição, como na investigação de Gabriel Barbosa e Rafael Devos (2017) acerca de técnicas de navegação. $\mathrm{O}$ engajamento prático com as técnicas aqui se remete ao caráter complexo da relação do humano com seu meio e das formas usadas para orientar objetos, como navios, no espaço. Trabalhos como tal mostram a riqueza dos potenciais diálogos dessa tradição com a ACT e com outras áreas pouco exploradas da antropologia.

\section{Antropologia, questôes ambientais e desenvolvimento}

Um conjunto dos mais vibrantes que se destacam nesse mapeamento feito aqui é a emergência com muita força de trabalhos que refletem sobre problemas ambientais e de desenvolvimento. Cabe dar ênfase especial a esse conjunto, pois ele representa um agregado novo e cada vez mais numeroso de investigaçóes cujo escopo combina ao mesmo tempo problemas clássicos e preo- cupaçôes novas da ACT e da própria antropologia. Ao mesmo tempo, por exemplo, em que se beneficia do descentramento do humano e da popularidade dos discursos em torno do Antropoceno (no sentido de uma provável nova era geológica em que o humano consiste em uma força de transformação do planeta, do clima e da geologia) (Crutzen, 2006; Palsson et al., 2013; Latour, 2014), esse conjunto de pesquisas considera problemas clássicos das ciências sociais brasileiras, como o desenvolvimento econômico e tecnológico.

Esse debate é feito com viés totalmente diferente, repensando a centralidade do econômico e seu privilégio epistêmico para falar do desenvolvimento, trazendo à tona problemas até então marginalizados ou simplesmente ignorados, como as zonas de conflito cosmológico e ontológico em jogo no avanço do desenvolvimento, como tem ocorrido no país. Além disso, esses trabalhos muitas vezes ampliam o escopo tradicional da ACT, por vezes demasiadamente associada ao estudo microscópico de práticas de laboratório ou interessada na produção do conhecimento e suas dinâmicas, para conjugar a produçáo da tecnociência e sua coproduçáo do mundo com todas as contradiçôes inerentes a isso, incluindo desigualdades, conflitos e hierarquias.

Essa atenção a temas em escala mais ampla do que o laboratório, que envolve também posiçôes inter e transdisciplinares, pode ser vista por exemplo no dossiê da revista Vibrant em seu volume 14 (2017), "Mining, violence and resistance". Na sombra das tragédias de Mariana e Brumadinho, vemos que o olhar antropológico para problemas de extração de recursos, conflitos ambientais e a produção do capitalismo e suas tecnociências associadas envolve temas 
clássicos e contemporâneos da disciplina, necessários para enfrentar questóes cada vez mais prementes, que colocam nossa existência no planeta em questão.

Zhouri (2017), por exemplo, na introdução desse dossiê, propóe questóes importantes para a antropologia da mineração que dialogam com a ACT na medida em que implicam questionar-se sobre grandes infraestruturas tecnológicas (de extração de recursos, por exemplo) e sua conexão com relações sociais de poder locais e globais, conflitos e disputas entre grupos. A autora indica também dilemas para a antropologia quando se insere nesses campos, que incluem, entre outros, a demanda por parte dos atores dessas arenas de conflito para que os/as antropólogos/as ajam como especialistas, consultores/as e mediadores/as. Tais demandas, ao mesmo tempo que ampliam o horizonte da prática antropológica nesses campos, multiplicam, segundo Zhouri (2017), os dilemas éticos, metodológicos e morais associados a esse tipo de pesquisa. De fato, tais dilemas são ainda um tópico incipiente na nossa reflexão e apontam caminhos produtivos em um período de multiplicação de desastres envolvendo práticas de extração de recursos.

Nessa direção, muitos elementos importantes desse conjunto de trabalhos ficam patentes: além daqueles já mencionados, o problema metodológico de como lidar com esse tipo de trabalho etnográfico vai forçar o/a antropólogo/a a questionar-se sobre seu possível distanciamento, dadas as pressões tanto para poder aproximar-se do objeto e para participar dos conflitos estudados enquanto um tipo de expertise engajada. O olhar sempre situado do/a antropólogo/a oferece um ponto de vista único e cada vez mais valorizado (e disputado, como fica claro no caso de Mariana, estudado diretamente por Zhouri).

Todavia, os problemas em torno da mineração no país não se limitam aos desastres em Minas Gerais e envolvem conflitos entre diferentes racionalidades, como no estudo de Raquel Rigotto (2017) sobre mineração de urânio no Ceará. Aqui fica clara a disputa entre dois tipos de percepção do território: uma vê a natureza como fonte de acúmulo, outra vê o território como fonte de memória. Para além disso, a autora analisa como a autoridade científica pode por vezes ser usada para legitimar práticas ambientalmente nocivas. A disputa de incertezas em controvérsias científicas frequentemente coloca moradores e locais em desvantagem em relação a técnicos e cientistas. Esse estudo enfatiza um problema analisado por vários trabalhos, uma questão que vai muito além dessa breve revisão: como pensar as epistemologias locais diante do avanço do desenvolvimento e dos grandes projetos extrativistas (Wright, Kapfhammer e Wiik, 2012)? A ACT vem dando uma bela contribuição a esse desafio, mas ele transcende a disciplina e requer muito mais esforços.

Outro tema importante a esse grupo de pesquisas é o conceito de desenvolvimento que aparece de diversas maneiras nos trabalhos aqui analisados. Leticia Cesarino (2012), por exemplo, em outro dossiê da Vibrant, intitulado "Anthropology, Cooperation and Development", faz um bom apanhado da chamada antropologia do desenvolvimento e trata do caso das então emergentes cooperaçóes técnicas que o Brasil tentava fazer com países da África (mostrando o quanto o contexto nacional e global mudou desde então). Seguir os fluxos de expertise e recursos entre países propóe dilemas ainda pouco explorados, impondo ao mesmo tempo uma volta a temas tra- 
dicionais ou mais comuns na disciplina, como relaçóes geopolíticas, mas pensando por um ponto de vista distinto de outras disciplinas, o papel do saber técnico nessas relaçôes e fluxos. Problemas perenes na antropologia, como a reflexividade que se impóe à produçáo do conhecimento, evocam tratamentos clássicos como o de David Mosse (2006, 2007): qual é o papel do antropólogo enquanto técnico e participante de cooperação? Onde estão ou devem estar nossas lealdades teóricas e práticas em campos em que essas lealdades entram em contradiçãa?

\section{Os problemas emergentes da antropologia da ciência e da tecnologia}

Neste tópico, deixamos o universo das publicaçóes para darmos alguma atenção ao que vem se apresentando de maneira crescente no plano da produção de trabalhos acadêmicos e nos eventos científicos.

Um levantamento no catálogo de teses e dissertaçôes da CAPES é revelador do significativo crescimento do campo desde 2010. A busca pela categoria antropologia da ciência, que abrange também antropologia da ciência e da tecnologia e antropologia da ciência e da técnica, seja na entrada por linhas de pesquisa (o que ocorre especificamente nos casos da Universidade Federal do Rio Grande do Sul - UFRGS e da Universidade de Brasília - UnB), seja por palavras-chave, mostra o total de 61 trabalhos. Destes, apenas sete foram defendidos entre 1998 e 2009, sendo a imensa maioria apresentada entre 2010 e 2018 . Sáo 19 teses de doutorado e 42 dissertaçóes de mestrado. Embora alguns programas multidisciplinares ou de áreas afins apareçam, 48 pesquisas foram conduzidas em programas de pós-graduação em antropologia social
(22), antropologia (21), ciências sociais/ antropologia (3) e sociologia e antropologia (2). Outro dado que se destaca é a forte presença de algumas instituiçôes, como a UnB (17 trabalhos), a UFRGS (15) e também a Universidade Federal de Minas Gerais (UFMG) (6), a Universidade de São Paulo (USP) (5) e a Universidade Federal do Rio de Janeiro (UFRJ) (5). A existência de grupos de pesquisa e pesquisadores/as bastante atuantes no campo vinculados a essas instituiçôes permite compreender esse quadro. No que se refere às temáticas, embora não haja condiçôes de tratar delas de modo detido neste artigo, é preciso dizer que são bastante variadas, indicando a mesma riqueza de abordagens e investimentos etnográficos que percebemos na análise dos temas nos eventos e nas publicaçốes da área.

Cabe acrescentar também que no início da última década foram criadas e institucionalizadas as disciplinas de Antropologia da Ciência e da Tecnologia nos cursos da área de ciências sociais e antropologia nas universidades brasileiras como UnB, UFRGS, USP, Universidade Federal de Santa Catarina (UFSC) e Universidade Estadual de Campinas (UNICAMP), em nível de graduação e pós-graduaçẫo, embora o tema já fosse alvo de discussão em outras propostas em diferentes cursos e instituiçôes. Uma análise dos programas de curso revela não só uma frequente atualização em relação ao campo internacional, como também a inclusão da produção nacional veiculada em livros, periódicos e trabalhos acadêmicos.

Em função desse já citado crescimento vigoroso, optamos por trazer um breve comentário acerca de como esse tema tem estado presente nos eventos cientificos. Têm destaque aqui as mesas-redondas, os grupos de trabalho e as conferências que ganharam 
cada vez mais espaço nas Reunióes Brasileiras de Antropologia (RBA), nos encontros da Associação Nacional de Pós-Graduação e Pesquisa em Ciências Sociais (ANPOCS), nas Reunióes de Antropologia do Mercosul (RAM), entre outros. Analisamos a presença do tema na $27^{\mathrm{a}}(2010), 2^{\mathrm{a}}(2012), 29^{\mathrm{a}}$ (2014), 30a (2016) e 31a (2018) RBA; entre o $34^{\mathrm{a}}(2010)$ e o $42^{\mathrm{a}}$ (2018) encontro da ANPOCS; e na $10^{a}(2013), 11^{\text {a }}$ (2015) e 12a (2017) RAM $^{9}$.

Para além disso, é na presente década que se consolidam as ReACT, que foram incluídas na análise, nas quais se concentram de forma mais importante os trabalhos desse campo e se podem perceber mais claramente seus movimentos. Consideramos a $3^{\mathrm{a}}$ (2011), a $4^{\mathrm{a}}$ (2013), a $5^{\mathrm{a}}$ (2015) e a 6a (2017) edição. Resultado da articulação entre vários grupos de pesquisa no campo da ACT, a ReACT tem como intuito promover um debate que discuta o potencial e as contribuições da antropologia na construção de perspectivas acerca das ciências/ conhecimentos/saberes, das tecnologias/ técnicas/inovações e das relações entre essas ciências e tecnologias e as formas de constituição da vida e do futuro que elas condicionam e que ajudam a coproduzir.

No total, para essa breve análise, foram considerados 20 eventos, tendo sido consultadas as documentaçóes referentes a 45 seminários temáticos, 30 grupos de trabalho e 32 mesas-redondas ${ }^{10}$. No que concerne às temáticas dos trabalhos apresentados, pudemos sistematizá-las de acordo com alguns grandes eixos e categorias-chave, conforme o que foi apresentado nos resumos. Elencamos esses temas de forma descritiva, sem o ordenamento por prioridade ou por importância relativa no campo.

Um dos eixos que articulam questóes mais gerais é o que aglutina discussóes referentes a multiplicidades ontológicas e diferentes modos de produzir conhecimentos/ saberes. Nesse tema, agrupamos trabalhos abordando as transversalidades e os embates entre ciências, os saberes tradicionais, a religião e a arte; xamanismo, espiritualidade e ciências; percepção ambiental e ontologias indígenas; saberes musicais; e inteligência artificial. Em outro eixo, pudemos ver a concentração de questóes ambientais, desenvolvimento e territórios. Aqui conjugamos trabalhos que abordam a produção de modos de monitoramento do território e do ambiente; conflitos ambientais, grandes empreendimentos de extração de recursos naturais e as disputas de expertises associadas aos problemas ambientais recentes; relaçôes entre populaçóes tradicionais (indígenas, quilombolas, ribeirinhos) e pesquisadores/ cientistas; processos e disputas de licenciamentos ambientais, conservação marinha e florestal; desastres ambientais e acidentes nucleares; agrobiodiversidade; práticas indígenas de manejo; uso de recursos hídricos; e agricultura e pecuária.

Já no tema politicas públicas e produção de conhecimentos, identificamos investigaçóes sobre as articulaçóes entre ciências e políticas de financiamento à pesquisa; circulação de conhecimento entre cientistas e gestores; políticas científicas; museus e institucionalização das ciências; infraestruturas para produção científica; políticas de inovação; novos ambientes da produção e uso do conhecimento; estratificação cientí-

9 Não foi possível acessar pela internet informaçóes a respeito da 9a RAM, realizada em 2011.

10 As referências aos anais consultados encontram-se na bibliografia. 
fica no Brasil; gênero nas instituiçôes científicas; avaliação de indicadores e periódicos científicos; e ensino de ciências nas escolas. $\mathrm{Na}$ interface com as políticas públicas, tem emergido um conjunto de trabalhos referentes ao tema dos direitos, tecnologias de governo e cidadanias, que incorpora discussóes relativas a biotecnologia na persecução criminal brasileira; tecnologias de identificação e reconhecimento; bancos de dados de perfis genéticos; tecnologias de vigilância; tecnologias biomédicas; produçáo de laudos; perícias; e serviços que atendem a populações específicas (como crianças e adolescentes em situação de rua).

Outro importante conjunto de investigaçóes centra-se no eixo corpo, saúde, biomedicina e tecnociências. Nesse caso, destacam-se os trabalhos sobre produção, usos e implicaçôes das ciências da vida; análises (históricas e contemporâneas) da construção do conhecimento em saúde, doenças e intervençôes biomédicas; estatuto dos medicamentos e farmaceuticalização de condiçôes de vida (transtornos de humor, déficit de atenção/hiperatividade, hormônios, drogas prossexuais, inibidores do apetite); biossocialidades; neurociências; neuroeconomia; medicina antienvelhecimento; bioarte; reprodução humana em laboratório; estatuto de embrióes e fetos; medicalização da reprodução; diagnóstico e aconselhamento genético; genética de populaçôes humanas; atuação dos profissionais de saúde; protocolos clínicos; regulamentação sanitária; relação entre profissionais e populações específicos; transplantes e artefatos biomédicos de assistência e monitoramento; tecnologias relativas a HIV/AIDS; e uso de classificaçôes racializantes.

Muitas vezes em articulação também com esse eixo, figuram os estudos em torno do eixo gênero, sexualidade e ciência. Aqui, têm relevância as discussóes tangentes a teorias de gênero e crítica feminista da ciência; conhecimento e práticas biomédicas relacionados a gênero e sexualidade (corporalidades, subjetividades e identidades de pessoas trans, intersex e cisgênero; padronização de corpos e identidades femininos e masculinos); práticas contraceptivas, biopolítica e controle da fertilidade; gênero e mercado; neurofeminismo; políticas públicas e legislação; uso de hormônios; diferenças cerebrais; e raça e gênero nas práticas biomédicas.

Cabe ainda fazer referência ao campo de estudos sobre as relaçóes multiespecificas, que têm aglutinado trabalhos acerca de animais de laboratório; animais humanizados; produção e consumo de produtos de origem animal; relação entre caçadores, fazendeiros e cientistas; manejo de espécies animais; doenças; e proteção animal. Também, apontam ao conjunto de investigaçôes relativas à antropologia digital/cibercultura, que têm agregado as discussóes a respeito de políticas etnográficas; interfaces com raça e gênero; intolerância e violência nas redes sociais; relacionalidades, parcerias amorosas e sexuais e aplicativos; redes de ação coletiva e processos identitários; internet em manifestaçôes públicas e atos políticos; produção de celebridades; produção de valor econômico; pornografia, lan houses populares; videovigilância e videovoyeurismo; idosos e tecnologia digital; internet e autorrepresentação indígena; e inclusão digital.

Por fim, é necessário mencionar a contínua presença dos estudos referentes a concepçóes e usos das técnicas. Nessa linha, destacam-se as discussóes no tocante às relaçóes pessoa-técnica-mundo em diversos contextos como pesca, construção civil, 
caça, extração da borracha, navegação; técnicas de plantio; práticas alimentares; uso de plantas medicinais; design; ferramentaria de santo, surfe; interação com animais; previsão do tempo; trabalhadores em mercados de rua; rendeiras, capoeiristas; e praticantes de musculação.

Como se pode perceber, há no campo mais geral da ACT que se manifesta nos eventos científicos grande variação temática e de perspectivas. Nesse agrupamento de eixos e subtemas não pretendemos ser exaustivos, já que seria inviável a compilação dos assuntos tratados em cada trabalho específico. Assim, essa descrição pareceu-nos ilustrativa da dinâmica atual desse campo. Ela permite, de alguma forma, uma visão geral dos interesses que têm mobilizado pesquisadores/as no campo da ACT hoje em dia e instiga a refletirmos sobre os cenários atuais e futuros.

\section{Considerações finais}

O que percebemos quando justapomos as leituras das publicaçóes é, em um plano, uma imensa variedade de objetos. Desde a análise da produção científica em laboratórios, passando por grandes projetos de desenvolvimento, tecnologias da vida etc., são muitos os focos que têm mobilizado pesquisadores/as de diferentes geraçóes, mas principalmente os/as mais jovens. Em outro plano, reconhecemos uma efervescência teórica pautada pela busca de novos horizontes ou pela retomada crítica de referências mais antigas que permitam entender os processos envolvendo a ciência e a tecnologia no mundo contemporâneo, em suas muitas complexidades. Além disso, o que notamos com nitidez é uma procura vigorosa por diálogos transversais, para além de circunscrições temáticas já há muito consolidadas. Talvez uma das grandes promessas do campo seja renovar a capacidade que temos de aprender com as diferenças. Nesse caso, tratamos das diferenças decorrentes da comparação etnográfica e de distintas posiçóes teórico-metodológicas que têm sido possíveis no encontro promovido pelos/as interessados/as em uma ACT.

Em termos mais gerais, se fosse possível destacar uma ideia central que parece permear, ao mesmo tempo, como esse campo tem se caracterizado, assim como promovido novos desafios, talvez seja o consistente e permanente problema da reflexividade antropológica e da situacionalidade do/a pesquisador/a cada vez mais associadas a questionamentos sobre a natureza ou o fim das intervençôes tecnocientíficas. Ao analisarmos as múltiplas interfaces entre ciências, tecnologias e sociedades, somos obrigados/as o tempo todo a repensarmos o próprio lugar das ciências, de modo geral, e da ciência antropológica, particularmente. É possível dizer que esse tipo de atenção singular aos lugares e às formas de produção de conhecimento e suas variadas possibilidades de materialização em políticas, artefatos, transformaçôes ambientais, corpos e subjetividades tem exigido uma reflexão constante acerca da produção de diferenças e desigualdades envolvidas nesses processos. A ACT tem caminhado na pretensão de dar conta da exposição dessas assimetrias (como as de gênero, raça/etnia, classe social, geração, geopolítica), mas ainda há muito o que fazer. A pergunta que permanece nesse horizonte, como inspiração para uma antropologia que se pretende engajada nos problemas contemporâneos, continua a ser em torno de para que e para quem uma ciência ou tecnologia é produzida. 


\section{Bibliografia}

ALLEBRANDT, D. La science de la parente: adoption, genetique et identite parmi les adoptes au Bresil. Vibrant: Virtual Brazilian Anthropology, v. 12, n. 1, p. 141-166, 2015. http://dx.doi.org/10.1590/1809$43412015 \mathrm{v} 12 \mathrm{n} 1 \mathrm{p} 141$

AURELIANO, W. D. A. Health and the Value of Inheritance: The meanings surrounding a rare genetic disease. Vibrant: Virtual Brazilian Anthropology, v. 12, n. 1, p. 109-140, 2015. http://dx.doi.org/10.1590/1809$43412015 \mathrm{v} 12 \mathrm{n} 1 \mathrm{p} 109$

BACHUR, J. P. Assimetrias da antropologia simétrica de Bruno Latour. Revista Brasileira de Ciências Sociais, v. 31, n. 92, p. 1-21, 2016. http://dx.doi.org/10.17666/319209/2016

BARAD, K. Meeting the Universe Halfway: Quantum Physics and the Entanglement of Matter and Meaning. Durham: Duke University Press, 2007.

BARAD, K. Posthumanist Performativity: Toward an Understanding of How Matter Comer to Matter. Signs, v. 28, n. 3, p. 801-831, 2003. http://dx.doi.org/10.1086/345321

BARBOSA, G. C.; DEVOS, R. Paralaxe e "marcação por terra": técnicas de navegação entre jangadeiros na Paraíba e no Rio Grande do Norte. Mana, v. 23, n. 3, p. 343-372, 2017. http://dx.doi.org/10.1590/1678$49442017 \mathrm{v} 23 \mathrm{n} 3 \mathrm{p} 343$

BIEHL, J. Antropologia no campo da saúde global. Horizontes Antropológicos, v. 17, n. 35, p. 227-256, 2011. http://dx.doi.org/10.1590/S0104-71832011000100009

BIRKE, L. Women, feminism and biology: the feminist challenge. Brighton: Harvester, 1986.

BLEIER, R. Science and gender: a critique of Biology and its theories on women. Nova York: Pergamon, 1984.

BONET, O. Sentindo o saber. Educação da atenção e medicina de família. Horizontes Antropológicos, v. 21, n. 44, p. 253-277, 2015. http://dx.doi.org/10.1590/S0104-71832015000200011

BUTLER, J. Bodies That Matter. Nova York: Routledge, 1993.

CALLON, M. Society in the making: The study of technology as a tool for sociological analysis. In: BIJKER, W. et al. (orgs.). The Social Construction of Technological Systems. Cambridge: MIT Press, 1987. p. 83-106.

CARVALHO, M. C. Produzindo Quimeras: Linhagens de roedores, cientistas de laboratório e as vicissitudes da experimentação animal. Vibrant: Virtual Brazilian Anthropology, v. 13, n. 2, p. 160-176, 2016. http://dx.doi. org/10.1590/1809-43412016v13n2p160

CESARINO, L. M. C. D. N. Anthropology of development and the challenge of South-South cooperation. Vibrant: Virtual Brazilian Anthropology, v. 9, n. 1, p. 507-537, 2012. http://dx.doi.org/10.1590/S180943412012000100017

COSTA, M. C. D.; FELTRIN, R. Desafios da Interseccionalidade em Gênero, Ciência e Tecnologia. Cadernos Pagu, v. 47, p. 1-9, 2016. http://dx.doi.org/10.1590/18094449201600470018

CRUTZEN, P. J. The "anthropocene". In: CRUTZEN, P. J. (org.). Earth system science in the anthropocene. Nova York: Springer, 2006. p. 13-18.

DE CASTRO, E. V. Perspectivismo e multinaturalismo na América indígena. São Paulo: Ubu, 2018.

DUARTE, L. F. D. Ciências Humanas e Neurociências: um confronto crítico a partir de um contexto educacional.

Revista Brasileira de Ciências Sociais, v. 33, n. 97, p. 1-20, 2018. http://dx.doi.org/10.1590/339702/2018 
DURKHEIM, E. As formas elementares da vida religiosa. São Paulo: Martins Fontes, 1996.

ENCONTRO ANUAL DA ANPOCS, 34., 2010, Caxambu. Anais Eletrônicos [...]. São Paulo: ANPOCS, 2010. Disponível em: <http://anpocs.com/index.php/34o-encontro-anual-2010>. Acesso em: 29 jan. 2019.

ENCONTRO ANUAL DA ANPOCS, 35., 2011, Caxambu. Anais Eletrônicos [...]. São Paulo: ANPOCS, 2011. Disponível em: <http://anpocs.com/index.php/35o-encontro-anual-2011>. Acesso em: 29 jan. 2019.

ENCONTRO ANUAL DA ANPOCS, 36., 2012, Águas de Lindoia. Anais Eletrônicos [...]. São Paulo: ANPOCS, 2012. Disponível em: <https://www.anpocs.com/index.php/36encontro-atual>. Acesso em: 29 jan. 2019.

ENCONTRO ANUAL DA ANPOCS, 37., 2013, Águas de Lindoia. Anais Eletrônicos [...]. São Paulo: ANPOCS, 2013. Disponível em: <http://anpocs.com/index.php/37o-encontro-anual-2013-sp-1400301266>. Acesso em: 29 jan. 2019.

ENCONTRO ANUAL DA ANPOCS, 38., 2014, Caxambu. Anais Eletrônicos [...]. São Paulo: ANPOCS, 2014. Disponível em: <https://www.anpocs.com/index.php/38-encontro>. Acesso em: 29 jan. 2019.

ENCONTRO ANUAL DA ANPOCS, 39., 2015, Caxambu. Anais Eletrônicos [...]. São Paulo: ANPOCS, 2015. Disponível em: <https://www.anpocs.com/index.php/39-encontro>. Acesso em: 29 jan. 2019.

ENCONTRO ANUAL DA ANPOCS, 40., 2016, Caxambu. Anais Eletrônicos [...]. São Paulo: ANPOCS, 2016. Disponível em: <http://anpocs.com/index.php/40o-encontro-anual-2016>. Acesso em: 29 jan. 2019.

ENCONTRO ANUAL DA ANPOCS, 41., 2017, Caxambu. Anais Eletrônicos [...]. São Paulo: ANPOCS, 2017. Disponível em: <https://www.anpocs.com/index.php/41o-encontro-anual-2017>. Acesso em: 29 jan. 2019.

ENCONTRO ANUAL DA ANPOCS, 42., 2018, Caxambu. Anais Eletrônicos [...]. São Paulo: ANPOCS, 2018. Disponível em: <https://anpocs.com/index.php/encontros/papers/42-encontro-anual-da-anpocs >. Acesso em: 29 jan. 2019.

EVANS-PRITCHARD, E. E. Bruxaria, oráculos e magia entre os Azande. Rio de Janeiro: Zahar, 2004.

FARO, L.; RUSSO, J. A. Testosterona, desejo sexual e conflito de interesse: periódicos biomédicos como espaços privilegiados de expansáo do mercado de medicamentos. Horizontes Antropológicos, v. 23, n. 47, p. 61-92, 2017.

FARO, L. et al. Homem com "H": ideais de masculinidade (re)construídos no marketing farmacêutico. Cadernos Pagu, n. 40, p. 287-321, 2013. http://dx.doi.org/10.1590/S0104-83332013000100009

FAUSTO-STERLING, A. Myths of the gender: biological theories about women and men. Nova York: Basic Books, 1985.

FISCHER, M. M. Four genealogies for a recombinant anthropology of science and technology. Cultural Anthropology, v. 22, n. 4, p. 539-615, 2007. https://doi.org/10.1525/can.2007.22.4.539

FLECK, L. Gênese e desenvolvimento de um fato científico. Belo Horizonte: Fabrefactum, 2010.

FONSECA, C. Deslocando o gene: o DNA entre outras tecnologias de identificaçăo familiar. Mana, v. 22, n. 1, p. 133-156, 2016. http://dx.doi.org/10.1590/0104-93132016v22n1p133

FONSECA, C. Time, DNA and documents in family reckonings. Vibrant: Virtual Brazilian Anthropology, v. 12, n. 1, p. 75-108, 2015. http://dx.doi.org/10.1590/1809-43412015v12n1p075

FONSECA, C. et al. (orgs.). Antropologia da Ciência e da Tecnologia: dobras reflexivas. Porto Alegre: Sulinaed, 2016a.

FONSECA, C. et al. (orgs.). Ciência, medicina e perícia nas tecnologias de governo. Porto Alegre: Editora da UFRGS/CEGOVed., 2016b. 
FONSECA, C.; MACHADO, H. (orgs). Ciência, identificaçáo e tecnologias de governo. Porto Alegre: Editora da UFRGS/CEGOVed., 2015.

FONSECA, C.; ROHDEN, F.; MACHADO, P. S. (orgs.). Ciências na vida: antropologia da ciência em perspectiva. São Paulo: Terceiro Nomeed, 2012.

FONSECA, C.; SÁ, G. J. S. Apresentação: Ciência, poder e ética: implicaçôes e desdobramentos antropológicos. Horizontes Antropológicos, v. 17, n. 35, p. 7-23, 2011. http://dx.doi.org/10.1590/S0104-71832011000100001

FOUCAULT, M. As palavras e as coisas: uma arqueologia das ciências humanas. São Paulo: Martins Fontes, 1999.

FREITAS, L. B.; LUZ, N. S. D. Gênero, Ciência e Tecnologia: estado da arte a partir de periódicos de gênero. Cadernos Pagu, v. 49, p. 1-26, 2017. http://dx.doi.org/10.1590/18094449201700490008

FULLWILEY, D. The Molecularization of Race: Institutionalizing Human Difference in Pharmacogenetics Practice. Science as Culture, v. 16, n. 1, p. 1-30, 2007. https://doi.org/10.1080/09505430601180847

GASPAR NETO, V. V.; SANTOS, R. V. Biorrevelaçōes: testes de ancestralidade genética em perspectiva antropológica comparada. Horizontes Antropológicos, v. 17, n. 35, p. 227-255, 2011. http://dx.doi.org/10.1590/S010471832011000100008

GIBBON, S.; NOVAS, C. Biosocialities, genetics and the social sciences: making biologies and identities. Abingdon: Routledge, 2007.

HARAWAY, D. A partilha do sofrimento: relaçôes instrumentais entre animais de laboratório e sua gente. Horizontes Antropológicos, v. 17, n. 35, p. 27-64, 2011. http://dx.doi.org/10.1590/S0104-71832011000100002

HARAWAY, D. Cyborgs and Symbionts: Living Together in the New World Order. In: GRAY, C. H. (org.). Cyborg Handbook. Nova York: Routledge, 1995. p. xi-xx.

HARAWAY, D. Primate Visions: Gender, race, and nature in the world of modern science. Nova York: Routledge, 1989.

HARAWAY, D. Simians, Cyborgs, and Women: The Reinvention of Nature. Nova York: Routledge, 1991.

HARAWAY, D. Situated Knowledges: The Science Question in Feminism and the Provilege of Partial Perspective. In: HARDING, S. (org.). The Feminist Stand Point Theory Reader: Intellectual and Political Controversies. Nova York: Routledge, 2004. p. 81-103.

HIRD, M. Feminist engagements with matter. Feminist Studies, v. 35, n. 2, p. 329-346, 2009.

HIRD, M. Sex, gender, and science. Houndmills: Palgrave, 2004.

JASANOFF, S. States of knowledge: the co-production of science and the social order. Nova York: Routledge, 2004.

JENSEN, C. B.; RÖDJE, K. (orgs.). Deleuzian Intersections: Science, Technology, Anthropology. Oxford: Berghahn Booksed, 2010.

KEITA, S. O. Y. et al. Conceptualizing Human Variation. Nature Genetics, v. 36, n. 11, p. s17-s20, 2004. https:// doi.org/10.1038/ng1455

KELLER, E. F. The century of the gene. Cambridge: Harvard University Press, 2009.

KNORR-CETINA, K. The Couch, the Cathedral and the Laboratory: On the relationship between Experiment and Laboratory in Science. In: PICKERING, A. (org.). Science as Practice and Culture. Chicago: University of Chicago Press, 1992. p. 113-138. 
KNORR-CETINA, K. The ethnographic study of scientific work: towards a constructivist interpretation of science. In: KNORR-CETINA, K.; MULKAY, M. (orgs.). Science observed: perspectives on the social study of science. Beverly Hills: Sage, 1983. p. 115-140.

LATOUR, B. Anthropology at the time of the Anthropocene - A personal view of what is to be studied. In: AMERICAN ANTHROPOLOGICAL ASSOCIATION ANNUAL MEETING. Palestra [...]. Washington, D.C., 2014.

LATOUR, B. Ciência em ação. São Paulo: Unesp, 2000.

LATOUR, B. Jamais Fomos Modernos. Rio de Janeiro: Editora 34, 1994.

LATOUR, B. Perspectivismo: "tipo" ou” bomba"? Primeiros Estudos, n. 1, p. 173-178, 2011. https://doi. org/10.11606/issn.2237-2423.v0i1p173-178

LATOUR, B. Por uma antropologia do centro. Mana, v. 10, n. 2, p. 397-413, 2004. http://dx.doi.org/10.1590/ S0104-93132004000200007

LATOUR, B.; WOOLGAR, S. A vida de laboratório: A produção dos fatos científicos. Rio de Janeiro: RelumeDumará, 1997.

LAW, J. Actor Network Theory and Material Semiotics. In: TURNER, B. (org.). The New Blackwell Companion to Social Theory. Malden: Blackwell Publishing, 2009. p. 141-158.

LAW, J.; MOL, A. (orgs.). Complexities: Social studies of knowledge practices. Durham: Duke University Press, 2002.

LIMA, B. S.; COSTA, M. C. D. Gênero, ciências e tecnologias: caminhos percorridos e novos desafios. Cadernos Pagu, n. 48, p. 1-39, 2016. http://dx.doi.org/10.1590/18094449201600480005

LOPES, M. M.; SOMBRIO, M. M. Apresentação. Cadernos Pagu, n. 49, p. 1-17, 2017. http://dx.doi.org/10.159 $0 / 18094449201700490005$

LUNA, N. From abortion to embryonic stem cell research: Biossociality and the constitution of subjects in the debate over human rights. Vibrant: Virtual Brazilian Anthropology, v. 12, n. 1, p. 167-203, 2015. http://dx.doi. org/10.1590/1809-43412015v12n1p167

MACEDO, J. L. D. The multiple meanings of "risk": views on the abortion of non-viable fetuses among Brazilian medical doctors and magistrates. Vibrant: Virtual Brazilian Anthropology, v. 12, n. 1, p. 204-230, 2015. http://dx.doi.org/10.1590/1809-43412015v12n1p204

MACHADO, P. S. (Des)fazer corpo, (re)fazer teoria: um balanço da produção acadêmica nas ciências humanas e sociais sobre intersexualidade e sua articulação com a produçáo latino-americana. Cadernos Pagu, v. 42, p. 141158, 2014. http://dx.doi.org/10.1590/0104-8333201400420141

MALINOWSKI, B. Os Argonautas do Pacífico ocidental. São Paulo: Abril, 1984.

MANICA, D. A desnaturalizaçáo da menstruação: hormônios contraceptivos e tecnociência. Horizontes Antropológicos, v. 17, n. 35, p. 197-226, 2011. http://dx.doi.org/10.1590/S0104-71832011000100007

MANICA, D.; NUCCI, M. Sob a pele: implantes subcutâneos, hormônios e gênero. Horizontes Antropológicos, v. 23, n. 47, p. 93-129, 2017. http://dx.doi.org/10.1590/s0104-71832017000100004

MARTIN, E. Anthropology and the Cultural Study of Science. Science, Technology and Human Values, v. 23, n. 1, p. 24-44, 1998. https://doi.org/10.1177\%2F016224399802300102

MCCALLUM, C. A.; ROHDEN, F. (orgs.). Corpo e saúde na mira da antropologia: ontologias, práticas, traduçóes. Salvador: EDUFBA/ABAed, 2015. 
M'CHAREK, A. Fragile differences, relational effects: Stories about the materiality of race and sex. European Journal of Women's Studies, v. 17, n. 4, p. 307-322, 2010. https://doi.org/10.1177\%2F1350506810377698

MINELLA, L. S. Temáticas prioritárias no campo de gênero e ciências no Brasil: raça/etnia, uma lacuna? Cadernos Pagu, n. 40, p. 95-140, 2013. http://dx.doi.org/10.1590/S0104-83332013000100003

MOL, A. Mind Your Plate! the Ontonorms of Dutch Dieting. Social Studies of Science, v. 43, n. 3, p. 379-396, 2013. https://doi.org/10.1177\%2F0306312712456948

MOL, A. The Body Multiple: Ontology in Medical Practice. Durham: Duke University Press, 2002.

MONTEIRO, M. Reconsiderando a etnografia da ciência e da tecnologia: tecnociência na prática. Revista Brasileira de Ciências Sociais, v. 27, n. 79, p. 139-151, 2012. http://dx.doi.org/10.1590/S0102-69092012000200009

MOSSE, D. Anti-social anthropology? Objectivity, objection, and the ethnography of public policy and professional communities. Journal of the Royal Anthropological Institute, v. 12, n. 4, p. 935-956, 2006. https://doi. org/10.1111/j.1467-9655.2006.00371.x

MOSSE, D. Notes on the ethnography of expertise and professionals in international development. In: ETHNOGRAPHY AND THE PUBLIC SPHERE, 3., 2007, Lisboa. Anais [...]. 2007.

MURA, F. De sujeitos e objetos: um ensaio crítico de antropologia da técnica e da tecnologia. Horizontes Antropológicos, v. 17, n. 36, p. 95-125, 2011. http://dx.doi.org/10.1590/S0104-71832011000200005

NEUMANN, M. A. Por uma arqueologia simétrica. Cadernos do Lepaarq, v. 5, n. 9/10, 2008. http://dx.doi. org/10.15210/lepaarq.v5i9/10.1209

NUCCI, M. Crítica feminista à ciência: das "feministas biólogas" ao caso das "neurofeministas". Estudos Feministas, v. 26, n. 1, p. 1-14, 2018. https://doi.org/10.1590/\%25x

OUDSHOORN, N. Astronauts in the sperm world: the renegotiation of masculine identities in discourses on male contraceptives. Men and Masculinities, v. 6, n. 4, p. 349-367, 2004. https://doi.org/10.1177\%2F1097184X03260959

OUDSHOORN, N. Beyond the natural body: an archeology of sex hormones. Londres: Routledge, 1994.

PALSSON, G. et al. Reconceptualizing the 'Anthropos' in the Anthropocene: Integrating the social sciences and humanities in global environmental change research. Environmental Science \& Policy, v. 28, p. 3-13, 2013. https://doi.org/10.1016/j.envsci.2012.11.004

PEREIRA, P. P. G. Limites, traduçóes e afetos: profissionais de saúde em contextos indígenas. Mana, v. 18, n. 3, p. 511-538, 2012a. http://dx.doi.org/10.1590/S0104-93132012000300004

PEREIRA, P. P. G. Variations Around Water: bodies, encounters and translation processes. Vibrant: Virtual Brazilian Anthropology, v. 9, n. 1, p. 154-180, 2012b. http://dx.doi.org/10.1590/S1809-43412012000100006

PREMEBIDA, A. Biotecnologias: Dimensões sociológicas e políticas. Jundiaí: Paco Editorial, 2011.

RABINOW, P. Antropologia da razão: ensaios de Paul Rabinow. Rio de Janeiro: Relume-Dumará, 1999.

RADOMSKY, G. F.; LEAL, O. F. From the production of rules to seed production: Global Intellectual Property and local knowledge. Vibrant: Virtual Brazilian Anthropology, v. 9, n. 1, p. 451-472, 2012. http://dx.doi. org/10.1590/S1809-43412012000100015

REUNIÁO BRASILEIRA DE ANTROPOLOGIA, 27., 2010, Belém. Anais Eletrônicos [...]. Belém: UFPA, 2010. Disponível em: <http://www.abant.org.br/conteudo/ANAIS/CD_Virtual_27_RBA/index.html>. Acesso em: 29 jan. 2019. 
REUNIÃO BRASILEIRA DE ANTROPOlOGIA, 28., 2012, São Paulo. Anais Eletrônicos [...]. São Paulo: PUCSP, 2012. Disponível em: <http://www.abant.org.br/conteudo/ANAIS/CD_Virtual_28_RBA/index.html>. Acesso em: 29 jan. 2019.

REUNIÃO BRASILEIRA DE ANTROPOLOGIA, 29., 2014, Natal. Anais Eletrônicos [...]. Brasília: Kiron, 2014. Disponível em: <http://www.abant.org.br/conteudo/ANAIS/29RBA/index.html>. Acesso em: 29 jan. 2019.

REUNiÁO BRASILEIRA DE ANTROPOlOGIA, 30., 2016, João Pessoa. Anais Eletrônicos [...]. João Pessoa: UFPB, 2016. Disponível em: <http://www.abant.org.br/conteudo/ANAIS/30rba/index.php>. Acesso em: 29 jan. 2019.

REUNIÃO BRASILEIRA DE ANTROPOLOGIA, 31., 2018, Brasília. Anais Eletrônicos [...]. Brasília: UnB, 2018. Disponível em: <http://www.evento.abant.org.br/rba/31RBA/>. Acesso em: 21 fev. 2019.

REUNIÃO DE ANTROPOLOGIA DA CIÊNCIA E TECNOLOGIA, III., 2011, Brasília. Anais Eletrônicos [...]. Brasília: UnB, 2011. Disponível em: <http://www.ige.unicamp.br/react/?q=content/ programa\%C3\%A7\%C3\%A3o-completa>. Acesso em: 29 jan. 2019.

REUNIÃO DE ANTROPOLOGIA DA CIÊNCIA E TECNOLOGIA, IV., 2013, Campinas. Anais Eletrônicos [...]. Campinas: UNICAMP, 2013. Disponível em: <https://4react.wordpress.com/>. Acesso em: 29 jan. 2019.

REUNIÃO DE ANTROPOlOGIA DA CIÊNCIA E TECNOLOGIA, V., 2015, Porto Alegre. Anais Eletrônicos [...]. Porto Alegre: UFRGS, 2015. Disponível em: <http://ocs.ige.unicamp.br/ojs/react/issue/view/70>. Acesso em: 29 jan. 2019.

REUniÁo DE ANTROpologia DA CIÊNCIA E TECNOlOGIA, VI., 2017, São Paulo. Anais Eletrônicos [...]. São Paulo: USP, 2017. Disponível em: <https://ocs.ige.unicamp.br/ojs/react/index>. Acesso em: 29 jan. 2019.

REUNiÃO DE ANTROpOlOGia DO MERCOSUl, X., 2013, Córdoba. Anais [...].Córdoba: Editora da Universidade Nacional de Córdoba, 2013.

REUNIÃO DE ANTROPOLOGIA DO MERCOSUL, XI., 2015, Montevidéu. Anais Eletrônicos [...]. Montevidéu: UdelaR, 2015. Disponível em: <http://xiram.com.uy/>. Acesso em: 29 jan. 2019.

REUNIÃO DE ANTROPOLOGIA DO MERCOSUL, XII., 2017, Posadas. Anais Eletrônicos [...]. Posadas: UNaM, 2017. Disponível em: <https://ram2017.com.ar/?p=2144>. Acesso em: 29 jan. 2019.

RHEINBERGER, H.-J. Beyond Nature and Culture: Modes of Reasoning in the Age of Molecular Biology and Medicine. In: LOCK, M. et al. (orgs.). Living and Working with the New Medical Technologies: Intersections of Inquiry. Cambridge: Cambridge University Press, 2000. p. 19-31.

RIFIOTIS, T. Etnografia no Ciberespaço como "repovoamento" e explicação. Revista Brasileira de Ciências Sociais, v. 31, n. 90, p. 85-98, 2016. http://dx.doi.org/10.17666/319085-98/2016

RIGOTTO, R. M. Contested Knowledges in the Environmental Conflict over Uranium and Phosphate Mining in Ceará - Brazil. Vibrant: Virtual Brazilian Anthropology, v. 14, n. 2, p. 184-204, 2017. http://dx.doi. org/10.1590/1809-43412017v14n2p184

ROBERTS, C. Messengers of Sex: Hormones, biomedicine and feminism. Nova York: Cambridge University Press, 2007.

ROHDEN, F. La production d'articulations et de mouvements pour la santé des hommes au Brésil: la sexualité comme porte d'entrée. Vibrant: Virtual Brazilian Anthropology, v. 12, n. 1, p. 231-259, 2015. http://dx.doi. org/10.1590/1809-43412015v12n1p231 
ROHDEN, F. Notas para uma antropologia a partir da produção do conhecimento, os usos das ciências, intervenções e articulaçōes heterogêneas. In: FONSECA, C. et al. (orgs.). Ciências na vida: Antropologia da ciência em perspectiva. São Paulo: Terceiro Nome, 2012. p. 49-57.

ROHDEN, F. "O homem é mesmo a sua testosterona”: promoção da andropausa e representações sobre sexualidade e envelhecimento no cenário brasileiro. Horizontes Antropológicos, v. 17, n. 35, p. 161-196, 2011.

ROHDEN, F. O império dos hormônios e a construção da diferença entre os sexos. História, Ciências, SaúdeManguinhos, v. 15, supl., p. 133-152, 2008. http://dx.doi.org/10.1590/S0104-59702008000500007

ROHDEN, F. "Os hormônios te salvam de tudo": produção de subjetividades e transformaçôes corporais com o uso de recursos biomédicos. Mana, v. 24, n. 1, p. 199-229, 2018. http://dx.doi.org/10.1590/167849442018v24n1p199

ROHDEN, F. Sexual desire, testosterone and biomedical interventions: managing female sexuality in "ethical doses". Vibrant: Virtual Brazilian Anthropology, v. 14, n. 3, p. 1-12, 2017. http://dx.doi.org/10.1590/180943412017v14n3p022

ROHDEN, F.; ALZUGUIR, F. V. Desvendando sexos, produzindo gêneros e medicamentos: a promoção das descobertas científicas em torno da ocitocina. Cadernos Pagu, n. 48, p. 1-45, 2016. http://dx.doi.org/10.1590 /18094449201600480002

ROHDEN, F.; RUSSO, J.; ROCA, A. Apresentação. Horizontes Antropológicos, v. 23, n. 47, p. 9-26, 2017. http:// dx.doi.org/10.1590/s0104-71832017000100001

ROSE, N. Molecular Biopolitics, Somatic Ethics and the Spirit of Biocapital. Social Theory and Health, v. 5, n. 1, p. 3-29, 2007. https://doi.org/10.1057/palgrave.sth.8700084

SÁ, G. J. S. "Abraços de mono": elos perdidos e encontros intersubjetivos em etnografia com primatólogos no Brasil. Mana, v. 16, n. 1, p. 179-211, 2010. http://dx.doi.org/10.1590/S0104-93132010000100008

SANTOS, R. V.; GIBBON, S.; BELTRÃO, J. (orgs.). Identidades emergentes, genética e saúde: perspectivas antropológicas. Rio de Janeiro: Editora Fiocruz, 2012.

SARTI, C. Corpo e doença no trânsito de saberes. Revista Brasileira de Ciências Sociais, v. 25, n. 74, p. 77-90, 2010. http://dx.doi.org/10.1590/S0102-69092010000300005

SAUTCHUK, C. E. Ciência e Técnica. In: DUARTE, L. F. D. (org.). Horizontes das ciências sociais no Brasil: Antropologia. São Paulo: ANPOCS, 2010. p. 97-123.

SAUTCHUK, C. E. Cine-weapon: The poiesis of filming and fishing. Vibrant: Virtual Brazilian Anthropology, v. 9, n. 2, p. 406-430, 2012. http://dx.doi.org/10.1590/S1809-43412012000200015

SAUTCHUK, C. E. (org.). Técnica e transformaçáo: perspectivas antropológicas. Rio de Janeiro: ABA Publicações, 2017.

SAUTCHUK, C. E.; SAUTCHUK, J. M. Enfrentando poetas, perseguindo peixes: sobre etnografias e engajamentos. Mana, v. 20, n. 3, p. 575-602, 2014. http://dx.doi.org/10.1590/S0104-93132014000300006

SEGATA, J. La cosmopolitique de la dépression: Biosocialité dans une ethnographie multi-espèces. Vibrant: Virtual Brazilian Anthropology, v. 12, n. 1, p. 290-320, 2015. http://dx.doi.org/10.1590/1809-43412015v12n1p290

SEGATA, J. O Aedes Aegypti e o Digital. Horizontes Antropológicos, v. 23, n. 48, p. 19-48, 2017. http://dx.doi. org/10.1590/s0104-71832017000200002 
SEGATA, J.; RIFIOTIS, T. (orgs.). Políticas etnográficas no campo da cibercultura. Brasília: ABA Publicações, 2016.

SEGATA, J.; RIFIOTIS, T. (orgs.). Políticas Etnográficas no campo da ciência e das tecnologias da vida. Porto Alegre: Editora da UFRGS, 2018.

SILVA, G.; DUARTE, L. F. D. Epigênese e epigenética: as muitas vidas do vitalismo ocidental. Horizontes Antropológicos, v. 22, n. 46, p. 425-453, 2016. http://dx.doi.org/10.1590/S0104-71832016000200015

SIMÓES, J. A. A dinâmica do campo: temas, tendências e desafios. In: SIMIÃO, D.; FELDMAN-BIANCO, B. (orgs.). O campo da antropologia no Brasil: retrospectiva, alcances e desafios. Rio de Janeiro: ABA, 2018. p. 57-82.

SOUZA, I. M. A. Afeto entre humanos e animais não-humanos no biotério. Revista Brasileira de Ciências Sociais, v. 32, n. 94, p. 1-21, 2017a. http://dx.doi.org/10.17666/329407/2017

SOUZA, I. M. A. Corpos comensuráveis: produção de modelos animais na pesquisa biomédica. Horizontes Antropológicos, v. 23, n. 48, p. 275-302, 2017b. http://dx.doi.org/10.1590/s0104-71832017000200012

SPIESS, M. R.; MATTEDI, M. A. Da associaçẫo à dissolução da rede sociotécnica do processador de textos fácil: subsídios para uma etnografia da tecnologia. Mana, v. 16, n. 2, p. 435-470, 2010. http://dx.doi.org/10.1590/ S0104-93132010000200008

STENGERS, I. A proposição cosmopolítica. Revista do Instituto de Estudos Brasileiros, v. 6, n. 69, p. 442-464, 2018. https://doi.org/10.11606/issn.2316-901X.v0i69p442-464

STRATHERN, M. Cortando a rede. In: STRATHERN, M. (org.). O efeito etnográfico e outros ensaios. Sáo Paulo: Cosac Naify, 2014. p. 259-319.

STRATHERN, M. The Gender of the Gift: Problems with Women and Problems with Society in Melanesia. Berkeley: University of California Press, 1988.

TRAMONTANO, L. A fixação e a transitoriedade do gênero molecular. Horizontes Antropológicos, v. 23, n. 47, p. 163-189, 2017. http://dx.doi.org/10.1590/S0104-71832017000100006

VANDER VELDEN, F. Inquietas Companhias: sobre os animais de criaçáo entre os Karitianas. São Paulo: Alameda, 2012.

WADE, P. et al. Mestizo genomics: Race mixture, nation, and science in Latin America. Durham: Duke University Press, 2014.

WILLIAMS, S.; MARTIN, P.; GABE, J. The pharmaceuticalisation of society? A framework for analysis. Sociology of Health and Illness, v. 33, n. 5, p. 710-725, 2011. https://doi.org/10.1111/j.1467-9566.2011.01320.x

WRIGHT, R. M.; KAPFHAMMER, W.; WIIK, F. B. The Clash of Cosmographies Indigenous Societies and Project Collaboration - Three ethnographic cases (Kaingang, Sateré-Mawé, Baniwa). Vibrant: Virtual Brazilian Anthropology, v. 9, n. 1, p. 382-450, 2012. http://dx.doi.org/10.1590/S1809-43412012000100014

ZHOURI, A. Introduction: Anthropology and knowledge production in a "minefield". Vibrant: Virtual Brazilian Anthropology, v. 14, n. 2, p. 72-80, 2017. http://dx.doi.org/10.1590/1809-43412017v14n2p072 


\title{
O encontro das antropologias do meio ambiente e dos desastres no Brasil
}

\author{
May Waddington Telles Ribeiro ${ }^{\mathrm{I}}$
}

\section{Introdução}

Enquanto a antropologia dos desastres se constitui hoje como um campo conceitualmente bem definido, a ideia de uma antropologia do meio ambiente apresenta-se como um oximoro dentro do qual termos irreconciliáveis travam uma verdadeira luta de titấs entre o conceito de uma "ciência do Homem" que rejeita naturalizaçôes dos fenômenos sociais e as consideraçóes sobre o "mundo da physis", objeto fulcral de variadas e sempre problemáticas disputas. ${ }^{1}$

O antropólogo Henyo Trindade Barretto Filho (2012a, p. 104-106; 2012b, p. 346-355) examina como a ciência ocidental adota definiçóes diferentes para a natureza baseado em sua posição externa ou interna em relação ao ser humano, de acordo com abordagens materialistas ou simbólicas, até que, paulatinamente, uma terceira definição de natureza como representação socialmen- te construída se estabelece entre as ciências humanas. $\mathrm{O}$ autor ressalta que mesmo nessa terceira vertente, pautada no relativismo cultural que reconhece a diversidade e rejeita universalizaçóes, o dualismo entre natureza e cultura persiste até surgirem novas perspectivas "monistas e integrativas", que tentam enfocar processos e relaçôes, percebendo a natureza como "artefato produzido pela(s) sociedade(s) sujeitas às leis do mercado".

A vastidáo do campo da antropologia do meio ambiente é proporcional, entáo, à tensão entre os termos cultura e physis. Este artigo contém uma reflexão sobre se uma "antropologia do meio ambiente" de fato existe, examinando como esta é definida pelos recortes escolhidos por diferentes grupos de antropólogos para tratar como objetos de pesquisa os problemas multifacetados que foram postos pela questáo ecológica à civilização ocidental a partir da década de $1960 .^{2}$

1 As tentativas iniciais de enquadramento da realidade física na antropologia materialista histórica de Leslie White e Julian Stewart depararam-se com os grandes voos conceituais do estruturalismo, que rejeitava a ideia de "adaptaçáo cultural” por meio de uma relaçáo processual de grupos com o local/ambiente. Veremos, na terceira parte deste artigo, como alguns desses preceitos da ecologia cultural de Stewart são retomados na antropologia do desastre.

2 O alarme inicial provocado por cientistas sobre o aquecimento global (Clube de Roma) e a poluição (Rachel Carlson) ajudou a conclamar uma reuniāo da Organização das Naçôes Unidas (ONU) voltada para a questão, em Estocolmo, em 1972. Ao longo das décadas seguintes, vimos os Estados criarem instituiçóes e departamentos específicos, assinarem convençóes e estabelecerem leis para controlar danos causados pelo desenvolvimento industrial. O crescimento da participação da sociedade civil (anos 1980) estimulou a entrada de empreendimentos de mercado na discussão (anos 1990) até o início de um esmorecimento do debate internacional e o ressurgimento do ideário desenvolvimentista mediante a ordem política conservadora e bélica que se estabeleceu com a Guerra do Iraque após o ataque às torres gêmeas nos Estados Unidos, em 11 de setembro de 2001.

\footnotetext{
${ }^{\text {I }}$ Programa de Pós-Graduação em Estado e Sociedade, Universidade Federal do Sul da Bahia - Itabuna (BA), Brasil.

E-mail: may.waddington@gmail.com
} 
Examina também a forma como diferentes grupos sediados em programas de pós-graduação e associaçóes acadêmicas reconfiguraram seu instrumental teórico e conceitual diante de tais recortes, alguns apresentando a intenção de estabelecer subdisciplinas enquanto outros, inversamente, aprofundam os questionamentos teórico-metodológicos da "boa e velha" antropologia rechaçando o título "ambiental", mesmo quando seu objeto preferencial de trabalho se debruça sobre tais questôes.

Encontramos reflexôes de fundo sobre o pensamento ocidental moderno estimuladas pela crise ecológica, como em $A$ invençâa ecológica (Carvalho, 2001), ou em $O$ mito moderno da natureza intocada (Diegues, 2008), assim como grandes reviravoltas em nossa visão da natureza através da história ambiental (Crosby, 2011) ou da relação entre questão ecológica e processos de negociação política, em José Augusto Pádua (1992). ${ }^{3}$ Embora estas, entre as muitas reflexóes de cunho epistemológico pertinentes à filosofia, à sociologia, à crítica marxista ou à educação, tenham estabelecido uma base para os diálogos interdisciplinares característicos da época, estaremos buscando, neste trabalho, aquelas mais circunscritas à própria antropologia, como o artigo intitulado "Natureza", de Barretto Filho (2012a), que apresenta um percurso teórico que se inicia com o conceito de adaptação da ecologia cultural seguindo até o entendimento integrativo do homem enquanto organismo modificador e coconstrutor do seu meio, em Bateson (1972) e Ingold $(1987 ; 2000)^{4}$ (Barretto Filho, 2012a).

Paul Little (2006) refere-se a três abordagens teóricas que pretenderam superar a divisão das esferas biológica e humana. A primeira, mais radical, resolve ignorar a linha divisória natureza/cultura. Little atribui a esta uma arrogância antropocêntrica que considera os humanos "tão potentes, e tão onipresentes" a ponto de já terem alterado como um todo o mundo biofísico, o que é, para ele, "um claro exagero". Na segunda abordagem, que Little considera uma "saída do impasse" entre natureza e cultura mais frutífera, uma "nova síntese biocultural" é proposta, aproximando disciplinas de ambos os lados da divisa por meio de um marco teórico unificado, sugerindo Bateson (1972), Goodman e Leatherman (1998) e, na "teoria ecológica propriamente dita", Holling e Sanderson (1996). A terceira abordagem, da "simetria epistemológica”, aponta para causas em ambos os lados da divisa, alertando contra o privilégio de uma em detrimento da outra:

$\mathrm{Na}$ implementação analítica dessa simetria, os cientistas sociais vêm usando o conceito de "agente natural", no qual as forças da natureza são consideradas como uma espé-

3 Pensando em termos de longa duração, Pádua (1992, p. 156-163) alerta para a relação entre o homem e a escassez definida como os limites de seu acesso a recursos naturais. Se na Antiguidade havia uma disponibilidade infinita, a escassez era definida pela limitação de meios técnicos de disponibilizar esses recursos. No período industrial privatista, em que a tecnologia abriu tais fronteiras, naturalizou-se uma ideia de disponibilidade infinita de recursos que orientou as expectativas de desenvolvimento em uma geopolítica colonial que prometia, a posteriori, uma equiparação entre naçōes e regiōes.

4 Um seminário importante realizado na Universidade Federal do Rio Grande do Sul (UFRGS), Porto Alegre, recebe Ingold e abre campo de diálogos para essa reflexão. Em Cultura, percepção e ambiente. Diálogos com Tim Ingold, organizado por Carlos Steil e Isabel Carvalho (2012), acaba comprovando a hipótese de que é o enquadramento teórico e a forma de se recortar os objetos de pesquisa dos diferentes autores que compuseram o livro o que poderia caracterizar uma antropologia do meio ambiente. 
cie de ator, no sentido de que "agem" sobre uma realidade determinada, mas que difere qualitativamente dos atores sociais, já que não têm "vontade" nem "intencionalidade". Como ambos os tipos de atores são tratados com o potencial de influir na construção de uma paisagem determinada, segue o princípio epistemológico de simetria (Law, 1987, p. 114 apud Little, 2006, p. 89, tradução livre da autora).

Assim, diante da "questão ecológica", a antropologia enfrentou os desafios que o mundo da physis apresentava à sua tradição teórica enquanto sua lente de observação enfocava seus antigos sujeitos de pesquisa sob novas correlações de forças políticas. Surgem demandas e oportunidades de financiamentos de pesquisas alterando a atividade de antropólogos tanto na direção de novos problemas quanto para sua redefinição enquanto "ambientais". Não se trata de um afastamento de seus temas de pesquisa anteriores, fossem esses grupos e comunidades indígenas, camponeses, sindicatos, trabalhadores ou outros, mas do reexame e reenquadramento do mundo pela lente específica do ambientalismo.

\section{O lugar da antropologia em meio ao adensamento do movimento social}

há de se argumentar que o próprio lugar da antropologia e o papel dos antropólogos se modificam diante da questão ecológica. À medida que a interdisciplinaridade imposta pela complexidade da questão ambiental provoca uma escuta renovada dos conhecimentos tradicionais, causa uma valorização da antropologia entre as ciências ocidentais. No ambiente de forte participação social dos anos de 1980 e 1990, incentivada por processos de redemocratização e grandes encontros internacionais, ${ }^{5}$ com estímulo às açóes que envolviam trocas de experiências, começava a constituir-se uma ecologia política agregando cientistas de diferentes áreas, aproximando-os de um universo anteriormente visitado preferencialmente pela antropologia. Ao mesmo tempo, lideranças indígenas e camponesas deixavam sua posição de "objetos de estudo" para emergirem como protagonistas na arena internacional por meio de movimentos sociais organizados, tais como, entre outros, a "Aliança dos Povos da Floresta", ${ }^{6}$ para quem a utilidade do antropólogo enquanto "intermediário" ou assessor se estabelece.

Durante o processo de redemocratização, a antropologia brasileira, sem qualquer pretensão de ser ambiental, já iniciava parcerias com organizaçóes não governamentais (ONGs) enquanto a luta do movimento indígena pela demarcação de terras foi gradualmente se fortalecendo. No início da década de 1980, por exemplo, foi realizado pelo projeto "Estudos sobre Terras Indígenas no Brasil: invasóes, uso do solo, recursos

5 Surgem, no ambiente pós-Rio-92, condiçôes de possibilidade que favorecem mudanças no "papel" do antropólogo, com participação em ações de governo, muitas delas mediadas por ONGs, por meio de financiamentos de fundos intergovernamentais para o financiamento de açōes in loco, como a execução de laudos demarcatórios, relatórios de identificação - Estudo de Impacto Ambiental (EIA) e seu respectivo Relatório de Impacto Ambiental (Rima) - e outras açóes em políticas públicas e projetos de desenvolvimento. A antropologia aplicada rompe o academicismo e se estabelece fora da universidade, ou "extramuros".

6 Liderada por índios e seringueiros como Chico Mendes, essa rede inter-regional articulou indígenas e o campesinato extrativista de outras regiōes, como Pará e Maranhão. 
naturais" (Peti) o mais extenso e difićlimo trabalho de levantamento manual de dados sobre as terras indígenas em arquivos da Fundação Nacional do Índio (Funai), do Instituto Nacional de Colonizaçáo e Reforma Agrária (Incra) e do Ministério da Reforma e do Desenvolvimento Agrário (Mirad) (1983-1992), ${ }^{7}$ sob a direçáo de João Pacheco de Oliveira, com a colaboraçáo de Antônio Carlos de Souza Lima. Partes importantes desse trabalho, tal como a listagem das terras indígenas, foi organizada em parceria com a ONG Cedi. ${ }^{8}$ Os resultados dessa pesquisa trouxeram informaçôes aos parlamentares durante a Constituinte de 1988, contribuindo para decisooes favoráveis aos povos indígenas.

Embora não houvesse nenhuma pretensão de se fazer uma antropologia ambiental, os autores relacionados ao projeto reconheceram que as condiçôes de demarcação de terras indígenas no Brasil se modificaram drasticamente a partir de 1991, na medida em que "o governo brasileiro passa a ver como positiva a possibilidade de financiamento externo para açôes de proteçấo ao meio ambiente, especialmente na Amazônia, o que irá implicar na homologação de muitas e extensas áreas indígenas" (Oliveira, 1998, p. 15-42). Porém, mais que um "efeito" da questão ambiental, podemos considerar que essa antropologia voltada para a etnologia e aplicada à demarcação de terras indígenas acabou por resultar em uma importante contribuição à antropologia do meio ambiente, por intermédio dos inúmeros profissionais da antropologia que produziram laudos e relatórios com informaçóes etnográficas (Souza Lima; Barretto Filho, 2005) sobre a relação e significados atribuídos por diferentes comunidades indígenas ao seu meio natural $e$ às suas formas de manejo, que, mesmo servindo a fins específicos, certamente compóem um acervo valiosíssimo para uma antropologia voltada para o ambiente.

Ao longo da década de 1980, o tema do conhecimento tradicional foi valorizado em um quadro internacional que aproximava biólogos da antropologia, como aqueles congregados na Sociedade Internacional de Etnobiologia (SIE), fundada pelos professores Darrell Posey ${ }^{10}$ e Olympio Serra, ${ }^{11}$ com a etnobiologia, através de Elaine Elizabetsky, ${ }^{12}$ em colaboração com o astrofísico da Universidade Estadual de Campinas Márcio D’Olney Campos, entre outros. A SIE reuniu uma prolífera produção intelectual versando sobre o conhecimento da natureza e o manejo ecológico indígena, em especial os Kayapó. Nesses documentos foram consideradas a cosmovisão e as diferenças epistemológicas dos nativos e seus pajés, que eram tidos como "verdadeiros cientistas", táo merecedores de títulos de doutoramen-

7 Uma ação conjunta das equipes do Programa de Pós-Graduação em Antropologia Social (PPGAS) e do Museu Nacional/Universidade Federal do Rio de Janeiro (UFRJ) (1983-1992).

8 Centro Ecumênico de Documentação e Informação, que após se juntar à SOS Mata Atlântica passou a se chamar Instituto Socioambiental (ISA).

9 A partir dos decretos de demarcação de terras indígenas, assinados pelo presidente Collor em 1992, fortaleceu-se a produção de laudos de demarcaçáo, que se iniciaram em forte parceria com a ONG Cedi (hoje ISA), cujos equipamentos de georreferenciamento facilitaram tais açōes também em outros programas de outras universidades.

10 Museu Goeldi e Universidade Federal do Maranhão (UFMA).

11 Universidade de Brasília (UnB).

12 UFRGS. 
to quanto os acadêmicos que os estudavam. Ficou estabelecido que a própria sobrevivência física desses grupos dependeria do "respeito" concedido às formas próprias de saber o mundo, sendo o direito à terra a base material imprescindível a essa sobrevivência. Foi produzido aí um importantíssimo e refinado legado intelectual sobre a formação dos regimes jurídicos internacionais na defesa dos direitos de povos indígenas ${ }^{13}$ que talvez pecasse, inicialmente, por usar "a linguagem do agressor", ao tentar estabelecer estratégias de defesa de direitos dos povos indígenas no âmbito da "propriedade intelectual" pertinente à lei das patentes. ${ }^{14}$

A SIE foi responsável por cunhar termos como "biopirataria", alertando contra a exploração comercial do conhecimento indígena. Clamava pelo reconhecimento do saber dos pajés, em sua Declaração de Belém, de 1988. Com caráter militante, reunia-se em países diferentes a cada dois anos formando uma rede internacional de alianças. Ajudou a promover o Encontro de Altamira, atraindo atenção mundial para a luta de povos indígenas do Brasil contra a barragem que hoje se concretiza em Belo Monte. Paralelamente à Conferência das Naçóes Unidas sobre o Meio Ambiente e o Desenvolvimento (Cnumad), na qual repre- sentantes políticos firmaram compromissos para sustar os males do desenvolvimento industrial (tais como a Agenda 21, a Convenção da Diversidade Biológica e a Convenção do Clima) — a SIE organizou o Parlamento da Terra pela Diversidade Biocultural, que reuniu lideranças indígenas de todo o Brasil e do mundo com juristas internacionais, ONGs brasileiras e estrangeiras, com importantes figuras exponenciais mundiais. ${ }^{15}$

$\mathrm{O}$ conhecimento dos sujeitos de estudo é, obviamente, inerente à antropologia. No entanto, enquadrado dentro da perspectiva ambiental, o termo "conhecimento tradicional", associado ao conceito de "povos tradicionais", no Brasil se estabeleceu em relação às unidades de conservação, com trabalhos do sociólogo Antônio Carlos Diegues, ${ }^{16}$ com estudos sobre o manejo de recursos naturais por comunidades caiçaras na Mata Atlântica, ilhas, áreas costeiras e grupos da Zona Úmida na Amazônia. Sua categorização de diferentes grupos enquanto "povos tradicionais" tem sido amplamente adotada como ponto de partida de estudos sobre a relação de grupos locais com seu ambiente, embora seja disputada por autores da antropologia que rejeitam uma classificação rígida na forma de "gabarito", propondo análises que incluam a formação de identidades em

13 Darrell Posey orgulhava-se de ter conseguido inserir no campo da discussão internacional a ideia de um "feixe de direitos" como um regime constituído por diferentes leis e convençôes internacionais de proteção jurídica dos povos indígenas, sem excluir outros aspectos da vida comunitária, como aqueles espirituais, tão pouco considerados pelas leis nacionais.

14 Ideia que mais tarde se complexificou em direitos difusos que contemplavam, para muito além da propriedade individual, a base do sistema jurídico da Convenção de 1930.

15 Como Paulo Freire, José Lutzemberger, Dalai Lama, Patativa do Assaré, Al Gore, príncipe Charles e Jane Fonda, entre muitos outros, em catorze dias de reuniôes que deram voz a negros, indígenas, camponeses e extrativistas os mais variados, ciganos, populaçōes de rua, assim como a especialistas em discussōes sobre cidades, comercialização, usos do georreferenciamento para a demarcação de terras indígenas e seus direitos territoriais e, principalmente, a proteção do conhecimento tradicional perante a nova exploração que entấo se anunciava desses saberes pela indústria farmacêutica em grande escala.

16 Programa de Pós-Graduação em Ciência Ambiental, Universidade de São Paulo (Procam/USP). 
relação com a construção do saber local. ${ }^{17}$ Suas publicaçóes, como $O$ mito moderno da natureza intocada (2008) ou Etnoconservação (2000), continuam a ser muito citadas, especialmente em ambientes interdisciplinares. ${ }^{18}$

A discussão sobre o conhecimento tradicional evoluiu tanto pela ação prática quanto pela produção intelectual dos antropólogos Mauro Almeida e Manuela Carneiro da Cunha, a partir de 1993, conforme demonstravam como os locais "ocupavam" a identidade de povos tradicionais, incorporando essa identidade na da luta política por direitos. O primeiro, professor da Unicamp, desenvolveu açóes de extensão em sindicatos rurais no Acre, na década de 1980, contribuindo com a formação do Conselho Nacional dos Seringueiros em convívio com Chico Mendes - talvez o ator individual que, por meio de sua luta e morte, tenha servido como o mais importante marco simbólico impulsionador do movimento ambientalista internacional. Entre os anos de 1989 e 1991, Mauro Almeida contribuiu com o mapeamento e a delimitação para a formação da Reserva Extrativista do Alto Juruá. Com forte interesse por teoria antropológica e pelos estudos de campesinato, em seus escritos ini- ciais sobre conhecimentos tradicionais, estes eram traduzidos pelo termo "tecnologia", em artigos como "Dilemas da razão prática: simbolismo, tecnologia e ecologia na floresta Amazônica", ainda em 1986, e "As colocaçôes como forma social, sistema tecnológico e unidade de recursos naturais" (1990). ${ }^{19}$

A fecundidade do encontro entre Mauro Almeida e Manuela Carneiro da Cunha reflete-se nos diversos projetos de pesquisa que foram desenvolvidos pela dupla, ${ }^{20}$ revelando a forte imbricaçáo do conhecimento tradicional com a questão da etnoconservação. Assinam juntos os artigos "Indigenous people, traditional people and conservation in the Amazon", na revista Daedalus (2000), e "Global environmental changes and traditional populations" (2001), entre outros. Essa vasta produção intelectual sobre o tema culmina na publicação da Enciclopédia da floresta: o Alto Juruá - prática e conhecimentos das populaçôes (2002).

Além de importantes manifestações públicas em defesa dos direitos indígenas na imprensa, Manuela Carneiro da Cunha tem mantido consistente participação técnica e política na Força Tarefa de Conhecimentos de Povos Indígenas e Comunidades Locais

17 Para uma discussão esclarecida a respeito dos dilemas trazidos por esse conceito, uma vez que é construído mediante a necessidade de se garantir direitos às populaçóes englobadas por áreas de unidades de conservação, ver Prado (2012, p. 175-177).

18 Seus projetos de pesquisa, como o atual, "Povos/Comunidades tradicionais e áreas protegidas no Brasil: conflitos e direitos" (USP/2010, em andamento), analisam conflitos socioambientais entre comunidades locais e áreas protegidas no Brasil.

19 A preocupação de Almeida com o manejo do território parece consolidar-se em "The management of conservation areas by traditional populations: the Case of the Upper Jurua Extractive Reserve" (1996), dando forma à linha de pesquisa em que atua ainda hoje: “Territorialidades e Processos Sociais” (Unicamp, 2010, em andamento).

20 "As populações tradicionais podem gerenciar áreas de conservação? Uma experiência na Reserva Extrativista do Alto Juruá" (1993-1995); "Populaçôes locais, agrobiodiversidade e conhecimentos tradicionais na Amazônia brasileira" (2005-2009); "Populações, agrobiodiversidade e conhecimentos tradicionais associados" (2009-2013); "Bases para um programa brasileiro de pesquisa intercultural e de fortalecimento da produção local de conhecimentos" (2009, em andamento); e "Povos indígenas e comunidades locais tradicionais no Brasil: contribuiçôes para a biodiversidade, ameaças e políticas públicas” (2018, em andamento). 
da Plataforma Intergovernamental sobre Biodiversidade e Serviços Ecossistêmicos ${ }^{21}$ e, desde 2014, a convite do governo federal do Brasil, como perita no Foro de Conhecimentos Tradicionais. ${ }^{22}$ Mauro Almeida, por sua vez, mantém forte atuação acadêmica e editorial, tendo contribuído com a constituição da Universidade da Floresta (Uniflora) ${ }^{23}$ nas comunidades em reservas extrativistas do Acre. ${ }^{24}$ Sua atuaçáo como professor orientador mantém bastante consistência em relação às temáticas aqui discutidas, tanto na Amazônia quanto entre os caiçaras da Mata Atlântica da Jureia, mas também com temas de fundo teórico-epistemológico sobre a aproximação entre natureza e cultura, conhecimento científico e tradicional, e entre outros que compóem o "corpus etnográfico" relacionado.

No âmbito da criação do Sistema Nacional de Unidades de Conservação (SNUC), houve um intenso debate em torno da definição de comunidades tradicionais, em meio às discussōes sobre políticas de conservação e de preservação da natureza que envolveram atores de várias instituiçóes de governo, assim como atores da sociedade civil organizados por ONGs e cientistas. A luta que se travou em torno desse conceito antevia consequências jurídicas importantes para as comunidades locais, caso a categoria fosse associada a uma condição temporal, como sugerido pelas noçôes de pré-colombiano, ancestral ou "habitantes desde tempos imemoriais" que aparecia no Projeto de Lei $\mathrm{n}^{\circ}$ 2.057, que dispóe sobre o Estatuto dos Povos Indígenas.

Porém, essa não foi a única tensão nesse espaço, no qual os antropólogos se inseriram como analistas das relações sociais e dos interesses em jogo nessa arena de disputa política e institucional, como aponta a dissertação de mestrado de Renata Sant'Anna (2003), orientada por Neide Esterci (PPGAS/UFRJ), Sistema Nacional de Unidades de Conservação: reflexóes antropológicas sobre a elaboração

21 Intergovernmental Science-Policy Platform on Biodiversity and Ecosystem Services (IPBES) (2014-2019).

22 Sua inegável contribuição é reconhecida tendo em vista a encomenda, pelo Ministério da Ciência, Tecnologia, Inovaçôes e Comunicaçōes (MCTIC), para "construir diagnóstico sobre as contribuiçôes dos povos indígenas e comunidades locais no Brasil para a geração, manutençáo ou conservação da biodiversidade e a recuperação de solos e outros serviços ecossistêmico" (Plataforma Lattes, consultado em 19 de março de 2019).

23 "A Universidade da Floresta (Uniflora) foi um projeto de universidade diferenciada elaborado com o intuito de incluir conhecimentos, e conhecedores, tradicionais no ensino superior brasileiro. O projeto foi redigido em fevereiro de 2004 na sede da Universidade Federal do Acre (UFAC) por representantes de universidades públicas brasileiras: a Universidade de Campinas (UNICAMP), a Universidade de Brasília (UnB), a Universidade Federal de Viçosa (UFV), a Universidade Federal do Acre (UFAC); por institutos nacionais de pesquisa: a Empresa Brasileira de Pesquisa Agropecuária (Embrapa), e o Instituto Nacional de Matemática Pura e Aplicada (IMPA); representantes da sociedade civil e do governo do estado do Acre.[...]. A ideia de criaçáo de uma nova universidade, que pudesse ter como professores também pessoas não formadas academicamente, como seringueiros, ribeirinhos e indígenas, promovendo uma interfase entre os conhecimentos tradicionais e acadêmico-científicos. A Uniflora estava baseada em três 'eixos' constituintes: Instituto da Biodiversidade e Manejo dos Recursos Naturais; Campus Floresta, em Cruzeiro do Sul; e o Centro de Formação e Tecnologias da Floresta (CEFLORA)”. Disponível em: https:/ensinosuperiorindigena.wordpress.com/atores/instituicoes/uniflora/. Acesso em: 19 mar. 2019.

24 Temas como: Articulaçöes para o desenvolvimento da floresta: populaçōes locais e políticas públicas em torno da natureza na microrregião de Cruzeiro do Sul - Acre, de Maíra Bueno de Carvalho (2013). Além de temas de fundo, tais como: Natureza e cultura na definição e delimitação do humano: debates e disputas entre antropologia e biologia (Dalgalarroto, 2013), ou Pontes e abismos entre conhecimento tradicional e conhecimento científico: relaçōes e dissençōes entre caiçaras e pesquisadores na Juréia (Rodrigo Ribeiro de Castro, 2017, em andamento). 
de uma lei ambiental. ${ }^{25}$ Destaca-se, nessa área, a produção de Henyo Trindade Barretto Filho, com sua tese de doutorado, $D a$ naçâo ao planeta através da natureza: uma tentativa de abordagem antropológica das unidades de conservação na Amazônia, publicada em 1997, mas também em $A$ história da conservação da natureza no Brasil como uma peleja moral (1998) e Utopias tecnológicas, distopias ecológicas e contrapontos românticos: "populaçôes tradicionais" e áreas protegidas nos trópicos (2001).

A difícil aproximação entre os termos cultura e physis na antropologia encontra uma tradução no conceito de "processo de territorialização", de João Pacheco de Oliveira, ${ }^{26}$ bom para pensar a relação de grupos indígenas com a materialidade de seu meio e com o Estado. Com simplicidade e precisão, o conceito incorpora a história à equação estimulando, assim, outros avanços teóricos acerca da prática da cultura sobre o meio físico, tais como a ideia de "terras tradicionalmente ocupadas", em Alfredo Wagner Bermo de Almeida ${ }^{27}$ (2004; 2008a; 2008b), a percepção de ondas de ocupação territorial, em Little (2018), ou de "dinâmica territorial”, em Mura (2019).

O projeto "Novas Cartografias Sociais da Amazônia", ${ }^{28}$ coordenado por Alfredo Wagner Berno de Almeida, mantém forte capilaridade na Amazônia e em especial no Maranhão, onde estabeleceu o Programa de Pós-Graduação em Cartografia Social e Política da Amazônia, ${ }^{29}$ e no Pará, com Rosa Acevedo Marin, no Núcleo de Altos Estudos Amazônicos (Naea) e o Programa de Pós-Graduação em Antropologia. ${ }^{30}$ Embora não constitua uma "antropologia ambiental" ou reivindique esse subcampo, podemos supor, claramente, que o registro etnográfico da relação direta que grupos camponeses de várias categorias, quilombolas e indígenas mantêm com seu meio físico venha a trazer enormes contribuições para consideraçôes ambientais.

De que modo não perceber como "ambiental" a análise que Alfredo Wagner faz da "racionalidade extrema", "econômica" ou "universal" por trás das políticas de ocupação da Amazônia e seu papel de promoção da invisibilidade a que são remetidos os grupos adaptados à vida na floresta e seus saberes locais? Em Antropologia dos Archivos da Amazônia, ao debater a noçâo de "vazio geográfico" que orienta as açôes do governo federal, Almeida (2008a) demonstra como a antecedência hierárquica das terminologias advindas das ciências biológicas e geográficas, ao deslocar uma noção "microbial" à análise social do que denomina "populaçôes", simultaneamente nomeia e categoriza como "indivíduos biológicos" ou "tipos antropogeográficos" os grupos etnicamente diferenciados, sobrepujando suas especificidades e diminuindo-os. Açóes de governo assim informadas, alega o autor, percebem $o$ meio físico como uma "camisa de força" a ser superada pela "ocupação racional".

25 Instituto de Filosofia, Ciências Humanas e Sociais (IFCHS/UFRJ).

26 PPGAS/Museu Nacional.

27 Autor que desenvolve uma metodologia de cartografia participativa para levantar o olhar dos próprios habitantes locais sobre as formas como ocupam e manejam seus territórios (2008).

28 PNCSA/Universidade Federal do Amazonas (Ufam).

29 PPGCSPA/Universidade Estadual do Maranhão (Uema).

30 PPGA/Universidade Federal do Pará (UFPA). 
O antropólogo americano radicado no Brasil Paul Little (2006) ${ }^{31}$ examina, partindo de dentro da antropologia e se contrapondo à abordagem transdisciplinar, os significados da ecologia política recorrendo à antiga solução da antropologia de resolver seus dilemas teóricos por meio de sua metodologia. Little nos conduz por uma análise das diferentes aproximaçôes feitas pela antropologia com o mundo biológico, desde a ecologia cultural de Stewart. ${ }^{32}$ Para o autor, a introdução da economia política no paradigma ecológico deu visibilidade aos "choques entre sistemas produtivos (e) os vínculos entre as mudanças econômicas e a crise ambiental", para os quais a antropologia traria o aporte de ajudar a compreender "os sistemas produtivos e tecnologias que empregam, os recursos naturais que exploram e as ideologias que utilizam para justificar seu modo de adaptação e as reivindicaçóes territoriais que defendem" (Little, 2006, p. 87-88). Nessa esfera, a etnografia é antes de tudo a etnografia do conflito, que, por sua vez, é ambiental. Diferencia-se, assim, das pretensôes holísticas de uma etnografia clássica que pretende registrar o mais próximo da inteireza possível o sistema de vida de um grupo.

Em um esforço teórico fino por uma antropologia ambiental, Little localiza o que chama de "três princípios duros do paradigma ecológico", indicando-os como amparos metodológicos em uma aplicação etnográfica: o foco sempre em relaçóes (sociais, naturais ou socioambientais), em vez de objetos substantivos; a contextualização da análise; e o uso de métodos processuais com o acompanhamento dos fluxos e a identificação da di- nâmica interna dos processos. Voltaremos a essa perspectiva ao final deste trabalho.

\section{Mirando as sociedades complexas: a virada infraestrutural}

O período de tomada de consciência da dimensão da crise ecológica coincidiu com a expansão da industrialização e da infraestrutura seletiva da modernidade para zonas periféricas do capitalismo, mas também com o processo de descolonizaçáo e o crescimento dos movimentos sociais em um novo ciclo de conflitos. Surgem enquadramentos e recortes de estudos antropológicos voltados para as formaçóes do capitalismo que provocam a devastação.

Em tempos de implantação de estruturas físicas de urbanização, como os sistemas de transportes, de saúde e de educação do pós-guerra, tanto a teoria da modernização quanto o pensamento marxista dirigiam grande parte de seus esforços à compreensão de como estender tais benesses para as áreas não alcançadas por esse sistema, tomando o desenvolvimento como o projeto capaz de promover a justiça social. Mesmo quando se adotava um ponto de vista crítico, estudava-se a periferia — zonas de pobreza como o campesinato nordestino e suas secas - em sua distância tanto física quanto social e política em relação a um centro promotor dessa mudança civilizadora. Tratava-se de uma antropologia da falta de acesso a tais benesses.

Essa percepção nos ajuda a reconhecer a importância do momento em que Lygia Sigaud, em estudos do campesinato e seus conflitos, voltou seu olhar aos "marcos da

31 Então no PPGAS/UnB.

32 A etnoecologia de Conklin (1954), a ecologia neofuncionalista de Rappaport (1968), a ecologia humana de Moran (1990), a ecologia processual de Bennett (1993), ou a ecologia espiritual de Kinsley (1995). 
política estatal de geração de eletricidade, via construçáo de grandes barragens" e seus efeitos sobre os camponeses que produziam em áreas alagadas (Sigaud, 1986; 1992), para entendermos o impacto fundamental que esse desvio do olhar no recorte do objeto de pesquisa promoveu sobre a antropologia, principalmente na esfera internacional. Examinando as decisôes da política de hidroeletricidade como resultado de "relaçôes sociais que se estabelecem entre os diferentes agentes sociais, dos enfrentamentos e dos conflitos aí implicados", Sigaud (1992, p. 19) antecipa elementos da antropologia do Estado, do desenvolvimento e alguns dos pressupostos específicos da antropologia dos desastres, como veremos adiante.

Também nos anos de 1980, Gustavo Lins Ribeiro propóe-se a fazer uma antropologia "das sociedades complexas" que aproxima autores da sociologia e da geografia, como Wallerstein, Giddens e Harvey, por meio de uma etnografia multissituada. Inaugura, com significativo impacto na antropologia internacional, a antropologia dos grandes projetos. Examinando o fluxo dos trabalhadores especializados da construçáo da Barragem de Yacyretá, executada por um consórcio internacional de empresas na fronteira da Argentina com o Paraguai, o autor analisa como estes se afastam de suas identidades de origem "assumindo a identidade de habitantes permanentes do circuito migratório dos grandes projetos, a identidade de bichos-de-obra" (Ribeiro, 1992b, p. 37). Porém, o autor realiza muito mais que isso ao examinar etnograficamente a agência dos empreendimentos revelando a concretude dessas formaçóes institucionais complexas em suas dinâmicas de ocupação do espaço. Lins Ribeiro lança máo do conceito de "grandes projetos", ${ }^{33}$ que define como sendo:

um acontecimento do sistema mundial e um segmento privilegiado do mercado da construção civil disputado intensamente pelas maiores companhias transnacionais e nacionais que operam no setor (com) características particulares que tornam possível que os consideremos como uma forma de produçáo vinculada à expansão de sistemas econômicos. Mais características podem ser sinteticamente agrupadas sob três dimensóes: o gigantismo, o isolamento e a temporariedade (Ribeiro, 1987, p. 8).

Embora nem todos venham a concordar com o pioneirismo aqui atribuído a Lygia Sigaud e a Gustavo Lins Ribeiro nesse percurso, o recorte escolhido por esses dois autores e o uso que fizeram de seu instrumental etnográfico tiveram forte influência na antropologia internacional, recentemente reconhecida no importante seminário ocorrido na Universidade de Estocolmo, "Ethnographies of Megaprojects, Social and Political Worlds of Large Scale Infrastructures" (2019), celebrando a ocasiáo dos 25 anos dos estudos de Lins Ribeiro em Yacyretá e da "virada infraestrutural que dele derivou na antropologia e disciplinas relacionadas", citando, entre os autores influenciados, Anand, Appel e Gupta, além de Harvey, Jensen e Morita e Larkin, conforme anunciado em seu material de divulgação.

Para a antropologia pós-colonial que começava a se formar, o enquadramento de Lins Ribeiro dessas estruturas concretas, múltiplas e com efeitos tấo claramente visíveis na sociedade e na natureza forneceu

33 Mais adiante, em outros trabalhos, o autor mostra como estes contribuem para formar a autoimagem de modernidade no sistema-mundo wallersteiniano, marcada por obras monumentais que servem a cada país como uma espécie de ingresso de membro no concerto das naçôes (Ribeiro, 1992). 
uma linguagem para se pensar sobre as novas formas de colonização em ação na América Latina e na África. Ao promover a ideia de universalidade e da inexorabilidade da evolução dessa formação social propalada como "civilização", o discurso a concretiza. ${ }^{34}$ Ao assumirem-se como subdesenvolvidos, os países e regióes que ficaram fora da distribuição inicial passaram a aceitar tais metas de crescimento infinito e de implantação da infraestrutura de modernizaçáo sem maiores questionamentos (Ribeiro, 1992a).

No Brasil, Peter Schröder ${ }^{35}$ lança uma linha de pesquisa na área da antropologia do desenvolvimento e, com admirável persistência, procura traçar uma agenda de estudos especificamente antropológica e as especificidades desse subcampo, ressaltando a forma como este propicia e valoriza a participação de antropólogos em projetos socioeconômicos na América Latina e na África. ${ }^{36}$ Entre os quesitos apontados por esse autor está justamente a inclusão da etnografia das políticas de Estado, das instituiçóes e dos conflitos.

No Piauí, o Grupo de Pesquisas Antropologia do Desenvolvimento e do Meio Am- biente no Piauí (Adma), ${ }^{37}, 38$ também buscava entender "o que faz um antropólogo do desenvolvimento" atento às necessidades por etnografias em situações de confronto, porém percebendo a imprescindível interface com a antropologia do Estado (Souza Lima, 2012a). Seu programa de pesquisas afirma:

buscar na formação discursiva os elementos constitutivos de uma ordem (Escobar, 1995) que organiza os esforços institucionais e constrói uma rede de atores posicionados assimetricamente em um campo (Lins Ribeiro, 2009) no qual se estabelece uma correlação de forças a fixar prioridades e conduzir decisóes que impactam fortemente a vida de populaçóes locais (Peet, 1999) (Waddington, 2013, p. 4).

Mirando o sistema que promove a ameaça ao ambiente, a antropologia encontra o seu foco preferencial nas relaçóes sociais em disputa sob o tema do conflito, agora ambiental. José Sérgio Leite Lopes $(2006)^{39}$ mostra como velhos conflitos se "ambientalizam" em processos que implicam

34 Com geógrafos que se voltaram para a análise do (fracasso) dos planos de desenvolvimento europeus na África, um conjunto de autores dedica-se "a analisar como o termo desenvolvimento passou a significar 'mais de tudo para todos" (Peet; Hartwick, 1999, p. 156-158) ou tudo enquanto desejável e contra o qual ninguém se manifesta. Enquanto a narrativa oculta o investimento feito e mais ainda, a seletividade com que este ocorreu, essa valoração lança à condiçáo de inferioridade as regióes que ficaram fora dos investimentos do pós-guerra atribuindo a elas a culpa pelo próprio atraso em relação ao centro irradiador dessas formaçóes.

35 Universidade Federal de Pernambuco (UFPE).

36 Sua preocupação com a definição do campo manifesta-se desde o pós-doc, entre 1995 e 1996, e publicações como "A antropologia do desenvolvimento: é possível falar de uma subdisciplina verdadeira?" (1997), ao longo do projeto de pesquisa desenvolvido na UFPE, "A situação atual da antropologia do desenvolvimento em comparaçáo nacional e internacional" (2001-2003), até quando apresenta "Os desafios para uma antropologia do desenvolvimento no cenário atual”, na 29a Reuniāo Brasileira de Antropologia, em 2014.

37 Vinculado ao Programa de Pós-Graduação em Antropologia da Universidade Federal do Piauí (PPGAnt/UFPI, 2008-2014).

38 O Adma promoveu pesquisas sobre a chegada dos grandes projetos naquele estado, em especial a expansão da soja e da monocultura do eucalipto, barragens e ferrovia norte-sul, entre 2008 e 2014.

39 UFRJ/Museu Nacional. 
simultaneamente "transformaçôes no Estado e no comportamento das pessoas", por meio da incorporação e da naturalização de uma nova questão pública, transformando a linguagem e as formas de institucionalização de tais conflitos. Examinando conflitos entre sindicatos, a Companhia Siderúrgica Nacional (CSN) e o município de Volta Redon$\mathrm{da}$, o autor identifica os primeiros processos pela poluição dos rios e contaminação dos trabalhadores, possibilitados pela lei de ação civil pública de 1985, apontando novas instituiçóes e agentes que derivam das mudanças engendradas pela Reunião de Estocolmo (Unep, 1972). Novos recursos surgem no horizonte de lutas antigas por meio de um processo historicamente situado, gerando novas legitimidades e atitudes.

O problema ambiental multifacetado e complexo exige interdisciplinaridade e uma participação efetiva dos profissionais na arena da ecologia política. Nesse âmbito, nasce, em 2001, a Rede Brasileira de Justiça Ambiental (RBJA), a partir de um encontro na Universidade Federal Fluminense (UFF), organizado por Selene Herculano, ${ }^{40}$ Henri Acselrad ${ }^{41}$ e José Augusto Pádua, ${ }^{42}$ com apoio da Federação de Órgãos para Assistência Social e Educacional (Fase) e da Fundação Oswaldo Cruz (Fiocruz), incluindo discussões sobre raça e gênero no plano da justiça/injustiça ambiental. Quase simultaneamente, entre os anos 2000 e 2002, estrutura-se a Associação Nacional de Programas de Pós-Graduaçáo em Ambiente e Sociedade (Anppas), criando um importante fórum de discussão com congressos bianuais e a revista Ambiente $\&$ Sociedade, um dos principais espaços para publicaçôes sobre o tema. ${ }^{43}$

$\mathrm{O}$ encontro fundador da RBJA atraiu profissionais de diferentes áreas, como Sociologia, História e Direito, e sua importância pode ser avaliada, hoje, na maneira como estimulou a criação ou influiu na configuração de grupos de pesquisa e programas de pós-graduação, inaugurando algumas novas tecnologias de observação e controle de informaçôes. ${ }^{44}$ Esses novos instrumentos e ferramentas de pesquisa e acompanhamento, com "feed de notícias, links com redes sociais, biblioteca contendo diferentes modalidades de produçáo acadêmica, entre outras ferramentas que possibilitam a divulgação e a atualização direta das narrativas sobre con-

40 Laboratório de Estudos de Cidadania, Territorialidade e Ambiente (Lacta) e Programa de Pós-Graduação em Sociologia e Direito (PGSD/UFF).

41 Instituto de Pesquisa e Planejamento Urbano e Regional (Ippur/UFRJ).

42 Programa de Pós-Graduação de Ciências Sociais em Desenvolvimento, Agricultura e Sociedade/Universidade Federal Rural do Rio de Janeiro (CPDA/UFRRJ).

43 Participaram da fundação da Anppas, em 2000: o Procam/USP; o Núcleo de Estudos e Pesquisas Ambientais (Nepam/Unicamp); o Naea/UFPa; o Centro de Desenvolvimento Sustentável (CDS/UnB); o CPDA/UFRRJ; o Programa de Pós-Graduaçáo Interdisciplinar em Ciências Humanas/Universidade Federal de Santa Catarina (PPGICH/UFSC); o Doutorado em Meio Ambiente e Desenvolvimento (Made)/ Universidade Federal do Paraná (UFPR) e o Programa de Pós-Graduação em Desenvolvimento e Meio Ambiente (Prodema). Disponível em: http://www.anppas.org.br/novosite/index.php?p=historia. Acesso em: 26 mar. 2019.

44 Tais como: Mapa de conflitos ambientais, no Rio de Janeiro (2002, Ippur/UFRJ), Mapa da injustiça ambiental e saúde e Mapa de combate ao racismo ambiental, ambos organizados por Tânia Bacelar (2001, Fiocruz), Mapa dos conflitos ambientais em Minas Gerais, por Andréa Zhouri (2007) (Universidade Federal de Minas Gerais — UFMG) e o Observatório Socioambiental de Barragens (2014-2018), por Carlos Wainer e Henri Acselrad (Ippur/UFRJ). 
flitos ambientais" (Zhouri, 2016a, p. 56), facilitaram as "devolutivas" e os trabalhos de extensão nas comunidades atingidas.

Como corolário da crítica a Sobradinho (Sigaud, 1986; 1992), a produção antropológica sobre barragens multiplica-se tanto no Nordeste, com Negociaçôes e resistências persistentes: agricultores e a barragem de Itaparica num contexto de descaso planejado (Scott, 2009), ${ }^{45}$ quanto na Amazônia, no confronto do etnólogo Baines (1994; 1997 $)^{46}$ com a Usina Hidrelétrica de Balbina e o deslocamento dos Waimiri-Atroari por ela promovido. O Naea publica um fascículo dos Cadernos Naea intitulado "Na trilha dos grandes projetos: modernização e conflito na Amazônia", no qual consta artigo da socióloga Edna Castro, "Resistência dos atingidos pela Barragem de Tucuruí e construção de entidades" (Castro, 1989). Atualmente, a construção da Barragem de Belo Monte tem gerado artigos e relatórios como os de Sônia Magalhães para a Sociedade Brasileira para o Progresso da Ciência (SBPC) e para o Comitê de Povos Tradicionais e Megaprojetos da Associação Brasileira de Antropologia (ABA), que se manifestam publicamente. Criam-se os Encontros Latino-Americanos de Ciências Sociais e Barragens, e a análise das políticas de hidroeletricidade e dos Megaprojetos rapidamente se transforma em um campo rico de estudos transdisciplinares, com Grupos de Trabalhos (GTs) e simpósios temáticos na Associação Nacional de Pós-Graduação e Pesquisa em Ciências Sociais (Anpocs), na Anppas, nas Reuniôes Brasileiras de Antropologia (RBAs) e em outros congressos de ciências sociais, com um conjunto variado de cientistas sociais e seus parceiros transdisciplinares - como o engenheiro Célio Bermann. ${ }^{47,48}$

Um dos principais grupos atuantes nessa esfera transdisciplinar, liderado por Henri Acselrad e Carlos Wainer, constituiu-se em torno do Laboratório Estado, Trabalho, Território e Natureza (ETTERN), no Ippur/UFRJ, voltando-se para o tema da hidroeletricidade por meio da linha de pesquisa "Setor Elétrico, Território, Meio Ambiente e Conflito Social" (Setmacs). Já, em 2002, haviam produzido o Mapa dos conflitos ambientais do Rio de Janeiro e depois estruturam firmemente um trabalho em torno do Observatório Socioambiental de Barragens (Osab). ${ }^{49}$ Ressaltamos como exemplo de resultados aplicados o relatório das barragens (Brasil, 2012), produto de quatro anos de trabalhos financiados pela Secretaria Nacional de Direitos Humanos em colaboração com o Movimento de Atingidos por Barragens, que reúne informações objetivas sobre os modos de negociação e atuação das empresas e consórcios de energia para subsidiar as organizaçóes que pretendem reagir contra os processos de expulsão.

\footnotetext{
45 UFPE.

46 PPGAS/UnB.

47 Programa de Pós-Graduação em Energia (PPGE/USP).

48 Com produção bibliográfica voltada para o tema da energia nos livros Energia no Brasil: para quê? Para quem? Crise e alternativas para um país sustentável (2002, Editora Livraria da Física); As novas energias no Brasil: dilemas da inclusão social e programas de governo (2007, Editora Fase), e os múltiplos artigos, como "Analysis and perspectives of the government programs to promote the renewable electricity generation in Brazil" (2007) e "Crise ambiental e as energias renováveis" (2008).
}

49 Osab e ETTERN (2012-2018). 


\section{Uma trajetória profissional que exemplifica o encontro entre a(s) antropologia(s) do meio ambiente no brasil e os estudos dos desastres}

Ao iniciarmos nossa aproximação com a antropologia dos desastres, pensamos ser interessante descrever uma trajetória que ilustra o encontro entre os recortes ambientais da antropologia brasileira em sua imbricaçáo com a ecologia política. A atuação da antropóloga Andréa Zhouri ${ }^{50}$ e suas contribuiçóes teóricas assumem as formas impostas pelo multifacetado problema ambiental ao trabalho do antropólogo, ilustrando como este passa a ser um saber aplicado e produzido em uma prática coletiva institucional e interinstitucional, que envolve simultaneamente ensino, pesquisa e extensão, voltando-se para a realidade local e global. Zhouri apresenta um desenvolvimento teórico importante sobre conflitos ambientais e os limites das negociaçóes entre grupos locais, empresas e Estado, até que o rompimento das barragens em Mariana e Brumadinho colocam-na face a face com a antropologia dos desastres, a quarta parte deste artigo, que veremos em seguida.

Interessada desde sempre nas questôes ambientais e movimentos sociais, seu percurso inicia-se com uma inversão da lente eurocêntrica da etnografia em sua tese de doutoramento sobre ambientalistas europeus na Amazônia. Na UFMG, ajuda a instituir o primeiro bacharelado de ciências socioambientais no Brasil. Embora permaneça sempre em estreito contato interdisciplinar e em articulação com diferentes programas, demonstra ao mesmo tempo um aprofundamento cada vez maior na antropologia (transita do Programa de Sociologia para o de Antropologia e Arqueologia, que também ajuda a criar na UFMG, e tem participação em GTs, simpósios especiais e comitês da Anpocs ${ }^{51}$ e ABA).

Rejeitando a externalidade contida nas noçôes de "impacto ambiental", Zhouri e colegas focam no conceito de "conflitos ambientais" enquanto "contradiçôes nas quais as vítimas não só são excluídas do chamado desenvolvimento como também assumem todo o ônus dele resultante", em uma abordagem que vê o meio ambiente como "cerne de disputas entre sujeitos que sustentam projetos distintos de sociedade" (Zhouri; Laschefski, 2010 , p. 4). Os autores concordam com Acselrad (2004, p. 4), que define tais conflitos como decorrentes de diferentes "práticas de apropriação técnica, social e cultural do mundo material", em que a base cognitiva dos sujeitos e suas visôes de mundo entram em disputa, estimulando-os a se organizarem enquanto sujeitos coletivos, não passivos. ${ }^{52}$

Zhouri atua no Grupo de Estudos em Temáticas Ambientais (Gesta), ${ }^{53}$ com análises de licenciamentos de barragens, acompanhamento de audiências públicas, contri-

50 Programa de Pós-Graduação em Antropologia (PPGAn/UFMG).

51 Em especial, o GT “Conflitos Ambientais”, organizado por Horácio Antunes (UFMA) e Raquel Rigotto (Universidade Federal do Ceará - UFC), desde 2004.

52 Zhouri e Laschefski (2010) identificam três diferentes modalidades não excludentes desses conflitos como sendo: conflitos distributivos (derivados de desigualdades sociais e de acesso a recursos naturais e institucionais); conflitos espaciais (nos quais um dano extrapola determinado território, invadindo outro); e conflitos territoriais (nos quais processos de apropriaçấo de terras afetam a base territorial de determinados grupos). A sobreposição entre essas modalidades é comum.

53 UFMG/2001, em andamento. 
buindo na resoluçáo de conflitos em Minas Gerais, além de açôes políticas e serviços importantes às comunidades, gerando inúmeras teses, dissertaçôes, trabalhos de conclusão de curso e publicaçóes, adotando instrumentos desenvolvidos a partir da reuniáo de fundação da RBJA, tais como o Mapa dos conflitos ambientais e o Observatório de Conflitos Ambientais de Minas Gerais (2012-2014).

$\mathrm{O}$ foco de análise de Zhouri e de seu grupo inclui, gradualmente, os minerodutos de Minas Gerais. Aponta, com propriedade, para o fato de que a atividade mineradora precisa ser compreendida dentro de um complexo que envolve a construção de hidroelétricas, a infraestrutura de transporte e de energia, além da expansão dos grandes plantios de eucalipto (Oliveira; Zhouri; Laschefski, 2010). Associando-se a outros pesquisadores, como Edna Castro (Naea/UFPA), Zhouri publica Mineração na América do Sul: neoextrativismo e lutas territoriais (Zhouri; Bolados; Castro, 2016).

Essa necessária inserção da antropologia brasileira no tema da mineração decorreu da enorme predominância que esses projetos assumiram na América Latina a partir da década de 1990. A desregulamentaçáo jurídica operacionalizada no período neoliberal com um modelo de concessôes de isençôes fiscais e de uma legislação ambiental leniente, engendrado no Chile de Pinochet, favoreceu a implantaçáo desse segundo ciclo de grandes projetos em toda a PanAmazônia. ${ }^{54}$ Pesados investimentos transpuseram a mineraçáo de países como a Austrália e os Estados Unidos para a América Latina, que, em
1996, já concentrava três quartos da atividade mineradora mundial (Aráoz, 2009).

Ao relatar como o trabalho extensionista do Gesta o aproximou das comunidades atingidas por projetos de mineração das empresas MMX/Anglo American em Conceição de Mato Dentro, em um ambiente de violenta truculência contra os comunitários e pesquisadores, Zhouri e colegas revelam a dinâmica autoritária das empresas:

São corporaçóes que transcendem as fronteiras nacionais, amparadas por grandes instituições financeiras e influentes no âmbito nacional. Mas, ao aterrissarem nas localidades, territórios de comunidades tradicionais, também considerados enclaves econômicos na ótica desenvolvimentista, acabam por dialogar com forças políticas conservadoras do lugar, reativando, assim, práticas coronelistas históricas, pensadas como extintas pela modernidade (Zhouri, 2016a, p. 65-66).

O gigantismo e a rapidez desse processo de neocolonização extrativista reforçaram a importância da análise de megaprojetos de mineração, diante de uma nova geração de conflitos ambientais. Se a sequência de grandes desastres como Cubatão, Chernobyl e Bhopal já havia desafiado as análises sociais no sentido de uma reflexão sobre a ideia de risco por meio de Giddens e Ulrich Beck, ao se depararem com a concretude dos desastres de Mariana e Brumadinho, uma nova exigência de aprofundamento teórico confrontou pesquisadores como Andréa Zhouri,

54 Peru, Bolívia e Equador adotaram programa semelhante em 1991; México, em 1992; Argentina, em 1993; Brasil, em 1996; Guatemala, em 199; Honduras, em 1998; Colômbia, em 2001 (Aráoz, 2009). 
Edna Castro, ${ }^{55}$ Renzo Taddei ${ }^{56}$ e colegas sociólogos como Norma Valencio. ${ }^{57}$

\section{A vulnerabilidade e o risco na antropologia dos desastres}

A pesquisa antropológica define desastre como um processo socionatural que envolve a combinação de um agente potencialmente destrutivo de um ambiente natural elou tecnológico com uma população em condição de vulnerabilidade produzida social e economicamente, em que os riscos têm sido construidos sobre uma base social. (García Acosta, 2018b, p. 1, tradução livre da autora). ${ }^{58}$

Interessante notar que uma das principais autoras da antropologia dos desastres atua no México, terra ancestral dos Aztecas e sua "religião do dia final", na qual sacrifícios sangrentos eram celebrados para evitar o próximo cataclisma. Virginia García Acos$\mathrm{ta}^{59}$ credita o início da antropologia dos desastres a autores ingleses como Firth, em seu retorno a Tikopia após um furacão no final da década de 1950. Esses pioneiros ingleses examinavam a mudança cultural mediante tornados e maremotos, sendo seguidos por estudos sobre erupçóes vulcânicas e furacóes na Oceania. ${ }^{60}$ García Acosta aponta para o interesse inicial desses pioneiros pelas mudanças no comportamento individual e coletivo e os efeitos que teriam na cultura, atribuindo o elemento do perigo do fenô- meno natural à construção de determinada cosmovisão.

Embora a perspectiva multievolucionista de Julian Stewart nos anos de 1960 não tenha dado impulso, por si só, à antropologia dos desastres, na década seguinte suas ideias a respeito da adaptação socioambiental puderam ser consideradas após uma série de terremotos graves na Europa e América Latina, assim como tornados, secas e inundaçôes que começam a estimular surgimento do desastre como um campo com especificidades. Enquanto um ressurgimento do interesse antropológico pelas adaptaçóes culturais e socioambientais desponta na antropologia ambiental, na antropologia dos desastres surge um forte questionamento sobre o que haveria nestes de "natural". A partir do final dos anos de 1970, o filósofo Anthony Oliver-Smith torna-se seu principal expoente definindo claramente um campo de estudos.

García Acosta ressalta que mais do que diferenças disciplinares, a antropologia dos desastres se constitui por uma mudança de paradigma que deixa de atribuir ao desastre apenas os fatores externos (como o natural), para buscar neles fatores internos, como a crescente vulnerabilidade social que situa determinados grupos em posiçóes de risco: "o desastre é o encontro de determinada ameaça com uma população em condições de risco" (García Acosta, 2004, p. 129). Para essa autora, especificamente, os estudos de longa duração braudelianos e

\section{UFPA.}

56 Universidade Federal de São Paulo (Unifesp), Instituto do Mar.

57 Núcleo de Estudos e Pesquisas Sociais em Desastres/Universidade Federal de São Carlos (Neped/UFSCar).

58 No original: "Anthropological research defines a disaster as a socionatural process involving the combination of a potentially destructive agent from a natural and/or technological environment and a population in a socially and economically produced condition of vulnerability, in which risks have been constructed on a social basis".

59 Centro de Investigaciones y Estudios Superiores en Antropología Social (Ciesas).

60 Em uma honrosa e curiosa exceção latino-americana, o antropólogo cubano Fernando Ortiz publica El huracan: su mitologia y sus símbolos (1947), que explora "a mitologia e o simbolismo" associados ao tornado na ilha. 
a antropologia histórica são fundamentais para que os processos de construçáo do risco e das condiçôes de vulnerabilidade sejam compreendidos como processos de acumulaçáo gradual e complexa na inter-relação com ameaças naturais, o que dificilmente seria percebido por abordagens sincrônicas estruturalistas.

Como um bom exemplo desse procedimento, temos o alerta de que náo devemos confundir risco e vulnerabilidade, visto que, apesar de imbricados, não são a mesma coisa. Enquanto a vulnerabilidade é socialmente construída e se refere à relação entre pessoas e o ambiente, o risco é desigualmente distribuído (Oliver-Smith, 2015 apud García Acosta, 2018a, p. 228).

Mesmo que a aplicabilidade dessa perspectiva a desastres provocados por rompimentos de barragens de mineraçáo ou vazamentos radioativos seja praticamente direta, os autores ressaltam que na esfera dos discursos políticos a ideia de que desastres sejam resultados de acidentes, de ameaças naturais ou de atos divinos continua propalada, não importa quanto a ciência indique que os níveis de risco e vulnerabilidade são socialmente construídos. Para Oliver-Smith, quanto maior a tecnologia de previsibilidade e identificação de riscos, menor o investimento em prevenção, e maior aquele a favor da mitigação/resposta. Essa dinâmica acaba engendrando mais desastres e mais manipulaçóes discursivas na esfera política, como uma forma de se encobrir interesses econômicos por trás de determinadas escolhas. Como tais condições são decorrentes de relaçóes de poder internos à sociedade, na medida em que são "socialmente organizados, culturalmente aprovados, economicamente materializados e política e legalmente reforçados" (Garcia Acosta, 2018a, p. 4, tradução livre da autora), transformam-se em um sistema que apresenta uma regularidade padronizada.

Esse padrão sistêmico permite que pesquisadores utilizem modelagens para prever um aumento na quantidade de desastres derivados tanto de forças naturais quanto de complexos tecnológicos, e o autor recomenda que se atentem para os desastres de porte médio e pequeno, que constituem parte do mesmo sistema. Oliver-Smith e colaboradores indicam que "um conjunto de processos sociais e econômicos similares em todo o mundo" produz uma espécie de "epidemia" de desastres, cuja causa está sempre relacionada com um modelo de desenvolvimento econômico que privilegia o crescimento sobre a sustentabilidade ambiental (Oliver-Smith et al., 2017).

Essa visão aproxima-se do enfoque da socióloga Norma Valencio. ${ }^{61}$ Essa autora, com intensa produção nacional e internacional na área, ${ }^{62}$ coordena, com Juliano Gonçalves, o grupo de pesquisas Neped, no qual dirige projetos de pesquisa como "Crise, criatividade e transformação: identificação das dinâmicas de agravamento e de enfrentamento de desastres através da abordagem de sistemas complexos" (2016, em andamento). ${ }^{63}$

\section{UFSCar.}

62 "Vulnerability as social oppression: the traps of risk-prevention actions" (Valencio; Valencio, 2017) e "Consideraçóes sociológicas acerca de desastres relacionados a barragens e a atual desproteção civil de comunidades ribeirinhas conviventes com o megaempreendimento hídrico de Belo Monte" (Valencio 2017).

63 Além de "Dinâmica de desastres e conexôes com outras crises: proposiçâo de um quadro analítico orientado para o incremento de políticas de proteção civil e resiliência social" (2018, em andamento) e "Desastres no Brasil: uma análise socioespacial da vulnerabilidade institucional através da evolução da decretação municipal de situação de emergência (SE) e de estado de calamidade pública/ECP” (2012-2014), entre outros. 
Para reagir a essa falta de "eficácia simbólica" das informaçóes cientificas sobre a sociedade e o senso comum que consiga provocar um efeito político, Oliver-Smith recomenda uma análise metacientífica e pesquisas que aumentem a clareza da visibilidade da construção social dos riscos. Recomenda fortemente investimentos na educação ambiental, para "alimentar os programas educacionais em todos os países e em todos os níveis (não apenas aqueles relacionados ao risco de desastres diretamente, mas também às oportunidades educacionais voltadas a áreas baseadas em desenvolvimento e meio ambiente)", além de alimentar o senso comum com "mensagens-chave que possam remodelar valores, percepçóes e comportamentos" (Oliver-Smith et al., 2017, p. 100).

Nesse sentido, uma interlocução interessante se dá com o antropólogo Renzo Taddei, com inserção nos estudos sociotécnicos, ${ }^{64}$ que publica, por exemplo, "O lugar do saber local (sobre ambiente e desastres)" (2015); "Sobre a invisibilidade dos desastres na antropologia brasileira" (2014); e "Os desastres em uma perspectiva antropológica” (2016). ${ }^{65}$

Finalmente, Oliver-Smith ressalta que a identificação da construção de riscos que produz desastres se dá mediante estudo dos “objetivos conflitantes dentro das estruturas dos sistemas socioculturais" (Oliver-Smith et al., 2017 , p. 102). Se o risco deriva da acumulação da vulnerabilidade associada ao perigo, sua identificação serve como um "sinal de alerta" de situações que são sistêmicas e presentes em diversos lugares, de forma interligada.

\section{Por trás de cada grande desastre, um grande projeto de desenvolvimento}

Retomamos, à guisa de conclusão, a trajetória de Zhouri como uma metáfora da aproximação entre a antropologia ambiental brasileira, por meio de seus recortes diferenciados, com a antropologia dos desastres. $\mathrm{O}$ momento do rompimento da Barragem do Fundão, com a imediata morte de dezenove pessoas, assalta a nossa personagem com toda a sua bagagem de pesquisadora, trazendo-a diretamente para dentro da temática ${ }^{66}$ dos desastres, com toda a sua rede de autores e temáticas associadas.

Se a "antropologia do meio ambiente" se realizou por meio de estudos de conhecimentos locais sobre o manejo da biodiversidade ou por meio das análises dos efeitos das políticas de Estado sobre território e comunidades, os autores da temática dos desastres indicam que o "biggest culprit" (o maior culpado) por trás dos desastres costuma ser um modelo de desenvolvimento que não só orienta, empodera e estabelece condiçôes de risco e vulnerabilidade, mas também - de forma importante - permite, propicia e viabiliza sua complexificação.

Quando Zhouri e colegas se referem à interligação entre plantio de eucalipto, barragens, estradas e linhôes de energia com a instalação da atividade mineradora, revelam

64 Unifesp/Baixada Santista e Programa de Pós-Graduação em Ciências Sociais (PPGCS/Unifesp).

65 Esse autor coordena o projeto de pesquisa "Climate Services Through Knowledge Co-Production: a Euro-South American Initiative for Strengthening Societal Adaptation Response to Extreme Events” (2016, em andamento), além de dirigir o Laboratório de Pesquisas em Interaçóes Sociotecnicoambientais (Lista).

66 Publica "O desastre da Samarco e a política das afetaçôes: classificaçôes e açôes que produzem o sofrimento social" (2016b) e "O desastre da Samarco em Mariana: colonialidade e sofrimento social" (Zhouri et al., 2016), um dos capítulos do livro Mineração na América do Sul: neoextrativismo e lutas territoriais (Zhouri; Bolados; Castro, 2016). 
o sistema de riscos em criaçáo. Os autores chegaram a tal conclusão por meio de um conjunto de etnografias locais e de trabalhos autorais coletivos. Não há dúvidas de que a etnografia local - táo importante para a compreensão dos efeitos do desenvolvimento e da relação com o meio biofísico - é o principal instrumento da identificação da construção de riscos propalada por Oliver-Smith. No entanto, fica claro que a precisão da definição do campo da antropologia dos desastres indicada na abertura deste artigo denota não apenas o amadurecimento de determinado campo da antropologia ao longo de um percurso no sentido do "trabalho normal" de Kuhn, mas pelo objeto (desastres) que se apresentou de forma unívoca, inicialmente, enquanto a crise ambiental se apresentava à antropologia brasileira como uma questão geral e, por isso, necessariamente recortada.

García Acosta mostra como três abordagens que poderiam ser consideradas antagônicas em outra situação - a crítica (do conflito), a dos sistemas que tende à harmonia e a ecologia política - convivem, na análise metodológica dos desastres, sendo todas necessárias para que se identifiquem as inequidades da distribuição ou o risco. Enquanto a teoria dos conflitos identifica problemas que Zhouri chamaria "de distribuição", a análise de sistemas examina a inter-relaçáo entre as partes de um todo complexo (ecológico), na qual o aporte da ecologia política revela, como nos disse Little, quais são os sistemas de produção e os interesses econômicos em jogo.

Existe uma clara aproximação entre a antropologia dos desastres e o recorte do desenvolvimento na antropologia ambiental, tanto pela visão de conjunto quanto pelo entendimento da ordem discursiva enquanto condição de possibilidade das situaçóes etnográficas em estudo. Mas se a antropologia do meio ambiente precisou desdobrar-se para reenquadrar seus temas de pesquisa diante de questóes multifacetadas, os estudos dos desastres, mesmo com as imbricadas interfaces com os outros campos do conhecimento, seguiram um percurso conceitualmente menos angustiado nesse sentido. $\mathrm{O}$ encontro que se deu em tempos mais recentes sob a égide de uma nova fase do capitalismo mundial, na qual o gigantismo dos consórcios provoca consequências globais e locais táo perigosas, parecia predestinado, e a trajetória de Zhouri aqui descrita representa suas condiçóes.

Diante das exigências que o problema de estudo apresenta a seus praticantes, podemos dizer que ambas se resolvem na ecologia política da maneira como fora proposta por Little ainda em 2006: enquanto procedimento metodológico para a etnografia do conflito, cujo foco se deverá voltar tanto para as relações sociais quanto para as naturais ou socioambientais; por meio de uma contextualização; e de forma processual, identificando a dinâmica interna dos processos, ao mesmo tempo em que acompanha seus fluxos.

\section{Bibliografia}

ACSELRAD, H. (org.). Conflitos ambientais no Brasil. Rio de Janeiro: Relume-Dumará, 2004.

ALMEIDA, A. W. B. Terras tradicionalmente ocupadas processos de territorializaçáo e movimentos sociais. Revista

Brasileira Estudos Urbanos e Regionais, v. 6, n. 1, p. 9-32, maio 2004. https://doi.org/10.22296/23171529.2004v6n1p9 
ALMEIDA, A. W. B. Antropologia dos Archivos da Amazônia. Rio de Janeiro: Casa 8; Fundação Universidade do Amazonas, 2008a.

ALMEIDA, A. W. B. Terra de quilombo, terras indígenas, "babaçuais livre", "castanhais do povo", faxinais e fundos de pasto: terras tradicionalmente ocupadas. 2. ed. Manaus: PGSCA/UFAM, 2008b.

ALMEIDA, M. W. B. Dilemas da razão prática: simbolismo, tecnologia e ecologia na Floresta Amazônica. Anuário Antropológico, Editora Universidade de Brasília, Tempo Brasileiro, p. 213-226, 1986.

ALMEIDA, M. W. B. As colocaçốes como forma social, sistema tecnológico e unidade de recursos naturais. Terra Indígena, ano VII, n. 54, p. 213-226, 1990. http://dx.doi.org/10.5433/2176-6665.2012v17n1p121

ALMEIDA, M. W. B. The management of conservation areas by traditional populations: the Case of the Upper Jurua Extractive Reserve. In: REDFORD, K. H.; MANSOUR, J. A. (eds.). Traditional peoples and biodiversity conservation in large tropical landscapes. Arlington (VA): America Verde Publications; The Nature Conservancy, 1996. p. 137-157.

ALMEIDA, M. W. B.; CARNEIRO DA CUNHA, M. Global environmental changes and traditional populations. In: HOGAN, D.; TOLMASQUIM, M. T. (eds.). Human dimensions of global environmental changes: Brazilian perspectives. Rio de Janeiro: Academia Brasileira de Ciência, 2001. p. 79-98.

ARÁOZ, H. M. Auge minero y dominción neocolonial en América Latina. Ecología política de las transformaciones socioterritoriales neoliberales. In: CONGRESO DE LA ASOCIACIÓN LATINOAMERICANA DE SOCIOLOGÍA E VIII JORNADAS DE SOCIOLOGÍA DE LA UNIVERSIDAD DE BUENOS AIRES, 27., 2009, Buenos Aires. Anais [...]. Buenos Aires: Asociación Latinoamericana de Sociología, 2009, p. 1-16.

BAINES, S. G. A Usina Hidrelétrica de Balbina e o deslocamento compulsório dos Waimiri-Atroari. Brasília, DF: UnB, 1994. p. 1-15 (Série Antropologia, 166). Disponível em: http://dan.unb.br/images/doc/Serie166empdf. pdf. Acesso em: 1 maio 2020.

BAINES, S. G. A Uma tradição indígena no contexto de grandes projetos: os Waimiri-Atroari. Anuário Antropológico, v. 21, n. 1, p. 67-81, 1997. Disponível em: https://periodicos.unb.br/index.php/anuarioantropologico/article/ view/6660. Acesso em: 14 maio 2020.

BARRETTO FILHO, H. T. Da naçáo ao planeta através da natureza: uma tentativa de abordagem antropológica das unidades de conservação na Amazônia. Brasília, DF: UnB, 1997. (Série Antropologia, 222).

BARRETTO FILHO, H. T. A história da conservação da natureza no Brasil como uma peleja moral. In: URBAN, T. (coord.). Saudade do Matáo: relembrando a história do conservacionismo no Brasil. Curitiba: UFPR, 1998. p. $279-284$.

BARRETTO FILHO, H. T. Utopias tecnológicas, distopias ecológicas e contrapontos românticos: "populaçóes tradicionais" e áreas protegidas nos trópicos. Sexta-Feira, v. 6, p. 139-152, 2001.

BARRETTO FILHO, H. T. Natureza. In: SOUZA LIMA, A. C. (coord.). Antropologia e direito: temas antropológicos para estudos jurídicos. Brasília, DF; Rio de Janeiro; Blumenau: Associação Brasileira de Antropologia; LACED; Nova Letra, 2012a. p. 103-109.

BARRETTO FILHO, H. T. Meio ambiente. In: SOUZA LIMA, A. C. (coord.). Antropologia e direito: temas antropológicos para estudos jurídicos. Brasília, DF; Rio de Janeiro; Blumenau: Associação Brasileira de Antropologia; LACED; Nova Letra, 2012b. p. 346-355.

BATESON, G. Steps to an ecology of mind. New York: Ballantine, 1972.

BERMANN, C. Energia no Brasil: para quê? Para quem? Crise e alternativas para um país sustentável. São Paulo: Editora Livraria da Física, 2002. 
BERMANN, C. As novas energias no Brasil: dilemas da inclusão social e programas de governo. Rio de Janeiro: Editora FASE, 2007a.

BERMANN, C. Analysis and perspectives of the government programs to promote the renewable electricity generation in Brazil. Energy Policy, v. 35, n. 5, p. 2.989-2.994, 2007 b.

BERMANN, C. Crise ambiental e as energias renováveis. Revista Ciência e Cultura, v. 50, n. 3, p. 20-29, set. 2008.

BRASIL. Projeto de Lei no 2.057, 23 de outubro de 1991. Dispóe sobre o Estatuto das Sociedades Indígenas. Brasília, DF: Câmara dos Deputados, 1991. Disponível em: https://www.camara.leg.br/proposicoesWeb/fichad etramitacao?idProposicao=17569. Acesso em: 8 maio 2020.

BRASIL. Conselho de Defesa dos Direitos da Pessoa Humana. Relatório final. Comissão Especial "Atingidos por Barragens”. Resoluçōes nos 26/06, 31/06, 01/07, 02/07, 05/07. Brasília, DF: CDDPH, 2012.

CARNEIRO DA CUNHA, M.; ALMEIDA, M. W. B. Indigenous people, traditional people and conservation in the Amazon. Daedalus - Journal of the American Academy of Arts and Sciences, v. 129, n. 2, p. 315-338, 2000.

CARNEIRO DA CUNHA, M.; ALMEIDA, M. W. B. (orgs.). Enciclopédia da floresta: o Alto Juruá - práticas e conhecimentos das populaçôes. São Paulo: Companhia das Letras, 2002.

CARVALHO, I. A invençáo ecológica: narrativas e trajetórias da educação ambiental. Porto Alegre: Editora da UFRGS; São Paulo: Cortez, 2001.

CARVALHO, M. B. Articulaçóes para o desenvolvimento da floresta: populaçóes locais e políticas públicas em torno da natureza na microrregiáo de Cruzeiro do Sul - Acre. 2013. Tese (Doutorado em Antropologia Social) — Universidade Estadual de Campinas, Campinas, 2013.

CASTRO, E. M. R. Resistência dos atingidos pela Barragem de Tucuruí e construção de entidades. Cadernos Naea, n. 10, p. 41-70, 1989. Na trilha dos grandes projetos: modernizaçáo e conflito na Amazônia.

CONGRESSO INTERNACIONAL DE ETNOBIOlOGIA, 1., 1988, Belém. Declaraçáo de Belém. Belém: MPEG, jul. 1988.

CROSBY, A. W. Imperialismo ecológico: a expansão biológica da Europa 900-1900. Traduçâo de José Augusto Ribeiro e Carlos Afonso Malferrari. São Paulo: Companhia das Letras, 2011.

DALGALARROTO, P. Natureza e cultura na definiçáo e delimitaçáo do humano: debates e disputas entre antropologia e biologia. 2013. Tese (Doutorado em Antropologia Social) - Universidade Estadual de Campinas, Campinas, 2013.

DIEGUES, A. C. S. Etnoconservaçáo: novos rumos para a conservaçâo da natureza. 1. ed. São Paulo: Hucitec; Nupaub/USP, 2000.

DIEGUES, A. C. S. O mito moderno da natureza intocada. 6. ed. São Paulo: Hucitec; Nupaub/USP, 2008.

ETHNOGRAPHIES OF MEGAPROJECTS, SOCIAL AND POLITICAL WORLDS OF LARGE SCALE INFRASTRUCTURES. Sweden: Stockholm University, Sept. 12-13, 2019.

GARCÍA ACOSTA, V. La perspectiva histórica en la antropología del riesgo y del desastre. Acercamientos metodológicos. Relaciones - Estudios de Historia y Sociedad, v. 25, n. 97, p. 123-142, 2004.

GARCÍA ACOSTA, V. Vulnerabilidade y risco. In: ROCHA, M. G., SARAVI, G. Vulnerabilidad y pobreza: debates y estudos contemporâneos en México. Ciudad de México: Centro de Investigacion y Estudos em Antropologia Social, 2018a. p. 212-239. 
GARCÍA ACOSTA, V. Disasters, Anthropology of. In: THE INTERNATIONAL ENCYCLOPEDIA OF ANTHROPOLOGY. Hoboken, NJ: John Wiley \& Sons, 2018b. https://doi.org/10.1002/9781118924396. wbiea1763

GOODMAN, A. H.; LEATHERMAN, T. L. (eds.). Building a new biocultural synthesis: political-economic perspectives on human biology. Ann Arbor: University of Michigan Press, 1998.

HOLLING, C. S.; SANDERSON, S. Dynamics of (dis)harmony in ecological and social systems. In: HANNA, S. S.; FOLKE, C.; MÄLER, K. (eds.). Rights to nature. Washington: Island Press, 1996. p. 57-85.

INGOLD, T. The appropriation of nature: essays in human ecology and social relations. Iowa: University of Iowa Press, 1987.

INGOLD, T. The perception of the environment: essays in livelihood, dwelling and skill. London: Routledge, 2000.

LAW, J. Technology and heterogeneous engineering: the case of Portuguese expansion. In: BIJKER, W. E.; HUGHES,

T. P.; PINCH, T. (eds.). The social construction of technological systems. Cambridge: MIT Press, 1987. p. 111-134.

LEITE LOPES, J. S. Sobre processos de "ambientalização" dos conflitos e sobre dilemas da participação. Horizontes Antropológicos, ano 12, n. 25, p. 31-64, jan./jun. 2006. http://dx.doi.org/10.1590/S010471832006000100003

LITTLE, P. E. Ecologia política como etnografia: um guia teórico e metodológico. Horizontes Antropológicos, v. 12, n. 25, p. 85-103, 2006. http://dx.doi.org/10.1590/S0104-71832006000100005

LITTLE, P. E. Territórios sociais e povos tradicionais do Brasil: por uma antropologia da territorialidade. Anuário Antropológico, v. 28, n. 1, p. 251-290, 2018.

MURA, F. À procura do "bom viver”: território, tradição de conhecimento e ecologia doméstica entre os Kaiowa. Rio de Janeiro: Associação Brasileira de Antropologia, 2019.

OLIVEIRA, J. P. Redimensionando a questão indígena no Brasil: uma etnografia das terras indígenas. In: OLIVEIRA, J. P. (org.). Indigenismo e territorializaçáo. Rio de Janeiro: Contra Capa Livraria, 1998. p. 15-42.

OLIVEIRA, R.; ZHOURI, A.; LASCHEFSKI, K. A supressão da vazante e o início do vazio: água e "insegurança administrada" no Vale do Jequitinhonha - MG. Anuário Antropológico, v. 2, p. 23-53, 2010.

OLIVER-SMITH, A. Hazards and disaster research in contemporary anthropology. In: WRIGHT, J. D. International Encyclopedia of the Social and Behavioral Sciences. 2. ed. Amsterdam: Elsevier, 2015. p. 546-553.

OLIVER-SMITH, A.; ALCÁNTARA-AYALA, I.; BURTON, I.; LAVELL, A. A construção social do risco de desastres: buscando as causas de fundo. In: MARCHEZINI, V.; WISNER, B.; LONDE, L. R.; SAITO, S. M. (orgs.). Reduçáo de vulnerabilidade ao desastre: do conhecimento à ação. São Carlos: Rima, 2017. p. 97114. Disponível em: https://www.researchgate.net/publication/324135848_A_construcao_social_do_risco_de_ desastres_buscando_as_causas_de_fundo. Acesso em: 25 mar. 2019.

ORTIZ, F. El huracán su mitología y sus símbolos. 1. ed. Ciudad Mexico: Fondo de Cultura Económica, 1947.

PÁDUA, J. A. Espacio público, intereses privados y política ambiental. Nueva Sociedad, n. 122, p. 156-163, nov./ dic. 1992.

PEET, R.; HARTWICK, E. Theories of development. London: Guilford Press, 1999.

PRADO, R. M. Viagem pelo conceito de populaçôes tradicionais, com aspas. In: STEIL, C. A.; CARVALHO, I. C. M. (orgs.). Cultura, percepçóes e ambiente: diálogo com Tim Ingold. São Paulo: Terceiro Nome, 2012. p. 73-187. 
RIBEIRO, G. L. Cuanto mas grande mejor? Proyectos de gran escala, una forma de produccion vinculada a la expansion de sistemas economicos. Desarrollo Economico, n. 105, p. 3-27, 1987.

RIBEIRO, G. L. Ambientalismo e desenvolvimento sustentado: ideologia e utopia no final do seculo XX. Ciência da Informaçáo, v. 21, n.1, p. 23-31, 1992a.

RIBEIRO, G. L. Bichos-de-obra. Fragmentação e reconstrução de identidades. Revista Brasileira de Ciências Sociais, n. 18, p. 30-40, 1992 b.

SANT'ANNA, R. Sistema Nacional de Unidades de Conservaçáo: reflexôes antropológicas sobre a elaboração de uma lei ambiental. 2003. Dissertação (Mestrado em Sociologia) — Universidade Federal do Rio de Janeiro, Rio de Janeiro, 2003.

SCHRÖEDER, P. A antropologia do desenvolvimento: é possível falar de uma subdisciplina verdadeira? Revista de Antropologia, v. 40, n. 2, p. 83-100, 1997. https://doi.org/10.1590/S0034-77011997000200003

SCHRÖEDER, P. Os desafios para uma antropologia do desenvolvimento no cenário atual. In: REUNIÃO BRASILEIRA DE ANTROPOLOGIA, 29., 2014, Natal. Anais [...]. Natal: RBA, 2014. p. 1.531.

SCOTT, P. Negociaçóes e resistências persistentes: agricultores e a barragem de Itaparica num contexto de descaso planejado. Recife: Editora Universitária da UFPE, 2009.

SIGAUD, L. Efeitos sociais de grandes projetos hidrelétricos: as barragens de Sobradinho e Machadinho. In: ROSA, L. P.; SIGAUD, L.; MIELNIK, O. (orgs.). Impactos de grandes projetos hidrelétricos e nucleares. Aspectos econômicos, tecnológicos, sociais e ambientais. São Paulo: Marco Zero, 1986. p. 83-166.

SIGAUD, L. O efeito das tecnologias sobre as comunidades rurais: o caso das grandes barragens. Revista Brasileira de Ciências Sociais, v. 7, n. 18, 18-40, 1992.

SOUZA LIMA, A. C. Dossiê Fazendo Estado. O estudo antropológico das açóes governamentais como parte dos processos de formação estatal. Revista de Antropologia, v. 55, n. 2, p. 559-564, 2012a.

SOUZA LIMA, A. C. Antropologia e direito: temas antropológicos para estudos jurídicos. 1. ed. Rio de Janeiro; Brasília: Contra Capa, 2012b.

SOUZA LIMA, A. C.; BARRETTO FILHO, H. T. (orgs.). Antropologia e identificaçáo: os antropólogos e a identificação de terras indígenas no Brasil, 1977-2002. Rio de Janeiro: Contra Capa Livraria, 2005.

STEIL, C.; CARVALHO, I. (orgs.). Cultura e ambiente: diálogo com Tim Ingold. São Paulo: Editora Terceiro Nome, 2012.

TADDEI, R. Sobre a invisibilidade dos desastres na antropologia brasileira. Waterlat-Gobacit Network Working Papers, v. 2, p. 20-30, 2014.

TADDEI, R. O lugar do saber local (sobre ambiente e desastres). In: SIQUEIRA, A.; VALENCIO, N.; SIENA, M.; MALAGOLI, M. A. (orgs.). Riscos de desastres relacionados à água: aplicabilidade de bases conceituais das ciências humanas e sociais para a análise de casos concretos. 1. ed. São Paulo: Rima, 2015. p. 311-327.

TADDEI, R. Os desastres em uma perspectiva antropológica. Com Ciência, v. 176, p. 1, 2016.

UNEP - United Nations Environment Programme. Declaration of the United Nations Conference on the Human Environment. Stockholm: Unep, 1972.

VALENCIO, N. Consideraçóes sociológicas acerca de desastres relacionados a barragens e a atual desproteção civil de comunidades ribeirinhas conviventes com o megaempreendimento hídrico de Belo Monte. In: MAGALHÃES, S. B.; CUNHA, M. C. (orgs.). A expulsão de ribeirinhos em Belo Monte. Relatório da SBPC. 1. ed. São Paulo: SBPC, 2017. p. 167-202. 
VALENCIO, N.; VALENCIO, A. Vulnerability as social oppression: the traps of risk-prevention actions. In: MARCHEZINI, V.; WISNER, B.; LONDE, L.; SAITO, S. (orgs.). Reduction of vulnerability to disasters: from knowledge to action. 1. ed. São Carlos: Rima Editora, 2017. p. 115-141.

WADDINGTON, M. A antropologia do desenvolvimento e meio ambiente no Piauí: a busca por um arcabouço teórico e metodológico. In: REUNIĀO EQUATORIAL DE ANTROPOLOGIA, 4., 2013; REUNIA̧O DE ANTROPÓlOGOS DO NORTE E NORDESTE, 13., 2013, Fortaleza. Anais [...]. Fortaleza: REA; Abanne, 2013.

ZHOURI, A. Tempos de forja e de Gesta: um percurso acadêmico por entre ambiente, cultura e poder. Belo Horizonte: UFMG, 2016a. Memorial elaborado como requisito para a designaçáo de Professora Titular da Carreira do Magistério Superior da UFMG.

ZHOURI, A. O desastre da Samarco e a política das afetaçôes: classificaçôes e açôes que produzem o sofrimento social. Ciência e Cultura, v. 68, n. 3, p. 36-40, jul. 2016b. http://dx.doi.org/10.21800/2317-66602016000300012

ZHOURI, A.; BOLADOS, P.; CASTRO, E. M. R. (orgs.). Mineraçáo na América do Sul: neoextrativismo e lutas territoriais. 1. ed. São Paulo: Annablume, 2016.

ZHOURI, A.; LASCHEFSKI, K. (orgs.). Desenvolvimento e conflitos ambientais. Belo Horizonte: Editora da UFMG, 2010. v. 1.

ZHOURI, A.; VALENCIO, N.; OLIVEIRA, R.; ZUCARELLI, M.; LASCHEFSKI, K.; SANTOS, A. F. M. O desastre da Samarco em Mariana: colonialidade e sofrimento social. In: ZHOURI, A.; BOLADOS, P.; CASTRO, E. (orgs.). Mineraçáo na América do Sul: neoextrativismo e lutas territoriais. 1. ed. São Paulo: Annablume, 2016. p. 45-66. 


\title{
Migrações e deslocamentos: balanço bibliográfico da produção antropológica brasileira entre 1940 e 2018
}

\author{
Bela Feldman-Bianco ${ }^{\mathrm{I}}$ \\ Liliana Sanjurjo ${ }^{\text {II }}$ \\ Douglas Mansur da Silva ${ }^{\text {III }}$
}

À memória de Giralda Seyferth (1943-2017)

\section{Introdução}

Neste texto, apresentamos um balanço bibliográfico parcial da produção antropológica brasileira sobre migraçóes e deslocamentos entre 1940 e 2018, com especial atenção aos avanços obtidos na última década (2008-2018). Com base nesse levantamento e análise de uma série de resenhas sobre a temática publicadas entre 1988 e 2018, visamos examinar o estado da arte dessa área de estudos, considerando a sua interdisciplinaridade e destacando a relação entre conjunturas históricas, problemáticas de pesquisa e paradigmas teórico-metodológicos adotados através de tempos e espaços.

A fim de proporcionar melhor compreensão da produção antropológica e suas interfaces com outras disciplinas, oferecemos primeiramente um sintético panorama histórico das relaçôes entre questôes migratórias, economia política, racialização, estruturas de dominação, desigualdades sociais e formação de nação. Não obstante a relação existente entre migração, raça e nação ter norteado o pensamento social brasileiro, escritos acadêmicos sobre a temática migratória no âmbito da institucionalização das ciências sociais foram inaugurados somente em 1940, com a publicação de Assimilação e populaçôes marginais no Brasil, de Emílio Willems (Seyferth, 1997, 2004b). Como veremos, entre as décadas de 1940 e fins de 1980 - quando prevalecia certa indiferenciação entre as ciências sociais - , pesquisadores centralizaram a sua atençáo nos antigos contingentes migratórios de várias nacionalidades que se radicaram no sul e no sudeste do país, priorizando o uso das categorias imigração e imigrantes. Se, entre 1940 e fins de 1970, predominaram abordagens assimilacionistas diversas, na década de 1970 novas pesquisas começaram a adotar paradigmas da etnicidade, relacionando nação e identidade étnica (Seyferth, 1982), com destaque para a utilização das noçóes comunidade étnical grupo étnico e fronteiras étnicas, propostas por Frederick Barth (1969).

\footnotetext{
IUniversidade Estadual de Campinas - Campinas (SP), Brasil. E-mail: bfb@uol.com.br IIUniversidade do Estado do Rio de Janeiro - Rio de Janeiro (RJ), Brasil. E-mail: lilisanj@yahoo.com.br IIIUniversidade Federal Fluminense - Volta Redonda (RJ), Brasil. E-mail: douglasmansur@id.uff.br
} 
Na década de 1990, estudiosos passaram a privilegiar a relaçáo entre emigração e imigração em uma conjuntura marcada pelos deslocamentos de brasileiros para o exterior, iniciados durante o governo Collor no contexto da crise global da década de 1980. Observa-se também um renovado interesse na imigração histórica no Brasil (Trpin; Jardim, 2015; Cavalcanti; Oliveira, 2018). Com o redirecionamento dos fluxos migratórios do sul para o norte global, surgiram novas temáticas de pesquisa e novos paradigmas transnacionais para a abordagem de campos e redes sociais de migrantes internacionais entre países de origem e recepção (Glick-Schiller; Basch; Blanc-Szanton, 1992; Feldman-Bianco, 1992) ou a formação de comunidades transnacionais (Kearney; Nagengast, 1989). Além do mais, em vez de se restringirem às categorias dicotômicas emigração e imigração, novos conceitos foram formulados entre $1990 \mathrm{e}$ os anos 2000 para salientar as relaçöes entre os movimentos de pessoas, signos e capitais ou as mobilidades e a relação entre circulação e globalização. Mais recentemente, novas propostas teórico-metodológicas procuram evitar o persistente nacionalismo metodológico que impregna os estudos migratórios (Glick-Schiller; Çaglar, 2011; Feldman-Bianco, 2011b; 2015; 2018a).

Conquanto a maioria das etnografias focalize migrantes radicados no Brasil ou os assim chamados brasileiros no exterior, desde a década de 1990 têm surgido projetos comparativos entre Brasil e outros países (Feldman-Bianco, 1997a; 2000a; 2001; 2011b; 2012; 2018a; Piscitelli, 2013; Trpin; Jardim, 2015; Pinto; Baeza, 2017). Embora em número reduzido, antropólogos e antropólogas do Brasil também têm conduzido investigaçôes sobre migrações e deslocamentos, principalmente na Améri- ca Latina, na América do Norte, na África e na Ásia, sem quaisquer relaçóes com os emigrantes brasileiros ou os imigrantes no Brasil (Feldman-Bianco, 1992; 1995; 1996; 1999; 2000b; 2009; 2011b; 2012; Hernandez, 2011; Lobo, 2014b; Thomaz, 2004b; 2006). Nota-se ainda progressivo empenho no acompanhamento de políticas migratórias, especialmente no que concerne à relação entre governabilidade tecnocrática, direitos humanos e securitização em um contexto marcado pela criminalizaçáo das migraçóes e dos deslocamentos. Sobretudo na última década, pesquisas com foco nos novos fluxos migratórios sul-sul - especialmente do Haiti, da África, da América Latina e da Ásia - estáo suscitando novas questôes sobre fronteiras, refúgio e refugiados. Ao mesmo tempo, novos paradigmas teórico-metodológicos enfatizam a necessidade de se levar em conta as várias escalas e tipos de deslocamento como parte dos mesmos processos sociais na atual conjuntura neoliberal (Feldman-Bianco, 2015; 2017; 2018a) e/ou lançam mão do conceito de tecnologias de governo, elaborado por Foucault (Fonseca et al., 2016).

Esses desenvolvimentos indicam a necessidade de se examinar historicamente a formação do campo de estudos sobre migraçóes e deslocamentos nas ciências sociais brasileiras e na antropologia, especialmente. Com base nesse panorama mais amplo sobre a produção do conhecimento, deter-nos-emos à avaliaçáo da literatura em três diferentes períodos históricos: entre 1940 e a década de 1980; os desdobramentos ocorridos entre 1990 e 2008; e os avanços obtidos na última década (2008-2018). Com base nesse balanço processual (e parcial) da bibliografia existente, poderemos delinear os avanços alcançados, assim como as limitaçóes e os desafios a serem confrontados. 


\section{Migrações e deslocamentos: contextualizações históricas}

Nossa perspectiva histórica e processual demanda considerar que embora a mobilidade humana seja milenar, os deslocamentos de pessoas pelo mundo se tornaram parte da formação do capital ainda durante a era das Grandes Navegaçôes e das exploraçôes marítimas, imbricando-se, assim, com a "invenção" da raça, o colonialismo, a expansão capitalista e as resultantes estruturas de dominação e desigualdades (Quijano, 2000; Feldman-Bianco, 2015). Posteriormente, com a formação do Estado nação no século XVIII, as construçóes de alteridade e a racializaçáo do outro - além do indígena, do negro, também do estrangeiro - passaram a constituir ameaças imanentes por trazerem à tona a questáo da cidadania e a relação entre o Estado e a nação (Bourdieu, 2004). Não por acaso, a seleçáo, o controle e a fiscalização sobre quem pode ou náo entrar, circular e sair por meio das fronteiras nacionais tornaram-se monopólio estatal. $\mathrm{O}$ aparato burocrático estatal abrangeu a criação de leis, políticas e regimes de identificação por meio da emissão de documentos destinados ao reconhecimento e ao controle de nacionais e não nacionais. Desse prisma, Torpey (1999) argumenta que os Estados-naçóes modernos e o sistema estatal internacional "monopolizaram os 'meios legítimos de movimento" de pessoas, tornando-as dependentes da autoridade estatal para se movimentarem especialmente, embora não exclusivamente, por meio das fronteiras internacionais.

O invento do passaporte em 1919 possibilitou o reconhecimento recíproco de documentos de viagem entre os Estados-naçóes (Torpey, 1999). Em seguida, como mostram Betts e Kainz (2017), a emissão de status de refúgio e documentos de viagem pelo Alto
Comissariado para Refugiados da antiga Liga das Naçóes permitiu acesso à Europa aos grupos deslocados pelo colapso de impérios. Essas iniciativas, em conjunto com uma série de convençóes elaboradas pela Organização Internacional do Trabalho entre 1925 e 1929 sobre os direitos dos trabalhadores aplicados às migraçôes, propiciaram as bases iniciais para a efetiva constituição de um regime global das migraçôes no decorrer das duas últimas décadas do século XX (Betts; Kainz, 2017). Já as principais estruturas criadas após a Segunda Guerra Mundial foram dirigidas aos refugiados. Embora formulada na década de 1990, a Convenção Internacional sobre os Direitos de todos os Trabalhadores Migrantes e suas Famílias entrou em vigor somente em 2003, e vários países, incluindo o Brasil, deixaram de ratificá-la.

A intensificaçáo dos deslocamentos humanos por meio de fronteiras nacionais em direção ao Norte Global - especialmente os do leste europeu e do norte da África à Comunidade Europeia, com o processo de regionalização da política migratória no espaço Schengen — norteou a expansão e a profissionalização de organizaçóes internacionais dedicadas à formulação e à exportação de políticas migratórias globais, inclusive para países da América do Sul. Essas políticas globais, de forte influência neoliberal, que enfatizam a governança migratória, combinando proteção às fronteiras e aos migrantes e que culminaram no Pacto Global das Migrações, estáo sendo acompanhadas por um crescente rigor no controle e na fiscalização por meio de medições biométricas e tecnologias de identificação dos sujeitos migrantes (Feldman-Bianco, 2018b; Dias, 2018).

Nesse cenário, as classificaçôes de migrantes e outras populaçóes subalternas, abarcando também raça, racialização e gênero, tornaram-se constitutivas das violências 
estruturais e estatais no passado e no presente. Tensóes e ambiguidades envolvendo projetos migratórios têm se interligado constantemente à problemática racial e à diferenciação histórica entre migrantes considerados desejáveis e indesejáveis. Nesse tocante, Seyferth (2002) nos adverte que, no caso brasileiro, a questão racial esteve implícita nos projetos imigrantistas desde 1818, ainda antes do termo raça fazer parte do nosso vocabulário científico e de preocupaçóes com a formaçáo nacional. Contudo, ressalta que a construção social da superioridade branca enquanto justificativa de um modelo de colonização centrado na pequena propriedade familiar, com base na vinda de imigrantes europeus, só ocorreu mais objetivamente a partir de meados do século XIX e, portanto, em uma conjuntura de formação de nação e de ideologias eugênicas e higienistas.

Não por acaso, como observa Domenech (2015), diante das ideologias racistas, as políticas migratórias estabelecidas na América do Sul — e não só no Brasil — visavam predominantemente ao branqueamento das naçóes por meio do recrutamento de determinados imigrantes europeus considerados os mais brancos e, como tal, agentes da civilização e do progresso. Essas políticas classificavam como indesejáveis os chineses, os doentes físicos e mentais, os "subversivos" - nomeadamente os anarquistas - e os delinquentes, marginais e transgressores de leis jurídicas e morais, como as prostitutas (também conhecidas como escravas brancas), os traficantes de prostitutas ou de entorpecentes.

Apesar de eventuais mudanças de legislação, as políticas de segurança nacional se perpetuaram e se intensificaram no decorrer do século XX, com períodos de maior exacerbação de nacionalismos, como no Brasil durante a Campanha de Nacionalização do
Estado Novo (1937-1945), na ditadura civil militar (1964-1985) e desde a posse de Bolsonaro em janeiro de 2019. No limiar do século XXI, junto ao processo de regionalização da política migratória ligado à constituição de um regime global de controle das migraçóes internacionais, as políticas de regulação tecnocrata de fluxos migratórios engendraram novas formas de organizar e classificar os fluxos migratórios, eventualmente adotadas pelos países sul-americanos. As antigas categorias e classificaçôes de indesejáveis foram subsumidas nas "novas ameaças" estabelecidas pela comunidade internacional, como o narcotráfico, o terrorismo, o tráfico de pessoas e a migração indocumentada (Domenech, 2015).

\section{Anos 1940-1980. A constituição de um campo de estudos sobre imigração no Brasil. De perspectivas assimilacionistas ao foco em etnicidade: temas e debates}

Como assinala Seyferth (2004b), a questão imigratória no Brasil tem sido estudada desde a segunda metade do século XIX por várias áreas de conhecimento, existindo vasta historiografia que inclui literatura produzida por imigrantes radicados no país. Nesse cenário, talvez não seja circunstancial o envolvimento de antropólogos e sociólogos imigrantes e descendentes de imigrantes na delimitação e no desenvolvimento do campo de estudos imigratórios nas ciências sociais brasileiras. As primeiras pesquisas de cunho antropológico e sociológico sobre a temática foram conduzidas pelo imigrante alemão Emilio Willems, docente da Faculdade de Filosofia, Letras e Ciências Humanas (FFL$\mathrm{CH}$ ) da Universidade de São Paulo (USP) e da Escola Livre de Sociologia e Política (ELSP) entre 1936 e 1948, em um período 
em que a formação em Ciências Sociais era recente e contava com o apoio de missóes estrangeiras.

Em uma conjuntura global de exacerbados nacionalismos e ideologias assimilacionistas, quando a Campanha de Nacionalização do Estado Novo (1937-1945) forçava o abrasileiramento (ou o caldeamento) e, portanto, a supressão das diferenças culturais e linguísticas da população alienígena (Seyferth, 2004b, p. 5), Willems (1940) priorizou inicialmente os conceitos de assimilação e marginalidade. Embora crítico da ditadura, seu Assimilação e populaçôes marginais no Brasil (Willems, 1940) — no qual salienta a resistência dos imigrantes alemães à assimilação — influenciou ao menos um oficial do Exército a pensar a nacionalização enquanto um processo educativo (Seyferth, 1997). Entrementes, como Oliveira (2018) nota, suas publicaçóes indicam uma lenta mudança da adoção de um modelo racial-assimilacionista para um modelo de transformaçôes culturais por meio de processos de aculturação de grupos imigrantes (Willems, $1940 ; 1941 ; 1944 ; 1946 ; 1947)^{1}$. Com observações de campo sobre processos de aculturação, suas opçóes teórico-metodológicas foram influenciadas por perspectivas assimilacionistas da antropologia e sociologia americanas com foco no contato cultural, representadas pela Escola de Chicago, liderada por Robert Redfield, assim como pelo culturalismo boasiano de Melville Hersko- witz, que lhe haviam sido apresentadas por Donald Pierson, professor da ELSP entre 1939 e 1959.

Dada a expansão dos interesses internacionais norte-americanos no Pós-Guerra e o influxo de novas verbas, Pierson conseguiu criar na ELSP um projeto institucional dirigido à divulgação e ao desenvolvimento da antropologia e da sociologia culturalista americana em São Paulo, que contou inclusive com um Programa de Pós-Graduação em Antropologia (Taniguti, 2018). Tendo em vista sua parceria com Pierson e a disponibilidade de verbas, Willems teve condiçóes de desenvolver projetos de investigaçáo que contaram com alunos tanto da USP quanto da ELSP (como Florestan Fernandes e Hiroshi Saito) e com colegas de ambas as universidades (como Herbert Baldus, da ELSP²; Egon Schaden e Gioconda Mussolini, da USP) ${ }^{3}$.

A imersão de Willems na literatura culturalista americana o levou a lançar, em 1946, uma edição expandida de seu livro sobre os alemães do Vale do Itajaí, intitulada $A$ aculturação dos alemães no Brasil (Seyferth 2004a; 2004b), assim como a realizar o primeiro estudo de comunidade no Brasil, conduzido no município de Cunha, São Paulo, cuja primeira edição veio a lume em 1948. Em um período em que o foco no contato cultural era predominante na antropologia e não só nos estudos migratórios, as investigaçóes sistemáticas de Willems sobre fenô-

1 A década de 1950, vários estudos utilizaram o paradigma da aculturação: entre outros, Wilson Martins (1989), sobre fenômenos de aculturação no Paraná; Fuji e Smith (1959), sobre a aculturação de imigrantes no Brasil; e Schaden (1956; 1957; 1973), sobre a aculturaçáo de japoneses e alemães no Brasil.

2 Embora Baldus e Egon Schaden fossem especialistas em etnologia indígena, ambos compartilhavam com Willems o interesse pela questão imigratória no país, assim como o foco em contato cultural e aculturação (vide Schaden, 1956), que, aliás, era à época também predominante nas investigaçốes sobre os índios no Brasil.

3 Seus estudos experimentais sobre imigrantes japoneses resultaram em artigos colaborativos com Herbert Baldus (Baldus; Willems, 1941; Willems; Baldus, 1942) e com o imigrante japonês Hiroshi Saito (Saito; Willems, 1947). 
menos presentes na vida de imigrantes foram reconhecidas, nas ciências sociais brasileiras, inclusive por seus críticos (Taniguti, 2018). Comparativamente, as suas tentativas de articular a análise de mudanças culturais por meio da aculturação com o estudo de comunidade foram alvo de ataques ferrenhos de Caio Prado Jr. (1948), Florestan Fernandes (1949) e seus discípulos — entre os quais, Carvalho Franco (1963), Cardoso de Oliveira (1964) e Ianni (1961b) — , assim como por Guerreiro Ramos (1948), Costa Pinto (1950), Manuel Diegues Jr. e Arthur Neiva (1956), entre outros.

Mesmo antes de externar sua crítica aos estudos de comunidade, Fernandes (1949), que fora assistente de pesquisa de Willems na investigação conduzida em Cunha, já havia manifestado a sua insatisfação com os enfoques culturalistas em artigo publicado ainda em 1948 na revista Sociologia, coeditada por Willems (Jackson, 2009). Para Taniguti (2018), essa visão crítica aos estudos de comunidade, junto à participação no projeto Tensions Affecting International Understandings (1947-1951) da Organização das Naçôes Unidas para a Educação, a Ciência e a Cultura (UNESCO), que abarcava tanto a temática racial quanto a da imigração, foram fundamentais para a elaboração de seus paradigmas sociológicos em uma conjuntura de pós-guerra, quando questóes relativas à industrialização e ao desenvolvimento econômico e social se tornavam centrais nas agendas de pesquisas de cientistas sociais.
Naquele contexto, novas abordagens sobre a questão imigratória, ancoradas em debates internacionais no âmbito desse projeto, com destaque à contribuiçãa de Samuel Noah Eisenstadt (1954; 1956) sobre a absorção e adaptação econômica de imigrantes nos processos de modernização em Israel, progressivamente passaram a utilizar a noção de integração para examinar as contribuiçóes positivas dos imigrantes às sociedades de destino ${ }^{4}$. Da mesma forma, Fernandes, cujo projeto original de doutorado havia sido sobre a religião de imigrantes sírio-libaneses para o qual realizou pesquisa parcial (Brasil Jr., 2010), priorizou análises assimilacionistas com foco na integração de imigrantes na sociedade de

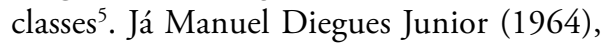
participante ativo do projeto Tensóes, destacou a relação entre Imigração, urbanização, industrialização. No caso de Fernandes, dada a sua participação também no projeto da UNESCO sobre relaçóes raciais no Brasil (Bastide; Fernandes, 1959), seus paradigmas incluíam perspectivas comparativas entre imigrantes e descendentes de escravos, no que tange à superposição entre raça e classe enquanto obstáculos à integração dos negros em uma sociedade de classes brasileira permeada por uma antiga ordem escravocrata que, em última análise, obstruía o florescimento da democracia no país $^{6}$. Como Cavalcanti e Oliveira (2018) relembram, também Alberto Guerreiro Ramos (1948), outro conhecido estudioso das

4 The positive contribution by immigrants, organizado por Handlin (1955), foi um dos livros resultantes desse projeto, que conta com um capítulo sobre o caso brasileiro de autoria de Emílio Willems. Outro livro, The cultural integration of immigrants, organizado por Borrie (1956), conta com contribuições de 17 países, entre os quais o Brasil, cujo capítulo é de autoria de Diegues Jr. e Neiva (1956).

5 Com base nessa pesquisa desenvolvida na década de 1950, Fernandes publicou artigos sobre sírio-libaneses, em 1956 e 1967.

6 Vide "Imigração e Relação Raciais" (Fernandes, 1966). 
relaçôes raciais no Brasil, abordou a relação entre imigração e preconceito.

Fernandes (1964; 1966) destacou a mobilidade social ascendente dos imigrantes em comparação às barreiras vivenciadas pelos descendentes de escravos, inclusive no mercado de trabalho. Essa formulação fundamentou o projeto de relaçóes raciais no Brasil Meridional, compreendendo uma série de investigaçôes conduzidas por alguns de seus discípulos sob sua coordenação, que resultaram em importantes publicaçóes ${ }^{7}$. Entre as várias publicaçóes advindas desse projeto, o estudo conduzido por Octavio Ianni em Curitiba sobressai por revelar os preconceitos sofridos pelos imigrantes poloneses, conhecidos pejorativamente como "polacos" (Oliveira, 2018). Entretanto, provavelmente em razão da ênfase dada à mobilidade social de imigrantes, ele se mostrou surpreso em descobrir que a discriminação e o preconceito não atingiam apenas descendentes de escravos africanos, mas também imigrantes poloneses (Ianni, 1960; 1961a; 1966). Se esses resultados indicam os limites de uma análise centrada táo somente nas relaçôes dicotômicas entre brancos e negros, o foco na mobilidade social de imigrantes incorre no perigo de se expor sua pretensa "integraçáo" na sociedade de classes unicamente como empreendedores ou trabalhadores, desconsiderando eventuais questóes relacionadas à etnicidade $e$ às diferenças culturais nos jogos de poder ${ }^{8}$.

Conquanto as perspectivas centradas na modernização e na integração de imigrantes na sociedade de classes começassem a dife- renciar, segundo Fernandes, a sociologia e a antropologia feitas no Brasil, suas concepçóes em conjunto com as de Eisenstadt exerceram certa influência nos estudos antropológicos sobre migraçôes. Basta lembrar que, apesar de Egon Schaden - expoente do enfoque de contato cultural nos estudos etnológicos e imigratórios - designar Eunice Durham e Ruth Cardoso a pesquisarem, respectivamente, imigração italiana (Durham, 1966) e imigração japonesa (Cardoso, 1959; 1963), ambas fizeram uso dos paradigmas de Fernandes e Eisenstadt. Posteriormente, em uma época de intensa migração interna, Durham (1973), deslocando-se dos estudos imigratórios para uma investigaçáo da migração rural-urbana, que refletia também seu interesse nas temáticas da família e da construção da periferia, valeu-se das abordagens de Eisenstadt na elaboração de seu clássico A caminho da cidade: a vida rural e a migração para São Paulo. Também Ruth Cardoso (Cardoso; Durham, 1972; Cardoso, 1994) enveredou em pesquisas sobre movimentos sociais na periferia com foco em populaçóes migrantes.

Entretanto, independentemente das várias contribuiçóes, tanto no que tange aos estudos que priorizam o contato cultural quanto a integração e a mobilidade social, chama a atenção a persistência por quase 40 anos de perspectivas assimilacionistas, sejam elas centradas na aculturação de imigrantes, sejam centradas em sua integração na sociedade de classes. Trata-se de uma literatura que tendeu a examinar a imigraçáo quase que exclusivamente na sociedade de destino

7 Por exemplo: Cor e mobilidade social em Florianópolis, de Fernando Henrique Cardoso e Octávio Ianni (1960); Capitalismo e escravidão no Brasil meridional. O negro na sociedade escravocrata do Rio Grande do Sul, de Fernando Henrique Cardoso (1962); e As Metamorfoses do Escravo. Apogeu e crise da escravatura no Brasil Meridional, de Octávio Ianni (1962).

8 Esse é o caso, por exemplo, do estudo de José de Souza Martins (1973) Conde Matarazzo: o empresário e a empresa. 
e a identificar imigrantes de acordo com suas nacionalidades a priori definidas e, portanto, naturalizadas, refletindo o nacionalismo metodológico já predominante naquela época.

Nesse contexto, Homens sem paz: os conflitos e os bastidores da emigração italiana, de Constantino Ianni (1963), foge à regra ao examinar criticamente a emigraçáo de italianos para as Américas e, especialmente, para o Brasil, antecipando-se em duas décadas à perspectiva transnacional de migrações (Glick-Schiller; Basch; Blanc-Szanton, 1992; Basch; Glick-Schiller; Szanton-Blanc, 1994). Centrando seu estudo na emigraçáo, Constantino Ianni revela as políticas do Estado italiano que produziam emigrantes e estimulavam a sua contínua ligação com a terra natal como parte constitutiva de sua política interna e internacional, assim como os interesses da indústria migratória que norteiam a emigraçáo e seus beneficiários. Ao mesmo tempo, retrata o drama da emigração, inclusive o retorno daqueles que não fizeram a "América", e o impacto da emigração na sociedade de origem. Essas problemáticas surgirão com força a partir da década de 1990, nos estudos migratórios realizados por antropólogos e antropólogas do Brasil especialmente, mas não apenas, nas investigaçôes sobre a migraçáo de brasileiros para o exterior.

Nos anos de 1970, ainda baseados em enfoques assimilacionistas, vários trabalhos sobre a questâo imigratória fo- ram publicados, entre os quais Azevedo (1975), Borges Pereira (1974), Vieira (1973), Saito e Maeyama (1973), Martins (1973) e Schaden (1973). Nessa década, segundo Oliveira (2018), a temática da imigração lentamente perdeu a importância na sociologia em razáo da primazia do conceito de classe social ante as noçóes de etnia, integração e aculturação, resultando em certa invisibilidade da questão imigratória. $\mathrm{Na}$ antropologia, enquanto os movimentos migratórios do campo para a cidade atraíam a atenção de pesquisadores, a noção de etnicidade ganhou ímpeto após a publicação de Ethnic Groups and Boundaries: The Social Organization of Culture Difference, de Fredrick Barth, $\mathrm{e}$ de Custom and Politics in Urban Afri$c a$, de Abner Cohen, ambos em 1969'. Como corolário, a partir de meados dos anos 1970, em um período de criação de Programas de Pós-Graduação em Antropologia Social, caracterizados pela inter-relação entre pesquisa e docência e formação de novas gerações de antropólogos, as prevalentes perspectivas assimilacionistas começaram a ser substituídas por paradigmas que priorizam as noçóes de etnicidade, grupo étnico e fronteiras étnicas não só nos estudos imigratórios, mas na antropologia em geral e, principalmente, nos campos mais amplos da etnologia indígena e (outras) populaçóes tradicionais ${ }^{10}$.

9 Vale ainda salientar que a ênfase em etnicidade também ocorreu em um período de mudança de ideologias nos Estados Unidos, da assimilação ao pluralismo cultural (Govers; Vermeulen, 2000).

10 As perspectivas da etnicidade foram influenciadas por duas vertentes da antropologia britânica: a de Edmund Leach, no caso de Fredrick Barth, e a da Escola de Manchester, no que concerne a Abner Cohen. A noção de "fricções étnicas" de Roberto Cardoso de Oliveira (1976) igualmente recebeu influências das etnografias manchesterianas. No que se refere à abordagem de Barth, seus preceitos extrapolaram o campo de estudos migratórios, exercendo especial influência nas áreas de etnologia indígena e outras populaçóes tradicionais por permitir expor os processos de autoidentificação do grupo étnico enquanto grupo de interesse, tornando-se ferramenta importante na elaboração de pareceres relacionados à demarcação de terras indígenas e quilombolas. 
Esses (então) novos paradigmas certamente renovaram os rumos da investigação com base, no entanto, em certas continuidades. Giralda Seyferth, referência obrigatória nos estudos antropológicos sobre imigraçáo no Brasil, destacou-se por examinar as relaçóes entre imigração, colonizaçáo e a antropologia do campesinato e das classes trabalhadoras, bem como por expor as conexóes intrínsecas entre nação, raça, minorias étnicas, relaçóes interétnicas, racismo e xenofobia com base em análises etno-históricas. Dessa perspectiva, voltou-se ao estudo dos antigos contingentes de imigrantes alemães do Vale do Itajaí-Mirim, em Santa Catarina, região da qual é originária e que havia sido foco das investigações de Emílio Willems.

No Mestrado, sob orientação de Luiz de Castro Faria, Seyferth focalizou os processos de formação, organização e estratégias de reprodução do campesinato alemão e seu papel no desenvolvimento regional desde a vinda dos primeiros contingentes de imigrantes à região, como parte da política de colonização do Estado brasileiro. Nessa pesquisa, Seyferth (1974) também se beneficiou de interlocuçóes com Francisca Keller (já referenciada como Francisca Vieira, 1973), cuja tese sobre imigração japonesa havia sido influenciada pelos preceitos de Eisenstadt, assim como de outros participantes do Projeto Comparativo de Desenvolvimento Regional: Nordeste e Centro-Oeste, então coordenado por Roberto Cardoso de Oliveira, no Museu Nacional. Com base nessa perspectiva, Seyferth contestou, com base em dados etno-históricos, a interpretação de Willems sobre a origem artesanal da industrialização de Brusque, demonstrando a existência de capital comercial local, a potencialidade de um mercado regional consumidor e a disponibilidade de mão de obra, assim como os processos de proletarização que começaram a ocorrer após a Segunda Guerra Mundial, quando as atividades industriais suplantaram as atividades agrícolas. Já em sua tese de doutorado, Nacionalismo e Identidade Étnica, orientada por Ruth Cardoso e publicada em 1982, apoiou-se nas abordagens de Barth e Weber a fim de examinar a ideologia germanista e o grupo étnico teuto-brasileiro no contexto da história de colonização e desenvolvimento de uma localidade do Vale do Itajaí. Ao mesmo tempo, continuou a focalizar a relação entre nação e minorias étnicas e a utilizar as noções de assimilação, aculturação e integraçâo de imigrantes na localidade (e país) de imigração.

Para além das relaçóes entre nação e identidade étnica, etnicidade e cidadania (Seyferth, 1983), assim como entre imigração, colonização e identidade étnica (Seyferth, 1987), Seyferth contribuiu, já na década de 1980, para discernir as relaçôes entre imigração e raça no pensamento social brasileiro. Enquanto as análises com foco em classe social e teoria da modernização enfatizaram a mobilidade social dos imigrantes em detrimento dos antigos escravos, ela dedicou atenção às conexôes entre imigração, miscigenação e branqueamento (Seyferth, 1985; 1986; 1991), trazendo à tona questóes relacionadas às hierarquias raciais e ao racismo (Seyferth, 1996; 2000; 2002), também estudadas por Ramos (1996). Contribuiu ainda para um conhecimento detalhado sobre políticas de colonização e imigração através do tempo (Seyferth, 1990; 2000; 2002). Não por acaso, durante a sua trajetória, Seyferth não só orientou pesquisas sobre os anti- 
gos contingentes de imigrantes de várias nacionalidades que se fixaram no Brasil, como Bahia (2000), Blanchette (2001), Mansur da Silva (2007), Moraes (1996), Renk (1990) e Santos (2004), como também orientou dissertações e teses sobre relaçóes raciais e étnicas, focalizando afro-brasileiros ou, ainda, populaçóes indígenas, entre outros temas ${ }^{11}$.

Por sua vez, em Negros estrangeiros: os escravos libertos e sua volta à África, Maria Manuela Carneiro da Cunha (1985) descortinou os limites da liberdade e de cidadania confrontados por esses migrantes forçados que haviam sido alforriados, examinando suas reconstruçóes identitárias. Combinando o estruturalismo de Lévi-Strauss com o processualismo de Abner Cohen e sua experiência enquanto estudiosa de questóes identitárias entre os Krahó, Carneiro da Cunha (1985) desvendou os complexos meandros da construção de identidade étnica, indicando como esses "brasileiros" procuraram manter, com base em suas experiências específicas, a língua portuguesa, o catolicismo como religião, assim como o calendário de rituais festivos brasileiros através das geraçōes. Várias publicações se seguiram sobre a volta de ex-escravos à África (cf., por exemplo, Guran, 2000).

Como veremos, nas décadas de 1990 e 2000, estudiosos das migraçóes internacionais persistiram em centralizar sua atenção às problemáticas relacionadas às identidades, à etnicidade e à cidadania. Voltaram-se também à investigação e ao acompanhamento de políticas migratórias e à construção da "ilegalidade", assim como ao estudo do mercado de trabalho laboral e, nesse contexto, à análise do retorno como parte do processo migratório. A opção por essas temáticas deve-se diretamente ao crescente redirecionamento dos movimentos migratórios do Sul global para o Norte global — especialmente dos brasileiros para o exterior - e, consequentemente, às novas formas securitárias de organizar os fluxos migratórios e classificar os indesejáveis em um cenário de expansão de ideologias e retóricas multiculturalistas no Norte global.

\section{Anos 1990-2000. Da inter-relação entre imigração e emigração aos movimentos transnacionais de pessoas, símbolos e capitais}

Em seu balanço sobre os estudos migratórios realizados no decorrer das duas últimas décadas do século XX, Assis e Sasaki (2001) nos informam que, não obstante o revigorado foco nas migraçóes históricas para o Brasil, menor atenção foi dedicada aos contingentes que chegaram ao país desde os anos 1970, oriundos, em sua maioria, da Coreia, da América Latina - particularmente da Bolívia — e da África. Notaram, entretanto, uma proliferação de estudos sobre as novas migraçóes de brasileiros que se espalhavam pelo mundo principalmente a partir da segunda metade dos anos 1990, a maioria em situação indocumentada. Esses desenvolvimentos expandiram o campo de estudos das migraçóes internacionais, resultando na criação de novos grupos de

11 Para melhor compreensão da trajetória intelectual de Seyferth, ver Santos e Reinheimer (2019). 
trabalho, linhas de pesquisa e centros de investigações sobre a temática ${ }^{12}$. Ao mesmo tempo, geraram novas questóes de pesquisa relacionadas especialmente à migração indocumentada, ao trabalho e à cidadania, ao gênero e a interseccionalidades e reconfiguraçôes identitárias no contexto de políticas norte-americanas e europeias de crescente securitização e, nesse sentido, à necessidade de adoçáo de novos paradigmas teórico-metodológicos ${ }^{13}$.

Nesse cenário, como parte do renovado interesse pelo estudo das migraçóes históricas com base em paradigmas que enfatizavam a identidade e a etnicidade, o grupo de pesquisa interdisciplinar História Social da Imigração para São Paulo (1880-1950), formado ainda no final dos anos 1980 no Instituto de Estudos Econômicos, Sociais e Políticos de São Paulo (IDESP), sob a coordenação de Boris Fausto e Sérgio Miceli, centralizou predominantemente a sua atençáo nas relaçóes entre imigração, mobilidade social e etnicidade no espaço urbano. Estudos de caso focalizando antigos contingentes de imigrantes de várias nacionalidades que haviam se radicado em cidades paulistas, resultaram em várias publicaçôes sobre Fazer a América (Fausto, 1999). Equacionando nacionalidade e grupo étnico, essas pesquisas focalizaram, entre outros, a mobilidade social de sírio-libaneses (Truzzi, 1991), as conexôes entre negócios e família entre armênios (Grün, 1992), os médicos italianos (Salles, 1997), a relação entre imigração e política (Fausto et al., 1995) e, ainda, o cancioneiro japonês (Sakurai, 1993) e a relação entre imigração e futebol (Araújo, 2000) no país de destino.

Também começaram a surgir, a partir da segunda metade da década de 1980, estudos no âmbito da antropologia brasileira sobre migraçôes transnacionais sem conexão com o Brasil, como a pesquisa etno-histórica de Bela Feldman-Bianco sobre os significados

12 Entre fins da década de 1980 e o ano 2000, foram criados, entre outros, o grupo de pesquisa interdisciplinar História Social da Imigração para São Paulo (1880-1950) no IDESP; o CEMI do Instituto de Filosofia e Ciências Humanas (IFCH) e linhas de pesquisa no NEPO, no Centro de Memória e no Núcleo de Estudos de Gênero Pagu, na Unicamp; um grupo de pesquisas sobre migraçôes internacionais no Centro de Estudos Rurais e Urbanos (CERU)/USP, além da formação do Núcleo Interdisciplinar de Estudos Migratórios (NIEM) na Universidade do Estado do Rio de Janeiro (UERJ) e que, posteriormente, foi transladado como laboratório e grupo de pesquisa para o Instituto de Pesquisa e Planejamento Urbano e Regional (IPPUR) da Universidade Federal do Rio de Janeiro (UFRJ). A missão do NIEM, de formação de uma biblioteca sobre migraçôes, refúgio e mobilidade espacial, resultou em um importante informativo diário sobre essas questôes a nível global, assim como diversas coletâneas com base na promoçáo de seminários sobre temáticas migratórias (Ferreira et al., 2010; Povoa Neto; Ferreira, 2005; Povoa Neto; Santos; Petrus, 2016; Santos et al., 2014; Seyferth et al., 2007; Zanini; Povoa Neto; Santos, 2013). Periódicos como Travessias, da Missão Paz, Revista Interdisciplinar da Mobilidade Humana (REMHU), do Centro Scalabriano de Estudos Migratórios (criada em 2006), e o Caderno de Debates sobre Migraçóes, Refúgio e Cidadania, do Instituto Migraçôes e Direitos Humanos (IMDH) vinculado à Congregação das Irmãs Scalabrianas, tornaram-se importantes veículos de difusão de pesquisas sobre as temáticas em pauta. Ademais, novos núcleos e laboratórios de pesquisa, tais como o Laboratório de Estudos Migratórios (LEM) da Universidade Federal de Sáo Carlos (UFSCar) e o Observatório das Migraçôes Internacionais (OBMigra) na Universidade de Brasília (UnB), assim como novos grupos e linhas de pesquisa sobre migrações e refúgio, foram criados por uma nova geração de pesquisadores.

13 A realização de estudos sobre brasileiros no exterior resultou também na atuação política de pesquisadores em defesa dos direitos de cidadania desses migrantes transnacionais, como já havia acontecido no passado, desde Emílio Willems, com relação aos imigrantes no Brasil. Essa atuação política também ocorre no presente, especialmente no que concerne aos migrantes transnacionais e outros deslocados residentes em várias localidades e regiōes do país. Embora merecendo atenção e análise, essa temática não pôde fazer parte do escopo desta resenha. 
das múltiplas temporalidades e espacialidades portuguesas inscritas em New Bedford, cidade secularmente conhecida como a capital dos portugueses nos Estados Unidos. Deparando-se, naquela época, com a reestruturação da economia política global, novas imaginaçôes de nação baseadas em população em vez de território, políticas norte-americanas que favoreciam a migração em cadeia e a renovaçáo dos contingentes migratórios em cidades americanas, pesquisadores da questão migratória nos Estados Unidos passaram a questionar o persistente foco nos "desenraizados" e noçôes tradicionais sobre migração, nacionalismo e cidadania restritas ao país de destino.

Em uma fase de elaboração da perspectiva transnacional das migraçóes (Glick-Schiller; Basch; Blanc-Szanton, 1992), quando se indagava se o transnacionalismo e a transmigração eram fenômenos novos ou antigos, Feldman-Bianco (1992) indicou que, embora imigrantes portugueses tivessem mantido conexôes com suas localidades de origem, a renovação desses contingentes migratórios entre as décadas de 1960 e 1980 resultou no aumento de suas conexôes, por meio da intensificação de campos sociais e práticas transnacionais e, ao mesmo tempo, em exacerbações de seu localismo como enclave étnico na cidade. Dessa perspectiva, analisou as construçóes diferenciais de gênero, classe, etnicidade e nacionalismo como produtos de forças que se estendem além da comunidade local e abrangem as construções raciais embutidas nos processos de reconfiguração da nação tanto em Portugal quanto nos Estados Unidos (Feldman-Bianco, 1991; 1992). Fazendo uso da linguagem visual e em diálogo com E. P. Thompson (1967) sobre a transição do "tempo natural" para o "tempo disciplinado do capitalismo industrial", seu estudo revelou como, nessa cidade industrial americana, homens e mulheres de origem rural, que se tornaram operários industriais, viviam simultaneamente essas distintas temporalidades e espacialidades, e como essa simultaneidade, exacerbada pela reelaboração no cotidiano de símbolos e práticas sociais associadas ao passado rural na terra natal, afetava as relações de gênero e entre gerações na casa transmigrante (Feldman-Bianco, 1991; 1997a; 1998; 1999).

Em uma conjuntura marcada por emergentes debates sobre globalização e o iminente desaparecimento dos Estados-naçôes, incluindo o Brasil (Ianni, 1992; Ortiz, 1996), Feldman-Bianco (1995) demonstrou, ao contrário, os processos de reconfiguração do Estado pós-colonial português e de suas narrativas nacionais em um contexto de restruturação do capitalismo global e de mudanças nos modos de governabilidade. Se o seu estudo de caso realizado nos Estados Unidos a levou a examinar a construção de uma nação desterritorializada portuguesa que incorpora sua população disseminada pelo mundo, sua pesquisa comparativa dos movimentos migratórios entre Portugal e Brasil the permitiu vislumbrar o aumento de controle nas fronteiras nacionais contra $o$ ingresso de imigrantes considerados indesejáveis e, desse ângulo, o simultâneo e inter-relacionado processo de reterritorialização do Estado pós-colonial português à Europa Fortaleza (Feldman-Bianco, 1995; 2001). Essa análise trouxe à tona questôes sobre colonialismo e pós-colonialismo, assim como a necessidade de uma abordagem mais ampla sobre as migrações, abrangendo não só os movimentos transnacionais de pessoas, mas também de símbolos, produtos e capitais (Feldman-Bianco, 2001).

Essa perspectiva mais ampla das migraçôes fundamentou o programa interdisciplinar e interinstitucional de pesquisas Identi- 
dades: Reconfiguraçôes de Cultura e Política - do Programa de Apoio a Núcleos de Excelência (Pronex) do Ministério da Ciência e Tecnologia (MCT)/Conselho Nacional de Desenvolvimento Científico e Tecnológico (CNPq) —, realizado entre 1997 e 2004 sob coordenação de Feldman-Bianco, no então recém-formado Centro de Estudos de Migrações Internacionais (CEMI) da Universidade Estadual de Campinas (Unicamp) ${ }^{14}$. Enquanto estudiosos das migraçóes no Brasil seguiam utilizando as categorias binárias emigração e imigração (Patarra, 1996; 2005) e a noção de grupo étnico de Barth, esse programa de pesquisas comparativas teve como objetivo examinar os movimentos de populaçóes, signos e capitais por meio de estudos históricos e contemporâneos, incluindo comparações internacionais, com ênfase nas políticas dos Estados-naçóes e na produção de identidades na intersecçáo da cultura e do poder.

Desse ângulo, a linha Nação e Diáspora se propôs a examinar comparativamente as populações em diáspora (incluindo a afro-brasileira), focalizando os paradoxos, as contradiçóes e os limites da política de identidade, enquanto cenários de luta para impor, manter, resistir ou contestar a perpetuação ou reconfiguração de múltiplas estruturas de dominação em diferentes conjunturas da história do capitalismo. Sua produção, entre o final da década de 1990 e meados de 2000, incluiu estudos históricos sobre o Império, processos de independência do Brasil e os contingentes migratórios portugueses, com atenção à formação de identidades nacionais e raciais na cidade do Rio de Janeiro, conflitos antilusitanos e uso de estereótipos em relação a essa população migrante (Ribeiro, 2000a; 2000b; 2001a; 2001b; 2002; 2003), assim como etno-histórias sobre as mobilizaçóes sociais de exilados portugueses de São Paulo em oposição ao salazarismo (Mansur da Silva, 2002; 2003; 2004; 2005). Etnografias também abordaram as dinâmicas identitárias e os dilemas políticos entre portugueses e descendentes na contemporaneidade (Caetano da Silva, 2002; 2003a; 2003b), bem como as relaçóes interétnicas em Lisboa, com foco em migrantes brasileiros e africanos no contexto da lusofonia (Santos, 2006; 2010), as mobilizações iniciadas por brasileiros de Lisboa por seus direitos de cidadania em Portugal e no Brasil (Feldman-Bianco, 2011a) e os processos de exotização entre imigrantes brasileiros no Porto (Machado, 2003). Investigaçôes ainda focalizaram lusofonia, nacionalidade e as "comemoraçôes" dos 500 anos no Brasil e em Portugal (Cunha, 2001; 2002; 2004; Oliveira Filho, 2002). Resultados de pesquisa e de seminários foram publicados em forma de coletâneas e dossiês, englobando comparaçôes entre Brasil e Portugal sobre trânsitos coloniais, ou seja, continuidades coloniais no pós-colonial (Bastos; Almeida; Feldman-Bianco, 2002; 2007; Feldman-Bianco, 2001), discursos nacionalistas e suas consequências (Machado, 2003), nação e identidade (Cunha, 2000; 2003) e naçáo e diáspora (Feldman-Bianco, 2010, 2011c). Englobaram também comparaçôes entre migrantes em Portugal, no Brasil e nos Estados Unidos (Feldman-Bianco, 1997b; Feldman-Bianco; Capinha, 1997), como também sobre latinidades (Castro, 2000) e contribui-

14 Desenvolvido entre 1997 e 2004, esse projeto resultou na publicação de 45 livros, mais de cem capítulos de livros e mais de 200 artigos em revistas nacionais e internacionais. Propiciou especialmente a formaçáo de pesquisadores, sendo 21 teses de doutorado, 24 dissertações de mestrado e 26 monografias de graduação defendidas no período. Vários desses estudantes se tornaram referência no campo das migraçôes internacionais. 
ções para políticas públicas (Castro; Berquó, $2001)^{15}$.

Nesse âmbito, deve-se destacar os diálogos dessa linha com antropólogos e historiadores do Brasil e de Portugal sobre as reconfiguraçóes e continuidades coloniais no pós-colonial (Bastos; Almeida; Feldman-Bianco, 2002; 2007), incluindo as pesquisas de Thomaz $(2001 ; 2002)$ sobre os processos de reconstrução de imaginários da nação portuguesa e seus espaços coloniais, focalizando as relaçóes entre a circulação de pessoas, ideias e narrativas luso-tropicalistas e a construção de representaçôes do "Terceiro Império Português" durante a ditadura salazarista. Posteriormente, Thomaz se voltou ao estudo da experiência colonial e pós-colonial moçambicana, empreendendo reflexôes sobre o processo de formação nacional (Thomaz, 2004a), relaçôes raciais, desigualdades, guerras e conflitos entre populaçōes nativas e estrangeiras (Thomaz, 2004b; 2006).

Comparativamente, a linha Espaço e Poder propôs-se a analisar as transformaçóes do espaço público como espaço de memória, especialmente em cidades e lugares designados como parte do patrimônio cultural nacional e mundial, com ênfase nas ações e nas produções simbólicas desenvolvidas por políticas governamentais, práticas profissionais e sociabilidades cotidianas da mídia e do mercado. Além de publicaçóes sobre a construção da lusofonia no contexto das comemoraçôes dos 500 anos e a relação entre patrimônio, nação e nacionalismos (Leite,
1998; Arantes, 2000), que dialogam com os estudos da linha Nação e Diáspora, as pesquisas realizadas incluíram questôes associadas ao patrimônio imaterial (Arantes, 2002) e a relação entre patrimônio cultural e consumo (Arantes, 1999; Leite, 2004). Deve-se, entretanto, destacar que, enquanto estudiosos da questão migratória se preocupavam à época primordialmente com questôes ao nível da naçâo e do nacionalismo em detrimento do fato de migrantes viverem em localidades (Feldman-Bianco, 2011b), pesquisadores dessa linha já se interessavam pelas interconexôes entre cidade, espaço e desigualdades, ou seja, pelo direito à cidade. Dessa perspectiva, realizaram investigaçôes em São Paulo (Arantes, 1997), em Campinas - enfatizando questôes de gênero e geração (Frangella, 2000; 2004) - e em Salvador, com foco nas relaçôes raciais (Pinho, 1999a; 1999b; 2001) e em corporalidade, raça e naçáo (Pinho, 2002).

Já a linha Grandes Movimentos Migratórios para o Brasil dedicou atenção especial às pesquisas históricas sobre a participação de imigrantes na construção da sociedade civil, da cultura, da política e da economia. Dado seu foco na história do trabalho, publicaçôes incluíram análises sobre corporativismo e fascismo nas origens das leis trabalhistas no Brasil (Hall, 2002), a história do trabalho urbano no século XX no Brasil (Ferreras; French, 1998) e a história e a historiografia comparativa das condiçôes de vida dos trabalhadores na Argentina e no

15 Após o encerramento desse projeto, as temáticas dessa linha se diversificaram, incluindo, além de pesquisas sobre exílio no âmbito das ditaduras argentina e brasileira (Sanjurjo, 2007; Azevedo, 2013), estudos sobre trabalho temporário nos Estados Unidos (Dias, 2007), movimentos sociais, seja no que se refere à política e a performances da diversidade (Müller, 2009), à construção da periferia no rap (Gimeno, 2009) e ainda à política, à cultura, à ideologia e ao trabalho no Software livre (Evangelista, 2010). A mudança de nome dessa linha para desloca(migra)mentos sinaliza também novas pesquisas que abordaram, nessa última década, migração como crime (Dias, 2014a), movimentos sociais de familiares de mortos e desaparecidos das ditaduras argentina (Sanjurjo, 2018) e brasileira (Azevedo, 2018), além de etnografia sobre o cotidiano na diáspora haitiana em uma cidade brasileira (Etcheberre, 2018), entre outros. 
Brasil (Ferreras, 1997) e, ainda, a história do movimento operário na cidade de São Paulo (Hall, 2004). Estudos sobre a militância política e sindical de imigrantes abordaram, entre outros temas, o fascismo e a imigração italiana no Brasil (Bertonha, 1999; 2004a) e na América Latina em perspectiva comparativa (Bertonha, 2000; 2004b), a propaganda anarquista no começo do século XX (Toledo, 1998; 2002), assim como análises sobre migrantes na cidade de São Paulo (Hall, 2004), com ênfase no antifascismo e na militância sindical de italianos (Biondi, 1999; 2002), nas divisóes entre republicanos e socialistas italianos (Biondi, 2000), entre fascistas e antifascistas nessa cidade (Bertonha, 1999), além de análises sobre fazendeiros paulistas e a imigração (Hall, 2003). Pesquisas também focalizaram os militantes judeus de esquerda mortos sob tortura no Brasil durante a ditadura militar (Kushnir, 2002), as estratégias organizativas e a mutualidade no movimento operário de Porto Alegre na primeira metade do século XX (Fortes, 1999) e a alimentação operária em Buenos Aires e no Rio de Janeiro entre 1930 e 1945 (Ferreras, 1997).

Esses estudos dialogam com pesquisas etno-históricas realizadas por discípulos de Seyferth, seja sobre grupos locais nazistas entre alemães no Rio de Janeiro e em Blumenau (Moraes, 2005), seja sobre o ativismo político de judeus de esquerda em São Paulo e no Rio de Janeiro (Bahia, 2010). Dialogam também com as etno-histórias sobre exilados realizadas no âmbito da linha Nação e Diáspora (Mansur da Silva, 2006; Sanjurjo, 2007; Azevedo, 2012; 2013), que evidenciam o importante papel de campos e redes sociais transnacionais na organização de atividades políticas, a exemplo do estudo de Mansur da Silva (2006; 2009; 2013), em que a articulação de uma oposição ao Estado Novo português e a inserção de cientistas e escritores no Brasil se valeram dessas redes, e de Azevedo (2012; 2013), no qual a ideia da formação de um "campo da esquerda transnacional" aparece nos trânsitos de exilados brasileiros entre diferentes localidades e países. Em diálogo comparativo, Azevedo e Sanjurjo (2013) examinaram ainda como, no contexto ditatorial do Cone Sul, as relaçôes entre imaginários de nação e reconstruçáo de identidades de exilados argentinos e brasileiros se deram não só com base em redes de solidariedade construídas transnacionalmente, mas em uma conjuntura marcada por políticas repressivas transnacionais, como a Operação Condor.

Por sua vez, a linha Migraçáo e Cidadania, à época também vinculada ao Núcleo de Estudos de População "Elza Berquó" (NEPO), focalizou predominantemente a migraçáo internacional de brasileiros para os Estados Unidos e o Japáo e suas questôes de identidade e cidadania, as relaçôes entre migração, mercado de trabalho e clandestinidade, as migraçôes de retorno dos japoneses do Brasil para o Japão e, ainda, a reconstrução de identidades étnicas de japoneses, africanos e italianos no Brasil. Deve-se atentar que as pesquisas dessa linha realizadas nos Estados Unidos ainda na década de 1990 examinaram a inserçấo de emigrantes brasileiros no contexto das novas migraçôes internacionais (Sales, 1995), especialmente no mercado de trabalho norte-americano (Scudeler, 1999), já indicando as crescentes restriçóes à entrada de migrantes estrangeiros nesse país (Sales; Goulart, 1996). Análises salientaram o cerco aos migrantes "clandestinos" (Monteiro, 1998), a criminalização e as percepçóes aparentemente paradoxais de migrantes sobre a legitimidade de sua condição clandestina (Sales, 1998), em uma conjuntura em que novas políticas migratórias no cenário norte-americano, assim como na 
Uniāo Europeia pós-Schengen, começavam a equiparar migrantes indocumentados categorizados como "ilegais" e "irregulares" - com o terrorismo, o tráfico de pessoas e o contrabando internacional. Vários desses estudos centralizaram sua atenção nos migrantes oriundos de Governador Valadares, com base em investigaçóes realizadas nessa cidade mineira (Fusco, 2002) ou entre essa cidade e a regiáo de Massachusetts, Estados Unidos, especialmente em localidades situadas na área de Boston (Assis, 2002; Martes, 1999; 2000; Monteiro, 1998; Sales, 1999a; 1999b). Outros priorizaram, na década de 2000, a migração feminina de Criciúma (Santa Catarina) para a regiáo de Boston e seus rearranjos familiares (Assis, 2004) e a de brasileiros e brasileiras para Miami e Framinghan (Boston), com ênfase na transformação desses cidadãos e cidadâs em grupo étnico nos Estados Unidos (Assis, 2004; Sales, 1999b). Outras problemáticas incluíram a relação entre migração e religião (Martes, 1999) e a questão geracional nas migraçóes (Sales, 1999c; 2001).

Já os estudos no âmbito dessa linha sobre os assim chamados dekasseguis começaram a ser realizados após a promulgação da Reforma Legislativa em 1990, por meio da qual o governo japonês, na tentativa de restringir a migraçáo indocumentada, principalmente de asiáticos, passou a favorecer e a regularizar a entrada de descendentes de japoneses nascidos no exterior como máo de obra barata para um mercado formado, em sua maioria, por pequenas e médias empresas japonesas que dão sustentação às grandes empresas de capital do Japão (Ferreira; Garcia, 2001; Assis; Sasaki, 2001). Dessa forma, como relembram Ferreira e Garcia (2001), o Estado japonês, que havia financiado no passado a migração de japoneses para o Brasil, passou a controlar a migração de brasileiros para o
Japão e, ao mesmo tempo, a evitar a entrada de outros migrantes. Dada essa política migratória associada à ida de trabalhadores de descendência japonesa ao Japão, não por acaso pesquisas focalizaram os trabalhadores nipo-brasileiros (Sasaki, 1995), inclusive a questáo do retorno (Sasaki, 1996) e suas ambiguidades e reconfigurações identitárias, categorizados como japoneses no Brasil e brasileiros no Japão (Oliveira, 1997; Sasaki, 1999; 2002), assim como suas redes sociais (Sasaki, 2003).

Cenas do Brasil Migrante (1999), coletânea organizada por Teresa Sales e Rossana Rocha Reis, reúne uma coleção de textos de pesquisadores dessa linha e de interlocutores que realizaram, na década de 1990, estudos de caso sobre a migração de brasileiros para os Estados Unidos e o Japão. Entre eles, está o estudo de Ribeiro (1999) com brasileiros na cidade de São Francisco, Califórnia, cujo enfoque recai nos processos de reconfiguraçâo identitária de migrantes no contexto do multiculturalismo norte-americano, e o de Soares (1999) com migrantes valadarenses em Boston, Massachusetts, que se debruça sobre as relações entre migração e mobilidade social nas localidades de origem e destino.

Em sua resenha, intitulada "Brasileiros no Exterior e Cidadania (1980-2005)", Machado (2015a), com base na produção bibliográfica sobre migração brasileira no período em pauta, realiza uma reflexão sobre questôes relacionadas ao acesso à cidadania desses migrantes em diversos contextos nacionais nos quais se inserem. Para tanto, leva em consideração que, com exceção do Japão, o alto número de brasileiros em situação indocumentada e, portanto, de "ilegalidade", torna-se relevante para a análise, dada a crescente securitização das políticas migratórias nacionais para onde os brasileiros migram e, por conseguinte, maior fiscalizaçáo e vigilân- 
cia nas fronteiras, especialmente nos casos da Europa pós-Schengen e dos Estados Unidos pós 11 de setembro de 2001. Dessa perspectiva, argumenta que os principais impasses ao acesso da cidadania devem-se à relação entre trabalho e (i)legalidade, discriminação social e reconfiguração nas relaçôes de gênero. Entretanto, acima de tudo, nesse seu balanço, aponta para a centralidade do trabalho no processo migratório, que parece englobar os demais temas (Machado, 2015a) ${ }^{16}$.

Nesse sentido, se as pesquisas sobre brasileiros no exterior expóem as dificuldades no acesso a direitos de cidadania e a situação de vulnerabilidade e exploração às quais os trabalhadores estão sujeitos, demonstram também como, do ponto de vista dos migrantes, não raras vezes, há uma percepção de aumento da cidadania no contexto migratório, mesmo em situação de indocumentação (Sales, 1999a). Como aponta Machado (2015a), essa percepçâo associa-se a um diferencial entre certo quantum de cidadania que cada país oferece a seus cidadãos. Além do mais, colocando em relevo a dimensão da agência, esses estudos destacam as estratégias adotadas por migrantes para enfrentar as adversidades, tais como a constituição de densas redes de solidariedade.

Um conjunto de etnografias realizadas junto a brasileiras e brasileiros em diferentes localidades dos Estados Unidos (Assis, 2002; 2004; 2011; Fleischer, 2002; Sales, 1999a), de Portugal (Machado, 2009; Santos, 2002), mas também com migrantes no Brasil (Jardim, 2000; 2007; 2009) e em Cabo Verde (Dias, 2006; Lobo, 2014b), voltou-se à análise da intersecção entre projetos migratórios, gênero, família e redes sociais, examinando as estratégias de inserção laboral e mobilidade social e geracional de migrantes. Se o enfoque na imigração como categoria resultou, historicamente, em análises e monografias direcionadas para a sociedade receptora, essas novas pesquisas, inspiradas na perspectiva transnacional, passaram a examinar náo só as experiências de migrantes nas localidades de destinos, mas também as suas relaçóes dinâmicas com as localidades de origem (Assis, 2002, 2007, 2011; Assis; Siqueira, 2009; Feldman-Bianco, 2001; 2011b; 2016; Dias, 2006; Lobo, 2014b; Jardim, 2000; 2007).

Tomando as problemáticas da ilegalidade, da cidadania, do trabalho e da identidade como eixos da análise e atentando para as dinâmicas contextuais de interação social, parte das etnografias realizadas junto às brasileiras e aos brasileiros no exterior, especialmente nos Estados Unidos e em Portugal, começou a revelar as estratégias laborais e os conflitos experimentados por migrantes, cujas vidas eram atravessadas por desigualdades estruturais e imaginários hegemônicos nacionais. Descreveram, assim, processos de racialização, exotização ou de "subordinação ativa" (Machado, 2005), nos quais migrantes mobilizavam situacionalmente identidades e estereótipos de brasilidade (Beserra, 2005; 2007; 2011; Frigério, 2002), conformando circuitos e redes de parentesco, amizades, ajuda e trabalho a fim de contornar a situação de indocumentaçáo e as políticas migratórias cada vez mais restritivas nos contextos norte-americano e europeu. Desse modo, examinaram também a constituição de mercados e nichos laborais segmentados

16 Dado o alto número de migrantes em situaçáo indocumentada, houve um interesse recorrente por parte do Estado brasileiro de quantificar (e, assim controlar) essa migraçâo. Também, como Feldman-Bianco (2011a) mostra, o aumento de securitização e vigilância nas fronteiras, junto à prisão de brasileiros e à mobilização de lideranças migrantes, levou à implementação de políticas públicas, especialmente na era Lula. 
e marcados diferencialmente por raça, gênero, classe, idade, etnicidade e nacionalidade (Beserra, 2003; 2005; 2011; Ribeiro, 1998b; 1999).

Ribeiro (1999) analisou os cenários e rituais de afirmação da identidade brasileira entre migrantes brasileiros em São Francisco, Califórnia, focalizando a mobilização de estereótipos de brasilidade e processos de segmentação étnica, hibridização e etnicização (Ribeiro, 1998b). Desse prisma, demonstrou como estereótipos nacionais ou étnicos podiam servir tanto como fonte de cooperação quanto de exploração e subordinação (Ribeiro, 1998a). O recurso aos estereótipos como forma de afirmação identitária também foi explorado na etnografia de Torresan (1994) realizada entre brasileiros em Londres, que se desdobrou em uma pesquisa levada a cabo em Lisboa, na qual analisou como jovens brasileiros de camadas médias negociavam identidades e posiçôes de classe no contexto migratório (Torresan, 2004; 2006; 2007).

Já Machado (2004; 2008; 2009) acompanhou as trajetórias de brasileiros no Porto, Portugal, que incorporavam estereótipos de brasilidade para garantir um lugar no "mercado da alegria", trabalhando preferencialmente como atendentes em restaurantes, bares, hotéis e comércio. Processos de racialização, exotização e de formação de "mercados étnicos" também foram foco dos estudos de Guizardi (2013) com brasileiros que transitam por meio das "redes da capoeira" na Espanha, e de Beserra (2011), em pesquisa sobre brasileiras e brasileiros que se movem por meio do mercado do samba, da capoeira e da Bossa Nova em Los Angeles (Beserra, 2003; 2005; 2007) e em Chicago (Beserra, 2011), nos Estados Unidos. Dias (2007; 2013), por sua vez, investigou as experiências de latino-americanos (entre os quais os brasileiros), neozelandeses, australianos e jamaicanos que - contando com vistos temporários, contratos de trabalho precarizados e trajetórias e condiçôes de vida bastante diversas - ocupavam posiçôes hierarquicamente diferenciadas em um resort turístico de Vermont, nos Estados Unidos. Vale mencionar ainda as pesquisas de Rial (2008; 2014) sobre jovens jogadores brasileiros circulando e "rodando" entre clubes de futebol no exterior.

Focalizando as relações entre migração, gênero e trabalho, Assis (2002; 2003; 2007; 2011), Martes (1999; 2000; 2001), Fleischer (2002; 2003) e Jesus (2003) trouxeram as experiências de brasileiras, majoritariamente valadarenses e criciumenses, trabalhando como "faxineiras" e em serviços domésticos em Boston, Estados Unidos, que buscavam se diferenciar por meio de sua identidade nacional nesse nicho laboral, destacando suas qualidades como "boas trabalhadoras". A relevância desses estudos foi demonstrar não apenas a construçấo de densas redes de solidariedade entre as trabalhadoras migrantes, mas também as ambiguidades, os conflitos, as clivagens e as competiçóes travadas nesse mercado de trabalho, seja entre brasileiras, seja entre migrantes de outras nacionalidades. Nesse ponto, vale notar que, dado o aumento da migração feminina para o exterior, o gênero tornou-se uma categoria de análise nessas etnografias realizadas por antropólogas e sociólogas.

Ainda no que tange à intersecção entre estudos migratórios e de gênero, cabe destacar as contribuiçóes de pesquisas realizadas a partir do Núcleo de Estudos de Gênero Pagu, da Unicamp que, em diálogo com os debates sobre nação, colonialismo e transnacionalismo desenvolvidos no âmbito do CEMI/Unicamp, trouxeram análises relevantes acerca de como gênero, raça, classe, geração e nacionalidade operam na migração 
e na produção de ilegalidades, desigualdades e violências. A esse respeito, vale destacar os estudos de Piscitelli (2001; 2004; 2007; 2008), Silva e Blanchette (2005) e Silva et al. (2005) que, com base em perspectivas feministas interseccionais e pós-coloniais, passaram a problematizar as relaçóes entre migração, gênero e sexualidade no contexto do turismo sexual internacional no Brasil. Sob esse mesmo prisma, Suzana Maia (2001; 2007; 2009a; 2009b; 2010; 2011; 2012) se voltou às trajetórias de mulheres brasileiras de camadas médias que trabalham como dançarinas eróticas em bares noturnos da cidade de Nova York, examinando as relaçôes entre migração, transnacionalismo, gênero, trabalho e representações da naçáo, com foco nas relações e interações cotidianas entre dançarinas e clientes e nas formas como identidades, posiçóes sociais, corporalidades, hierarquias e desejos são construídas no contexto transnacional.

Especialmente as pesquisas de Piscitelli (2001; 2004) realizadas em Fortaleza, Brasil, junto a trabalhadoras(es) do sexo, para além da análise em processos de exotização, foram pioneiras na apreensão das dinâmicas e das categorias de diferenciação presentes nesse contexto, com ênfase nas conceitualizaçôes (sobre gênero, raça, sexualidade e nacionalidade) de estrangeiros(as) à procura de sexo e de mulheres e homens nativos que travavam relacionamentos com visitantes internacionais. Como veremos mais adiante, acompanhando as trajetórias de suas interlocutoras, posteriormente os estudos de Piscitelli (2007; 2008) se desdobraram em pesquisas sobre as experiências de brasileiras na Europa (especialmente na Itália e na Espanha) que migram acompanhando ou convidadas por turistas sexuais, e/ou de mulheres e travestis que circulam e se inserem nos mercados transnacionais do sexo.
Em um contexto de fusão dos campos migratório, de gênero e justiça criminal no âmbito das políticas migratórias globais - particularmente a partir da aprovação da Convenção de Palermo das Naçóes Unidas em 2000, que inseriu a questáo do "contrabando de migrantes" e do "tráfico de pessoas" na agenda política internacional —, tanto as pesquisas de Sprandel (2005) quanto as de Piscitelli contribuíram com o desenvolvimento de análises críticas sobre a vinculação entre turismo sexual, tráfico de pessoas e o deslocamento de mulheres e travestis brasileiras (e de outros países do Sul global) para a Europa. Além de questionar os pânicos morais presentes nos debates sobre $t u$ rismo sexual e tráfico de mulheres para fins de exploração sexual (Piscitelli, 2004; Silva et al., 2005), os estudos realizados junto a mulheres e transgêneros deportadas da Europa revelaram como gênero, raça, classe, nacionalidade e sexualidade incidem na produção da ilegalidade e nos processos de criminalização das migraçóes.

Observa-se assim como, ao longo da década de 1990 e da primeira metade dos anos 2000, diferentes perspectivas transnacionais foram adotadas em diversos estudos, com distintas temáticas, focalizando sobretudo as relações entre migração, nação, trabalho, identidade, cidadania e indocumentação. $\mathrm{Na}$ próxima década, como veremos, paradigmas transnacionais e a abordagem de campos e redes sociais de migrantes entre países de origem e recepção, além do foco nos trânsitos, nas circulações e nas relaçôes entre movimentos de pessoas, signos e capitais, continuarão pautando, em grande medida, os estudos nessa área temática.

Importa notar que as análises sobre a produção da ilegalidade, propiciadas principalmente por pesquisas realizadas entre brasileiras e brasileiros no exterior, darão 
vazão, na década seguinte, a maior interesse na investigação de políticas migratórias e de novas formas securitárias de governar os fluxos migratórios e classificar os indesejáveis. Além disso, se as etnografias realizadas entre a década de 1990 e meados dos anos 2000 ampliaram o diálogo entre diferentes campos de estudo - especialmente os campos de estudos migratórios, de gênero e de justiça criminal — , na próxima década, a análise de padróes recorrentes nas formas de controle das fronteiras e dos fluxos (que abrangem diferentes cenários e incidem sobre populações diversas) exigirão não só a combinação de diversas áreas temáticas (tais como estudos migratórios e urbanos), mas também o desenvolvimento de novos paradigmas teórico-metodológicos que permitam uma abordagem mais ampla e comparativa dos deslocamentos (Feldman-Bianco, 2015; 2017; 2018a).

\section{Anos 2008-2018. Da perspectiva transnacional aos estudos sobre (i)mobilidades, deslocamentos, despossessão e violência}

Ao longo da última década, os estudos e as preocupaçóes relativas à ampliação de direitos de cidadania, vinculadas à questão da pobreza, do trabalho, da informalidade e da ilegalidade - predominantes, até a primeira metade da década de 2000 , não só no campo de estudos migratórios, mas também nos estudos urbanos - , desdobraram-se em análises sobre precarização, criminalização e violência, com foco nas práticas sociais que definem as fronteiras entre pessoas, corpos, fluxos, mercados e territórios regulares/irregulares, legais/ilegais ou lícitos/ilícitos. Seja focalizando migrantes, seja focalizando outras populaçóes consideradas perigosas e indesejadas, novas pesquisas nos falam de pessoas que são percebidas como ameaças à ordem pública (ou à nação) - e que no registro da "guerra à subversão" (no passado ditatorial) ou da "guerra ao crime" (na presente forma democrática), tornam-se vidas potencialmente matáveis (Sanjurjo; Feltran, 2015). É sobre elas que incide risco maior à deportação, ao deslocamento forçado, ao aprisionamento e, no limite, à morte violenta, segundo clivagens de classe, raça, gênero, lugar de moradia e proximidade com mercados informais/ilegais/ilícitos.

Por um lado, essa tendência segue mudanças conjunturais, quando pesquisas de campo etnográficas são realizadas em meio a um crescente processo de precarização, securitização e militarização da vida social, atrelado à implementaçáo de políticas de corte neoliberal. Por outro lado, associa-se à incorporação de abordagens teóricas, que vão desde a perspectiva foucaultiana - que informa trabalhos sobre tecnologias e formas de governo que produzem mobilidade/imobilidade, circulação/contenção, vida/morte - até abordagens interseccionais e pós-coloniais - que inspiram reflexôes sobre processos de subjetivação e a incidência de marcadores sociais diversos na delimitação de fronteiras sociais. Cruzados à perspectiva transnacional, esses diálogos permitem perceber processos similares que produzem, em escala global, deslocamentos, desigualdades e acessos diferenciais a direitos de cidadania, exigindo, por sua vez, o desenvolvimento de novos olhares e paradigmas teórico-metodológicos.

Assumindo esse desafio, Feldman-Bianco sugere a adoção de uma perspectiva global das migraçôes e dos deslocamentos para analisar e teorizar a respeito de vários tipos, escalas e espaços das mobilidades e das imobilidades à luz dos interstícios da dominação e do poder como parte inerente à reestrutu- 
ração do capitalismo global (Feldman-Bianco, 2015; 2017; 2018a). Ademais, como uma autocrítica da abordagem transnacional elaborada nas últimas décadas, a autora chama a atenção para a importância de considerar, nas pesquisas etnográficas, a perspectiva escalar, trazendo à tona não só a escala da cidade, mas também a crítica ao nacionalismo metodológico (Glick-Schiller; Çaglar, 2011; Feldman-Bianco, 2009; 2011b; 2012), assim como a necessidade de problematizar a produção de categorias como "migrante" e "refugiado", evitando tomá-las como dado $a$ priori (Feldman-Bianco et al., 2011c).

Não obstante essas críticas, parte das pesquisas sobre migraçôes realizadas na última década continuou se beneficiando tanto da perspectiva transnacional quanto dos estudos de gênero, família e parentesco ${ }^{17}$, bem como dos debates sobre trocas econômicas, afetivas e materiais na antropologia ${ }^{18}$. Olhando para os idiomas nativos de conexáo e "desnaturalizando" concepçôes de família e parentesco, diversos estudos associam movimentos migratórios à circulação de pessoas, objetos e afetos, colocando em relevo a mútua constituição entre projetos migratórios e familiares e a emergência de novas dinâmicas sociais, em que ganha centralidade uma ampla rede de parentes e uma pluralidade de práticas de cuidado e co-habitação (Bongianino, 2015; Jardim, 2007; 2009; Lobo, 2011; 2013; 2014b; Machado, 2017; Machado; Kebbe; Silva, 2008).

Alguns trabalhos descrevem redes familiares imbricadas em fluxos transnacionais que, apesar da ausência contínua dos parentes e da distância física prolongada, constroem relaçóes por meio de formas va- riadas de cosubstancialidade (Machado, 2010; 2014; 2015b). A constante circulação de pessoas, dinheiro, objetos e encomendas (Lobo, 2008; 2010; 2011; 2013; 2014a; Vasconcelos, 2018) e o investimento em projetos familiares - como a construçáo da "casa" familiar que impulsiona, muitas vezes, o próprio projeto migratório (Handerson, 2010, 2015; Machado, 2010; 2014; 2015b) - mobilizam e movimentam tanto os que partem quanto os que ficam, produzindo parentesco e novas práticas de maternidade (Capernedo; Nardi, 2017) e de organização familiar (Jardim, 2007; 2009; Scott, 2011; Scott et al., 2015).

Por outra parte, Fonseca (2006; 2009; 2011), ao mesmo tempo que se referencia nos estudos de família e parentesco, encontra também na perspectiva foucaultina de biopolítica e nos estudos sobre ciência (Latour, 2005) caminhos sugestivos para a análise das "tecnologias de governo" que informam o tema da circulação e adoção transnacional de crianças. Ao questionar a ideia de "global versus local" e de fluxos unidirecionais, a autora examina as dinâmicas relacionais entre fatores "externos", especialistas "locais" e mídia, investigando como formas globais operam por meio de circuitos transnacionais, em que bens, pessoas e ideias transitam por meio de situações mediadas e permeadas por relaçóes desiguais de poder, tendo os sentidos de seus elementos modificados (Fonseca, 2009).

Especialmente na última década, o enfoque em "tecnologias de governo", junto aos debates sobre transnacionalismo e globalização, influenciaram significativamente os estudos antropológicos nessa área temática.

17 Strathern (1992) e Carsten (2004), entre outras.

18 Appadurai (2008), Miller (2010), Zelizer (2009), entre outros. 
Se as "tecnologias de governo" encontram-se imbricadas em políticas de governança, passou-se a examiná-las, como lembra Fonseca (2011), como parte das estratégias dos Estados para ditar comportamentos, moralidades e estilos nacionais de cidadania, revelando novas formas de controle e de gestáo de populaçôes, territórios, migraçóes e fronteiras. Inspiradas nessa perspectiva, e focalizando os dispositivos e as formas de governo das migrações e do refúgio no Brasil, Jardim (2012; 2015; 2016; 2017), Facundo Navia (2016; 2017), Perin (2013) e Vieira (2017) analisam as rotinas burocráticas de instituiçóes e agentes dedicados à questão migratória, as práticas de categorização e definição do estatuto jurídico de pessoas em deslocamento e os efeitos da multiplicidade de temporalidades, saberes e lógicas administrativas nas vidas migrantes (Vianna; Facundo, 2015). Desse modo, as autoras demonstram não só como o Estado se faz no cotidiano (Das e Poole, 2004; Souza Lima, 1995), mas também como a "razão humanitária" (Fassin, 2003; 2012) vem permeando as políticas migratórias no país.

Em um contexto global marcado pelo predomínio de retóricas humanitárias e pelo crescente processo de securitizaçáo e criminalização das migraçôes, categorias como contrabando de migrantes e tráfico de pessoas ganham proeminência, informando os debates públicos concernentes às migraçóes no Brasil. Nesse panorama, uma série de trabalhos examina, desde a década de 2000 , as políticas migratórias no que se refere a dinâmicas e escalas inter-relacionadas nos planos locais, nacionais e globais (Feldman-Bianco, 2018b), problematizando a difusão e a ressignificação da noção de tráfico de pessoas e contrabando de migrantes no contexto brasileiro (Dias, 2014a; 2014b; 2015; 2017; Dias; Sprandel, 2011; Sprandel; Dias, 2010; Sprandel, 2005; 2016). Como desdobramento de análises iniciadas na década anterior (Feldman-Bianco, 2000b; 2001; 2002), esses estudos analisam a fusão dos campos migratório e de justiça criminal no âmbito das políticas migratórias nacionais e globais, questionando a consequente articulação entre migração e segurança e entre migração irregular e circulação de bens ilegais e ilícitos.

Outro conjunto de trabalhos (Blanchette; Silva, 2011, 2018; Pelúcio, 2009; Piscitelli, 2013; Silva; Blanchette, 2005; Silva; Blanchette; Bento, 2018; Teixeira, 2008), que dialoga especialmente com perspectivas feministas reconhecidas como transnacionais, pós-coloniais e interseccionais ${ }^{19}$, analisa criticamente a vinculação entre turismo sexual, tráfico de pessoas e o deslocamento de mulheres e travestis brasileiras para países da Europa, tornadas alvos preferenciais dessas políticas - que suspostamente visam combater tais crimes e proteger suas vitimas potenciais. Conforme já mencionado, tendo como pioneiros os estudos de Piscitelli (2001; 2004) e Silva e Blanchette (2005) sobre "turismo sexual" no Brasil, essas etnografias trazem as experiências de mulheres e travestis que circulam e se inserem nos mercados transnacionais do sexo, demonstrando as linhas tênues entre "tráfico" e "resgate", desestabilizando os discursos que as situam no lugar de vitimas e questionando as políticas que limitam seus trânsitos e criminalizam suas práticas e seus estilos de vida. Em vez de máfias que aliciam e lucram com

19 Anthias e Yuval-Davis (1992), Brah (2006), Cabezas (2009), Constable (2009), Kempadoo (2004), McClintock (1995), entre outras. 
o tráfico de pessoas, esses estudos trazem as percepçóes de pessoas que falam de redes de ajuda que viabilizam seus projetos migratórios e buscas variadas por realização pessoal; tampouco é de máfias que essas migrantes relatam temer, mas de blitz das polícias que encarceram prostitutas e deportam migrantes indocumentadas (Piscitelli, 2008; 2011; Lowenkron; Piscitelli, 2015; Piscitelli; Lowenkron, 2015).

Importa notar que se em um primeiro momento esses estudos questionavam os pânicos morais presentes nos debates sobre turismo sexual e tráfico de mulheres para fins de exploração sexual (Piscitelli, 2004; Silva et al., 2005), como já salientado, posteriormente, busca-se situar os trânsitos dessas mulheres no âmbito das discussōes sobre migração internacional e tráfico de pessoas a fim de compreender as dimensóes de agência presentes nessas articulaçôes, as implicaçôes culturais, políticas e econômicas dessas mobilidades e as distinçôes corporificadas por essas mulheres em suas interaçóes com parceiros sexuais (Piscitelli, 2007; 2010; 2013). Em seus estudos de longa duração, Piscitelli sobretudo vem perscrutando como gênero, imbricado com outros marcadores sociais (classe, cor, idade, nacionalidade, sexualidade), permeia a inserção de brasileiras no exterior e como essas marcas de diferenciação mantêm relaçóes não apenas com a circulação entre países e setores do mercado do sexo, mas também com o deslocamento entre mercados do sexo e do casamento (Piscitelli, 2012; 2018), em um contexto de políticas restritivas relativas ao combate à prostituição e à migração irregular (Piscitelli, 2013).
Essas análises pautaram outras pesquisas que examinam como o gênero, imbricado com outras categorias de diferenciação, opera na migração, a exemplo do estudo de França (2017) sobre a produção de uma nova categoria de refugiados com base na orientação sexual e na identidade de gênero ("refugiados LGBTI"), parcialmente reconhecida por agências migratórias internacionais. Há também pesquisas como a de Togni (2014), com jovens brasileiros em Portugal, que trata das relaçóes entre mobilidade, gênero e sexualidade; de Rangel (2018), com dançarinos(as) brasileiros(as) nos Estados Unidos, que analisa processos de materialização e comercialização de corpos nacionalizados, e de Debert (2016), com mulheres da América Latina, da África e da Ásia na Itália, que examina as relaçôes entre gênero, trabalho e cuidado. Já Padovani (2016; 2017; 2018a; 2018b), cuja etnografia foi realizada com brasileiras presas em Barcelona e estrangeiras presas em São Paulo, incorpora aos debates sobre interseccionalidades e migrações as discussóes sobre margens urbanas, crime, prisão e ilegalismos ${ }^{20}$, analisando a produção de redes de afetos e "amores" vividos por meio de penitenciárias femininas. Tomando a prisão como instituiçáo produtora de relaçôes, Padovani examina como os trânsitos dessas mulheres são atravessados por mercados sexuais e matrimoniais e pelas tramas (i)legais dos mercados de drogas local e transnacional.

Nota-se, assim, desde a década de 2000 , uma convergência - no que se refere a perspectivas teórico-metodológicas e questóes de pesquisa - entre áreas temáticas diversas, como estudos migratórios, estudos urba-

20 Biondi (2014), Das e Poole (2004), Feltran (2011), Godoi (2015a), Godoi, Araújo e Mallart (2019), Hirata (2018), Mallart (2014; 2019), Marques (2009), Telles (2010), Telles e Hirata (2007; 2010), entre outros. 
nos e de gênero. Cresce daí o interesse em ampliar o enfoque comparativo sobre tipos variados de deslocamentos para analisar processos sociais que transpassam fronteiras e as experiências não só de refugiados e migrantes, mas também de outras populaçóes consideradas indesejadas, periféricas e marginalizadas (Feldman-Bianco, 2015; 2017; 2018a). Em uma conjuntura marcada pelo capitalismo neoliberal, pela precarização da vida, pela despossessão e pela criminalização da pobreza, tal convergência vem permitindo examinar as relaçóes entre mobilidades e imobilidades e a produção de desigualdades e violências em perspectiva global (Feldman-Bianco, 2015).

No âmbito dos estudos urbanos, diferentes pesquisas também problematizam as ambiguidades constitutivas de formas de governo que combinam políticas humanitárias, de cuidado e proteção, com políticas securitárias, de controle e repressão (Fassin, 2005). Estudos realizados junto a pessoas em situação de rua (De Lucca, 2013; Carriconde, 2019) descrevem os trânsitos dessas populaçóes itinerantes, que circulam entre ruas, abrigos, instituições assistenciais e prisionais; espaços destinados à gestão daqueles considerados perigosos e indesejáveis. Por sua vez, a etnografia de Rui $(2012 ; 2014)$ sobre territorialidades de uso de crack - especialmente a cracolândia paulistana, uma modalidade de territorialidade itinerante (Frúgoli Jr.; Spaggiari, 2011) constituída de fluxos e movimentaçóes em torno à região da Luz - expóe tentativas de controle estatal dessa populaçáo considerada abjeta, nas quais se mesclam gerenciamento do espaço com dispositivos de assistência e repressão, cuidado e vigilância, culminando, por vezes, em episódios de dispersão e remoção violentos (Mallart et al., 2017). Processo semelhante foi observado pela autora em estudo de caso no Rio de Janeiro, onde usuários de crack foram transformados em "refugiados da pacificação" no contexto de produção da "Cidade Olímpica" (Rui, 2018).

Pesquisas realizadas durante a preparação do Rio de Janeiro para os Mega Eventos Esportivos dáo conta dos processos de remoção e militarização de favelas e periferias, com foco nas políticas de reurbanização, reordenamento e revitalizaçâo urbana (Leite et al., 2018; Magalhães, 2013; 2019), que alteraram os fluxos e os usos do espaço da cidade, impactando também outras cidades-sede da Copa do Mundo, como Porto Alegre (Mesomo; Damo, 2016) e Recife (Scott; Moura, 2014). Outros trabalhos enfatizam a dimensão do cotidiano, a micropolítica e as estratégias de resistência de moradores de favelas e ocupaçóes ameaçados de remoção, examinando os fluxos desses moradores, cujos movimentos encontram-se associados às dinâmicas de despejos e organização de novas ocupaçôes (Guterres, 2014; 2016; Birman; Fernandes; Pierobon, 2014; Moura, 2016). Esses estudos revelam tanto a produção de densas redes de solidariedade como forma de contornar a precariedade (Pierobon, 2018) quanto os anseios de pessoas que recusam o padrão periférico de moradia e optam em permanecer em regióes centrais da cidade, visando ao maior acesso à mobilidade, serviços e equipamentos urbanos (Fernandes, 2013; 2015).

Acompanhando a expansão carcerária no país nas duas últimas décadas, e considerando que uma parcela significativa da população brasileira é afetada pela experiência prisional, cresce também o interesse na realização de etnografias sobre (e em) prisóes. Focalizando a ampla circulação de repertórios, códigos e práticas que transitam por entre as "fronteiras porosas" das prisóes, uma série de trabalhos aponta para a potencialidade 
de abordar os bairros periféricos em continuidade analítica com as prisóes, (Biondi, 2014; Feltran, 2010; Godoi, 2015a; 2015b; Hirata, 2018; Mallart; Rui, 2016; Marques, 2009; Padovani, 2018b). Essas pesquisas examinam os fluxos e as conexôes entre espaços prisionais, territorialidades e populações - no que se refere a práticas, público-alvo, disciplinamento moral, dinâmicas comerciais e repertório coercitivo e assistencial do Estado (Mallart; Rui, 2016). Nesse contexto, surgem também análises sobre a incidência da experiência prisional entre povos indígenas, como o estudo de Baines (2015) em penitenciárias de Boa Vista (Roraima) e o de Nascimento (2014) sobre a situação de crianças caiová internadas em abrigos em cidades do Mato Grosso do Sul.

Outras pesquisas se voltam à produção das periferias como espaços de margem e como alvo de projetos discricionários de ordem pública (Leite, 2012), ou ainda às gramáticas morais, às lutas por "justiça" e às formas de resistência de familiares de vítimas da violência institucional (Araújo, 2014; Azevedo, 2018; Farias, 2014; Freire, 2010; Ota, 2019; Lacerda, 2015; Vianna, 2013; Vianna; Farias, 2011), incluindo análises sobre a articulação de ativismos globais (Sanjurjo, 2017). Colocando em diálogo suas pesquisas sobre a gestão estatal das mortes de moradores de favelas, Barros e Farias (2017), por exemplo, refletem sobre os deslocamentos políticos entre centro e periferia, as marcas da violência deixadas em corpos periféricos e as conexóes políticas entre fronteiras territoriais e corporais.

Se entre as décadas de 1990 e meados de 2000 pesquisadores de diversas disciplinas se voltaram ao estudo da migração internacional de brasileiros, desde a chegada em 2010 de migrantes do Haiti, vítimas do terremoto, a atenção se voltou ao estudo das novas migraçôes para o Brasil, em um contexto marcado pelo progressivo afluxo de migrantes e solicitantes de refúgio de inúmeros países da África e do Oriente Médio, assim como pela contínua migração intracontinental. Diversas pesquisas realizadas junto a migrantes latino-americanos e do Caribe abordam os trânsitos e as redes sociais que possibilitam a chegada ao Brasil e a manutenção de vínculos com o país de origem. Sejam redes familiares, de trabalho ou de comércio, legais ou clandestinas, essas se constituem desde antes da vinda e se (re)configuram no Brasil, a par de outras redes de acolhimento, de caráter institucional, laico ou religioso. São exemplos os trabalhos desenvolvidos por Sidney Silva (2006) com bolivianos e os do mesmo autor (Silva, 2017) e de Handerson (2017) com os haitianos. Já os trabalhos de Césaro e Zanini (2018) e de Carlos Silva (2018) tratam dos efeitos das práticas transmigrantes para o comércio local em cidades brasileiras. Particularmente, Silva (2018) analisa o estabelecimento de migrantes chineses no comércio popular do centro de São Paulo, propondo-se náo somente a localizar processos migratórios no espaço, mas também a examinar como a migraçáo reestrutura a localidade e articula dinâmicas socioeconômicas transnacionais, problematizando a ideia de nicho ou bairro étnico (cuja tendência seria atribuir certa uniformidade em relaçáo a territórios da cidade e aos próprios migrantes).

Há também trabalhos realizados junto a migrantes árabes, paraguaios, colombianos e venezuelanos, cujo enfoque são as relaçôes e as tensões em regióes fronteiriças, nos quais as categorias acionadas reportam à mobilidade e ao caráter transfronteiriço desses fluxos (Albuquerque, 2010; Albuquerque; Paiva, 2015; Scott; Vasconcelos, 
2015; Rabossi, 2010; 2015) ${ }^{21}$. Especificamente as pesquisas de Handerson (2010) sobre a diáspora haitiana no Brasil trazem farto material etnográfico acerca das circulaçóes e das transitoriedades dos haitianos antes e depois de sua passagem pelo Brasil. Considerando-os como diáspora ou emigrantes - categorias mobilizadas pelos próprios migrantes —, Handerson demonstra como seus interlocutores, ao mesmo tempo em que recusam o termo refugiado, atribuído pelo Estado brasileiro e comumente associado ao haitiano no imaginário brasileiro, buscam constituir-se como diáspora, categoria com sentidos nativos e que associa valores positivos à mobilidade. $\mathrm{O}$ termo diáspora também é acionado pelas interlocutoras cabo-verdianas de Lobo e Venancio (2017), pelas interlocutoras palestinas de Jardim (2000; 2007; 2009) e por migrantes muçulmanos, de modo geral (Pinto, 2011; 2015).

Observa-se também, na última década, um renovado interesse no estudo de migraçóes históricas e de novos contingentes migratórios do e para o Brasil. Nesse âmbito, além da continuidade de análises voltadas à constituição de grupos étnicos — com ênfase em diferentes elementos étnicos acionados, como língua (Seyferth, 2004a), socialização (Seyferth, 2017), festas (Santos, 2015), religião (Bahia, 2011; Guérios, 2012), trabalho como ethos (Zanini; Santos, 2009; Santos; Zanini, 2012; Santos, 2014) —, outros trabalhos passaram a destacar a existência de vínculos, trocas e circularidades entre, pelo menos, dois Estados-naçôes. $\mathrm{O}$ aumento dos fluxos e das pesquisas sobre a emigração de brasileiros a partir da década de 1990 viabilizou estudos sobre as "migraçóes de retorno" de descendentes de (i)migrantes históricos (Assis; Zanini; Beneduzi, 2013; Machado, 2011), destacando-os como (trans)migrantes, no sentido do movimento e da circularidade.

Cabe ainda destacar as pesquisas coordenadas por Machado (2011) sobre "japonesidades", que reúne trabalhos etnográficos realizados entre descendentes e não descendentes de migrantes japoneses, atentando para as múltiplas e variadas formas de torna-se japonês no Brasil. A partir da noçâo de "diferencialidades", Machado (2013; 2015b) empreende uma reflexão crítica aos conceitos de "cultura", "identidade" e "etnicidade", comumente empregados nos estudos migratórios, buscando distanciar-se de uma perspectiva analítica cuja tendência é objetificar as diferenças culturais. Por outro lado, Motta (2011), em O Japão não é longe daqui: consumo e estilos de vida, analisa questóes relacionadas à interculturalidade no nordeste brasileiro. $\mathrm{Na}$ intersecção entre migração e educação, há também estudos sobre estudantes estrangeiros no Brasil, área inaugurada por Neusa Gusmão, cujas pesquisas com universitários originários de países africanos de língua oficial portuguesa em Portugal e no Brasil destacam questôes associadas à diáspora negra, à afirmaçẫo da negritude, intelectualidade negra e mobilidade social (Gusmão, 2005; 2009; 2014; 2015), temática que vem atraindo a atençấo de an-

21 Vale aqui mencionar a pesquisa de Sprandel (1992; 2002; 2006), realizada ainda na década de 1990, sobre migrantes brasileiros no Paraguai ("brasiguaios") que buscavam analisar construçôes identitárias e conflitos em regiôes de fronteira. 
tropólogas, a exemplo do estudo de Mungoi $(2012)^{22}$.

Ampliando o enfoque comparativo, percebe-se também como, nos últimos anos, a temática dos deslocamentos entra na agenda de pesquisa de antropólogas(os) que atuam junto a comunidades indígenas, ribeirinhas e quilombolas, ou que trabalham na interface entre antropologia e meio ambiente. Um conjunto relevante de trabalhos vem analisando os deslocamentos e os conflitos socioambientais associados à expansão do agronegócio, à mineração e à construção de grandes projetos de infraestrutura. Focalizando os impactos da mineração industrial e da construção de hidrelétricas na Amazônia, as pesquisas de longa duração de Baines têm trazido contribuições relevantes às discussóes concernentes às relações entre povos indígenas, direitos territoriais, políticas indigenistas e projetos de desenvolvimento econômico (Baines, 1993; 2001; 2011; 2013; 2014; 2017). Há também estudos recentes que examinam processos de expropriaçáo territorial e recriação cultural de comunidades indígenas e ribeirinhas atingidas ou ameaçadas de deslocamento compulsório em razão da construção de barragens e usinas hidrelétricas em diversas regiōes da Amazônia brasileira (Loures, 2018; Oliveira; Cohn, 2014), no Vale do Jequitinhonha (Zhouri; Oliveira, 2005; Teixeira; Zhouri, 2013) e no nordeste do país (Scott, 2009; 2012; 2013).

Processos de expropriação e retomada territorial, assim como a dimensão das memórias e das lutas pela permanência no território, são foco também de diversas pesquisas realizadas junto a comunidades indígenas e quilombolas, trazendo à tona os sentidos atribuídos a esses movimentos e suas relaçôes com aspectos cosmológicos e/ou demandas políticas em razão de conflitos territoriais e/ou de ordens diversas (Alarcon, 2018; Costa, 2017; Costa, 2016; Fernandes; Góes, 2018; Ioris, 2018; Oliveira, 2012; Oliveira, 2018; Ramos, 2017; Silva; Mura, 2018). Por fim, vale destacar os recentes estudos sobre desastres ambientais decorrentes da atividade mineradora que focalizam a "violência epistemológica" e os efeitos colonizadores dos discursos de modernizaçâao e desenvolvimento (Zhouri; Texeira, 2010; Zhouri, 2018), assim como o sofrimento social constitutivo da experiência de deslocamento e das lutas por reparação empreendidas por comunidades atingidas pelo rompimento de barragens (Ferreira, 2017; Losekann, 2017; Zhouri et al., 2016; Zhouri et al., 2017).

Para além da ênfase em questóes de gênero, raça e racismo, nota-se como as pesquisas realizadas na última década estão marcadas por um interesse crescente na análise dos deslocamentos, dos trânsitos, dos fluxos, das circulaçóes, das mobilidades e das imobilidades - e suas conexôes com a formação, a expansão e as disputas por mercados, e com a produção de violências e desigualdades. Em grande medida, essa mudança no foco das investigaçốes deve-se aos novos problemas e questóes de pesquisa trazidos pelas etnografias produzidas no período, que exigiram, por sua vez, uma progressiva convergência entre diferentes áreas temáticas - particularmente entre

22 Vale ainda mencionar as coletâneas Imigração Boliviana no Brasil (Baeninger, 2012), Imigração Haitiana no Brasil (Baeninger et al., 2016) e Migraçôes Venezuelanas (Baeninger; Silva, 2018), que constituem esforços importantes de reunir pesquisas sobre migrantes da Bolívia, do Haiti e da Venezuela, mas que resvalam, entretanto, para um nacionalismo metodológico. 
estudos urbanos, migratórios e de gênero —, além da mobilização e da elaboração de novos paradigmas teórico-metodológicos.

Por um lado, as perspectivas transnacionais para a abordagem de campos e redes sociais de migrantes internacionais entre países de origem e recepção (Glick-Schiller; Basch; Blanc-Szanton, 1992; Feldman-Bianco, 1992) e os novos conceitos formulados, entre 1990 e os anos 2000, salientando as relaçóes entre os movimentos de pessoas, signos e capitais ou as mobilidades e a relação entre circulação e globalização, além da crítica ao nacionalismo metodológico (Glick-Schiller; Çaglar, 2011; Feldman-Bianco, 2011b; 2015; 2018a), continuam influenciando estudos nessas diversas áreas temáticas.

Por outro lado, sobretudo no âmbito da antropologia e sociologia urbana, o paradigma da mobilidade e a noção de territórios circulatórios, elaborados no final dos anos 1980 por Alain Tarrius (1989; 1993; 2000), deram vazão a análises sobre as relaçóes entre movimentos migratórios e a estruturação de redes transnacionais de comércio ambulante, com ênfase nos trânsitos de populaçóes subalternizadas, protagonistas do processo designado mundialização por baixo, como bem apontam Freire-Medeiros, Telles e Allis (2018). Nessa área temática, as contribuiçóes críticas trazidas por autores como Isaac Joseph (1998) e Yves Grafmayer (Grafmayer; Joseph, 1994) também foram relevantes por permitirem ampliar a noção de mobilidade para além do foco em processos de estratificação e mudança de nível social referidos a estruturas próprias ao interior dos Estados- -naçóes, associando o termo aos conceitos de circulação e acessibilidade (Freire-Medeiros; Telles; Allis, 2018 ${ }^{23}$.

Foucault (2008) é outro autor que tem importância decisiva tanto nos estudos urbanos quanto em diversas outras áreas temáticas, pautando análises sobre tecnologias de governo, gestão diferencial dos ilegalismos (Telles, 2010) e produção de formas mercantilizadas e securitárias de controle dos fluxos (Telles, 2015). No que tange particularmente à intersecção entre estudos migratórios e de gênero, para além das perspectivas transnacionais, do paradigma da mobilidade e do próprio Foucault, as perspectivas feministas reconhecidas como transnacionais, pós-coloniais e interseccionais (Anthias; Yuval-Davis, 1992; Brah, 2006; Cabezas, 2009; Constable, 2009; Kempadoo, 2004; McClintock, 1995) oferecem caminhos sugestivos para a análise de como gênero, imbricando com outras categorias de diferenciação, opera na migração e na produção de desigualdades.

Por sua vez, as reflexóes de David Harvey (2005) sobre neoliberalismo, a partir do conceito de acumulação por despossessão, assim como as análises críticas de Saskia Sassen (2014) sobre novas formas brutais de expulsão - que se expressam no aumento do número de pessoas, empreendimentos e lugares expelidos do coração da ordem social - inspiram pesquisas e a formulação de novos paradigmas para uma análise mais ampla dos deslocamentos e suas relaçóes com processos de despossessão e a produçáo de violências e desigualdades na atual conjuntura do capitalismo neoliberal (Feldman-Bianco, 2015; 2017; 2018a).

23 No campo dos estudos urbanos, vale também destacar a influência do novo paradigma das mobilidades elaborado a partir dos anos 1990 por John Urry $(2000$; 2007), especialmente em pesquisas voltadas às temáticas do turismo em favelas, mídia e consumo (Freire-Medeiros, 2013; Freire-Medeiros; Vilarouca; Menezes, 2013; Freire-Medeiros; Menezes, 2016; Freire-Medeiros; Name, 2017). 


\section{Considerações finais:} avanços, limites e desafios

Neste texto, examinamos a formação, a consolidação e as transformaçóes do campo de estudos migratórios no Brasil por meio da produçáo bibliográfica realizada entre 1940 e 2018. Essa análise desses quase 80 anos de investigaçôes acadêmicas revela que, apesar dos inegáveis avanços obtidos e do surgimento de projetos comparativos ou voltados a outros contextos nacionais, a maioria das pesquisas focaliza migrantes internacionais e/ou outros deslocados no ou do país. Portanto, estamos aparentemente construindo uma antropologia em casa das migraçôes e dos deslocamentos, mas cujos enfoques e paradigmas expóem diálogos, influências, tendências e debates internacionais, com base em pesquisas realizadas em diferentes conjunturas históricas.

Assim, entre as décadas de 1940 e 1970, em consonância com as tendências acadêmicas internacionais, pesquisadores adotaram abordagens assimilacionistas, enfatizando a aculturação dos modos de vida ou (no Pós-Guerra) a integração de imigrantes à sociedade de classes por meio do desenvolvimento econômico e da mobilidade social no país de radicação. A progressiva substituição de perspectivas assimilacionistas por estudos da etnicidade ocorreria em finais da década de 1960 e, com mais vigor, de $1970 \mathrm{em}$ diante, quando imigrantes passaram a ser examinados enquanto grupo étnico no país de destino.

Nos Estados Unidos, por exemplo, a viragem de ideologias assimilacionistas pelo pluralismo cultural constituiu estratégia de governo e de instituições filantrópicas americanas voltadas ao controle e à despolitização do movimento negro que, incorporando por extensão os pobres urbanos por meio da dis- tribuiçáo de recursos segundo linhas étnicas (Glick-Schiller, 2010), estimularam o florescimento da etnicidade. Em comparação, no Brasil, os preceitos de Fredrick Barth sobre etnicidade, grupo étnico e fronteiras étnicas atraíram, ainda durante a ditadura civil militar (1964-1985), discípulos de Florestan Fernandes dos campos da etnologia indígena, como Roberto Cardoso de Oliveira, e das migraçôes, como Francisca Keller.

Nesse âmbito, além de Giralda Seyferth ter sido uma das primeiras antropólogas a examinar, ancorada em Barth e Weber, as relaçôes entre nação e identidade étnica, suas investigaçóes etno-históricas contribuíram para conectar diferentes campos de estudos (como campesinato, colonização, imigração, classe, raça e racismo), artificialmente separados por um arraigado positivismo nas ciências sociais. Diferentemente de Florestan Fernandes - cuja proposta de comparar e contrapor o acesso diferencial de imigrantes e descendentes à mobilidade social restringiu a análise da questão racial aos descendentes de escravos e, ao mesmo tempo, invisibilizou a imanente racialização, discriminação e reelaboração das diferenças étnicas e culturais do "outro", estrangeiro —, Seyferth justapôs migração, raça e nação. Consequentemente, ajudou-nos a entender as conexóes entre migração, miscigenação e branqueamento, assim como hierarquias raciais e racismo no pensamento social brasileiro. O seu contínuo e detalhado mapeamento das políticas brasileiras de colonização e imigração constitui aporte significativo ao campo de estudos migratórios no Brasil.

Além do renovado interesse em estudos sobre os antigos contingentes de imigrantes e seus descendentes no Brasil, assistimos desde os finais dos anos de 1980, e mais veementemente a partir das décadas de 1990 e 2000, a expansão do campo de estudos 
migratórios, expressa pela criação de centros e núcleos, projetos comparativos e interdisciplinares, grupos e linhas de pesquisa, grupos de trabalho que contaram com financiamentos, assim como pela emergência de revistas, informes e outras publicações voltadas à temática. Enquanto pesquisadores dos antigos contingentes migratórios no Brasil tenderam a manter sua atenção às questôes relacionadas à identidade étnica, a migração de brasileiros para o exterior, iniciada em decorrência da crise econômica dos anos de 1980, ampliou o foco das investigaçôes, gerando novas questóes de pesquisa, acopladas à adoção de perspectivas transnacionais de migração — não só de pessoas, mas também de signos, produtos e capitais — em uma conjuntura marcada pela crescente criminalização de migrantes internacionais em situação indocumentada.

Como corolário, sequências de pesquisas de campo sincrônicas ou etno-históricas realizadas especialmente entre migrantes brasileiros radicados em diversas localidades dos Estados Unidos e de países membros da União Europeia, como Portugal e Espanha, confrontaram o desafio de examinar as relaçóes entre a construção de clandestinidade e ilegalidade, projetos familiares, trabalho e cidadania, gênero e interseccionalidades, e reconfiguraçóes identitárias no contexto do estabelecimento de políticas de viés securitário. Sucessivas descobertas de pesquisas direcionaram diversos estudos para o acompanhamento de novas problemáticas, alterando os focos de pesquisa - tais como o turismo sexual às migraçóes - e demandando a interconexão entre diferentes campos de estudo, tais como gênero e migraçóes; gênero, migraçôes e justiça criminal; migraçóes, continuidades coloniais e direitos humanos e assim por diante.
Também as etnografias realizadas em cidades do Brasil de onde saíram os brasileiros que foram viver no exterior ou naquelas onde mais recentemente se estabeleceram os novos contingentes de migrantes, oriundos de países da África, do Oriente Médio, da América Latina e do Caribe, da China, entre outros (muitos dos quais solicitantes de refúgio que escaparam de guerras e regimes autoritários), exigiram a reavaliação das questóes e dos focos de pesquisa. Especialmente os acontecimentos envolvendo a chegada no país de "refugiados climáticos" do Haiti em 2010 atraíram a atenção de estudantes e pesquisadores, estimulando o interesse em pesquisas sobre novos fluxos migratórios, trazendo à tona novos temas de investigação e motivando novas interconexôes entre campos de estudo.

Devemos atentar que, além de desafiarem o imanente positivismo, essas junções entre campos incluem áreas de estudos mais recentes, tais como gênero, violência e direitos humanos. Porém, acima de tudo, essas junçôes e interconexóes nos orientam a discernir melhor as complexidades dos processos sociais, além de nos dar condiçóes para elaborar novos paradigmas ou incorporar outros já existentes. Afinal, como Eric Wolf nos ensina, os conceitos e os modelos devem ser tratados como um kit de ferramentas, que podem nos conduzir a "uma avaliação crítica dos modos como formulamos e respondemos certas questôes e as limitaçôes que trazemos a essas tarefas" (Wolf, 1988, p. 321). Entretanto, é a etnografia, especialmente a etno-histórica, que, ao fornecer ferramentas para a contínua reavaliação de nossas ideias, revela-nos novos horizontes e elementos para refletir e mudar a teoria (Vincent, 1991).

Em um cenário mundial caracterizado por intensos deslocamentos sociais e ecológicos, expulsóes, brutalidade, acumulação por 
despossessão, precariedade da vida humana e criminalização da pobreza, a análise de padrôes recorrentes nas formas de controle das fronteiras e de populaçôes diversas em diferentes contextos, através do tempo e do espaço, levou à incorporaçáo de abordagens teóricas que vão desde a perspectiva foucaultiana de tecnologias de governo até abordagens interseccionais e pós-coloniais. Ao mesmo tempo, está em elaboração um paradigma mais amplo e comparativo de deslocamentos para analisar e teorizar a respeito de vários tipos, escalas e espaços das mobilidades e das imobilidades à luz dos interstícios da dominação e do poder, que são percebidos como parte inerente à reestruturação do capitalismo global (Feldman-Bianco, 2015; 2017; 2018a). Procuram-se, assim, expor políticas, padróes e processos similares que produzem deslocamentos, desigualdades, despossessão e violências em relação a diferentes populaçôes à margem.

Desse prisma, enquanto examinamos, entre 1940 e meados dos anos 2000, a produção bibliográfica mais direcionada às migraçôes internacionais, utilizamos esse emergente e mais amplo paradigma de migraçóes e deslocamentos para expor políticas e processos sociais similares que estão ocorrendo em várias áreas temáticas, seja migraçóes, estudos urbanos, etnologia indígena, desastres ambientais causados por grandes projetos desenvolvimentistas, entre outros.

Entretanto, com os avanços obtidos, confrontamos persistentes limitaçóes, principalmente no que se refere ao nacionalismo metodológico que impregna a maior parte da produção bibliográfica examinada. Não raras vezes, migrantes internacionais são nomeados por sua nacionalidade e associados ao seu país de origem, desconsiderando assim a heterogeneidade dessas populaçóes e a pluralidade de formas a partir das quais elas próprias se nomeiam e se diferenciam, e em que situaçóes. Tende-se ainda a tomar como dado, e assim naturalizar, os imigrantes enquanto grupo étnico, em vez de se examinar quando e em que situaçóes a etnicidade acontece e quando sáo acionadas outras identidades. Além do mais, embora migrantes vivam em cidades, deixa-se de se analisar a escala da cidade e as formas de inserção desses protagonistas e suas relaçóes com outros migrantes e nacionais. $\mathrm{O}$ mesmo ocorre em pesquisas que focalizam outras populaçôes da cidade.

Além da necessidade de problematizar essas questóes e dirimir esses entraves, estamos confrontando desde a ascensáo da extrema direita, ameaças à democracia e à ordem constitucional à perda de direitos e ao aumento da violência, do racismo e da xenofobia contra migrantes, indígenas, afro-brasileiros - enfim, uma escalada das políticas draconianas de criminalização da pobreza e da despossessão, já apontadas nesse balanço bibliográfico. Nesse sentido, torna-se crucial estudar as relações entre as políticas atuais, a ascensão da extrema direita e o foco em deslocamentos não somente no que se refere à produção de conhecimento, mas também à ação social.

\section{Bibliografia}

ALARCON, D. F. The return of relatives: processes of mobilisation and village construction among the Tupinambá of Serra do Padeiro, southern Bahia, Brazil. Vibrant, v. 15, n. 2, 2018. https://doi.org/10.1590/1809$43412018 \mathrm{v} 15 \mathrm{n} 2 \mathrm{a} 401$ 
ALBUQUERQUE, J. L. C. A dinâmica das fronteiras: os brasiguaios na fronteira entre o Brasil e o Paraguai. São Paulo: Annablume/FAPESP, 2010. 265 p.

ALBUQUERQUE, J. L. C.; PAIVA, L. F. S. Entre naçôes e legislaçôes: algumas práticas de "legalidade" e "ilegalidade" na tríplice fronteira amazônica. Revista Ambivalências, v. 3, n. 5, p. 85-114, 2015. https://doi. org/10.21665/2318-3888.v3n5p115-148

ANTHIAS, F.; YUVAL-DAVIS, N. Racialized boundaries: race, nation, gender, colour and class and the anti-racist struggle. Londres: Routledge, 1992.

APPADURAI, A. The Social Life of Things. Cambridge e Nova York: Cambridge University Press, 2008.

ARANTES, A. A. A Guerra dos Lugares. In: FORTUNA, C. (org.). Cidade, Cultura e Globalizaçáo: Ensaios de sociologia. Oeiras: Celta, 1997. p. 259-270.

ARANTES, A. A. Guia Cultural do Museu Aberto do Descobrimento. Campinas: Andrade e Arantes, 2002.

ARANTES, A. A. (org.). O espaço da diferença. Campinas: Papirus, 2000.

ARANTES, A. A. Paisagens Paulistanas: transformações do espaço público. Campinas: Editora da Unicamp, 1999.

ARAÚJO, F. Das “técnicas” de fazer desaparecer corpos: desaparecimentos, violência, sofrimento e política. Rio de Janeiro: Lamparina, 2014.

ARAÚJO, J. R. Imigraçáo e Futebol: o caso Palestra Itália. São Paulo: IDESP/Sumaré, 2000.

ASSIS, G. de O. De Criciúma para o mundo: Os novos fluxos da população brasileira: gênero e rearranjos familiares. In: MARTES, A. C.; FLEISCHER, S. Fronteiras cruzadas: etnicidade, gênero e redes sociais. São Paulo: Paz e Terra, 2003.

ASSIS, G. de O. De Criciúma para o mundo: rearranjos familiares e de gênero dos novos migrantes brasileiros. Florianópolis: Editora Mulheres, 2011.

ASSIS, G. de O. De Criciúma para o mundo: rearranjos familiares e de gênero nas vivências dos novos migrantes brasileiros. Tese (Doutorado em Ciências Sociais) - Universidade Estadual de Campinas, Campinas, 2004.

ASSIS, G. de O. Estar aqui... estar lá uma cartografia da vida entre os Estados Unidos e o Brasil. Campinas: Nepo/ Unicamp, 2002. (Textos NEPO, 41.)

ASSIS, G. de O. Mulheres imigrantes no passado e no presente: gênero, redes sociais e migraçôes internacionais. Revista Estudos Feministas, v. 15, n. 3, p. 745-772, 2007.

ASSIS, G. de O.; SASAKI, E. M. Os novos migrantes do e para o Brasil: um balanço da produção bibliográfica. In: CASTRO, M. G. (org.). Migraçôes internacionais: contribuiçôes para políticas. Brasília: CNPD, 2001. p. 615-669.

ASSIS, G. de O.; SIQUEIRA, S. Mulheres emigrantes e a configuração de redes sociais: construindo conexôes entre o Brasil e os Estados Unidos. REMHU, v. 17, n. 32, 2009.

ASSIS, G. de O.; ZANINI, M. C.; BENEDUZI, L. F. Ítalo-Brasileiros na Itália no século XXI: "retorno" à terra dos antepassados, impasses e expectativas. REMHU, v. 21, p. 139-162, 2013.

AZEVEDO, D. Ausências incorporadas: etnografia entre mortos e desaparecidos políticos no Brasil. São Paulo: Editora Unifesp, 2018.

AZEVEDO, D. Os melhores anos de nossas vidas: narrativas, trajetórias e trajetos de exilados brasileiros em Moçambique. São Paulo: Annablume, 2013. 
AZEVEDO, D. Trajetórias militantes: do Brasil a Moçambique nas redes da esquerda internacional. Etnográfica, Lisboa, v. 16, n. 3, p. 461-486, 2012. https://doi.org/10.4000/etnografica.2085

AZEVEDO, D.; SANJURJO, L. Between dictatorships and revolutions: narratives of Argentine and Brazilian exiles. Vibrant, v. 10, n. 2, 2013. http://dx.doi.org/10.1590/S1809-43412013000200010

AZEVEDO, T. de. Italianos e gaúchos. Rio de Janeiro/Brasília: Ed. Cátedra/Fundação Nacional Pró-Memória, 1975.

BAENINGER, R. Imigração Boliviana no Brasil. Campinas: NEPO/UNICAMP, 2012.

BAENINGER, R. et al. (orgs.). Imigraçáo Haitiana no Brasil. Jundiaí: Paco Editorial, 2016.

BAENINGER, R.; SILVA, J. C. J. (orgs.). Migraçōes Venezuelanas. Campinas: NEPO/UNICAMP/FAPESP, 2018.

BAHIA, J. D. do V. Imigração judaica e ativismo político nas cidades do Rio de Janeiro e de São Paulo. In: PACELI, A. et al. (orgs.). A experiência migrante: deslocamentos e reconstruçóes. Rio de Janeiro: Garamond, 2010.

BAHIA, J. D. do V. O tiro da bruxa: identidade, magia e religiáo entre os camponeses pomeranos do Espírito Santo. Tese (Doutorado) - Universidade Federal do Rio de Janeiro, Rio de Janeiro, 2000.

BAHIA, J. D. do V. O tiro da bruxa: identidade, magia e religião entre os imigrantes alemães. Rio de Janeiro: Garamond, 2011. 410 p.

BAINES, S. G. A Política Indigenista Governamental e Os Waimiri-Atroari: Administraçôes Indigenistas, Mineração de Estanho e A Construção de "Autodeterminação Indígena" Dirigida. Revista de Antropologia, São Paulo, v. 36, p. 207-237, 1993. https://doi.org/10.11606/2179-0892.ra.1993.111395

BAINES, S. G. A situação prisional de indígenas no sistema penitenciário de Boa Vista, Roraima. Vivência: Revista de Antropologia, v. 1, n. 46, p. 143-155, 2015.

BAINES, S. G. A usina hidrelétrica Balbina e o Programa Waimiri-Atroari - (des)articulação da etnicidade. In: RODRIGUES, L. C.; SILVA, I. B. P. (orgs.). Saberes locais, experiências transnacionais: interfaces do fazer antropológico. Fortaleza: ABA Publicaçôes, 2014. p. 207-217.

BAINES, S. G. As Terras Indígenas no Brasil e a "regularizaçáo" da implantação de grandes usinas hidrelétricas e projetos de mineração na Amazônia. Série Antropologia, Brasília, v. 300, p. 1-16, 2001.

BAINES, S. G. Globalization and the Impacts of Large-Scale Development Projects on Indigenous Peoples of the Brazilian Amazon. Latinam-Zine, v. 1, n. 1, p. 70-77, 2011.

BAINES, S. G. Povos Indígenas na Fronteira Brasil-Guiana e os megaprojetos de integração econômica. Ciência e Cultura, v. 65, n. 1, p. 40-42, 2013. http://dx.doi.org/10.21800/S0009-67252013000100016

BAINES, S. G. Projetos de desenvolvimento na Amazônia e as estratégias de grandes empresas. Abya-Yala: Revista sobre Acesso à Justiça e Direitos nas Américas, v. 1, n. 1, p. 297-314, 2017. https://doi.org/10.26512/abyayala.v1i1.6785

BALDUS, H.; WILLEMS, E. Casas e túmulos de japoneses no Vale do Ribeira de Iguape. Revista do Arquivo Municipal, v. 77, p. 121-137, 1941.

BARROS, R.; FARIAS, J. Political displacements between the periphery and the center through territories and bodies. Vibrant, v. 14, n. 3, 2017. https://doi.org/10.1590/1809-43412017v14n3p279

BARTH, F. Ethnic Groups and Boundaries. Bergen/Londres: Universitetforlaget/George Alle \& Unwin, 1969.

Basch, L.; Glick-Schiller, N.; Szanton-Blanc, C. Nations Unbound: Transnational Projects, Postcolonial Predicaments and Deterritorialized Nation-States. Nova York, Gordon e Breach: Routledge, 1994. 
BASTIDE, R.; FERNANDES, F. Brancos e negros em Sáo Paulo. São Paulo: Companhia Editora Nacional, 1959.

BASTOS, C.; ALMEIDA, M. V. de; FELDMAN-BIANCO, B. (orgs.). Trânsitos coloniais: diálogos críticos lusobrasileiros. Campinas: Editora da Unicamp, 2007.

BASTOS, C.; ALMEIDA, M. V. de; FELDMAN-BIANCO, B. (orgs.). Trânsitos coloniais: diálogos críticos lusobrasileiros. Lisboa: Imprensa de Ciências Sociais, 2002.

BERTONHA, J. F. Fascismo, antifascismo y las comunidades italianas en Brasil, Argentina y Uruguay: Una perspectiva comparada. Estudios Migratorios Latinoamericanos, v. 14, n. 42, p. 111-133, 2000.

BERTONHA, J. F. Fascismo e emigração italiana. In: SILVA, C. T. (org.). Enciclopédia de guerras e revoluçóes do século XX: as grandes transformaçóes do mundo contemporâneo. Rio de Janeiro: Elsevier, 2004a. p. 295-296.

BERTONHA, J. F. O antifascismo italiano no Brasil: comparações internacionais e vivências transnacionais. Anuario IEHS, Tandil, v. 19, p. 63-78, 2004 b.

BERTONHA, J. F. Sob a sombra de Mussolini: os italianos de São Paulo e a luta contra o fascismo, 1919-1945. São Paulo: Annablume, 1999.

BESERRA, B. Brazilian Immigrants in the United States: Cultural Imperialism and Social Class. Nova York: LFB Scholarly Publishing, 2003.

BESERRA, B. From Brazilians to Latinos? Racialization and Latinidad in the Making of Brazilian Carnival in Los Angeles. Latino Studies, v. 3, p. 53-75, 2005. https://doi.org/10.1057/palgrave.lst.8600131

BESERRA, B. Sob a sombra de Carmen Miranda e do carnaval: brasileiras em Los Angeles. Cadernos Pagu, v. 28, p. 313-344, 2007. https://doi.org/10.1590/S0104-83332007000100014

BESERRA, B. The reinvention of Brazil and other metamorphoses in the world of Chicago Samba. Vibrant, v. 8, n. 1, p. 117-145, 2011. https://doi.org/10.1590/S1809-43412011000100005

BETTS, A.; KAINZ, L. The History of Global Governance. Refugee Studies Centre, Working Paper Series, v. 122, p. 1-18, 2017.

BIONDI, K. Etnografia do movimento: território, hierarquia e lei no PCC. Tese (Doutorado) - Programa de PósGraduação em Antropologia Social, Universidade Federal de São Carlos, São Carlos, 2014.

BIONDI, L. Entre associaçóes étnicas e de classe. Os processos de organizaçáo política e sindical dos trabalhadores italianos na cidade de Sáo Paulo. Tese (Doutorado em História Social) - Universidade Estadual de Campinas, Campinas, 2002.

BIONDI, L. Identidade de classe e identidade nacional entre solidariedade e conflito: Socialistas e republicanos italianos na São Paulo do início do século XX e suas relaçôes com as associaçóes patrícias e o nascente sindicalismo. Estudos Ibero-Americanos, v. 26, n. 1, p. 131-162, 2000. http://dx.doi.org/10.15448/1980864X.2000.1.24789

BIONDI, L. Sociedades italianas de socorro mútuo e política em São Paulo entre o século XIX e o século XX. Travessia, Revista do Migrante, v. 34, p. 5-12, 1999.

BIRMAN, P.; FERNANDES, A.; PIEROBON, C. Um emaranhado de casos: tráfico de drogas, estado e precariedade em moradias populares. Mana, v. 20, n. 3, p. 431-460, 2014. http://dx.doi.org/10.1590/S010493132014000300001

BLANCHETTE, T. G. Gringos. Dissertação (Mestrado em Antropologia Social) - Universidade Federal do Rio de Janeiro, Rio de Janeiro, 2001. 
Blanchette, T. G.; SILVA, A. P. da. A vítima designada: Representaçōes do tráfico de pessoas o Brasil. Revista Brasileira de Ciências Sociais, v. 33, n. 98, 2018. http://dx.doi.org/10.1590/339807/2018

Blanchette, T. G.; SILVA, A. P. da. O mito de Maria, uma traficada exemplar: confrontando leituras mitológicas do tráfico com as experiências de migrantes brasileiros, trabalhadores do sexo. REHMU, ano XIX, n. 37, p. 79-105, jul./dez. 2011.

BONGIANINO, C. F. Crescendo pessoas, relaçôes e lugares: experiências cabo-verdianas sobre família e mobilidade. Cadernos Pagu, v. 45, p. 111-133, 2015. http://dx.doi.org/10.1590/18094449201500450111

BORGES PEREIRA, J. B. Italianos no mundo rural paulista. São Paulo: Pioneira/IEB-USP, 1974.

BOURDIEU, P. Preface. In: SAYAD, A. The Suffering of the Immigrant. Cambridge: Polity Press, 2004. p. xi-xiv.

BRAH, A. Diferença, diversidade, diferenciação. Cadernos Pagu, n. 26, p. 329-365, 2006.

BRASIL JR., A. O imigrante e seus irmãos: as pesquisas empíricas de Florestan Fernandes e Gino Germani. Lua Nova, n. 81, p. 175-213, 2010. http://dx.doi.org/10.1590/S0102-64452010000300008

CABEZAS, A. Economies of desire. Sex and tourism in Cuba and the Dominican Republic. Filadélfia: Temple University Press, 2009.

CAETANO DA SILVA, E. Dialéticas da inclusão e da exclusão: Lideranças portuguesas de São Paulo e a questão da invisibilidade. Convergência Lusíada, Real Gabinete Português de Leitura, v. 19, p. 120-136, 2002.

CAETANO DA SILVA, E. Entre as glórias renovadas do Império e o discurso da irmandade: História, política e identidade num enredo luso-brasileiro. Temáticas, v. 10, n. 19/20, p. 35-59, 2003 a.

CAETANO DA SILVA, E. La saudade des jeunes et la modernité des anciens: constructions culturelles de ressemblance et de différence parmi les migrantes portugais et luso-descendants de São Paulo. Revue Annuelle du Groupe Anthropologie du Portugal, Paris, n. 9, p. 47-59, 2003b.

CAPERNEDO, M.; NARDI, H. Maternidade transnacional e produção de subjetividade: as experiências de mulheres brasileiras imigrantes vivendo em Londres. Cadernos Pagu, n. 49, 2017. https://doi.org/10.1590/180944492 01700490012

CARDOSO, F. H. Capitalismo e escravidáo no Brasil meridional. O negro na sociedade escravocrata do Rio Grande do Sul. São Paulo: Difusão Europeia do Livro, 1962.

CARDOSO, F. H.; IANNI, O. Cor e mobilidade social em Florianópolis. São Paulo: Companhia Editora Nacional, 1960.

Cardoso, R. C. L. A trajetória dos movimentos sociais. In: DAGNINO, E. (org.). Os anos 90: política e sociedade no Brasil. São Paulo: Brasiliense, 1994.

CARDOSO, R. C. L. O agricultor e o profissional liberal entre os Japoneses no Brasil. Revista de Antropologia, v. 11, n. 1-2, p. 53-60, 1963. https://doi.org/10.11606/2179-0892.ra.1963.110687

CARDOSO, R. C. L. O papel das associaçóes juvenis na aculturação dos japoneses. Revista de Antropologia, v. 7, n. 1-2, p. 101-122, 1959. https://doi.org/10.11606/2179-0892.ra.1959.110393

CARDOSO, R. C. L.; DURHAM, E. R. Estrutura familiar e mobilidade social: estudo dos japoneses no Estado de São Paulo. São Paulo: Universidade de São Paulo, 1972.

CARDOSO DE OLIVEIRA, R. Identidade, etnia e estrutura social. São Paulo: Pioneira, 1976. 
CARdoso DE OliveirA, R. O índio e o Mundo dos Brancos. São Paulo: Difusão Europeia, 1964.

CARNEIRO DA CUNHA, M. Negros estrangeiros: os escravos libertos e sua volta à África. São Paulo: Brasiliense, 1985.

CARRICONDE, R. M. “Cair na Rede”: circulaçóes desde abrigos da cidade. Tese (Doutorado em Ciências Sociais) - Programa de Pós-Graduaçáo em Ciências Sociais, Universidade do Estado do Rio de Janeiro, Rio de Janeiro, 2019.

CARSTEN, J. After Kinship. Cambridge: Cambridge University Press, 2004.

CARVALHO FRANCO, M. S. O estudo sociológico de comunidades. Revista de Antropologia, v. 11, n. 1-2, p. 29-39, 1963. https://doi.org/10.11606/2179-0892.ra.1963.110684

CASTRO, M. G. (org.). Dossiê Identidades, Alteridades, Latinidades. Caderno CRH, Salvador, v. 32, jan./jun. 2000.

CASTRO, M. G.; BERQUÓ, E. (orgs.). Migraçôes internacionais e políticas: Algumas experiências internacionais. In: CASTRO, M. G.; BERQUÓ, E. (orgs.). Migraçóes internacionais: contribuiçôes para políticas. Brasília: Comissão Nacional de População e Desenvolvimento, 2001. p. 15-32.

CAVALCANTI, L.; OLIVEIRA, M. O tema das migraçôes internacionais na Sociologia no Brasil. Revista Brasileira de Sociologia, v. 6, n. 12, p. 88-113, 2018. http://dx.doi.org/10.20336/rbs.235

CÉSARO, F. S. de; ZANINI, M. C. C. “Tem que estar bonito pra vender": a produçấo senegalesa de espaços de venda em Santa Maria (Rio Grande do Sul, Brasil). REMHU, Brasília, v. 26, n. 52, p. 95-110, jan./abr. 2018.

COHEN, A. Custom and Politics in Urban Africa: A Study of Hausa Migrants in Yoruba Towns. Los Angeles e Berkeley: University of California Press, 1969.

CONSTABLE, N. The commodification of intimacy: marriage, sex and reproductive labour. Annual Review of Anthropology, v. 38, p. 49-64, 2009. https://doi.org/10.1146/annurev.anthro.37.081407.085133

COSTA, J. B. de A. Negros do norte de Minas: expropriados, excluídos, criminalizados e construtores de si como sujeitos de direitos constitucionais. In: OLIVEIRA, O. M. de (org.). Direitos quilombolas \& dever de Estado em 25 anos da Constituiçáo Federal de 1988. Rio de Janeiro: Associaçăo Brasileira de Antropologia, 2016.

COSTA, P. H. M. de A. Entre os documentos e as retomadas: movimentos da luta quilombola em Brejo dos Crioulos (MG). In: EILBAUM, L.; SCHUCH, P.; CHAGAS, G. F. (orgs.). Antropologia e Direitos Humanos 7. Rio de Janeiro: Associação Brasileira de Antropologia, 2017.

COSTA PINTO, L. de A. Pesquisas sobre a Bahia. A Tarde, Salvador, p. 3, 27 out. 1950.

CUNHA, E. L. Comemoraçôes dos Descobrimentos: reconfiguraçốes contemporâneas da nacionalidade no Brasil e em Portugal. In: GROSSEGESSE, O. (org.). O Estado do Novo Futuro: Brasil e Portugal entre Identidade e Globalização. Berlim: Tranvía-Verlag Walter Frey, 2004. p. 66-87.

CUNHA, E. L. Margens: multiculturais, diaspóricas, pós-coloniais. Margens/Márgenes, v. 1, n. 3, p. 16-21, 2003.

CUNHA, E. L. O Brasil ao alcance de todos: imagens da nacionalidade e comemoraçóes dos 500 anos do descobrimento. Revista Semear, v. 5, p. 87-105, 2001.

CUNHA, E. L. O Brasil no imaginário português. Revista Semear, v. 6, p. 143-155, 2002.

CUNHA, E. L. (org.). Dossiê Nação e Identidades. Caderno CRH, Salvador, n. 33, 2000.

DAS, V.; POOLE, D. State and its margins: comparative ethnographies. In: DAS, V.; POOLE, D. Anthropology in the Margins of the State. Santa Fé: School of American Research Press, 2004. p. 3-33. 
DE LUCCA, D. Nem dentro, nem fora do albergue: transformaçôes e usos de um dispositivo da assistência. In: CUNHA, N. V.; FELTRAN, G. S. (orgs.). Sobre periferias: novos conflitos no Brasil contemporâneo. Rio de Janeiro: Lamparina \& FAPERJ, 2013.

DEBERT, G. G. Migrações e o Cuidado do idoso. Cadernos Pagu, n. 46, p. 129-149, 2016. https://doi.org/10.159 $0 / 18094449201600460129$

DIAS, G. M. Experiências de trabalho temporário nos Estados Unidos: uma abordagem etnográfica do Okemo. Dissertação (Mestrado em Antropologia Social) - Universidade Estadual de Campinas, Campinas, 2007.

DIAS, G. M. Governabilidade Migratória e Organismos Internacionais. In: LIMA, A. C. S. et al. (orgs.). A Antropologia e a Esfera Pública no Brasil. Brasília: ABA Publicações, 2018. p. 611-627.

DIAS, G. M. Migraçáo e Crime: desconstruçáo das políticas de segurança e tráfico de pessoas. Tese (Doutorado em Antropologia Social) - Universidade Estadual de Campinas, Campinas, 2014 a.

DIAS, G. M. Migração, segurança e governabilidade migratória. O papel dos Organismos Internacionais. Crítica y Emancipación, v. 6, n. 11, p. 557-579, 2014 b.

DIAS, G. M. Notas sobre as negociaçōes da "Convenção do Crime" e dos protocolos adicionais sobre tráfico de pessoas e contrabando de migrantes. REMHU, Brasília, v. 23, n. 45, jul./dez. 2015. https://doi.org/10.1590/19808585250319880004511

DIAS, G. M. The experience of guestworkers at a United States Tourist Resort. Vibrant, v. 10, n. 2, p. 198-228, 2013. https://doi.org/10.1590/S1809-43412013000200007

DIAS, G. M. Trata de personas, tráfico de migrantes y la gobernabilidad de la migración a través del crimen. Etnográfica, v. 21, n. 3, p. 541-554, 2017. https://doi.org/10.4000/etnografica.5026

DIAS, G. M.; SPRANDEL, M. A. Reflexôes sobre políticas para migraçôes e tráfico de pessoas no Brasil. REMHU, v. 19, n. 37, p. 59-77, 2011.

DIAS, J. B. Projetos migratórios e relaçôes familiares em Cabo Verde. REMHU, v. 14, n. 26/27, 2006.

DIEGUES JR., M. Imigraçáo, urbanizaçáo, industrializaçáo. Rio de Janeiro: Centro Brasileiro de Pesquisas Educacionais/MEC, 1964.

DIEGUES JR., M.; NEIVA, A. H. The cultural assimilation of immigrants in Brazil. In: BORRIE, W. D. (org.). The cultural integration of immigrants: a survey based upon the papers and proceedings of the UNESCO conference held in Havana. Paris: UNESCO, 1956. p. 181-233.

DOMENECH, E. O controle da imigração "indesejável”: expulsão e expulsabilidade na América do Sul. Ciência e Cultura, v. 67, n. 2, p. 25-29, 2015. http://dx.doi.org/10.21800/2317-66602015000200010

DURHAM, E. A caminho da cidade: a vida rural e a migração para São Paulo. São Paulo: Perspectiva, 1973.

DURHAM, E. Mobilidade e Assimilação. A história do imigrante italiano num município paulista. São Paulo: Instituto de Estudos Brasileiros, 1966.

EISENSTADT, S. N. Sociological Aspects of the Economic Adaptation of Oriental Immigrants in Israel: A Case Study in the Process of Modernization. Economic Development and Cultural Change, v. 4, n. 3, p. 269-278, 1956. https://doi.org/10.1086/449717

EISENSTADT, S. N. The absorption of immigrants. Londres: Routledge \& Kegan Paul, 1954. 
ETcheberre, R. Cotidiano na Diáspora: Uma etnografia sobre haitianas na cidade de Santa Barbara D’Oeste, interior de Sáo Paulo. Dissertação (Mestrado em Antropologia Social) - Universidade Estadual de Campinas, Campinas, 2018.

EVANGELISTA, R. de A. Traidores do Movimento: política, cultura, ideologia e trabalho no Software Livre. Tese (Doutorado em Antropologia Social) - Universidade Estadual de Campinas, Campinas, 2010.

FACUNDO NAVIA, A. Êxodos, refúgios e exílios Colombianos no Sul e Sudeste do Brasil. Rio de Janeiro: Papéis Selvagens, 2017.

FACUNDO NAVIA, A. Romanticismo do exílio e anonimato do refúgio: comunidades morais e administração de populaçōes e trânsitos no Brasil contemporâneo. In: POVOA NETO, H.; SANTOS, M. de O.; PETRUS, R. (orgs.). Migraçóes: rumos, tendências e desafios. São Paulo: Polo Books, 2016. p. 199-214.

FARIAS, J. Governo das mortes: uma etnografia da gestáo de populaçóes de favelas no Rio de Janeiro. Tese (Doutorado) - Programa de Pós-Graduaçáo em Sociologia e Antropologia, Universidade Federal do Rio de Janeiro, Rio de Janeiro, 2014.

FASSIN, D. Compassion and Repression: The Moral Economy of Immigration Policies in France. Cultural Anthropology, v. 20, n. 3, p. 362-387, 2005.

FASSIN, D. Gobernar por los cuerpos, políticas de reconocimiento hacia los pobres y los inmigrantes em Francia. Cuadernos de Antropología Social, n. 17, p. 49-78, 2003. https://doi.org/10.34096/cas.i17.4599

FASSIN, D. Humanitarian Reason. Berkeley: University of California Press, 2012.

FAUSTO, B. (org.). Fazer a América: a Imigração em Massa para a América Latina. São Paulo: EDUSP, 1999.

FAUSTO, B. et al. (orgs.). Imigraçáo e Política em Sáo Paulo. São Carlos: EdUFSCar, 1995.

FELDMAN-BIANCO, B. A Família na Diáspora e a Diáspora na Família. In: ALMEIDA, H. B.; CAPELATO, M. H. (orgs.). Manifestaçóes Culturais nas Américas: Relaçōes de Gênero e Diversidade Cultural. São Paulo e Rio de Janeiro: EDUSP/Expressão e Cultura, 1999. p. 253-273.

FELDMAN-BIANCO, B. A Saudade Portuguesa na América: Artefatos Culturais, Histórias Orais e a Tradução de Culturas. Revista Crítica de Ciências Sociais, n. 45, p. 113-126, 1996.

FELDMAN-BIANCO, B. Anthropology and Ethnography: The Transnational Perspective on Migration and Beyond. Etnográfica, v. 22, n. 1, p. 195-215, 2018a. https://doi.org/10.4000/etnografica.5203

FELDMAN-BIANCO, B. Apresentação: Deslocamentos, Desigualdades e Violência de Estado. Ciência e Cultura, v. 67, n. 2, p. 20-24, 2015. http://dx.doi.org/10.21800/2317-66602015000200009

FELDMAN-BIANCO, B. Brazilians in Portugal, Portuguese in Brazil: Cultural Constructions of Sameness and Difference. Identities: Global Studies in Culture and Power, v. 8, n. 4, p. 607-650, 2001. https://doi.org/10. 1080/1070289X.2001.9962710

FELDMAN-BIANCO, B. Caminos de ciudadanía: emigración, movilizaciones sociales y políticas do Estado brasileiro. In: FELDMAN-BIANCO, B. et al. (orgs.). La construcción social del sujeto migrante en América Latina: prácticas, representaciones y categorías. Equador: Flacso, 2011a. p. 235-280.

FELDMAN-BIANCO, B. Desarrolos de la perspectiva transnacional: Migración, ciudad y económia política en la interseccion de la antropología y la historia. In: BESSERER, F. (org.). Intersecciones Urbanas: Ciudad Transnacional, Ciudad Global. Ciudad de México: Editorial UAM - Collección Estudios Transnacionales, 2016. p. 57-86. 
FELDMAN-BIANCO, B. Deslocamentos. In: CAVALCANTI, L. et al. (orgs.). Dicionário crítico de migraçóes internacionais. Brasília: Editora Universidade de Brasília, 2017.

FELDMAN-BIANCO, B. Entre a "fortaleza" da Europa e os laços afetivos da "irmandade" luso-brasileira: um drama familiar em um só ato. In: BASTOS, C.; ALMEIDA, M. V.; FELDMAN-BIANCO, B. (orgs.). Trânsitos coloniais: diálogos críticos luso-brasileiros. Lisboa: Imprensa de Ciências Sociais, 2002. p. 385-415.

FELDMAN-BIANCO, B. Globalizaçáo, antigos imaginários e reconfiguraçóes de identidade: percursos de uma pesquisa comparativa. Cadernos CRH, v. 13, n. 33, p. 27-48, 2000a. http://dx.doi.org/10.9771/ccrh. v13i33.18567

FELDMAN-BIANCO, B. Imigração, Confrontos Culturais e (Re)construçôes de Identidade Feminina: O Caso das Intermediárias Culturais. Horizontes Antropológicos, v. 3, n. 5, p. 65-83, 1997 a.

FELDMAN-BIANCO, B. Immigration, Cultural Contestations and the Reconfiguration of Identities. Journal of Latin American Anthropology, v. 4, n. 1-2, p. 126-141, 2000 b.

FELDMAN-BIANCO, B. Introdução. Revista Crítica de Ciências Sociais, v. 48, p. 1-8, 1997 b.

FELDMAN-BIANCO, B. Multiple Layers of Time and Space: The Construction of Class, Ethnicity and Nationalism among Portuguese immigrants. In: SCHILLER, N. G.; BASCH, L.; BLANC-SZANTON, C. (eds.). Towards a Transnational perspective on Migration: Race, Class, Ethnicity and Nationalism Reconsidered. Nova York: New York Academy of Science, 1992. p. 145-174.

FELDMAN-BIANCO, B. O Brasil frente ao regime global de controle das migraçôes: Direitos humanos, securitização e violências. Revista Travessias, v. 31, n. 83, p. 11-36, 2018 b.

FELDMAN-BIANCO, B. Reconstruindo a Saudade Portuguesa em Vídeo: Histórias orais, artefatos visuais e a tradução de códigos culturais na pesquisa etnográfica. In: FELDMAN-BIANCO, B.; LEITE, M. L. M. (orgs.). Desafios da Imagem: Iconografia, fotografia e vídeo nas ciências sociais. Campinas: Papirus, 1998. p. 289-304.

FELDMAN-BIANCO, B. Reinventando a Localidade: Globalização Heterogênea, Escala da Cidade e a Incorporação Desigual de Migrantes Transnacionais. Horizontes Antropológicos, v. 15, n. 31, p. 19-50, 2009. https://doi. org/10.1590/S0104-71832009000100002

FELDMAN-BIANCO, B. Remaking Locality: Uneaven Globalization and Unequal incorporation of Transmigrants. In: GLICK-SCHILLER, N.; ÇAGLAR, A. (orgs.). Locating Migration: Rescaling Cities and Migrants. Chicago: Cornell University Press, 2011b.

FELDMAN-BIANCO, B. Saudade. Watertown: Documentary Educational Resources, 1991. 59 min.

FELDMAN-BIANCO, B. The Aftermath of a Rape Case: The Politics of Migrants' Unequal Incorporation in NeoLiberal Times. In: BARBER, P. G.; LEMB, W. (orgs.). Migration in the 21st Century: Political Economy and Ethnography. Nova York: Taylor \& Francis/Routledge, 2012.

FELDMAN-BIANCO, B. The State, Saudade and the Dialectics of Deterritorialization and Reterritorialization, in working paper. Oficina do CES, n. 46, 1995.

FELDMAN-BIANCO, B. (org.). Naçóes e Diásporas. Estudos Comparativos entre Brasil e Portugal. Campinas: Editora da Unicamp, 2010.

FELDMAN-BIANCO, B. et al. Introducción. In: FELDMAN-BIANCO, B. La construcción social del sujeto migrante en América Latina: prácticas, representaciones y categorías. Equador: Flacso, 2011c. p. 15-27.

FELDMAN-BIANCO, B.; CAPINHA, G. (orgs.). Dossiê Identidades. Revista Crítica de Ciências Sociais, Coimbra, v. 48, 1997. 
FELTRAN, G. Fronteiras de tensão: política e violência nas periferias de São Paulo. São Paulo: Editora Unesp/ CEM-Cebrap, 2011.

FELTRAN, G. The management of violence on the São Paulo periphery: the repertoire of normative apparatus in the "PCC era". Vibrant, v. 7, n. 2, p. 109-134, 2010.

FERNANDES, A. Dois agenciamentos e uma ocupaçáo de moradia. In: LEITE, M. et al. (orgs.). Dispositivos urbanos e trama dos viventes: ordens e resistências. Rio de Janeiro: Fundação Getúlio Vargas, 2015. p. 250-279.

FERNANDES, A. dos S. Escuta Ocupaçáo: Arte do contornamento, viraçáo e precariedade no Rio de Janeiro. Tese (Doutorado em Ciências Sociais) - Universidade do Estado do Rio de Janeiro, Rio de Janeiro, 2013.

FERNANDES, F. A aculturação dos sírios e libaneses em São Paulo. Revista Etapas, ano I, n. 11, 1956.

FERNANDES, F. A integraçáo do negro na sociedade de classes. São Paulo: Dominus, 1964.

FERNANDES, F. Imigração e relaçôes raciais. Revista de Civilizaçáo Brasileira, n. 8, p. 75-95, 1966.

FERNANDES, F. O Brasil e o mundo árabe. Revista Etapas, ano XII, n. 131, p. 33-37, 1967.

FERNANDES, F. Resenha de "A aculturaçâo dos alemães no Brasil" de Emílio Willems. Revista do Arquivo Municipal, ano XV, CXXII (2): 205-218, 1949.

FERNANDES, R. C.; GÓES, P. R. H. Kaingang ethnic territories. Vibrant, v. 15, n. 2, 2018. http://dx.doi. org/10.1590/1809-43412018v15n2a407

FERREIRA, A. P. et al. (orgs.). A Experiência Migrante: entre deslocamentos e reconstruçóes. Rio de Janeiro: Garamond, 2010.

FERREIRA, L. da S. S. Conflito, mobilização e violações de direitos: atingidos pela mineração e a luta por justiça nas reuniōes da Rede de Acompanhamento Socioambiental (REASA) em Conceição do Mato Dentro/MG. In: EILBAUM, L.; SCHUCH, P.; CHAGAS, G. F. (orgs.). Antropologia e Direitos Humanos 7. Rio de Janeiro: Associação Brasileira de Antropologia, 2017. p. 81-113.

FERREIRA, R. H.; GARCIA, L. B. dos R. O papel do Estado na Migração Internacional: O exemplo dos Dekasseguis. Scripta Nova, v. 57, n. 94, ago. 2001.

FERRERAS, N. Historia e historiografía de las condiciones de vida de los trabajadores en la Argentina y el Brasil. Un analisis comparativo de Buenos Aires y Rio de Janeiro. Pós-História, Assis, v. 5, p. 11-32, 1997.

FERRERAS, N. Imigrantes, criollos e a alimentação porteña. Buenos Aires, final do século XIX e início do século XX. Revista de Estudos Históricos, v. 1, n. 33, p. 97-115, 2004.

FERRERAS, N.; FRENCH, J. D. Urban labor history in twentieth century Brazil. In: LATIN AMERICAN INSTITUTE. The Brazilian Curriculum Guide Specialized Bibliography. Albuquerque: University of New Mexico, 1998. (Série 2.)

FLEISCHER, S. Passando a América a limpo: o trabalho de housecleaners brasileiras em Boston. Massachussets. São Paulo: Annablume, 2002.

FLEISCHER, S. Uma faxina na identidade de emigrantes brasileiras. Cadernos de Campo, São Paulo, v. 11, n. 11, p. 49-67, 2003. https://doi.org/10.11606/issn.2316-9133.v11i11p49-67

FONSECA, C. Da circulação de crianças à adoção internacional: questóes de pertencimento e posse. Cadernos Pagu, n. 26, p. 11-43, 2006. https://doi.org/10.1590/S0104-83332006000100002 
FONSECA, C. Tecnologias de Governo, Família e Humanitarismo em um Mundo Globalizado. Revista Brasileira de Informaçáo Bibliográfica em Ciências Sociais, São Paulo, n. 72, p. 7-39, 2011.

FONSECA, C. Transnational Negotiations of the Mechanisms of Governance: Regularizing Child Adoption. Vibrant, Brasília, v. 6, n. 1, 2009.

FONSECA, C. et al. Apresentação - Tecnologias de governo: apreciação e releituras em antropologias. Horizontes Antropológicos, ano 22, n. 46, p. 9-34, 2016. http://dx.doi.org/10.1590/S0104-71832016000200001

FORTES, A. Da solidariedade à assistência: Estratégias organizativas e mutualidade no movimento operário de Porto Alegre na primeira metade do século XX. Cadernos AEL, v. 6, n. 10/11, p. 173-218, 1999.

FOUCAULT, M. Segurança, território, população: curso dado no Collège de France (1977-1978). Tradução de Eduardo Brandão. São Paulo: Martins Fontes, 2008.

FRANÇA, I. L. "Refugiados LGBTI": direitos e narrativas entrecruzando gênero, sexualidade e violência. Cadernos Pagu, n. 50, 2017. https://doi.org/10.1590/18094449201700500006

FRANGELLA, S. M. Corpos urbanos errantes: uma etnografia da corporalidade de moradores de uma rua em Sáo Paulo. Tese (Doutorado em Ciências Sociais) - Universidade Estadual de Campinas, Campinas, 2004.

FRANGELLA, S. M. Fragmentos de corpo e gênero entre meninos e meninas de rua. Cadernos Pagu, n. 14, p. 201$234,2000$.

FREIRE, J. Quando as emoções dão formas às reivindicaçôes. In: COELHO, M. C.; REZENDE, C. B. (orgs.). Cultura e sentimentos: ensaios em antropologia das emoçōes. Rio de Janeiro: FAPERJ, 2010. p. 168-196.

FREIRE-MEDEIROS, B. Touring Poverty. Londres/Nova York: Routledge, 2013. (Advances in Sociology Series.)

FREIRE-MEDEIROS, B.; MENEZES, P. As viagens da favela e a vida social dos suvenires. Sociedade e Estado, Brasília, v. 31, n. 3, p. 651-670, 2016.

FREIRE-MEDEIROS, B.; NAME, L. Does the Future of the Favela Fit in an Aerial Cable Car? Examining tourism mobilities and urban inequalities through decolonial lens. Canadian Journal of Latin American and Caribbean Studies, v. 42, n. 1, p. 1-16, 2017. https://doi.org/10.1080/08263663.2017.1281944

FREIRE-MEDEIROS, B.; TELLES, V. da S.; ALLIS, T. Apresentação: Por uma teoria social on the move. Tempo Social, v. 30, n. 2, p. 1-16, 2018. https://doi.org/10.11606/0103-2070.ts.2018.142654

FREIRE-MEDEIROS, B.; VILAROUCA, M. G.; MENEZES, P. International tourists in a "pacified" favela: profiles and attitudes. The case of Santa Marta, Rio de Janeiro. Die Erde, Berlim, v. 144, n. 2, p. 147-159, 2013. https:// doi.org/10.12854/erde-144-11

FRIGÉRIO, A. A alegria é somente brasileira. A exotização dos migrantes brasileiros em Buenos Aires. In: FRIGÉRIO, A.; RIBEIRO, G. L. (orgs.). Argentinos e brasileiros: encontros, imagens e estereótipos. Petrópolis: Vozes, 2002. p. 15-40.

FRÚGOLI JR., H.; SPAGGIARI, E. Networks and Territorialities: an ethnographic approach to the so-called cracolândia ["crackland"] in Săo Paulo. Vibrant, v. 8, n. 2, 2011. http://dx.doi.org/10.1590/S180943412011000200027

FUJI, Y.; SMITH, L. The acculturation of the Japanese immigrants in Brazil. Gainsville: University of Florida Press, 1959.

FUSCO, W. Redes Sociais na Migraçáo Internacional: o caso de Governador Valadares. Campinas: Unicamp, 2002. p. 1-96. (Textos Nepo, 40.) 
GIMENO, P. C. Poética Versão: a construçáo da periferia no rap. Dissertação (Mestrado em Antropologia Social) - Universidade Estadual de Campinas, Campinas, 2009.

GLICK-SCHILLER, N. A Global Perspective on Transnational Migration: Theorizing Migration without Methodological Nationalism. In: BAUBÖCK, R.; FAIST, T. (orgs.). Diaspora and Transnationalism: Concepts, Theories and Methods. Amsterdam: University of Amsterdam and IMISCOE, 2010. p. 109-129.

GLICK-SCHILLER, N.; BASCH, L.; BLANC-SZANTON, C. Towards a Transnational Perspective on Migration: Race, Class, Ethnicity and Nationalism Considered. Nova York: New York Academy of Sciences, 1992.

GLICK-SCHILlER, N.; ÇAGLAR, A. (orgs.). Locating Migration: Rescaling Cities and Migrants. Chicago: Cornell University Press, 2011.

GODOI, R. Fluxos em cadeia: as prisóes em Sáo Paulo na virada dos tempos. Tese (Doutorado) - Programa de Pós-Graduação em Sociologia, Universidade de São Paulo, São Paulo, 2015a.

GODOI, R. Vasos comunicantes, fluxos penitenciários: entre dentro e fora das prisōes de São Paulo. Vivência: Revista de Antropologia, v. 1, n. 46, p. 131-142, 2015b.

GODOI, R.; ARAÚJO, F.; MALLART, F. Espacializando a prisão: a conformação dos parques penitenciários em São Paulo e no Rio de Janeiro. Novos Estudos CEBRAP, v. 38, n. 3, p. 591-611, 2019. https://doi.org/10.25091/ s01013300201900030003

GOVERS, C.; VERMEULEN, H. The anthropology of ethnicity: beyond "Ethnic groups and boundaries". Amsterdá: Het Spinhuis, 2000.

GRAFMAYER, Y.; JOSEPH, I. (orgs.). L'École de Chicago: naissance de l'écologie urbaine. Paris: Aubier, 1994.

GRÜN, R. Negócios \& famílias: armênios em São Paulo. São Paulo: IDESP/Editora Sumaré, 1992.

GUÉRIOS, P. R. A imigraçáo ucraniana ao Paraná: memória, identidade e religiāo. Curitiba: Editora UFPR, 2012.

GUERREIRO RAMOS, A. Imigraçáo e Preconceito. Revista do Conselho de Imigraçáo e Colonizaçáo, v. 9, n. 3, p. 131-132, 1948.

GUIZARDI, M. L. Para pensar las redes transnacionales: Itinerarios e historias migratorias de los capoeiristas brasileños en Madrid. Vibrant, v. 10, n. 2, p. 229-271, 2013. https://doi.org/10.1590/S1809-43412013000200008

GURAN, M. Agudás: Os "brasileiros” do Benin. Rio de Janeiro: Nova Fronteira/Gama Filho, 2000.

GUSMÂO, N. M. M. Africanos no Brasil, hoje: imigrantes, refugiados e estudantes. In: MALOMALO, B.; FONSECA, D. J. F.; BADI, M. K. (orgs.). Diáspora Africana e migraçáo na era da globalizaçáo: experiências de refúgio, estudo, trabalho. Curitiba: CRV, 2015. p. 129-144.

GUSMÃO, N. M. M. Dossiê Ensino Superior e circulação internacional de estudantes: os Palop no Brasil e em Portugal. Pro-Posiçóes, Campinas, v. 20, n. 1, p. 15-20, 2009. https://doi.org/10.1590/S0103-73072009000100002

GUSMÃO, N. M. M. Intelectuais negros: migração e formação entre conflitos e tensōes. O Público e o Privado, n. 23, p. 39-54, 2014.

GUSMÃO, N. M. M. Os Filhos da África em Portugal: Antropologia, multiculturalidade e educação. Belo Horizonte: Autêntica, 2005.315 p.

GUTERRES, A. dos S. A resiliência enquanto experiência de dignidade: antropologia das práticas políticas em um cotidiano de lutas e contestaçóes junto a moradoras ameaçadas de remoçáo nas cidades sede da Copa do Mundo 2014 (POA e RJ). Tese (Doutorado em Antropologia Social) - Universidade Federal do Rio Grande do Sul, Porto Alegre, 2014. 
GUTERRES, A. dos S. O rumor e o terror na construção de territórios de vulnerabilidade na zona portuária do Rio de Janeiro. Mana, v. 22, n. 1, p. 179-209, 2016. https://doi.org/10.1590/0104-93132016v22n1p179

HALL, M. Corporativismo e fascismo: As origens das leis trabalhistas brasileiras. In: ARAÚJO, A. (org.). Do corporativismo ao neoliberalismo. São Paulo: Boitempo, 2002. p. 13-28.

HALL, M. Imigrantes na cidade de São Paulo. In: PORTA, P. (org.). História da cidade de Sáo Paulo. São Paulo: Paz e Terra, 2004. v. 3. p. 121-151.

HALL, M. Os fazendeiros paulistas e a imigraçăo. In: SILVA, F. T. (org.). República, Liberalismo, Cidadania. Piracicaba: Editora Unimep, 2003. p. 153-161.

HANDERSON, J. As dinâmicas da mobilidade haitiana no Brasil, no Suriname e na Guiana Francesa. Tese (Doutorado em Antropologia Social) - Universidade Federal do Rio de Janeiro, Rio de Janeiro, 2010.

HANDERSON, J. Diáspora, Refugiado, Migrante. Perspectiva Etnográfica em mobilidade e Transfronteiriça. Sociedade e Cultura, v. 20, n. 2, p. 173-192, 2017. https://doi.org/10.5216/sec.v20i2.53071

HANDERSON, J. Diáspora. Sentidos Sociais e mobilidades haitianas. Horizontes Antropológicos, ano 21, n. 43, p. 51-78, 2015. http://dx.doi.org/10.1590/S0104-71832015000100003

HANDLIN, $O$. The positive contribution by immigrants: a symposium prepared for UNESCO by the International Sociological Association and the International Economic Association. Paris: UNESCO, 1955.

HARVEY, D. A brief History of neoliberalism. Oxford: Oxford University Press, 2005.

HERNANDEZ, H. R. G. Ma(d)jermanes: passado colonial e presente diasporizado. Reconstruçáo etnográfica de um dos últimos vestígios do socialismo colonial europeu. Tese (Doutorado em Antropologia Social) Universidade Estadual de Campinas, Campinas, 2011.

HIRATA, D. Sobreviver na adversidade: entre o mercado e a vida. São Carlos: EdUFSCar, 2018.

IANNI, C. Homens sem Paz: os conflitos e os bastidores da emigração italiana. São Paulo: Difusão Europeia do Livro, 1963.

IANNI, O. A situação social do polonês em Curitiba. Sociologia, v. XXXIII, n. 4, p. 375-388, 1961a.

IANNI, O. A Sociedade Global. São Paulo: Civilização Brasileira, 1992.

IANNI, O. As Metamorfoses do Escravo. Apogeu e crise da escravatura no Brasil Meridional. São Paulo: Difusão Europeia do Livro, 1962.

IANNI, O. Do polonês ao polaco. In: IANNI, O. Raças e classes sociais no Brasil. São Paulo: Civilização Brasileira, 1966. p. 117-146.

IANNI, O. Do polonês ao polaco. Revista do Museu Paulista, Nova Série, São Paulo, v. XII, p. 315-338, 1960.

IANNI, O. Estudo de comunidade e conhecimento científico. Revista de Antropologia, v. 9, n. 1-2, p. 109-119, 1961b. https://doi.org/10.11606/2179-0892.ra.1961.110417

Ioris, E. M. Memory regimes, struggles over resources and ethnogenesis in the Brazilian Amazon. Vibrant, v. 15, n. 2, 2018. http://dx.doi.org/10.1590/1809-43412018v15n2a405

JACKSON, L. C. Divergências teóricas, divergências políticas: a crítica da USP aos "estudos de comunidades". Cadernos de Campo, v. 18, n. 18, p. 273-280, 2009. https://doi.org/10.11606/issn.2316-9133.v18i18p273-280 
JARDIM, D. F. "As mulheres voam com seus maridos": a experiência da diáspora palestina e as relaçóes de gênero. Horizontes Antropológicos, v. 15, n. 31, p. 189-217, 2009. http://dx.doi.org/10.1590/S010471832009000100008

JARDIM, D. F. Diásporas, Viagens e Alteridades: as Experiências Familiares dos Palestinos no Extremo-sul do Brasil. Horizontes Antropológicos, Porto Alegre, v. 6, n. 14, p. 39-69, 2000. http://dx.doi.org/10.1590/S010471832000001400003

JARDIM, D. F. Etnografía entre aduanas. Reflexiones acerca de las formas difusas del control migratório. Temas de Antropología e Migracion, n. 3, p. 6-22, 2012.

JARDIM, D. F. Famílias palestinas no extremo sul do Brasil e na diáspora: experiências identitárias e aduaneiras. Cadernos Pagu, n. 29, p. 193-225, 2007. http://dx.doi.org/10.1590/S0104-83332007000200009

JARDIM, D. F. Imigrantes ou refugiados? As tecnologias de governamentalidade e o êxodo palestino rumo ao Brasil no século XX. Horizontes Antropológicos, v. 22, n. 46, p. 243-271, 2016.

JARDIM, D. F. Imigrantes ou Refugiados? Tecnologias de Controle e as Fronteiras. Jundiaí: Paco Editorial, 2017.

JARDIM, D. F. Os caminhos do cadastro e outros obstáculos da visibilização do imigrante no Brasil. In: FONSECA, C.; MACHADO, H. (orgs.). Ciência, identificaçáo e tecnologias de governo. Porto Alegre: Editora da UFRGS, 2015. p. 76-95.

JESUS, S. M. Protagonistas de um Brasil imaginário: Faxineiras brasileiras em Boston. In: MARTES, A. C. B.; FLEISCHER, S. (orgs.). Fronteiras cruzadas: etnicidade, gênero e redes sociais. São Paulo: Paz e Terra, 2003.

JOSEPH, I. La ville sans qualités. La Tour d'Aigues: Editions de l'Aub, 1998.

KEARNEY, M.; NAGENGAST, C. Anthropological Perspectives on Transnational Communities in Rural California. Davis: California Institute for Rural Studies, 1989.

KEMPADOO, K. Sexing the Caribbean: gender, race and sexual labour. Abingdon: Routledge, 2004.

KUSHNIR, B. Nem bandidos, nem heróis: Os militantes judeus de esquerda mortos sob tortura no Brasil (19691975). In: KUSHNIR, B. (org.). Perfis cruzados: Trajetórias e militância política no Brasil. Rio de Janeiro: Imago, 2002. p. 215-234.

LACERDA, P. M. Meninos de Altamira: violência, luta política e administração pública. Rio de Janeiro: Garamond, 2015.

LATOUR, B. Reassembling the social: An introduction to actornetwork theory. Oxford: Oxford University Press, 2005.

LEITE, M. P. "Da "metáfora da guerra" ao projeto de "pacificação": favelas e políticas de segurança pública no Rio de Janeiro”. Revista Brasileira de Segurança Pública, São Paulo, v. 6, n. 2, p. 374-389, ago./set. 2012.

LEITE, M. P. et al. Militarizaçáo no Rio de Janeiro: da Pacificação à Intervençăo. Rio de Janeiro: Mórula, 2018.

LEITE, R. P. de S. A Nação como sistema e os novos nacionalismos. Lua Nova, n. 44, p. 191-211, 1998. https://doi. org/10.1590/S0102-64451998000200009

LEITE, R. P. de S. Contra-usos da cidade: lugares e espaço público na experiência urbana contemporânea. Campinas/ Sergipe: Editora Unicamp/Editora UFS, 2004.

LOBO, A. And When the Women Leave? Female Emigration from Boa Vista. In: CARLING, J.; BATALHA, L. (orgs.). Transnational Arquipelago. Perspectives on Cape Verdean Migration and Diaspora. Amsterdá: Amsterdam University Press, 2008. p. 131-144. 
LOBO, A. Crianças em cena. Sobre mobilidade infantil, família e fluxos migratórios em Cabo Verde. Revista Ciências Sociais Unisinos, v. 49, n. 1, p. 64-74, 2013.

LOBO, A. Just bring me a little letter?: the flow of things in Cape Verde transnational family relations. Etnografica, v. 18 , n. 3, p. 461-480, $2014 a$.

LOBO, A. Making Families: Child mobility and familiar organization in Cape Verde. Vibrant, v. 8, n. 2, p. 197-219, 2011. https://doi.org/10.1590/S1809-43412011000200009

LOBO, A. Mantendo relaçóes à distância. O papel do fluxo de objetos e informaçōes na configuração de relações familiares transnacionais em Cabo Verde. In: TRAJANO FILHO, W. (org.). Lugares, pessoas e grupos: as lógicas do pertencimento em perspectiva internacional. Brasília: Athalaia, 2010. p. 29-46.

LOBO, A. Tão Longe, Táo Perto: famílias e movimentos na ilha da Boa Vista de Cabo Verde. Brasília: ABA Publicaçôes, 2014b.

LOBO, A.; VENANCIO, V. Com parente se negocia? Redes migratórias e o comércio transnacional em Cabo Verde. Cadernos de Campo: Revista de Ciências Sociais, n. 23, p. 25-44, 2017.

LOSEKANN, C. "It was no accident!": The place of emotions in the mobilization of people affected by the collapse of Samarco's tailings dam in Brazil. Vibrant, Brasília, v. 14, n. 2, 2017. https://doi.org/10.1590/1809$43412017 \mathrm{v} 14 \mathrm{n} 2 \mathrm{p} 102$

LOURES, R. O Governo Karodaybi e seus guerreiros invencíveis: Grandes Projetos na Amazônia versus o Movimento Munduruku Ipereğ Ayú. Vibrant, v. 15, n. 2, 2018. https://doi.org/10.1590/1809-43412018v15n2a404

LOWENKRON, L.; PISCITELLI, A. Trabajadoras sexuales, policía, migración y trata internacional de seres humanos en dos lados del océano. In: DAICH, D.; SIRIMARCO, M. (orgs.). Género y violencia en el mercado del sexo. Política, policía y prostitución. Buenos Aires: Biblos, 2015a. p. 173-203.

MACHADO, I. J. de R. Afetividade e poder entre os imigrantes brasileiros no Porto. Cadernos Pagu, n. 23, p. 257278, 2004. https://doi.org/10.1590/S0104-83332004000200009

MACHADO, I. J. de R. Brasileiros no Exterior e cidadania (1980-2005). Tomo, n. 26, p. 211-245, 2015a.

MACHADO, I. J. de R. Brazilian immigration and the reconstruction of racial hierarquies of the Portuguese Empire. In: FREDERIKSEN, B.; SORESEN, N. (orgs.). Beyond Home and exile: Making sense of the move. Denmark: Roskilde, 2003. p. 127-144.

MACHADO, I. J. de R. Cárcere Público: Processos de exotizaçáo entre brasileiros no Porto. Lisboa: Imprensa de Ciências Sociais, 2009.

MACHADO, I. J. de R. Deslocamentos e Parentesco. São Carlos: EdUFSCar, 2015 b.

MACHADO, I. J. de R. Identidade e subordinação ativa: uma etnografia dos imigrantes brasileiros no Porto. In: LIMA, R. K. (org.). Antropologia e Direitos Humanos 3. Niterói: EdUFF, 2005. p. 185-240.

MACHADO, I. J. de R. Movimentos e parentesco: sobre as especificidades dos deslocamentos. Campos, Curitiba, v. 15, n. 2, p. 27-42, 2017. http://dx.doi.org/10.5380/campos.v15i2.46040

MACHADO, I. J. de R. Parentesco e diferencialidades: alternativas à identidade e às fronteiras étnicas no estudo das migraçōes. In: FELDMAN-BIANCO, B. (org.). Desafios da Antropologia Brasileira. Brasília: ABA, 2013. p. 153-173.

MACHADO, I. J. de R. Reordenaçóes da Casa no contexto migratório de Governador Valadares, Brasil. Etnográfica, Lisboa, v. 14, n. 1, p. 5-26, 2010. https://doi.org/10.4000/etnografica. 140 
MACHADO, I. J. de R. Sobre os processos de exotização na imigração internacional brasileira. Revista de Antropologia, v. 51, n. 2, p. 700-733, 2008. https://doi.org/10.1590/S0034-77012008000200010

MACHADO, I. J. de R. (org.). Dossiê Brasil/Portugal: Discursos nacionalistas e suas consequências. Temáticas, Campinas, v. 10, n. 19/20, p. 7-8, 2002.

MACHADO, I. J. de R. (org.). Japonesidades Multiplicadas. São Carlos: EdUFSCar, 2011.

MACHADO, I. J. de R. (org.). Valadares em família: experiências etnográficas e deslocamentos. Brasília: ABA, 2014.

MACHADO, I. J. de R.; KEBBE, V. H.; SILVA, C. R. da. Notas sobre a família transnacional. REMHU, Brasília, v. 16, n. 30, p. 79-98, 2008.

MAGALHÂES, A. O "legado" dos megaeventos esportivos: a reatualização da remoção de favelas no Rio de Janeiro. Horizontes Antropológicos, v. 19, n. 40, p. 89-118, 2013. https://doi.org/10.1590/S010471832013000200004

MAGALHÃES, A. Remoçóes de favelas no Rio Janeiro: entre formas de controle e resistências. Curitiba: Appris, 2019. $327 \mathrm{p}$.

MAIA, S. Brazilian Erotic Dancers in New York: Desire and National Identity. Tese (Doutorado em Antropologia) - Graduate Center, City University of New York, Nova York, 2007.

MAIA, S. M. Brazilian Women Crossing Borders. In: AARON, J.; ALTINK, H.; WEEDON, C. (orgs.). Gendering Border Studies. Cardiff: University of Wales Press, 2010. p. 63-82.

MAIA, S. Cosmopolitismo, desejos e afetos: sobre mulheres brasileiras e seus amigos transnacionais. In: PISCITELLI, A.; ASSIS, G. O.; OLIVAR, J. M. N. (orgs.). Gênero, sexo, amor e dinheiro: mobilidades transnacionais envolvendo o Brasil. Campinas: UNICAMP/PAGU, 2011. p. 363-384.

MAIA, S. Intersections of the Transnational: Brazilian dancers in New York City gentlemen's bars. Vibrant, v. 6, n. 1, p. 37-64, 2009a.

MAIA, S. Sedução e identidade nacional: dançarinas eróticas brasileiras no Queens, Nova York. Revista Estudos Feministas, v. 17, n. 3, p. 769-797, 2009b. https://doi.org/10.1590/S0104-026X2009000300009

MAIA, S. Stripping on the margins: Brazilian women immigrants and the new geography of New York City. 2001. (mimeo.)

MAIA, S. Transnational Desires: Brazilian Erotic Dancers in New York. Nashville: Vanderbilt University Press, 2012.

MALLART, F. Cadeias dominadas: a Fundação CASA, suas dinâmicas e as trajetórias de jovens internos. São Paulo: Terceiro Nome/Fapesp, 2014.

MALLART, F. Findas linhas: circulaçóes e confinamentos pelos subterrâneos de Sáo Paulo. Tese (Doutorado em Sociologia) - Universidade de São Paulo, São Paulo, 2019.

MALLART, F. et al. Fazer sumir: políticas de combate à cracolândia. Le Monde Diplomatique Brasil, 1º jul. 2017.

MALLART, F.; RUI, T. Por uma etnografia das transversalidades urbanas: entre o mundão e os dispositivos de controle. In: MELO, J.; SIMIÃO, D.; BAINES, S. (orgs.). Ensaios sobre Justiça, Reconhecimento e Criminalidade. Natal: EDUFRN/ABA, 2016. p. 433-456.

MANSUR DA SILVA, D. A oposiçáo ao Estado Novo no exílio brasileiro (1956-1975). Lisboa: Imprensa de Ciências Sociais, 2006. 
MANSUR DA SILVA, D. A oposição no exílio e a memória da "resistência” ao Estado Novo em São Paulo. Revista Migraçóes, n. 5, p. 239-254, 2009.

MANSUR DA SILVA, D. Exilados anti-salazaristas e suas relaçóes com os nacionalismos e a questáo colonial. In: PÓVOA NETO, H.; FERREIRA, A. P. (orgs.). Cruzando Fronteiras Disciplinares. Um panorama dos estudos migratórios. Rio de Janeiro: Revan/FAPERJ, 2005. p. 57-79.

MANSUR DA SILVA, D. Intelectuais Portugueses Exilados no Brasil (1926-1974): aspectos metodológicos de uma pesquisa. Estudios Avanzados Interactivos, Santiago, v. 3, n. 5, p. 20, 2004.

MANSUR DA SILVA, D. Intelectuais Portugueses Exilados no Brasil. Formaçáo e transferência cultural, século XX. Tese (Doutorado em Antropologia Social), Universidade Federal do Rio de Janeiro, Rio de Janeiro, 2007.

MANSUR DA SILVA, D. O Portugal Democrático: Uma resistência pertinaz. Convergência Lusíada, v. 19, p. 108$119,2002$.

MANSUR DA SILVA, D. Portuguese writers and scientists exiled in Brazil (1945-1974). Vibrant, v. 10, n. 2, 2013.

MANSUR DA SILVA, D. Tensóes pós-coloniais entre imigrantes portugueses em São Paulo. Temáticas, v. 10, n. 19/20, p. 61-74, 2003.

MARQUES, A. Crime, proceder, seguro: um experimento antropológico a partir de relaçóes entre ladróes. Dissertação de Mestrado (Programa de Pós-Graduação em Antropologia Social) - Universidade de São Paulo, São Paulo, 2009.

MARTES, A. C. B. A emigração brasileira e os pequenos empresários. In: CASTRO, M. G.; BERQUÓ, E. (orgs.). Migraçóes internacionais: contribuições para políticas. Brasília: CNPD, 2001. p. 375-393.

MARTES, A. C. B. Brasileiros nos Estados Unidos: um estudo sobre imigrantes em Massachusetts. São Paulo: Paz e Terra, 2000.

MARTES, A. C. B. Os Imigrantes Brasileiros e as Igrejas em Massachusetts. In: REIS, R. R.; SALES, T. (orgs.). Cenas de Um Brasil Migrante. São Paulo: Boitempo, 1999.

MARTINS, J. de S. Conde Matarazzo: O Empresário e a Empresa. São Paulo: Hucitec, 1973.

MARTINS, W. Um Brasil diferente: ensaio sobre fenômenos de aculturação no Paraná. São Paulo: T. A. Queiroz, 1989.

MCCLINTOCK, A. Imperial Leather. Nova York: Routledge, 1995.

MESOMO, J.; DAMO, A. Remoção de populaçōes em meio urbano: princípios, tecnologias e a mediação dos impactos a partir de Porto Alegre. In: URIARTE, U. M.; MACIEL, M. E. (orgs.). Patrimônio, Cidades e Memória Social. Salvador: EDUFBA, 2016. p. 73-94.

MILLER, D. Stuff. Cambridge: Polity Press, 2010.

MONTEIRO, J. A. II RIRA 96: Fechando o cerco aos clandestinos nos EUA. Travessia, n. 30, 1998.

MORAES, L. E. de S. Ein Volk. Ein Reich. Ein Führer: a seçáo brasileira do Partido Nazista e a questáo nacional. Dissertaçáo (Mestrado em Antropologia Social) - Universidade Federal do Rio de Janeiro, Rio de Janeiro, 1996.

MORAES, L. E. de S. Konflikt und Anerkennung: Die Ortsgruppen der NSDAP in Blumenau und in Rio de Janeiro. Berlim: Metropol Verlag, 2005.

MOTTA, A. O Japão náo é longe daqui: consumo e estilos de vida. Tóquio: Japan Foundation, 2011. 
MOURA, A. B. de M. Remoçóes forçadas, moradas desmanteladas: uma intervençáo estatal no Loteamento Sáo Francisco. Dissertação (Mestrado em Antropologia), Universidade Federal de Pernambuco, Recife, 2016.

Müller, P. R. Políticas e performances da diversidade: Etnografia de um circuito musical intercultural em Sáo Paulo. Dissertação (Mestrado em Antropologia Social) - Universidade Estadual de Campinas, Campinas, 2009.

MUNGOI, D. M. D. C. J. Ressignificando Identidades: um estudo antropológico sobre experiências migratórias dos estudantes africanos no Brasil. REMHU, v. 20, n. 38, p. 125-139, jan./jun. 2012. http://dx.doi.org/10.1590/ S1980-85852012000100008

NASCIMENTO, S. J. do. Múltiplas vitimizaçôes: crianças indígenas Kaiowá nos abrigos urbanos do Mato Grosso do Sul. Horizontes Antropológicos, v. 20, n. 42, p. 265-292, 2014. http://dx.doi.org/10.1590/s010471832014000200011

OLIVEIRA, A. C. de. Japoneses no Brasil ou Brasileiros no Japáo? A trajetória de uma identidade em um contexto migratório. Dissertação (Mestrado em Sociologia) - Universidade Estadual de Campinas, Campinas, 1997.

OLIVEIRA, F. C. B. de. Quando resistir é habitar: lutas pela afirmaçáo territorial dos Kaiabi no Baixo Teles Pires. Brasília: Paralelo 15, 2012.

OLIVEIRA, J. P. de. Fighting for lands and reframing the culture. Vibrant, v. 15, n. 2, 2018. http://dx.doi. org/10.1590/1809-43412018v15n2a400

OLIVEIRA, J. P. de; COHN, C. (orgs.). Belo Monte e a questão indígena. Brasília: ABA, 2014.

OLIVEIRA, M. de. A sociologia da imigração no Brasil entre as décadas de 1940 e 1970. Sociologias, v. 20, n. 49, p. 198-228, 2018. http://dx.doi.org/10.1590/15174522-02004906

OLIVEIRA FILHO, J. F. Leituras pós-coloniais de comemorações lusófonas: Guerras de realidade \& ficção. Semear, Rio de Janeiro, n. 7, p. 111-126, 2002.

ORTIZ, R. Mundializaçáo e Cultura. São Paulo: Brasiliense, 1996.

OTA, M. E. De fábrica de marginal a mães guerreiras: uma etnografia sobre a luta de mães de vítimas da violência do Estado. Tese (Doutorado em Sociologia) - Instituto de Estudos Sociais e Políticos, Universidade do Estado do Rio de Janeiro, Rio de Janeiro, 2019.

PADOVANI, N. C. Enredando muros e fronteiras: documentos, cartas de amor e o governo das relaçóes entre prisôes de São Paulo e Barcelona. In: FELDMAN-BIANCO, B. et al. (orgs.). Migraçáo e Exílio. São Carlos: EdUFSCar, 2018a. p. 253-290.

PADOVANI, N. C. Sobre Casos e Casamentos: Afetos e amores através de penitenciárias femininas em São Paulo e Barcelona. São Carlos: Editora UFSCar, 2018b.

PADOVANI, N. C. Tráfico de mulheres nas portarias das prisōes ou dispositivos de segurança e gênero nos processos de produção das "classes perigosas". Cadernos Pagu, n. 51, 2017. http://dx.doi.org/10.1590/1809444920170 0510003

PADOVANI, N. C. Tramas de afetos e transaçốes: relaçôes tecidas por brasileiras presas em Barcelona. Transgressóes: Ciências Criminais em Debate, v. 4, n. 1, p. 133-149, 2016.

PATARRA, N. Emigraçáo e Imigraçáo Internacionais no Brasil Contemporâneo. 2. ed. São Paulo: UNPFA, 1996.

PATARRA, N. Migraçôes Internacionais de e para o Brasil Contemporâneo: volumes, fluxos, significados e políticas. Sáo Paulo em Perspectiva, v. 19, n. 3, p. 23-33, 2005. http://dx.doi.org/10.1590/S0102-88392005000300002 
PELÚCIO, L. "Sin papeles" pero con glamur: Migración de travestis brasileñas a España (Reflexiones iniciales). Vibrant, v. 6, n. 1, 2009.

PERIN, V. P. P. Um Campo de Refugiados sem Cercas: etnografia de um aparato transnacional de governo de populaçóes refugiadas. Dissertação (Mestrado em Sociologia) - Universidade Federal de São Carlos, São Carlos, 2013.

PIEROBON, C. Tempos que duram, lutas que náo acabam: o cotidiano de Leonor e sua ética de combate. Tese (Doutorado) - Universidade do Estado do Rio de Janeiro, Rio de Janeiro, 2018.

PINHO, O. S. de A. Corporalidade Afrodescendente, Nação e Emancipação. Boletim Informativo do Projeto Ató Irê Religióes Afro-Brasileiras e Saúde, v. 1, n. 2, p. 4-5, 2002.

PINHO, O. S. de A. Espaço, Poder e Relaçōes Raciais: O caso do Centro Histórico de Salvador. Afro-Asia, Salvador, n. 21/22, p. 257-274, 1999a. http://dx.doi.org/10.9771/aa.v0i21-22.20969

PINHO, O. S. de A. Fogo na Babilônia: Reggae, Black Counterculture, and Globalization in Brazil. In: PERRONE, C.; DUNN, C. (orgs.). The Internationalization of Brazilian Music. Gainesville: University of Florida Press, 2001. p. 224-242.

PINHO, O. S. de A. Só Se Vê na Bahia: A Imagem Típica e a Imagem Crítica do Pelourinho Afro-Baiano. In: CAROSO, C.; BACELAR, J. (orgs.). Brasil: Um País de Negros? Rio de Janeiro: Pallas, 1999b. p. 87-112.

PINTO, P.; BAEZA, C. The Syrian Uprising and Mobilization of the Syrian Diaspora in South America. Middle East Report, n. 284/285, p. 26-29, 2017.

PINTO, P. G. Arab Ethnicity and Diasporic Islam: A Comparative Approach to Processes of Identity and Religious Codification in the Muslim Communities in Brazil. Comparative Studies of South Asia, Africa, and the Middle East, v. 31, n. 2, p. 312-330, 2011. http://doi.org/10.1215/1089201x-1264253

PINTO, P. G. The Religious Dynamics of the Syrian-Lebanese and Palestinian Communities in Brazil. Mashriq \& Mahjar, v. 3, n. 1, p. 30-40, 2015.

PISCITELLI, A. Between Trafficking Discourses and Sexual Agency. In: ZHENG, T. (org.). Sex Trafficking, Human Rights and Social Justice. Londres: Routledge, 2010. p. 1-25.

PISCITELLI, A. Corporalidade em confronto: brasileiras na indústria do sexo na Espanha. Revista Brasileira de Ciências Sociais, v. 22, n. 64, p. 17-32, jun. 2007. https://doi.org/10.1590/S0102-69092007000200002

PISCITELLI, A. Entre a Praia de Iracema e a Uniáo Européia: turismo sexual internacional e migraçáo feminina. In: PISCITELLI, A.; GREGORI, M. F.; CARRARA, S. (orgs.). Sexualidades e saberes, convençóes e fronteiras. Rio de Janeiro: Garamond, 2004. p. 250-270.

PISCITELLI, A. Entre as "máfias" e a "ajuda": a construção de conhecimento sobre tráfico de pessoas. Cadernos Pagu, n. 31, p. 29-63, 2008. https://doi.org/10.1590/S0104-83332008000200003

PISCITELLI, A. From Programs to Help and Marriage: Transnational Sexual, Economic and Affective Exchanges among Brazilian Women. In: GORES, C.; FERNANDES, N. (orgs.). Intimate Mobilities, Sexual Economies, Marriage and Migration in a Disparate World. Nova York: Berghahn, 2018. p. 167-189.

PISCITELLI, A. Gringos nos trópicos: gênero e nacionalidade no marco do turismo sexual em Fortaleza. In: CASTRO, M. G.; BERQUÓ, E. (orgs.). Migraçóes internacionais: contribuições para políticas. Brasília: CNPD, 2001. p. 589-613.

PISCITELLI, A. Migración, género y sexualidad. Brasileñas en los mercados del sexo y del casamiento en Espańa. Mora, n. 18, p. 97-116, 2012. https://doi.org/10.34096/mora.n18.329 
PISCITELLI, A. Procurando vítimas do tráfico de pessoas: brasileiras na indústria do sexo na Espanha. REMHU, v. 19, n. 37, p. 11-26, jul./dez. 2011.

PISCITELLI, A. Trânsitos: brasileiras nos mercados transnacionais do sexo. Rio de Janeiro: EDUERJ/Garamond/ CLAM, 2013.

PISCITELLI, A.; LOWENKRON, L. Categorias em movimento: a gestão de vítimas do tráfico de pessoas na Espanha e no Brasil. Ciência e Cultura, v. 67, n. 2, p. 35-39, 2015b. http://dx.doi.org/10.21800/231766602015000200012

POVOA NETO, H.; FERREIRA, A. P. (orgs.). Cruzando fronteiras disciplinares. Um panorama dos estudos migratórios. Rio de Janeiro: Revan, 2005.

POVOA NETO, H.; SANTOS, M. de O.; PETRUS, R. (orgs.). Migraçóes: rumos, tendências e desafios. Rio de Janeiro: Polo Books, 2016.

PRADO JR., C. Métodos sociológicos. Fundamentos, n. 7/8, p. 23-30, 1948.

QUIJANO, A. Colonialidad del poder y clasificación social. Journal of World-System Research, v. 6, n. 2, p. 342386, 2000. https://doi.org/10.5195/jwsr.2000.228

RABOSSI, F. Interações e estereótipos: os árabes de Foz do Iguaçu e Ciudad Del Este a partir do comércio de fronteira. In: FERREIRA, A. P. et al. (orgs.). A experiência migrante: entre deslocamentos e reconstruçóes. Rio de Janeiro: Garamond, 2010. p. 249-265.

RABOSSI, F. Tempo e movimento em um mercado de fronteira: Ciudad del Este, Paraguai. Revista Sociologia e Antropologia, v. 5, n. 2, p. 405-434, 2015. http://dx.doi.org/10.1590/2238-38752015v523

RAMOS, A. M. Las memorias Mapuche del "regreso": De los contextos de violencia y los desplazamientos impuestos a la poética de la reestructuración. In: VERDUM, R.; IORIS, E. M. (orgs.). Autodeterminação, autonomia territorial e acesso à justiça: povos indígenas e movimento na América Latina. Rio de Janeiro: ABA, 2017. p. 203-228.

RAMOS, J. S. Dos males que vêm com o sangue: as representaçôes raciais e a categoria do imigrante indesejável nas concepções sobre imigração da década de 20. In: MAIO, M. C.; SANTOS, R. V. (orgs.). Raça, Ciência e Sociedade. Rio de Janeiro: Editora da Fiocruz/Centro Cultural Banco do Brasil, 1996. p. 59-84.

RANGEL, E. Brazilian dancers: corpos exibíveis em um circo norte-americano. Cadernos Pagu, n. 52, 2018. http:// dx.doi.org/10.1590/18094449201800520017

RENK, A. A. A Luta da Erva: um ofício étnico da naçáo brasileira no Oeste Catarinense. Dissertação (Mestrado em Antropologia Social) - Universidade Federal do Rio de Janeiro, Rio de Janeiro, 1990.

RIAL, C. Circulation, bubbles, returns: the mobility of Brazilians in the football system. In: ELIOTT, R.; HARRIS, J. (orgs.). Football and Migration: Perspectives, places, players. Londres/Nova York: Routledge, Taylor and Francis Group, 2014. p. 61-75.

RIAL, C. Rodar: a circulação dos jogadores de futebol brasileiros no exterior. Horizontes Antropológicos, v. 14, n. 30, p. 21-65, 2008. http://dx.doi.org/10.1590/S0104-71832008000200002

RIBEIRO, G. L. Goiânia, Califórnia: vulnerabilidade, ambiguidade e cidadania transnacional. Série Antropologia, Brasília, v. 235, p. 1-22, 1998a.

RIBEIRO, G. L. Identidade brasileira no espelho interétnico: essencialismos e hibridismos em San Francisco. Série Antropologia, Brasília, v. 241, p. 1-28, 1998 b. 
RIBEIRO, G. L. O Que faz o Brasil, Brazil. In: REIS, R. R.; SALES, T. (orgs.). Cenas do Brasil Migrante. São Paulo: Boitempo, 1999. p. 45-85.

RIBEIRO, G. S. A Guerra aos portugueses no Rio de Janeiro dos anos de 1890. Oceanos, Lisboa, p. 86-87, 2001a.

RIBEIRO, G. S. A liberdade em construçáo: identidade nacional e conflitos antilusitanos no Primeiro Reinado. Rio de Janeiro: Relume-Dumará, 2002.

RIBEIRO, G. S. Antes sem pão do que sem Pátria: o antiportuguesismo nos anos da década de 1920. Convergência Lusíada, v. 2, p. 147-162, 2001b.

RIBEIRO, G. S. As noites das garrafadas: uma história entre outras de conflitos antilusitanos e raciais na Corte do Rio de Janeiro - 1831. Luso-Brazilian Review, v. 37, n. 2, p. 59-74, 2000a.

RIBEIRO, G. S. Desenlaces no Brasil pós-colonial: A construção de uma identidade nacional e a Comissão Mista Brasil - Portugal para o reconhecimento da Independência. Revista Convergência Lusíada, v. 20, p. 79-95, 2003.

RIBEIRO, G. S. Imigração portuguesa e cotidiano no Rio de Janeiro do século XIX. Revista Ibero-Americana, v. 26, n. 1, p. 93-106, 2000b. http://dx.doi.org/10.15448/1980-864X.2000.1.24787

RUI, T. Da deriva pela Av. Brasil à ficação numa esquina na Maré: usuários de crack, refugiados da "pacificação". In: LEITE, M. et al. (orgs.). Militarizaçáo no Rio de Janeiro: da pacificação à intervenção. Rio de Janeiro: Mórula, 2018. p. 57-69.

RUI, T. Nas tramas do crack: etnografia da abjeção. São Paulo: Terceiro Nome, 2014.

RUI, T. Vigiar e Cuidar: notas sobre a atuação estatal na "cracolândia". Revista Brasileira de Segurança Pública, v. 6, n. 2, p. 336-351, 2012.

SAITO, H.; MAEYAMA, T. (orgs.). Assimilaçáo e integração dos japoneses no Brasil. Petrópolis/São Paulo: Vozes/ Edusp, 1973.

SAITO, H.; WILLEMS, E. Shindô-Renmei. Um problema de aculturação. Revista de Sociologia, v. 9, n. 2, p. 133$152,1947$.

SAKURAI, C. Romanceiro da Imigraçáo Japonesa. São Paulo: IDESP/Editora Sumaré, 1993.

SALES, T. A Legitimidade da Condição Clandestina. Travessia, v. 30, p. 13-16, 1998.

SALES, T. Brasileiros Longe de Casa. São Paulo: Cortez, 1999a.

SALES, T. Constructing an Ethnic Identity: Brazilian immigrants in Boston, Mass. Migration World Magazine, v. 27, n. 1, p. 15-21, 1999b.

SALES, T. O Brasil No Contexto das Novas Migraçôes Internacionais. Travessia, v. 21, p. 5-8, 1995.

SALES, T. Pensando a Terceira Idade da Primeira Geração de Imigrantes Brasileiros nos Estados Unidos. Travessia, v. 35, p. 32-36, 1999c.

SALES, T. Segunda Geração de Imigrantes Brasileiros nos EUA. In: CASTRO, M. G. (org.). Migraçóes Internacionais: Contribuiçôes para Políticas. Brasília: Comissão Nacional de População e Desenvolvimento (CNPD), 2001. p. 361-374.

SALES, T.; GOULART, R. América, país de imigrantes e as crescentes restriçôes aos imigrantes estrangeiros nos Estados Unidos. Travessia, v. 25, p. 10-14, 1996. 
SALES, T.; REIS, R. Cenas do Brasil Migrante. São Paulo: Boitempo, 1999.

SALLES, M. do R. Médicos Italianos em São Paulo. São Paulo: Fapesp/Idesp/Editora Sumaré, 1997.

SANJURJO, L. Narrativas do exílio argentino no Brasil: naçáo, memórias e identidades. Dissertação (Mestrado em Antropologia Social) - Universidade Estadual de Campinas, Campinas, 2007.

SANJURJO, L. Our Dead Can Speak: Social Displacements, Affects, and Political Action in Comparative Perspective. Vibrant, v. 14, n. 3, p. 1-19, 2017. https://doi.org/10.1590/1809-43412017v14n3p113

SANJURJO, L. Sangue, Identidade e Verdade: Memórias sobre o passado ditatorial na Argentina. São Carlos: EdUFSCar, 2018.

SANJURJO, L.; FELTRAN, G. Sobre Lutos e Lutas: Violência de Estado, Humanidade e Morte em dois contextos etnográficos. Ciência \& Cultura, v. 67, n. 2, p. 40-45, 2015. http://dx.doi.org/10.21800/231766602015000200013

SANTOS, G. A. P. D. A Construção da Lusofonia no Portugal Pós-Colonial: Estratégias das Associaçóes Imigrantes de Lisboa. In: FELDMAN-BIANCO, B. (org.). Naçóes e Diásporas. Estudos Comparativos entre Brasil e Portugal. Campinas: Editora da Unicamp, 2010. p. 189-222.

SANTOS, G. A. P. D. Encontros, Alianças e Desencontros: Partidos, Associaçōes de Imigrantes e o Estado Português nos Embates em torno da Política para Imigrantes. In: MACHADO, I. J. R. (org.). Um Mar de Identidades. A Imigração Brasileira em Portugal. São Carlos: EdUFSCar, 2006. p. 103-130.

SANTOS, G. A. P. D. Relaçóes interétnicas em Lisboa: imigrantes brasileiros e africanos no contexto da lusofonia. Dissertação (Mestrado em Antropologia Social) - Universidade Estadual de Campinas, Campinas, 2002.

SANTOS, M. de O. A emergência discursiva do conceito de "pioneiro italiano" como marcador identitário e delimitador de fronteiras étnicas. Tessituras, Pelotas, v. 2, n. 1, p. 40-52, 2014.

SANTOS, M. de O. Bendito é o fruto. Festa da Uva e identidade entre os descendentes de imigrantes italianos. Rio de Janeiro: Léo Christiano Editorial, 2015. 230 p.

SANTOS, M. de O. Bendito é o fruto: festa da uva e identidade entre os descendentes de imigrantes italianos de Caxias do Sul. Tese (Doutorado) - Universidade Federal do Rio de Janeiro, Rio de Janeiro, 2004.

SANTOS, M. de O. et al. Caminhos da migraçáo: memória, integração e conflitos. Rio de Janeiro: Léo Christiano Editor, 2014.

SANTOS, M. de O.; REINHEIMER, P. Giralda Seyferth: muito além da Migração. Brasília: ABA Publicaçôes / São Leopoldo: Oiko, 2019.

SANTOS, M. de O.; ZANINI, M. C. C. Ferrovias, etnicidade e processos migratórios: ascensão social e alteridades no mundo do trabalho. Política \& Trabalho, v. 1, n. 37, p. 283-297, 2012.

SASAKI, E. M. Dekassseguis: Japanese-Brazilian migrants in Japan and the identity question. Bulletin of PortugueseJapanese Studies, Lisboa, v. 4, p. 111-141, 2002.

SASAKI, E. M. Dekasseguis Retornados. Revista Brasileira de Estudos da População, v. 13, n. 1, p. 99-100, 1996.

SASAKI, E. M. Dekasseguis: trabalhadores nipo-brasileiros no Japão. Travessia: Revista do Migrante, v. 21, p. 2022, 1995.

SASAKI, E. M. Movimentos dekassegui: a experiência migratória e identitária dos brasileiros descendentes de japoneses no Japão. In: REIS, R. R.; SALES, T. (orgs.). Cenas do Brasil migrante. São Paulo: Boitempo, 1999. p. 343-374. 
SASAKI, E. M. Redes Sociales de Migrantes Brasileños Descendientes de Japoneses de Maringá para Japón. JCAS Symposium Series, v. 19, p. 421-453, 2003.

Sassen, S. Expulsions: Brutality and Complexity in the Global Economy. Cambridge, MA, Londres: Harvard University Press, 2014.

SCHADEN, E. Aculturação de alemães e japoneses no Brasil. Revista de Antropologia, v. 4, n. 1, p. 41-46, 1956. https://doi.org/10.11606/2179-0892.ra.1956.110334

SCHADEN, E. O estudo socioantropológico da aculturação dos alemães no Brasil. Revista do Arquivo Municipal, São Paulo, v. 36, n. 185, 1973.

SCHADEN, E. Problemas de aculturação no Brasil. In: REUNIĀO BRASILEIRA DE ANTROPOLOGIA, 2., 1957, Bahia. Anais [...]. 1957.

SCOTT, R. P. Duplamente atingidas: violência, mulheres e políticas do estado numa grande barragem no Nordeste. Revista Anthropológicas, v. 23, n. 1, p. 189-201, 2012.

SCOTT, R. P. Families, Nations and Generations in Women’s International Migration. Vibrant, Brasília, v. 8, n. 2, 2011. https://doi.org/10.1590/S1809-43412011000200013

SCOTT, R. P. Negociaçóes e Resistência Persistentes: agricultores e a barragem de Itaparica num contexto de descaso planejado. Recife: Editora Universitária da UFPE, 2009. 290 p.

SCOTT, R. P. Projetos de desenvolvimento no rio São Francisco: administrando vocaçōes e desigualdades. Campos, Curitiba, v. 14, n. 1-2, p. 15-36, 2013.

SCOTT, R. P. et al. As rearticulaçôes de sociabilidade decorrentes de migraçōes internacionais. Áltera, v. 1, n. 1, p. 37-53, 2015.

SCOTT, R. P.; MOURA, A. B. de M. Desapropriaçôes, resistências e o megaevento da Copa do Mundo: tempo, poder e projetos de desenvolvimento. Revista Anthropológicas, v. 25, n. 2, p. 94-132, 2014.

SCOTT, R. P.; VASCONCELOS, I. dos S. Mulheres migrantes na fronteira Brasil/Venezuela: casamentos, cuidados e poderes de práticas familiares. Estudos de Sociologia, v. 2, n. 21, p. 1-29, 2015.

SCUDELER, V. C. Imigrantes valadarenses no mercado de trabalho dos EUA. In: REIS, R. R.; SALES, T. (orgs.). Cenas do Brasil migrante. São Paulo: Boitempo, 1999. p. 193-233.

SEYFERTH, G. A Antropologia e a Teoria do Branqueamento da Raça no Brasil: a tese de João Batista de Lacerda. Revista do Museu Paulista, v. 30, p. 81-98, 1985.

SEYFERTH, G. A assimilação dos imigrantes como questão nacional. Mana, v. 3, n. 1, p. 95-131, 1997. https://doi. org/10.1590/S0104-93131997000100004

SEYFERTH, G. A Estratégia do Branqueamento. Ciência Hoje, v. 5, n. 25, p. 54-57, 1986.

SEYFERTH, G. A ideia de cultura teuto-brasileira: literatura, identidade e os significados da etnicidade. Horizontes Antropológicos, v. 10, n. 22, p. 149-197, 2004a. https://doi.org/10.1590/S0104-71832004000200007

SEYFERTH, G. A imigraçáo alemã no Vale do Itajaí-Mirim. Porto Alegre: Movimento/SAB, 1974.

SEYFERTH, G. A imigração no Brasil: comentários sobre a contribuição das Ciências Sociais. Revista Brasileira de Informaçáo Bibliográfica em Ciências Sociais, v. 57, p. 7-47, $2004 \mathrm{~b}$.

SEYFERTH, G. As identidades dos imigrantes e o melting pot nacional. Horizontes Antropológicos, v. 6, n. 14, p. 143-176, 2000. https://doi.org/10.1590/S0104-71832000001400007 
SEYFERTH, G. Colonização, imigração e a questão racial no Brasil. Revista USP, n. 53, p. 117-149, 2002. https:// doi.org/10.11606/issn.2316-9036.v0i53p117-149

SEYFERTH, G. Construindo a nação: hierarquias raciais e o papel do racismo na política de imigração e colonização. In: MAIO, M. C.; SANTOS, R. V. (orgs.). Raça, Ciência e Sociedade. Rio de Janeiro: Editora da Fiocruz/ Centro Cultural Banco do Brasil, 1996. p. 41-58.

SEYFERTH, G. Etnicidade e Cidadania: algumas consideraçôes sobre bases étnicas de mobilização política. Boletim do Museu Nacional, Zoologia, n. 42, p. 1-16, 1983.

SEYFERTH, G. Imigração, Colonização e Identidade Étnica (notas sobre a emergência da etnicidade em grupos de origem europeia no sul do Brasil). Revista de Antropologia, v. 29, p. 57-71, 1987. https://doi. org/10.11606/2179-0892.ra.1986.111143

SEYFERTH, G. Imigraçáo e cultura no Brasil. Brasília: Editora da Universidade de Brasília, 1990.

SEYFERTH, G. Nacionalismo e identidade étnica. Florianópolis: Fundação Catarinense de Cultura, 1982.

SEYFERTH, G. Os Paradoxos da Miscigenação: observaçōes sobre o Tema Imigração e Raça no Brasil. Estudos AfroAsiáticos, v. 20, p. 165-185, 1991.

SEYFERTH, G. Socializaçấo e etnicidade: a questão escolar teuto-brasileira (1850-1937). Mana, v. 23, n. 3, p. 579607, 2017. https://doi.org/10.1590/1678-49442017v23n3p607

SEYFERTH, G. et al. (orgs.). Mundos em Movimento: ensaios sobre migraçóes. Santa Maria: EDUFSM, 2007.

SILVA, A. B. da; MURA, F. Territory and domestic ecology among the Kaiowa of Mato Grosso do Sul. Vibrant, v. 15, n. 2, 2018. https://doi.org/10.1590/1809-43412018v15n2a402

SILVA, A. P. da; BLANCHETTE, T. "Nossa Senhora da Help": sexo, turismo e deslocamento transnacional em Copacabana. Cadernos Pagu, n. 25, p. 249-280, 2005. https://doi.org/10.1590/S0104-83332005000200010

SILVA, A. P. da; BLANCHETTE, T. G.; BENTO, A. R. Cinderela traída: análise de um mito brasileiro sobre o tráfico de pessoas. In: FELDMAN-BIANCO, B. et al. (orgs.). Migraçáo e Exílio. São Carlos e Viçosa: EdUFSCar/ Editora UFV, 2018. p. 291-331.

SILVA, A. P. da et al. Prostitutas, "traficadas" e pânicos morais: uma análise da produção de fatos em pesquisas sobre o "tráfico de seres humanos". Cadernos Pagu, n. 25, p. 153-184, 2005. https://doi.org/10.1590/S010483332005000200007

SILVA, C. F. da. Conexões Brasil-China: a migração chinesa no centro de São Paulo. Cadernos Metrópole, v. 20, n. 41, p. 223-243, 2018. https://doi.org/10.1590/2236-9996.2018-4111

SILVA, S. A. Bolivianos em São Paulo: entre o sonho e a realidade. Estudos Avançados, v. 20, n. 57, p. 157-170, 2006. https://doi.org/10.1590/S0103-40142006000200012

SILVA, S. A. Imigração e redes de acolhimento: o caso dos haitianos no Brasil. Revista Brasileira de Estudos de Populaçáo, v. 34, n. 1, p. 99-117, 2017. http://dx.doi.org/10.20947/S0102-3098a0009

SOARES, W. Emigração e (i)mobilidade residencial: momentos de ruptura na reprodução/continuidade da segregação social no espaço urbano. In: REIS, R. R.; SALES, T. (orgs.), Cenas do Brasil Migrante. São Paulo: Boitempo, 1999. p. 167-192.

SOUZA LIMA, A. C. de. Um grande cerco de paz: poder tutelar, indianidade e formaçáo do Estado no Brasil. Petrópolis: Vozes, 1995. 
SPRANDEL, M. A. Aqui não é como na casa da gente...: comparando agricultores brasileiros na Argentina e no Paraguai. In: FRIGÉRIO, A.; RIBEIRO, G. L. (orgs.). Argentinos e brasileiros: encontros, imagens e estereótipos. Petrópolis: Vozes, 2002. p. 187-207.

SPRANDEL, M. A. Brasiguaios: conflito e identidade em fronteiras internacionais. Dissertação (Mestrado em Antropologia) - Museu Nacional, Universidade Federal do Rio de Janeiro, Rio de Janeiro, 1992.

SPRANDEL, M. A. Brasileiros na fronteira com o Paraguai. Estudos Avançados, v. 20, n. 57, p. 137-156, 2006.

SPRANDEL, M. A. Tráfico de seres humanos: novas categorias, antigos problemas. In: SERVIÇO PASTORAL DOS MIGRANTES (org.). Travessia na desordem global. São Paulo: Paulinas, 2005. p. 187-207.

SPRANDEL, M. A. "Vou pra rua e bebo a tempestade": observaçôes sobre os dissabores do guarda-chuva do tráfico de pessoas no Brasil. Cadernos Pagu, n. 47, 2016. https://doi.org/10.1590/18094449201600470009

SPRANDEL, M. A.; DIAS, G. M. A temática do tráfico de pessoas no contexto brasileiro. REMHU, v. 18, n. 35, p. 155-170, 2010.

STRATHERN, M. Reproducing the Future: Essays on Anthropology, Kinship and the New Reproductive Technologies. Nova York: Routledge, 1992.

TANIGUTI, G. O imigrante segundo as ciências sociais brasileiras, 1940-1960. Sociologias, v. 20, n. 49, p. 142-196, 2018. http://dx.doi.org/10.1590/15174522-02004905

TARRIUS, A. Anthropologie du mouvement. Caen: Paradigme, 1989.

TARRIUS, A. Les nouveaux cosmopolitisme: mobilités, identités, territoires. La Tour d'Aigues: Editions de l'Aub, 2000.

TARRIUS, A. Territoires circulatoires et espaces urbains: différentiation des groupes migrants. Les Annales de la Recherche Urbaine, n. 59-60, p. 51-60, 1993.

TEIXEIRA, F. do B. L'Italia dei Divieti: entre o sonho de ser européia e o babado da prostituição. Cadernos Pagu, n. 31, p. 275-308, 2008. https://doi.org/10.1590/S0104-83332008000200013

TEIXEIRA, R. O. S.; ZHOURI, A. O Desconhecido, o Imprevisto, o Irreparável: a implantação da barragem de Murta e o sistema de uso e transmissão da terra no Médio Jequitinhonha. Campos, Curitiba, v. 14, n. 1-2, p. 57-73, 2013. http://dx.doi.org/10.5380/campos.v14i1/2.42473

TELLES, V. A cidade nas fronteiras do legal e ilegal. Belo Horizonte: Argymentym, 2010.

TELLES, V. Cidade: produçấo de espaços, formas de controle e conflitos. Revista de Ciências Sociais, Fortaleza, v. 46, n. 1, p. 15-41, jan./jun. 2015.

TELLES, V. da S.; HIRATA, D. Cidade e práticas urbanas: nas fronteiras incertas entre o ilegal, o informal e o ilícito. Estudos Avançados, São Paulo, v. 21, n. 61, p. 173-192, 2007. https://doi.org/10.1590/S010340142007000300012

TELlES, V. da S.; HIRATA, D. Ilegalismos e jogos de poder em São Paulo. Tempo Social, São Paulo, v. 22, n. 2, p. 39-59, 2010. https://doi.org/10.1590/S0103-20702010000200003

THOMAZ, O. R. Ecos do Atlântico Sul: Representaçôes sobre o Terceiro Império Português. Rio de Janeiro: Editora da Universidade Federal do Rio de Janeiro, 2002.

THOMAZ, O. R. Entre inimigos e traidores: suspeitas e acusaçôes no processo de formação nacional no Sul de Moçambique. Travessias, n. 4-5, p. 269-288, $2004 a$. 
THOMAZ, O. R. Narrativas da precariedade: desigualdade e diversidade num contexto pós-colonial. Indianos hindus em Inhambane, Moçambique. In: LIENHARD, M. (org.). Discursos sobre 1(a) pobreza. América Latina y/e países luso-africanos. Frankfurt am Main: Nexos y Diferencias, 2006. p. 133-144.

THOMAZ, O. R. O bom povo português: usos e costumes d'aquém e d'além mar. Mana, v. 7, n. 1, p. 55-87, 2001. https://doi.org/10.1590/S0104-93132001000100004

THOMAZ, O. R. Relaçôes raciais em Moçambique: histórias sobre guerras, nativos e estrangeiros. In: PEIXOTO, F.; PONTES, H.; SCHWARCZ, L. M. (orgs.). Antropologias, Histórias, Experiências. Belo Horizonte: Editora UFMG, 2004b. p. 199-220.

THOMPSON, E. P. Time, work-discipline and industrial capitalism. Past and Present, n. 38, p. 56-97, 1967.

TOGNI, P. C. A Europa é o Cacém: mobilidades, gênero e sexualidade nos deslocamentos de jovens brasileiros para Portugal. Tese (Doutorado em Antropologia Social) - Instituto Universitário de Lisboa, Lisboa, 2014.

TOLEDO, E. Em torno do jornal o Amigo do Povo: Os grupos de afinidade e a propaganda anarquista em São Paulo nos primeiros anos deste século. Cadernos AEL, n. 8/9, p. 89-116, 1998.

TOLEDO, E. Entre naçóes: a imigraçáo italiana e o sindicalismo revolucionário em Sáo Paulo. Circulaçáo de ideias e experiências na militância sindical transnacional entre 1890 e o advento do fascismo. Tese (Doutorado em História Social) - Universidade Estadual de Campinas, Campinas, 2002.

TORPEY, J. The invention of the Passport: Surveillance, Citizenship and the State. Cambridge: Cambridge University Press, 1999.

TORRESAN, A. Emoçôes fora do lugar: negociando amizade em Lisboa. In: MACHADO, I. J. R. (org.). Um mar de identidades. A imigração brasileira em Portugal. São Carlos: EdUFSCar, 2006. p. 26-48.

TORRESAN, A. How Privileged Are They? Middle-Class Brazilian Immigrants in Lisbon. In: VERED, A. (org.) Going First Class? New Approaches to Privileged Travel and Movement. Londres e Nova York: Berghahn, 2007. p. 103-125.

TORRESAN, A. Loud and Proud: Immigration and Identity in a Brazilian/Portuguese Postcolonial Encounter in Lisbon, Portugal. Tese (Doutorado em Antropologia Social/Visual) - University of Manchester, Manchester, 2004.

TORRESAN, A. Quem Parte, Quem Fica: uma etnografia sobre imigrantes brasileiros em Londres, Inglaterra. Dissertaçáo (Mestrado em Antropologia Social) - Universidade Federal do Rio de Janeiro, Rio de Janeiro, 1994.

TRPIN, V.; JARDIM, D. Tendencias de los estudios migratorios en Brasil y Argentina: desafíos actuales. Odisea. Revista de Estudios Migratorios, n. 2, p. 134-157, 2015.

URRY, J. Sociology beyond societies. Londres/Nova York: Routledge, 2000.

URRY, J. Mobilities. Cambridge: Polity Press, 2007.

VASCONCELOS, I. dos S. Receber, enviar e compartilhar comida: aspectos da migração venezuelana em Boa Vista, Brasil. REMHU, Brasília, v. 26, n. 53, p. 135-151, maio/ago. 2018. http://dx.doi.org/10.1590/198085852503880005309

VIANNA, A. Tempos, dores e corpos: consideraçôes sobre a "espera" entre familiares de vítimas de violência policial no Rio de Janeiro. In: BIRMAN, P.; LEITE, M.; MACHADO, C. (orgs.). Dispositivos urbanos e tramas dos viventes: ordens e resistências. Rio de Janeiro: FGV, 2013. p. 405-418.

VIANNA, A.; FARIAS, J. A guerra das mães: dor e política em situaçóes de violência institucional. Cadernos Pagu, n. 37, p. 79-116, 2011. http://dx.doi.org/10.1590/S0104-83332011000200004 
VIANNA, A. R. B.; FACUNDO, A. Tempos e deslocamentos na busca por justiça entre "moradores de favelas" e "refugiados". Ciência e Cultura, v. 67, n. 2, p. 46-50, 2015. http://dx.doi.org/10.21800/231766602015000200014

VIEIRA, F. I. S. O Japonês na Frente de Expansáo Paulista. São Paulo: Livraria Pioneira/Editora da USP, 1973.

VIEIRA, R. O governo da mobilidade Haitiana no Brasil. Mana, v. 23, n. 1, p. 229-254, 2017. http://dx.doi. org/10.1590/1678-49442017v23n1p229

VINCENT, J. Engaging historicism. In: FOX, R. (comp.). Recapturing anthropology. Santa Fé, Novo México: School of American Research Press, 1991. p. 45-58.

TRUZZI, O. De Mascates a Doutores. Sírios e Libaneses em São Paulo. São Paulo: Idesp/Editora Sumaré, 1991.

WILLEMS, E. A aculturaçáo dos alemães no Brasil. São Paulo: Companhia Editora Nacional, 1946.

WILLEMS, E. Acculturation and the horse complex among German-Brazilians. American Anthropologist, v. 46, n. 2, p. 153-161, 1944.

WILLEMS, E. Assimilaçáo e populaçóes marginais no Brasil. São Paulo: Companhia Editora Nacional, 1940.

WILLEMS, E. Cunha. Tradição e transição em uma cultura rural do Brasil. São Paulo: Secretaria da Agricultura, Diretoria de Publicidade Agrícola, 1947.

WILLEMS, E. Recreação e assimilação entre imigrantes alemães e japoneses e seus descendentes. Sociologia, v. 3, n. 4, p. 302-310, 1941.

WILLEMS, E.; BALDUS, H. Cultural Change among Japanese Immigrants in Brazil. Sociology and Social Research: An International Journal, v. 26, n. 6, p. 525-537, 1942.

WOLF, E. Inventing society. American Ethnologist, v. 15, n. 4, p. 752-761, 1988. https://doi.org/10.1525/ ae.1988.15.4.02a00100

ZANINI, M. C.; POVOA NETO, H.; SANTOS, M. de O. (orgs.). Migraçóes Internacionais: valores, capitais e práticas em deslocamento. Santa Maria: EDUFSM, 2013.

ZANINI, M. C.; SANTOS, M. de O. O trabalho como categoria étnica: um estudo comparativo da ascensão social de imigrantes italianos e seus descendentes no Rio Grande do Sul (1875-1975). REMHU, Brasília, v. 17, n. 33, p. 175-196, 2009.

ZELIZER, V. La negociación de la intimidad. México: Fondo de Cultura Económica, 2009.

ZHOURI, A. Megaprojects, epistemological violence and environmental conflicts in Brazil. Perfiles Economicos, $\mathrm{n}$. 5, p. 7-33, 2018. https://doi.org/10.22370/rpe.2018.5.1235

ZHOURI, A. et al. O desastre de Mariana: colonialidade e sofrimento social. In: ZHOURI, A.; BOLADOS, P.; CASTRO, E. (orgs.). Mineraçáo na América do Sul: neoextrativismo e lutas territoriais. São Paulo: Annablume, 2016. p. 45-66.

ZHOURI, A. et al. The Rio Doce Mining Disaster in Brazil: between policies of reparation and the politics of affectations. Vibrant, Brasília, v. 14, n. 2, 2017. https://doi.org/10.1590/1809-43412017v14n2p081

ZHOURI, A.; TEIXEIRA, R. O. Developmental Projects and Violence in Rural Brazil: The case of Hydroelectric Dams. In: VEMURI, S. (org.). Connected Accountabilities: Environmental Justice and Global Citizenship. Oxford: University of Oxford, 2010. p. 197-217.

ZHOURI, A.; OLIVEIRA, R. Paisagens Industriais e Desterritorialização de Populaçôes Locais: Conflitos socioambientais em projetos hidrelétricos. Teoria \& Sociedade, Belo Horizonte, v. 12, n. 2, p. 10-28, 2005. 


\title{
O ensino de Antropologia e a formação de antropólogos no Brasil hoje: de tema primordial a campo (possível) de pesquisa (antropológica)
}

\author{
Guillermo Vega Sanabria ${ }^{\mathrm{I}}$ \\ Luiz Fernando Dias Duarte ${ }^{\mathrm{II}}$
}

Em 1948, em uma palestra chamada "Os grandes problemas da antropologia brasileira”, Arthur Ramos, titular da cátedra de Antropologia e Etnografia na Faculdade Nacional de Filosofia da Universidade do Brasil, concluía peremptoriamente: "Os 'grandes problemas da antropologia brasileira' se convertem num único problema: o da deficiência técnica do ensino e da pesquisa das disciplinas antropológicas em nosso meio" (Ramos, 2015, p. 212). Para Ramos, que, em 1941, havia fundado a Sociedade Brasileira de Antropologia e Etnologia e, nessa altura, mostrava-se preocupado com os aspectos organizacionais e a política das ciências sociais no Brasil, a instauração de um verdadeiro "ambiente universitário" devia ser acompanhada de intensas modificações na estrutura do ensino, inclusive de antropologia, no intuito de superar sua "deficiência técnica" (Ramos, 2015; ver a apresentação de Duarte ao mesmo texto, p. 195-199).

A observação de Ramos era confirmada, poucos anos depois, por Egon Schaden (1954, p. 10) no artigo "Problemas do ensino de Antropologia": "Para a formação de antropólogos e de técnicos de antropologia são insuficientes as possibilidades existentes na atual organizaçáo de nossas Faculdades de Filosofia. Seria recomendável a criação de secçôes [sic] ou mesmo institutos de antropologia”. Schaden, catedrático da recém-criada cadeira de Antropologia na Universidade de São Paulo (USP), também se mostrava a favor da criação de "licenciaturas" em antropologia, como forma de assegurar uma formação especializada na área. Por outra parte, já no início da década de 1960, as jovens Eunice Durham e Ruth Cardoso publicavam o artigo "O ensino da Antropologia no Brasil" e faziam o seguinte balanço, em uma época em que os dados sobre o sistema nacional de ciência escasseavam em geral:

[u]ma análise cuidadosa da situação brasileira encontra grandes dificuldades iniciais. Não possuímos dados precisos sequer sobre o número de estabelecimentos onde se leciona Antropologia, e as indicaçôes sobre programas, número de alunos, qualificaçâo de professores, etc., são extremamente incompletas (Durham; Cardoso, 1961, p. 91).

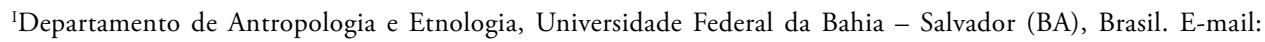
guillermo.sanabria@ufba.br

"Programa de Pós-Graduação em Antropologia Social do Museu Nacional, Universidade Federal do Rio de Janeiro Rio de Janeiro (RJ), Brasil. E-mail: Ifdduarte@mn.ufrj.br
} 
Ao mesmo tempo, essas autoras constatavam que, comparado com o número de universidades que em outros países lecionavam antropologia à época, "o ensino de Antropologia parece estar extremamente desenvolvido em nosso meio" (Durham; Cardoso, 1961, p. 92). Todavia, esse fato correspondia, segundo elas, a uma "hipertrofia", dado que o número de instituiçóes que ofereciam a disciplina, basicamente destinada a completar a formação especializada em outras áreas, contrastava com a ausência de uma especialização em antropologia.

$\mathrm{O}$ quadro desenhado por Ramos (2015), Schaden (1954) e Durham e Cardoso (1961) serve claramente como contraponto para verificarmos o quanto e como a formação de antropólogos no país mudou desde então. Um dos sinais mais notáveis dessa mudança é, com efeito, o fato de que "o espaço institucional consagrado para sua reprodução (o dos programas de pós-graduação) passou por uma rápida e diversificada expansão" (Simião, 2018, p. 24-25). Além da formação especializada em antropologia ser um fato desde 1968, por meio da criação dos cursos de pós-graduação stricto sensu, assistimos, a partir da década de 2000, ao rápido aumento no número deles. Dos 11 programas de pós-graduação existentes em 2004, passamos, hoje, para 31, sendo 11 exclusivamente no nível de mestrado, 19 com mestrado e doutorado e um curso de mestrado profissional ${ }^{1}$. Conforme o último Relatório de avaliação dos cursos da área de Antropologia/Arqueologia pela Coordenação de Aperfeiçoamento de Pessoal de Nível Superior (Capes, 2017), até o fim de 2016 havia 1.212 estudantes de mestrado e 993 de doutorado. No período 2013-2016, foram defendidas 1.226 dissertaçóes e 432 teses nos programas de Antropologia e Arqueologia no Brasil. O número de antropólogos e arqueólogos que atuavam como professores nesses mesmos programas era de $444 \mathrm{em}$ 2016 (CAPES, 2017, p. 2-3).

Ademais, mesmo que a pós-graduação continue a ser o locus de especialização por excelência, ela deixou de ser, também na década de 2000, o espaço exclusivo do ensino de antropologia no país. Existe, agora, maior número de cursos de graduação em ciências sociais, nos quais a divisão em "três áreas" se tornou canônica e a antropologia, parte indispensável do tripé — junto à sociologia e à ciência política. Esse cenário na graduação transformou-se ainda mais com a criação de cursos de graduação em antropologia na mesma década - hoje são em torno de 17 cursos, todos sediados em universidades federais (ver Brasil, 2019a). E ainda em que pese suas idas e vindas, a obrigatoriedade do ensino de sociologia no ensino médio, a partir de 2009, garantiria, por essa via, mais um espaço de crescimento do ensino da disciplina no Brasil. Conta-se, ainda, com o ensino de antropologia como componente obrigatório em cursos de graduação e pós-graduação em outras áreas. Assim sendo, a espirituosa afirmação que Manuela Carneiro da Cunha fizera sobre a disciplina em geral poderia valer, pelo menos em certo sentido, também para seu ensino: "como vocês sabem, não se faz mais antropologia como antigamente... Graças a Deus, aliás" (Carneiro da Cunha, 2009, p. 386).

Neste trabalho, examinamos a produção sobre o ensino da disciplina a partir da organização de eventos acadêmicos, as publicaçóes nos quatro periódicos mais antigos

1 Dados de Brasil, 2019b. O Mestrado Profissional em Culturas Africanas, da Diáspora e dos Povos Indígenas é oferecido pela Universidade de Pernambuco (UPE) desde 2018. 
e entre os mais prestigiados da área, assim como de dissertaçóes, teses e outras publicaçôes acadêmicas. Em que pese o interesse primordial no tema, apontamos o tratamento subordinado que ele tem recebido na antropologia nacional. Apontamos, ademais, alguns desafios e caminhos nesse sentido, especialmente no que tange à possibilidade de considerar o ensino como objeto de pesquisa por direito próprio. Sendo um exercício inédito nos balanços bibliográficos realizados até agora na área, nossa abordagem privilegia o ensino referido à formação de antropólogos no âmbito dos programas de pós-graduação em antropologia e, em menor grau, dos recém-criados cursos de graduação. Deixamos de fora, assim, uma considerável produção sobre o tema, a cargo de antropólogos, cientistas sociais e outros profissionais que atuam em programas de ciências sociais e interdisciplinares, de educação, de história etc., assim como na educação básica. Ao optar por esse recorte damos destaque, como se verá adiante, às dinâmicas do campo intelectual da disciplina no país, assim como aos limites e aos desafios produzidos ao tratar do ensino nesse quadro. Um limite, atrelado às dinâmicas do campo, consiste no fato de que quando, nesse contexto, fala-se em "antropologia” quer-se dizer, a rigor, "antropologia social", sem que eventuais discussóes sobre o ensino em outros subcampos disciplinares sejam consideradas, por exemplo (cf. Santos, 2011) ${ }^{2}$.

\section{Um tema primordial}

O ensino de antropologia é um tema primordial no duplo sentido do termo: tem sido objeto de interesse desde os primórdios da disciplina no país e tem sido fundamental no seu processo de institucionalização e reconhecimento público. O ensino já era tema central durante a organização do que devia ter sido o Primeiro Congresso de Antropologia no Brasil, previsto para o ano de 1949, em Salvador (ver Azeredo, 1986, p. 247259). O artigo $2^{\circ}$ do Anteprojeto de Regulamento do evento estabelecia como objetivo:

Reunir os especialistas brasileiros, professores e pesquisadores, para um amplo e livre debate de todos os aspectos, quer positivos ou negativos, passados e presentes, das nossas atividades de ensino e de pesquisa no setor das ciências antropológicas, bem como para uma tentativa de elaboração de diretrizes e bases de um planejamento nos dois setores - ensino e pesquisa — de amplitude nacional (Azeredo, 1986, p. 249).

A programação do Congresso contemplava os seguintes temas: "01 Arqueologia", "02 Antropologia Física”, "03 Linguística”, "04 Etnologia Indígena”, "05 Antropologia Cultural”, "06 Ensino de Antropologia”, “07 Antropologia Aplicada”, "08 Imigração”, "09 Teoria e Métodos", "10 Etnologia Negra” e "11 Aculturação". Para tratar do "Ensino de Antropologia” contava-se com Arthur Ramos ("O ensino de Antropologia nas Faculdades de Filosofia”), Plínio Ayrosa ("A cadeira de Tupi-Guarani”), José Bonifácio Martins Rodrigues (sem que conste título ou tema de sua apresentação) e Álvaro Fróes da Fonseca (“O ensino de Antropologia na Faculdade de Medicina") (Azeredo, 1986, p. 257-259).

$\mathrm{Na}$ que finalmente seria a I Reunião Brasileira de Antropologia (RBA), realizada no Rio de Janeiro em 1953, o tema volta a

2 Agradecemos os comentários dos pareceristas anônimos da Revista Brasileira de Informação Bibliográfica em Ciências Sociais (BIB) e a generosa leitura e sugestóes da professora Mariza Peirano e do professor Rodrigo Rosistolato. 
estar presente. $\mathrm{Na}$ ocasião, foram apresentadas as comunicaçóes "Problemas do ensino da Antropologia”, por Egon Schaden, e "Possibilidades de exercício de atividades docentes, de pesquisa e técnico-profissionais por antropólogos no Brasil”, de Mário Wagner Vieira da Cunha. Em palavras de Roberto Cardoso de Oliveira (2004, p. 15), "pode-se dizer que esses dois assuntos abriram a $1^{\mathrm{a}}$ Reunião Brasileira de Antropologia”. Segundo o mesmo autor, o ensino e as atividades técnico-profissionais teriam sido tratados em dois "simpósios". O de ensino teve como relatores Marina São Paulo de Vasconcelos, da Faculdade Nacional de Filosofia da Universidade do Brasil; Egon Schaden, da Faculdade de Filosofia, Letras e Ciências Humanas (FFLCH) da USP; e Rubo Müller, da Escola de Sociologia e Política de São Paulo. O simpósio sobre atividade técnico-profissional teve como relatores Heloisa Alberto Torres, Diretora do Museu Nacional; Mário Wagner Vieira da Cunha, Diretor do Instituto de Administração da USP; e José Loureiro Fernandes, da Faculdade de Filosofia da Universidade Federal do Paraná (UFPR).

$\mathrm{Na}$ II RBA, realizada em Salvador em 1955, foram mantidos os eixos temáticos da primeira reunião, a saber: "I. Pré-História (Paleontologia Humana e Arqueologia)"; "II. Antropologia Física"; "III. Antropologia Cultural e Social”; "IV. Linguística”; "V. Folclore"; e, de novo, "VI. Problemas profissionais e de ensino da Antropologia" (Associação Brasileira de Antropologia - ABA, 1957; Carvalho, 2006, p. 299; Consorte, 2006, p. 166). O programa da reuniáo previa um simpósio coordenado por Egon Schaden, sob o título "Problemas de ensino em Antropologia”, assim como o que parece ser uma comunicação, intitulada "A Antropologia nos cursos da Fundação Getúlio Vargas”, por Maria Alice Pessoa. Nos trabalhos constantes dos anais, acham-se ainda as seguintes comunicações: "Curso de Aperfeiçoamento em Antropologia Cultural”, por Luiz de Castro Faria, tratando do curso criado em março de 1955 no Museu do Índio; "Cadeira de etnografia e língua Tupi”, por Darcy Ribeiro, tratando da disciplina criada por lei de 1954 na Faculdade Nacional de Filosofia da Universidade do Brasil; "Antropologia e educação popular”, por Margarida Maria Sinay Neves, tratando das "diferenças culturais" no contexto de intervençôes educacionais e sanitárias nas camadas populares e da utilidade da antropologia na formação de assistentes sociais, médicos e educadores.

No "Relatório geral" da III RBA, realizada em Recife em 1958, Manuel Diégues Jr., Secretário-Geral da recém-criada ABA (constituída durante a II RBA, em 1953), observa que, considerando os temas das comunicaçóes apresentadas tanto nas "sessóes de trabalho" quanto nas mesas-redondas, tinha-se a seguinte distribuição: "5 sobre assuntos indígenas; 5 sobre pesquisa e ensino de antropologia; 4 sobre estudos de comunidade; 2 sobre aculturação; 2 sobre assuntos relativos ao negro; 2 sobre folclore; 1 sobre arqueologia; 1 sobre migraçôes internas; e 1 sobre estudos de 'fazenda"' (ABA, 1959, p. 265). Tratando da pesquisa e do ensino de antropologia, Diégues Jr. (ABA, 1959, p. 267-268) faz uma síntese das comunicaçóes apresentadas, entre as quais merece destaque a de Antônio Rubo Müller, "Reflexões do trabalho de campo na didática da antropologia", que teria sido apresentada tanto na terceira "sessão de estudos" quanto em uma das duas mesas-redondas previstas na III RBA. Essa mesa-redonda, especificamente, tinha por título "Experiências pessoais no 
trabalho de campo do antropólogo" ${ }^{\text {. Con- }}$ siderando os oito anos em que as atividades da ABA estiveram praticamente suspensas (de 1966 a 1974), em meio às dificuldades criadas pela ditadura militar da época (Corrêa, 2003, p. 27 e p. 37), é muito significativo que a retomada dos encontros regulares da RBA, a partir de 1974, pautasse de novo a discussão sobre o ensino. A que seria a IX RBA (Florianópolis, 1974) tinha na sua programação três mesas-redondas com os seguintes temas: "Ensino e pesquisa em Antropologia no Brasil"; "A Antropologia em ação: o problema das minorias"; e "Contribuiçấo da Antropologia ao processo de desenvolvimento brasileiro" (Santos, 2006b, p. 67; Santos, 2006a, p. 53).

Aliás, dois anos antes da IX RBA e no encalço de atividades similares realizadas em outros lugares do país (Santos, 2006b, p. 66), aconteceu em Florianópolis a I Reunião de Professores de Antropologia do Sul do Brasil, na qual Luís Carlos Halfpap apresentaria a comunicação "O ensino de Antropologia no Sul do Brasil" (Vega Sanabria, 2005, p. 14; Santos, 2006a, p. 50). Tanto a Reunião quanto o trabalho de Halfpap revelam o interesse que o ensino de antropologia já despertava para além dos centros acadêmicos, tais como São Paulo e Rio de Janeiro. Conforme Santos, essa reunião de professores de antropologia em Florianópolis "tomou como referência as reunióes que vinham sendo efetivadas pelo professor pe. Pedro Ignácio Schmitz, titular de Antropologia da
Universidade Federal do Rio Grande do Sul, com os professores que trabalhavam no interior daquele Estado" (Santos, 2006a, p. 50). A respeito dessas reunióes, organizadas por Schmitz nos anos de 1960 e 1970, Teixeira também aponta:

Ele foi bem-sucedido em sua iniciativa de reunir professores de Antropologia e Arqueologia que atuavam no Rio Grande do Sul. Com duração de dois ou três dias e em clima de companheirismo, propiciavam a discussão de programas, a apresentação de pesquisas e a atualização na literatura antropológica (Teixeira, 2006, p. 146) .

Conforme o levantamento de eventos acadêmicos que apresentamos no Apêndice 1 , as discussōes sobre o ensino de antropologia e a formação do antropólogo acontecem ininterruptamente desde o ano 2000, com um ou mais eventos a cada ano desde entáo. Verifica-se também a realização de, pelo menos, 66 eventos no período de 46 anos, que vai de 1972 a 2018.

Ora, se a realizaçáo de eventos acadêmicos é um indicador nítido do interesse pelo tema ao longo da história da disciplina no país, igual atenção merece o fato de que, também desde cedo, ele ganhou um lugar em publicaçôes acadêmicas especializadas. Muito embora o espaço seja comparativamente bem menor, é possível constatar desde já que trabalhos sobre o ensino de antro-

3 Os Anais da II e da III RBA encontram-se disponíveis no site da ABA (ABA, 1957; 1959). A IV RBA aconteceu em Curitiba, em 1959; a V em Belo Horizonte, em 1961; a VI em São Paulo, em 1963; a VII em Belém, em 1966; e a VIII em São Paulo, em 1971. Para uma síntese das condiçóes em que esses eventos se sucederam, ver Corrêa (2003) e Santos (2006a, p. 10). Sem ter tido acesso aos anais dessas reunióes, apenas fazemos menção a elas aqui. Contudo, é plausível supor que o tema tenha continuado a fazer parte das discussōes nas RBA.

4 Para uma apreciaçáo do lugar destacado que o ensino adquire na produção de histórias "locais" e "regionais" da antropologia no Brasil, ver os depoimentos nas celebraçóes dos 50 anos da ABA (Eckert; Godoi, 2006). Ver também Brandão e Motta (2003) sobre a antropologia no Norte e no Nordeste; Beltrão (2004) e Almeida (2019) sobre a antropologia na Amazônia; e Santos, Helm \& Teixeira (2006) sobre a antropologia no Sul. 
pologia têm encontrado lugar também nos periódicos nacionais indexados de maior reconhecimento na área, como nas quatro revistas que examinaremos a seguir. Além de sua antiguidade, elas foram escolhidas considerando sua classificação nos estratos A1 e A2 do Qualis CAPES. Ademais, impunha-se a condição prática de que os periódicos disponibilizassem seus arquivos on-line. Isso significa, evidentemente, que não fizemos aqui uma revisão exaustiva, nem foram contemplados todos os periódicos que poderiam ser citados. Contudo, os quatro escolhidos são um recorte expressivo, pertinente e suficiente para desenvolver o argumento que surge desta revisão bibliográfica. As quatro publicaçóes escolhidas foram: a Revista de Antropologia, o Anuário Antropológico, a revista Mana e a revista Horizontes Antropológicos.

A Revista de Antropologia, fundada em 1953 por Egon Schaden na USP, incluía em seu primeiro número a comunicação que o próprio Schaden tinha apresentado na I RBA, "Problemas do ensino da Antropologia"s. Em 1955, publicaria o texto de Mário Wagner Vieira da Cunha, "Possibilidades de exercício de atividades docentes, de pesquisa e técnico-profissionais por antropólogos no Brasil", apresentado também na I RBA. Nos anos seguintes, outros textos tratando do ensino de antropologia apareceriam na revista: "O trabalho interdisciplinar em Antropologia", no qual Luiz de Castro Faria tece algumas consideraçóes sobre o treinamento dos antropólogos físicos (v. 7, n. 1-2, 1959); "O ensino da Antropologia no Brasil”, por Eunice Durham e Ruth Cardoso
(1961), citado anteriormente; "A antropologia na Universidade de São Paulo: histórico e situação atual", no qual Alba Costa Maciel, Diva Andrade e Eunides do Vale apresentam um detalhado balanço da disciplina nessa universidade, da criação da cadeira de Antropologia em 1941 até 1977 (seção "Noticiário", v. 21 n. 1, 1978). O volume 22 (de 1979) também incluía dois textos sobre o ensino: "Ensino pós-graduado, teoria e pesquisa antropológica", de Pedro Agostinho; e "A pesquisa como base para o ensino de pós-graduação", de Eduardo Diatay Bezerra de Menezes; ambos trabalhos apresentados originalmente no "Simpósio sobre ensino e pesquisa em Antropologia”, na XI RBA (Recife, 1978).

Após interregno de quase 25 anos sem publicaçóes a respeito, a edição comemorativa dos 50 anos da Revista de Antropologia (v. 46, n. 2, 2003) trouxe uma série de resenhas históricas, balanços, depoimentos e homenagens que, embora não o tivessem como foco, referem-se de novo ao ensino (ver, por exemplo, o artigo de Peixoto; Simóes, 2003). Depois vieram os textos "O Museu Paulista e a história da antropologia no Brasil entre 1946 e 1956”, por Mariana Françozo (v. 48, n. 2, 2005), e "Gioconda Mussolini: uma travessia bibliográfica”, por Andrea Ciacchi (v. 50, n. 1, 2007). A revista dedicaria ainda um dossiê a Gioconda Mussolini no segundo número de 2015, organizado também por Andrea Ciacchi. No mesmo número, inclui-se o texto "De Lévi-Strauss aos índios na universidade. Entrevista com Manuela Carneiro da Cunha", por Edson Tosta

5 A Revista de Antropologia é conceito A2 no Qualis CAPES. A antropologia foi, antes que a sociologia e a ciência política, a primeira área das ciências sociais no Brasil a ter um periódico próprio, a saber, a Revista de Antropologia. Ela se tornou órgáo oficial da ABA, em 1956, e da Sociedade Brasileira de Sociologia, a partir de 1958 (Peixoto; Simôes, 2003, p. 387). Na pesquisa, foram consultados todos os números disponíveis, de 1954 a 2018, em http:// www.revistas.usp.br/ra/issue/archive (consulta feita em fevereiro de 2019). 
Matarezio Filho (v. 58, n. 2, 2015). Recentemente, a revista organizou um dossiê intitulado "Ações afirmativas dos Programas de Pós-Graduação em Antropologia”, abordando diversos aspectos das políticas de inclusão para indígenas e negros (v. 60, n. 1, 2017). Nos mais de 65 anos da Revista de Antropologia, junto a textos como os mencionados anteriormente, acham-se também inúmeras homenagens, obituários, memoriais e entrevistas de figuras pioneiras e de destaque da antropologia nacional. Aqui, como nos outros periódicos elencados, esses documentos revestem algum interesse tratando-se do ensino, uma vez que, nesses casos, trajetórias individuais de docentes e pesquisadores se confundem facilmente com a história institucional da disciplina no Brasil.

No Anuário Antropológico, fundado por Roberto Cardoso de Oliveira em 1976 na Universidade de Brasília (UnB), também se acham diversas reflexôes sobre o ensino ${ }^{6}$. O número de 1982 dedica a seção "Depoimentos" à "Antropologia no Brasil"; dela constam contribuiçốes como: "A antropologia no Brasil. Depoimento sem compromissos de um militante em recesso", de Luiz de Castro Faria; "Os primeiros tempos da antropologia em São Paulo", de Egon Schaden; e "Primeiros mestres da antropologia nas Faculdades de Filosofia", de Thales de Azevedo. O número de 1983 prestigia Castro Faria, na seção "Homenagem”, com contribuiçôes como: "A arqueologia no Brasil: o papel do professor Castro Faria", de Maria da Conceição de Moraes Coutinho Beltrão; "Castro Faria e a voca- ção etnológica”, de Alcida Rita Ramos; e "A linguística no Museu Nacional: o papel de Luiz Castro Faria", de Yonne Leite. O número de 1985 traz, na seçâo "Conferência", o texto "O que é isso que chamamos de Antropologia brasileira?", de Roberto Cardoso de Oliveira. Treze anos depois, o número de 1996 apresenta a seçáo chamada "Formação de antropólogos", com os seguintes trabalhos: "Sobre a formação de antropólogos", de Klaas Woortmann; "Totens e xamãs na pós-graduação", de Claudia Fonseca; e "Sociedades tribais, urbanas e camponeses, uma proximidade desejável: notas para um curso de graduação em antropologia social", de Ana Maria de Niemeyer (1996). Após seis anos, no número de 2002-2003, Roberto Cardoso de Oliveira relata o quadro histórico do ensino no contexto da criação e da atuação da ABA no texto "Cinco décadas de reunióes e a consolidação do campo antropológico". O número de 2006 inclui o artigo "O ofício do antropólogo, ou como desvendar evidências simbólicas", de Luís Roberto Cardoso de Oliveira, abordando o trabalho do antropólogo em outros contextos, fora da universidade. Dez anos depois, o Anuário homenageia Mariza Peirano com vários textos, entre os quais se destaca "Em busca de dragóes: Mariza Peirano e a arte de ensinar antropologia", de Christine de Alencar Chaves (v. 41, n.1).

Na revista Mana, criada em 1995 no Programa de Pós-Graduação em Antropologia Social (PPGAS) do Museu Nacional, encontra-se uma série de trabalhos que, ao tratar da história da antropologia ou do pró-

6 Foram consultados os sumários e os resumos das ediçóes publicadas de 1976 a 2018, disponíveis em http://www. dan.unb.br/anuarioantropologico-sumarios (consulta em janeiro de 2019). O Anuário Antropológico encontra-se no nível A2 do Qualis CAPES. 
prio PPGAS, fazem alguma referência ao ensino 7 . O número de 1998 inclui o artigo "Lévi-Strauss no Brasil: a formação do etnólogo", de Fernanda Peixoto; o de 2002 traz o artigo "Diálogos Jê: a pesquisa Krahô e o projeto Harvard-Museu Nacional", em que Júlio Cezar Melatti rememora um dos projetos de pesquisa que deram origem ao PPGAS, após a reforma universitária da década de 1960. Em 2008, publica-se o "Dossiê - Homenagem aos fundadores", com textos como "Trajetórias convergentes: Cardoso de Oliveira e Maybury-Lewis", de Roque de Barros Laraia; "A terceira margem de RCO", de Otávio Velho; "Lembranças", de Mariza Peirano; e "Um semeador da antropologia: os antropólogos como nativos e seus ritos", de João Pacheco de Oliveira (v. 14, n. 2). O segundo número de 2009 traz o artigo "Fundamentos empíricos da razão antropológica: a criação do PPGAS e a seleção das espécies científicas", de Afrânio Garcia Jr. Quatro anos depois, uma entrevista a Lygia Sigaud, realizada por Guillermo Vega Sanabria, sob o título "O mundo desmagicizado", trata concretamente do ensino no PPGAS do Museu Nacional (v. 19, n. 3, 2013). Publica-se, depois, a palestra inédita de Arthur Ramos (2015), "Os grandes problemas da antropologia brasileira", "à qual fizemos" referência no início; no mesmo ano, aparece ainda o artigo "A antropologia historicizada ou Os índios de Fenimore Cooper. 'Clássicos' e 'história' no ensino de antropologia no Brasil", de Guillermo Vega Sanabria (2015), tratando do currículo na pós-graduação.
Por fim, a revista Horizontes Antropológi$\cos ^{8}$, criada em 1995 na Universidade Federal do Rio Grande do Sul (UFRGS), dedicou um dos seus primeiros números às "Histórias da antropologia" (ano 3, n. 7, 1997), com textos sobre a disciplina na Argentina, no Uruguai, no Paraguai e no Brasil. Entre eles, o artigo "O espartilho de minha avó: linhagens femininas na antropologia”, de Mariza Corrêa, que alcançaria grande destaque nas discussóes sobre a história da antropologia nacional. Mencione-se também o artigo "Os programas de pós-graduação em Antropologia Social do Museu Nacional, Universidade de Brasília, Universidade de Sáo Paulo e Universidade Estadual de Campinas", de Christina Rubim. Quatro anos depois, foi publicado o texto "Avaliação dos programas de pós-graduação: do ponto de vista de um nativo", de Claudia Fonseca (2001). Após mais de dez anos, viria à luz "O legado da antropologia brasileira: relato de Roque de Barros Laraia" (v. 20, n. 42, 2014). Ao longo da história da revista, encontra-se, de novo, considerável número de homenagens e entrevistas a antropólogos. Recentemente, a Horizontes Antropológicos publicou um número especial sobre "Cultura e aprendizagem" (ano 21, n. 44, 2015) e outro sobre "Antropologia, etnografia e educação" (ano 23, n. 49, 2017), contudo o ensino de antropologia não foi objeto de nenhuma dessas duas ediçóes.

Embora a lista anterior não esgote as publicações sobre o ensino de antropologia e a formação de antropólogos nos periódicos

7 Foram consultados todos os números, de 1995 a 2018, disponíveis em https://www.revistamana.org/nuacutemeros.html (consulta em janeiro/fevereiro de 2019). A revista Mana é classificada no nível A1 do Qualis CAPES.

8 Foram consultados todos os arquivos, a partir da edição do ano 3, n. 6, out. 1997 até a última edição de 2018, disponíveis em https://www.ufrgs.br/ppgas/ha/index.php/pt/menu/numeros-anteriores (consulta feita em fevereiro de 2019). A revista encontra-se no nível A1 do Qualis CAPES. 
nacionais ${ }^{9}$, ela estabelece um ponto de referência plausível para apreciar os trabalhos produzidos nessa seara. Observa-se de início que, como sugerido antes, a produção sobre o ensino de antropologia parece encontrar um lugar mais provável nos eventos acadêmicos do que nos periódicos científicos da área (cf. Apêndice 1). De fato, a maior parte dessas publicações é formada por textos idealizados como conferências, comunicaçóes e reflexôes pessoais, apresentadas originalmente em eventos acadêmicos. Por outra parte, os textos parecem ganhar um espaço nesses periódicos na medida em que, fundamentalmente, constituem memórias da história disciplinar no país, relatos de trajetórias acadêmicas e homenagens a figuras já consagradas na antropologia brasileira. Daí o tom reminiscente e laudatório de muitos desses trabalhos. Em outros casos, os textos têm um caráter eminentemente opinativo, baseados na experiência qualificada dos autores como professores de antropologia e na sua reflexão pessoal sobre a própria prática (pedagógica e antropológica). Como alguns autores advertem alhures, tais textos não provêm de pesquisas sistemáticas sobre $o$ assunto, nem têm qualquer pretensão teórica (ver, por exemplo, DaMatta, 1979; Guedes, 2004). Em geral, o traço mais notável desse conjunto talvez seja a emergência de uma reflexão sobre o ensino de antropologia atrelada à história/historicização da disciplina no país. Isso vale, diga-se de passagem, para publicaçóes e empreendimentos de mais fôlego empírico e analítico, como veremos adiante.

O predomínio dessa literatura de cunho memorialístico, opinativo e baseada nos testemunhos pessoais dos autores, pode ser entendido à luz de uma prática mais ou menos institucionalizada na antropologia, assinalada por Peirano (apud Vega Sanabria, 2015, p. 610): tanto a história quanto os textos introdutórios sobre a própria disciplina são feitos, via de regra, por antropólogos estabelecidos e quase sempre no final de suas carreiras. Isso porque, como sugere essa autora, a "credibilidade" e a "legitimidade" das narrativas encontram-se diretamente vinculadas ao sucesso da trajetória dos autores e ao fato de serem contemporâneos dos eventos que narram. Contudo, mesmo que dita literatura possa ser vista como um esforço (nativo) por elaborar vivências pessoais em uma perspectiva mais reflexiva e objetivante, é preciso atentar para os limites que dela decorrem ao tratarmos do ensino de antropologia e da formação de antropólogos. Nas palavras de Vega Sanabria (2015, p. 60):

9 Nesse sentido, ver, por exemplo, o número especial da revista Anthropológicas (Universidade Federal de Pernambuco - UFPE), sob o título "Pós-graduação em Antropologia da UFPE. 20 Anos de Pós-Graduação em Antropologia: Memória, Tradição \& Perspectivas" (1997). Na mesma revista, ver também o "Dossiê: Antropologia, educação, alteridades e desigualdades" (v. 27, n. 1, 2016) e, no mesmo ano, a "Edição Comemorativa dos 40 Anos do Programa do Pós-Graduação em Antropologia da Universidade Federal de Pernambuco (1976-2016)" (v. 27, n. 2, 2016). A revista Ilha (Universidade Federal de Santa Catarina - UFSC) publicou o dossiê "Orientaçáo" (v. 6, n. 1-2, 2004) e as ediçóes especiais em homenagem a Sílvio Coelho dos Santos (v. 10, n. 1, 2008) e Alberto Guerreiro Ramos (v. 18, n. 1, 2016). Na revista Sociedade e Cultura (Universidade Federal de Goiás - UFG), ver o "Dossiê: Ciências Sociais UFG: 50 anos" (v. 17, n. 2, 2014). Na Amazônica. Revista de Antropologia (Universidade Federal do Pará - UFPA), ver os textos publicados sob o título "Simpósio Antropologia em Foco" (v. 1, n. 1, 2009) e o artigo "Intelectualmente 'impuros e maculados': reflexôes sobre a formação em antropologia biológica no diálogo com outros campos da antropologia", de Ricardo Ventura Santos (v. 3, n. 1, 2011). Enfim, menciona-se o "Dossiê Ensino de antropologia”, publicado na revista Café com Sociologia (v. 4, n. 2, 2015). 
O fato de esses textos privilegiarem reminiscências e quase sempre resultarem do compromisso militante dos autores impede tomá-los como única base do estudo do campo antropológico. Tal como alertaram Latour e Woolgar ao fazerem um balanço da literatura sobre a ciência e as práticas científicas, é necessário reconhecer que "por mais estimulantes que sejam essas obras, elas não podem remediar a ausência de pesquisa, de observação direta, de contradição”.

\section{Por que o interesse no ensino?}

Algumas autoras têm sugerido que o interesse no ensino de antropologia no Brasil ganhou força a partir dos anos 1980 (Peirano, 1999, p. 244; Peixoto, 1998, p. 79) ou 1990 (Feldman-Bianco, 2013, p. 38; Grossi; Tassinari; Rial, 2006, p. 200). Entre as razóes apontadas para tanto, encontram-se as reformas introduzidas pelas agências financiadoras e as discussóes sobre avaliação e tempos de titulação na pós-graduação, a criação de cursos de graduação na área e a expansão do mercado de trabalho para antropólogos. Contudo, como visto anteriormente, as reflexóes sobre o ensino remetem a preocupaçôes mais antigas. Longe de naturalizá-la, cumpre se perguntar por que razão a discussão sobre o ensino da disciplina adquire a importância que parece ter na antropologia no Brasil. Conforme Vega Sanabria (2005, p. 13), a princípio é possível considerar pelo menos três ideias que retomam reflexôes mais amplas, propostas localmente nesse sentido.

Em primeiro lugar, tendo em vista a relação existente no Brasil entre ensino da disciplina e institucionalização dela, tal interesse corresponderia a um desdobramento de um momento histórico específico da an- tropologia, do mesmo modo que as reflexóes sobre o trabalho de campo tiveram crucial importância na primeira metade do século XX (Peirano, 1995; 2006). Em segundo lugar, a atenção dedicada ao ensino seria mais uma forma de atualizar a capacidade de autorreflexão atribuída com frequência à antropologia (Corrêa, 1997; Godoi; Debert; Pontes, 2002). Enfim, esse interesse resultaria do progressivo "deslizamento" que, nas últimas décadas, teria levado a antropologia feita no Brasil "de um pólo onde a noção de diferença definidora da disciplina era (ou pretendia ser) radical, para outro onde nós mesmos, cientistas sociais, somos o Outro" (Peirano, 1999, p. 234). A passagem da busca da "alteridade radical" para a busca da "alteridade próxima" ou "minima" teria conduzido à crescente série de estudos atentando às biografias intelectuais de cientistas sociais, à caracterização da antropologia feita no Brasil, sua historiografia e sua sociogênese, assim como a algumas reflexões sobre seu ensino (ver Peirano, 1999, p. 244-246 para referências).

A dimensão de autorreflexão envolvida na formação antropológica tem, diga-se de passagem, grandes implicaçóes para a compreensão e a estruturação do ensino em sua dimensão cotidiana, prática. Coerentemente com a crescente ênfase na reflexividade do pesquisador em relação à sua própria identidade (pessoal e sociocultural), ao lidar com os fenômenos sociais alheios, busca-se evitar uma excessiva formalização da transmissão de conhecimentos canônicos, em favor da frequentação das "monografias" (trabalhos etnográficos densos) ou da experiência imediata de campo (participação, afetação etc.). $\mathrm{O}$ ensino da antropologia se torna, assim, uma espécie de prolegômeno à imersão subjetiva na lide de pesquisa - 
locus por excelência de um "verdadeiro" aprendizado. Isso reforça o papel dos orientadores em detrimento das disciplinas obrigatórias, mesmo que não seja propriamente frequente a ida ao campo em grupos de que participem os orientadores ${ }^{10}$.

Nesse quadro, a relação entre o ensino de antropologia e a institucionalizaçáo da disciplina no Brasil merece consideração especial. Isso porque, como tem sido mostrado por vários autores, o foco no ensino revela aspectos centrais do processo de emergência e consolidação da antropologia no país, assim como da estrutura do sistema educacional em que ela se insere (notadamente nos cursos de graduação e pós-graduaçáo na universidade). Desse modo, por exemplo, o ensino da disciplina aparece como um assunto embutido nos vários trabalhos desenvolvidos no Projeto História da Antropologia no Brasil (PHAB), coordenado por Mariza Corrêa na Universidade Estadual de Campinas (Unicamp). Com o PHAB, Corrêa levaria a cabo o que talvez seja, até hoje, o maior e mais sistemático investimento de pesquisa nesse sentido ${ }^{11}$. Na mesma direçấo, também são fundamentais os trabalhos reunidos por Miceli $(1995$; 2001) nos dois volumes da História das Ciências Sociais no Brasil, os quais trazem contribuiçóes específicas sobre a institucionalização da antropologia no país e, nesse contexto, lançam luz sobre o ensino da disciplina. Particularmente, destaquem-se as contribuiçôes de Mariza Corrêa (1995) sobre a antropologia no Brasil de 1960 a 1980 e de Fernanda Peixoto (2001) sobre a presença de franceses e norte-americanos nas ciências sociais brasileiras.

O ensino aparece, assim, como uma concretização, um sinal a partir do qual pode ser traçado o surgimento, a paulatina autonomização e a profissionalização da antropologia. Desse ponto de vista, desde o início, institucionalização da disciplina no país tem significado, a rigor, pesquisar e ensinar (na universidade). Daí a indissociabilidade, no Brasil, entre pesquisa antropológica e ensino universitário. Primeiro por meio das cadeiras nas faculdades de filosofia e, depois, dos programas de pós-graduação - passando pelos cursos de aperfeiçoamento, de extensão e de especialização que foram oferecidos, a partir da década de 1950, em museus de vários lugares do país ${ }^{12}$. O vínculo entre ensino e pesquisa como pedras fundamentais da institucionalização da disciplina, aliás, já era explícito

10 Ver, por exemplo, a distinção feita por Duarte (2006) entre "formação" e "ensino" na antropologia e em outras ciências humanas.

11 Vejam-se as dissertaçōes de Ribas (1990), O Brasil é dos brasilianos: medicina, antropologia e educação na figura de Roquette-Pinto; Peixoto [Massi] (1991), Estrangeiros no Brasil: a missão francesa na Universidade de São Paulo; Rosa (1993), A aliança e a diferença: uma leitura do itinerário intelectual de Charles Wagley; Passador (2002), Herbert Baldus e a antropologia no Brasil; assim como a tese de Rubim (1996), Antropólogos brasileiros e a antropologia no Brasil: a era da pós-graduação.

12 Os cursos de especialização tinham sido instituídos no Brasil pela Portaria Ministerial no 497, de 15 de outubro de 1947. Os primeiros cursos especializados de antropologia começaram a ser ofertados, em 1953, por Darcy Ribeiro e Roberto Cardoso de Oliveira no Museu do Índio e, posteriormente, no Museu Nacional; igualmente, foram oferecidos cursos de extensão, aperfeiçoamento, especialização e outras iniciativas similares, a partir de 1961, pela Divisão de Antropologia do Museu Goeldi e pela Faculdade Filosofia da Universidade do Pará e das quais foram professores, entre outros, Eduardo Galvão, Protásio Frikel, Napoleăo Figueiredo, Edson Diniz, Isolda Albuquerque e Klaas Woortmann (cf. Corrêa, 1995; Arnaud, 1981, p. 145). Posteriormente, seriam criados também os cursos da UFSC em 1976 (Santos, 2006a, p. 55), da Universidade Federal do Paraná (UFPR) em 1972 (Helm, 2006, p. 112) e da UFGRS em 1974 (Teixeira, 2006, p. 165). 
na Resolução de constituição da $\mathrm{ABA}$, em 1955. O artigo $2^{\circ}$ desse documento declarava: "A Associação Brasileira de Antropologia é um órgão de âmbito nacional destinado a congregar os especialistas em Antropologia com exercício nos setores profissionais do ensino e da pesquisa” (ABA, 1957, p. 11). Dito vínculo também fica evidente na forma como as trajetórias individuais de figuras principais na institucionalização da disciplina são elaboradas, como sugere a seguinte declaração de Florestan Fernandes (apud Peirano, 1992, p. 75, grifos nossos):

Estávamos em uma nova era, para mim, e as minhas responsabilidades sofriam uma transformaçáo rápida, quantitativa e qualitativa. Graças à transferência para a Cadeira de Sociologia I [...] e, em seguida, ao contrato como professor em substituição a Roger Bastide, eu me via diante da oportunidade de contar com uma posição institucional para pôr em prática as concepçóes que formara a respeito do ensino da sociologia e da investigação sociológica.

Desse modo, não surpreende que autores como Cardoso de Oliveira (1997) e Corrêa (1995; 2011), ao tratar da história e do ensino de antropologia no país, tenham dado especial atenção à criação e à consolidação dos departamentos e dos programas de pós-graduação, assim como à criação e ao papel desempenhado pela $\mathrm{ABA}$, adotando o que Peirano (2000, p. 219) chama de "olhar institucional”. Isso porque, como também assinala Duarte (2010, p. 17):

A prática antropológica se dá majoritariamente nos departamentos universitários e nos programas de pós-graduação que constituem, provavelmente, sua espinha dorsal ins- titucional. Como não havia até recentemente cursos de graduação em Antropologia, os de pós-graduação desempenhavam e desempenham ainda um papel arregimentador e organizador fundamental. Há toda uma bibliografia sobre as condições do ensino da disciplina. [...] Essa literatura de avaliação sobre as condiçóes presentes no exercício da atividade antropológica complementa um considerável esforço de interpretação geral do sentido da Antropologia desenvolvida no contexto brasileiro [...].

Esse enfoque pode ser explicado ainda pelo fato de que, conforme Peixoto, no Brasil, como na França sob o impulso do projeto durkheimiano, o "campo por excelência das batalhas travadas pela legitimação das ciências sociais" é seu estabelecimento no ensino superior (Peixoto, 2001, p. 496). A constatação do vínculo entre ensino e institucionalização da disciplina é basilar para pensarmos como pesquisar o ensino constitui um caminho legítimo e produtivo analiticamente na hora de compreender as condições sociológicas em que a antropologia no país é possível. Todavia, o ensino emerge como objeto de pesquisa digno não apenas pelo que possa revelar da sociedade da qual a antropologia, enquanto disciplina científica, faz parte (Elias, 1982, p. 3; Peirano, 1999, p. 228), mas também porque, com base nele, é possível lançar luz sobre a cultura que, enquanto comunidade de especialistas, os antropólogos constituem e reproduzem por meio da formação dos seus novos membros.

\section{Um paradoxo notável}

O fato de o ensino ter recebido atenção fundamentalmente pela sua centralidade na história da institucionalização da disciplina 
tem criado, porém, um paradoxo notável. Se, por um lado, tal tratamento lhe garantiu desde cedo sua incorporação na agenda de discussóes dos antropólogos no país, por outro, tem-no fadado a uma posição analiticamente subordinada, dificultando sua compreensão como um objeto de estudo por direito próprio. Essa afirmação parece tanto mais plausível quanto o ensino de antropologia (e das outras ciências sociais) tem sido deixado de lado nos balanços disciplinares mais importantes feitos até agora no país. Referimo-nos, em concreto, aos três volumes de $O$ que ler na Ciência Social brasileira (1970-1995) (Miceli, 1999), com especial atenção ao volume 1 , dedicado à antropologia, e, ainda, ao quarto volume dessa mesma coleção, publicado como $O$ que ler na Ciência Social brasileira (19702002) (Miceli, 2012) ${ }^{13}$. O ensino tampouco é contemplado nos três volumes da coletânea mais recente, Horizontes das Ciências Sociais no Brasil (Martins; Martins, 2010; Martins; Lessa, 2010); especialmente no volume correspondente à antropologia (Martins; Duarte, 2010). Embora a lista de trabalhos nessa ocasião fosse maior (14 em vez dos cinco da primeira coletânea), Duarte observara que "uma primeira ausência grave" nessa empreitada foi "a das rubricas separadas de História da Antropologia e de Teoria Antropológica”
(Duarte, 2010, p. 14). Trata-se precisamente daquelas que teriam oferecido alguma possibilidade de que o ensino fosse abordado, pelo menos tacitamente. Tal ausência pode ser efeito, já nessa altura, de uma nova configuração das linhas de pesquisa dos programas de pós-graduação, pois, como observa Simóes (2018, p. 71):

\begin{abstract}
[A] História provavelmente refletia a relevância conferida a estudos e pesquisas de história da antropologia e história das ciências sociais, nos anos 1980 e 1990; atualmente, parece refluir como designação temática, sem registro de criação de novas linhas de pesquisa, no período recente.
\end{abstract}

O corolário de ter no ensino um tema primordial para a história institucional, mas secundário analiticamente, é irônico, pois, como aponta Pierrot, são os antropólogos, talvez, "os que dão maior importância às aprendizagens, aqueles que afirmam que tudo se aprende e, portanto, que nada é inato" (Pierrot, 2015, p. 50). Porém, são eles mesmos os que, "paradoxalmente, se interessam menos" em saber como tudo isso acontece (Pierrot, 2015, p. 50). Ironias à parte, considerar o ensino como objeto de análise por direito próprio significa, em primeiro lugar, levar a sério a natureza cultural dos pro-

13 O volume 1 contém os trabalhos "Violência e crime", de Alba Zaluar; "Etnologia brasileira", de Eduardo Viveiros de Castro; "Antropologia no Brasil (alteridade contextualizada)", de Mariza Peirano; "Questão racial e etnicidade", de Lilia Schwarcz; e "Religióes e dilemas da sociedade brasileira", por Paula Montero. O artigo "Intelectuais brasileiros", de Miceli, no volume 2, permite identificar algumas abordagens teóricas no estudo dos intelectuais no país e, com base em algumas delas, compreender o contexto geral do surgimento das universidades e de outras instituiçóes acadêmicas, assim como o surgimento de especialistas em algumas áreas, incluindo as ciências sociais. No volume 4, encontram-se o artigo "Estudos sociológicos sobre educação no Brasil", de Clarissa Eckert Baeta Neves, que faz referência aos trabalhos sobre educação superior e universidades públicas; e o "Comentário crítico", feito por Carlos Benedito Martins. Martins destaca a introdução do ensino de sociologia, primeiro nos cursos secundários e, depois, nos cursos superiores, a propósito da que seria a "forte afinidade" da sociologia com o "campo educacional brasileiro" (Martins, 2012, p. 445). Embora os textos de Miceli, Baeta Neves e Martins muito contribuam para conhecer o contexto mais amplo do surgimento da antropologia no Brasil, é evidente que nenhum deles tem o ensino de qualquer disciplina como foco. 
cessos de produção, comunicação e aquisiçáo de conhecimentos... também na própria disciplina. Em segundo lugar, atentar para problemas que exprimem a especificidade dos processos de ensino, de aprendizagem e, em geral, os processos educacionais.

Entre esses problemas, vale mencionar, pelo menos, a cultura organizacional das instituiçóes e dos grupos de especialistas responsáveis pelo ensino, a configuração dos currículos em relação ao cânone disciplinar, a qualidade do ensino e a avaliaçáo dos aprendizados, assim como a formação dos professores universitários. O vínculo entre pesquisa antropológica e ensino da disciplina no Brasil pode ser explorado empiricamente, por exemplo, a partir da sociogênese dos currículos nos cursos de graduação e pós-graduação. Assim, em um caso emblemático, o desenvolvimento dos projetos de Roberto Cardoso de Oliveira e os primeiros estudantes-pesquisadores sobre "frentes de expansão" em zonas de índios e camponeses teria dado origem à oferta de duas das três disciplinas obrigatórias da matriz curricular inicial do PPGAS do Museu Nacional: [Organização Social e] Parentesco e Sociedades Camponesas, respectivamente ${ }^{14}$. A disciplina Antropologia Urbana, a terceira do tripé original, parece ter tido origem nos novos arranjos do corpo docente do PPGAS, após a chegada de Gilberto Velho.

Alguns desses assuntos, por sinal, prenunciavam-se nos "problemas" e "deficiências" apontados pelas reflexóes pioneiras sobre o ensino de antropologia e a formação de antropólogos no Brasil (Ramos, 2015; Schaden, 1954; Cunha, 1955; Durham; Cardoso, 1961; Agostinho, 1979; Menezes, 1979). Eles merecem ser retomados hoje, ainda que, provavelmente, por razôes diferentes. Isso porque, como dito no início, o cenário atual da formação na disciplina, notadamente na universidade, parece bem mais diversificado e ao mesmo tempo muito mais complexo (ver os trabalhos reunidos por Simiáo; Feldman-Bianco, 2018).

$\mathrm{O}$ ensino da disciplina vai além da formação de antropólogos. As reflexôes nesse sentido muito se beneficiam das contribuiçóes de antropólogos que atuam fora dos cursos de antropologia, assim como de outros profissionais no ensino básico (por exemplo, Dauster; Tosta; Rocha, 2014; Gusmão, 2016; Beserra; Lavergne, 2016; Rosistolato; Prado, 2015). Via de regra, tais contribuições são publicadas em periódicos de outras áreas, notadamente da educação, e resta ainda uma avaliaçẫo dessa produção acadêmica. No que tange à antropologia, a lista de pesquisas empíricas e sistemáticas tendo o ensino como objeto por si mesmo é ainda curta. Entre esses trabalhos vale mencionar algumas dissertaçóes e teses produzidas nos cursos de pós-graduação em antropologia, tais como Gutiérrez Mendoza (1994), sobre um departamento de antropologia em uma universidade brasileira; Rubim (1996), acerca do surgimento dos primeiros quatro programas de pós-graduação no país; Vega Sanabria (2005), quanto aos currículos e à formação na pós-graduação; Sartori (2010), sobre o ensino de antropologia em cursos de graduação que não formam antropólogos; e Schweig (2015), a respeito do ensino de sociologia na educação básica de uma perspectiva antropológica. Eles têm em comum a busca por uma abordagem propriamente teórica do ensino e das instituiçóes educativas e por um embasamento empírico da pes-

14 Ver Corrêa (1995, p. 42-43); ver também, na p. 44, os comentários sobre o "Estudo comparativo do desenvolvimento regional". 
quisa por meio da observação participante, entrevistas, pesquisa em arquivos e mesmo alguma estatística ${ }^{15}$.

Pelo escopo dos trabalhos e pelo papel central da $\mathrm{ABA}$, nessa lista merecem menção à parte, a seguir, as publicaçóes promovidas pela Associação desde meados da década de 1990. Tais publicaçóes encetaram-se com $O$ ensino de antropologia no Brasil. Temas para uma discussão (ABA, 1995). Na sequência, vieram à luz: "O campo da antropologia no Brasil" (Trajano; Ribeiro, 2004); Ensino de antropologia no Brasil: formação, práticas disciplinares e além-fronteiras (Grossi; Tassinari; Rial, 2006) - que republicou os textos de 1995 -; "Experiências de ensino e prática em antropologia no Brasil" (Tavares; Guedes; Caroso, 2010); Antropologia visual: perspectivas de ensino e pesquisa (Ferraz; Mendonça, 2014); e $O$ campo da antropologia no Brasil: retrospectiva, alcances e desafios (Simião; Feldman-Bianco, 2018). É plausível supor ainda que outras publicaçóes tenham sido feitas antes. Maggie e Gontijo, ao falar da criação da então Comissão de Ensino de Antropologia da ABA em 2004, referem-se à "continuação da tradição" que teria sido inaugurada pela Associação "desde que Castro Faria escreveu, em 1963, um balanço dos quatro campos da disciplina no Brasil - Arqueologia, Etnologia, Antropologia Biológica e Linguística" (Maggie; Gontijo, 2006, p. 364), apresentado originalmente na IV
RBA. Diante do engajamento da ABA e da importância desses empreendimentos, mas também de seus limites, é possível elencar outras contribuições e esboçar, quiçá, uma agenda própria para o ensino enquanto atividade profissional (dos professores de antropologia em diferentes âmbitos) e enquanto campo de pesquisa antropológica (dos pesquisadores em antropologia).

\section{Ensinar antropologia no Brasil hoje}

A partir da década de 2000, no encalço de uma nova etapa de relativa expansão do sistema de educação superior no país, vários temas ganharam impulso nas discussões sobre ensino de antropologia. Por exemplo, o que era tido como paulatina diversificação do mercado de trabalho dos antropólogos, para além da docência e da pesquisa universitária ${ }^{16}$; o encurtamento dos tempos de titulação e a avaliação dos programas de pós-graduação (Fonseca, 2001; Seyferth, 2004); o surgimento dos cursos de graduação em antropologia (Eremites de Oliveira, 2014; os trabalhos de Grossi, Maggie, Trajano, Santos e Goldemberg reunidos por Grossi, Tassinari e Rial, 2006; e os de Trajano, Nascimento e Rosa \& Reith na primeira parte de Tavares; Guedes; Caroso, 2010); os aspectos didáticos do ensino de antropologia nos cursos da área e em outros cursos (Beserra; Lavergne, 2016; Cohn, 2011; Cordovil, 2008; Ferraz;

15 Para tanto, foi consultado Catálogo de Teses e Dissertaçôes da CAPES. Disponível em: <https://catalogodeteses. capes.gov.br/catalogo-teses/\#!/>. Acesso em: fev. 2019.

16 Ver especialmente os trabalhos do "Encontro de ensino de antropologia: Diagnóstico, mudanças e novas inserçóes no mercado de trabalho" (Grossi; Tassinari; Rial, 2006). Essa ideia também se encontra em alguns dos trabalhos reunidos por Trajano e Ribeiro (2004); nos Anais da Oficina "Antropologia extramuros: campo profissional e as novas responsabilidades sociais e políticas" (Silva, 2008), assim como nos trabalhos da segunda parte de Tavares, Guedes \& Caroso (2010), em Feldman-Bianco (2013) e em Franch, Andrade e Amorim (2015). Para um balanço crítico das previsóes de ampliação e diversificação do mercado de trabalho dos antropólogos no Brasil, ver Machado (2018) e Teixeira (2018). Nem aqui, nem nos outros temas que elencamos a seguir fazemos citaçóes exaustivas, mas sinalizamos trabalhos que permitem distinguir alguns desdobramentos e abordagens na discussão sobre o ensino de antropologia. 
Mendonça, 2014; Guedes, 2004; Groisman, 2006; Gama; Fleischer, 2016; Kuschnir, 2014; Sartori, 2015); e, após a reintrodução da sociologia no ensino médio, o lugar da antropologia nesse e outros níveis educacionais (Oliveira; Brum, 2015 e os trabalhos reunidos por Oliveira; Brum, 2015). Agora que esse ciclo de expansáo foi encerrado e se verifica um aumento significativo do número de cursos de antropologia, começam a ser feitos balanços do novo quadro institucional da disciplina no Brasil. Alguns autores chamam a atençáo, particularmente, para a configuração de um campo disciplinar hierárquico, segmentado e endógamo (Simiáo, 2018), caracterizado pelo predomínio dos programas mais antigos na configuração dos currículos, das agendas de pesquisa, das redes de colaboração e dos recursos disponíveis (Simóes, 2018; Schuch, 2018; Miranda, 2018; Trajano, 2018); na formação, no recrutamento e na circulação de docentes, assim como nos estilos do fazer antropológico daqueles que passam a atuar nos programas mais novos (Simóes, 2018; Trajano, 2018; Machado, 2018; Miranda, 2018).

É nesse contexto que as velhas e as novas questóes sobre o ensino da disciplina se colocam, ao mesmo tempo em que, como sugerido antes, a possibilidade de tratar o ensino de antropologia como objeto de estudo (antropológico) em seus próprios termos precisa ser considerada. Porém, dita empreitada exige, antes de mais nada, reconhecer uma séria dificuldade que, em geral, enfrentam as questóes educacionais nas ciências sociais, a saber: a dificuldade de dotar as abordagens sociológicas dos fenômenos educacionais da mesma densidade analítica e da mesma consistência metodológica que outros temas têm merecido. Tassinari, ao refletir sobre o desenvolvimento da etnologia indígena $\mathrm{e}$ os desafios da educação escolar indígena no Brasil, assinala, por exemplo, a existência de

uma lacuna que fora apontada por Aracy Lopes da Silva (2001) entre uma produção antropológica que produziu refinadas análises sobre a noção de pessoa, cosmologias, parentesco, de um lado, e outra mais descritiva das situaçóes concretas da educação escolar, fruto do engajamento, no mais das vezes, dos mesmos antropólogos. A autora se propunha a pensar "nas razóes das dificuldades de rendimento teórico de um tema que é social e politicamente importante para as populaçóes indígenas e com o qual os etnólogos se veem frequentemente envolvidos" (LOPES DA SILVA 2001: 31), concluindo que essa lacuna é também fruto do silêncio da etnologia nacional a respeito de questóes educativas (Tassinari, 2016, p. 45, grifos nossos).

As "dificuldades de rendimento teórico" das questóes educacionais continua sendo, decerto, um desafio para a antropologia como um todo. No caso do ensino da própria disciplina, tais dificuldades talvez possam ser compreendidas ainda, ao menos em parte, à luz do tratamento subordinado que, como já foi dito, o tema tem recebido. Tratamento esse, aliás, que parece persistir até hoje. Se até a década de 1990 o interesse acadêmico no assunto era subordinado à produção de uma história da institucionalização da disciplina no país, após o início das publicaçóes da ABA focando especificamente o ensino, ele pode ser caracterizado agora como um interesse preponderante nos aspectos organizacionais do "campo da antropologia no Brasil". Por aspectos "organizacionais" referimo-nos, notadamente, à expansão, ao financiamento e à avaliação da pós-graduação; à configuração das linhas 
de pesquisa e das subáreas de especialização disciplinar; à relativa circulação de recursos e pessoas por meio das publicaçóes, da composição de bancas de mestrado e doutorado e do recrutamento de quadros docentes nas universidades; às redes de cooperaçáo dos grupos de pesquisa por meio da chamada internacionalização; à trajetória e à "empregabilidade" dos egressos, assim como às contingências a que estão submetidas as áreas de atuação profissional dos antropólogos (ver Trajano; Ribeiro, 2004; Simião; Feldman-Bianco, 2018).

$\mathrm{O}$ que está em foco nesse tratamento mais recente é, como apontado por Simião, a urgência de responder "às rápidas e significativas transformações" da disciplina, que exigem "novas abordagens de gestão" (Simião, 2018, p. 16). Trata-se de uma escolha pertinente e necessária porque, por um lado, garante a perspectiva "institucional" que tem favorecido as discussóes sobre o ensino (Cardoso de Oliveira, 1997; Corrêa, 1995; 2011; Peirano, 2000). Por outro, porque tem estimulado a produção sistemática de dados empíricos e de análises de mais fôlego. Contudo, ainda há um espaço considerável para uma reflexáo na qual as preocupaçóes propriamente didáticas, junto a abordagens microssociológicas e etnográficas da sala de aula de antropologia, possam prosperar e ser consideradas em todo seu potencial ${ }^{17}$. Assim sendo, dois assuntos que estáo no âmago dessa discussáo revestem particular interesse, nesse momento, ao pensarmos em uma agenda de pesquisa para o ensino de antropologia e a formação de antropólogos porque eles despontam como condiçóes sine qua non da reprodução disciplinar e da qualidade da formação na área, a saber: o currículo e a formação docente.

\section{O currículo em antropologia}

Um traço notável do ensino nos cursos de antropologia no Brasil é a homogeneidade das matrizes curriculares e até das bibliografias. Embora dito traço venha sendo apontado há algum tempo, ao menos no que tange aos cursos de pós-graduação (Schwarcz, 2006; Debert, 2004; Vega Sanabria, 2005; 2015), nota-se também como ele é reforçado pela dinâmica institucional descrita anteriormente. Isso porque, tratando-se da configuraçáo dos currículos, mais uma vez, os modelos dos programas mais antigos operam como referência principal dos programas mais novos (Trajano, 2018). Se, por um lado, tal homogeneidade contrasta com as dificuldades produzidas pela heterogeneidade da estrutura curricular e a dispersão de conteúdos e de orientações teóricas da formação em outros países (Vega Sanabria, 2005, p. 100), também é verdade que ela produz o que Sprandel e Barreto Fo. (2018) chamaram de "inércia do currículo" e da formação. Conforme esses mesmos autores, um efeito dessa inércia é a incapacidade para contemplar no ensino da disciplina outras necessidades de treinamento, como as experimentadas pelos antropólogos que atuam em atividades e áreas fora das universidades.

Outro fato notável nesse nível é, mutatis mutandis, a replicação na graduação, seja em cursos de ciências sociais ou de antropologia, do modelo curricular predominante na pós-graduação (Cordovil, 2008, p. 5; Tavares; Guedes; Caroso, 2010, p. 21; Vega Sanabria,

17 Ver, por exemplo, os trabalhos da primeira parte de Ferraz e Mendonça (2014), a propósito do ensino de antropologia visual no Brasil, e Beserra e Lavergne (2016). Para trabalhos fora do Brasil, veja-se, por exemplo, Rice, McCurdy e Lukas (2010). 
2015; 2018). Particularmente, em virtude de certa linearidade na organizaçáo dos conteúdos obrigatórios, como evidenciada na sequência, bastante comum na graduação, de matérias como Antropologia I, Antropologia II, Antropologia III etc., coroada, em alguns casos, por uma Antropologia no Brasil ou matéria similar. Isso parece especialmente plausível quando considerada a organização, igualmente comum na pós-graduação, de matérias como Teoria I e Teoria II, Teorias Clássicas e Teorias Contemporâneas e seus equivalentes. Em ambos os casos, tais arranjos privilegiam uma compreensão tida como canônica por antropólogos profissionais, baseada na historicização do próprio campo disciplinar por meio da sucessão de "escolas de pensamento" antropológico (Vega Sanabria, 2015). Tal arranjo pressupóe, ademais, uma espécie de folk psychology dos professores de antropologia acerca da natureza acumulativa e progressiva das aprendizagens dos estudantes. Em última análise, o que esses arranjos curriculares — isto é, culturais revelam ao mesmo tempo é:

- uma teoria nativa da configuraçáo do conhecimento antropológico;

- uma teoria nativa da aprendizagem (de antropologia) dos professores de antropologia (Vega Sanabria, 2018).

\section{A formação docente (dos professores de antropologia)}

Outro assunto praticamente intocado nas discussóes sobre o ensino da disciplina no Brasil é a formação de professores. Isto é, dos professores universitários de antropologia. Embora a pós-graduação surgisse no país com o intuito inicial de formar os quadros docentes do ensino superior, dita formação tem sido entendida quase sempre como sinônimo de especializaçáo disciplinar. No período que antecedeu a criação dos programas de pós-graduação, Durham e Cardoso (1961) referiam-se à necessidade de "qualificaçáo do quadro docente" para falar da falta de formação especializada em antropologia. Professores "altamente qualificados" significava, nesse contexto, "com formação na área”, em contraste com o predomínio de autodidatas e de profissionais formados em outros campos - notadamente na medicina - nos primeiros anos da antropologia acadêmica no país (Corrêa, 1995; Debert, 2004). As exigências de conhecimento disciplinar especializado começariam a ser satisfeitas definitivamente com a criação dos programas de pós-graduação em antropologia e, depois, pela exigência de doutorado para o exercício da docência universitária. Contudo, como bem sabem os alunos de qualquer área na universidade, por mais completa e sofisticada que uma formação disciplinar possa ser, ela, per se, está longe de garantir qualificação pedagógica para ensinar. Todavia, eis aqui um novo paradoxo: mesmo a antropologia no Brasil sendo basicamente "um campo de professores" (Simião, 2018, p. 21; ver também Machado, 2018, p. 243), nem dita qualificaçáo faz parte do nosso treinamento explícito como futuros (potenciais?) docentes universitários, nem tem sido uma preocupação nas discussóes sobre o ensino da disciplina.

Em um certo sentido, a formação docente faz parte das preocupaçóes ao redor do ensino de antropologia, porém com um claro viés. Como observa Tassinari, de novo no caso da educação indígena, "as discussóes sobre o ensino de Antropologia tendem a se ampliar e complexificar, à medida que compreendem reflexôes sobre a formação de professores, a inclusão de indígenas no 
Ensino Superior e as Açôes Afirmativas" (Tassinari, 2016, p. 47). Tassinari também aponta que "essa relaçáo entre a formação do campo da Antropologia e as políticas de formação de professores e de escolarização de indígenas merece ser melhor investigada, como têm demonstrado algumas pesquisas que venho orientando sobre outros contextos nacionais [...]" (Tassinari, 2016, p. 54). Contudo, ao falar de formação de professores, Tassinari, como outros antropólogos que se interessam no assunto, refere-se basicamente aos professores indígenas formados nas licenciaturas interculturais e aos professores do ensino básico (cf. Brum; Jesus, 2018; Gusmão, 2016; Oliveira; Rúa, 2017; Rosistolato; Prado, 2015). Resta ainda colocar a própria formação dos professores universitários de antropologia nessa pauta, especialmente no contexto da crescente heterogeneidade das instituiçóes, dos alunos e, sobretudo, dos próprios professores (para uma das poucas reflexóes nesse sentido, ver Sartori, 2010; 2015) ${ }^{18}$.

A falta de uma reflexáo sobre a formação pedagógica dos professores de antropologia fica palpável, justamente, nas tensões suscitadas nos programas de graduação e de pós-graduação stricto sensu com o ingresso, para citar apenas um exemplo, de alunos indígenas, seja ou não por meio de ações afirmativas. Decerto não se trata dos mesmos desafios do ensino a indígenas em seu meio de origem ou em contextos altamente especializados como podem ser as licenciaturas interculturais, mas da transmissão da antropologia ocidental (suas teorias, suas práticas, sua racionalidade) a sujeitos sociais oriundos de contextos culturais totalmente diferentes.
Embora o assunto seja objeto de discussões informais frequentes, não parece haver ainda uma reflexão sistemática e pública sobre essa nova frente do ensino da antropologia no país - felizmente cada vez mais frequente, mas infelizmente quase sempre improvisada.

Considerar esses assuntos exige alargar o foco da discussão e reconhecer que as dificuldades dos alunos (indígenas ou não) para se apropriar da cultura universitária refletem não apenas seu eventual despreparo ou as carências do seu background social e acadêmico, mas também o despreparo da universidade como instituição e as carências da formação pedagógica dos professores universitários. Nesse sentido, junto às frequentes discussóes sobre as mudanças no perfil dos alunos universitários de hoje, quiçá também seja mister uma reflexão mais franca sobre as transformações ocorridas no perfil dos próprios professores. Aliás, a despeito do tom, ora de denúncia, ora de condescendência, que impera ao se falar das mudanças na demografia universitária nos últimos anos, dois apontamentos cabem aqui, pelo menos no que tange aos alunos. Em primeiro lugar, a aparente democratizaçáo do acesso à universidade contrasta com o predomínio, ao menos até 2012, de egressos das pós-graduaçôes em antropologia procedentes das camadas da população com mais alta escolaridade (ver dados e um balanço bem ponderado dessa questão em Teixeira, 2018; Machado, 2018). Em segundo lugar, como nós, os professores universitários de antropologia, sabemos, as dificuldades dos alunos existem. Porém, como os relatos a seguir sugerem, talvez elas possam consistir em um problema bem mais antigo e não em um produto da

18 A respeito, vale mencionar também o pungente relato dos participantes na mesa-redonda "Novas universidades, novos campi, novas antropologias: docências, alteridades e expansão do Ensino Superior no Brasil”, organizada por Rafael Noleto (Universidade Federal de Pelotas - UFPel), na 31ª RBA (Brasília, 2018). 
mais recente expansão da universidade. Por exemplo, ao tratar da implantaçáo do ensino de antropologia na UFRGS, Teixeira faz o seguinte relato do oferecimento de uma disciplina sobre questóes africanas na década de 1960:

Como a maior parte da literatura que consegui reunir era em inglês, cuja leitura raríssimos alunos dominavam, me vi forçado a fazer diversas traduçóes mais ou menos resumidas, para uso deles. Além de me exigir um grande esforço, isto também representou uma certa temeridade, porém, com resultado bastante satisfatório. Temeridade porque, sendo medíocre meu conhecimento de inglês, de modo quase autodidata, me vi forçado a desenvolver sua leitura (Teixeira, 2006, p. 154).

$\mathrm{Na}$ mesma direção, Helm aponta, a propósito da reestruturação da especialização em antropologia da UFPR na década de 1980, que "a nova fase foi marcada por uma sensível modificação no perfil de sua clientela" (Helm, 2006, p. 115). Pensar na formação pedagógica dos professores de antropologia de modo algum significa passar a exigir, ingenuamente, formação em licenciatura ou qualquer requerimento dessa ordem, mas promover de maneira sistemática a reflexão sobre as práticas de ensino e de aprendizagem na formação em antropologia. Os professores universitários de antropologia, a princípio, ocupam uma posição privilegiada nesse debate, uma vez que a própria disciplina os mune da reflexividade indispensável para atentar para sua prática de ensino como um elemento central de sua prática profissional. Trata-se, em última análise, de atualizar no ensino o pressuposto de reflexividade e de permanente tentativa de objetivação da nossa experiência como antropólogos... também no universo cultural da sala de aula.

\section{Usar o saber antropológico no ensino de antropologia}

O principal corolário do balanço aqui proposto talvez seja como aproveitar melhor o saber disciplinar e o saber pedagógico dos professores de antropologia para entendermos o ensino e a aprendizagem da nossa disciplina - especialmente em tempos em que a nobre tradição das ciências humanas e sociais no país é submetida a crescentes pressóes e desqualificaçóes ${ }^{19}$. Porém, sobretudo, diante dos desafios didáticos e políticos que advêm, como apontado anteriormente, de um ambiente institucional cada vez mais hetero-

19 Enquanto preparamos este trabalho, diariamente são tomadas decisões e anúncios são feitos pelo atual governo sobre o corte radical de investimentos públicos nas Instituiçôes de Educação Superior. Os cortes comprometem despesas essenciais, tais como água, eletricidade, telefone, serviços de limpeza, vigilância, manutenção etc., e também bolsas e o financiamento da pesquisa. A situação, já incerta e dramática, vê-se agravada pela desqualificação das ciências humanas, particularmente da filosofia e da sociologia, associadas pelos membros do governo ao que chamam de "balbúrdia" e "marxismo cultural" [sic] nas universidades. Em geral, trata-se de um movimento com uma agenda reacionária e ultraconservadora no país, que tem como marca um anti-intelectualismo delirante, ataques à autonomia universitária e à liberdade de cátedra, assim como a perseguição aos estudos de gênero, de direitos humanos, do meio ambiente e de outras pautas caras às ciências humanas contemporâneas. Essa situação, que já se prenunciava mesmo em anos anteriores, tem suscitado reflexōes urgentes entre os antropólogos no Brasil; infelizmente, elas têm deixado de fora os desafios colocados especificamente para o ensino de antropologia dentro e fora da sala de aula. A respeito, veja-se, por exemplo, o dossiê organizado por Machado, Motta e Facchini (2018), publicado pela Revista de Antropologia sob o sugestivo título "Quem tem medo dos antropólogo(a)s? Práticas científicas em novos cenários políticos". 
gêneo e complexo. Um efeito desse cenário é o surgimento do que Lawrence Kohlberg (Power; Higgins; Kohlberg, 2011) chama de "atmosfera moral", isto é, uma espécie de clima social dentro da sala de aula, nem sempre favorável ou bem-disposto com relação aos ensinamentos antropológicos. Tal atmosfera coloca em xeque, cada vez mais amiúde, os pressupostos do que até agora entendíamos como o cânone da disciplina. É em um contexto como esse que, para bem e para mal, somos compelidos a refletir sobre nosso trabalho como formadores. Apontamos anteriormente pelo menos dois temas, o currículo e a formaçáo pedagógica dos docentes de antropologia, que poderiam ser parte central de uma agenda sobre o ensino no curto prazo. Porém, as possibilidades são múltiplas e, decerto, dependem do compromisso, dos interesses e das necessidades dos próprios antropólogos, enquanto pesquisadores e professores. Fala-se amiúde, provavelmente com boa intenção, da importância e do benefício de "ensinar o método etnográfico" e de incorporar a leitura de boas etnografias no ensino. Todavia, nosso principal desafio nesse nível talvez seja como encarar etnograficamente nosso trabalho de ensino e como adensar antropologicamente nossas reflexóes sobre o processo cultural que é a reprodução da nossa própria disciplina. Trata-se, afinal, de sabermos se é possível produzirmos alguma antropologia quando refletimos sobre nossa experiência como professores de antropologia, se é possível alguma (boa) antropologia do ensino de antropologia.

\section{BIBLIOGRAFIA}

AGOSTINHO, P. Ensino pós-graduado, teoria e pesquisa antropológica. Revista de Antropologia, v. 22, p. 133-142, 1979. https://doi.org/10.11606/2179-0892.ra.1979.110809

ALMEIDA, A. W. B. Os programas de pós-graduaçáo em antropologia na Amazônia. Rio de Janeiro: ABA, 2019.

ARNAUD, E. Os estudos de Antropologia no Museu Emílio Goeldi. Acta Amazonica, v. 11, n. 1, supl., p. 137-148, 1981. http://dx.doi.org/10.1590/1809-43921981111s137

ASSOCIAÇÃO BRASILEIRA DE ANTROPOLOGIA (ABA). REUNIĀO BRASILEIRA DE ANTROPOLOGIA, 2., 1957. Anais [...]. 1957. Disponível em: <http://www.portal.abant.org.br/2017/03/14/anais-2-rba/>. Acesso em: fev. 2019.

ASSOCIAÇÃO BRASILEIRA DE ANTROPOLOGIA (ABA). REUNIÃO BRASILEIRA DE ANTROPOLOGIA, 3., 1959. Anais [...]. 1959. Disponível em: <http://www.portal.abant.org.br/2017/03/14/anais-3-rba/>. Acesso em: fev. 2019.

ASSOCIAÇÃO BRASILEIRA DE ANTROPOLOGIA (ABA). O ensino de antropologia no Brasil. Temas para uma discussão. Rio de Janeiro: ABA, 1995.

AZEREDO, P. R. Antropólogos e pioneiros. A história da Sociedade Brasileira de Antropologia e Etnologia. São Paulo: FFLCH/USP, 1986.

BELTRÃO, J. F. Amazônia e antropologia: gradaçôes de um enredamento secular. In: TRAJANO FILHO, W.; RIBEIRO, G. L. (orgs.). O Campo da Antropologia no Brasil. Rio de Janeiro: Contracapa/Associação Brasileira de Antropologia, 2004. p. 187-208. 
BESERRA, B.; LAVERGNE, R. F. Etnografando a sala de aula: contribuiçōes da antropologia à formação de professores. Anthropológicas, ano 20, v. 27, n. 1, p. 72-101, 2016.

BRANDÃO, M. do C.; MOTTA, A. (orgs.). Aproximaçóes. Antropologia no Norte e Nordeste. Recife: Bargaço, 2003.

BRASIL. Ministério da Educação. Cadastro Nacional de Cursos e Instituiçóes de Educaçáo Superior e-MEC. Brasil: Ministério da Educação, 2019a. Disponível em: <http://emec.mec.gov.br>. Acesso em: 6 maio 2019.

BRASIL. Ministério da Educação. Coordenação de Aperfeiçoamento de Pessoal de Nível Superior (Capes). Plataforma Sucupira. Brasil: Ministério da Educação, 2019b. Disponível em: <https://sucupira.capes.gov.br/sucupira/ public/consultas/coleta/programa/quantitativos/quantitativoAreaConhecimento.jsf;jsessionid=RrFiwkeaNWcL +ePH42JqY51j.sucupira-215?areaAvaliacao=35>. Acesso em: 19 fev. 2019.

BRUM, C. K.; JESUS, S. C. de. Antropologia como educação: um diálogo sobre experiências de ensino da antropologia em cursos de formação de professores e seus desafios. Ciências Sociais Unisinos, v. 54, n. 2, p. 217-228, 2018. http://doi.org/10.4013/csu.2018.54.2.09

CARDOSO DE OLIVEIRA, R. Cinco décadas de reuniōes e a consolidação do campo antropológico (Em memória de Luiz de Castro Faria, primeiro presidente da ABA). Anuário Antropológico/2002-2003. Rio de Janeiro: Tempo Brasileiro, 2004. p. 9-25.

CARDOSO DE OLIVEIRA, R. Sobre o pensamento antropológico. 2. ed. Rio de Janeiro: Tempo Brasileiro, 1997.

CARNEIRO DA CUNHA, M. Conversa com Manuela Carneiro da Cunha. In: CARNEIRO DA CUNHA, M. Cultura com aspas e outros ensaios. São Paulo: Cosac Naify, 2009. p. 375-387.

CARVALHO, M. do R. G. ABA, 50 anos. In: ECKERT, C.; PIETRAFESA, E. (orgs.). Homenagens: Associaçáo Brasileira de antropologia: 50 anos. Blumenau: Nova Letra, 2006. p. 299-308.

COHN, C. O ensino de antropologia da saúde na graduação: uma experiência. Saúde e Sociedade, v. 20, n. 1, p. 41-49, 2011.

CONSORTE, J. G. Revivendo os 50 anos da ABA. In: ECKERT, C.; PIETRAFESA, E. (orgs.). Homenagens: Associação Brasileira de antropologia: 50 anos. Blumenau: Nova Letra, 2006. p. 165-172.

COORDENAÇÃO DE APERFEIÇOAMENTO DE PESSOAL DE NÍVEL SUPERIOR (CAPES). Relatório de avaliaçáo quadrienal 2017. Antropologia e arqueologia. Brasília: Coordenação de Aperfeiçoamento de Pessoal de Nível Superior/Diretoria de Avaliação, 2017.

CORDOVIL, D. Formação de antropólogos no Brasil ontem e hoje. PRACS: Revista de Humanidades do Curso de Ciências Sociais UNIFAP, v. 1, n. 1, dez. 2008.

CORRÊA, M. A antropologia no Brasil (1960-1980). In: MICELI, S. (org.). História das Ciências Sociais no Brasil. São Paulo: Sumaré \& FAPESP, 1995. v. 2. p. 25-106.

CORREAA, M. As Reunióes Brasileiras de Antropologia: cinquenta anos (1953-2003). Campinas: Editora da Unicamp/Brasília (DF): ABA, 2003.

CORRÊA, M. Dona Heloisa e a pesquisa de campo. Revista de Antropologia, v. 40, n. 1, p. 11-54, 1997. http:// dx.doi.org/10.1590/S0034-77011997000100002

CORRÊA, M. O mato \& o asfalto. Campos da antropologia no Brasil. Sociologia \& Antropologia, v. 1, n. 1, p. 209-229, 2011. http://dx.doi.org/10.1590/2238-38752011v119

CUNHA, M. W. V. da. Possibilidades de exercício de atividades docentes, de pesquisa e técnico-profissionais por antropólogos no Brasil. Revista de Antropologia, São Paulo, v. 3, n. 2, p. 105-114, 1955. https://doi. org/10.11606/2179-0892.ra.1955.110331 
DAMATTA, R. Notas para uma pedagogia antropológica. Fórum Educacional, Rio de Janeiro, v. 3, n. 1, p. 13-29, 1979.

DAUSTER, T.; TOSTA, S. P.; ROCHA, G. (orgs.). “Discutindo a relaçáo”: antropologia e educação a partir de uma experiência de ensino, pesquisa e orientação. Belo Horizonte: Autêntica, 2014.

DEBERT, G. Formação e ensino. In: TRAJANO, W.; RIBEIRO, G. L. O campo da antropologia no Brasil. Brasília: ABA; Rio de Janeiro: Contra Capa, 2004. p. 143-162.

DUARTE, L. F. D. Apresentação de Ramos, Arthur. Os grandes problemas da antropologia brasileira. Mana, v. 21, n. 1, p. 195-199, 2015.

DUARTE, L. F. D. Formação e ensino na antropologia social: os dilemas da universalização romântica. In: GROSSI, M.; TASSINARI, A.; RIAL, C. (orgs.). Ensino de antropologia no Brasil: formação, práticas disciplinares e além-fronteiras. Blumenau: Nova Letra, 2006. p. 17-36.

DUARTE, L. F. D. O campo atual da Antropologia no Brasil. In: MARTINS, C. B. (coord.); DUARTE, L. F. D. (org.). Horizontes das Ciências Sociais no Brasil. Antropologia. São Paulo: Anpocs/Barcarolla/Discurso Editorial, 2010. p. 13-23.

DURHAM, E. R.; CARDOSO, R. C. L. O ensino da antropologia no Brasil. Revista de Antropologia, São Paulo, v. 9, n. 1-2, p. 91-108, 1961.

ECKERT, C.; GODOI, E. P. de (org.). Homenagens: Associação Brasileira de antropologia: 50 anos. Blumenau: Nova Letra, 2006.

EDITOR, O. E. XII Reunião Brasileira de Antropologia. Revista de Antropologia, v. 24, p. 171-174, 1981. https:// doi.org/10.11606/2179-0892.ra.1981.110977

ELIAS, N. Scientific establishments. In: ELIAS, N.; MARTINS, H.; WELLEY, R. (orgs.). Scientific establishments and hierarchies. Dobrecht, Boston, Londres: D. Reidel Publishing Company, 1982. p. 3-69.

EREMITES DE OLIVEIRA, J. Jus sperniandi: proposta de criação de uma graduação em antropologia em Mato Grosso do Sul, Brasil. Cadernos do LEPAARQ, v. 11, n. 21, p. 8-43, 2014. http://dx.doi.org/10.15210/lepaarq.v11i21.2802

FELDMAN-BIANCO, B. (org.). Desafios da antropologia brasileira. Brasília: ABA, 2013.

FERRAZ, A. L. M. C.; MENDONÇA, J. M. de. Antropologia visual: perspectivas de ensino e pesquisa. Brasília, DF: ABA, 2014.

FONSECA, C. Avaliação dos programas de pós-graduação: do ponto de vista de um nativo. Horizontes Antropológicos, v. 7, n. 16, p. 261-275, 2001. http://dx.doi.org/10.1590/S0104-71832001000200014

FRANCH, M.; ANDRADE, M.; AMORIM, L. (orgs.). Antropologia em novos campos de atuaçáo: debates e tensōes. João Pessoa: Mídia/ABA Publicaçōes, 2015.

GAMA, F.; FLEISCHER, S. Na cozinha da pesquisa: relato de experiência na disciplina "Métodos e técnicas em Antropologia Social”. Cadernos de Arte e Antropologia, v. 5, n. 2, p. 109-127, 2016.

GODOI, E. P. de; DEBERT, G.; PONTES, H. (orgs.). Antropologia na pós-Graduaçáo. Campinas: IFCHUnicamp, 2002.

GROISMAN, A. Ensino de antropologia em "outros cursos". In: GROSSI, M.; TASSINARI, A.; RIAL, C. (orgs.). Ensino de antropologia no Brasil: formação, práticas disciplinares e além-fronteiras. Blumenau: Nova Letra, 2006. p. 333-349.

GROSSI, M.; TASSINARI, A.; RIAL, C. (orgs.). Ensino de antropologia no Brasil: formação, práticas disciplinares e além-fronteiras. Blumenau: Nova Letra, 2006. 
GUEDES, S. L. Produzir antropólogos: algumas reflexōes. Ilha. Revista de Antropologia, v. 6, n. 1/2, p. 183-196, 2004.

GUSMÃO, N. Antropologia, cultura e educação na formação de professores. Anthropológicas, ano 20, v. 27, n. 1, p. 45-71, 2016.

GUTIÉRREZ MENDOZA, E. S. Uma “aldeia” de antropólogos: a antropologia em Brasília. Dissertação (Mestrado) - Programa de Pós-Graduação em Ciências Sociais, Universidade de Brasília, Brasília, 1994.

HELM, C. A antropologia no Paraná. In: SANTOS, S. C. et al. (orgs.). Memória da antropologia no Sul do Brasil. Florianópolis: Editora da UFSC/ABA, 2006. p. 81-123.

KUSCHNIR, K. Ensinando antropólogos a desenhar: uma experiência didática e de pesquisa. Cadernos de Arte e Antropologia, v. 3, n. 2, p. 23-46, 2014.

MACHADO, I. J. de R. Opulência e escassez: sobre os egressos dos doutorados em antropologia no Brasil (2004-2012). In: SIMIÃO, D. S.; FELDMAN-BIANCO, B. (orgs.). O campo da antropologia no Brasil: retrospectiva, alcances e desafios. Rio de Janeiro: ABA, 2018. p. 231-258.

MACHADO, L. Z.; MOTTA, A.; FACCHINI, R. (orgs.). Quem tem medo dos antropólogo(a)s? Práticas científicas em novos cenários políticos. Revista de Antropologia, v. 61, n. 1, p. 9-32, 2018. https://doi.org/10.11606/21790892.ra.2018.145509

MAGGIE, Y.; GONTIJO, F. Comissão de Ensino de Antropologia. Gestão 2004-2006. Apresentação. In: GROSSI, M.; TASSINARI, A.; RIAL, C. (orgs.). Ensino de Antropologia no Brasil: formação, práticas disciplinares e além-fronteiras. Blumenau: Nova Letra, 2006. p. 363-366.

MARTINS, C. B. Estudos sociológicos sobre educação no Brasil (Comentário crítico). In: MICELI, S. (org.). O que ler na Ciência Social brasileira (1970-2002). São Paulo: Sumaré/Anpocs, 2012. p. 439-455.

MARTINS, C. B. (coord.); DUARTE, L. F. D. (org.). Horizontes das Ciências Sociais no Brasil: Antropologia. São Paulo: Barcarolla, 2010.

MARTINS, C. B. (coord.); LESSA, R. Horizontes das Ciências Sociais no Brasil: Ciência Política. São Paulo: Barcarolla, 2010. 400 p.

MARTINS, C. B. (coord.); MARTINS, T. de S. H. H. (org.). Horizontes das Ciências Sociais no Brasil: Sociologia. São Paulo: Barcarolla, 2010.

MENEZES, E. D. B. A pesquisa como base para o ensino de pós-graduação. Revista de Antropologia, v. 22, p. 143-149, 1979.

MICELI, S. (org.). História das Ciências Sociais no Brasil. São Paulo: Sumaré, 1995. v. 2.

MICELI, S. (org.). História das Ciências Sociais no Brasil. 2 ed. São Paulo: Sumaré, 2001.

MICELI, S. (org.). O que ler na Ciência Social brasileira (1970-1995). São Paulo: Sumaré, 1999. v. 2.

MICELI, S. (org.). O que ler na Ciência Social brasileira (1970-2002). São Paulo: Sumaré/Anpocs, 2012. v. 4.

MIRANDA, A. P. M. de. Políticas de financiamento e de avaliação das pós-graduações em antropologia. Desafios e perspectivas. In: SIMIÁO, D. S.; FELDMAN-BIANCO, B. (orgs.). O campo da antropologia no Brasil: retrospectiva, alcances e desafios. Rio de Janeiro: ABA, 2018. p. 131-167.

MULLER, L. H. A. et al. Jornada de reflexóes sobre o ensino de antropologia social no Rio Grande do Sul. In: GROSSI, M.; TASSINARI, A.; RIAL, C. (orgs.). Ensino de Antropologia no Brasil: formação, práticas disciplinares e além-fronteiras. Blumenau: Nova Letra, 2006. p. 415-423. 
NIEMEYER, A. M. de. Sociedades tribais, urbanas e camponeses, uma proximidade desejável: notas para um curso de graduação em antropologia social. Anuário Antropológico, p. 49-66, 1996.

OLIVEIRA, A. Um balanço da discussão sobre ensino na Associação Brasileira de Antropologia. Cadernos da Associaçáo Brasileira de Ensino de Ciências Sociais, v. 1, n. 1, p. 80-91, 2017.

OLIVEIRA, A.; BRUM, C. K. (orgs.). Revista Café com Sociologia, v. 4, n. 2, 2015. (Dossiê Ensino de Antropologia.)

OLIVEIRA, A.; RÚA, M. Formação de professores para o ensino de Antropologia no Brasil e na Argentina. Perspectiva, v. 35, n. 1, p. 92-112, 2017. http://dx.doi.org/10.5007/2175-795X.2017v35n1p92

PASSADOR, L. H. Herbert Baldus e a antropologia no Brasil. Dissertação (Mestrado) - Universidade Estadual de Campinas, Campinas, 2002.

PEIRANO, M. A antropologia como ciência social no Brasil. Etnográfica, v. 4, n. 2, p. 219-232, 2000.

PEIRANO, M. A favor da etnografia. Rio de Janeiro: Relume-Dumará, 1995.

PEIRANO, M. Antropologia no Brasil (alteridade contextualizada). In: MICELI, S. (org.). O que ler na Ciência Social brasileira (1970-1995). São Paulo: Sumaré, 1999. v. 2. p. 225-266.

PEIRANO, M. Um ponto de vista sobre o ensino da antropologia. In: GROSSI, M.; TASSINARI, A.; RIAL, C. (orgs.). Ensino de Antropologia no Brasil: formação, práticas disciplinares e além-fronteiras. Blumenau: Nova Letra, 2006. p. 77-103.

PEIRANO, M. Uma antropologia no plural. Três experiências contemporâneas. Brasília: Editora da UnB, 1992.

PEIXOTO, F. Estrangeiros no Brasil: a missão francesa na Universidade de São Paulo. Dissertação (Mestrado) Universidade Estadual de Campinas, Campinas, 1991.

PEIXOTO, F. Franceses e norte-americanos nas Ciências Sociais brasileiras: 1930-1960. In: MICELI, S. (org.). História das Ciências Sociais no Brasil. 2. ed. São Paulo: Sumaré, 2001. v. 1. p. 477-531.

PEIXOTO, F. Lévi-Strauss no Brasil: a formação do etnólogo. Mana, v. 4, n. 1, p. 79-107, 1998. http://dx.doi. org/10.1590/S0104-93131998000100004

PEIXOTO, F; SIMÓES, J. A. A Revista de Antropologia e as ciências sociais em São Paulo: notas sobre uma cena e alguns debates. Revista de Antropologia, v. 46, n. 2, p. 383-409, 2003. http://dx.doi.org/10.1590/S003477012003000200009

PIERROT, A. Aprendizagem e representação. Os antropólogos e as aprendizagens. Horizontes Antropológicos, v. 21, n. 44, p. 49-80, 2015. http://dx.doi.org/10.1590/S0104-71832015000200004

POWER, C.; HIGGINS, A.; KOHLBERG, L. From Lawrence Kohlberg's Approach to Moral Education. Schools: Studies in Education, v. 8, n. 1, p. 97-106, 2011.

RAMOS, A. Os grandes problemas da antropologia brasileira. Mana, v. 21, n. 1, p. 195-212, 2015. http://dx.doi. org/10.1590/0104-93132015v21n1p195

RIBAS, J. B. C. O Brasil é dos brasilianos: medicina, antropologia e educaçáo na figura de Roquette-Pinto. Dissertação (Mestrado) - Universidade Estadual de Campinas, Campinas, 1990.

RICE, P. C.; MCCURDY, D. W.; LUKAS, S. A. (orgs.). Strategies in teaching anthropology. Upper Saddle River: Pearson Education, 2010.

ROSA, F. T. R. S. A aliança e a diferença: uma leitura do itinerário intelectual de Charles Wagley. Dissertaçấo (Mestrado) - Universidade Estadual de Campinas, Campinas, 1993. 
ROSISTOLATO, R.; PRADO, A. P. do. O lugar da antropologia na formação de educadores. Revista Café com Sociologia, v. 4, n. 2, p. 98-111, 2015.

RUBIM, C. de R. Antropólogos brasileiros e a antropologia no Brasil: a era da pós-graduaçáo. Tese (D)outorado. - Universidade Estadual de Campinas, Campinas, 1996.

SANTOS, R. V. Intelectualmente "impuros e maculados": reflexóes sobre a formação em antropologia biológica no diálogo com outros campos da antropologia. Amazônica. Revista de Antropologia, v. 3, n. 1, p. 10-31, 2011. http://dx.doi.org/10.18542/amazonica.v3i1.628

SANTOS, S. C. dos. A antropologia em Santa Catarina. In: SANTOS, S. C. dos. et al. (orgs.). Memória da antropologia no Sul do Brasil. Florianópolis: Editora da UFSC/ABA, 2006a. p. 17-80.

SANTOS, S. C. dos. A atuação da ABA diante das demandas sociais e políticas: A importância da Reunião de 1974. In: ECKERT, C.; PIETRAFESA, E. (orgs.). Homenagens: Associação Brasileira de antropologia: 50 anos. Blumenau: Nova Letra, 2006b. p. 63-70.

SANTOS, S. C. dos; HELM, C. M. V.; TEIXEIRA, S. A. (orgs.). Memória da antropologia no Sul do Brasil. Florianópolis: Editora da UFSC/ABA, 2006.

SARTORI, A. J. A “experiência” como mediadora no ensino da antropologia para quem náo vai ser antropólogo. Tese (Doutorado) - Universidade Federal de Santa Catarina, Florianópolis, 2010.

SARTORI, A. J. O ensino da Antropologia nos cursos de licenciatura e bacharelado: "o que" ensinam e "como" ensinam. Revista Café com Sociologia, v. 4, n. 2, p. 112-130, 2015.

SCHADEN, E. Problemas do ensino de Antropologia. Revista de Antropologia, v. 2, n. 1, p. 1-10, 1954. https://doi. org/10.11606/2179-0892.ra.1954.110268

SCHUCH, P. A dinâmica do campo: redes de pesquisa e colaboração. In: SIMIÃO, D. S.; FELDMAN-BIANCO, B. (orgs.). O campo da antropologia no Brasil: retrospectiva, alcances e desafios. Rio de Janeiro: ABA, 2018. p. 83-103.

SCHWEIG, G. R. Aprendizagem e ciência no ensino de Sociologia na escola: um olhar desde a Antropologia. Tese (Doutorado) - Universidade Federal do Rio Grande do Sul, Porto Alegre, 2015.

SEYFERTH, G. O papel do financiamento e da avaliaçáo na constituiçáo do campo disciplinar. In: TRAJANO, W.; RIBEIRO, G. L. O campo da antropologia no Brasil. Brasília: ABA; Rio de Janeiro: Contra Capa, 2004. p. 93-116.

SILVA, G. (org.). Antropologia extramuros. Novas responsabilidades sociais e políticas dos antropólogos. Brasília: Paralelo 15/ABA, 2008.

SIMIÃO, D. S. Introdução. In: SIMIÃO, D. S.; FELDMAN-BIANCO, B. (orgs.). O campo da antropologia no Brasil: retrospectiva, alcances e desafios. Rio de Janeiro: ABA, 2018. p. 9-28.

SIMIÃO, D. S.; FELDMAN-BIANCO, B. (orgs.). O campo da antropologia no Brasil: retrospectiva, alcances e desafios. Rio de Janeiro: ABA, 2018.

SIMÓES, J. A. A dinâmica do campo: temas, tendências e desafios. In: SIMIÃO, D. S.; FELDMAN-BIANCO, B. (orgs.). O campo da antropologia no Brasil: retrospectiva, alcances e desafios. Rio de Janeiro: ABA, 2018. p. 57-82.

SPRANDEL, M. A.; BARRETO Fo., H. T. Profissionais com formação em antropologia para que? Uma apreciação das transformações contemporâneas no campo de atuação profissional em antropologia. In: SIMIÃO, D. S.; FELDMAN-BIANCO, B. (orgs.). O campo da antropologia no Brasil: retrospectiva, alcances e desafios. Rio de Janeiro: ABA, 2018. p. 259-283. 
TASSINARI, A. Memorial de atividades acadêmicas. Concurso para a promoção à classe E com denominação de Professora Titular da Carreira do Magistério Superior. Florianópolis: Departamento de Antropologia/CFCH/ UFCS, 2016.

TAVARES, F.; GUEDES, S. L.; CAROSO, C. Experiências de ensino e prática em Antropologia no Brasil. Brasília: Ícone, 2010.

TEIXEIRA, C. Egressos dos mestrados em antropologia no Brasil (2004-2012). In: SIMIĀO, D. S.; FELDMANBIANCO, B. (orgs.). O campo da antropologia no Brasil: retrospectiva, alcances e desafios. Rio de Janeiro: ABA, 2018. p. 205-229.

TEIXEIRA, S. A. A antropologia no Rio Grande do Sul. In: SANTOS, S. C. dos et al. (orgs.). Memória da antropologia no Sul do Brasil. Florianópolis: Editora da UFSC/ABA, 2006. p. 127-204.

TRAJANO, W. Formação, ensino e reprodução nos programas de antropologia. In: SIMIÂO, D. S.; FELDMANBIANCO, B. (orgs.). O campo da antropologia no Brasil: retrospectiva, alcances e desafios. Rio de Janeiro: ABA, 2018. p. 169-204.

TRAJANO, W.; RIBEIRO, G. L. O campo da antropologia no Brasil. Brasília: ABA; Rio de Janeiro: Contra Capa, 2004.

VEGA SANABRIA, G. A antropologia historicizada ou Os índios de Fenimore Cooper. "Clássicos" e "história" no ensino de antropologia no Brasil. Mana, v. 21, n. 3, p. 609-639, 2015.

VEGA SANABRIA, G. O ensino de antropologia no Brasil: um estudo sobre as formas institucionalizadas de transmissáo da cultura. Dissertação (Mestrado) - Universidade Federal de Santa Catarina, Florianópolis, 2005.

VEGA SANABRIA, G. Teaching anthropology for first-year students at university: Diversity experiences, moral development and curriculum in a Social Sciences major. In: CONFERENCE OF THE IUAES WORLD CONGRESS, 18., 2018. Anais [...]. Florianópolis: Tribo da Ilha, 2018. v. 2. p. 2307-2322.

SCHWARCZ, L. M. Ensino de pós-graduaçáo em Antropologia: algumas primeiras notas comparativas. In: GROSSI, M. P.; TASSINARI, A.; RIAL, C. (orgs.). Ensino de antropologia no Brasil: formação, práticas disciplinares e além-fronteiras. Florianópolis: Nova Letra, 2006. p. 231-248. 


\section{Apêndice - Lista parcial de eventos sobre o ensino de antropologia e a formação de antropólogos no Brasil (1972-2018). ${ }^{20}$}

\begin{tabular}{|c|c|c|c|}
\hline Evento & Ano & Lugar & Organizadores \\
\hline $\begin{array}{l}\text { "1a. Reunião [ou Encontro] de professores de antropologia do Sul do } \\
\text { Brasil" [cf. Santos, 2006a, p. 50]. }\end{array}$ & 1972 & Florianópolis & UFSC \\
\hline $\begin{array}{l}\text { MR: "Ensino e pesquisa em antropologia". } \\
\text { (9a. Reuniáo Brasileira de Antropologia) [Santos, 2006b, p. 67]. }\end{array}$ & 1974 & $\begin{array}{l}\text { Florianópolis, } \\
\text { SC }\end{array}$ & ABA/UFSC \\
\hline $\begin{array}{l}\text { "Mesa-redonda sobre ensino e pesquisa". } \\
\text { (10. Reunião Brasileira de Antropologia) [Revista de Antropologia, v. } \\
\text { 21, n. } 2,1978] .\end{array}$ & 1976 & Salvador, BA & ABA/UFBA \\
\hline $\begin{array}{l}\text { "Pesquisa no ensino de antropologia (Simpósio e Mesa-redonda)". } \\
\text { (11 1. Reunião Brasileira de Antropologia) [Revista de Antropologia, v. } \\
\text { 21, n. 2, 1978]. }\end{array}$ & 1978 & Recife, PE & ABA/UFPE \\
\hline $\begin{array}{l}\text { SE: "O ensino da antropologia biológica" (I e II). } \\
\text { (12. Reunião Brasileira de Antropologia) [Revista de Antropologia, v. 24, 1981]. }\end{array}$ & 1980 & $\begin{array}{l}\text { Rio de Janeiro, } \\
\text { RJ }\end{array}$ & $\begin{array}{l}\text { ABA/Museu } \\
\text { Nacional }\end{array}$ \\
\hline $\begin{array}{l}\text { GT: "O ensino de antropologia". } \\
\text { (13a. Reunião Brasileira de Antropologia) [Revista de Antropologia, v. 25, 1982]. }\end{array}$ & 1982 & São Paulo, SP & ABA/USP \\
\hline $\begin{array}{l}\text { DB: "Problemas atuais da antropologia brasileira". } \\
\text { (16. Reunião Brasileira de Antropologia). }\end{array}$ & 1988 & Campinas & ABA/Unicamp \\
\hline $\begin{array}{l}\text { RE: "Antropologia no Brasil: ensino, pesquisa e mercado de trabalho" } \\
\text { [ou "Reunião nacional sobre antropologia no Brasil, pesquisa, ensino e } \\
\text { mercado de trabalho". Cf. Helm, 2006, p. 112]. }\end{array}$ & 1988 & Recife, PE & $\begin{array}{l}\mathrm{ABA} / \mathrm{CNPq} / \\
\quad \text { UFPE }\end{array}$ \\
\hline $\begin{array}{l}\text { GT: "Ensino, pesquisa e profissionalização da antropologia". } \\
\text { (2a. Reuniáo de Antropólogos do Norte e Nordeste). }\end{array}$ & 1991 & Recife, PE & ABA/UFPE \\
\hline
\end{tabular}

Continua...

20 A lista inclui atividades desenvolvidas em eventos nacionais, tais como a Reunião Brasileira de Antropologia, e em eventos internacionais, tais como a Reunião de Antropologia do Mercosul (RAM) e o congresso da Associação Latino-americana de Antropologia (ALA), porque elas têm sido quase sempre iniciativas de pesquisadores no Brasil e dáo continuidade às discussóes sobre ensino no país. Como apontado por Oliveira, ao fazer um balanço de tais discussôes em duas ediçóes recentes da RBA, "esse movimento indica o desenvolvimento de uma preocupaçáo posta na agenda acadêmica da Antropologia brasileira e latino-americana de forma mais ampla, que tange ao ensino de Antropologia e à formaçăo antropológica em diversas modalidades de ensino" (Oliveira, 2017, p. 86). A lista baseia-se no levantamento inicial feito por Vega Sanabria (2005, p. 12). Nesse trabalho, constam as fontes utilizadas para identificar boa parte dos eventos realizados entre 1974 e 2004. Para os eventos posteriores a esse período foram consultados os anais da RBA e os Relatórios de gestáo das Diretorias da ABA disponíveis no site da associação. As consultas desses e de outros documentos e sites na internet (por exemplo, o da Revista de Antropologia da USP) foram realizadas ao longo do segundo semestre de 2018 e em janeiro/fevereiro de 2019. Igualmente, foram úteis para identificar os eventos elencados os trabalhos de Corrêa (2003); Eckert e Godoi (2006); Grossi, Tassinari e Rial (2006); e Santos, Helm e Teixeira (2006). Nota-se que a lista foca nos eventos sobre "ensino de antropologia" e o "ofício do antropólogo", e deixa de fora eventos com foco nas "ciências sociais" e na "pós-graduação" em geral, assim como outros temas relacionados (reforma universitária, avaliação, financiamento etc.). Esses temas têm sido objeto de amplas e permanentes discussóes, especialmente pela Associaçáo Nacional de Pós-Graduação e Pesquisa em Ciências Sociais (Anpocs). A respeito, ver os programas, os resumos e os relatórios-técnicos do Encontro Anual da Anpocs de 1977 a 2018, assim como a última edição do chamado "Livro dos nomes" [2016], disponíveis no site da Anpocs. Tampouco foram incluídos outros eventos, como os grupos de trabalho e outras atividades sobre antropologia e/da/na educação na RBA, apesar de que, eventualmente, eles também têm dado espaço para discussóes sobre ensino de antropologia. Nota-se também nesse levantamento o papel destacado da ABA como promotora e organizadora dos eventos. 
Apêndice - Continuação.

\begin{tabular}{|c|c|c|c|}
\hline Evento & Ano & Lugar & Organizadores \\
\hline $\begin{array}{l}\text { GT: "O ensino de antropologia em cursos fora das ciências humanas e sociais". } \\
\text { (17². Reunião Brasileira de Antropologia). }\end{array}$ & 1992 & $\begin{array}{l}\text { Belo Horizonte, } \\
\text { MG }\end{array}$ & ABA/UFMG \\
\hline $\begin{array}{l}\text { OF: "Experiências didáticas em antropologia". } \\
\text { (4a. Reuniâo Brasileira de Antropologia-Região Sul). }\end{array}$ & 1993 & $\begin{array}{l}\text { Florianópolis, } \\
\text { SC }\end{array}$ & UFSC \\
\hline $\begin{array}{l}\text { FR: "O ensino das ciências sociais em questấo: O caso da antropologia”. } \\
\text { (18 } 8^{\circ} \text {. Encontro Anual da Anpocs) [Peirano, 2006, p. 10; Programa e } \\
\text { resumos do evento]. }\end{array}$ & 1994 & Caxambu, MG & Anpocs \\
\hline $\begin{array}{l}\text { OF: "Experiências didáticas em antropologia". } \\
\text { (19 . Reuniâo Brasileira de Antropologia). }\end{array}$ & 1994 & Niterói, RJ & ABA/UFF \\
\hline EN: “Ensino da antropologia” [Peirano, 2006, p. 16; Grossi et al., 2006, p. 10]. & 1995 & Rio de Janeiro, RJ & ABA/UFRJ \\
\hline $\begin{array}{l}\text { OF: "Ensino de antropologia". } \\
\text { (4a. Reunião de Antropólogos do Norte e Nordeste). }\end{array}$ & 1995 & João Pessoa, PA & UFPA \\
\hline $\begin{array}{l}\text { SE: "Antropologia, universidade e sociedade". } \\
\left(22^{\mathrm{a}} . \text { Reunião Brasileira de Antropologia). }\right.\end{array}$ & 2000 & Brasília, DF & $\mathrm{ABA} / \mathrm{UnB}$ \\
\hline SE: "A formação do antropólogo na pós-graduaçáo". & 2001 & Campinas, SP & ABA/Unicamp \\
\hline $\begin{array}{l}\text { SE: "A formação do antropólogo na graduaçáo". } \\
\text { (7ª Reuniáo de Antropólogos do Norte e Nordeste). }\end{array}$ & 2001 & Recife, PE & UFPE \\
\hline $\begin{array}{l}\text { SE: "A formação do antropólogo na graduação". } \\
\text { (4ª Reunião de Antropologia do Mercosul). }\end{array}$ & 2001 & Curitiba, PR & UFPR \\
\hline $\begin{array}{l}\text { EN: "Ensino de antropologia: diagnóstico, mudanças e novas inserçôes } \\
\text { no mercado de trabalho". }\end{array}$ & 2002 & $\begin{array}{l}\text { Florianópolis, } \\
\text { SC }\end{array}$ & $\begin{array}{l}\text { ABA/CAPES/ } \\
\text { UFSC }\end{array}$ \\
\hline $\begin{array}{l}\text { FE: "A formação do antropólogo". } \\
\text { (23ª. Reunião Brasileira de Antropologia). }\end{array}$ & 2002 & Gramado, RS & ABA/UFRGS \\
\hline $\begin{array}{l}\text { OF: "Antropologia extramuros: campo profissional e as novas } \\
\text { responsabilidades sociais e políticas". }\end{array}$ & 2002 & Niterói, RJ & $\mathrm{ABA} / \mathrm{UFF}$ \\
\hline $\begin{array}{l}\text { FR: "O fazer antropológico e a orientaçáo". } \\
\text { (5a. Reuniáo de Antropologia do Mercosul). }\end{array}$ & 2003 & $\begin{array}{l}\text { Florianópolis, } \\
\text { SC }\end{array}$ & ABA/UFSC \\
\hline $\begin{array}{l}\text { FR: "O campo da antropologia no Brasil". } \\
\text { (27‥ Encontro Anual da Anpocs) [Programa e resumos do evento]. }\end{array}$ & 2003 & Caxambu, MG & Anpocs \\
\hline $\begin{array}{l}\text { SE: "O campo da antropologia no Brasil". } \\
\text { FP: "Arquivos e histórias da antropologia no Brasil". } \\
\text { (24ª . Reunião Brasileira de Antropologia). }\end{array}$ & 2004 & Olinda, PE & ABA/UFPE \\
\hline "50 anos da Associação Brasileira de Antropologia”. & 2005 & Várias cidades & $\mathrm{ABA}$ \\
\hline $\begin{array}{l}\text { "Simpósio sobre o ensino da Antropologia no Brasil e na América Latina". } \\
\text { (6a. Reunião de Antropologia do Mercosul) [Maggie; Gontijo, 2006, p. 365]. }\end{array}$ & 2005 & $\begin{array}{l}\text { Montevidéu, } \\
\text { Uruguai }\end{array}$ & ABA/Udelar \\
\hline $\begin{array}{l}\text { "Jornada de reflexốes sobre o ensino de antropologia no Rio Grande do } \\
\text { Sul" [Muller et al., 2006, p. 422-423]. }\end{array}$ & 2005 & Porto Alegre, RS & $\mathrm{ABA}$ \\
\hline $\begin{array}{l}\text { SE: "Ensino de antropologia na graduação: Ciências sociais ou antropologia?". } \\
\text { OF: "O ensino de antropologia e a profissionalização do antropólogo no } \\
\text { Brasil: discussóes sobre o ensino de antropologia". } \\
\text { CC: "Ensino de antropologia em cursos diversos". } \\
\text { "Reunião da Comissão de Ensino de Antropologia (CEA) da ABA". } \\
\text { (25a. Reunião Brasileira de Antropologia). }\end{array}$ & 2006 & Goiânia, GO & $\begin{array}{l}\text { ABA/UFG/ } \\
\text { UCG }\end{array}$ \\
\hline
\end{tabular}

Continua... 
Apêndice - Continuaçáo.

\begin{tabular}{|c|c|c|c|}
\hline Evento & Ano & Lugar & Organizadores \\
\hline $\begin{array}{l}\text { "Reunião sobre ensino em antropologia - Comissão de Ensino de } \\
\text { Antropologia da ABA". } \\
\text { (7ª Reunião de Antropologia do Mercosul) [Relatório de Gestão 2006- } \\
\text { 2008/ABA]. }\end{array}$ & 2007 & Porto Alegre, RS & $\mathrm{ABA}$ \\
\hline $\begin{array}{l}\text { MR: "Ensino de antropologia no Norte e no Nordeste: raízes, contextos } \\
\text { e perspectivas". } \\
\text { ( } 1^{\text {a }} \text {. Reunião Equatorial de Antropologia }-10^{\text {a }} \text {. Reunião de Antropólogos } \\
\text { Norte-Nordeste). }\end{array}$ & 2007 & Aracaju, SE & ABA/UFS \\
\hline $\begin{array}{l}\text { FR: "O ensino e a formação em antropologia no Brasil". } \\
\text { (31\%. Encontro Anual da Anpocs) [Programa e resumos do evento]. }\end{array}$ & 2007 & Caxambu, MG & Anpocs \\
\hline $\begin{array}{l}\text { SE: "O ensino de antropologia em diferentes contextos nacionais". } \\
\text { SE: "Ensino da antropologia visual: perspectivas e alcances". } \\
\text { "Reunião do GT Ofício do antropólogo da ABA". } \\
\text { "Reuniáo da Comissão de Ensino da ABA". } \\
\text { (26a. Reunião Brasileira de Antropologia) }\end{array}$ & 2008 & $\begin{array}{l}\text { Porto Seguro, } \\
\text { BA }\end{array}$ & ABA/UFBA \\
\hline $\begin{array}{l}\text { MR: "As graduaçóes em antropologia no Brasil e o ofício de antropólogo". } \\
\text { (2a. Reunião Equatorial de Antropologia/ } 11^{\circ} \text {. Encontro dos Antropólogos } \\
\text { do Norte e do Nordeste) [Relatório de Gestão 2008-2010/ABA]. }\end{array}$ & 2009 & Natal, RN & ABA/UFRN \\
\hline $\begin{array}{l}\text { MR: "História da antropologia na Amazônia: memória e opções } \\
\text { epistemológicas". } \\
\text { FE: "Graduaçáo em antropologia no Brasil: experiências e perspectivas". } \\
\text { FE: "O campo de atuaçáo dos antropólogos no Brasil". } \\
\text { FE: "Ensino de pós-graduação e avaliação". } \\
\text { Reunião de trabalho da Comissão de Ensino de Antropologia e o ofício } \\
\text { do Antropólogo. } \\
\text { (27ª Reunião Brasileira de Antropologia). }\end{array}$ & 2010 & Belém, PA & ABA/UFPA \\
\hline $\begin{array}{l}\text { FR: "Desafios e perspectivas para a antropologia no Brasil a partir da } \\
\text { criaçáo dos cursos de graduação". } \\
\text { (3a. Reunião Equatorial de Antropologia/12o. Encontro dos Antropólogos } \\
\text { do Norte e do Nordeste) [Relatório de Gestâo 2011-2012/ABA]. }\end{array}$ & 2011 & Boa Vista, RR & ABA/UFRR \\
\hline $\begin{array}{l}\text { FR: "O exercício da antropologia fora da academia: caracterizando } \\
\text { saberes e identificando potencialidades". } \\
\text { MR: "Avaliação do ensino superior: O ENADE de Ciências Sociais". } \\
\text { GT: "Antropologia visual: história, ensino e perspectivas de pesquisa". } \\
\text { (28. Reunião Brasileira de Antropologia). }\end{array}$ & 2012 & São Paulo, SP & ABA/PUC-SP \\
\hline $\begin{array}{l}\text { GT: "Ensino de antropologia". } \\
\left(10^{\mathrm{a}} . \text { Reunião de Antropologia do Mercosul). }\right.\end{array}$ & 2013 & $\begin{array}{l}\text { Córdoba, } \\
\text { Argentina }\end{array}$ & \\
\hline $\begin{array}{l}\text { FR: "A prática antropológica: ética, profissionalização e novos desafios" } \\
\text { [Portal da ABA]. }\end{array}$ & 2013 & Boa Vista, RR & ABA/UFRR \\
\hline $\begin{array}{l}\text { SE: "O ensino de antropologia: expandindo fronteiras no século XXI". } \\
\text { SE: "O ofício de antropólogo/a". } \\
\text { MR: "Ensino de antropologia visual: experiências e projetos". } \\
\text { GT: "Desafios profissionais e espaços de embate: demandas e questôes } \\
\text { em torno da atuaçáo antropológica". } \\
\text { GT: "Ensinar e aprender antropologia". } \\
\text { (29a. Reunião Brasileira de Antropologia) }\end{array}$ & 2014 & Natal, RN & ABA/UFRN \\
\hline "Formação e profissionalização dos(as) antropólogos(as)". & 2014 & Pelotas, RS & UFPel/ABA \\
\hline
\end{tabular}


Apêndice - Continuaçáo.

\begin{tabular}{|c|c|c|c|}
\hline Evento & Ano & Lugar & Organizadores \\
\hline $\begin{array}{l}\text { MR: "Povos indígenas e ensino superior no Norte/Nordeste". } \\
\text { MR: "Políticas da diversidade na Universidade: experiências e resultados". } \\
\text { MR: "O lugar da antropologia na formação docente". } \\
\text { GT: "Antropologia(s), novos e antigos cenários e os desafios de reflexão/atuaçáo". } \\
\text { (5a. Reuniâo Equatorial de Antropologia e } 16^{2} \text {. Reunião de Antropólogos } \\
\text { do Norte e Nordeste) }\end{array}$ & 2015 & Maceió, AL & ABA/UFAL \\
\hline 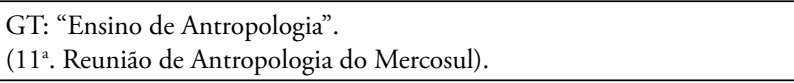 & 2015 & $\begin{array}{l}\text { Montevidéu, } \\
\text { Uruguai }\end{array}$ & Udelar \\
\hline $\begin{array}{l}\text { "Sessão III: O ensino de antropologia hoje e no futuro". } \\
\text { (Seminário } A B A+60 \text { ) [Relatório de Gestão 2015-2016/ABA]. }\end{array}$ & 2015 & Brasília, DF & $\mathrm{ABA}$ \\
\hline $\begin{array}{l}\text { FR: "Diversidade e ensino superior". } \\
\text { GT: "Ensinar e aprender antropologia". } \\
\text { GT: "Fantasmas dentro da máquina? O ofício antropológico dentro e na } \\
\text { órbita da institucionalidade estatal". } \\
\text { OF: "Inserção profissional do/a antropólogo/a". } \\
\text { OF: "Como ensinar e aprender História da África". } \\
\text { (30.. Reunião Brasileira de Antropologia) }\end{array}$ & 2016 & João Pessoa, PB & $\mathrm{ABA} / \mathrm{UFPB}$ \\
\hline "O ensino e a pesquisa em Antropologia na Zona da Mata mineira I". & 2016 & Viçosa, MG & DCS/UFV \\
\hline $\begin{array}{l}\text { GT: "Ensino de antropologia". } \\
\text { (5\%. Congresso da Associação Latino-americana de Antropologia). }\end{array}$ & 2017 & $\begin{array}{l}\text { Bogotá, } \\
\text { Colômbia }\end{array}$ & ALA \\
\hline "O ensino e a pesquisa em antropologia na Zona da Mata mineira II". & 2017 & Viçosa, MG & DCS/UFV \\
\hline $\begin{array}{l}\text { GT: "Ensinar e aprender antropologia". } \\
\text { MR: "Novas universidades, novos campi, novas antropologias: docências, } \\
\text { alteridades e expansão do Ensino Superior no Brasil". } \\
\text { (31ª . Reunião Brasileira de Antropologia). }\end{array}$ & 2018 & Brasília, DF & UnB/ABA \\
\hline
\end{tabular}

UFSC: Universidade Federal de Santa Catarina; MR: mesa-redonda; ABA: Associação Brasileira de Antropologia; UFBA: Universidade Federal da Bahia; UFPE: Universidade Federal de Pernambuco; SE: seminário/seminário especial; GT: grupo de trabalho; USP: Universidade de São Paulo; DB: debate; Unicamp: Universidade Estadual de Campinas; RE: reunião; CNPq: Conselho Nacional de Desenvolvimento Científico e Tecnológico; UFMG: Universidade Federal de Minas Gerais; OF: oficina; FR: fórum; Anpocs: Associação Nacional de Pós-Graduação e Pesquisa em Ciências Sociais; UFF: Universidade Federal Fluminense; EN: encontro; UFRJ: Universidade Federal do Rio de Janeiro; UFPA: Universidade Federal do Pará; UnB: Universidade de Brasília; UFPR: Universidade Federal do Paraná; CAPES: Coordenação de Aperfeiçoamento de Pessoal de Nível Superior; FE: fórum especial; UFRGS: Universidade Federal do Rio Grande do Sul; UFRR: Universidade Federal de Roraima; FP: fórum de pesquisas; CC: comunicaçóes coordenadas; UFG: Universidade Federal de Goiás; UCG: Universidade Católica de Goiás; UFS: Universidade Federal de Sergipe; PUC-SP: Pontifícia Universidade Católica de São Paulo; UFRN: Universidade Federal do Rio Grande do Norte; UFPel: Universidade Federal de Pelotas; UFAL:Universidade Federal de Alagoas; UFPB: Universidade Federal da Paraíba; DCS: Departamento de Ciências Sociais; UFV: Universidade Federal de Viçosa; ALA: Associação Latino-Americana de Antropologia. 


\title{
Movimentos sociais contemporâneos: um balanço da produção de teses e dissertações em antropologia (2008-2018)
}

\author{
Paula Alegria ${ }^{\mathrm{I}}$ \\ Lucas Bulgarelli ${ }^{1}$ \\ Rosana Pinheiro-Machado ${ }^{\text {II }}$
}

\section{Introdução}

$\mathrm{Na}$ literatura acadêmica sobre movimentos sociais, persiste uma divisão entre os chamados antigos (AMS) e novos movimentos (NMS). Ainda que a precisão dessas categorias seja questionada, elas continuam sendo amplamente empregadas nas ciências sociais, uma vez que demarcam uma diferença importante entre os movimentos de classe da primeira metade do século XX (os antigos) e os movimentos de identidades coletivas e estilo de vida que se tornam mais expressivos na segunda metade do século (os novos), e que não adotam apenas a questão econômica ou produtiva como eixo central. No século XXI, é possível ainda observar uma terceira categoria, a qual tem sido denominada "novíssimos" (NVMS) movimentos sociais (Day, 2004), mas também "movimentos antiausteridade" (Della Porta, 2015), "protestos cidadão" (Gerbaudo, 2017) etc. Trata-se de movimentos anticapitalistas que tiveram sua gênese nos movimentos antiglobalizaçáo da virada do milênio. Impulsionados pelo uso das novas tecnologias digitais, esses movimentos têm se valido de um repertório de táticas que se inspira no anarquismo e no marxismo autonomista, como a horizontalidade ${ }^{1}$, a prefiguração ${ }^{2}$ e a ação direta ${ }^{3}$ (Graeber, 2002).

Um dos limites dos usos das categorias de AMS, NMS e NVMS é que elas seguem um ritmo de transformaçóes sociais e políticas do Norte Global, mesmo que tais mudanças tenham afetado o Hemisfério Sul. Além disso, essa demarcação corresponde a modelos sociológicos de categorização e análise que não necessariamente possuem paralelo na produção antropológica. Soma-se a isso o fato de que, por muito tempo, o tema dos movimentos sociais náo foi preponderante na teoria feita na antropologia (Escobar, 1992; Gibb, 2001). Nos anos 1990, Escobar (1992) notava que os estudos norteadores teóricos da disciplina inviabilizavam a dis-

1 Modelos decisórios não hierárquicos, que evitam deliberação de cima para baixo.

2 Princípio de que os movimentos nâo podem reproduzir em sua organização as opressōes que combatem.

3 Táticas ativistas que dispensam caminhos intermediários e buscam formas de agir mais diretas e imediatas.

\footnotetext{
IDepartamento de Antropologia, Universidade de São Paulo - São Paulo (SP), Brasil. E-mails: paulaalegriab@gmail.com, lucasbulgarelli@usp.br

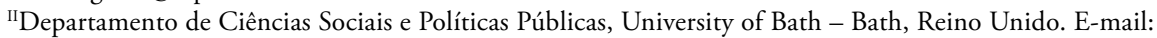
rpinheiromachado@yahoo.com.br
} 
cussão por estarem voltados à questão da textualidade, à teoria da prática ou a debates conceituais abstratos, definidos na academia ocidental, mas com pouca conexão com as lutas políticas e populares que emergiram na virada do milênio.

A própria obra de Arturo Escobar (1992; 2011; 2018) foi fundamental para situar o estudo dos movimentos na centralidade antropológica, mas desde uma perspectiva do campo, engajada e conectada à produção realizada na América Latina. No Brasil, não se pode dizer que o tema tenha sido negligenciado. Muito pelo contrário: a história da antropologia do/no Brasil, em muitos momentos, confunde-se com o processo de nation-building (Peirano, 2000) e com a resistência de movimentos baseados em identidades coletivas (como gênero, sexualidade, raça/cor e etnia). Logo, os temas acerca da identidade e dos modos de vida que marcam o recorte dos NMS são fundantes e estruturantes da disciplina.

$\mathrm{O}$ recorte de nosso artigo recai sobre os movimentos sociais contemporâneos que explodiram no Brasil e que possuem diversas características dos NVMS. O país vivenciou um verdadeiro boom da ação coletiva das mobilizações de massa e da formação de coletivos descentralizados, tendo a internet como meio de mobilização, especialmente entre a juventude. $\mathrm{O}$ marco desse formato de atuação no Brasil foram as Jornadas de Junho de 2013, inicialmente convocadas por grupos anarquistas e autonomistas organizados pela pauta do transporte público - como o Movimento do Passe Livre e o Bloco de Lutas. Grandes manifestaçôes reivindicavam a melhoria de bens públicos e colocavam-se contra a corrupção em todo o país. Desde então, o país tem vivido um ciclo incessante de grandes marchas que têm conformado subjetividades políticas, como as que se destacaram na Primavera Feminista de 2015 (movimento de mulheres que tomou as ruas e as redes contra a opressão de gênero) e nas Ocupaçóes de 2016 (quando estudantes secundaristas e universitários ocuparam escolas, universidades e reitorias em defesa do ensino público). Ainda que grupos conservadores e de direita tenham ganhado expressão e igualmente ocupado as ruas no mesmo período, o interesse acadêmico por eles na antropologia ainda figura incipiente nas produçóes.

Como todo processo emergente, os NVMS não possuem uma forma acabada. Nós entendemos que os ciclos mais recentes de mobilização possuem algumas características distintivas, que vêm se repetindo nas manifestaçóes de resistência que têm ocorrido do Occupy Wall Street, nos Estados Unidos, ao Ni Una a Menos, na Argentina, por exemplo. Todavia, isso náo significa que haja um rompimento com os NMS. Quando focamos a produção brasileira dos últimos anos sobre movimentos sociais, fica mais nítido que as categorias NMS e NVMS se sobrepóem. Por um lado, os movimentos de feministas, LGBT e negros, por exemplo, são uma expressão da luta contra as opressóes de gênero, sexualidade e raça dos NMS. A emergência desses movimentos no país coincidiu temporalmente com as lutas por reconhecimento em diversas partes do mundo nas últimas décadas do século XX. Por outro lado, a novidade do século XXI, especialmente no caso brasileiro, é que grandes mobilizaçóes de massa que aconteceram nos últimos anos, as quais seriam expressóes paradigmáticas dos NVMS, também impactaram, expandiram e transformaram a onda do ativismo que vinha crescendo no país graças à conquista de direitos sociais e políticas culturais, a qual foi impulsionada nos governos federais do Partido dos Trabalhadores (PT) entre 2002 e 2016. 
O efeito dessa explosão recente de movimentos sociais no Brasil pode ser claramente observado nas produçóes acadêmicas da antropologia nos últimos anos. Este artigo traz um levantamento bibliográfico das dissertaçóes e teses sobre movimentos sociais contemporâneos entre os anos de 2008 e 2018. Olhando para essa produção recente, acreditamos que possui continuidades e rupturas significativas com os estudos de movimentos sociais brasileiros que os precederam. Esses estudos avançam na tradição do entendimento etnográfico das lutas dos grupos oprimidos por raça, etnia, classe, gênero e sexualidade. Além disso, os trabalhos buscam maior diálogo com as questóes conceituais do campo interdisciplinar dos movimentos sociais, aliando-se ao estudo dos NVMS, observando as demandas dos grupos, mas também suas táticas de organização, especialmente nas expressóes mais descentralizadas que se manifestam nas explosóes de coletivos nos últimos anos no Brasil.

Nesse sentido, os estudos emergentes sugerem que existe uma transformação dos movimentos sociais do século XXI. Ao focarem em expressóes da ação coletiva mais "autogestadas" e até "espontâneas", tais pesquisas apontam um esgotamento de um modelo de organização da sociedade civil que prevaleceu nas últimas décadas do século XX, qual seja, aquele cujos limites entre movimentos sociais e organizaçóes não governamentais (ONGs) de direitos humanos se confundem (Jad, 2007). A explosão de coletivos nos últimos anos no Brasil segue um modelo menos formal de organização popular — ou simplesmente grassroots (de raiz). Essa é uma hipótese que merece maior investigação empírica para além da pesquisa bibliográfica.

A justificativa sobre a opçáo de selecionar trabalhos finais de pesquisadores de pós-graduação se sustenta em três pilares: prático, epistemológico e político. Esses pilares são igualmente importantes para elucidar a novidade que esse recorte oferece aos estudos de movimentos sociais no Brasil. Pragmaticamente, ainda que exista uma produção consagrada de pesquisadores estabelecidos no campo de gênero, sexualidade e relaçóes étnico-raciais, a crescente produção de cunho etnográfico acerca de lógicas emergentes de luta no Brasil, especialmente a que foi impulsionada pós-junho de 2013, é bastante recente e foi pouco publicada em formato de artigos acadêmicos por uma questão de temporalidade. Sáo poucos os artigos publicados em periódicos quando comparados ao número de trabalhos finais de pós-graduandos. Entre as pesquisas pós-graduadas na área de antropologia, pudemos mapear mais de uma centena de teses e dissertaçóes.

Epistemologicamente, entendemos que esse novo momento do Brasil ajudou a fortalecer uma geração de antropólogos engajados e ativistas. Isso não significa, como já mencionado, que a antropologia brasileira, por sua própria história na periferia do sistema mundial, algum dia não tenha sido engajada na luta por igualdade e reparação de direitos sociais e políticos e no próprio debate sobre a construção da identidade nacional. Referimo-nos aqui, portanto, a uma nova geração de pesquisadores que é fruto da expansão do ensino superior e das políticas de ação afirmativas das universidades debatidas e defendidas por aqueles que os precederam. Muitas vezes, os autores são etnógrafos nativos, e também ativistas, que se descrevem como afetados pelos movimentos sociais contemporâneos, sendo eles os próprios sujeitos e observadores das transformaçôes recentes do país.

Por fim, há ainda uma motivação política que justifica essa escolha. Atualmente, sob o governo de extrema-direita de Jair Bolsonaro (filiado ao Partido Social Liberal à 
época da eleição), o Brasil atravessa uma fase marcada pelo anti-intelectualismo e pelo ataque direto à produção científica das ciências humanas. Tem sido frequente o escracho público, realizado por membros do governo, de teses e dissertaçôes de antropologia, as quais são caracterizadas como irrelevantes para $\mathrm{o}$ país. Nosso objetivo nesse levantamento bibliográfico é dar visibilidade aos trabalhos de uma geração de pesquisadores diretamente ameaçada, a qual é responsável por uma produção robusta da pós-graduação no Brasil. Cumprindo seu papel acadêmico, esses trabalhos são ferramentas fundamentais para documentar e interpretar as transformações recentes por que a sociedade brasileira tem passado nos últimos anos.

\section{Notas metodológicas}

O levantamento bibliográfico realizou-se com base em teses e dissertaçóes disponíveis no catálogo da Coordenação de Aperfeiçoamento de Pessoal de Nível Superior (CAPES) ${ }^{4}$. Foram filtrados os trabalhos defendidos entre 2008 e 2018 vinculados aos programas de pós-graduação em: antropologia; antropologia social; ciências sociais com área de concentração em antropologia; sociologia e antropologia com área de concentraçáo em antropologia ${ }^{5}$. $\mathrm{O}$ foco em produçóes defendidas exclusivamente nesses departamentos orientou o filtro de buscas na plataforma da CAPES para fins metodológicos, o que exclui o levantamento de pesquisas antropológicas vinculadas a programas de pós-graduação multidisciplinares, como aqueles ligados à saúde coletiva, à mídia e à cultura, por exemplo. Tal escolha metodológica, ao mesmo tempo que tornou possível a operacionalização do levantamento em termos pragmáticos, deixa de fora possíveis pesquisas na área da antropologia conduzidas em departamentos que extrapolam a grande área das ciências sociais.

4 Disponível em: <https://catalogodeteses.capes.gov.br/catalogo-teses>. Acesso em: 10 mar. 2020.

5 Foram mapeadas teses e dissertaçôes defendidas nos seguintes programas de pós-graduação (PPG) em antropologia ou antropologia social: PPG em antropologia social da Universidade de São Paulo; PPG em antropologia social da Universidade Estadual de Campinas; PPG em antropologia social da Universidade Federal de São Carlos; PPG em antropologia social/Museu Nacional da Universidade Federal do Rio de Janeiro; PPG em antropologia da Universidade Federal Fluminense; PPG em antropologia da Universidade Federal de Minas Gerais; PPG em antropologia social da Universidade Federal do Rio Grande do Sul; PPG em antropologia da Universidade Federal de Pelotas; PPG em antropologia da Universidade Federal do Paraná; PPG em antropologia social da Universidade Federal de Santa Catarina; PPG em antropologia social da Universidade Federal do Rio Grande do Norte; PPG em antropologia da Universidade Federal de Sergipe; PPG em antropologia da Universidade Federal de Pernambuco; PPG em antropologia da Universidade Federal da Paraíba; PPG em antropologia da Universidade Federal da Bahia; PPG em antropologia social da Universidade Federal de Alagoas; PPG em antropologia da Universidade Federal do Piauí; PPG em antropologia da Fundação Universidade Federal do Piauí; PPG em antropologia social da Universidade Federal de Goiás; PPG em antropologia social da Universidade de Brasília; PPG em antropologia social da Universidade Federal da Grande Dourados; PPG em antropologia da Universidade Federal do Pará; PPG em antropologia social da Universidade Federal do Amazonas. Incluem-se também teses e dissertaçóes com área de concentração em antropologia defendidas em PPG em ciências sociais ou em sociologia e antropologia: PPG em ciências sociais da Universidade Estadual de Campinas; PPG em ciências sociais da Universidade Federal de São Paulo; PPG em ciências sociais da Universidade Estadual Paulista; PPG em sociologia e antropologia da Universidade Federal do Rio de Janeiro; PPG em ciências sociais da Universidade Estadual do Rio de Janeiro; PPG em ciências sociais da Pontifícia Universidade Católica do Rio de Janeiro; PPG em ciências sociais da Universidade Federal de Juiz de Fora; PPG em ciências sociais da Universidade Federal de Santa Maria; PPG em ciências sociais da Universidade do Vale do Rio dos Sinos; PPG em ciências sociais da Universidade Estadual do Oeste do Paraná. 
Consideraram-se apenas as pesquisas cujo campo etnográfico se concentrava no meio urbano. Para fins de análise, privilegiaram-se as produçóes sobre movimentos sociais contemporâneos exclusivamente vinculados à vida na cidade. Apesar da relevância da produção teórica e da importância no âmbito político, as produçôes sobre movimentos atribuídos às populações rurais, camponesas, tradicionais, quilombolas $\mathrm{e}$ indígenas foram descartadas em função do enfoque do artigo e das limitaçóes inerentes à análise. Destacam-se balanços dedicados a esses movimentos em outros artigos desta coletânea. Os mecanismos de busca obedeceram à procura por palavras-chave centrais para o campo semântico em torno dos movimentos sociais contemporâneos, como: ativismos; lutas; coletivos; movimentos antiglobalização; movimento negro; movimento feminista; movimento LGBT; junho de 2013; ocupaçóes; conservadorismo; marchas; movimento de moradia etc. Com base no resultado da busca por meio das palavras-chave, seguimos para a seleção de dissertaçôes e teses que versassem diretamente sobre movimentos sociais, lutas e açôes coletivas, não bastando que o trabalho versasse sobre formas e noçóes políticas. Além disso, a busca permitiu identificar novas palavras-chave que expandiram o escopo da investigação para diferentes formatos de atuação política. Com isso, foram adicionadas também palavras-chave relacionadas, como: Marcha da Maconha; Marcha das Vadias; parada LGBT; pró-impeachment; feminismos jovens; Copa; horizontalidade; autonomia etc.

A combinação desses critérios de análises resultou na identificação de 170 teses e dissertaçóes. Em termos geográficos, embora o mapeamento contemple todas as regióes do país, a distribuição geográfica revela-se desigual comparativamente. As pesquisas concen- tram-se na Região Sudeste (45,29\%), seguida pela Região Sul $(25,29 \%)$, Região Nordeste (16,47\%), Regiáo Centro-Oeste (10,58\%) e, por último, Região Norte (2,35\%). Assumimos que a desproporcionalidade entre as regióes se deve, ao menos em parte, em razão das escolhas metodológicas adotadas. Tendo em vista os limites do texto e os temas abordados por outros artigos desta coletânea, foram priorizados movimentos sociais de caráter urbano e que estivessem diretamente relacionados com formatos mais horizontais de atuação política, baseados em identidades coletivas ou ainda pautados em modelos associativos descentralizados concentrados em lutas por reparação e equiparação de direitos.

Por fim, a escolha metodológica não descarta a importância de outros espaços de produção de conhecimento em antropologia, como as publicaçóes de artigos em periódicos, livros e eventos científicos. Entre estes últimos, vale destacar grupos de trabalho, mesas-redondas, fóruns, simpósios, conferências e outros espaços propiciados pelos encontros anuais da Associação Nacional de Pós-Graduação e Pesquisa em Ciências Sociais (ANPOCS) e as reunióes bienais da Associação Brasileira de Antropologia (ABA), fundamentais para os avanços teórico-metodológicos da conformação dos campos de estudo anteriormente referidos, do ponto de vista acadêmico e também político. Como salientamos, a opção pelo levantamento de pesquisas pós-graduadas, no entanto, justifica-se pelo esforço de recortar uma produção em ascendente proliferação entre pesquisadores da nova geração, cujo fôlego se renova em função do enfoque analítico sobre repertórios que lhes são contemporâneos, atrelados substancialmente à expansão dos programas de pós-graduação nos últimos anos e à consequente diversificação das linhas de pesquisa a esses vinculados. 


\section{Dos movimentos antiglobalização aos coletivos horizontais}

No fim dos anos 1990 e no início dos 2000, o cenário político internacional era marcado pela presença de manifestantes contrários à ordem mundial neoliberal, os chamados movimentos antiglobalização, reconhecidos na literatura acadêmica como a gênese dos NVMS. Os protestos desse ciclo contestatório chegaram à produção antropológica de teses e dissertaçôes no Brasil com uma análise sobre a política antiglobalização em manifestaçôes de rua na Europa e nos Estados Unidos (Giovanni, 2008) e com uma investigação sobre os discursos zapatistas em torno das experiências da globalizaçáo e do neoliberalismo no México (Lima, 2009).

Os ecos desse tipo de organização política inspiraram uma série de movimentos sociais no país marcados por uma linguagem organizativa pautada pela contestaçáo das injustiças do sistema capitalista e pelas noçôes de auto-organização, horizontalidade e autonomia em relação ao Estado, aos partidos políticos e às organizaçóes institucionalizadas, como entidades, conselhos e sindicatos. Tais repertórios informam desde as teses e dissertaçôes sobre o Fórum Social Mundial no Brasil (Giovanni, 2013) até os estudos sobre o Movimento Passe Livre (Pantoja, 2017) e as demais lutas pelo transporte público (Muhale, 2014).

Esse contexto é marcado ainda pela explosão de coletivos políticos voltados para a produçáo de ativismos jovens e diferentes formas de ação coletiva, analisadas etnograficamente pela chave da horizontalidade e da auto-organização (ou autogestão), considerando-as, muitas vezes, categorias dotadas de heterogeneidade nos usos e nos sentidos atribuídos pelos sujeitos de pesquisa, como no caso de pesquisas sobre os coletivos militantes das juventudes de periferia em São Paulo e no Rio de Janeiro (Carmo, 2016; Souza, 2017).

No período analisado, a articulaçáo entre movimentos sociais contemporâneos, expressôes culturais e performances artísticas também surge atrelada a repertórios de engajamento pautados pelas práticas da democracia direta, como na configuração de coletivos horizontais e experiências de ocupaçóes auto-organizadas. Os denominados coletivos culturais chamam a atenção na produção acadêmica com o fortalecimento de espaços alternativos de produção cultural na década de 1990 e início dos anos 2000. É o caso de coletivos de produção audiovisual na cidade de São Paulo (Aderaldo, 2013) e dos coletivos culturais ligados à rede Fora do Eixo, objeto de análise de duas pesquisas dedicadas a etnografias em Porto Alegre e no interior de Sáo Paulo (Irisarri, 2015; Mazzer, 2016). Em todas essas produções, vale destacar a dimensão da autonomia e da ocupaçáo urbana/da cidade/de espaços públicos como traços marcantes.

Nesse sentido, abordagens sobre a perspectiva da horizontalidade e da autonomia nos movimentos sociais contemporâneos aparecem fortemente atreladas às novas tecnologias digitais de comunicação, tanto para o desenvolvimento do potencial de mobilização política nas ruas pelo ciberativismo (Silva, 2012) quanto como parte constitutiva da elaboração desses ativismos na internet (Silva, R. Souza, 2017).

Outros trabalhos mapeados indicam forte relaçáo desses movimentos com os ativismos contemporâneos em torno dos marcadores sociais da diferença, como gênero, raça e classe. É o caso das pesquisas dedicadas ao ativismo de mulheres "periféricas" nas culturas do funk, do hip hop e do graffiti por meio dos coletivos feministas e/ou antirracistas (Ramos, 2016; Samico, 2013; Araujo, 2016; Freitas, 2017); aos engajamentos po- 
líticos de jovens negros e/ou periféricos do movimento hip hop (Maffioletti, 2013; Pereira, R., 2016); às práticas artísticas e aos engajamentos políticos de coletivos de funk (Lucena, 2016); e também aos grupos formados por rappers (Souza, 2009).

A produção dá lugar ainda a uma análise mais ampla dos modos de fazer cultura e política, no contexto da construção de uma política nacional de cultura e da proliferação das experiências de democracia participativa no país (Muniagurria, 2016).

\section{Movimentos de moradia urbanos}

Os formatos ativistas do fim do século XX informaram também análises etnográficas sobre a constituição dos movimentos de moradia urbanos no Brasil. Nos estudos antropológicos de 2008 a 2018, no que tange às teses e dissertaçôes, nota-se a problematização das configuraçôes em torno da dicotomia entre o caráter autonomista ou autônomo e institucionalizado das lutas em relação ao Estado para a composição de modos de organização da luta por moradia nas cidades. As análises descrevem o caráter polissêmico, situacional e relacional das categorias atreladas a esse repertório de engajamento em contextos que se desdobram desde as ocupaçôes de moradia em Sáo Paulo (Aquino, 2009; 2015; Paterniani, 2013), em Fortaleza (Lima, 2012), em São José dos Campos (Andrade, 2010; Barretti, 2018) e no Rio de Janeiro (Ostrower, 2012). Nessas produçóes, é notável o esforço de tornar complexa a recorrente cisão entre antigos e novos movimentos sociais. Nos estudos mapeados, vale destacar também a perspectiva das táticas de ocupaçáo como um modo privilegiado de resistência, costurando analiticamente a dimensão do direito à moradia a categorias como família, casa e luta.

\section{Movimentos antiproibicionistas e canábicos}

O campo de estudos sobre movimentos sociais na antropologia, no período analisado, contempla também análises em teses e dissertaçôes sobre o surgimento das marchas da Maconha no Brasil e os impasses judiciais relacionados à autorização para a realização de manifestaçốes contrárias à proibição e à criminalização das drogas. Em um contexto de expansão dos movimentos marcados pelas lutas antiglobalização, as marchas da Maconha (que se autodeclaram coletivos) encontram espaços de convergência em manifestaçóes como o Fórum Social Mundial (FSM). Entre 2008 e 2018, os debates sobre um modelo alternativo ao combate de guerra às drogas se fortalece, abrindo espaço para a criação de coletivos antiproibicionistas.

As pesquisas mapeadas sobre o tema concentraram atenção nas experiências e trajetórias que viabilizaram a constituição de um movimento pró-cannabis no Rio de Janeiro (Silvestrin, 2013) e de coletivos antiproibicionistas em Natal (Campos, 2013), nas dimensóes da criminalização do uso recreativo para a situação das liberdades individuais e dos direitos na Bahia (Santos, F., 2017), bem como os conflitos e as lutas pela liberação da maconha na Colômbia (Sierra, 2018). Embora de forma incipiente, a produção também proporcionou importantes aportes sobre o uso medicinal do canabidiol em crianças com epilepsia, articulando noçóes como cuidado, solidariedade e ativismo entre pacientes e familiares (Oliveira, 2016).

\section{Movimentos ambientalistas e abolicionismo animal}

Nos últimos anos, dissertações e teses empenharam-se também em analisar mo- 
vimentos sociais em torno dos animais, da ecologia e/ou do meio ambiente. Esses trabalhos concentram atenção especial nos movimentos vegano e vegetariano atrelados aos direitos animais e ao abolicionismo animal, sobretudo a partir de 2012. No período analisado, as pesquisas enfatizaram aspectos sobre símbolos e moralidades atinentes ao movimento vegetariano (Lira, 2013), diferentes configuraçóes de ideias e práticas que norteiam a luta de vegetarianas em defesa dos animais (Almeida, 2012), os engajamentos e mobilizaçóes políticas nos processos de atribuição e reconhecimento de identidades no movimento vegano (Vilela, 2013), bem como as mobilizaçôes do veganismo não só em relação aos hábitos alimentares, mas também na indústria do entretenimento (rodeios, touradas e circos, por exemplo) e na produção científica que lança máo de testes em animais (Ferrigno, 2012).

Tal conjunto de trabalhos conta também com pesquisa que traz à tona a categoria de bem-estar animal, em referência à adoção de medidas que reduzam o sofrimento dos animais, especialmente na produção de gado de corte (Froehlich, 2016), e uma etnografia sobre movimentos sociais de escala internacional que articulam a defesa dos alimentos orgânicos à educação para a mudança de hábitos alimentares e de consumo (Schneider, 2015). No mesmo âmbito, as produçóes sobre alimentação e meio ambiente lançam luz sobre os movimentos de agricultura urbana, como aqueles ligados à agroecologia e à expansão das hortas comunitárias na cidade (Machini, 2018).

De modo mais abrangente, as etnografias destacam ainda a construçáo da ideia dos animais como sujeitos de direitos por parte dos movimentos, seja pelo combate a todo tipo de "exploração animal” (Franco, 2015), seja pela defesa da extensão aos não huma- nos da mesma "consideração moral" (Souza, 2013).

\section{Jornadas de junho e pós-junho de 2013}

Os protestos de junho de 2013, comumente associados ao repertório de luta dos NVMS em razão da descentralização das açôes coletivas auto-organizadas, são objeto de pesquisa em teses e dissertaçóes no campo da antropologia desde 2016. O caráter complexo, polissêmico e heterogêneo dos eventos, suas consequências e desdobramentos são temas de análises etnográficas sobre práticas políticas e formas de organização (Monteiro, M., 2018; Lobato, 2016; Cabral, 2016) e sobre a força do midiativismo como uma alternativa à grande imprensa na consolidação das redes sociais como um espaço de disputas e tensôes (Moreira, 2016).

A ampla gama de análises sobre os movimentos sociais contemporâneos no Brasil pós-junho se estende também à rede de contestaçóes aos megaeventos sediados no país entre 2013 e 2016. A série de despejos e remoçóes forçadas em torno das grandes obras para a Copa das Confederaçóes (2013), Copa do Mundo (2014) e Jogos Olímpicos (2016) - como construçóes de estádios, arenas, avenidas e sistemas de transporte - impulsionou protestos de rua, ocupaçóes de moradia auto-organizadas e a formação de coletivos políticos horizontais e comitês populares nas cidades-sede dos megaeventos.

Nesse período, palavras de ordem como "Não vai ter Copa!" ou "Copa pra quem?" espalharam-se em manifestaçôes e intervençóes populares. Rio de Janeiro e Porto Alegre, as cidades com maior número de remoçôes, foram palco de lutas, mobilizaçóes coletivas e ocupaçóes (Gutterres, 2014; Mesomo, 2014; Fernandes, 2013). O movimento Resistência Aldeia Maracanã ganhou projeção 
nacional quando a ocupação de diferentes etnias indígenas no antigo Museu do Índio se tornou alvo de disputa entre o Estado e os ocupantes no entorno do estádio do Maracanã (Pinto, V., 2014). Em Pernambuco, a demolição de moradias no âmbito das obras de mobilidade para a Copa do Mundo também foi tema de dissertação dedicada ao loteamento São Francisco, no município de Camaragibe, na região metropolitana do Recife (Moura, 2016).

Além disso, outros movimentos de ocupação associados a essas experiências surgem como um campo profícuo de análises a respeito dos eventos pós-junho de 2013. Nas teses e dissertaçóes dos últimos anos, as etnografias alcançam processos políticos quanto à ocupação como tática de luta privilegiada a partir de então, em contextos que se desdobram para além do escopo da luta por moradia e atingem movimentos pelo transporte público (Segarra, 2015), pela educação em escolas públicas (Barbosa, 2018), em ocupaçóes culturais e/ou artísticas (Gonçalves, 2017; Leite, 2018) e coletivos de ativistas urbanos pela ocupaçáo de espaços públicos (Trindade, 2016).

\section{Movimentos sociais conservadores}

Ainda é incipiente a produção de pesquisas antropológicas que trataram de analisar a atuaçáo de movimentos sociais conservadores, liberais e/ou de direita nos tempos atuais. As dissertaçóes e teses encontradas a esse respeito entre 2008 e 2018 articularam temas e repertórios diversos que váo do "ódio" e "neonazismo" (Dias, 2018) ao "protagonismo" e "pró-liberalismo" (Barbieri, 2018). Publicados mais recentemente, são estudos que enveredaram por pesquisa de campo e documental para mapear grupos e identificar atores e eventos. Tais investiga- çôes ampliam os desafios ético-metodológicos de constituição da alteridade nas relaçôes estabelecidas entre antropólogo e campo.

\section{Movimentos religiosos}

No período de 2008 a 2018, há ainda pesquisas antropológicas em teses e dissertaçôes que se propuseram a refletir sobre a incidência política de movimentos sociais de cunho religioso. Há nelas uma ênfase nos processos de diversificaçáo da atuação política de grupos religiosos, como a realização de grandes eventos organizados por igrejas e congregaçóes ou a incidência em universidades por meio da criação de coletivos cristãos. Nesse sentido, é possível encontrar pesquisas que se dedicaram a realizar etnografias sobre movimentos católicos conservadores (Testa, 2013) ou sobre coletivos universitários cristãos (Rocha, 2011).

O surgimento de eventos cristáos de grande escala, como a Marcha para Jesus, também foi acompanhado em investigaçóes antropológicas dedicadas a compreender a constituição de coletividades evangélicas (Silva, R. Sant'anna, 2017). Além da atuação política de grupos cristãos, foi possível encontrar análises sobre os impasses entre religiāo e ciência no movimento neoateísta (Gordon, 2011).

Puderam-se mapear também produçóes em antropologia que tangenciam a temática dos movimentos sociais e discursos religiosos na intersecção entre os direitos humanos e o Islã no Brasil (Manfrinato, 2016) e no Marrocos (Slenes, 2014). Além disso, as pesquisas direcionadas às religióes de matriz afro-brasileira ofereceram análises a respeito da produção de políticas públicas e do fazer social em terreiros. As dissertações investigaram a regulamentação de rituais religiosos afro-brasileiros (Boniolo, 2014), bem como 
o uso de noçóes como ação política e trabalho social entre sacerdotes do candomblé (Renou, 2011).

\section{Movimentos feministas e LGBT}

A consolidação das linhas de pesquisa sobre gênero e sexualidade propiciou a profusão do interesse em trabalhos sobre as transformaçóes que marcaram os movimentos feministas e LGBT na última década. Esse campo de estudos cresce significativamente nos anos 2000, pela expansão dos programas de pós-graduação do Brasil e pela diversificação das suas linhas de pesquisa, e ganha proeminência no levantamento de teses e dissertaçóes defendidas no âmbito dos marcadores sociais da diferença e dos seus crescentes processos de politização nos departamentos de antropologia entre 2008 e 2018. As pesquisas acompanham também a diversificação de formatos ativistas e a proliferação de novos repertórios relacionados às práticas, expressóes e identidades em termos de gênero e sexualidade.

No período analisado, o campo de pesquisas sobre as dinâmicas e as mudanças dos movimentos feministas contemporâneos evidencia-se a partir da década de 2010 em torno dos protestos que se identificam com as práticas autonomistas e de liberdade sexual no combate à violência sexual e de gênero ${ }^{6}$ e em defesa dos direitos reprodutivos ${ }^{7}$, sobretudo nos protestos da Marcha das Vadias, a partir de 2011, e durante a Primavera das Mulheres, em 2015 (Souza, 2015; Morais, 2015; Vargas, 2016; Batista, 2017; Gomes, 2018). Nesse sentido, destacam-se também os estudos etnográficos sobre formas horizontais de organização das feministas autônomas, seja em perspectiva comparada com as feministas institucionalizadas nos processos de renovação geracional (Silva, 2010; Carmo, 2018), seja nas intersecçóes entre música e feminismos no movimento riot grr$r l$ (Silva, 2018).

É considerável o aumento no número de produçóes com enfoque na multiplicidade de diferenciaçóes em articulação, as chamadas interseccionalidades. Nota-se a proliferação de pesquisas sobre o movimento feminista centradas na articulação com diferenças em termos de raça e classe, sobretudo. No âmbito dos feminismos negros, destacam-se teses e dissertaçóes sobre a condição da mulher negra nos processos de politização das diferenças associadas às suas experiências particulares em relação às desigualdades, à colonização, ao racismo e ao sexismo (Correia, 2015; Alves, 2018; Souza,

6 A gama de trabalhos associados às temáticas de violência contra a mulher é extensa. Teses e dissertaçốes sobre violência sexual, violência doméstica e a Lei no 11.430/2006 (Lei Maria da Penha) figuram entre as mais numerosas de toda a produção acerca das temáticas de gênero na antropologia. Ante os limites deste artigo, cujo escopo se restringe às configuraçôes de movimentos sociais propriamente ditos, não será possível nos determos nessa vasta produção. Da longa lista de teses e dissertaçóes sobre o tema em antropologia entre 2008 e 2018, ver mais: Andrade, 2018; Andrade, 2012; Lins, 2014; Brocksom, 2010; Garcia, 2016; Reis, 2016; Silva, 2013; Farias, 2015; Nadai, 2012; Silva, M., 2017.

7 O aborto, no âmbito dos direitos reprodutivos e sexuais, coloca-se entre as pautas históricas do movimento feminista brasileiro desde a década de 1970, quando se intensifica a luta para reformar o Código Penal em relação à legalização da prática. Desde então, a pauta é alvo de produçôes de teses e dissertações em antropologia. Reformulaçóes e balanços sobre o aborto no campo de estudos sobre moralidades e processamentos penais estão entre as referências, de 2008 a 2018: Porto, 2009; Viana, 2015; Beltrame, 2016; Sousa, 2016; Tussi, 2014; Rangel, 2015; Arnaud, 2008; Ferreira, E., 2012; Silva, M., 2017; Valpassos, 2011; Potechi, 2013. 
2018; Mello, 2016) ou em relaçáo à arte e ao espaço urbano (Ferreira, 2017). No bojo das produçôes sobre gênero, interseccionalidades e movimentos sociais, mapeamos também uma produção no campo da antropologia sobre prostituição feminina e militância (Olivar, 2010).

A figura da mãe e as questôes ligadas à maternidade e ao parto também revigoram o campo dos estudos sobre movimentos feministas contemporâneos no Brasil. A partir de 2011, cresce a produção de teses e dissertaçóes que redimensionam os significados políticos atribuídos à maternidade e à saúde feminina, abrindo diálogos entre feministas, mães e adeptas do parto humanizado (Trotta, 2017; Segata, 2017; Carneiro, 2011; Rodrigues, 2015; Simas, 2016; Mendonça, 2013; Santos, 2016; Hirsch, 2014; Pulhez, 2015).

Ante a emergência crescente de reaçóes conservadoras com base no debate sobre família e gênero, despontam ainda pesquisas que oferecem tanto perspectivas que corroboram as tensôes históricas entre o movimento feminista e as diferentes religiosidades quanto abordagens que desestabilizam vozes religiosas oficiais em torno de pautas relativas ao aborto, às questóes de gênero na escola e ao "empoderamento" feminino no campo religioso. Entre esses estudos, podem-se mapear trabalhos que analisam a atuação da ONG feminista Católicas pelo Direito de Decidir (Silva, 2015), as lideranças femininas neopentecostais (Pinto, A., 2014), o movimento feminista ecumênico brasileiro (Duarte, 2018) e a atuação política de conservadores religiosos no espaço público (Freire, 2018).

Já no campo das transformaçóes de formatos de atuação política dos ativismos relacionados às lutas LGBT e trans, houve um interesse de pesquisas sobre a atuação de ONGs, associaçóes, paradas do orgulho, grupos políticos e demais formatos associativos que viabilizaram açôes políticas coletivas voltadas para estratégias como incidência política e visibilidade (Barbosa, 2010; Lopes, 2011; Ferreira, G., 2012; Aguião, 2014; Zanoli, 2015; Miranda, 2017; Franco, 2018). É possível encontrar nessas pesquisas uma ênfase nas limitaçôes e dificuldades de implementação de modelos associativos mais estruturados e hierárquicos, como os ativismos formatados em ONGs, quando não a avaliaçáo acerca de um determinado esgotamento de formatos de atuação mais institucionalizados. Vale destacar que o período analisado é marcado pela sobreposiçấo de modelos de atuaçáo política mais ou menos institucionais, de modo que as ONGs ainda despontam como objeto de análise também na luta feminista em pesquisa sobre a configuração dos ativismos contra o assédio sexual no Egito (Fontoura, 2016).

A diversificação de formatos associativos apareceu em estudos sobre grupos de mães de pessoas LGBT (Novais, 2018) e igrejas inclusivas (Jesus, 2012; Honorato, 2016; Oliveira, 2017). Houve também pesquisas voltadas para lutas que articulam gênero e sexualidade em contextos de movimentos estudantis (Alegria, 2016; Barbosa, 2018) e em iniciativas voltadas para cursinhos populares LGBT (Silva, T., 2017). Ainda que incipiente, vale destacar o interesse da antropologia nas expressôes e identidades de gênero dissidentes dos formatos reconhecidos e legitimados socialmente, como aquelas que são reivindicadas por pessoas não binárias (Krasota, 2016). Nessas pesquisas, enfatizaram-se articulaçóes derivadas dos trabalhos de campo entre práticas sexuais, açóes políticas e processos de subjetivação inerentes à constituição de identidades e identificaçôes.

Nesse sentido, chama a atenção a profusão de pesquisas que se dedicaram a ana- 
lisar práticas políticas e ativismos de travestis, mulheres trans, homens trans e pessoas intersexuais. Parte delas concentrou atenção em procedimentos, protocolos, dinâmicas, agentes e equipamentos de Estado direcionados ao atendimento especializado a essas populaçóes. As produçóes também analisaram documentos judiciais e administrativos (Zahra, 2014; Alexandre, 2015; Nunes, 2016; Pereira, D., 2016), elaboraram reflexóes sobre saberes, práticas e produção de conhecimento (Barbosa, 2015) e refletiram sobre temporalidades e reivindicaçóes nos protocolos adotados na atuação de médicos e operadores de saúde para pessoas transexuais (Almeida, 2018) e intersexuais (Machado, 2008).

No contexto das transformaçóes nos formatos ativistas e da proliferação de repertórios de engajamento, vale destacar ainda o uso de novas tecnologias e dispositivos de comunicação nas análises recentes, levando em consideração os espaços virtuais, as redes sociais e a internet. Esse conjunto de pesquisas destacou a emergência de novos formatos e repertórios de atuação política LGBT e feminista em redes sociais, como o Twitter e o Facebook, em blogs e sites (Falcão, 2017; Bulgarelli, 2018; Junior, 2018; Silveira, 2013).

A partir de 2015, os estudos direcionados às abordagens que buscaram refletir sobre o corpo e as dinâmicas de constituição da identidade de homens trans (Rego, 2015), bem como a respeito das experiências de gravidez, gestação e reprodução entre homens trans (Monteiro, A., 2018), também ganharam destaque nas produçóes antropológicas de teses e dissertaçóes sobre a relação entre identidades de gênero e transmasculinidades. Além disso, outras questóes sobre saúdes e direitos, reconhecimentos e agências foram abordadas em pesquisas que se dedicaram a estudar o ativismo e o fazer político de homens trans (Cordeiro, 2016; Ribeiro, 2018).
Por fim, eventos marcantes também ganharam espaço nos estudos antropológicos inseridos no campo dos estudos de gênero e sexualidade. Investigaçóes que se dedicaram a retratar tragédias em boates LGBT (Arosi, 2017) ou que se ocuparam de reconstituir redes que formaram uma imprensa lésbica brasileira (Maia, 2017) enveredaram por diferentes caminhos na tentativa de reconfigurar contextos e perspectivas em etnografias.

\section{Raça e movimento negro}

No campo dos estudos antropológicos sobre os marcadores sociais da diferença, raça também surge como uma categoria central de análise em teses e dissertaçóes entre 2008 e 2018. A incidência significativa de pesquisas que articulam noções como raça e relaçóes étnico-raciais, política e movimentos sociais, apontam, ao menos em parte, para uma dedicação de antropólogos/as brasileiros/as em estudos em comunidades quilombolas e tradicionais e em investigaçóes teóricas que consideram a relevância das diferenciaçóes produzidas com base e por meio de categorias como raça, etnia, racismo, etnicidade, etnocídio, identidades, colonialidade. Além disso, chama a atenção o surgimento de abordagens e questóes teórico-metodológicas em pesquisas mais recentes com o potencial de sugestionar transformaçóes e reconfiguraçóes tanto nas práticas e formulaçóes do movimento negro como nos estudos antropológicos que se dedicaram a estudar tais fenômenos.

Foi possível verificar a existência de pesquisas que investigam formatos de participação entre sociedade civil e poder público, reforçando o caráter de sobreposição de modelos de atuação entre NMS e NVMS identificados em lutas políticas com base em raça e etnia. A incidência institucional 
de militantes negros/as em espaços de articulaçáo socioestatal foi observada por meio de discussóes sobre intolerância religiosa em conselhos municipais voltados para questóes étnico-raciais (Almeida, R., 2014).

Partindo de pesquisas que analisaram lutas e açóes políticas no âmbito dos movimentos negros urbanos, identificou-se ênfase em discussóes a respeito das lutas antirracistas e das relaçóes raciais. Emergem dessas pesquisas categorias como branquitude e negritude, além de distintos formatos classificatórios na constituição das diferenciaçóes internas no movimento negro e também a respeito de suas práticas e concepçóes de atuação política (Sales, 2015; Lopes, 2016; Silva, G., 2017).

Chama a atenção a quantidade de dissertaçóes que, desde 2012, passou a articular questóes envolvendo gênero e raça/etnia em torno de debates sobre corpo, cabelo, estética, identidade e empoderamento. Um conjunto diversificado de aportes teórico-metodológicos e investimentos etnográficos em trabalhos de campo possibilitaram pesquisas sobre empoderamento de mulheres negras (Santos, 2012), transição capilar (Gomes, 2017; Aguiar, 2018) e o cabelo como performance identitária (Quintão, 2013). A articulação desses temas com o crescente uso de redes sociais também apareceu em análises recentes que se dedicaram a acompanhar páginas no Facebook sobre empoderamento de mulheres negras (Maia, 2018) e sobre os intercruzamentos entre transiçáo capilar, consumo e interseccionalidade no YouTube (Matos, 2017).

Notam-se também pesquisas de doutorado dedicadas à investigaçáo de ativismos e movimentos negros em contextos geográficos inter-regionais e internacionais. As produçóes acadêmicas sobre lutas antirracistas em Cuba (Souza, 2015) e sobre a articulação entre violência e território nos movimentos negros da regiáo do Pacífico colombiano
(Rojas, 2016) apresentaram aportes importantes para se obter uma compreensão mais alargada das dinâmicas de lutas de movimentos negros latinos e caribenhos. Discussóes em torno das cotas étnico-raciais e das políticas públicas e de reparação ofereceram análises tanto sobre a implementação de políticas públicas de enfoque étnico-racial em países do Cone Sul (López, 2009) e de açôes afirmativas em cursos de direito e medicina no Brasil (Assis, 2014) quanto sobre uma política de saúde voltada para a população negra em Maceió (Santos, R., 2017).

Entre 2008 e 2018, vale destacar a incidência de pesquisas sobre diferentes tipos de violência que consideraram uma abordagem racial dos fenômenos estudados. A seguir, serão apresentadas teses e dissertaçóes que trataram da violência policial e militar durante as ditaduras militares latino-americanas e já no contexto de democratização de países latinos. De certo modo, o recorte desses estudos permite problematizar os efeitos do processo brasileiro de transição democrática para as configuraçóes contemporâneas de forças judiciais e policiais e o seu impacto na reprodução sistemática de violências contra determinadas populaçóes nos espaços urbanos.

\section{Ditadura militar e violência policial}

É possível verificar na produção de pesquisas antropológicas brasileiras um conjunto de dissertaçóes e teses sobre ditaduras militares na América Latina, mortos e desaparecidos políticos em regimes de exceçóes e mobilização política de familiares em torno da memória de seus entes vitimados pela violência de Estado. No caso brasileiro, o lapso entre o fim da ditadura militar (1985) e a instauração de uma Comissáo Nacional da Verdade (2011) acarretou impactos tanto para a responsabilização sobre as mortes e os desaparecimentos 
ocorridos durante o período militar como em relação ao processo de democratização das instâncias do Estado, sobretudo aquelas vinculadas às forças policiais, judiciais e militares. Tais impactos são notáveis na literatura produzida no período analisado.

Algumas produçóes ajudam a compreender os processos de anistia e reparação do Estado pela perseguiçáo política cometida durante a ditadura militar brasileira (Rosito, 2010), bem como a produção da memória sobre o passado ditatorial argentino (Sanjurjo, 2013). Tanto nessas pesquisas como em investigações dedicadas a compreender os sentidos processados nos contextos de exumação de corpos de desaparecidos políticos do período ditatorial (Ribeiro, 2015), é possível observar uma incidência de investigaçóes que se debruçaram sobre o contexto tardio de produção de memória e verdade sobre as ditaduras latino-americanas. Destaque especial deve ser feito a um conjunto de teses que recuperou processos de reconstituição de parentesco entre netos apropriados pela ditadura (Massa, 2016), bem como as lutas de familiares de mortos e desaparecidos (Goes, 2012; Azevedo, 2016) em ditaduras militares.

As consequências a respeito da incompletude dos processos de transição democrática, sobretudo em relação às forças judiciais e policiais, aparecem em um conjunto de pesquisas que tratam sobre a violência policial e urbana. No contexto da cidade do Rio de Janeiro, há um empenho em etnografias sobre a violência e a implementação de medidas de pacificação em favelas (Toscano, 2015). Um conjunto expressivo de análises buscou compreender as dinâmicas envolvendo mães que perderam seus filhos em contextos de violência (Arosi, 2013; Lima, 2013; Santos, 2018) ou que lutam pela sobrevivência e liberdade de filhos encarcerados (Mestre, 2016). A violência direcionada a jovens e adolescentes ainda é analisada com base em eventos que marcaram a sociedade e ganharam repercussão (Lacerda, 2012), mobilizando a opinião pública a respeito de temas como tortura e homicídio.

\section{Conclusão}

Este artigo realizou um levantamento bibliográfico sobre movimentos sociais no período de dez anos (2008-2018) no campo da antropologia. A pesquisa no catálogo de teses e dissertaçóes da CAPES apontou que, no Brasil, as fronteiras entre os NMS e NVMS são porosas, uma vez que ambas formas de ação coletiva se estabelecem mutuamente na profusão do ativismo contemporâneo. Os trabalhos aqui revisados apontaram que os movimentos antiglobalização foram precursores das novas formas de organização mais descentralizadas que vieram a explodir no Brasil do século XXI, especialmente com a profusão de coletivos horizontais.

As Jornadas de Junho de 2013, a Primavera Feminista em 2015 e as Ocupaçôes Secundaristas em 2016 foram eventos-chave da história recente da política do país, estimulando o interesse de pesquisa em formas de lutas como ocupaçóes, coletivos e manifestaçôes de massa. Além disso, o levantamento também apontou que temáticas consolidadas na antropologia há muitas décadas, como gênero, sexualidade e raça, expandiram ainda mais seu alcance, sugerindo crescente interesse em entender o papel das novas tecnologias digitais, das Primaveras e das grandes marchas na constituição desses movimentos.

Não há dúvidas de que esse campo robusto de trabalhos empíricos etnográficos reflete as transformaçóes por que o Brasil passou no século XXI. Essas mudanças no cenário político nacional conformaram novas subjetividades de ativistas e de pesquisa- 
dores. Existe uma nova geração de pós-graduandos em antropologia que é fruto desse momento nacional e que procura interpretar, muitas vezes de um ponto de vista engajado, tais transformaçóes. Vale ainda notar que o levantamento bibliográfico abarcou trabalhos defendidos até 2018 - ano em que a extrema-direita venceu o pleito eleitoral com a vitória presidencial de Jair Bolsonaro. Pode-se conjecturar que essa mesma geração também responderá à necessidade de se compreender etnograficamente as novas direitas e o conservadorismo e suas articulaçóes com as raízes culturais do autoritarismo brasileiro.
Por fim, o artigo apresenta algumas limitaçóes. Apesar do esforço no mapeamento de tais produçóes, é imprescindível destacar o caráter parcial e preliminar dos dados levantados, pois invariavelmente há lacunas importantes, e recai sobre os autores a responsabilidade sobre a ausência de trabalhos que, porventura, náo apareçam citados. O caráter panorâmico da análise, em razão tanto da abrangência do enfoque encomendado quanto das limitaçóes inerentes a um artigo, justifica a necessidade de um diagnóstico mais denso e aprofundado sobre os dados levantados em termos qualitativos.

\section{Bibliografia}

ADERALDO, Guilherme Andre. Reinventando a "cidade": disputas simbólicas em torno da produçáo e exibiçáo audiovisual de "coletivos culturais" em Sáo Paulo. Tese (Doutorado em Antropologia Social) - Universidade de São Paulo, São Paulo, 2013.

AGUIÃO, Silvia. Fazer-se no "Estado": uma etnografia sobre o processo de constituiçáo dos "LGBT" como sujeitos de direitos no Brasil contemporâneo. Tese (Doutorado em Ciências Sociais) - Universidade Estadual de Campinas, Campinas, 2014.

AGUIAR, Tais Rodrigues. Cabelo além da estética: transiçóes capilares e identitárias pelas negras. Dissertação (Mestrado em Antropologia) - Universidade Federal de Pelotas, Pelotas, 2018.

ALEGRIA, Paula. Sexualidade, política e juventude: uma etnografia das configuraçóes de experimentaçáo da sexualidade e do movimento estudantil entre alunos de uma escola pública. Dissertação (Mestrado em Ciências Sociais) - Pontifícia Universidade Católica do Rio de Janeiro, Rio de Janeiro, 2016.

ALEXANDRE, Juliana Ribeiro. Emoçóes, documentos e subjetivaçáo na construçáo de transexualidades em Joáo Pessoa/PB. Dissertação (Mestrado em Antropologia Social) - Universidade Federal do Rio Grande do Norte, Natal, 2015.

ALMEIDA, Anderson Santos. Vidas em espera: uma etnografia sobre a experiência do tempo no processo transexualizador. Dissertação (Mestrado em Antropologia Social) - Universidade Federal de Goiás, Goiânia, 2018.

ALMEIDA, Igor Cirilo Faria. "Náo queremos gaiolas maiores, queremos gaiolas vazias": uma etnografia de “defensoras" de animais e vegetarianas. Dissertação (Mestrado em Antropologia Social) - Universidade Federal de Goiás, Goiás, 2012.

ALMEIDA, Rosiane Rodrigues de. Quem foi que falou em igualdade?”: controvérsias em torno dos usos e significados da categoria intolerância religiosa entre os membros do Conselho Municipal de Defesa dos Direitos do Negro da cidade do Rio de Janeiro (Comdedine-Rio). Dissertação (Mestrado em Antropologia) - Universidade Federal Fluminense, Niterói, 2014. 
ALVES, Thais da Rosa. Entre a política e o movimento: as concepçóes e as práticas políticas de mulheres negras no Morro da polícia/Porto Alegre. Dissertação (Mestrado em Ciências Sociais) - Universidade do Vale do Rio dos Sinos, São Leopoldo, 2018.

ANDRADE, Fabiana de. Fios para traçar, jogos para armar: o fazer policial nos crimes de violência doméstica e familiar contra a mulher. Dissertação (Mestrado em Antropologia Social) - Universidade Estadual de Campinas, Campinas, 2012.

ANDRADE, Fabiana de. Mas vou até o fim: narrativas femininas sobre experiências de amor, sofrimento e dor em relacionamentos violentos e destrutivos. Tese (Doutorado em Antropologia Social) - Universidade de São Paulo, São Paulo, 2018.

ANDRADE, Inácio de Carvalho Dias. Movimento social, cotidiano e política: uma etnografia da questáo identitária dos sem-teto. Dissertaçăo (Mestrado em Antropologia Social) - Universidade de São Paulo, São Paulo, 2010.

AQUINO, Carlos Roberto Filadelfo de. A coletivizaçáo como processo de construçáo de um movimento de moradia: uma etnografia do Movimento Sem-Teto do Centro (MSTC). Dissertação (Mestrado em Antropologia Social) - Universidade de São Paulo, São Paulo, 2009.

AQUINO, Carlos Roberto Filadelfo de. A luta está no sangue: família, política e movimentos de moradia em Sáo Paulo. Tese (Doutorado em Antropologia Social) - Universidade de São Paulo, São Paulo, 2015.

ARAUJO, Ayni Estevão de. Entre manas e manos: uma etnografia com o movimento de mulheres do hip hop e a Casa do Hip Hop Sanca. Dissertaçáo (Mestrado em Antropologia Social) - Universidade Federal de São Carlos, São Carlos, 2016.

ARNAUD, Lívia Krause. Mulheres e abortos: negociando moralidades. Dissertação (Mestrado em Antropologia Social) - Universidade Federal do Rio de Janeiro, Rio de Janeiro, 2008.

AROSI, Ana Paula. A vítima como categoria política: um estudo etnográfico sobre o movimento de familiares de vítimas de violência no Rio Grande do Sul e no Rio de Janeiro. Dissertaçấo (Mestrado em Antropologia Social) - Universidade Federal do Rio Grande do Sul, Porto Alegre, 2013.

AROSI, Ana Paula. "Lutar náo é loucura": gestáo de desastres, de crises psicológicas e movimentos de familiares de vítimas após o incêndio na boate Kiss. Tese (Doutorado em Antropologia Social) - Universidade Federal do Rio Grande do Sul, Porto Alegre, 2017.

ASSIS, Yérsia Souza de. A experiência das açóes afirmativas na Universidade Federal de Sergipe: os cursos de Direito e Medicina. Dissertação (Mestrado em Antropologia) - Universidade Federal de Sergipe, Aracaju, 2014.

AZEVEDO, Desirée de Lemos. "A única luta que se perde é aquela que se abandona”: etnografia entre familiares de mortos e desaparecidos no Brasil. Tese (Doutorado em Antropologia Social) - Universidade Estadual de Campinas, Campinas, 2016.

BARBIERI, Alexia Oliveira. A nova onda liberal: uma etnografia do protagonismo e engajamento pró-liberalismo no Brasil contemporâneo. Dissertação (Mestrado em Antropologia Social) - Universidade Federal do Rio Grande do Sul, Porto Alegre, 2018.

BARBOSA, Bruno Cesar. Imaginando trans: saberes e ativismos em torno das regulaçóes das transformaçóes corporais do sexo. Tese (Doutorado em Antropologia Social) - Universidade de São Paulo, São Paulo, 2015.

BARBOSA, Fernanda Stroher. Ocupo, logo existo: ocupaçóes secundaristas e o tecer de outra educaçáo possível. Dissertação (Mestrado em Ciências Sociais) - Universidade Federal de Santa Maria, Santa Maria, 2018.

BARBOSA, Luanna Mirella de Souza. Localidade ou metrópole? Demonstrando a capacidade de atuaçáo política das travestis no mundo-comunidade. Dissertação (Mestrado em Antropologia Social) - Universidade de Brasília, Brasília, 2010. 
BARRETTI, Fabricio dos Santos. O germinar do Pinheirinho dos Palmares: etnografia das relaçóes entre removidos, movimento social e Estado. Dissertação (Mestrado em Antropologia Social) - Universidade Federal de São Carlos, São Carlos, 2018.

BATISTA, Paula Nogueira Pires. "Nós comemos e regurgitamos": feminismos transnacionais e coalizóes potenciais a partir da Marcha das Vadias de Goiânia/GO. Dissertação (Mestrado em Antropologia Social) Universidade Federal de Goiás, Goiânia, 2017.

BELTRAME, Priscilla Braga. Aborto: a controvérsia das feminilidades. Dissertação (Mestrado em Antropologia) Universidade Federal de Pernambuco, Recife, 2016.

BONIOLO, Roberta Machado. "Um tempo que se faz novo": o encantamento de uma política pública voltada à regulamentaçáo dos rituais de religióes afro-brasileiras. Dissertação (Mestrado em Antropologia) Universidade Federal Fluminense, Niterói, 2014.

BROCKSOM, Sandra. Vidas e(m) leis: uma etnografia a partir da Lei Maria da Penha. Dissertação (Mestrado em Antropologia Social) - Universidade Federal do Paraná, Curitiba, 2010.

BULGARELLI, Lucas. [ALERTA TEXTÁO] - Estratégias de engajamento político do movimento LGBT da cidade de Sáo Paulo em espaços de interaçáo online e off-line (2015-2016). Dissertação (Mestrado em Antropologia Social) - Universidade de São Paulo, São Paulo, 2018.

CABRAL, Claudia Peixoto. Os dois lados do espelho: protestos de junho de 2013 - construçáo de discurso de poder e controle social. Dissertaçáo (Mestrado em Antropologia Social) - Universidade Federal de Goiás, Goiânia, 2016.

CAMPOS, Natália de. Militância, organizaçáo e mobilizaçáo antiproibicionista da maconha: coletivos, eventos e marchas em Natal (RN). Dissertação (Mestrado em Antropologia Social) - Universidade Federal do Rio Grande do Norte, Natal, 2013.

CARMO, Iris Nery do. O "rolê feminista": uma etnografia entre feministas autônomas em grandes capitais brasileiras. Tese (Doutorado em Ciências Sociais) - Universidade Estadual de Campinas, Campinas, 2018.

CARMO, Milena Mateuzi. Margem adentro: políticas sociais, sujeitos e resistências na zona sul de Sáo Paulo. Dissertação (Mestrado em Antropologia Social) - Universidade de São Paulo, São Paulo, 2016.

CARNEIRO, Rosamaria Giatti. Cenas de parto e políticas do corpo: uma etnografia de experiências femininas de parto humanizado. Tese (Doutorado em Ciências Sociais) - Universidade Estadual de Campinas, Campinas, 2011.

CORDEIRO, Ana Carolina Silva. Gênero, corpo, saúde e direitos: experiência e narrativas de homens (trans) e homens (boys) em espaços públicos. Dissertação (Mestrado em Antropologia) - Universidade Federal de Pernambuco, Recife, 2016.

CORREIA, Ana Paula de Santana. Mulheres da periferia em movimento: um estudo sobre novas trajetórias do feminismo. Dissertação (Mestrado em Ciências Sociais) - Universidade Federal de São Paulo, São Paulo, 2015.

DAY, Richard. From hegemony to affinity: The political logic of the newest social movements. Cultural Studies, v. 18, n. 5, p. 716-748, 2004. https://doi.org/10.1080/0950238042000260360

DELLA PORTA, Donatella. Social movements in times of austerity: bringing capitalism back into protest analysis. Londres: John Wiley \& Sons, 2015.

DIAS, Adriana Abreu Magalhães. Observando o ódio: entre uma etnografia do neonazismo e a biografia de David Lane. Tese (Doutorado em Antropologia Social) - Universidade Estadual de Campinas, Campinas, 2018. 
DUARTE, Tatiane dos Santos. Sobre persistências históricas ou sobre insistentes rebeldias feministas no movimento ecumênico brasileiro. Tese (Doutorado em Antropologia Social) - Universidade de Brasília, Brasília, 2018.

ESCOBAR, Arturo. Culture, practice and politics: anthropology and the study of social movements. Critique of Anthropology, v. 12, n. 4, p. 395-432, 1992. https://doi.org/10.1177\%2F0308275X9201200402

ESCOBAR, Arturo. Encountering development: the making and unmaking of the Third World. Princeton: Princeton University Press, 2011.

ESCOBAR, Arturo. The making of social movements in Latin America: identity, strategy, and democracy. Nova York: Routledge, 2018.

FALCÃO, Thiago Oliveira. Memes, textóes e problematizaçóes: sociabilidade e política a partir de uma comunidade de LGBT universitários no Facebook. Dissertação (Mestrado em Antropologia Social) Universidade Estadual de Campinas, Campinas, 2017.

FARIAS, Lillyane Priscila Silva de. “A justiça penal não se realiza a qualquer preço": etnografia de processos envolvendo estupro de vulnerável no RN. Dissertação (Mestrado em Antropologia Social) - Universidade Federal do Rio Grande do Norte, Natal, 2015.

FERNANDES, Adriana dos Santos. Escuta Ocupaçáo: arte do contornamento, viraçáo e precariedade no Rio de Janeiro. Tese (Doutorado em Ciências Sociais) - Universidade Estadual do Rio de Janeiro, Rio de Janeiro, 2013.

FERREIRA, Emilia Juliana. Um grande júri: análise do processamento penal do aborto. Dissertação (Mestrado em Antropologia Social) - Universidade Federal de Santa Catarina, Florianópolis, 2012.

FERREIRA, Glauco Batista. Arco-íris em disputa: a "Parada da Diversidade" de Florianópolis entre políticas, sujeitos e cidadanias. Dissertaçáo (Mestrado em Antropologia Social) - Universidade Federal de Santa Catarina, Florianópolis, 2012.

FERREIRA, Glauco Batista. Arte, ativismo e espaço urbano na Baía de São Francisco através das açóes do Queer Women of Color Media Arts Project - QWOCMAP. Tese (Doutorado em Antropologia Social) - Universidade Federal de Santa Catarina, Florianópolis, 2017.

FERRIGNO, Mayra Vergotti. Veganismo e libertaçáo animal: um estudo etnográfico. Dissertação (Mestrado em Antropologia Social) - Universidade Estadual de Campinas, Campinas, 2012.

FONTOURA, Renata Moreira. Retóricas, embates e mediaçóes na construçáo da categoria de assédio sexual no Cairo, Egito: uma etnografia na ONG Harassmap. Dissertação (Mestrado em Antropologia) - Universidade Federal Fluminense, Niterói, 2016.

FRANCO, Ana Paula Perrota. Humanidade estendida: a construçáo dos animais como sujeito de direitos. Tese (Doutorado em Sociologia e Antropologia) - Universidade Federal do Rio de Janeiro, Rio de Janeiro, 2015.

FRANCO, José Luiz de Moraes. Cores e Dores do Movimento LGBT de Belém do Pará: trajetória, participaçáo e luta. Tese (Doutorado em Antropologia) - Universidade Federal do Pará, Belém, 2018.

FREIRE, Laura. Retomando a consciência: reaçóes conservadoras a partir do debate sobre família e gênero. Dissertação (Mestrado em Ciências Sociais) - Universidade Estadual do Oeste do Paraná, Toledo, 2018.

FREITAS, Thayanne Tavares. Pintando com elas: uma etnografia a partir do coletivo de graffiti Freedas Crew. Dissertação (Mestrado em Antropologia) - Universidade Federal do Pará, Belém, 2017.

FROEHLICH, Graciela. O bem-estar na carne: um estudo antropológico sobre as relaçóes entre humanos e animais a partir da categoria de "bem-estar animal". Tese (Doutorado em Antropologia) - Universidade de Brasília, Brasília, 2016. 
GARCIA, Isis de Jesus. A produçáo de justiça: um estudo sobre o juizado de violência doméstica e familiar contra a mulher. Tese (Doutorado em Antropologia Social) - Universidade Federal de Santa Catarina, Florianópolis, 2016.

GERBAUDO, Paolo. The mask and the flag: populism, citizenism, and global protest. Oxford: Oxford University Press, 2017.

GIBB, Robert. Toward an anthropology of social movements. Journal des Anthropologues, n. 85-86, p. 233-253, 2001. https://doi.org/10.4000/jda.2904

GIOVANNI, Julia Ruiz di. Cadernos do outro mundo: o Fórum Social Mundial em Porto Alegre. Tese (Doutorado em Antropologia Social) - Universidade de São Paulo, São Paulo, 2013.

GIOVANNI, Julia Ruiz di. Seattle, Praga, Gênova: política anti-globalizaçáo pela experiência da açáo de rua. Dissertação (Mestrado em Antropologia Social) - Universidade de São Paulo, São Paulo, 2008.

GOES, Roderlei Nagib. Dos filhos (desaparecidos) deste solo é máe gentil? Tese (Doutorado em Antropologia Social) - Universidade de Brasília, Brasília, 2012.

GOMES, Carla de Castro. Corpo, emoçáo e identidade no campo feminista contemporâneo brasileiro: a Marcha das Vadias do Rio de Janeiro. Tese (Doutorado em Sociologia e Antropologia) - Universidade Federal do Rio de Janeiro, Rio de Janeiro, 2018.

GOMES, Larisse Louise Pontes. “Posso tocar no seu cabelo?” Entre o liso e o crespo: transiçáo capilar, uma (re)construçáo identitária? Dissertação (Mestrado em Antropologia Social) - Universidade Federal de Santa Catarina, Florianópolis, 2017.

GONÇALVES, Guilherme Neves. De cháo e portóes: a ocupaçáo cultural de um instituto psiquiátrico e as relaçóes entre arte, política e espaço no contemporâneo. Tese (Doutorado em Ciências Sociais) - Pontifícia Universidade Católica do Rio de Janeiro, Rio de Janeiro, 2017.

GORDON, Flavio. A Cidade dos Brights: Religiáo, Política e Ciência no Movimento Neo-Ateísta. Tese (Doutorado em Antropologia Social) - Universidade Federal do Rio de Janeiro, Rio de Janeiro, 2011.

GRAEBER, David. The new anarchists. New Left Review, v. 13, n. 6, p. 61-73, 2002.

GUTTERRES, Anelise dos Santos. A resiliência enquanto experiência de dignidade: antropologia das práticas políticas em um cotidiano de lutas e contestaçóes junto a moradoras ameaçadas de remoçáo nas cidades sede da Copa do Mundo 2014 (Porto Alegre, RS e Rio de Janeiro, RJ). Tese (Doutorado em Antropologia Social) - Universidade Federal do Rio Grande do Sul, Porto Alegre, 2014.

HIRSCH, Olivia. O parto "natural" e "humanizado": um estudo comparativo entre mulheres de camadas populares e médias no Rio de Janeiro. Tese (Doutorado em Ciências Sociais) - Pontifícia Universidade Católica do Rio de Janeiro, Rio de Janeiro, 2014.

HONORATO, Isabelle Brambilla. Entre tensionamentos e disputas: família, religiáo e o processo de se assumir entre os jovens de uma Igreja inclusiva de Manaus. Dissertaçáo (Mestrado em Antropologia Social) Universidade Federal do Amazonas, Manaus, 2016.

IRISARRI, Victoria. Fora do eixo, dentro do mundo: política, mercado e vida cotidiana em um movimento brasileiro de produçáo cultural. Tese (Doutorado em Antropologia Social) - Universidade Federal do Rio Grande do Sul, Porto Alegre, 2015.

JAD, Islah. NGOs: Between buzzwords and social movements. Development in Practice, v. 17, n. 4-5, p. 622-629, 2007. 
JESUS, Fátima Weiss de. Unindo a cruz e o arco-íris: vivência religiosa, homossexualidade e trânsitos de gênero na Igreja da Comunidade Metropolitana de Sáo Paulo. Tese (Doutorado em Antropologia Social) - Universidade Federal de Santa Catarina, Florianópolis, 2012.

JUNIOR, Luiz Augusto Mugnai Vieira. Quantas curtidas merece essa trans?: A recepçáo da transexualidade nas mídias digitais. Tese (Doutorado em Ciências Sociais) - Universidade Estadual Paulista Júlio de Mesquisa Filho, Marília, 2018.

KRASOTA, Alisson Gebrim. Uma noçáo de pessoa trans não binária. Dissertação (Mestrado em Antropologia) Universidade Federal do Paraná, Curitiba, 2016.

LACERDA, Paula Mendes. O "caso dos meninos emasculados de Altamira": polícia, justiça e movimento social. Tese (Doutorado em Antropologia Social) - Universidade Federal do Rio de Janeiro, Rio de Janeiro, 2012.

LEITE, Luciana de Lima Lopes. OCUPAR É REXISTIR! Práticas artísticas como tática de resistência nas ocupaçóes do Coletivo OcupARTHE em Teresina (2014). Dissertação (Mestrado em Antropologia) Universidade Federal do Piauí, Teresina, 2018.

LIMA, Andressa Lídicy Morais. Okupar, resistir, insistir: uma etnografia das práticas de ocupaçáo urbana Fortaleza/Ceará. Dissertação (Mestrado em Antropologia Social) - Universidade Federal do Rio Grande do Norte, Natal, 2012.

LIMA, Anna Georgea Franco Feitosa Mayer de Araujo. Rituais da dor (uma análise do grupo Máes na Dor de João Pessoa PB) - Dissertação (Mestrado em Antropologia). Universidade Federal da Paraíba, João Pessoa, 2013.

LIMA, Junia Marusia Trigueiro de. O caminhar das palavras: um estudo sobre formas de resistência no discurso zapatista. Dissertação (Mestrado em Antropologia Social) - Universidade de Brasília, Brasília, 2009.

LINS, Beatriz Accioly. A lei nas entrelinhas: a Lei Maria da Penha e o trabalho policial em duas Delegacias de Defesa da Mulher de Sáo Paulo. Dissertação (Mestrado em Antropologia Social) - Universidade de São Paulo, São Paulo, 2014.

LIRA, Luciana Campelo de. Limites e paradoxos da moralidade vegan: um estudo sobre as bases simbólicas e morais do vegetarianismo. Tese (Doutorado em Antropologia) - Universidade Federal de Pernambuco, Recife, 2013.

LOBATO, Caio Pereira. Devir-democrático e alter-políticas: ensaio etnográfico sobre assembleias populares horizontais do Rio de Janeiro. Dissertaçáo (Mestrado em Antropologia Social) - Universidade Federal do Rio de Janeiro, Rio de Janeiro, 2016.

LOPES, Joyce Souza. Lugar de branca/o e a/o "branca/o fora do lugar": representaçóes sobre a branquitude e suas possibilidades de antirracismo entre negra/os e branca/os do/no Movimento Negro em Salvador-BA. Dissertação (Mestrado em Antropologia) - Universidade Federal de Pelotas, Pelotas, 2016.

LOPES, Paulo Victor Leite. Sexualidade e construçáo de si em uma favela carioca: pertencimentos, identidades, movimentos. Dissertação (Mestrado em Antropologia Social) - Universidade Federal do Rio de Janeiro, Rio de Janeiro, 2011.

LÓPEZ, Laura Cecília. “Que América Latina se sincere”: uma análise antropológica das políticas e poéticas do ativismo negro em face às açóes afirmativas e às reparaçóes no Cone Sul. Tese (Doutorado em Antropologia Social) - Universidade Federal do Rio Grande do Sul, Porto Alegre, 2009.

LUCENA, Francisca Marcela Andrade. $\mathbf{O}$ funk, o bloco e a rua: práticas artísticas e engajamentos políticos com o Bloco APAFunk. Dissertação (Mestrado em Antropologia) - Universidade Federal Fluminense, Niterói, 2016.

MACHADO, Paula Sandrini. O sexo dos anjos: representaçóes e práticas em torno do gerenciamento sociomédico e cotidiano da intersexualidade. Tese (Doutorado em Antropologia Social) - Universidade Federal do Rio Grande do Sul, Porto Alegre, 2008. 
MACHINI, Mariana Luiza Fiocco. Nas fissuras do concreto: política e movimento nas hortas comunitárias da cidade de Sáo Paulo. Dissertação (Mestrado em Antropologia Social) - Universidade de São Paulo, São Paulo, 2018.

MAFFIOLETTI, Cassio de Albuquerque. Retomando a nossa esquina: o movimento hip hop e suas formas de fazer política em Porto Alegre. Dissertação (Mestrado em Antropologia Social) - Universidade Federal do Rio Grande do Sul, Porto Alegre, 2013.

MAIA, Camila Pereira. Corpo e estética corporal: o papel das páginas do Facebook no empoderamento de mulheres negras. Dissertaçáo (Mestrado em Antropologia) - Universidade Federal do Paraná, Curitiba, 2018.

MAIA, Carolina. Entre armários e caixas postais: escritas de si, correspondências e constituiçáo de redes na imprensa lésbica brasileira. Dissertação (Mestrado em Antropologia Social) - Universidade Federal do Rio de Janeiro, Rio de Janeiro, 2017.

MANFRINATO, Helena de Morais. Islá, mídia e direitos humanos: políticas de representação e visibilidade a partir do agenciamento de uma rede de instituiçóes islâmicas no pós-onze de setembro. Dissertação (Mestrado em Antropologia Social) - Universidade de São Paulo, São Paulo, 2016.

MASSA, Jimena Maria. "Restituiçáo de identidades" e construçáo de parentesco em casos de "netos/as apropriados/as" pela ditadura militar argentina. Tese (Doutorado em Antropologia Social) - Universidade Federal de Santa Catarina, Florianópolis, 2016.

MATOS, Lídia de Oliveira. Transiçáo capilar: cabelos, consumo e interseccionalidade no ciberespaço. Dissertação (Mestrado em Antropologia) - Universidade Federal de Sergipe, Aracaju, 2017.

MAZZER, Fernando Lopes. Economia do desejo e desejo de economia: retroalimentaçáo e troca em coletivos da rede fora do eixo no interior de Sáo Paulo. Dissertaçáo (Mestrado em Antropologia Social) - Universidade Federal de São Carlos, São Carlos, 2016.

MELLO, Jaffia Alves de. Em meio a desafios e conquistas: ativismo feminino popular no grupo Espaço Mulher de Passarinho. Dissertação (Mestrado em Antropologia) - Universidade Federal de Pernambuco, Recife, 2016.

MENDONÇA, Sara Sousa. Mudando a forma de nascer: agência e construçóes de verdades entre ativistas pela humanizaçáo do parto. Dissertaçáo (Mestrado em Antropologia) - Universidade Federal Fluminense, Niterói, 2013.

MESOMO, Juliana Feronatto. Cotidiano em suspenso: remoçáo de populaçóes e mobilizaçáo coletiva no contexto de duplicaçáo da Avenida Tronco em Porto Alegre-RS. Dissertação (Mestrado em Antropologia Social) - Universidade Federal do Rio Grande do Sul, Porto Alegre, 2014.

MESTRE, Simone de Oliveira. "Máes guerreiras": uma etnografia sobre máes de jovens encarcerados em Porto Velho/RO. Dissertação (Mestrado em Antropologia) - Universidade Federal de Minas Gerais, Belo Horizonte, 2016.

MIRANDA, Sabrina Aguiar. “A trilha do arco-íris”: uma etnografia das sociabilidades políticas do Grupo Rainbow em Resende-RJ. Dissertaçáo (Mestrado em Antropologia) - Universidade Federal Fluminense, Niterói, 2017.

MONTEIRO, Anne Alencar. Homens que engravidam: um estudo etnográfico sobre parentalidades trans e reproduçáo. Dissertação (Mestrado em Antropologia) - Universidade Federal da Bahia, Salvador, 2018.

MONTEIRO, Marina. "De pedra e pau”: etnografia sobre o levante popular de junho de 2013 na cidade do Rio de Janeiro e suas continuidades. Tese (Doutorado em Antropologia Social) - Universidade Federal de Santa Catarina, Florianópolis, 2018. 
MORAIS, Janaína de Araújo. "Liberdade ainda que vadia": uma etnografia sobre a Marcha das Vadias do Rio de Janeiro 2013. Dissertaçấo (Mestrado em Ciências Sociais) - Universidade Federal de Juiz de Fora, Juiz de Fora, 2015.

MOREIRA, Raffaella May Fryer. “A gente tava ali”: Repensando a verdade com midiativistas no Rio de Janeiro. Dissertação (Mestrado em Antropologia Social) - Universidade Federal do Rio de Janeiro, Rio de Janeiro, 2016.

MOURA, Alice Bezerra de Mello. Remoçóes forçadas, moradas desmanteladas: uma intervençáo estatal no Loteamento Sáo Francisco. Dissertação (Mestrado em Antropologia) - Universidade Federal de Pernambuco, Recife, 2016.

MUHALE, Miguel Joaquim Justino. Lutar, criar, poder popular: uma perspectiva etnográfica do Bloco de lutas pelo Transporte público em Porto Alegre/RS. Dissertação (Mestrado em Antropologia Social) - Universidade Federal do Rio Grande do Sul, Porto Alegre, 2014.

MUNIAGURRIA, Lorena Avellar de. As políticas da cultura: uma etnografia de trânsitos, encontros e militância na construçáo de uma política nacional de cultura. Tese (Doutorado em Antropologia Social) - Universidade de São Paulo, São Paulo, 2016.

NADAI, Larissa. Descrever crimes, decifrar convençóes narrativas: uma etnografia entre documentos oficiais da Delegacia de Defesa da Mulher de Campinas em casos de estupro e atentado violento ao pudor. Dissertação (Mestrado em Antropologia Social) - Universidade Estadual de Campinas, Campinas, 2012.

NOVAIS, Kaito Campos de. Gestos de amor, gestaçốes de lutas: uma etnografia desenhada sobre o Movimento Mães pela Diversidade. Dissertação (Mestrado em Antropologia Social) - Universidade Federal de Goiás, Goiânia, 2018.

NUNES, Marina Cápua. Processo de Transexualizaçáo: uma trajetória de militância trans na cidade de Juiz de Fora (2011-2016). Dissertação (Mestrado em Ciências Sociais) - Universidade Federal de Juiz de Fora, Juiz de Fora, 2016.

OLIVAR, José Miguel Nieto. Guerras, trânsitos e apropriaçóes: políticas da prostituição feminina a partir das experiências de quatro mulheres militantes em Porto Alegre. Tese (Doutorado em Antropologia Social) Universidade Federal do Rio Grande do Sul, Porto Alegre, 2010.

OLIVEIRA, Fabiana Santos Rodrigues de. Maconheirinhos: cuidado, solidariedade, e ativismo de pacientes e seus familiares, em torno do óleo de maconha rico em canabidiol (CBD). Dissertação (Mestrado em Antropologia Social) - Universidade de Brasília, Brasília, 2016.

OLIVEIRA, Luiz Gustavo Silva de. “O Senhor é meu pastor e ele sabe que eu sou gay”: etnografando duas igrejas inclusivas na cidade de Sáo Paulo. Dissertação (Mestrado em Ciências Sociais) - Pontifícia Universidade Católica do Rio de Janeiro, Rio de Janeiro, 2017.

OSTROWER, Isabel Milanez. Cuidar da casa e lutar pela moradia: a política vivida em uma ocupaçáo urbana. Tese (Doutorado em Antropologia Social) - Universidade Federal do Rio de Janeiro, Rio de Janeiro, 2012.

PANTOJA, Leila Saraiva. “Náo leve flores”: crônicas etnográficas junto ao Movimento Passe Livre-DF. Dissertaçấo (Mestrado em Antropologia Social) - Universidade de Brasília, Brasília, 2017.

PATERNIANI, Stella Zagatto. Política, fabulaçáo e a ocupaçáo Mauá: etnografia de uma experiência. Dissertaçâo (Mestrado em Antropologia Social) - Universidade Estadual de Campinas, Campinas, 2013.

PEIRANO, Mariza. A antropologia como ciência social no Brasil. Etnográfica, v. 4, n. 2, p. 219-232, 2000.

PEREIRA, Denis da Silva. Violência Contra LGBT's em Manaus e agências da resistência e do enfrentamento: estudo de uma disputa territorial assimétrica dos campos da moral e do Direito. Tese (Doutorado em Antropologia Social) - Universidade Federal do Amazonas, Manaus, 2016. 
PEREIRA, Renata de Mello Cerqueira. O que acontece embaixo da ponte? Juventudes e ocupaçáo de espaço público. Dissertação (Mestrado em Antropologia) - Universidade Federal de Sergipe, Aracaju, 2016.

PINTO, Ana Cândida Pena Vieira. Presença feminina na liderança neopentecostal brasileira: as profetisas do Espírito Santo e novas formas de adesáo religiosa. Dissertação (Mestrado em Antropologia Social) Universidade de Brasília, Brasília, 2014.

PINTO, Vinicius Cruz. “ALDEIA RESISTE!”: uma etnografia das estratégias políticas da "Aldeia Maracanã” no Rio de Janeiro. Dissertação (Mestrado em Antropologia) - Universidade Federal Fluminense, Niterói, 2014.

PORTO, Rozeli Maria. Aborto legal e o "cultivo ao segredo": dramas, práticas e representaçóes de profisionais de saúde, feministas e agentes sociais no Brasil e em Portugal. Tese (Doutorado em Antropologia Social) Universidade Federal de Santa Catarina, Florianópolis, 2009.

POTECHI, Bruna. Quando começa a pessoa legal? O nascituro no legislativo brasileiro. Dissertação (Mestrado em Antropologia Social) - Universidade Federal de São Carlos, São Carlos, 2013.

PULHEZ, Mariana Marques. Mulheres mamíferas: práticas da maternidade ativa. Dissertação (Mestrado em Antropologia Social) - Universidade Estadual de Campinas, Campinas, 2015.

QUINTÃO, Adriana Maria Penna. O que ela tem na cabeça? Um estudo sobre o cabelo como performance identitária. Dissertaçăo (Mestrado em Antropologia) - Universidade Federal Fluminense, Niterói, 2013.

RAMOS, Izabela Nálio. Entre "perifeminas" e “minas de artilharia”: participaçáo e identidade de mulheres no hip hop e no funk. Dissertação (Mestrado em Antropologia Social) - Universidade de São Paulo, São Paulo, 2016.

RANGEL, Marcia Maria Rodrigues. Aborto: o segredo em julgamento. Dissertação (Mestrado em Antropologia Social) - Universidade Federal da Grande Dourados, Dourados, 2015.

REGO, Francisco Cleiton Vieira Silva do. Viver e esperar viver: corpo e identidade na transiçáo de gênero de homens trans. Dissertaçáo (Mestrado em Antropologia Social) - Universidade Federal do Rio Grande do Norte, Natal, 2015.

REIS, Izis Morais Lopes dos. Diálogos e conflitos entre campos de conhecimento: o Ministério Público após a Lei Maria da Penha. Tese (Doutorado em Antropologia Social) - Universidade de Brasília, Brasília, 2016.

RENOU, Mariana Vitor. Oferenda e lixo religioso: como um grupo de sacerdotes do candomblé angola de Nova Iguaçu "faz o social". Dissertação (Mestrado em Antropologia Social) - Universidade Federal do Rio de Janeiro, Rio de Janeiro, 2011.

RIBEIRO, Amanda Brandão. Relampejos do passado: inscrição da morte no espaço público através da exumaçáo de corpos de desaparecidos políticos da ditadura militar brasileira. Dissertação (Mestrado em Antropologia Social) - Universidade de São Paulo, São Paulo, 2015.

RIBEIRO, Daniel de Oliveira Medeiros. Negociando com as normas: transexualidades masculinas, reconhecimentos e agências. Dissertação (Mestrado em Ciências Sociais) - Universidade Federal de Juiz de Fora, Juiz de Fora, 2018.

ROCHA, Rodrigo Carlos da. Projetos e cotidiano de um movimento cristáo na Universidade de Brasília: o NVC. Dissertação (Mestrado em Antropologia Social) - Universidade de Brasília, Brasília, 2011.

RODRIGUES, Laís Oliveira. Parir é libertário: etnografia em um grupo de apoio ao parto humanizado de Recife/ PE. Tese (Doutorado em Antropologia) - Universidade Federal de Pernambuco, Recife, 2015.

ROJAS, Mauricio Pardo. Movimentos negros na regiáo do Pacífico Colombiano: organizaçóes, violência e território. Tese (Doutorado em Antropologia Social) - Universidade Federal de Santa Catarina, Florianópolis, 2016. 
ROSITO, João Baptista Álvares. O Estado pede perdáo: a reparaçáo por perseguiçáo política e os sentidos da anistia no Brasil. Dissertaçáo (Mestrado em Antropologia Social) - Universidade Federal do Rio Grande do Sul, Porto Alegre, 2010.

SALES, Natalia. Fazendo movimento negro: sentidos de política e relaçóes raciais na micropolítica do(s) movimento(s) negro(s) de Duque de Caxias/RJ. Dissertação (Mestrado em Antropologia) - Universidade Federal Fluminense, Niterói, 2015.

SAMICO, Shirley de Lima. Um estudo sobre a participaçáo de jovens e mulheres no movimento hip hop. Dissertação (Mestrado em Antropologia) - Universidade Federal de Pernambuco, Recife, 2013.

SANJURJO, Liliana Lopes. Sangue, identidade e verdade: memórias sobre o passado ditatorial na Argentina. Tese (Doutorado em Antropologia Social) - Universidade Estadual de Campinas, Campinas, 2013.

SANTOS, Cinthia Marques. Sonhos em movimento: perspectivas de empoderamento de mulheres negras. Dissertação (Mestrado em Antropologia Social) - Universidade Federal de Goiás, Goiânia, 2012.

SANTOS, Fabiano Cunha dos. "Pode queimar, tá legalize": uma antropologia sobre o uso recreativo de drogas na cidade. Tese (Doutorado em Antropologia) - Universidade Federal da Bahia, Salvador, 2017.

SANTOS, Janrryer Mota. Sangue, silêncio e revolta: uma etnografia com mães que perderam seus filhos nas lutas faccionais do crime ou pela violência policial. Dissertaçāo (Mestrado em Antropologia) - Universidade Federal Fluminense, Niterói, 2018.

SANTOS, Renata de Oliveira Braga dos. Guerra e parto: uma análise antropológica sobre a humanizaçáo do nascimento em Belo Horizonte. Dissertação (Mestrado em Antropologia Social) - Universidade Federal de Minas Gerais, Belo Horizonte, 2016.

SANTOS, Roberta Dayanne de Oliveira. "Eu náo vejo muitos negros aqui": uma etnografia sobre a Política Nacional de Saúde Integral de Populaçáo Negra em Maceió. Dissertaçáo (Mestrado em Antropologia Social) - Universidade Federal de Alagoas, Maceió, 2017.

SCHNEIDER, Kamila Guimarães. “A revolução está no prato”: do global ao local no movimento slow food. Dissertação (Mestrado em Antropologia Social) - Universidade Federal de Santa Catarina, Florianópolis, 2015.

SEGARRA, Josep Juan. "Paz entre nós, guerra aos senhores!": uma etnografia sobre o bloco de lutas pelo transporte público e a ocupaçáo da Câmara de Vereadores de Porto Alegre. Dissertação (Mestrado em Antropologia Social) - Universidade Federal do Rio Grande do Sul, Porto Alegre, 2015.

SEGATA, Juliara Borges. "Mamáes ativas": etnografia de um grupo de gestantes. Dissertaçáo (Mestrado em Antropologia Social) - Universidade Federal do Rio Grande do Norte, Natal, 2017.

SIERRA, Andres Leonardo Gongora. Farmacopeia política: uma etnografia do antiproibicionismo e as lutas pela libertaçáo da maconha na Colômbia. Tese (Doutorado Antropologia Social) - Universidade Federal do Rio de Janeiro, Rio de Janeiro, 2018.

SILVA, Anelise Fróes da. Mulheres em movimento(s): estudo etnográfico sobre a inserçáo de feministas e lésbicas em movimentos sociais institucionalizados e autônomos na cidade de Porto Alegre/RS. Dissertaçáo (Mestrado em Antropologia Social) - Universidade Federal de Santa Catarina, Florianópolis, 2010.

SILVA, Gracielle da Costa. Movimento negro ou movimentos negros? As múltiplas vozes da militância antirracista em Campina Grande-PB. Dissertação (Mestrado em Antropologia) - Universidade Federal de Pernambuco, Recife, 2017.

SILVA, Julia do Carmo da. Feministas por opçáo, católicas pelo direito de decidir: agentes feministas na Igreja Católica. Dissertação (Mestrado em Ciências Sociais) - Universidade Federal de Santa Maria, Santa Maria, 2015. 
SILVA, Maynara Costa de Oliveira. A via crucis da legalidade: violência sexual, aborto e objeçáo de consciência em uma maternidade potiguar. Dissertação (Mestrado em Antropologia Social) - Universidade Federal do Rio Grande do Norte, Natal, 2017.

SILVA, Priscilla Monteiro do Nascimento. Performances de gênero e música: etnografia de um movimento riot grrrl no Rio de Janeiro. Dissertação (Mestrado em Antropologia) - Universidade Federal Fluminense, Niterói, 2018.

SILVA, Raquel Sant'anna. A naçáo cujo Deus é o Senhor: a imaginaçáo de uma coletividade evangélica a partir da Marcha para Jesus. Tese (Doutorado em Antropologia Social) - Universidade Federal do Rio de Janeiro, Rio de Janeiro, 2017.

SILVA, Raquel Souza da. Poder, tecnologias digitais e política partidária: a "ideologia horizontal" e os movimentos sociais “\#RevoltadoBusão” e “\#ForaDilma” em Natal-RN. Tese (Doutorado em Antropologia) - Universidade Federal Fluminense, Niterói, 2017.

SILVA, Raquel Souza da. Twitter e ciberativismo: o movimento social da hashtag \#ForaMicarla em Natal-RN. Dissertaçấo (Mestrado em Antropologia Social) - Universidade Federal do Rio Grande do Norte, Natal, 2012.

SILVA, Sarah Araujo Teixeira e. Para além do silêncio: os discursos femininos sobre as marcas da violência conjugal. Dissertação (Mestrado em Antropologia) - Fundação Universidade Federal do Piauí, Teresina, 2013.

SILVA, Tamires Barbosa Rossi. Experiências multissituadas: entre cursinhos trans e ativismos: quais narrativas, que cidadania é essa? Dissertação (Mestrado em Ciências Sociais) - Universidade Estadual Paulista "Júlio de Mesquita Filho", Marília, 2017.

SILVEIRA, Natália Alves Cardoso Orlandi. "Os assuntos que discutimos são a cara da nossa luta”: um estudo antropológico dos debates feministas em meio às possibilidades de sociabilidade online. Dissertaçáo (Mestrado em Antropologia Social) - Universidade Federal do Rio Grande do Sul, Porto Alegre, 2013.

SILVESTRIN, Mauro Leno. O movimento pró canábis no Rio de Janeiro (2002-2012): experiências, trajetórias e atores. Dissertação (Mestrado em Antropologia Social) - Universidade Federal do Paraná, Curitiba, 2013.

SIMAS, Raquel. Doulas e o movimento pela humanizaçáo do parto: poder, gênero e a retórica do controle das emoçôes. Dissertação (Mestrado em Antropologia) - Universidade Federal Fluminense, Niterói, 2016.

SLENES, Rebecca de Faria. Negociaçáo de sentidos: violência e direitos da mulher na prática de ONGs em Marrocos. Dissertação (Mestrado em Antropologia Social) - Universidade Estadual de Campinas, Campinas, 2014.

SOUSA, Cassia Helena Dantas. Mulheres e itinerários abortivos: etnografia sobre os "caminhos" do misoprostol na capital norteriograndense. Dissertação (Mestrado em Antropologia Social) - Universidade Federal do Rio Grande do Norte, Natal, 2016.

SOUZA, Aline Ribeiro Quintanilha de. "Nossa bandeira é nosso peito": gênero, corporalidade e política na Marcha das Vadias do Rio de Janeiro. Dissertação (Mestrado em Antropologia) - Universidade Federal Fluminense, Niterói, 2015.

SOUZA, Angela Maria de. A caminhada é longa... e o chão tá liso: o movimento hip hop em Florianópolis e Lisboa. Tese (Doutorado em Antropologia Social) - Universidade Federal de Santa Catarina, Florianópolis, 2009.

SOUZA, Julia Machado. O fim do antropocentrismo? Propostas para repensar o não humano a partir de militâncias em defesa dos animais na cidade de Florianópolis - SC. Dissertação (Mestrado em Antropologia Social) - Universidade Federal de Santa Catarina, Florianópolis, 2013. 
SOUZA, Patricia Lanes Araujo de. Entre becos e ONGs: etnografia sobre engajamento militante, favela e juventude. Tese (Doutorado em Antropologia) - Universidade Federal Fluminense, Niterói, 2017.

SOUZA, Priscila do Rocio Oliveira de. Celebrando corpos, debatendo movimentos: a sexualidade da mulher negra das redes às festas negras em SP. Dissertação (Mestrado em Antropologia) - Universidade Federal do Paraná, Curitiba, 2018.

TESTA, Sabrina. Os mínimos indícios de comunhâo e libertaçáo: etnografia de um movimento católico conservador. Dissertação (Mestrado em Antropologia Social) - Universidade Federal de Santa Catarina, Florianópolis, 2013.

TOSCANO, Gabriel Bayarri. Novos conflitos nas cidades e antigas práticas policiais: análise dos mecanismos de mediaçáo em favelas atendidas pelas Unidades de Polícias Pacificadoras - UPPs. Dissertação (Mestrado em Antropologia) - Universidade Federal Fluminense, Niterói, 2015.

TRINDADE, Analice Ohashi da. "Vale a pena acreditar na cidade": o movimento ativista em Curitiba e suas práticas. Dissertação (Mestrado em Antropologia) - Universidade Federal do Paraná, Curitiba, 2016.

TROTTA, Clara Cazarini. Entre uma mãe e uma feminista: relaçóes entre feminismos e maternidades. Dissertação (Mestrado em Antropologia) - Universidade Federal de Minas Gerais, Belo Horizonte, 2017.

TUSSI, Fernanda Pivato. Aborto vivido, aborto pensado: aborto punido? As (inter)faces entre as esferas pública e privada em casos de aborto no Brasil. Dissertação (Mestrado em Antropologia Social) - Universidade Federal do Rio Grande do Sul, Porto Alegre, 2014.

VALPASSOS, Carlos Abrãao Moura. Abortos e histórias sobre eles. Tese (Doutorado em Sociologia e Antropologia) - Universidade Federal do Rio de Janeiro, Rio de Janeiro, 2011.

VARGAS, Janaína Charao. Corpo, experiência e feminismo: um estudo do movimento Marcha das Vadias em Santa Maria. Dissertação (Mestrado em Ciências Sociais) - Universidade Federal de Santa Maria, Santa Maria, 2016.

VIANA, Priscila de Souza. Gênero, poder e silêncio: um olhar antropológico sobre narrativas de aborto. Dissertação (Mestrado em Antropologia) - Universidade Federal de Sergipe, Aracaju, 2015.

VILELA, Diego Breno Leal. Ativismo vegano em Natal: uma etnografia de mobilizaçáo política, alimentaçáo ética e identidades. Dissertação (Mestrado em Antropologia Social) - Universidade Federal do Rio Grande do Norte, Natal, 2013.

ZAHRA, Vivian Manfrim Muhamed. As representaçóes da(o)s transexuais nas aldeias arquivos do TJRS: alteraçáo do nome social, eis a grande questáo. Dissertaçáo (Mestrado em Antropologia) - Universidade Federal da Grande Dourados, Dourados, 2014.

ZANOLI, Vinícius Pedro C. Fronteiras da política: relaçóes e disputas no campo do movimento LGBT em Campinas (1995-2013). Dissertação (Mestrado em Antropologia Social) - Universidade Estadual de Campinas, Campinas, 2015. 


\section{Introdução}

Este artigo se propóe a revisar a produção antropológica sobre museus nos últimos dez anos (2009-2019). A empreitada de um balanço dessa natureza não deixa de ser um desafio na medida em que essa produçáo de conhecimento, quando comparada a outras áreas de pesquisa, é relativamente recente e sua organização sistemática no âmbito das ciências sociais, especialmente na antropologia, data praticamente dos últimos decênios do século XX. Além disso, boa parte dela encontra-se difusa em revistas não necessariamente especializadas na área da antropologia, em dossiês temáticos, livros e coletâneas, monografias, dissertaçóes, teses e textos apresentados em simpósios, congressos e outros canais da comunicação acadêmica.

Enquanto critério organizativo e analítico, o reagrupamento temático do material analisado, relacionado a antropologia e museus, é sempre uma tarefa arriscada. Isso porque determinados temas se entrecruzam e até se ramificam, algumas vezes se aproximam e outras náo. Assim como em toda revisão bibliográfica, a sua abrangência impóe certas clivagens, o que exige alguns recortes e limites conforme as estratégias perseguidas. Desse modo, buscou-se, na medida do possível, mapear algumas tendências mais recorrentes e outras insurgentes nas últimas décadas. A opção de análise adotada é qualitativa, orientada por critérios cronológicos.

Embora a classificação proposta busque dialogar com algumas tentativas de rastreamento anteriores, o propósito deste levantamento responde a critérios elaborados pelos autores deste balanço em razáo do material pesquisado e analisado. Por essa razão, preferiu-se organizar temas em torno de suas recorrências ao invés da identificação a eixos conceituais. Recorrências temáticas foram inferidas com base em indicadores que correspondem a campos de pesquisas empíricas e, com isso, evitou-se o enquadramento dessa produção a tendências teóricas como critério classificatório. Nos limites desse trabalho não foram analisadas perspectivas teóricas utilizadas pelos autores, em alguns casos apenas referenciadas.

Embora o período analisado seja preferencialmente os últimos dez anos, isso náo se tornou fator impeditivo de cotejar com a produçáo de anos anteriores, o que permite melhor identificar continuidades e mu-

\footnotetext{
IUniversidade Federal de Pernambuco - Recife (PE), Brasil. E-mail: antonio-motta@uol.com.br

${ }^{\mathrm{II}}$ Universidade Federal de Goiás - Goiânia (GO), Brasil. E-mail: belatamaso@gmail.com
} 
danças nos temas pesquisados, assim como acompanhar e avaliar comparativamente o crescimento dessa produção com base em um conjunto mais amplo.

Convém também assinalar que se analisou a produçáo de conhecimento antropológico sobre museus com base em alguns critérios:

- publicaçóes impressas e digitais organizadas pelo Comitê de Patrimônio e Museus da Associação Brasileira de Antropologia (ABA);

- capítulos publicados em livros diversos; e

- artigos em periódicos de antropologia el ou museologia e de algumas áreas afins, entre os de maior relevância e, quando possível, avaliados pelo sistema Qualis da Coordenação de Aperfeiçoamento de Pessoal de Nível Superior (Capes).

Em razão dos próprios limites deste balanço, a produção de dissertações e teses nos programas de antropologia e de áreas afins foram consultadas e não analisadas, servindo como indicadores numéricos de expansão da área. Do mesmo modo, os trabalhos publicados em anais de reunióes e congressos foram apenas consultados quantitativamente, o que sinaliza uma crescente ampliação dessa área, notadamente nos últimos dez anos.

Para o rastreamento de palavras-chave, utilizou-se temas que derivam de uma especificidade antropológica e de interfaces correlatas com museus. Como critério de busca, utilizou-se bases digitais em bibliotecas, com menções à palavra "museus" nos trabalhos acadêmicos selecionados e sua respectiva associação com a palavra "antropologia", de modo a corroborar a inserçáo de cada trabalho dentro da perspectiva da antropologia dos museus. Além disso, o mapeamento de títulos dos livros e dos ar- tigos foi correlacionado aos autores e coautores sugeridos.

$\mathrm{O}$ artigo se estrutura em sete tópicos. O primeiro tópico focaliza a reaproximação da antropologia com os museus, tendo como ênfase mudanças operadas ao longo do tempo, a considerar os museus como um lócus privilegiado da diversidade sociocultural no país. O segundo tópico trata do período de expansão do campo museal com base na criação de políticas culturais favoráveis, na criação de novos cursos de museologia, no papel institucional desempenhado pelo Comitê de Patrimônio e Museus da ABA e em condiçôes que permitiram a consolidaçáo de uma produção de conhecimento sistemática sobre antropologia e museus. O terceiro tópico focaliza a importância do diálogo travado entre antropologia, museologia e áreas afins voltadas para o entendimento dos museus como fenômenos socioculturais relevantes. $\mathrm{O}$ quarto tópico busca revisitar, situar e contextualizar cronologicamente, ao longo das últimas décadas, diferentes narrativas sobre o campo da antropologia dos museus, dialogando com tentativas de balanços anteriores. O quinto tópico examina a produção dos últimos dez anos buscando estabelecer interconexóes temáticas com o conjunto da produção analisada. $\mathrm{O}$ sexto tópico analisa algumas tendências mais recentes, identificando rupturas e continuidades, e o sétimo e último tópico sugere novas tendências de abordagem temáticas.

\section{Quando antropologia e museus se reencontram}

As afinidades eletivas entre antropologia e museus são irrefutáveis e, de certo modo, inseparáveis da própria história da antropologia. Apesar disso, as instituiçóes museais 
não ficaram incólumes às revisões críticas por parte de antropólogas e antropólogos que têm se debruçado sobre os mais diversos enfoques ao mesmo tempo em que buscam repensar abordagens já existentes com base em novas perspectivas.

$\mathrm{Na}$ antropologia brasileira, um dos primeiros a chamar a atençáo para a reaproximação mais recente entre antropologia e museus foi José Reginaldo Santos Gonçalves, em artigo publicado em 2005 no Boletim Informativo e Bibliográfico de Ciências Sociais (BIB). Nele, Gonçalves traça um amplo panorama sobre coleçóes, museus e patrimônios sob a perspectiva teórica e analítica de uma antropologia dos objetos. Adverte o autor que concomitantemente à reaproximação dos antropólogos com os museus, verifica-se:

um trabalho de problematização sistemática (e denúncia) do papel desempenhado por essas instituiçóes enquanto mediadores sociais, simbólicos e políticos no processo de representações ideológicas sobre diversos grupos e categorias sociais, especialmente aqueles que foram tradicionalmente eleitos como "objetos" de estudo da antropologia (Gonçalves, 2005, p. 10).
Com efeito, algumas mudanças conceituais se sucederam cronologicamente no campo da história da antropologia e dos museus, possibilitando revisóes críticas e teóricas que têm permitido à antropologia lançar novas perspectivas de interpretação sobre os museus. Ao longo do tempo, mudanças paradigmáticas sobrevieram: modelos taxonômicos serviram como ferramentas importantes para o evolucionismo, sendo utilizados para inventariar coleçóes de objetos nos museus. ${ }^{1}$ Com o apogeu culturalista, ${ }^{2}$ os acervos etnográficos foram convertidos em marcadores singulares de determinadas culturas e, mais recentemente, conforme assinala Regina Abreu, Manuel Ferreira Lima Filho e Renato Athias (2016, p. 7), prepondera a tendência revisionista de considerar os "museus como sintoma de práticas sociais e de poder".

Inicialmente identificados como projetos de construção da nacionalidade, alguns museus adquiriram no presente novos significados sociais e políticos e, por isso, já não são pensados unicamente como espaços de produção de memórias nacionais hegemônicas nem como lugares para conservação de relíquias e de conhecimentos perdidos em épocas passadas, alinhados ao ideal civilizatório da nação — prática então recorrente

1 No século XIX, esse tipo de museu foi marcado pelo apogeu do colecionismo etnográfico, por meio do qual foi possível identificar, classificar e reconhecer diferentes tipos de povos graças a inventários sistemáticos de suas culturas materiais. Foi nessa época que a pesquisa antropológica deu ênfase ao estudo descritivo e comparativo de culturas materiais e, por isso, as coleçóes etnográficas se prestaram como fontes do conhecimento científico para investigar processos evolutivos da espécie humana. Guiados por critérios evolucionistas, os objetos eram classificados e catalogados de forma unilinear e náo contextual, sendo ressaltadas suas qualidades funcionais externas. Sobre o assunto, consultar Stocking (1985) e Abreu e Russi (2018).

2 Sob a influência de Franz Boas, os acervos etnográficos começaram a ser classificados e organizados em razão do contexto original a que pertenciam — isso baseado no princípio de que cada cultura continha em si seus próprios valores e sua própria história. Com isso, buscou-se preservar as múltiplas funçôes e significados dos objetos e de suas morfologias, sendo os artefatos considerados não apenas pelo seu valor estético, mas, sobretudo, pelo valor de uso, de técnicas de fabricação, de transmissão de saber e importância enquanto expressão ou testemunho de determinada cultura. Por outro lado, isso permitiu também que tais objetos pudessem estabelecer relaçóes de filiaçōes entre elementos semelhantes, embora provenientes de culturas diferentes. Sobre o assunto, consultar Motta (2018b, p. 343-350). 
nos primeiros museus construídos no Brasil, na segunda metade do século XIX. ${ }^{3}$

Mais recentemente, o que tem preponderado com maior frequência entre as instituições museais é a fragmentação de grandes narrativas, que geralmente urdiam construçóes discursivas e expográficas sobre uma identidade nacional que se queria hegemônica. Isso porque desde a segunda metade do século XX o projeto político de uma unidade étnica nacional foi contestado, do mesmo modo que suas formas de representaçôes monoétnicas e monoculturais da sociedade nacional que objetivavam apagar as diferenças culturais (Motta, 2018c).

Com isso, o ponto de inflexão narrativo, adotado por alguns museus, tem se deslocado para as diferenças socioculturais e, assim, a "nação" com seus diferentes grupos étnicos e a sociedade nacional que a compóe passaram a ser compreendidas, representadas e exibidas em alguns espaços museais, por meio de sua pluralidade cultural e dinâmicas histórico-sociais contraditórias, tendo como foco expositivo uma intricada rede de relaçóes assimétricas de poder que refletem até hoje disparidades sociais seculares no país (Motta, 2018c).

Por conta disso, alguns museus ganharam maior potência e visibilidade com o protagonismo de micronarrativas individuais e coletivas, tendo como principal destaque os chamados atores sociais da diversidade, comprometidos com o reconhecimento das diferenças culturais enquanto valor ético e político fundamentais. Ao adotar tal postura, alguns deles abandonaram a voz factual, baseada em uma série de eventos históricos que se desdobram cronologicamente, em favor de um ponto de vista nem sempre consensual. Essa perspectiva crítico-analítica tem mobilizado a atenção de boa parte da produção acadêmica antropológica sobre os museus e os patrimônios nos últimos anos. ${ }^{4}$

Tais mudanças conceituais na construção de novas narrativas museológicas, espelhadas também em suas práticas museográficas, em certo sentido, respondem também a determinadas conquistas democráticas ocorridas nos últimos anos. É que as políticas públicas da cultura encamparam o conceito de diversidade e de direitos culturais diferenciados com ressonância no campo dos museus e da "patrimonialização das diferenças" (Abreu, 2015).

Como resultado de certos avanços político-democráticos, especialmente no curto período de 2003 a 2016, as diferenças culturais passaram, com maior frequência, a orientar as construçóes discursivas a respeito das novas noçóes de cidadania, reivindicadas e negociadas por movimentos sociais junto ao Estado, sendo incorporadas à Constituição Federal de 1988. Isso se deve principalmente a um conjunto de mudanças conceituais operadas no campo dos direitos relacionados às chamadas políticas de identidade e ao reconhecimento de direitos culturalmente diferenciados e que têm ainda hoje ecoado nos museus e nos estudos antropológicos sobre eles. ${ }^{5}$

\section{Efervescência e consolidação da pesquisa antropológica sobre museus}

O período de 2003 a 2016 foi auspicioso para o campo dos museus e do patrimô-

3 Sobre o assunto, consultar Motta (2018c, p. 337-350).

4 Sobre o assunto, ver Motta (2018a, p. 157-165).

5 Sobre o assunto, ver Motta (2019, p. 268-261). 
nio, coincidindo não apenas com uma reviravolta nas perspectivas conceituais adotadas pelas instituições museais, como também na esfera das políticas culturais, que permitiram alocar maiores recursos no campo da cultura, impulsionando a criação de novas instituiçóes museais por todo o território nacional, com escalas e missóes diferenciadas. Soma-se a isso a criação do Instituto Brasileiro de Museus (Ibram) em 2009, a constituição do Sistema Nacional de Museus, que aglutinou redes de sistemas estaduais e municipais em todo o país, assim como outras açóes culturais que impactaram positivamente o campo museal. ${ }^{6}$

Em proporcional intensidade, o campo museológico também conheceu uma efervescência nunca imaginada. Com a implementação do Programa de Apoio a Planos de Reestruturação e Expansão das Universidades Federais (Reuni) foram criados 12 novos cursos de bacharelado em museologia, juntando-se aos dois já existentes: Universidade Federal do Estado do Rio de Janeiro (Unirio) (1932) e Universidade Federal da Bahia (UFBA) (1969). ${ }^{7}$ Com a criação de novos cursos de museologia, alguns deles sediados em departamentos de antropologia ou áreas afins, foi possível incrementar um diálogo ainda mais próximo com a antropologia, atraindo estudantes interessados em estreitar conhecimentos entre a museologia e as ciências sociais, seja por meio da criação de grupos de pesquisa, com a participação de alunos de graduação de museologia, seja por meio da formação de redes acadêmicas e encontros regionais e nacionais.

Ancorado fortemente nesse processo de ampliação e democratização da educação e da cultura no Brasil, o Comitê de Patrimônio e Museus da ABA desempenhou um papel seminal na consolidação de uma vertente importante na antropologia brasileira: a dos museus que, por sua vez, tem intensificado e fortalecido cada vez mais o diálogo com o dos patrimônios culturais. Embora sejam campos autônomos, museus e patrimônios estabelecem maior ou menor aproximação a depender do recorte empírico, teórico el ou metodológico. Considerando essa proximidade, o Comitê de Patrimônios da ABA, criado em 2004, observou a necessidade de incluir "museus" em seu nome, visto que desde sua criação estimulava e abrigava ambos os temas (museus e patrimônios) nas mais diversas atividades, tais como grupos de trabalho, mesas-redondas, simpósios e minicursos. Assim, a partir de 2010 o comitê passa a ser designado Comitê de Patrimônios e Museus.

Tal efervescência, em certa medida, deve-se também a um contexto colaborativo firmado entre academia e instituiçóes museais. Nesse sentido, o Museu Nacional da Universidade Federal do Rio de Janeiro (UFRJ) desempenhou papel relevante por meio de açóes de pesquisa envolvendo antropólogos, assim como o Centro Nacional de Folclore e Cultura Popular (CNFCP) junto ao Museu de Folclore Edison Carnei-

6 No início de sua criação, o Ibram teve na presidência o antropólogo e museólogo José Nascimento Júnior, tendo como Diretor do Departamento de Processos Museais o museólogo Mário de Souza Chagas. Ambos se empenharam em estabelecer um diálogo muito próximo com as ciências sociais e, especialmente, com a antropologia.

7 Acrescenta-se a esses, em 1978, o curso de museologia da Fundação Escola de Sociologia e Política de São Paulo (FESPSP), o primeiro do estado de São Paulo e que teve como uma de suas idealizadoras a museóloga Waldisa Russio. Posteriormente, em 1985, Russio também contribui para a formatação do Instituto de Museologia de São Paulo. Ambas as instituiçōes davam preferência para o ensino de pós-graduação. 
ro, no Rio de Janeiro. Outra instituiçâo de fundamental importância nessa fase de consolidação do campo de pesquisa sobre antropologia e museus foi o Museu do Homem do Nordeste (MHN), da Fundação Joaquim Nabuco, no Recife, que na década de 1980 contou com o empenho do museólogo Mário de Souza Chagas no processo de diálogo acadêmico. Da mesma forma, outras instituições colaboraram para o fortalecimento dessa área de pesquisa, tais como o Museu Paraense Emilio Goeldi (Universidade Federal do Pará - UFPA), o Museu Antropológico (Universidade Feder al de Goiás UFG) e o Museu Paulista (Universidade de São Paulo - USP). Daí decorre uma boa produção antropológica sobre museus, especialmente se levarmos em consideração que a maior parte dela resulta do esforço comum de antropólogas e antropólogos vinculados ao Comitê de Patrimônio e Museus da ABA, destacando-se na área dos museus, particularmente, a atuaçáo pioneira e o empenho da antropóloga Regina Abreu e de outros nomes igualmente significativos na formação e na consolidação desse campo de pesquisa na antropologia brasileira. ${ }^{8}$ Essa sinergia coletiva tem levado o Comitê da $\mathrm{ABA}$ a organizar e publicar sistematicamente livros impressos e digitais, disponibilizando-os no seu portal, além de promover uma série de atividades acadêmicas com o objetivo de ampliar e aprofundar discussões nessa área.
Condiçôes excepcionais de fomentos às pesquisas e a organizaçáo de eventos foram igualmente vetores importantes para o desenvolvimento do campo aqui analisado. Várias foram as Reuniôes Brasileiras de Antropologia (RBA) promovidas pela $A B A$ que propiciaram a realizaçáo de pré-eventos e atividades organizadas pelo Comitê de Patrimônio e Museus, como também a presença sistemática desse comitê durante as reunióes da Anpocs e outras homólogas. Acrescenta-se a isso a participação dos estudantes de museologia em reuniôes e congressos diversos, a exemplo do Seminário Brasileiro de Museologia (Sebramus) que, a cada dois anos, reúne profissionais das áreas da museologia, da antropologia e afins. Outro momento de fomento ocorre por meio do Encontro Nacional dos Estudantes de Museologia (Enemu).

Por outro lado, não se pode minimizar o papel desempenhado pelo Ibram, que até sua existência, em outubro de 2018, como autarquia do Ministério da Cultura, foi responsável por um programa de apoio e fomento que patrocinou vários encontros e seminários em diferentes estados brasileiros, envolvendo sobretudo a Rede de Memória e Pontos de Memória, que integra a chamada museologia social. ${ }^{9}$

Em resposta a essas demandas foi criado em 2009 o Programa Pontos de Memória, com o objetivo de apoiar a criaçáo de museus nas regiōes metropolitanas atendidas

8 A criação do GT de Patrimônio da ABA (depois Comitê de Patrimônio e Museus) contou também com o apoio decisivo de Manuel Ferreira Lima Filho, José Reginaldo Gonçalves, Cornelia Eckert, Bartolomeu Tito, Maria Eunice Maciel, entre outros que propuseram GTs na RBA e na Associaçáo Nacional de Pós-Graduaçấo e Pesquisa em Ciências Sociais (Anpocs) em uma época em que poucos ainda pesquisavam essa temática.

9 De acordo com Chagas (2014, p. 19-20), "A museologia social no Brasil continua desenvolvendo-se em ritmo intenso e já agora às margens do poder público e sem pedir permissão para existir, ainda que a obrigação e a responsabilidade do poder público em relação a esses e outros temas não deva ser diminuída. A Rede Cearense de Museus Comunitários, a Rede dos Pontos de Memória e Iniciativas Comunitárias em Memória e Museologia Social do Rio Grande do Sul e a Rede LGBT de Memória e Museologia social estão em plena atuação". Acrescente-se ainda a Rede de Museologia Social do Rio de Janeiro e a Rede SP de Museologia Social. 
pelo Programa Nacional de Segurança Pública com Cidadania (Pronasci) do Ministério da Justiça, contando com o apoio da Organização dos Estados Ibero-americanos (OEI). Tal programa se propôs a estimular e apoiar o protagonismo comunitário, condição considerada fundamental para que os museus venham a se transformar em instrumento de mudança social e de desenvolvimento sustentável.

Além disso, o Ibram realizou, até o ano de 2017, o Fórum Nacional de Museus, evento bienal e de grande abrangência nacional que reuniu museólogos e profissionais de museus de todo o país, assim como antropólogos e áreas afins, em torno de temas variados e modalidades experimentais nessa área. Um dos objetivos práticos do fórum era avaliar e delinear diretrizes para a Política Nacional de Museus (PNM) e a consolidação das bases para a implantação de modelo de gestão integrada dos museus, representado pelo Sistema Brasileiro de Museus (SBM). ${ }^{10}$

Parte desse avanço considerável deve-se igualmente à emergência de novas possibilidades de atuação de antropólogos e antropólogas na esfera pública, especialmente nos museus, concorrendo assim para a surgimento de novos temas de pesquisa. Convém notar que em se tratando de duas áreas de pesquisa autônomas e com trajetórias diferenciadas - antropologia e museologia —, muitos museólogos utilizam-se frequentemente de perspectivas antropológicas para refletir sobre temas correlacionados aos museus. Provavelmente em razão da significativa presença de alunos graduados em museologia nos cursos de pós-graduação em antropologia, algumas temáticas relacionadas aos museus ganharam centralidade em alguns mestrados e doutorados de antropologia, propiciando a introdução de novos temas que têm exigido das teorias antropológicas interlocução constante não apenas com as teorias museológicas, mas também com outras áreas afins que dialogam com o campo museal, tais como história, sociologia, filosofia, artes e comunicações, entre outras.

O fluxo de conhecimento da antropologia, direcionado para a museologia, também se intensificou na última década deste século. Ocorre que alguns cursos de bacharelado em museologia, sobretudo aqueles criados depois do Reuni, incluíram em suas grades curriculares disciplinas de antropologia, como também criaram disciplinas de antropologia voltadas para teoria e compreensáo dos museus. ${ }^{11}$ Desse modo, antropologia e museus cada vez mais têm caminhado e convergido por linhas tênues que na maioria das vezes aproximam antropólogos e museólogos em torno de perspectivas comuns - outras vezes o ponto de inflexão entre ambos se bifurca, conforme as necessidades e os interesses teóricos próprios a cada área.

10 É importante assinalar que o Ibram, durante a gestáo do antropólogo José Nascimento Júnior, em conjunto com a ABA, criou o Prêmio Mário de Andrade, dedicado a teses e dissertaçốes sobre patrimônios e museus. Esse prêmio foi muito importante para divulgar os trabalhos da área, mas não teve continuidade nas outras gestôes do Ibram e da ABA.

11 Um dos primeiros cursos de museologia no Brasil no âmbito do projeto Reuni, com perfil voltado para a antropologia e os museus, foi o curso de bacharelado em museologia da Universidade Federal de Pernambuco (UFPE), criado em 1998 com o empenho do antropólogo Antonio Motta em colaboração com o museólogo Mário de Souza Chagas. A estrutura disciplinar criada permitiu à museologia dialogar com as ciências sociais e, sobretudo, com a antropologia, buscando desenvolver experiências no campo da museologia social. 


\section{No emaranhar de fronteiras}

Os liames que costumam acercar antropólogos, museólogos e afins em torno de temas e objetos comuns, muitas vezes, concorrem para que seus caminhos se entrecruzem e suas fronteiras de conhecimento se embaralhem. Com efeito, no debate entre antropologia e museus, não raras as vezes, o ponto de interseção entre margens disciplinares é rompido em razáo do diálogo e dos interesses comuns que se estabelecem entre pesquisadores.

Entretanto, há um lado positivo no emaranhar de fronteiras. Isso na medida em que as trocas interdisciplinares possibilitam a criação de uma interlocução intelectual dinâmica e criativa, fora dos limites estritamente disciplinares instituídos por cada área. Tal abertura favorece a ampliação e o fortalecimento de uma discussão recíproca entre a antropologia, a museologia e algumas áreas afins, urdida em torno de um ideal comum: os museus.

Por outro lado, se considerarmos apenas as reflexóes feitas por profissionais da antropologia sobre os museus, deixando de lado a produção dos profissionais da museologia e de áreas afins, que adotam igualmente uma perspectiva antropológica, a avaliação dessa produção de conhecimento específica poderia se tornar ofuscada qualitativa e numericamente, como também minimizaria a importância de uma rede colaborativa em expansão. Por essa razão, talvez seja mais frutífero considerarmos a produçáo antropológica sobre museus com base em um esforço interdisciplinar comum, que envolve sobretudo profissionais da antropologia, da museologia e de diversas outras áreas disciplinares - tais como arqueologia, história, arquitetura, design, geografia, filosofia, etnomusicologia, entre outras - empenhados fundamentalmente na consecução de um programa de pesquisa conjunto, cujo principal objetivo é a discussão e a aplicaçáo crítica da teoria e dos métodos - inspirados na antropologia e nas ciências sociais - para o entendimento dos museus como fenômenos socioculturais relevantes.

Em razão disso, serão aqui contempladas as contribuições de antropólogo(a)s, museólogo(a)s e áreas afins quando o tipo de abordagem se revelar mais pela sensibilidade antropológica do que propriamente pelo vínculo institucional a uma área disciplinar específica. Além disso, convém ressaltar que tal opção buscou priorizar essencialmente temas relacionados ao campo museal, levando em conta a capacidade de diálogo crítico com temas antropológicos relacionados a alteridades, diversidades culturais, identidades, memórias sociais, diferentes formas e modos de organização material e simbólica, de interaçóes sociais, políticas, econômicas e de poder, em detrimento da mera identificação a um campo disciplinar encerrado em si mesmo como meio exclusivo para o reconhecimento e a legitimação desse tipo de produçáa.

Outro aspecto a ser considerado é que muitos antropólogos publicam frequentemente artigos em periódicos da área de museologia, alguns deles reconhecidos pelo Sistema de Avaliação Qualis Periódico da Capes, porém na área de Ciências Sociais Aplicadas (CSA1) - na qual a museologia está inserida. A contrapartida também é verdadeira: muito(a)s museólogo(a)s vêm colaborando em publicaçóes organizadas por antropólogos - seja em livros, seja em revistas avaliadas pela área de antropologia na Capes —, além de participarem de encontros e seminários na área da antropologia, muito(a)s dele(a)s participando de atividades promovidas pelo Comitê de Patrimônio e Museus da ABA. 


\section{Tecendo alguns parâmetros}

embora não se disponha de balanços mais sistemáticos anteriores ou mesmo de um rastreamento mais recente da produção antropológica sobre museus, existem, contudo, algumas referências importantes sobre a emergência e a consolidação dessa produçáo de conhecimento. Uma delas é o artigo de Gonçalves (2005), aqui já referido, e, mais recentemente, o artigo intitulado $A$ trajetória do GT de Patrimônios e Museus da Associação Brasileira de Antropologia, de Regina Abreu e Manuel Ferreira Lima Filho, publicado em 2012. Neles, os autores traçam um excelente balanço das açôes desenvolvidas pelo antigo Grupo de Trabalho (GT) e atual Comitê de Patrimônio e Museus da ABA, sistematizando alguns eixos de pesquisa na área da antropologia dos museus e do patrimônio.

Servindo como uma espécie de "estado da arte", o artigo cobre praticamente o período de emergência das pesquisas nessa área, tendo como ponto de corte cronológico 2012, ano em que foi compilado e publicado em livro pela ABA. Além de os autores identificarem alguns eixos importantes nos estudos sobre museus, sugerem que essa área de conhecimento, de fato, conquistou sua autonomia heurística na medida em que os museus deixaram de servir apenas como "pano de fundo" para ganharem centralidade no campo da pesquisa antropológica, com ênfase na "compreensáo de valores sociais e sistemas simbólicos" (Abreu; Lima Filho, 2012, p. 29). Ademais, os autores mencionados buscaram, na medida do possível, não separar as duas áreas de conhecimento, demonstrando que museus e patrimônios adquiriram, cada vez mais, contornos menos definidos ao intensificar o diálogo recíproco por meio de problemáticas transversais.
É importante também notar que o interesse da antropologia pelo campo museal se intensificou sobretudo a partir dos últimos decênios do século passado, conforme já havia notado José Reginaldo Gonçalves (1995, p. 62):

Se, a partir dos anos vinte e trinta deste século, houve um progressivo afastamento dos antropólogos, ou da pesquisa e teoria antropológica em relaçáo aos museus, a partir dos anos oitenta verifica-se uma reaproximação. Desde a última década (1980) tem sido produzida extensa bibliografia de pesquisa e interpretação antropológica sobre museus nas modernas sociedades ocidentais.

Acompanhando essa linha de compreensão, em uma publicação de 2007 , Regina Abreu e Manuel Ferreira Lima Filho observaram que o interesse de antropólogos por museus emergiu, com maior sistematicidade, a partir dos anos 1980 e 1990, focado sobretudo nas "práticas de colecionamento de objetos museológicos" (Abreu; Lima Filho, 2007, p. 27). Eles sugerem que é nesse momento inicial em que se desenha um eixo importante de pesquisa nessa área. Inicialmente esse eixo temático seria orientado por uma perspectiva histórica - com ênfase no estudo da memória e identidade nacionais brasileiras e que contemplava o processo de Nation-building e a construção de símbolos nacionais - e também por algumas questôes relacionadas ao pensamento social brasileiro, porém tendo como ângulo privilegiado o conhecimento de acervos e coleçốes de museus históricos e etnográficos.

Para esse fato já havia também chamado a atenção Mário de Souza Chagas em sua publicação Museu, museologia e pensamento social brasileiro, ao refletir sobre o interesse despertado pelo tema dos museus no campo 
das ciências sociais. Contudo, pondera o autor que nessa época havia um diálogo pouco sistemático entre museólogos, antropólogos, sociólogos e cientistas políticos, observando a existência de "um interesse rarefeito no que tange à adoção do museu como um objeto de estudo" (Chagas, 2014, p. 21). Entretanto, identifica alguns nomes da antropologia e das ciências sociais que à época começavam a surgir e cujo interesse temático se voltava para o campo museal: Regina Abreu, José Reginaldo Santos Gonçalves, Myriam Sepúlveda dos Santos e Lilia Schwarcz (Chagas, 2014, p. 22).

Provavelmente umas das reivindicaçóes mais vigorosas como área de pesquisa deu-se nesse período, isto é, na virada das décadas de 1990 e 2000, com uma geração de pesquisadores que despontava nos quadros universitários do país, especialmente nos cursos de pós-graduação em antropologia e de ciências sociais.

Um dos marcos importantes dessa fase é o trabalho de Regina Abreu, apresentado como dissertação ao Programa de Pós-Graduação em Antropologia Social do Museu Nacional em 1991, intitulado Sangue, nobreza e politica no templo dos imortais: um estudo antropológico da Coleção Miguel Calmon no Museu Histórico Nacional, posteriormente publicado em livro, sob o título $A$ fabricação do imortal, em 1996. Influenciada pelo conceito de semióforo de Pomian (1984) e por referências antropológicas de base maussiana, a autora analisa com habitual acuidade a coleção de Miguel Calmon, destacado político e historiador da República Velha, doada ao Museu Histórico Nacional em 1936. A coleção é analisada pela autora com base em ângulos diversos que revelam tanto a construção biográfica do colecionador quanto a construção narrativa da brasilidade, presentes no sistema de objetos então musealizado.
Recorrendo também a uma perspectiva histórica, Myrian Sepúlveda dos Santos, socióloga com sensibilidade antropológica, concluiu em 1989, no Instituto Universitário de Pesquisas do Rio de Janeiro (IUPERJ), a dissertação intitulada História, tempo $e$ memória: um estudo sobre museus a partir da observação feita no Museu Imperial e no Museu Histórico Nacional. Trata-se de uma pesquisa, com forte inspiração bejaminiana, voltada para a formação e a constituição de dois importantes acervos museológicos. Tais acervos são vistos e interpretados pela autora como uma escrita museológica do passado e que oscila entre memória e história, todavia passível de escolhas conforme a narrativa que se pretende enunciar. Posteriormente, a autora incluiu parte dessa discussão, acrescida de uma reflexão mais aprofundada e ampliada, no livro $A$ escrita do passado em museus históricos, lançado em 2006.

Com inflexão historiográfica e interlocução com o pensamento social brasileiro, a antropóloga e historiadora Lilia Moritz Schwartz publicou em 1989 "O nascimento dos museus brasileiros, 1870-1910", ensaio incluído no livro História das ciências sociais no Brasil, organizado por Sergio Miceli (1989). Nele, a autora discute a chamada "era dos museus" no Brasil a partir da qual é analisado o processo de formação e produção de conhecimentos etnográficos, buscando identificar nas instituiçóes museais estudadas alguns modelos classificatórios, oriundos das ciências naturais. Em 1993, a autora publicou o livro $O$ espetáculo das raças, inicialmente tese de doutorado em antropologia na Universidade de São Paulo (USP), com maior ênfase na história da antropologia. É no capítulo dedicado aos museus etnográficos em que são analisados os papéis específicos dessas instituiçôes de pesquisas que buscavam dialogar, no último quartel do 
século XIX e no início do século XX, com modelos evolucionistas e darwinistas sociais focados então na questão racial do país.

Com inspiração mais conceitual e preocupaçóes teóricas que dialogam com os patrimônios e transversalmente com os museus, José Reginaldo Santos Gonçalves apresentou em 1989, ao Departamento de Antropologia da Universidade de Virgínia, nos Estados Unidos, a tese de douramento intitulada Rediscoveries of Brazil: Nation and Cultural Heritage as Narratives. Posteriormente, o autor a transformou em livro, $A$ retórica da perda: os discursos do patrimônio cultural do Brasil (1996).

Fincada em uma perspectiva mais afeita à história da antropologia no Brasil, Luís Donisetti Grupioni publicou em 1998 o livro Coleçōes e expediçôes vigiadas: os etnólogos no Conselho de Fiscalização das Expedições Artísticas e Cientificas no Brasil, fruto da dissertação de mestrado em antropologia apresentada na USP em 1997. Apesar de o foco principal da pesquisa incidir sobre o Conselho de Fiscalização como instrumento para pensar o campo indigenista e a participação de alguns etnólogos nacionais e estrangeiros no desenvolvimento da antropologia no Brasil, a formação de coleções e acervos etnográficos ocupa, contudo, lugar de destaque na análise empreendida pelo autor. No capítulo 5 do livro, o autor analisa a prática do colecionismo de Curt Nimuendajú que serviu como intermediário da saída do Brasil de objetos e coleçóes etnográficas para alguns museus europeus. Com base nessa perspectiva, sugere o autor que tanto os museus quanto o colecionamento de objetos etnográficos dei- xariam de ser prioridades para a antropologia depois da institucionalização das ciências sociais nas universidades.

Partindo de outro ângulo interpretativo, o do chamado pensamento social brasileiro, Mario de Souza Chagas apresentou em 2003, na Universidade do Estado do Rio de Janeiro (UERJ), sua tese de doutoramento intitulada Imaginação museal: museu, memória e poder em Gustavo Barroso, Gilberto Freyre e Darcy Ribeiro. Uma das preocupaçôes centrais do trabalho era compreender e interpretar as narrativas e a "imaginação museal" dos três autores. Esse exercício hermenêutico o levou a pensar e ler os museus como construções narrativas ligadas a práticas sociais e políticas dos autores estudados, imbricadas, todavia, na imaginação poética de cada um deles. Desse modo, sugere o autor que tais pensadores foram responsáveis pela constituição de coleções que também podem ser lidas como constructos de suas próprias narrativas subjetivas e poéticas, próprias de seus modos de ver e conceber o mundo, geralmente associadas a imaginários nacionais.

Nesse período inicial, muitos antropólogos e cientistas sociais trilharam pelo campo temático da história da antropologia e dos museus, do pensamento social brasileiro, e também por um repertório conceitual - já destacados por Abreu e Lima Filho (2012) -, que incluíam temas como colecionismo, objetos etnográficos, exposiçôes, museus e representaçốes das culturas, museus e autorrepresentaçóes, com especial inflexão nos grupos indígenas e seus artefatos de cultura material e imaterial. ${ }^{12}$

12 Vários foram os trabalhos publicados. Destacam-se como referências cronológicas no campo dos museus em geral, do colecionismo e sistema de objetos e, principalmente, de coleçôes e museus indígenas as seguintes publicaçôes: Menezes (1987); Gallois (1989); Souza Lima (1989); Gruber (1994); Abreu (2003); Ferreira e Gomes (1999); Van Velthem (2004); Oliveira (2007); Kersten e Bonin (2007); Vidal (2008); Santos (2000; 2002); Gonçalves (2016). 
Cabe assinalar que o interesse da antropologia e de áreas afins pelo estudo dos museus e patrimônio ampliou consideravelmente no primeiro decênio deste século. Provavelmente um dos marcos cronológicos importantes e de impacto para o alargamento desse campo de estudo, aqui analisado, coincide como o momento de promulgação do Decreto no 3.551, de 4 de agosto de 2000, que instituiu o Registro de Bens Culturais de Natureza Imaterial que constituem patrimônio cultural brasileiro, criou o Programa Nacional do Patrimônio Imaterial e, por conseguinte, implementou uma política pública que regulamentava e assegurava direitos culturais, conforme os preceitos da Constituição Cidadã de 1988.

Tal conquista contribuiu não apenas para alavancar pesquisas na área do patrimônio cultural, como também na área dos museus, já que o conceito de imaterialidade ou intangibilidade se tornou premissa importante para se pensar novos arranjos e desafios para os acervos, para novas formas de colecionamento e concepçóes museais que então surgiam. Um bom exemplo do que se pretende enunciar é o livro publicado em 2003, organizado por Regina Abreu e Mário de Souza Chagas, intitulado $\mathrm{Me}$ mória e patrimônio: ensaios contemporâneos. Nele, os autores reúnem um bom número de contribuiçôes, de sensibilidades intelectuais diversas, em torno de novos conceitos de patrimônio cultural, dos museus e suas novas práticas discursivas de colecionamento. No que tange ao campo dos museus, o relevo dado aos museus históricos, à memória, às formas de colecionamento e narrativas sobreleva em boa parte dos ensaios, porém com matizes hermenêuticos e de compreen- sões teóricas distintos (Santos, 2003; Chagas, 2003b; Gonçalves, 2003; Dias, 2003). Há nessa mesma publicação variação temática que considera outras tipologias museais, a exemplo do ensaio $A$ descoberta do museu pelos indios, de José Ribamar Bessa Freire. Nele, Bessa analisa seis experiências relacionadas a museus e exposiçóes de patrimônios indígenas, sugerindo que os povos indígenas já não aceitam ser representados e musealizados de forma passiva nos museus tradicionais, reivindicando protagonismo enquanto agentes e detentores de suas próprias memórias.

A afirmação desse campo de estudo parece ganhar maior relevo na $25^{\mathrm{a}} \mathrm{RBA}$, na cidade de Goiânia, em 2006. Durante o evento, o então GT Patrimônio da ABA reuniu significativo número de especialistas nacionais e internacionais em torno de atividades diversas dedicadas ao patrimônio e aos museus, incluindo, entre outras, um simpósio intitulado Antropologia e museus: revitalizando o diálogo. ${ }^{13}$

Durante as várias atividades propostas pelo GT, novos temas emergiram, fortalecendo substancialmente os estudos da antropologia dos museus, o que se comprova por meio da publicação, em 2007, de duas coletâneas que reuniram antropólogos e afins em torno de discussóes temáticas e conceituais diversas.

Na primeira coletânea, intitulada Antropologia e patrimônio cultural: diálogo e desafios contemporâneos (2007), organizada por Manuel Ferreira Lima Filho, Jane Felipe Beltrão e Cornelia Eckert, observa-se bom número de artigos sobre o tema patrimônio cultural e algumas contribuiçóes mais direcionadas aos museus e coleçóes etnográficas, a exemplo dos artigos de Chagas (2007), Museu do

13 Ver: Bezerra e Lima Filho (2006) (publicação lançada durante a 25a RBA); Beltrão e Caroso (2007). 
Índio: uma instituição singular e um problema universal; Faulhaber (2007), Traduçôes Magüta: pensamento Ticuna e patrimônio cultural; e Corrêa (2007), Metamorfoses conceituais do Museu de Magia Negra: primeiro patrimônio etnográfico do Brasil (sobre o acervo afro-brasileiro do Museu de Magia Negra no Rio de Janeiro).

A segunda coletânea, intitulada Museus, coleçôes e patrimônio: narrativas polifônicas (2007), é organizada por Regina Abreu, Mário de Souza Chagas e Myrian Sepúlveda dos Santos. Nela, abriram-se novas perspectivas temáticas e de compreensão conceitual da antropologia dos museus, reunindo antropólogos, museólogos e de áreas afins, como historiadores, sociólogos, arquitetos, biólogos etc. Sugerem os organizadores que a referida coletânea se deve notadamente ao esforço conjunto de redes de pesquisadores que já vinham atuando nos principais encontros organizados pelo Comitê de Patrimônio da ABA, particularmente nas RBAs e nas regionais de antropologia: Reunião Equatorial de Antropologia (REA) e Reunião de Antropologia do Mercosul (RAM) - do mesmo modo, em encontros anuais da Anpocs, da Associação Brasileira de Museologia (ABM) e no âmbito de parcerias entre universidades nacionais e estrangeiras, por meio de grupos de pesquisa dedicados ao estudo dos museus, das memórias, das coleçóes e do patrimônio cultural.

Nessa coletânea, grosso modo, dois grandes eixos estruturam as contribuiçóes relacionadas aos museus e suas abordagens conceituais. $\mathrm{O}$ primeiro incide sobre o tema "museus como narrativas ou práticas discursivas", eixo de pesquisa já identificado por Abreu e Lima Filho (2012) e que inclui o estudo de narrativas simbólicas e práticas de representações diversas, sejam no campo da política, da memória, do poder, sejam rela- cionadas à dimensão simbólica da cultura nos espaços museais. Mais próximo a esse tipo de compressão, destaca-se na coletânea organizada por Abreu, Chagas e Santos (2007) o artigo de Ferraz (2007), que busca refletir criticamente sobre os desafios da política oficial face à preservação da memória da ditadura militar no Brasil. De acordo com a visão da autora, tal política privilegiou monumentos celebrativos, arquivos, coleçóes e museus em detrimento dos próprios sujeitos envolvidos, sendo relegados à margem dessa história. $\mathrm{O}$ argumento usado é de que nas disputas sobre o passado, o presente pode servir como vetor importante para se pensar uma sociedade mais justa e suas formas de representar a realidade. Em outra direção temática, Sansi-Roca (2007), antropólogo do Goldsmiths College, de Londres, empreende uma análise sobre as transformações do valor museográfico de objetos do candomblé em Salvador no século XX. O autor tenta mostrar que os valores atribuídos aos objetos musealizados também acompanham transformaçóes sociais e de sensibilidades, despertando nos grupos e comunidades envolvidos novas possibilidades de pertencimento social e identitário.

O segundo eixo analítico do livro é dedicado à produçâo de alteridades e suas diferenças culturais, reunindo trabalhos que buscam refletir sobre colecionismo e o papel dos museus face às transformaçôes e aos desafios no mundo contemporâneo. Abrindo a seção, Abreu (2007, p. 114) imprime o tom ao debate: "Como os museus e as instituições de patrimônio vêm trabalhando com o tema da alteridade?". Em sintonia com o questionamento lançado, a antropóloga portuguesa Dias (2007) desenvolve uma análise sobre alguns usos expográficos de acervos etnográficos, tomando como referência o Museu do Quai Branly, em Paris. De modo 
crítico, observa que a tendência excessiva em estetizar objetos e coleçóes etnográficas, por vezes, compromete alguns valores intrínsecos que são atribuídos a cada cultura. Com foco nos museus brasileiros, Abreu (2007) analisa, sob o ângulo histórico e com olhar etnográfico, diferentes dinâmicas, tipologias e concepçóes de museus, trazendo alguns desafios para se pensar o presente. Ao se debruçar sobre modos de coleta e formação de uma coleção, Couto (2007, p. 180) recupera a história do Museu do Índio e de "categorias de pensamento" utilizadas por Darcy Ribeiro. $\mathrm{Na}$ condição de narrador dessa coleçáo, Darcy Ribeiro inicia a "imortalidade" dos objetos, de si próprio e do museu que idealizou imprimindo à coleção novos significados e simbolismos, com o intuito de que essa coleção pudesse representar o patrimônio cultural dos povos indígenas brasileiros.

$\mathrm{Na}$ mesma seara de debate sobre coleçôes, museus e pluralidade cultural, Paiva (2007) analisa etnograficamente a experiência do Museu do Negro, no Rio de Janeiro — gerido pela Irmandade de Nossa Senhora do Rosário e São Benedito dos Homens Pretos -, com base em determinadas categorias classificatórias utilizadas pelos seus idealizadores e que, segundo a autora, ajudam a problematizar e a pensar os limites de musealização de acervos e suas representações. O tema da diversidade cultural é retomado por Bruno (2007) com base em uma experiência museal em espaço urbano. A autora relata um estudo de caso museológico que resultou na "Expedição São Paulo 450 anos", cuja finalidade era a implantação do programa museológico do Museu da Cidade de São Paulo. Modulando a discussão, Nascimento Júnior (2007) sugere um novo caminho para o diálogo entre antropologia, museus e museologia com base em trocas e experiências conjuntas.
Ainda no mesmo ano, veio à lume o livro de Gonçalves (2007), Antropologia dos objetos: coleçôes, museus e patrimônios. Trata-se de uma referência importante para os estudos dos museus e do patrimônio cultural. Diversos artigos compóem o quadro do livro, a maioria publicada em periódicos e capítulos de livros produzidos entre os anos de $1989 \mathrm{e}$ 2005, o que se complementa ao já clássico $A$ retórica da perda (1996) e, posteriormente, $A$ alma das coisas: patrimônio, materialidade e ressonância (Gonçalves; Bitar; Guimarães, 2013). Em termos genéricos, os ensaios reunidos em Antropologia dos objetos exploram papéis e funçôes que os objetos materiais notadamente aqueles que integram coleçóes privadas ou de museus - desempenham tanto como marcadores de identidades quanto referências determinantes no processo de formação e constituição da percepção subjetiva (individual ou coletiva). Em última instância, o argumento de fundo é pensar a função cotidiana dos objetos materiais na formação das autoconsciências individual e coletiva, buscando mostrar como, em certa medida, os objetos são capazes de reinventar os próprios indivíduos. Todavia, um dos pontos altos da reflexão do autor é pensar os patrimônios culturais enquanto produçáo discursiva, podendo emergir de um autor posicionado, mas com "ressonância" junto a um público mais amplo.

Um ano depois, em 2008, surgiu uma nova contribuiçấo nấo menos relevante ao debate sobre museus: Objetos alheios, histórias compartilhadas: o uso do tempo em um museu etnográfico, livro publicado no mesmo ano por Andrea Roca. Resultado de sua dissertação de Mestrado no Museu Nacional, em 2006, a autora analisa o Museu Etnográfico Juan Bautista Ambrosetti, em Buenos Aires, com base em uma perspectiva etnográfica sobre as produçóes e as transmis- 
sões de temporalidades distintas no referido museu. $\mathrm{O}$ fulcro principal da argumentação gira em torno da compreensáo e do entendimento dos "usos do tempo" enquanto categoria analítica, utilizados pelo museu para os visitantes. Ao longo dos capítulos, a autora busca identificar as transformaçōes e os enredos temporais que se foram urdindo no museu, refletidos sobretudo nas açôes educativas direcionadas ao público visitante. Além disso, busca analisar o uso de temporalidades específicas, identificando-as a determinadas escolhas políticas. Isso na medida em que os usos dessas temporalidades são capazes de provocar mudanças na produção de visibilidade e legitimidade históricas relacionadas aos objetos, às coleçóes e a suas narrativas. Sob a inspiração de Johannes Fabian, a autora propóe os usos do tempo no museu como um dos elementos-chave para a compreensão do reconhecimento da condição coetânea dos grupos que se veem representados nos museus.

\section{Interconexões temáticas}

O corpus pesquisado nos últimos dez anos (2009-2019) sugere diferentes vertentes teóricas e temáticas, a depender do foco e do objeto investigado. Uma delas tem continuidade na história da antropologia, considerando o processo de inserção dos antropólogos nos museus e seus envolvimentos na formação de coleçóes nessas instituiçóes, cujo desdobramento contempla: as relaçóes da disciplina com a construçáo do discurso nacional e/ou colonial, as relaçóes de poder dominantes nos museus, a formação de acervos historiográficos e etnográficos, entre outros aspectos. Para esses casos, a perspectiva historiográfica é ainda recorrente em alguns trabalhos, porém sem perder o foco nas instituiçóes museais e suas dinâmicas, seja por meio de estudos de casos, situados em contextos históricos específicos, seja por meio de perspectiva interpretativa de longa duração.

Uma boa síntese desse modo de compreensão histórica e de suas transformaçôes no campo dos museus de antropologia é o artigo de Abreu e Russi (2018) intitulado Cartografia dos museus de antropologia no Brasil: onde o outro nos habita. Valendo-se de ampla reflexão sobre o papel desempenhado pelas primeiras instituiçôes museais no Brasil, as autoras chamam atenção para a importância dos museus na construção da ideia de nação, tendo como princípio a coleta seletiva e acumulativa de objetos considerados relevantes para a conservação de conhecimentos perdidos em épocas passadas com o propósito de divulgar a missão civilizatória da nação. De acordo com a interpretação oferecida pelas autoras, foi esse o modelo inicialmente abraçado por alguns museus de sensibilidade histórica e antropológica que também eclipsavam a presença de determinados segmentos étnicos de uma comunidade nacional imaginada. Como reflexo de mudanças ocorridas em contextos diferenciados, com ênfase no nacional e suas fases, os museus de antropologia adotaram visōes e narrativas igualmente diversificadas: da exaltação de uma "identidade nacional" aos "museus como instrumentos de políticas sociais" (Abreu; Russi, 2018, p. 245). Por fim, as autoras analisam o protagonismo de povos indígenas e quilombolas e outras minorias sociais, rurais e urbanas que criaram os seus próprios museus, os chamados "museus de si”, associados a um novo cenário político nas práticas do colecionamento. Acompanhando tais mudanças, os museus se viram forçados a redefinirem não somente suas prioridades e seus repertórios temáticos, como também ampliarem um diálogo cada vez mais simétrico e equitativo entre culturas. 
Há, naturalmente, diferenças sensíveis quanto às temáticas e relevos históricos apresentados na produção aqui analisada. Alguns autores preferiram se debruçar sobre formações de coleçôes etnográficas, exposiçôes, representaçóes museográficas em contextos históricos específicos, especialmente direcionados a grupos indígenas. Observa-se, contudo, uma continuidade com propostas anteriormente mencionadas, o que reforça o entrelaçamento de várias geraçóes de pesquisadores em torno de temas e questóes comuns a esse campo de conhecimento.

Por razóes óbvias, temas relacionados a museus e etnicidade, especialmente experiências com museus indígenas, têm sido mais recorrentes na produçáo aqui analisada. Sua recepção pode ser mensurada por meio de um bom número de artigos publicados em periódicos e livros. ${ }^{14}$ Era também de se esperar que alguns trabalhos, focados no campo da etnicidade, contemplassem coleçóes e acervos etnográficos africanos e afro-brasileiros em museus. Ao analisarem as coleçôes de museus históricos, alguns artigos observam com certa frequência a exclusão da memória afro-brasileira. A desvalorização da presença e da participação africana na formação cultural brasileira tem se tornado preocupação de muitos pesquisadores. Nessa direção, alguns trabalhos exploram diferentes aspectos de acervos e coleçóes com o propósito de revisitar criticamente e desconstruir narrativas expográficas construídas com base em ideologias de exclusão, de racismo explícito ou velado, reivindicando o "lugar de fala" e maior inclusão e participação de afrodescendentes nos museus hegemônicos. ${ }^{15}$

Entretanto, nem tudo pode ser reduzido a esse repertório temático. Em proporçôes diferenciadas, outros horizontes conceituais foram igualmente contemplados. Um bom exemplo é a coleção Museu, Memória e Cidadania do programa editorial do Ibram, que contemplou a publicação de teses, dissertaçóes, ensaios e pesquisas que tratam de questôes museológicas e de relações mais amplas estabelecidas entre museus e sociedade, cobrindo diferentes temáticas não necessariamente ligadas a coleçôes e acervos étnicos com base em estudos produzidos em programas de pós-graduação de museologia, antropologia, história e outras disciplinas das ciências humanas que buscam ampliar a capacidade inventiva de novos temas de compreensão da cultura e sociedade. ${ }^{16}$ Além disso, vários são os trabalhos publicados que envolvem diferentes aspectos da presença da cultura popular em acervos museais, processos de musealização das culturas populares, questionamentos sobre a imaterialidade de patrimônios culturais em acervos museais, ideologias museais de autores emblemáticos do pensamento social brasileiro etc. ${ }^{17}$

14 Agostinho (2019); Ewbank (2018); Guerra e Benchimol (2017); Kok (2018); Martinez (2012); Montez (2011); Santos (2019); Silva (2015); Vieira (M. C., 2019); Duarte (2019); Britto, Aguiar e Aguiar (2019); França (2017); Van Velthem e Benchimol (2018); Schröder (2012); Van Velthem (2012); Roca (2015); Bevilacqua (2017); Veloso Júnior (2019); Döpcke (2011); Lima Filho (2017); Silva (2015); Dias e Souza Lima (2012); Rodrigues (2018); Montechiare (2016); Sanjad (2002; 2010); Russi e Kieffer-Døssing (2018; 2019).

15 Com esse foco, destacam-se: Britto, Aguiar e Aguiar (2019); Cunha (2019); Soares e Agostinho (2016); Dantas (2014); Bitencourt (2018); Nogueira (2018); Santos (2005b); Castro e Santos (2019).

16 Entre os temas publicados, destacam-se: Dellamore (2011); Gonçalves (2007); Ribeiro (2008); Roca (2008); Chagas (2009); Kubrusly (2011); Lerner (2013); Sanjad (2010).

17 Fabris e Corrêa (2019); Cavignac (2016). 
Dentro dessa linha de intençấo e de pesquisa há de se destacar a publicaçáo em 2012 do livro organizado por Izabela Tamaso e Manuel Ferreira Lima Filho: Antropologia e patrimônio cultural: trajetórias e conceitos. Um dos focos dessa publicaçáo é direcionado ao tratamento antropológico diversificado dedicado a coleçóes em museus de antropologia, assim como outros questionamentos no plano de uma antropologia dos museus e processos de musealização. No livro, destacam-se os capítulos: Katarina Real (1927-2006) e os maracatus Nação Estrela Brilhante, em que a autora Kubrusly (2012) busca questionar alguns limites e ambivalências do processo de musealizaçáo de determinados objetos ("O que significa um maracatu ir para o museu? E para quem?"); "Visite o Brasil no Museu Rossini Tavares de Lima": embates, experimentações e exibiçōes, em que o autor Reis (2012) apresenta uma descrição etnográfica do processo de concepção desse museu, situado na cidade de São Paulo, destacando momentos diferenciados, como o de sua criaçáo até o momento de encerramento dessa instituiçáa, ao mesmo tempo em que analisa os conflitos conceituais que envolvem concepçóes sobre cultura popular, sistema classificatório de seu acervo e novos desafios para se pensar a gestấo museal; e Musealização de eventos críticos: análise da tensão entre múltiplas narrativas da dor, em que a autora Silva (2012) problematiza algumas narrativas relacionadas à dor e ao sofrimento ocasionados pelo desastre do Césio em Goiânia e que resultaria no desejo de criaçáo de um museu/ memorial. Ao analisar criticamente as diferentes propostas elaboradas e os influxos políticos externos, a autora conclui que tal ideia não logrou êxito na medida em que se optou pelo apagamento simbólico do evento.

Ainda nesse contexto, começaram também a surgir novas abordagens temáticas e teóricas que acompanhavam mudanças conceituais operadas no campo museal. Uma delas é a preocupação com a atualização temporal de acervos e iniciativas expográficas experimentais em instituiçóes museais. Alguns trabalhos começaram a discutir as relaçôes assimétricas de poder e dominação que se construíram ao longo de séculos e que envolvem objetos e coleções. Para isso, são questionados a origem, o sentido e os significados de algumas formas de coleçôes e constituição de acervos, assim como os limites éticos e as políticas de aquisição.

No quadro dessas mudanças, algumas questôes são problematizadas e discutidas: Como e por que determinados objetos chegaram a ser incorporados aos acervos? Quais os critérios ou sistemas seletivos e classificatórios atribuídos aos objetos para que esses integrem um determinado tipo de coleção? Qual a importância da biografia social desses objetos para os grupos sociais que neles se veem cognitivamente representados? Quais os dilemas éticos e morais referentes à permanência de determinados objetos em museus?

De acordo com o corolário pós-colonial, cujo mote premente é "descolonizar os museus", esses "outros" que integravam metonimicamente as coleçôes já não devem ser visualizados como objetos passivos e exotizados, mas como sujeitos e interlocutores ativos, necessariamente implicados em processos de negociaçôes, mediaçóes e decisôes nos museus. Ancorado nessa linha de preocupação, o livro Questóes indígenas e museus: debates e possibilidades, organizado por Marília Xavier Cury, Camilo de Mello Vasconcellos e Joana Montero Ortiz e publicado em 2012, pode ser tomado como referência. A publicação tem como propósito discutir as relaçóes entre museus e patrimônios culturais indígenas considerando o legado desses povos na forma- 
ção cultural e identitária paulista por meio da problematização de acervos etnológicos, coleções etnográficas, exposiçóes e ações curatoriais, entre outros temas. Mais recentemente, veio à lume outra publicação da mesma série: Museus etnográficos e indígenas - aprofundando questóes, reformulando açóes, organizada por Cury (2020). O dado novo é que se trata da iniciativa do Museu Índia Vanuíra de reunir alguns especialistas de museologia, mas, sobretudo, lideranças indígenas que falam na "primeira pessoa" e discorrem sobre os próprios direitos, tais como o de autonarrativas nos museus, de curadorias compartilhadas e gestóes de coleçóes, entre outros temas que valorizam direitos culturalmente diferenciados. Em direção parecida, mas com forte inflexão histórica, está o livro intitulado $D e$ acervos coloniais aos museus indigenas: formas de protagonismo e de construção da ilusão museal (2019), organizado por João Pacheco de Oliveira e Rita de Cássia Melo Santos. O livro reúne artigos e ensaios acadêmicos que buscam explorar diferentes experiências e práticas de coleta de objetos etnográficos, de formação de coleçóes etnográficas, processos curatoriais compartilhados, vistos sob a perspectiva de superação dos museus coloniais, analisados de modo crítico com base em novos desafios políticos reivindicados por aqueles que se autoidentificam ou se reconhecem como "povos indígenas". Outra importante contribuição nessa linha temática, porém com outra perspectiva analítica, é o livro Coleçôes étnicas e museologia compartilhada (2019), organizado por Manuel Ferreira Lima Filho e Nuno Porto.

Sob outro ângulo, as coleções foram também tema de análise em um dossiê publicado na Vibrant - Virtual Brazilian Anthropology, "Culture Heritage and $\mathrm{Mu}$ seums", organizado por Antônio Arantes e Antonio Motta em 2013. Nele estão reunidos trabalhos que exploram linhas temáticas relacionadas a processos de musealização, de colecionamento, coleçóes etnográficas, tipologia e escalas museais diferenciadas, entre outras vertentes analíticas, com base em um acentuado interesse por novos desafios contemporâneos que envolvem antropologia e museus. Entre os trabalhos dedicados aos museus, destacam-se:

- o artigo The city museum of São Paulo: a new design for museums in the era of the megacity, em que Franco (2013) reflete sobre a possibilidade de novas formas de colecionamentos contemporâneos que retratam a diversidade cultural de experiências da vida urbana, acompanhando novas concepçôes de espaços museais, como é o caso de um projeto de museu da cidade de São Paulo;

- o artigo Sorcery objects under institutional tutelage: magic and power in ethnographic collections, em que Rafael e Maggie (2013) refletem sobre outras modalidades de colecionamento e de coleçóes. Nesse ensaio os autores analisam duas coleçôes de objetos confiscados nos terreiros de cultos afro-brasileiros: a Coleção de Magia Negra no Museu da Polícia Civil do Rio de Janeiro e a Coleção Perseverança do Instituto Histórico e Geográfico de Maceió, Alagoas;

- o artigo Challenges to digital patrimonialization: Heritage.org/ Digital Museum of African and Afro-Brazilian Memory, em que Sansone (2013) investiga as formas de colecionamento digitais, discutindo os desafios do uso de tecnologias digitais para disseminar informaçóes sobre o patrimônio cultural museológico afro-brasileiro;

- o artigo Within the dialog between anthropology and museums: the Reference Center for Brazilian Football, em que Azevedo e Alfonsi (2013), também com 
foco em novas tecnologias digitais aplicadas a museus, discutem o processo de construçáo de registros da memória e da prática de jogar futebol na cidade de São Paulo com o objetivo de trazer uma experiência inovadora em museus;

- o artigo Anthropology in the Museum: reflections on the curatorship of the Xikrin Collection, em que Silva e Gordon (2013), em outra direção temática, tomam como foco uma experiência curatorial compartilhada da coleção etnográfica Xikrin, analisando dinâmicas entre antropólogos, povos indígenas e museus;

- o artigo Visible art, invisible artists? The incorporation of Aboriginal objects, em que Goldstein (2013), com base em outro ângulo - o de incorporação de objetos indígenas da arte aborígene australiana em espaços museais -, analisa o crescente interesse do público australiano por esse tipo de arte, observando, contudo, a contradiçáo de que os autores e detentores desse patrimônio (objetos aborígenes) são silenciados ou ignorados pelo mesmo público que os apreciam apenas como artefatos artísticos, visualizados nas vitrines nos museus; e

- o artigo Kuahi: the indians of the Lower Oiapoque and their museum, em que Vidal (2013), também com o olhar atento aos museus indígenas, analisa o processo de construção do museu dos povos indígenas do Oiapoque (Amapá) com base na própria experiência como antropóloga na regiáo de Oiapoque. $\mathrm{O}$ artigo vem acompanhado de um vídeo etnográfico produzido por Regina Abreu.
Nessa linha geral de questionamento, outras perspectivas são consideradas em artigos e livros publicados aqui mencionados. Geralmente, nos debates dedicados aos museus de antropologia é tônica recorrente o protagonismo de povos indígenas que criaram os próprios museus: os chamados "museus de si”. Conforme é destacado em vários textos, tais iniciativas deram vozes a determinados grupos que outrora constituíam as figuras de alteridade nas macronarrativas nacionais, expostas nas vitrines dos museus históricos, de ciências e de antropologia. O que se vai observar como denominador comum nos museus relacionados a povos indígenas e outros grupos étnicos é a transformação de práticas de colecionamento tradicionais em lutas pelo reconhecimento de seus direitos e suas memórias. Por outro lado, como mostram alguns trabalhos aqui analisados, isso impóe desafios para os museus. De acordo com alguns casos relatados neste artigo, esses museus já não deveriam falar em nome desses "outros", nem tampouco representá-los cognitivamente sem a consulta prévia do que eles pensam e como querem ver a si próprios e se autorrepresentarem nos museus. Alguns artigos e capítulos de livros — cada um a seu modo - tratam de questóes relacionadas a esses desafios. ${ }^{18}$

Outra contribuição do Comitê de Patrimônio e Museus da ABA é o livro organizado por Abreu, Lima Filho e Athias (2016): $M u-$ seus e atores sociais: perspectivas antropológicas. A coletânea é pensada com base em uma antropologia dos museus que se propóe a refletir criticamente sobre novos desafios de compreensão e entendimento de processos mu-

18 Araújo (2017); Gomes e Oliveira (2010); Gomes e Vieira Neto (2018); Gomes (2018); Alcântara (2019); Russi e Abreu (2019); Van Velthem, Kukawka e Joanny (2017); Vieira (M. A. N., 2019); Shepard Jr. (2017); Garces (2017); Dias (2019); Augustat e Kapfhammer (2017); Athias (2016); Cury (2016); Abreu e Oliveira (2016); Lima Filho (2016); Lima (2016). 
seais, de acervos e coleçôes, como também de exposiçóes e suas narrativas, além de práticas curatoriais compartilhadas. A coletânea reúne trabalhos de alguns antropólogos que buscam refletir temas ligados a coleçóes etnográficas, processos expositivos (Oliveira; Santos, 2016), museus e cultura popular (Cavignac, 2016), narrativas e memórias coletivas em espaços urbanos (Abreu; Oliveira, 2016) e retóricas expositivas (Lima, 2016). Com inflexão analítica no diálogo intercultural nos museus, destacam-se as contribuiçôes de Marília Xavier Cury (2016) sobre museus e indígenas; o trabalho de Manuel Ferreira Lima Filho (2016, p. 184), que explora os "significados das coisas na configuração dos níveis cosmológicos Karajâ" da coleção William Lipkind do Museu Nacional; e Renato Athias (2016), que se debruça sobre a patrimonializaçáo de objetos indígenas vivos em museus.

Nesse compasso dinâmico do Comitê da ABA, veio à lume em 2019 o livro organizado por Izabela Tamaso, Renata de Sá Gonçalves e Simone Vassalo dedicado a um tema emergente direcionado ao papel de antropólogo(a)s na esfera das políticas públicas de cultura e suas agências no âmbito do patrimônio e dos museus, reiterando o engajamento político dessas instituiçôes na luta por diretos culturalmente diferenciados. Complementando o tema da gestão e das políticas culturais no âmbito do patrimônio e dos museus, destaca-se igualmente a seção organizada por Tamaso, Gonçalves e Vassallo
(2019) no livro A antropologia e a esfera pública no Brasil: perspectivas e prospectivas sobre a Associação Brasileira de Antropologia no seu $60^{\circ}$ aniversário (2018), que inclui dois artigos sobre o tema das políticas públicas sobre museu (Motta; Oliveira, 2018) e sobre patrimônio (Arantes, 2018).

Ainda com a intençáo de contemplar algumas tendências mais recentes no campo da antropologia dos museus, Maciel e Abreu (2019) organizaram o dossiê "Antropologia dos Museus". Os trabalhos nele reunidos, cada um a seu modo, buscam repensar criticamente o lugar dos museus de antropologia, alguns deles a considerar objetos e coleçôes como mediadores de relaçôes sociais, aptos a promoverem o diálogo crítico com diferentes grupos étnicos e minorias sociais convidados a intervirem nos museus e neles se verem representados. Em diálogo com questôes também relacionadas a coleçốes e processos de musealização, Valdivieso e Lima Filho organizaram o dossiê "Coleções Etnográficas e Processos Museológicos” (2019). ${ }^{19}$

\section{De insurgências a ressurgências}

Um divisor de águas decisivo para o fortalecimento e a expansão do campo de estudos aqui analisado é o diálogo da antropologia como a nova museologia, que a partir dos anos 1990 se tornaria no Brasil mais conhecida pela denominação "museologia social" ou "sociomuseologia". ${ }^{20}$ De acordo com as

19 A destacar as seguintes contribuiçôes: Gomes (2019); Delâtre e Robert (2019); Bollettin (2019); Mano (2019); Ortiz (2019).

20 Moutinho (2014, p. 423) define a sociomuseologia como uma "abordagem multidisciplinar [que] visa consolidar o reconhecimento da museologia como recurso para o desenvolvimento sustentável da humanidade, assentada na igualdade de oportunidades e na inclusão social e econômica. A Sociomuseologia assenta a sua intervenção social no patrimônio cultural e natural, tangível e intangível da humanidade. O que caracteriza a Sociomuseologia năo é propriamente a natureza dos seus pressupostos e dos seus objetivos, como acontece em outras áreas do conhecimento, mas a interdisciplinaridade com que apela a áreas do conhecimento perfeitamente consolidadas e as relaciona com a Museologia propriamente dita". 
observaçôes de um de seus mais destacados expoentes, Chagas, a museologia social:

[...] está comprometida com a redução das injustiças e desigualdades sociais; com o combate aos preconceitos; com a melhoria da qualidade de vida coletiva; com o fortalecimento da dignidade e da coesão social; com a utilização do poder da memória, do patrimônio e do museu a favor das comunidades populares, dos povos indígenas e quilombolas, dos movimentos sociais, incluindo aí o movimento LGBT, o MST e outros (Chagas; Gouveia, 2014a, p. 17).

Novos temas e materiais de pesquisa emergiriam nesse cenário. Já não se trata apenas de estudar os modelos de museus tradicionais, geralmente calcados na legitimidade de seus acervos e coleçóes, tampouco as representaçóes do passado. Alguns trabalhos demonstram que os museus também são capazes de atualizar o presente por meio de disputas de narrativas e lutas por memórias, podendo ser entendidos como veículos de transformaçóes sociais e de agendas políticas. Em parte isso se deve ao protagonismo de novos sujeitos de direito que ascenderam à cena pública, muitos deles oriundos de movimentos sociais que eclodiram durante o processo de redemocratização do país nos anos 1980, tornando-se porta-vozes das reivindicaçóes de indígenas, negros, afrodescendentes, quilombolas, populaçóes rurais, jovens das periferias urbanas, mulheres, lésbicas, gays, transexuais, transgêneros, mora- dores de rua, "sem-terra", "sem teto", entre outros.

Um exemplo disso é o dossiê "Museologia Social", organizado por Chagas e Gouveia (2014), que póe em evidência "narrativas polifônicas" com base em trocas colaborativas e simétricas entre agentes sociais, grupos étnicos, minorias sociais, profissionais da museologia, da antropologia e de diferentes áreas do conhecimento. Para os casos dos museus comunitários, indígenas, quilombolas e outras tipologias análogas, forças sociais são mobilizadas em torno das narrativas sociomuseais com base em diferentes situaçóes de conflitos, disputas e negociaçóes de sentidos direcionadas para a definição e o conceito daquilo que se pretende musealizar. ${ }^{21}$

Desse modo, a nova retórica da identidade das minorias e das políticas de reconhecimento ou reparatórias passa a constituir uma importante categoria discursiva e aplicativa a compor e influenciar a agenda das políticas públicas no país, especialmente dos museus, que a partir de então passaram frequentemente a ser entendidos, em sua extensão semântica, como instituiçóes sociais com agendas políticas. Nessa perspectiva de compreensão, muitos trabalhos foram publicados em livros, dossiês temáticos e artigos periódicos, com enfoques diferenciados. ${ }^{22}$

Outras tipologias e escalas de museus foram igualmente contempladas pela perspectiva mais ampla da museologia social. Museus territoriais, ecomuseus e similares são analisados como experiências que envolvem conquistas coletivas de direitos e cidadania,

21 No dossiê "Museologia Social" destacam-se: Santos (2014, p. 329-336); Dalla Zen (2014, p. 355-372); Gomes e Vieira (2014, p. 389-414); Silva e Januário (2014, p. 415-420); Sperb e Hansen (2014, p. 251-271); Pires (2014, p. 225-238).

22 Consultar: Cordeiro (2019); Portilho (2018); Abreu e Chagas (2007); Vieira (2007); Ferreira (2007); Tolentino e Franch (2017); Alcântara e Gontijo (2015); Heitor (2018); Sá Barreto, Menezes Neto e Lima (2019). 
atuando como uma espécie de ferramenta que garante a participação de comunidades na construção e na gestão de políticas públicas criadas durante o período de ordem democrática no país. ${ }^{23}$

Temos até aqui uma amostra representativa de alguns temas recorrentes e outros emergentes que se integram ao repertório da produção aqui analisada. Todavia, cumpre destacar a presença de novos marcadores temáticos que surgiram mais recentemente. Uma das tônicas é pensar os museus como parte de um mundo em transformação, em que fronteiras geográficas diminuíram ou até mesmo desapareceram com o desencaixe do espaço-tempo. Nesse sentido, o papel do imaterial e dos serviços ligados à produçáo desse imaterial é certamente uma das características mais evidentes do mundo contemporâneo, marcado em grande medida pela desmaterialização e pela virtualizaçáo da vida social, inclusive dos museus, como recurso tecnológico empregado para diferentes finalidades. Assim, os chamados museus digitais também se tornaram temas de pesquisa, com diferentes focos de inflexão. ${ }^{24}$

Todavia, entre os indicadores de maior recorrência temática, destacam-se artigos e capítulos de livros dedicados a experiências com "museus afrodigitais". Trata-se de um projeto acadêmico em rede que envolveu diversos antropólogos - Sansone (UFBA), Motta (UFPE), Ferretti (UFMA), Santos
(UFRJ) - em torno de temas ligados à produção de memórias sociais e demandas identitárias de populações do continente africano e de afrodescendentes no Brasil, tendo como interfaces processos de patrimonialização e musealização digitais, curadorias digitais, restituiçóes de acervos digitais etc. Um dos temas recorrentes nesses trabalhos é a inflexão analítica sobre diferentes formas de discriminação racial, ao mesmo tempo que consideram os espaços museais - sejam presenciais, sejam virtuais - ferramentas políticas de denúncia social, sendo capazes de dialogar e contribuir com políticas indenitárias e açôes afirmativas na luta contra o preconceito. ${ }^{25}$

Outro elo de diálogo entre antropologia e museus são processos curatoriais em exposiçóes temporárias ou de longa duração dedicadas a temas contemporâneos, como também curadorias compartilhadas, encampando novas formas de expressão como recurso expográfico e museográfico. ${ }^{26}$ No âmbito da teoria dos objetos, os museus têm igualmente buscado novas formas de entendimento e interpretaçáo, entre elas, a de que os objetos podem ter suas próprias agências, permitindo, assim, constituírem sistemas de ação, o que explica, em alguns casos, por que os objetos etnográficos musealizados foram capazes de resistir às representaçóes atemporais que os museus costumavam geralmente impor sobre eles e suas

23 Entre outras contribuiçóes, destacam-se: Ribeiro e Moreira (2014, p. 289-305); Botelho e Paolino (2014, p. 307313); Martins (2014, p. 315-328); Costa, Delambre e Ferrari (2015, p. 337-353). Em outra direção de enfoque e perspectiva conceitual sobre ecomuseus, é possível considerar os artigos de Santos (2005a) e Soares (2014; 2015).

24 Dodebei (2006); Gouveia e Dodebei (2007); Galvão e Bernardes (2011); Machado (2017); Brisa (2017); Coutinho e Santos (2009); Diniz e Oliveira (2015); Eichler e Del Pino (2007); Lima (2019); Machado e Soares (2018); Roza (2014).

25 Entre as contribuiçóes desse projeto, destacam-se: Santos (2010, 2012); Ferretti (2012); Sansone (2013); Silva (2019); Gonçalves e Castro (2018); Martins (2019).

26 Motta (2012); Motta e Oliveira (2013; 2014); Menezes Neto e Costa (2019); Russi e Abreu (2019); Lima Filho e Porto (2019). 
coleçôes. Desse modo, alguns museus passaram a considerar seus objetos e suas coleçóes como mediadores de relaçôes sociais, aptos a promoverem o diálogo crítico com diferentes grupos étnicos e em sua diversidade social e cultural, convidados para intervirem nos museus e neles se verem representados.

Do mesmo modo, algumas exposiçóes têm sugerido propostas inovadoras, encampando temas como o de gênero, sexualidade, identidades não binárias, LGBT e Queer Museu etc. Nos últimos anos, observa-se um percentual significativo de trabalhos que têm questionado hierarquias de poder, direitos sexuais e reprodutivos, diversidade sexual e de gênero como categoria de inclusão nos espaços museais. ${ }^{27}$

Há também mudanças qualitativas no diálogo entabulado entre antropologia e museus. Tanto o uso da historicidade, direcionado a diferentes momentos e períodos da constituição de coleções e formaçóes de acervos étnicos nos museus, quanto a inflexão dada ao sistema de objetos com base em representaçóes conceituais vinculadas a determinados contextos têm, pouco a pouco, cedido espaço para a investigaçáo de novos fenômenos contemporâneos, relacionados às transformaçóes do campo museal no presente.

\section{Um campo em movimento}

Acompanhando discussóes teóricas atuais no campo da antropologia e das ciências sociais em geral, algumas tendências aqui analisadas têm buscado desconstruir narrativas museais do passado, ainda sedimentadas no presente, por meio de novos olhares de compreensáo da realidade. Como se pode perceber, tais mudanças sinalizam uma direção positiva na abertura dos museus para o experimento, para a pluralidade de vozes, de narrativas e representaçóes mais inclusivas, rompendo com moldes datados, de representaçóes passadas.

Ao que tudo indica, essa é também uma das orientaçóes mais recentes do campo aqui analisado. Isso porque a emergência de novos temas tende a acompanhar as mudanças operadas no campo heurístico da antropologia. Como se sabe, a partir da década de 1980, a antropologia começou a abandonar cada vez mais uma concepção estrutural da vida social para adotar uma perspectiva mais dinâmica, em que os sujeitos, em sua diversidade social e não apenas étnica e/ou cultural, pudessem se tornar protagonistas de mudanças na cena política e intervir no presente.

Como observado no levantamento aqui realizado, infere-se que essa produção cresceu quantitativamente e sua diversidade temática demonstra também acentuado crescimento nos últimos dez anos. Ademais, essa produção mais recente tem revisitado criticamente antigos temas de pesquisa, como também abarcado novos campos temáticos e introduzido novas questóes conceituais e metodológicas no debate sobre antropologia e museus.

Outra tendência observada é a predominância de formulaçóes e reflexóes teóricas sobre campos empíricos tradicionalmente visitados. Como já havia chamado a atenção Roberto Cardoso de Oliveira, uma das tradiçóes que marcam o campo de formação da antropologia brasileira é a forte presença da etnologia indígena e a da chamada antropologia da sociedade nacional (Cardoso de

27 Destacam-se: Almeida e Almeida (2019); Amaral (2019); Baptista e Boita (2014; 2017a; 2017b); Baptista et al. (2019); Pinto (2012); Baptista (2019); Baptista e Boita (2014); Vaquinhas (2014); Audebert, Wichers e Queiroz, (2019); Rechena (2014). 
Oliveira, 1985), aqui representada pelas coleçóes etnográficas e pelas questóes tratadas à luz de processos históricos que envolvem representaçôes do passado, de memórias nacionais, identidades e diferentes fases $\mathrm{da}$ construção da Nação.

Tal sensibilidade fixaria um tipo de orientação que Cardoso de Oliveira (1985, p. 230) identificou para o caso brasileiro como a "preponderância do objeto real sobre objetos teoricamente construídos", reproduzindo assim uma tradição que conflui quase sempre para a autorreferência nacional. No caso aqui analisado, observa-se um esforço mais recente dessa superação na medida em que alguns pesquisadores tendem a redirecionar suas formas de olhar e de repensar seus objetos de pesquisa com base em constructos teóricos aplicados ao campo empírico dos museus e de suas novas formas de comunicação e expressão. Desse modo, isso tem possibilitado à produção mais recente atualizar o seu repertório temático em razão da análise de novos fenômenos socioculturais no campo museal, que além de seus acervos tradicionais, envolvem também mudanças e relaçóes sociais mais amplas na esfera da política, da economia e do poder. Nota-se igualmente maior abertura e questionamento teórico e metodológico dos pesquisadores alinhados ao debate internacional. Não obstante a tais avanços, alguns temas ainda têm sido pouco considerados nessa produção mais recente, notadamente os relacionados à arte contemporânea produzida por grupos étnicos nacionais e internacionais. Há várias tendências culturais oriundas de sociedades africanas em contextos urbanos e transnacionais, como o "afrofuturismo", assim como outras vanguardas artísticas asiáticas e latino-americanas conectadas a museus e galerias de arte internacionais, embrin- cadas no consumo e no desejo de inserção em processos culturais de mundialização. Observa-se também acentuada tendência crítica de "descolonizar os museus" e, mais recentemente, o questionamento à presença de monumentos públicos que exaltam personagens históricos controversos, tornando-se alvo de protestos e de pautas polêmicas em escala global.

Como foi observado anteriormente, no Brasil, parte desse considerável avanço se deve também às conquistas democráticas no campo da cultura e especialmente no campo dos museus e das políticas culturais que possibilitaram a emergência de novos campos de atuação para antropólogos e antropólogas na esfera pública e principalmente nos museus, concorrendo assim para o surgimento de novos temas de pesquisa.

Todavia, o período em que se encerra essa revisão do campo não é um dos mais promissores. Isso porque coincide com circunstâncias adversas que impactam o campo museal e o do patrimônio cultural. Com a imposição de medidas sanitárias de contenção à pandemia da Covid-19, o confinamento social tem imposto novos desafios aos museus como também às manifestaçóes da cultura imaterial, notadamente as que envolvem celebraçôes e práticas da vida social. Soma-se a isso o momento crítico de uma nova ruptura da institucionalidade democrática no Brasil, marcada pelo retrocesso, pela intolerância, pela repressão e pela censura.

$\mathrm{O}$ discurso do atual governo tem sido autoritário e restritivo a todos os avanços e as conquistas na área da cultura, anteriormente comentados, principalmente no que diz respeito aos direitos fundamentais e, mais ainda, à lógica das políticas identitárias que até então definiram a pauta do debate público com ganhos para políticas culturais direcionadas aos museus e aos patrimônios cultu- 
rais. ${ }^{28}$ Acrescente-se ao quadro o incêndio ocorrido em setembro de 2018 que destruiu um dos principais patrimônios museológicos brasileiros: o Museu Nacional. Trata-se da primeira instituição museal brasileira que completou 200 anos de existência no ano em que ocorreu o sinistro.

Como é sabido, uma das primeiras medidas na atual conjuntura política foi a extinção do Ministério da Cultura (MinC), que ganhou novo status de secretaria especial de cultura, sendo incorporada ao recém-criado Ministério da Cidadania e, posteriormente, ao Ministério do Turismo. Esse ministério absorveu também dois importantes órgãos anteriormente vinculados ao MinC: o Instituto do Patrimônio Histórico e Artístico Nacional (Iphan) e o Ibram. Com a extinção de uma poderosa autarquia que foi o Ibram para se tornar uma secretaria de museus no Ministério do Turismo, ações culturais direcionadas aos museus encontram-se paralisadas e alguns deles sem recursos financeiros para se manterem. No âmbito do patrimônio cultural há um desmonte violento que atinge frontalmente a sua principal instituiçáo nacional, o Iphan, comprometendo e ameaçando sua política de preservação, salvaguarda e memória de patrimônios culturais no país.

O discurso político nesse contexto neoconservador e autoritário, além de descaracterizar a importância da cultura, da ciência e tecnologia, faz-se especialmente presente nas acusaçóes, nas perseguiçóes tanto ao fazer antropológico e das ciências sociais quanto das populaçóes que sempre foram parceiras na construção de conhecimentos, dos patrimônios e dos museus, e que se encontram seriamente ameaçadas. Provavelmente de- correrão, desse contexto atual, impactos incomensuráveis na área aqui analisada.

\section{Agradecimentos}

Os autores agradecem a Regina Abreu pela leitura do texto e a Mana Rosa e Camila Maria Santos pela ajuda no levantamento do material de pesquisa.

\section{Revistas}

Foram alvo deste balanço as produçóes publicadas nas seguintes revistas: Anais do Museu Paulista: História e Cultura Material; Artefactum; Boletim do Museu Paraense Emilio Goeldi - Ciências Humanas; Brazilian Journal of Information Science: Research Trends; Cadernos de Pesquisa do CDHIS; Cadernos de Sociomuseologia; Cadernos do CEOM; Ciência da Informação; Comunicação e Sociedade; Cultura Histórica \& Patrimônio; DataGramaZero - Revista de Ciência da Informação; Em Questão; Ensino Em Re-Vista; Estudos de Sociologia; Horizonte Antropológico; Informação e Sociedade: Estudos; Journal Virtual Reality; Mana; Memória e Informação; MIDAS - Museus e Estudos Interdisciplinares; MUSAS - Revista Brasileira de Museus e Museologia; Museologia \& Interdisciplinaridade; Museologia e Patrimônio; Museu da Paisagem - Narrativas e Experiência do Lugar; O Caráter Politico dos Museus; Páginas A\&rB, Arquivos e Bibliotecas; Perspectivas em Ciência da Informação; RENOTE - Revista Novas Tecnologias na Educação; Revista Arqueologia Pública; Revista Brasileira de Ciências Sociais; Revista Cubana de Información y Comunicación; Revista de Arqueologia Pública; Revista de

28 Sobre o assunto, consultar: Motta (2018d, 2019). 
Estudos de Conflito e Controle Social; Revista do Centro de Pesquisa e Formação; Revista Eletrônica Ventilando Acervos; Revista História Hoje; Revista Iberoamericana de Turismo - RITUR; Revista Internacional de Humanidades; Revista Memória; Revista Memória LGBTIQ+; Revista Morpheus - Estudos Interdisciplinares em Memória Social; Revista Museu Virtual; e Tempo.

\section{Eventos}

Também foram observadas as publicaçôes contidas nos anais dos seguintes even- tos: Encontro Nacional de Pesquisa em Ciência da Informação (Enancib) (2010; 2012; 2016; 2017); Encontro Nacional de Pesquisa em Ciência da Informação; II Sebramus; II Seminário de Pesquisa em $\mathrm{Mu}-$ seologia dos Países de Língua Portuguesa e Espanhola; III Sebramus; IX Jornada Internacional de Políticas Públicas; Seminário Internacional em Direitos Humanos e Sociedade; VII Reunião de Antropologia da Ciência e da Tecnologia; XI Congresso Brasileiro de Ciências da Comunicação na Região Nordeste; XI Congresso de Ciências da Comunicação na Região Nordeste.

\section{Bibliografia}

ABREU, R. A fabricaçáo do imortal: memória, história e estratégias de consagração no Brasil. Rio de Janeiro: Roco, 1996.

ABREU, R. Entre o universal e o singular, o museu. Notas sobre a experiência dos índios waiāpi no Museu do Índio. In: BITTENCOURT, J. N.; BENCHETRIT, S. F.; TOSTES, V. L. B. História representada: o dilema dos museus. Rio de Janeiro: MHN; IPHAN; Mine, 2003. p. 157-172.

ABREU, R. Museus etnográficos e práticas de colecionamento: antropofagia dos sentidos. Revista do Patrimônio Histórico e Artístico Nacional, v. 31, p. 100-125, 2005.

ABREU, R. Patrimonializaçáo das diferenças e os novos sujeitos de direito coletivo no Brasil. In: TARDY, C.; DODEBEI, V. (orgs.). Memória e novos patrimônios. 1. ed. Marseille: OpenEdition Press, 2015. v. 1, p. 67-93.

ABREU, R.; CHAGAS, M. (orgs.). Memória e patrimônio: ensaios contemporâneos. Rio de Janeiro: Lamparina, 2003.

ABREU, R.; CHAGAS, M. Museu da Favela da Maré: memórias e narrativas a favor da dignidade social. Musas Revista Brasileira de Museus, n. 3, 2007.

ABREU, R.; CHAGAS, M. S.; SANTOS, M. S. (orgs.). Museus, coleçốes e patrimônios: narrativas polifônicas. Rio de Janeiro: Garamond Universitária; Brasília, DF: Ministério da Cultura, Instituto do Patrimônio Histórico e Artístico Nacional, Departamento de Museus e Centro Culturais, 2007.

ABREU, R.; LIMA FILHO, M. F. A antropologia e o patrimônio cultural no Brasil. In: LIMA FILHO, M. F.; BELTRÃO, J. F.; ECKERT, C. (orgs.). Antropologia e patrimônio cultural: diálogos e desafios. Blumenau: Nova Letra, 2007. p. 21-43.

ABREU, R.; LIMA FILHO, M. F. A trajetória do GT de Patrimônios e Museus da Associação Brasileira de Antropologia. In: TAMASO, I.; LIMA FILHO, M. F. (orgs.). Antropologia e patrimônio cultural: trajetórias e conceitos. 1. ed. Goiânia: Editora da UFG, 2012. p. 25-57.

ABREU, R.; LIMA FILHO, M. F.; ATHIAS, R. (orgs.). Museus e atores sociais: perspectivas antropológicas. 1. ed. Recife: Editora UFPE; Brasília, DF: ABA Publicaçōes, 2016. 
ABREU, R.; OLIVEIRA, R. A. Museus, narrativas e memória coletiva no Rio de Janeiro. In: ABREU, R.; LIMA FILHO, M. F.; ATHIAS, R. (orgs.). Museus e atores sociais: perspectivas antropológicas. 1. ed. Recife: Editora UFPE; Brasília, DF: ABA Publicaçōes, 2016. p. 111-133.

ABREU, R.; RUSSI, A. Cartografia dos museus de Antropologia no Brasil: onde o outro nos habita. In: COSTA, A. L. A.; LEMOS, E. B. R. (orgs.). Anais - 200 anos de museus no Brasil: desafios e perspectivas. Brasília, DF: Instituto Brasileiro de Museus, 2018. p. 232-268.

AGOSTINHO, M. B. A exposição antropológica brasileira de 1882: a sala Lund e a exibição de remanescentes humanos no Museu Nacional. Revista Eletrônica Ventilando Acervos, v. especial, n. 1, p. 36-48, 2019.

ALCÂNTARA, C. F. S. M. Museus em periferias urbanas brasileiras. Horizontes Antropológicos, v. 25, n. 53, p. 169-201, 2019. https://doi.org/10.1590/s0104-71832019000100007.

ALCÂNTARA, C. F. S. M.; GONTIJO, F. S. Os museus, as coisas e as comunidades: novas percepções a partir do Bairro da Terra Firme em Belém, PA. Revista Eletrônica Ventilando Acervos, v. 3, n. 1, p. 92-109, nov. 2015.

ALMEIDA, J. C.; ALMEIDA, J. A. O caso "QUEER MUSEU - cartografias da diferença na arte brasileira" e o sistema de classificação etária de exposiçōes no direito brasileiro. In: SEMINÁRIO INTERNACIONAL EM DIREITOS HUMANOS E SOCIEDADE, 2., 2019, Criciúma. Anais [...]. Criciúma: Unesc, 2019.

AMARAL, F. Os quatro caminhos para o lete: o mergulho de objetos, coleções e acervos LGBTTQ na desmemória. In: SEMINÁRIO INTERNACIONAL DE MUSEOLOGIA, 2., 2014, Goiânia. Anais [...]. Goiânia: Seminário Internacional de Museologia, maio 2014, v. 1, n. 1, p. 237-249.

AMARAL, F. Museus, uso social da informação e homofobia institucional: uma perspectiva documentária. In: SEMINÁRIO BRASILEIRO DE MUSEOLOGIA, 2., 2019, Recife. Anais [...]. Recife: SEBRAMUS, 2019.

ANDRADE, R. S. G. Etnicidade e fronteira nas práticas de colecionamento no médio Araguaia. In: LIMA FILHO, M. F.; PORTO, N. (orgs.). Coleçóes étnicas e museologia compartilhada. Goiânia: Editora da Imprensa Universitária, 2019. p. 193-222.

ARANTES, A. A. Fórum Interamericano e Caribenho do Patrimônio Cultural - um breve histórico de sua constituição. In: SOUZA LIMA, A. C.; BELTRÃO, J. F.; LOBO, A.; CASTILHO, S.; LACERDA, P.; OSÓRIO, P. (orgs.). A antropologia e a esfera pública no Brasil: perspectivas e prospectivas sobre a Associação Brasileira de Antropologia no seu $60^{\circ}$ aniversário. Rio de Janeiro: E-papers; Brasília, DF: Associação Brasileira de Antropologia, 2018. p. 493-501.

ARANTES, A. A.; MOTTA, A. (orgs.). Dossier "Cultural Heritage and Museums". Vibrant - Virtual Brazilian Anthropology, v. 10, n. 1, Jan./June 2013.

ARAÚJO, H. M. M. Museu da Maré: entre educação, memórias e identidades. Boletim do Museu Paraense Emílio Goeldi. Ciências Humanas, v. 12, n. 3, p. 939-949, 2017. http://dx.doi.org/10.1590/1981.81222017000300015.

ATHIAS, R. Objetos indígenas vivos em museus: temas e problemas sobre a patrimonialização. In: ABREU, R.; LIMA FILHO, M. F.; ATHIAS, R. (orgs.). Museus e atores sociais: perspectivas antropológicas. 1. ed. Recife: Editora UFPE; Brasília, DF: ABA Publicaçóes, 2016. p. 189-211.

ATHIAS, R. Entre máscaras, maracás, imagens e objetos xamânicos em museus. In: LIMA FILHO, M. F.; PORTO, N. (orgs.). Coleçóes étnicas e museologia compartilhada. Goiânia: Editora da Imprensa Universitária, 2019. p. $165-192$.

ATHIAS, R.; GOMES, A. O. (orgs.). Coleçóes etnográficas, museus indígenas e processos museológicos. Recife: Editora UFPE, 2018. 
AUDEBERT, A.; WICHERS, C. A. de M.; QUEIROZ, M. S. Interfaces críticas entre museologia, museus e gênero. In: ARAÚJO, B. M. et al. Museologia e suas interfaces críticas [recurso eletrônico]: museu, sociedade e os patrimônios. Recife: Editora UFPE, 2019. p. 96-110.

AUGUSTAT, C.; KAPFHAMMER, W. Looking back ahead: a short history of collaborative work with indigenous source communities at the Weltmuseum Wien. Boletim do Museu Paraense Emílio Goeldi. Ciências Humanas, v. 12, n. 3, p. 749-764, 2017. https://doi.org/10.1590/1981.81222017000300005.

AZEVEDO, C. A.; ALFONSI, D. A. Within the dialog between anthropology and museums: the Reference Center for Brazilian Football. Vibrant - Virtual Brazilian Anthropology, v. 10, n. 1, p. 552-575, June 2013.

BAPTISTA, J. Nada de novo front: o episódio QueerMuseu enquanto continuidade da LGBTFobia nacional e museológica. In: ARAÚJO, B. M. Museologia e suas interfaces críticas [recurso eletrônico]: museu, sociedade e os patrimônios. Recife: Editora UFPE, 2019. p. 82-95.

BAPTISTA, J.; BOITA, T. Protagonismo LGBT e museologia social: uma abordagem afirmativa aplicada à identidade de gênero. Cadernos do CEOM, v. 27, n. 41, p. 175-192, 2014.

BAPTISTA, J.; BOITA, T. Museologia comunitária, comunidades LGBT e Direitos Humanos: estratégias de superação de fobias à diversidade sexual no Brasil. Ventilando Acervos, n. 1, p. 132-146, 2017a. https://doi. org/10.36572/csm.2017.vol.54.02.

BAPTISTA, J;; BOITA, T. Museologia e Comunidades LGBT: mapeamento de açóes de superaçâo das fobias à diversidade em museus e iniciativas comunitárias do globo. 2017. Cadernos de Sociomuseologia, v. 54. s.1, p. 29-56, 2017b. https://doi.org/10.36572/csm.2017.vol.54.02.

BELTRÃO, J. F.; CAROSO, C. Patrimônio, linguagens e memória social: problemas, estudos e visôes no campo da antropologia. In: LIMA FILHO, M. F.; BELTRÃO, J. F.; ECKERT, C. Antropologia e patrimônio cultural: diálogos e desafios contemporâneos. Blumenau: Nova Letra, 2007. p. 45-55.

BEVILACQUA, J. R. S. As esculturas cokwe como respostas às assimetrias civilizacionais. Anais do Museu Paulista: História e Cultura Material, v. 25, n. 2, p. 117-139, 2017. https://doi.org/10.1590/1982-02672017v25n2d05.

BEZERRA, M.; LIMA FILHO, M. F. Os caminhos do patrimônio no Brasil. Revista de Arqueologia, v. 19, n. 1, p. 147-150, 2006. https://doi.org/10.24885/sab.v19i1.221.

BITENCOURT, R. Desafios da diversidade: a diáspora negra e os museus. In: COSTA, A. L. A.; LEMOS, E. B. R. (orgs.). Anais - 200 anos de museus no Brasil: desafios e perspectivas. Brasília, DF: Ibram, 2018. p. 290-297.

BOLLETTIN, P. As vidas dos artefatos Ameríndios amazônicos numa coleçáo etnográfica italiana. Revista Anthropológicas, v. 30, n. 2, p. 63-90, 2019.

BOTELHO, M.; PAOLINO, C. Ecomuseu Rural de Barra Alegre preservando o patrimônio presente nas áreas rurais. Cadernos do CEOM, n. 41, p. 307-313, 2014.

BRISA, Z. Virtual ou não: eis a questão! - conceitos fundamentais para a (des) construção de um museu dito "virtual". Cadernos de Sociomuseologia, v. 53, n. 9, 2017. https://doi.org/10.36572/csm.2017.vol.53.12

BRITTO, C. C.; AGUIAR, F. J. F.; AGUIAR, J. C. T. Encruzilhadas museológicas: ressonâncias da presença/ausência de Exu no Museu Afro-Brasileiro de Sergipe. Anais do Museu Paulista: História e Cultura Material, v. 27, 2019.

BRITTO, C. C.; CUNHA, M. N. B.; CERÁVOLO, S. M. (orgs.). Estilhaços da Memória: o Nordeste e a reescrita das práticas museais no Brasil. Goiânia: Editora Espaço Acadêmico, 2020.

BRUNO, M. C. O. Patrimônio, identidades e metodologias de trabalho: um olhar museológico sobre a exposição São Paulo 450 anos. In: ABREU, R.; CHAGAS, M. S.; SANTOS, M. S. (orgs.). Museus, coleçóes e patrimônios: 
narrativas polifônicas. Rio de Janeiro: Garamond Universitária; Brasília, DF: Ministério da Cultura, Instituto do Patrimônio Histórico e Artístico Nacional, Departamento de Museus e Centro Culturais, 2007. p. 324-332.

CARDOSO DE OLIVEIRA, R. O que é isso que chamamos de antropologia brasileira?. In: CARDOSO DE OLIVEIRA, R. Sobre o pensamento antropológico. Rio de Janeiro: Tempo Brasileiro; Brasília: CNPq, 1988. p. $109-128$.

CASTRO, M. B.; SANTOS, M. S. Abdias do Nascimento e o Museu de Arte Negra. MODOS - Revista de História da Arte, v. 3, n. 3, p. 174-189, 2019. https://doi.org/10.24978/mod.v3i3.4235

CAVIGNAC, J. A. O museu sonhado: folclore e antropologia em terras potiguares. In: ABREU, R.; LIMA FILHO, M. F.; ATHIAS, R. (orgs.). Museus e atores sociais: perspectivas antropológicas. 1. ed. Recife: Editora UFPE; Brasília, DF: ABA Publicaçōes, 2016. p. 73-110.

CHAGAS, M. Imaginaçáo museal: museu, memória e poder em Gustavo Barroso, Gilberto Freyre e Darcy Ribeiro. Tese (Doutorado) - Universidade do Estado do Rio de Janeiro, Rio de Janeiro, 2003a.

CHAGAS, M. S. Memória política e política de memória. In: ABREU, R.; CHAGAS, M. S. (orgs.). Memória e patrimônio: ensaios contemporâneos. Rio de Janeiro: Lamparina, 2003b. p. 136-167.

CHAGAS, M. S. Museu do Índio: uma instituiçâo singular e um problema universal. LIMA FILHO, M. F; BELTRÃO, J. F.; ECKERT, C. Antropologia e patrimônio cultural: diálogos e desafios contemporâneos. Blumenau: Nova Letra, 2007. p. 175-198.

CHAGAS, M. S. A imaginaçáo museal: museu, memória e poder em Gustavo Barroso, Gilberto Freyre e Darcy Ribeiro. Brasília, DF: IBRAM, 2009.

CHAGAS, M. S. Museu, museologia e pensamento social brasileiro. Cadernos do CEOM, v. 18, n. 21, p. 13-44, 2014. Dossiê "Museus: pesquisa, acervo, comunicação".

CHAGAS, M. S.; GOUVEIA, I. Museologia social: reflexões e práticas (à guisa de apresentação). Cadernos do CEOM, v. 27, n. 41, p. 9-22, 2014. Dossiê "Museologia Social”.

CORDEIRO, T. O. A. As dimensóes da construção social do patrimônio no Museu Vivo do São Bento. Cadernos do CEOM, v. 32, n. 51, p. 59-69, 2019.

CORRÊA, A. F. Metamorfoses conceituais do Museu de Magia Negra: primeiro patrimônio etnográfico do Brasil. In: LIMA FILHO, M. F.; BELTRÃO, J. F.; ECKERT, C. Antropologia e patrimônio cultural: diálogos e desafios contemporâneos. Blumenau: Nova Letra, 2007. p. 287-318.

COSTA, K.; DELAMBRE, D.; FERRARI, P. A. Ecomuseu Nega Vilma: patrimônio cultural no pico do Santa Marta. Cadernos do CEOM, v. 27, n. 41, p. 337-353, 2014.

COUTINHO, P. A.; SANTOS, V. D. Projeto ex-votos do Brasil: o museu digital dos ex-votos e a comunicação através dos signos ex-votivos. In: CONGRESSO DE CIÊNCIAS DA COMUNICAÇÃO NA REGIÃO NORDESTE, 11., 2009, Teresina. Anais [...]. Teresina: Intercom, 2009. p. 01-09.

Couto, T. H. P. A tradução do objeto do "outro". In: ABREU, R.; CHAGAS, M. S.; SANTOS, M. S. (orgs.). Museus, coleçóes e patrimônios: narrativas polifônicas. Rio de Janeiro: Garamond Universitária; Brasília, DF: Ministério da Cultura, Instituto do Patrimônio Histórico e Artístico Nacional, Departamento de Museus e Centro Culturais, 2007. p. 179-202.

CUNHA, M. N. B. Museus, memórias e culturas afro-brasileiras. Revista do Centro de Pesquisa e Formaçáo, n. 5, p. $78-88,2019$.

CURY, M. X. Relaçōes (possíveis) museus e indígenas - em discussão uma circunstância museal. In: ABREU, R.; 
LIMA FILHO, M. F.; ATHIAS, R. (orgs.). Museus e atores sociais: perspectivas antropológicas. 1. ed. Recife: Editora UFPE; Brasília, DF: ABA Publicaçóes, 2016. p. 149-170.

CURY, M. X. Museus etnográficos e indígenas: aprofundando questôes, reformulando açōes. São Paulo: Secretaria de Cultura e Economia Criativa: ACAM Portinari: Museu de Arqueologia e Etnologia da Universidade de Sáo Paulo: Museu Índia Vanuíre, 2020.

CURY, M. X.; VASCONCELLOS, C. M.; ORTIZ, J. M. (orgs.). Questóes indígenas e museus: debates e possibilidades. 1. ed. Brodowski: ACAM Portinari: Museu de Arqueologia e Etnologia da Universidade de Sáo Paulo: Secretaria de Estado da Cultura, 2012. (Museu Aberto Collection).

DALLA ZEN, A. M. Entre a utopia e a atopia: a experiência do Programa Lomba do Pinheiro, Memória, Informação \& Cidadania, Porto Alegre-RS. Cadernos do CEOM, v. 27, n. 41, p. 355-372, 2014.

DANTAS, B. G. Tambores silenciosos: a saga dos objetos de terreiros no acervo do IHGSE. Revista do Instituto Histórico e Geográfico de Sergipe, v. 1, n. 44, p. 21-50, 2014.

DELAÎTRE, A.; ROBERT, P. De l'Amazonie Brésilienne aux Musées Français: parcours de collections et processus de légitimation. Revista Anthropológicas, v. 30, n. 2, p. 38-62, 2019.

DELLAMORE, C. Marcas da clandestinidade: memórias da ditadura militar brasileira. Brasília, DF: IBRAM, 2011.

DIAS, C. C.; LIMA, A. C. S. O Museu Nacional e a construçāo do patrimônio histórico nacional. Revista do Patrimônio Histórico e Artístico Nacional, n. 3, p. 199-221, 2012.

DIAS, C. C. M. G. A trajetória de um "museu de fronteira": a criação do Museu da Imagem e do Som e os aspectos da identidade carioca (1960-1965). In: ABREU, R.; CHAGAS, M. (orgs.). Memória e patrimônio: ensaios contemporâneos. Rio de Janeiro: Lamparina, 2003. p. 199-213.

DIAS, J. B. Histórias contadas: análise de uma experiência entre os Anishinabe. Horizontes Antropológicos, v. 25, n. 53, p. 257-281, 2019. https://doi.org/10.1590/s0104-71832019000100010.

DIAS, N. Antropologia e museus: que tipo de diálogo?. In: ABREU, R.; CHAGAS, M. S.; SANTOS, M. S. (orgs.). Museus, coleçôes e patrimônios: narrativas polifônicas. Rio de Janeiro: Garamond Universitária; Brasília, DF: Ministério da Cultura, Instituto do Patrimônio Histórico e Artístico Nacional, Departamento de Museus e Centro Culturais, 2007. p. 126-137.

DINIZ, L. A. G.; OLIVEIRA, A. J. A. Museu digital e nanoarte: novos sujeitos para novos conteúdos. ARTEFACTUM - Revista de Estudos em Linguagens e Tecnologia, v. 11, n. 2, 2015.

DODEBEI, V. Patrimônio e memória digital. Revista Morpheus - Estudos Interdisciplinares em Memória Social, v. 5, n. 8, p. 1-15, 2006.

DÖPCKE, W. Ordem, exotismo e raça - representaçôes “do outro" num museu da província prussiana (1854-1943). Revista Eletrônica do Programa de Pós-Graduaçáo em Museologia e Patrimônio, v. 4, n. 2, p. 3-25, 2011.

DUARTE, L. F. D. O Museu Nacional: ciência e educação numa história institucional brasileira. Horizontes Antropológicos, v. 25, n. 53, p. 359-384, 2019. https://doi.org/10.1590/s0104-71832019000100013.

EICHLER, M. L.; DEL PINO, J. C. Museus virtuais de ciências: uma revisão e indicaçôes técnicas para o projeto de exposiçóes virtuais. RENOTE - Revista Novas Tecnologias na Educaçáo, v. 5, n. 2, p. 1-13, 2007. https://doi. org/10.22456/1679-1916.14377.

EWBANK, C. O. Antropólogos, curadores de museus e museografia durante a gestão de Heloísa Alberto Torres no Museu Nacional (1938-1955). MUSAS - Revista Brasileira de Museus e Museologia, n. 8, p. 8-22, 2018. 
EWBANK, C. O.; LIMA FILHO, M. F. Por detrás de uma coleçấo do Museu Nacional do Rio de Janeiro: vozes, silêncios e desafios. Midas - Museus e estudos interdisciplinares, v. 8, p. 1-17, 2017. https://doi.org/10.4000/ midas. 1233 .

FABRIS, Y.; CORREAA, R. O. (Re) encenando o popular: narrativas sobre a cultura brasileira em uma exposição. Horizontes Antropológicos, v. 25, n. 53, p. 203-225, 2019. https://doi.org/10.1590/s010471832019000100008 .

FAULHABER, P. Traduçôes Magüta: pensamento Ticuna e patrimônio cultural. In: LIMA FILHO, M. F.; BELTRÃO, J. F.; ECKERT, C. Antropologia e patrimônio cultural: diálogos e desafios contemporâneos. Blumenau: Nova Letra, 2007. p. 145-156.

FERRAZ, J. A. F. Os desafios da preservação da memória na ditadura no Brasil. In: ABREU, R.; CHAGAS, M. S.; SANTOS, M. S. (orgs.). Museus, coleçóes e patrimônios: narrativas polifônicas. Rio de Janeiro: Garamond Universitária; Brasília, DF: Ministério da Cultura, Instituto do Patrimônio Histórico e Artístico Nacional, Departamento de Museus e Centro Culturais, 2007. p. 20-47.

FERREIRA, C. M.; LIMA, R. G. O museu de folclore e as artes populares. Revista do Patrimônio Histórico e Artístico Nacional, n. 28, p. 100-119, 1999.

FERREIRA, N. S. A. Um museu vivo, chamado Sacaca. Musas - Revista Brasileira de Museus e Museologia, n. 3, p. 109-116, 2007.

FERRETTI, S. Museus afrodigitais e políticas patrimoniais. São Luís: EDUFMA, 2012.

FRANÇA, B. L. F. C. De mercadoria a patrimônio nacional: arte e tecnologia indígena na formação de uma coleção para o Museu Nacional (1979-1981). Revista Eletrônica Ventilando Acervos, v. 5, n. 2, p. 56-77, nov. 2017.

FRANCO, M. I. M. The city museum of São Paulo: a new design for city museums in the era of the megacity. Vibrant - Virtual Brazilian Anthropology, v. 10, n. 1, p. 253-274, June 2013. http://dx.doi.org/10.1590/ S1809-43412013000100013.

FREIRE, J. R. B. A descoberta do museu pelos índios. In: ABREU, R.; CHAGAS, M. (orgs.). Memória e patrimônio: ensaios contemporâneos. Rio de Janeiro: Lamparina, 2003. p. 217-253.

GALLOIS, D. Acervo etnográfico como centro de comunicação intercultural. Ciências em Museus, v. 1, n. 2, p. 137-142, 1989.

GALVÃO, G. K. A.; BERNARDES, D. M. A organização da informação como instrumento de preservação e acesso ao Museu Virtual da Coleção Etnográfica Carlos Estevão de Oliveira. Museologia e Patrimônio - Revista Eletrônica do Programa de Pós-graduaçáo em Museologia e Patrimônio, v. 4, n. 2, p. 131-144, 2011.

GARCES, C. L. L. et al. Conversaçôes desassossegadas: diálogos sobre coleçôes etnográficas com o povo indígena Ka’apor. Boletim do Museu Paraense Emílio Goeldi. Ciências Humanas, v. 12, n. 3, p. 713-734, 2017. http:// dx.doi.org/10.1590/1981.81222017000300003.

GOLDSTEIN, I. S. Visible art, invisible artists? The incorporation of Aboriginal objects and knowledge in Australian museums. Vibrant - Virtual Brazilian Anthropology, v. 10, n. 1, p. 469-493, June 2013.

GOMES, A. O. Por uma epistemologia dos museus indígenas: temas e problemas. Revista AntHropológicas, v. 30, n. 2, p. 05-37, 2019.

GOMES, A. O. Porque tudo o que é coisa que está no museu é nosso! Museus indígenas, mobilizaçôes étnicas e a Rede Indígena de Memória e Museologia Social. In: COSTA, A. L. A.; LEMOS, E. B. R. (orgs.). Anais - 200 anos de museus no Brasil: desafios e perspectivas. Brasília, DF: Instituto Brasileiro de Museus, 2018. p. 269-288. 
GOMES, A. O.; OLIVEIRA, A. A. R. A construção social da memória e o processo de ressignificação dos objetos no espaço museológico. Museologia e Patrimônio, v. 3, n. 2, p. 42-55, 2010.

GOMES, A. O.; VIEIRA, J. P. A rede cearense de museus comunitários: processos e desafios para a organização de um campo museológico autônomo. Cadernos do CEOM, v. 27, n. 41, p. 389-414, 2014.

GOMES, A. O.; VIEIRA NETO, J. P. Projeto Historiando: inventários participativos e musealização do patrimônio cultural em comunidades indígenas no Ceará. Musas - Revista Brasileira de Museus e Museologia, n. 8, p. 72-96, 2018.

GONÇALVES, J. R. S. Rediscoveries of Brazil: nation and cultural heritage as narratives. 1989. Tese (Doutorado) Universidade de Virgínia, Charlottesville, 1989.

GONÇALVES, J. R. S. O templo e o fórum: reflexóes sobre museus, antropologia e cultura. In: CHUVA, M. (org.). A invençáo do patrimônio. Brasília, DF: Instituto do Patrimônio Histórico e Artístico Nacional, 1995. p. 62.

GONÇALVES, J. R. S. A retórica da perda: os discursos do patrimônio cultural no Brasil. Rio de Janeiro: Editora UFRJ; Brasília, DF: Ministério da Cultura, Instituto do Patrimônio Histórico e Artístico Nacional, 1996.

GONÇALVES, J. R. S. O patrimônio como categoria de pensamento. In: ABREU, R.; CHAGAS, M. S. (orgs.). Memória e patrimônio: ensaios contemporâneos. Rio de Janeiro: Lamparina, 2003. p. 25-33.

GONÇALVES, J. R. S. Antropologia dos objetos: coleçōes, museus e patrimônios. BIB - Revista Brasileira de Informaçáo Bibliográfica em Ciências Sociais, v. 60, p. 7-26, 2005a.

GONÇALVES, J. R. S. Os museus e a representação do Brasil. Revista do Patrimônio Histórico e Artístico Nacional, v. 31, p. 254-273, 2005b.

GONÇALVES, J. R. S. Antropologia dos objetos: coleçôes, museus e patrimônios. Rio de Janeiro: Brasília: Ministério da Cultura, Instituto do Patrimônio Histórico e Artístico Nacional, Departamento de Museus e Centro Culturais, 2007.

GONÇALVES, J. R. S.; BITAR, N. P.; GUIMARÃES, R. S. (orgs.). A alma das coisas: patrimônios, materialidade e ressonância. Rio de Janeiro: Mauad; Faperj, 2013.

GONÇALVES, M. A. R.; CASTRO, M. B. A feira das yabás e o Projeto "Museu afrodigital rio: memória entre geraçóes nos quintais do samba da Grande Madureira”. Outros Tempos - Pesquisa em Foco-História, v. 15, n. 25, p. 95-107, 2018. https://doi.org/10.18817/ot.v15i25.638.

GOUVEIA, I.; DODEBEI, V. Memórias de pessoas, de coisas e de computadores: museus e seus acervos no ciberespaço. MUSAS - Revista Brasileira de Museus e Museologia, n. 3, p. 93-100, 2007.

GRUBER, J. Museu Magüta. Piracema - Revista de Arte e Cultura, p. 84-94, 1994.

GRUPIONI, L. D. B. Coleçóes e expediçóes vigiadas: os etnólogos no Conselho de Fiscalização das Expedições Artísticas e Científicas no Brasil. São Paulo: Editora Hucitec, 1998.

GUERRA, C. B.; BENCHIMOL, A. C. Dois momentos da coleção Aparai no Museu Paraense Emílio Goeldi: Curt Nimuendajú em 1915 e Otto Schulz-Kampfhenkel em 1935-37. Museologia e Patrimônio, v. 10, n. 2, p. 92-116, 2017.

HEITOR, G.; CHAGAS, M. (orgs.). O pensamento museológico de Gilberto Freyre. Recife: Editora Massangana, 2017.

HEITOR, G. K. Museu plebeu: digressóes sobre o Museu da Beira da Linha do Coque (Recife-PE). In: SOARES, B. B.; BROWN, K.; NAZOR, O. (orgs.). Defining museums of the $21^{\text {st }}$ century: plural experiences. 1. ed. Paris: ICOM/ICOFOM, 2018. v. 1, p. 99-104. 
KERSTEN, M. S. A.; BONIN, A. Para pensar os museus, ou 'Quem deve controlar a representação do significado dos outros?’. MUSAS - Revista Brasileira de Museus e Museologia, n. 3, p. 117-128, 2007.

KOK, G. A fabricação da alteridade nos museus da América Latina: representações ameríndias e circulação dos objetos etnográficos do século XIX ao XXI. Anais do Museu Paulista: História e Cultura Material, v. 26, e06d1, 2018. https://doi.org/10.1590/1982-02672018v26e06d1.

KUBRUSLY, C. Q. Katarina Real (1927-2006) e os maracatus Nação Estrela Brilhante. In: TAMASO, I. M.; LIMA FILHO, M. F. (orgs.). Antropologia e patrimônio cultural: trajetórias e conceitos. Brasília, DF: Associação Brasileira de Antropologia, 2012. p. 401-426.

KUBRUSLY, C. Q. A experiência etnográfica de Katarina Real (1927-2006): colecionando maracatus em Recife. Brasília: Instituto Brasileiro de Museus, 2011.

LANGER, J.; RANKEL, L. F. Cultura material e civilizaçẫo: a exposição antropológica de 1882. Cadernos do CEOM, v. 19, n. 24, p. 13-30, 2014.

LERNER, K. Memórias da dor: coleções e narrativas sobre o Holocausto. Brasília: Instituto Brasileiro de Museus, 2013.

LIMA, D. F. C. Musealização/Patrimonialização no espaço eletrônico Museu Virtual. Memória e Informaçáo, v. 3, n. 2, p. 86-105, 2019.

LIMA, N. C. Pensando retóricas expositivas no Museu Antropológico da Universidade Federal de Goiás (UFG). In: ABREU, R.; LIMA FILHO, M. F.; ATHIAS, R. (orgs.). Museus e atores sociais: perspectivas antropológicas. 1. ed. Recife: Editora UFPE; Brasília, DF: ABA Publicaçóes, 2016. p. 135-145.

LIMA, N. C.; LEITÃO, R. M. Patrimônio cultural Iny-Karajá e política de salvaguarda: diálogo intercultural e trabalho compartilhado. In: LIMA FILHO, M. F.; PORTO, N. (org.). Coleçóes étnicas e museologia compartilhada. Goiânia: Editora da Imprensa Universitária, 2019. p. 223-260.

LIMA, P. E. F. À luz do presente: problemas do pensamento museológico de Gilberto Freyre. Museologia \& Interdisciplinaridade, v. 8, n. 16, p. 330-334, 2019. https://doi.org/10.26512/museologia.v8i16.26203.

LIMA FILHO, M. F. O fluxo das coisas Karajá e a coleção William Lipkind do Museu Nacional: a construção de um diálogo intercultural. In: ABREU, R.; LIMA FILHO, M. F.; ATHIAS, R. (orgs.). Museus e atores sociais: perspectivas antropológicas. 1. ed. Recife: Editora UFPE; Brasília, DF: ABA Publicaçōes, 2016. p. 171-188.

LIMA FILHO, M. F. Coleçáo William Lipkind do Museu Nacional: trilhas antropológicas Brasil-Estados Unidos. Mana, v. 23, n. 3, p. 473-509, 2017. http://dx.doi.org/10.1590/1678-49442017v23n3p473.

LIMA FILHO, M. F.; ATHIAS, R. Dos museus etnográficos às etnografias dos museus: o lugar da antropologia na contemporaneidade. In: RIAL, C.; SCHWADE, E. (orgs.). Diálogos antropológicos contemporâneos. Rio de Janeiro: ABA, 2016. p. 71-83.

LIMA FILHO, M. F.; BELTRÃO, J. F.; ECKERT, C. Antropologia e patrimônio cultural: diálogos e desafios contemporâneos. Blumenau: Nova Letra, 2007.

LIMA FILHO, M. F.; PORTO, N. (orgs.). Coleçóes étnicas e museologia compartilhada. Goiânia: Editora da Imprensa Universitária, 2019.

LIMA FILHO, M. F. et al. Interculturalidade e saberes compartilhados: estudo da Coleção William Lipkind (19381939) do Museu Nacional/UFRJ. In: LIMA FILHO, M. F.; PORTO, N. (orgs.). Coleçóes étnicas e museologia compartilhada. Goiânia: Editora da Imprensa Universitária, 2019. p. 43-66.

MACHADO, M. Antropologia digital e experiências virtuais do museu de favela. Curitiba: Appris Editora, 2017. 
MACHADO, M.; SOARES, A. Ativação e consumo digital no Museu de Favela. Memória e Informaçáo, v. 2, n. 1, p. 51-65, jan./jun. 2018.

MACIEL, M. E.; ABREU, R. Antropologia dos museus: um campo de estudos em expansão. Horizontes Antropológicos, v. 25, n. 53, p. 7-15, 2019. https://doi.org/10.1590/s0104-71832019000100001.

MANO, M. Inimigos, jaguares e espíritos: os outros e suas transformaçóes. Revista Anthropológicas, v. 30, n. 2, p. 91-119, 2019.

MARTINEZ, P. H. The nation by the plume nature and society in the Museu do Índio (Rio de Janeiro, 1953-1957). Anais do Museu Paulista: História e Cultura Material, v. 20, n. 2, p. 119-149, 2012. https://doi.org/10.1590/ S0101-47142012000200005.

MARTINS, C. D. Coleção Mario de Andrade no Museu Afrodigital - Estação Pernambuco: um estudo sobre repatriação digital de acervos. Museologia \& Interdisciplinaridade, v. 8, n. 16, p. 301-309, jul./dez. 2019. https://doi.org/10.26512/museologia.v8i16.27326.

MARTINS, M. T. R. Ecomuseu da Amazônia: uma experiência ao serviço do desenvolvimento comunitário no município de Belém-PA. Cadernos do CEOM, v. 27, n. 41, p. 315-328, 2014.

MENEZES, C. Museu vivo: o Museu do Índio do Rio de Janeiro. Rio de Janeiro: FUNAI, 1987.

Menezes, R. C. Os objetos religiosos cabem em quais vitrines? In: LIMA FILHO, M. F.; PORTO, N. (orgs.). Coleçóes étnicas e museologia compartilhada. Goiânia: Editora da Imprensa Universitária, 2019. p. 102-192.

MENEZES NETO, H.; COSTA, S. O Antropoceno no Museu do Amanhã (RJ): perspectivas críticas à exposição de longa duração. Museologia e Patrimônio - Revista Eletrônica do Programa de Pós-Graduaçáo em Museologia e Patrimônio, v. 12, n. 1, p. 118-138, 2019.

MONTECHIARE, R. Coleçôes e objetos em diálogo com as linguagens expositivas do museu antropológico. Museologia e Patrimônio - Revista Eletrônica do Programa de Pós-Graduaçáo em Museologia e Patrimônio, v. 9, n. 1, p. 114-133, 2016.

MONTEZ, L. B. No rastro de um colecionador incansável: alguns problemas relacionados à pesquisa sobre Johann Natterer e sua expediçẫo científica no Brasil. MUSAS - Revista Brasileira de Museus e Museologia, n. 5, p. 60-79, 2011.

MOTTA, A. Museu Afro digital. Estudos Universitários, v. 27, p. 225-228, 2011.

MOTTA, A. Da África em casa à África fora de casa (Notas sobre uma exposição em trânsito). In: DIAS, J. B.; LOBO, A. S. África em movimento. Brasília, DF: Brasília, DF: ABA Publicaçôes, 2012. p. 245-270.

MOTTA, A. Museos y la política del reconocimiento. In: SANZ, N. (ed.). Museuns \& Dialogue betwenn cutures. Mexico City: UNESCO, 2018a. p. 157-165.

MOTTA, A. Museos. In: BAZTÁN, Á. A. (ed.). Diccionario temático de antropología cultural. Madrid: Delta Publicacciones, 2018b. p. 343-350.

MOTTA, A. O narrador inconfiável: do museu como consagração da nação ao museu como lugar de reconstruçóes políticas e culturais para as diferenças. In: COSTA, A. L. A.; LEMOS, E. B. R. (orgs.). Anais - 200 anos de museus no Brasil: desafios e perspectivas. Brasília, DF: Instituto do Patrimônio Histórico e Artístico Nacional, 2018c. p. 337-350.

MOTTA, A. Memórias plurais e direitos culturais. Outros Tempos, v. 15, n. 25, p. 84-94, $2018 \mathrm{~d}$. 
MOTTA, A. Direitos culturais e açōes museais. In: GONÇALVES, R. S.; VASSALLO, S. P. (org.). A antropologia na esfera pública: patrimônios culturais e museus. Goiânia: Editora Imprensa Universitária, 2019. p. 268-261. E-book.

MOTTA, A.; OLIVEIRA, L. A. Dramatização e patrimonialização de diferenças culturais: a experiência museográfica como ato performático. In: SANDRONI, C. (org.). Patrimônio cultural em discussáo: novos desafios teóricometodológicos. Recife: Editora Universitária, 2013. p. 175-193.

MOTTA, A.; OLIVEIRA, L. A. Identidades performadas no museu: dramatização e patrimonialização de diferenças culturais numa narrativa expográfica. In: PONTES Jr., G.; CASTRO, M. B.; SANTOS, M. S. (orgs.). Diálogos interdisciplinares: literatura e políticas culturais. Rio de Janeiro: Editora UFRJ, 2014. p. 83-101.

MOTTA, A.; OLIVEIRA, L. Cultura nas malhas da política: patrimônio, museus e o direito à diferença. Revista Anthropológicas, v. 26, n. 2, p. 105-133, 2015.

MOTTA, A.; OLIVEIRA, L. Políticas da cultura na cena pública: patrimônio, museus e o direito à diferença. In: SOUZA LIMA, A. C.; BELTRÃO, J. F.; LOBO, A.; CASTILHO, S.; LACERDA, P.; OSÓRIO, P. (orgs.). A antropologia e a esfera pública no Brasil: perspectivas e prospectivas sobre a Associaçáo Brasileira de Antropologia no seu $60^{\circ}$ aniversário. Rio de Janeiro, Brasília: E-papers/Associação Brasileira de Antropologia, 2018. p. $467-492$.

MOUTINHO, M. C. Definição evolutiva de sociomuseologia: proposta de reflexão. Cadernos do CEOM, v. 27, n. 41, p. 423-427, 2014. Dossiê "Museus: pesquisa, acervo, comunicaçáo".

NASCIMENTO JÚNIOR, J. Antropologia e museus: revitalizando o diálogo. In: ABREU, R.; CHAGAS, M. S.; SANTOS, M. S. (orgs.). Museus, coleçóes e patrimônios: narrativas polifônicas. Rio de Janeiro: Garamond Universitária; Brasília, DF: Ministério da Cultura, Instituto do Patrimônio Histórico e Artístico Nacional, Departamento de Museus e Centro Culturais, 2007. p. 262-274.

NOGUEIRA, N. Quebrando 200 anos de silêncio: a presença das memórias afro-brasileiras nos museus. In: COSTA, A. L. A.; LEMOS, E. B. R. (orgs.). Anais - 200 anos de museus no Brasil: desafios e perspectivas. Brasília, DF: Instituto Brasileiro de Museus, 2018. p. 298-305.

OLIVEIRA, J. P. O retrato de um menino Bororo: narrativas sobre o destino dos índios e o horizonte político dos museus, séculos XIX e XXI. Tempo, v. 12, n. 23, p. 73-99, 2007. https://doi.org/10.1590/S141377042007000200006 .

OLIVEIRA, J. P.; SANTOS, R. C. M. Descolonizando a ilusão museal: etnografia de uma proposta expositiva. In: ABREU, R.; LIMA FILHO, M. F.; ATHIAS, R. (orgs.). Museus e atores sociais: perspectivas antropológicas. 1. ed. Recife: Editora UFPE; Brasília, DF: ABA Publicaçóes, 2016. p. 17-56.

OLIVEIRA, J. P.; SANTOS, R. C. M. (orgs.). De acervos coloniais aos museus indígenas: formas de protagonismo e de construção da ilusão museal. João Pessoa: Editora da UFPB, 2019.

ORTIZ, R. I. Artes, artefatos e cosmologia entre os Guarani (Nhandeva) em Dourados (MS). Revista Anthropológicas, v. 30, n. 2, p. 120-155, 2019.

PAIVA, A. L. S. Museu dos Escravos, Museu da Abolição: o Museu do Negro e a arte de colecionar para patrimoniar. In: ABREU, R.; CHAGAS, M. S.; SANTOS, M. S. (orgs.). Museus, coleçóes e patrimônios: narrativas polifônicas. Rio de Janeiro: Garamond Universitária; Brasília, DF: Ministério da Cultura, Instituto do Patrimônio Histórico e Artístico Nacional, Departamento de Museus e Centro Culturais, 2007. p. 203-228.

PEREIRA, E. Exercício breve sobre a formação de series etnográficas a partir de coleçōes etnológicas. In: LIMA FILHO, M. F.; PORTO, N. (orgs.). Coleçóes étnicas e museologia compartilhada. Goiânia: Editora da Imprensa Universitária, 2019. p. 14-42. 
PINTO, R. Museus e diversidade sexual: reflexōes sobre mostras LGBT e Queer. Revista Arqueologia Pública, v. 5 , n. 1 [5], p. 44-55, 2012.

PIRES, V. S. Para o levante da multidão, uma museologia da monstruosidade?. Cadernos do CEOM, v. 27, n. 41, p. $225-238,2014$.

POMIAN, K. Coleção. Enciclopédia Einaudi, v. 1, p. 51-86, 1984.

PORTILHO, A. S. O Museu de Favela e a produção do espaço no Pavão-Pavãozinho e Cantagalo (Rio de Janeiro/RJ). Cadernos do CEOM, v. 31, n. 49, p. 92-102, 2018.

PORTO, N. Para uma prática curatorial comprometida com justiça social. In: LIMA FILHO, M. F.; PORTO, N. (orgs.). Coleçóes étnicas e museologia compartilhada. Goiânia: Editora da Imprensa Universitária, 2019. p. 43-66.

RAFAEL, U. N.; MAGGIE, Y. Sorcery objects under institutional tutelage: magic and power in ethnographic collections. Vibrant - Virtual Brazilian Anthropology, v. 10, n. 1, p. 276-342, June 2013.

RECHENA, A. Museologia social e gênero. Cadernos do CEOM, v. 27, n. 41, p. 153-174, 2014.

REIS, D. "Visite o Brasil no Museu Rossini Tavares de Lima": embates, experimentaçôes e exibiçôes. In: TAMASO, I. M.; LIMA FILHO, M. F. (orgs.). Antropologia e patrimônio cultural: trajetórias e conceitos. Brasília, DF: Associação Brasileira de Antropologia, 2012. p. 427-466.

RIBEIRO, R. A. Moradas da memória: uma história social da casa-museu de Gilberto Freyre. Brasília, DF: Instituto Brasileiro de Museus, 2008.

RIBEIRO, T. S. D.; MOREIRA, I. C. Ecomuseu de Itaipu e Programa Cultivando Água Boa: gestão patrimonial comunitária na Bacia Paraná 3. Cadernos do CEOM, v. 27, n. 41, p. 289-305, 2014.

ROCA, A. Acerca dos processos de indigenização dos museus: uma análise comparativa. Mana, v. 21, n. 1, p. 123-156, 2015. https://doi.org/10.1590/0104-93132015v21n1p123.

ROCA, A. C. M. Objetos alheios, histórias compartilhadas: os usos do tempo em um museu etnográfico. Rio de Janeiro: Brasília: Ministério da Cultura; Instituto do Patrimônio Histórico e Artístico Nacional; Departamento de Museus e Centro Culturais, 2008.

RODRIGUES, R. O. Escrita e projeto museológico: uma análise a partir do Museo Nazionale Preistorico Etnografico Luigi Pigorini di Roma. Ilha Revista de Antropologia, v. 20, n. 2, p. 133-153, 2018. https://doi. org/10.5007/2175-8034.2018v20n2p133.

ROZA, L. M. Heterogeneidade temática e usos da memória de uma experiência histórica: uma visita ao Museu Digital da Memória Afro-Brasileira e Africana. Revista História Hoje, v. 3, n. 6, p. 223-238, 2014. https://doi. org/10.20949/rhhj.v3i6.145.

RUSSI, A. Coleçôes etnográficas, povos indígenas e práticas de representação: as mudanças nos processos museais com as experiências colaborativas. Sociedade e Cultura, v. 21, n. 1, p. 72-94, 2018. https://doi.org/10.5216/ sec.v21i1.54881.

RUSSI, A.; ABREU, R. "Museologia colaborativa": diferentes processos nas relaçôes entre antropólogos, coleçóes etnográficas e povos indígenas. Horizontes Antropológicos, v. 25, n. 53, p. 17-46, 2019. https://doi. org/10.1590/s0104-71832019000100002.

RUSSI, A.; KIEFFER-DØSSING, A. Museums and indigenous memory: the Katxuyana's collections and the contemporaneity of musealized material culture. Museum and Society, v. 17, n. 3, p. 494-509, 2019. https:// doi.org/10.29311/mas.v17i3.2980. 
SÁ BARRETO, F.; MENEZES NETO, H.; LIMA, G. De. Museus e cultura política. In: ARAÚJO, B. M. et al. Museologia e suas interfaces críticas [recurso eletrônico]: museu, sociedade e os patrimônios. Recife: Editora UFPE, 2019. p. 130-146.

SANJAD, N. Emílio Goeldi e o Museu Paraense. In: SANJAD, N.; VAN VELTHEM, L. H. (orgs.). Reencontros: Emílio Goeldi e o Museu Paraense. Belém: Museu Paraense Emílio Goeldi, 2002. p. 17-21.

SANJAD, N. A coruja de Minerva: o Museu Paraense entre o Império e a República (1866-1907). Brasília, DF: Instituto Brasileiro de Museus; MPEG; Fiocruz, 2010.

SANSI-ROCA, R. De armas do fetichismo a patrimônio cultural: as transformaçōes do valor museográfico do Candomblé em Salvador da Bahia no século XX. In: ABREU, R.; CHAGAS, M. S.; SANTOS, M. S. (orgs.). Museus, coleçóes e patrimônios: narrativas polifônicas. Rio de Janeiro: Garamond Universitária; Brasília, DF: Ministério da Cultura, Instituto do Patrimônio Histórico e Artístico Nacional, Departamento de Museus e Centro Culturais, 2007. p. 95-112.

SANSONE, L. Memórias da África: patrimônios, museus e políticas das identidades. Salvador: EDUFBA, 2012.

SANSONE, L. Challenges to digital patrimonialization: heritage.org/ digital Museum of African and Afro-Brazilian Memory. Vibrant - Virtual Brazilian Anthropology, v. 10, n. 1, p. 343-386, Jan./June 2013. https://doi. org/10.1590/S1809-43412013000100015.

SANTOS, M. S. História, tempo e memória: um estudo sobre museus a partir da observação feita no Museu Imperial e no Museu Histórico Nacional. 1989. Dissertaçáo (Mestrado) - Instituto Universário de Pesquisas do Rio de Janeiro, Universidade Cândido Mendes, Rio de Janeiro, 1989.

SANTOS, M. S. Os museus brasileiros e a constituição do imaginário nacional. Sociedade e Estado, v. 15, n. 2, p. $271-302,2000$.

SANTOS, M. S. Políticas da memória na criação dos museus brasileiros. Cadernos de Sociomuseologia, v. 19, n. 19, 2002.

SANTOS, M. S. Museu Imperial: a construção do Império pela República. In: ABREU, R.; CHAGAS, M. (orgs.). Memória e patrimônio: ensaios contemporâneos. Rio de Janeiro: Lamparina, 2003. p. 115-135.

SANTOS, M. S. Os conflitos entre natureza e cultura na implementação do Ecomuseu Ilha Grande. História, Ciências, Saúde-Manguinhos, v. 12, p. 381-400, 2005a. http://dx.doi.org/10.1590/S0104-59702005000400020.

SANTOS, M. S. Representations of black people in Brazilian museums. Museum and Society, v. 3, n. 1, p. 51-65, 2005 b.

SANTOS, M. S. A escrita do passado em museus históricos. Rio de Janeiro: Garamond Universitária; Brasília: Ministério da Cultura; Instituto do Patrimônio Histórico e Artístico Nacional; Departamento de Museus e Centro Culturais, 2006.

SANTOS, M. S. Museu digital da memória afro-brasileira: algumas questóes In: MUSEU DE ASTRONOMIA E CIÊNCIAS AFINS. O caráter político dos museus. Rio de Janeiro: MAST, 2010. v. 12, p. 75-88.

SANTOS, M. S. Museu digital da memória afro-brasileira: um ato de resistência. In: SANSONE, L. (org.). A política do intangível: museus e patrimônios em nova perspectiva. Salvador: EDUFBA, 2012. p. 277-293.

SANTOS, R. C. Becos e vielas do Museu de Favela. Cadernos do CEOM, v. 27, n. 41, p. 329-336, 2014.

SANTOS, R. C. M. Um antropólogo no museu: Edgar Roquette-Pinto e o exercício da antropologia no Brasil nas primeiras décadas do século XX. Horizontes Antropológicos, n. 53, p. 283-315, 2019. 
SCARPELLI, C. D. B. Marcas da clandestinidade: memórias da ditadura militar brasileira. 2009. Dissertação (Mestrado em Memória Social) - Universidade Federal do Estado do Rio de Janeiro, Rio de Janeiro, 2009.

SCHRÖDER, P. Curt Nimuendajú e os museus etnológicos na Alemanha. Revista Anthropológicas, v. 22, n. 1, p. 141-160, 2012.

SCHWARCZ, L. K. M. O nascimento dos museus brasileiros, 1870-1910. In: MICELI, S. (org.). História das ciências sociais no Brasil. São Paulo: Finep: Vértice, 1989. v. 1.

SCHWARCZ, L. K. M. O espetáculo das raças: cientistas, instituições e questão racial no Brasil: 1870-1930. São Paulo: Companhia das Letras, 1995.

SHEPARD JR., G. H. et al. Objeto, sujeito, inimigo, vovô: um estudo em etnomuseologia comparada entre os Mebêngôkre-Kayapó e Baniwa do Brasil. Boletim do Museu Paraense Emílio Goeldi. Ciências Humanas, v. 12, n. 3, p. 765-787, 2017. http://dx.doi.org/10.1590/1981.81222017000300006.

SILVA, A. L. Quando as musas vestem o hábito: diálogo entre antropologia, museologia e história à soleira dos museus missionários. Museologia \& Interdisciplinaridade, v. 4, n. 7, p. 91-111, 2015. https://doi.org/10.26512/ museologia.v4i7.16775.

SILVA, J. B. Museus digitais: desafios e disputa por memórias. In: FURTADO, C. A.; SANSONE, L. (org.). Lutas pela memória em África. Salvador: EDUFBA, 2019. p. 69-92.

SILVA, R. M.; JANUÁRIO, R. Rede de Museologia Social do Rio de Janeiro. Cadernos do CEOM, v. 27, n. 41, p. 415-420, 2014.

SILVA, F. A.; GORDON, C. Anthropology in the museum: reflections on the curatorship of the Xikrin Collection. Vibrant - Virtual Brazilian Anthropology, v. 10, n. 1, p. 425-468, June 2013.

SILVA, T. C. Musealização de eventos críticos: análise da tensão entre múltiplas narrativas da dor. In: TAMASO, I. M.; LIMA FILHO, M. F. (org.). Antropologia e patrimônio cultural: trajetórias e conceitos. Brasília, DF: Associação Brasileira de Antropologia, 2012. p. 497-526.

SIMÃO, M. S. Museu, memória e cultura afro-brasileira. Brasília, DF: Instituto Brasileiro de Museus, 2018.

SOARES, B. B. Os mitos do ecomuseu: entre representação e a realidade dos museus comunitários. Revista Musas Revista Brasileira de Museus e Museologia, n. 6, p. 30-47, 2014.

SOARES, B. B. A invenção do ecomuseu: o caso do Écomusée du Creusot Montceau-les-Mines e a prática da museologia experimental. Mana, v. 21, n. 2, p. 267-295, 2015. http://doi.org/10.1590/0104-93132015v21n2p267.

SOARES, M. C.; AGOSTINHO, M. B. A coleção ovimbundu do Museu Nacional, Angola 1929-1935. Mana, v. 22, n. 2, p. 493-518, 2016. https://doi.org/10.1590/1678-49442016v22n2p493.

SOARES, M. C.; AGOSTINHO, M. B.; LIMA, R. C. Conhecendo a exposiçáo Kumbukumbu do Museu Nacional. Rio de Janeiro: Museu Nacional; UFRJ, 2016.

SOARES, M. C.; LIMA, R. C. A africana do Museu Nacional: história e museologia. In: AGOSTINI, C. (org.). Objetos da escravidáo: abordagens sobre a cultura material da escravidão e seu legado. Rio de Janeiro: 7 Letras, 2013. p. 337-360.

SOUZA LIMA, A. C. Os museus de história natural e a construçáo do indigenismo. Notas para uma sociologia das relaçôes entre campo intelectual e campo político no Brasil. Revista de Antropologia, v. 30/32, p. 277-329, 1989.

SOUZA limA, A. C.; BelTRÃO, J. F.; LOBO, A.; CASTILHO, S.; LACERDA, P.; OSÓRIO, P. (orgs.). A antropologia e a esfera pública no Brasil: perspectivas e prospectivas sobre a Associação Brasileira de Antropologia no seu $60^{\circ}$ aniversário. Rio de Janeiro: E-papers; Brasília, DF: Associação Brasileira de Antropologia, 2018. 
SPERB, A. T.; HANSEN, P. R. S. A continuidade do Museu de Rua. Cadernos do CEOM, v. 27, n. 41, p. 251-271, 2014.

STOCKING, G. W. Essays on museums and material culture. In: STOCKING, G. W. Objects and others: essays on museums and material culture. Madison, Wisconsin: The University of Wisconsin Press, 1985. p. 3-14.

TAMASO, I. M.; GONÇALVES, R. S.; VASSALLO, S. P. (org.). A antropologia na esfera pública: patrimônios culturais e museus. Goiânia: Editora Imprensa Universitária, 2019. E-book.

TAMASO, I. M.; LIMA FILHO, M. F. (orgs.). Antropologia e patrimônio cultural: trajetórias e conceitos. Brasília, DF: Associação Brasileira de Antropologia, 2012.

TOLENTINO, A.; FRANCH, M. Espaços que suscitam sonhos: narrativas de memórias e identidades no Museu Comunitário Vivo Olho do Tempo. João Pessoa: Editora da UFPB, 2017.

VALDIVIESO, S. C.; LIMA FILHO, M. F. (orgs.). Apresentação ao Dossiê: Coleções Etnográficas e Processos Museológicos. Revista Anthropológicas, v. 30, n. 2, p. 1-4, 2019.

VAN VELTHEM, L. H. A coleção etnográfica do Museu Paraense Emílio Goeldi: memória e conservação. MUSAS - Revista Brasileira de Museus e Museologia, v. 1, n. 1, p. 121-134, 2004.

VAN VELTHEM, L. H. O objeto etnográfico é irredutível? Pistas sobre novos sentidos e análises. Boletim do Museu Paraense Emílio Goeldi. Ciências Humanas, v. 7, n. 1, p. 51-66, 2012.

VAN VELTHEM, L. H.; BENCHIMOL, A. Museus, coleções, exposições e povos indígenas. Em Questáo, v. 24, n. 2, p. 468-486, 2018. https://doi.org/10.19132/1808-5245242.468-486.

VAN VELTHEM, L. H.; KUKAWKA, K.; JOANNY, L. Museus, coleçôes etnográficas e a busca do diálogo intercultural. Boletim do Museu Paraense Emílio Goeldi. Ciências Humanas, v. 12, n. 3, p. 735-748, 2017. https://doi.org/10.1590/1981.81222017000300004.

VAQUINHAS, I. Museus do feminino, museologia de género e o contributo da história. MIDAS - Museus e Estudos Interdisciplinares, n. 3, 2014. https://doi.org/10.4000/midas.603.

VELOSO JÚNIOR, C. R. Índice de objetos, índice de histórias: o catálogo geral das coleçōes de antropologia e etnografia do museu nacional. Ventilando Acervos, v. 1, p. 71-89, 2019.

VIDAL, L. B. O museu dos povos indígenas do Oiapoque - Kuahí. Gestão do patrimônio cultural pelos povos indígenas do Oiapoque, Amapá. Revista do Museu de Arqueologia e Etnologia, supl. 7, p. 109-115, 2008. https://doi.org/10.11606/issn.2594-5939.revmaesupl.2008.113500.

VIDAL, L. B. Kuahí: the indians of the Lower Oiapoque and their museum. Vibrant - Virtual Brazilian Anthropology, v. 10, n. 1, p. 387-423, June 2013.

VIEIRA, A. C. P. Maré: casa e museu, lugar de memória. MUSAS - Revista Brasileira de Museus e Museologia, $\mathrm{n}$. 3, p. 153-160, 2007.

VIEIRA, M. A. N. Dja Guata Porã: o rio indígena que desaguou no MAR. Horizontes Antropológicos, v. 25, n. 53, p. 227-256, 2019. http://dx.doi.org/10.1590/s0104-71832019000100009.

VIEIRA, M. C. A Exposição Antropológica Brasileira de 1882 e a exibição de índios botocudos: performances de primeiro contato em um caso de zoológico humano brasileiro. Horizontes Antropológicos, v. 25, n. 53, p. 317357, 2019. http://dx.doi.org/10.1590/s0104-71832019000100012. 


\title{
Antropologia da saúde: entre práticas, saberes e políticas
}

\author{
Sônia Weidner Maluf ${ }^{\mathrm{I}}$ \\ Érica Quinaglia Silva ${ }^{\text {II }}$ \\ Marcos Aurélio da Silva ${ }^{\text {III }}$
}

O tema dos processos de adoecimento, saúde e cura, incluindo todos os aspectos que se ligam a ele, tanto relacionados à experiência subjetiva, como dor, aflição e sofrimento, quanto aqueles mais evidentemente do mundo social, tais como os diferentes sistemas médicos e de cura e as políticas e micropolíticas em saúde, sempre foi um desafio para a antropologia. Em primeiro lugar, por ser um tema cuja narrativa hegemônica está em outro campo, o biomédico, e com o qual os estudos antropológicos de saúde se defrontam e, eventualmente, confrontam ou dialogam. Em segundo lugar, está ligado, em muitos momentos, às tênues fronteiras entre a antropologia da saúde e outras áreas, como a saúde coletiva, o que se acentuou nos últimos anos com a entrada significativa de antropólogos(as) em programas e cursos dessa e de outras áreas, deixando-nos a pergunta de qual seria, então, a especificidade da antropologia diante dos outros estudos sociais da saúde. Em terceiro lugar, para falar de um desafio ou mais propriamente de um dilema interno à própria disciplina, ligado à especificidade do tema da saúde ou à sua diluição em outras dimensóes da experiência social, está a indagação do quanto os estudos antropológicos sobre saúde constituem, ou não, uma subárea ou um campo específico da disciplina.

Como veremos mais adiante, essas questôes estão presentes nas várias narrativas sobre a trajetória da antropologia da saúde no Brasil, mas parece ser consenso, nos últimos balanços feitos, a ideia de que ela já se constitui em um campo ou programa próprio de pesquisa, ensino e produção acadêmica na antropologia brasileira. A análise da produção antropológica sobre saúde nos últimos dez anos nos apontou alguns aspectos desse campo que serão retomados mais adiante no detalhamen-

\footnotetext{
'Programa de Pós-Graduação em Antropologia Social, Universidade Federal de Santa Catarina - Florianópolis (SC), Brasil; Programa de Pós-Graduação em Antropologia, Universidade Federal da Paraíba - João Pessoa (PB), Brasil. E-mail: soniawmaluf@gmail.com

"IPrograma de Pós-Graduação em Ciências e Tecnologias em Saúde, Universidade de Brasília - Brasília (DF), Brasil; Programa de Pós-Graduação em Antropologia, Universidade Federal do Pará - Belém (PA), Brasil. E-mail: equinaglia@yahoo.com.br

IIIInstituto de Saúde Coletiva, Programa de Pós-Graduaçấo em Antropologia Social, Universidade Federal de Mato Grosso - Cuiabá (MT), Brasil. E-mail: marcoaureliosc@hotmail.com
} 
to do material levantado, mas que consideramos importante mencionar de início.

O primeiro deles é que, concordando com os últimos balanços, hoje, a antropologia da saúde constitui um campo consolidado de pesquisa no Brasil, tendo passado por mudanças importantes tanto no volume da produção quanto nas abordagens. Ganhou voo próprio, como mostram os vários Grupos de Trabalho (GTs) sobre o tema nas Reuniōes Brasileiras de Antropologia (RBA), Reunióes de Antropologia do Mercosul e Congressos Brasileiros de Saúde Coletiva, além da presença nos congressos da Associação Latino-Americana de Antropologia e, especialmente, nas Reunióes de Antropologia da Saúde (RAS) já realizadas no país (I, II e III RAS - respectivamente em João Pessoa, em 2015; em Brasília, em 2017; e em Natal, em 2019). ${ }^{1}$ Ademais, o campo da antropologia da saúde compôs publicaçóes de artigos avulsos e em dossiês em periódicos, coletâneas, livros monográficos, teses e dissertaçóes. Esse campo conforma, ainda, grupos e redes de pesquisa em diversos programas espalhados pelo país. Houve também a ampliação do leque de objetos de pesquisa: dos temas clássicos da antropologia, tais como as práticas e os saberes locais relacionados ao adoecimento e à cura, envolvendo experiências, itinerários e práticas terapêuticas, aos estudos que se debruçam sobre a biomedicina como objeto de pesquisa, os medicamentos, os protocolos e as tecnologias, os agentes humanos e não humanos (tais como as pesquisas sobre medicamentos e sobre os chamados vetores e agentes das doenças), as políticas públicas e os agenciamentos sociais em saúde, além de pesquisas cujos temas ga- nharam dinâmica própria, como saúde indígena e saúde mental.

O segundo aspecto é a constatação de que se trata de um campo que está atento aos problemas emergentes e emergenciais da saúde da população. No caso da pauta emergente, um exemplo é o diabetes e a depressão. No caso das pautas emergenciais, o Zika vírus pode ser considerado emblemático em relação à possibilidade de uma rápida resposta dada pelas pesquisas antropológicas, resguardando a profundidade dos dados etnográficos e de sua compreensão.

O terceiro aspecto que os estudos recentes mostram é que a antropologia da saúde no Brasil tem cada vez mais deslocado ou diluído o dilema entre o relativismo radical e a produçáo de uma pesquisa implicada e mesmo aplicada, em diálogo com outros campos e demandas. As relaçōes com as fronteiras da disciplina ganham outra qualidade: o relativismo radical não se sustenta mais no isolamento disciplinar, mas começa a se colocar à prova em outras dinâmicas de fazer pesquisa e produzir conhecimento, como as pesquisas em rede, interdisciplinares, reunindo pesquisadores(as) de diferentes áreas, e outras experiências. Ganham peso também pesquisas voltadas para o projeto de uma etnografia crítica, em que o engajamento reflexivo se volta para a desnaturalização do que aparece como dado ou autoevidente, para uma compreensão das relaçôes de poder estabelecidas nos processos de saúde e adoecimento e na afirmação dos princípios constitucionais, da saúde como direito da população e dever do Estado.

$\mathrm{O}$ quarto aspecto está relacionado às transformaçôes no campo da antropologia

1 Lembrando que o primeiro encontro temático específico de pesquisadores da área foi o I Encontro Nacional em Antropologia Médica, realizado em 1993, em Salvador, Bahia, e que resultou na coletânea Saúde e doença: um olhar antropológico (Alves; Minayo, 1994). 
da saúde no Brasil. Essas transformaçôes seguem, de um lado, dinâmicas próprias à produção do conhecimento, tais como a emergência de novas questóes teóricas e de novos objetos; a influência de outras áreas, não apenas ligadas aos estudos de saúde, mas também aos estudos de gênero e sexualidade, raça, deficiência, entre outros, que têm ganhado força na antropologia brasileira; e também os modos como se estrutura o próprio campo científico no país, por meio de financiamentos, bolsas etc. De outro lado, estão as mudanças provocadas por interpelaçôes decorrentes das circunstâncias sociais, políticas e econômicas mais amplas, ou seja, os acontecimentos históricos e conjunturais. As rupturas provocadas no contexto de crise vivenciado no país, com o retrocesso no acesso a direitos e a fragilização das políticas públicas em vários setores, a partir de 2016, tornaram-se objeto de debate em espaços antropológicos, como a II RAS ${ }^{2}$ e a $31^{\text {a }}$ RBA. $^{3}$

Nesse cenário, o objetivo deste artigo foi rever a produção dos últimos dez anos (20102019), buscando entender os novos caminhos percorridos por esse campo de pesquisa já consolidado na antropologia brasileira. Para isso, retomamos os aspectos centrais da trajetória desse campo nas décadas anteriores, em diálogo com os balanços precedentes, e mapeamos a produçấo recente, utilizando os bancos de dados que consideramos os mais relevantes, a fim de traçar as temáticas $\mathrm{e}$ as abordagens centrais e, finalmente, fazer uma análise qualitativa sobre o que configura a antropologia da saúde no Brasil ou, mais amplamente, os estudos antropológicos de saúde-doença. Não deixamos de abordar os diferentes enquadres sócio-históricos dessa produção, partindo do princípio de que a antropologia segue dinâmicas internas e externas ao próprio campo, o que inclui diálogos inter e transdisciplinares, delimitação de fronteiras e margens, ao mesmo tempo que está permanentemente exposta aos contextos etnográficos e à realidade social e política mais ampla. Essa tarefa foi realizada a partir dos seguintes procedimentos complementares: uma compreensão mais qualitativa do campo e do estado da arte atual e outra que buscou alguma representatividade (não ao ponto de usar técnicas bibliométricas), abordando o conjunto da produção antropológica dos últimos dez anos.

\section{Balanços anteriores: as narrativas sobre a formação e a trajetória da antropologia da saúde no Brasil}

Retomar balanços anteriores é um modo de acessar as diferentes narrativas sobre a formação e o desenvolvimento da antropologia da saúde no Brasil. As pesquisas antropológicas sobre saúde no Brasil já foram objeto de diversos balanços nos últimos 25 anos. ${ }^{4}$

No balanço acerca da produção acadêmica em antropologia e saúde nos anos 1980, uma das primeiras autoras a tentar dar um apanhado geral das pesquisas no Brasil, Canesqui (1994) observa que, apesar da vitalidade e da expansão dos interesses antro-

2 A II RAS, realizada em dezembro de 2017 em Brasília, teve como tema "Antropologias e políticas em contextos de crise".

3 O tema da 31 a RBA, realizada em dezembro de 2018, em Brasília, foi "Direitos Humanos e a Antropologia em Ação". Essa reuniáo contou com diversas mesas tematizando o fazer antropológico diante do novo contexto político do país.

4 Minayo (1998), Canesqui (1994; 2003), Sarti (2010) e Langdon, Follér e Maluf (2012), além de dossiês em periódicos, coletâneas, livros monográficos, teses e dissertaçōes dedicados ao tema. 
pológicos sobre saúde naquele momento, não havia consenso entre os(as) antropó$\operatorname{logos}$ (as) sobre constituir esses estudos em uma subárea da antropologia. Ela menciona alguns temas que teriam predominado nos estudos nas décadas de 1970 e 80 , como as práticas alimentares e nutricionais; a loucura, a saúde mental, o nervoso, o campo $p s i \mathrm{e}$ as instituiçóes psiquiátricas; as resistências à dominação médica; outros sistemas de cura ligados a diferentes cosmologias; as práticas $\mathrm{e}$ as representaçóes populares de doença e cura, incluindo as medicinas populares; e as abordagens a partir das práticas e das representaçôes de diferentes classes sociais sobre os processos de saúde, adoecimento e cura. A autora alerta para o caráter inacabado do levantamento feito, tendo deixado de lado alguns temas que também foram objeto de pesquisa antropológica nas décadas em questão, entre os quais a saúde indígena, os serviços e profissionais de saúde, a sexualidade, a reprodução e o HIV/Aids.

Em outro balanço, esse sobre os anos 1990, Canesqui (2003) delineia a tensão dentro do campo antropológico entre, de um lado, os proponentes de uma delimitação mais forte das fronteiras da antropologia com outros campos, como o da saúde coletiva, estratégia que predominou nos vários GTs e atividades nas reunióes da Associação Brasileira de Antropologia (ABA) e da Associação Nacional de Pós-Graduação e Pesquisa em Ciências Sociais (Anpocs) e, de outro lado, aqueles com propostas mais pragmáticas e voltadas para uma interlocução mais intensa com áreas como a epidemiologia, o planejamento em serviços de saúde e a psiquiatria. Essa constataçáo evidencia uma das questóes que têm marcado a trajetória dos estudos antropológicos de saúde no Brasil: o quanto o objeto das pesquisas sobre saúde delinearia uma subárea ou um campo dentro da disciplina ou não. A autora destaca a proposta de Minayo (1998) sobre a relevância de se fazer diferentes tipos de pesquisa antropológica, a básica, a estratégica e a operacional. Entre os temas e as abordagens centrais das pesquisas na década de 1990, Canesqui (2003) enfatiza as relaçốes sociais em torno da doença, a doença como experiência, as narrativas dessas experiências, as pesquisas sobre HIV/Aids - muitas das quais desenvolvidas junto a serviços públicos de atenção à saúde-, e os estudos sobre doença dos nervos e sobre as especificidades das representaçóes das classes populares e trabalhadoras sobre corpo e pessoa. As pesquisas e as produçóes analisadas, segundo a autora, falariam menos da doença em si e mais de suas conexóes com dimensóes culturais mais amplas.

Já em seu balanço da primeira década do século XXI, Sarti (2010) insere inicialmente o tema da saúde na dimensão mais ampla das emoçóes e do sofrimento, temas clássicos da antropologia, e parte da constataçáo de que a antropologia da saúde já se constituía naquele momento como um verdadeiro campo (no sentido dado ao conceito por Pierre Bourdieu) dentro da disciplina, com suas alianças e disputas. A autora destaca algumas temáticas específicas que teriam marcado o campo nos anos iniciais do novo século, em um contexto de ascensão das biotecnologias. Para Sarti (2010), as tensóes iniciais que marcaram a formaçáo do campo, entre antropologia e biomedicina, entre o pragmatismo da segunda e a reflexividade da primeira (Duarte, 1998), já não têm tanto peso na produção de uma antropologia da saúde amadurecida e que se confronta, em seu novo momento (fim dos anos 1990 e primeira década dos anos 2000), com os dilemas e as questôes próprias da antropologia, o que inclui uma relativização radical da biomedicina tornada palco da pesquisa antro- 
pológica (Sarti, 2010). A autora reconhece a seletividade do levantamento feito, no qual algumas tendências e temáticas ganham mais relevância, entre elas aquelas que reforçam a perspectiva dessa abordagem "radicalmente relativizadora" da disciplina. Basicamente duas vertentes de análise são descritas, uma voltada para as discussôes sobre o individualismo moderno, a partir de Louis Dumont (1993), e outra para as questóes do corpo e da experiência da doença, centrais na antropologia médica nos Estados Unidos.

Parte importante das pesquisas abordadas no período é realizada diretamente em ambientes médicos, como hospitais e serviços de saúde, sobre a formação de profissionais, as tecnologias biomédicas, incluindo as reprodutivas e a "virada biológica" no campo psi e da saúde mental. A ética em pesquisa também ganha destaque no período, com os debates em torno das especificidades da antropologia e das ciências humanas e sociais em geral, pouco reconhecidas pela Resolução no 196/1996, entáo em vigor, e que ainda hoje têm atingido centralmente as pesquisas sociais em saúde.

Em outro artigo de balanço do campo, Langdon, Follér e Maluf (2012) argumentam que é possível identificar a formação da antropologia da saúde como um programa específico de pesquisas ${ }^{5}$ já a partir dos anos $1980,{ }^{6}$ com uma identidade própria e paradigmas teóricos e analíticos singulares e diferenciados em relação à antropologia médica do Atlântico Norte. As autoras consideram, ainda, as forças estruturais internas e externas que possibilitam ou dificultam a formação e a expansáo desse programa de pesquisas, entre as quais a estrutura acadêmica, o financiamento, os perfis de interesse e ethos dos(as) pesquisadores(as) e os contextos histórico-sociais, políticos e econômicos. Em seu balanço, as autoras apontam uma questáo importante relacionada ao pouco impacto internacional dessa produçáo, que já é quantitativamente importante.

Esses vários balanços mostram que, da década de 1980 à primeira década do século XXI, o campo da antropologia da saúde se desenvolveu e se consolidou como uma vertente importante da antropologia brasileira. $\mathrm{O}$ que vamos observar a seguir em relação à produção da última década, entre $2010 \mathrm{e}$ 2019, é uma expansão considerável do número de trabalhos e da diversidade temática, assim como algumas mudanças significativas em relação a abordagens, focos, objetivos e lastros institucionais das pesquisas antropológicas em saúde.

\section{Mapeamento das publicações: rastreando o campo}

O mapeamento que fizemos da produção em antropologia da saúde no Brasil na

5 As autoras utilizam o conceito de "programa de pesquisas" a partir da definição dada por Arturo Escobar (2004; 2005), no qual se reúnem aspectos como o caráter emergente e coeso e a articulação em pesquisas, reunióes, publicaçóes, conceitos comuns e redes que se estendem para além dos limites disciplinares, incluindo pesquisadores(as) de outras áreas que trabalham com os mesmos objetivos, questôes e temas. No caso da antropologia da saúde no Brasil, essas articulaçôes transdisciplinares perpassam diferentes áreas, tais como a saúde coletiva, a sociologia da saúde, a medicina social, a psicologia social, a psicologia política, a nutrição e as ciências farmacêuticas.

6 Das primeiras décadas do século XX até a década de 1970, o tema da saúde e da doença esteve presente nos estudos, inicialmente sob a marca evolucionista das abordagens sobre práticas religiosas populares, loucura e pensamento primitivo, cura e religiosidade, e posteriormente em abordagens sobre práticas populares em saúde, mas ainda não se constituindo em um campo ou programa de pesquisa. 
última década segue dois procedimentos complementares. Inicialmente, buscamos fazer um levantamento o mais completo e extenso possível (mesmo sabendo que não conseguiríamos acessar toda a produção), a fim de obter uma visão fiel e representativa do conjunto da produçáo no campo (e entender a sua extensão no que diz respeito a periódicos mais recorrentes, considerando também a importância, para a área, das publicaçóes em livros monográficos e coletâneas). ${ }^{7}$ A partir daí, construímos uma análise mais qualitativa, mapeando temáticas, abordagens e, finalmente, analisando o que esses últimos dez anos trouxeram de novo para o campo da antropologia da saúde e para a antropologia brasileira de modo geral.

Para isso, foram selecionadas algumas bases de dados nas quais foi feito o levantamento: portal Scientific Electronic Library Online (SciELO), com base em alguns termos de busca por assunto (com prioridade para cruzamentos entre antropologia e saúde e percorrendo todos os sumários das revistas de antropologia e de saúde coletiva que constam do portal); banco de teses e dissertações da Coordenação de Aperfeiçoamento de Pessoal de Nível Superior (Capes); dados dos programas de pós-graduação em antropologia que constam dos
Relatórios de Avaliaçấo de área da Capes; periódicos de antropologia e saúde coletiva que não estão no SciELO; coleçóes específicas de livros, como as coleçôes "Antropologia e Saúde" e "Saúde e Povos Indígenas", ambas da Fundação Oswaldo Cruz (Fiocruz), e a coleção "Brasil Plural" (resultado da parceria entre o Instituto Nacional de Ciência e Tecnologia (INCT) Brasil Plural e a Editora da Universidade Federal de Santa Catarina - EdUFSC); e edições avulsas de livros monográficos e coletâneas, incluindo as decorrentes de encontros e seminários sobre o tema. ${ }^{8}$ Esse levantamento já nos deu uma ideia da amplitude da produçáo e das tênues fronteiras com outras áreas e, por isso, tivemos que fazer alguns cortes: priorizar artigos publicados em periódicos de antropologia indexados e artigos publicados em outros periódicos cujos(as) autores(as) são antropólogos(as), mesmo que atuem em outros programas de pós-graduação. Alguns trabalhos se posicionavam na fronteira entre antropologia da saúde e da ciência e tecnologia, e, nesses casos, optamos por fazer o corte a partir da autodefinição contida nas palavras-chave ou nas apresentações dos dossiês.

Foram levantados mais de 150 artigos avulsos publicados em periódicos, ${ }^{9}$ cerca de

7 Amplitude que nos proporcionou visualizar a disseminação desse campo antropológico em diversos programas de pós-graduação do país de diversas regiôes.

8 Privilegiamos citar neste artigo de balanço os artigos e outras publicaçōes produzidos com base em pesquisas antropológicas, não contemplando teses e dissertaçôes - apesar de termos feito um levantamento no banco de teses e dissertaçóes da Capes para mapear as temáticas mais recorrentes - nem pesquisas dos campos adjacentes, tais como saúde coletiva, saúde pública, sociologia da saúde etc.

9 A pesquisa foi feita nos seguintes periódicos: Anthropológicas; Anuário Antropológico; Mana; Horizontes Antropológicos; Vibrant; Mediaçōes - Revista de Ciências Sociais; R@u: Revista de Antropologia da UFSCar; Cadernos de Saúde Pública; Ciência \& Saúde Coletiva; História, Ciências, Saúde - Manguinhos; Interface - Comunicação, Saúde, Educação; Cadernos Pagu; Physis; Psicologia \& Sociedade; Revista Brasileira de Ciências Sociais; Saúde e Sociedade; Saúde em Debate; Revista de Ciências Sociais - Politica \& Trabalho; REMHU; Revista Brasileira de Enfermagem; Revista de Nutrição; Revista Latino-Americana de Enfermagem; Revista de Saúde Pública; Direito GV; Texto \& Contexto Enfermagem; Trabalho, Educação e Saúde; e Práxis Educativa. 
15 dossiês temáticos, ${ }^{10}$ em torno de 20 livros monográficos ${ }^{11}$ e cerca de 15 coletâneas, ${ }^{12}$ ressaltando que, apesar do esforço feito, não conseguimos cobrir toda a produção do período e, decerto, involuntariamente, trabalhos ficaram de fora. Resguardando a grande produção em artigos avulsos durante o período, é preciso assinalar a importância que os dossiês temáticos, as coletâneas e os livros monográficos têm no campo. Atribuímos isso à emergência de temas novos, à consolidação de temáticas e à importância dos encontros específicos e dos GTs na área da antropologia da saúde sistematica-

10 Foram levantados os seguintes dossiês temáticos: "Antropologia e medicamentos" (R@u, v. 4, n. 1, 2012); "Patrimônio em saúde" (Amazônica, v. 5, n. 2, 2013); "Bioidentidades, biossocialidades e espaços sociais" (Vivência, v. 1, n. 41, 2013); "Health, Ilness and Biosociality" (Vibrant, v. 12, n. 1, 2014); "Antropologia das doenças de longa duração" (Política \& Trabalho, n. 42, 2015); "Gênero e Saúde" (Vivência, v. 1, n. 48, 2016); "Gênero e cuidado" (Cadernos Pagu, n. 46, 2016); "A biomedicalização dos corpos brasileiros: perspectivas antropológicas" (História, Ciências, Saúde - Manguinhos, v. 23, n. 1, 2016); "Perspectivas indígenas e o campo da saúde" (Amazônica, v. 9, n. 2, 2017); "Etnografando experiências do adoecimento e medicalização no Brasil" (Equatorial, v. 4, n. 7, 2018); "Bioética é ética na pesquisa social: dilemas e perspectivas" (Amazônica, v. 10, n. 2, 2018); "Zika vírus" (Interface, v. 22, n. 66, 2018); "Deficiências, Gênero e Cuidados" (Anthropológicas, v. 29, n. 2, 2018); e "Saúde e direitos da populaçấo trans" (Cadernos de Saúde Pública, v. 35, n. 4, 2019).

11 Entre eles, podem ser citados "Nosso remédio é a palavra": uma etnografia sobre o modelo terapêutico de Alcoólicos Anônimos (Campos, 2010); As representaçôes sociais e a experiência com o Diabetes: um enfoque socioantropológico (Barsaglini, 2011); Parteiras, buchudas e aperreios: uma etnografia do cuidado obstétrico não oficial na cidade de Melgaço, Pará (Fleischer, 2011); Imagens de cura: ayahuasca, imaginação, saúde e doença na Barquinha (Mercante, 2012); A custódia e o tratamento psiquiátrico no Brasil: censo 2011 (Diniz, 2013); Medicinas indígenas e as políticas da tradição: entre discursos oficiais e vozes indígenas (Ferreira, 2013a); Processos de alcoolização indígena no Brasil: perspectivas plurais (Souza, 2013); Os médicos da pessoa: um olhar antropológico sobre a medicina de família no Brasil e na Argentina (Bonet, 2014); "Pressäo alta no cotidiano": representaçōes e experiências (Canesqui, 2015b); A cosmopolítica da gestação, do parto e do pós-parto: autoatenção e medicalização entre os indios Munduruku (Dias-Scopel, 2018); Além do que se vê: magnetismos, ectoplasmas e paracirurgias (Chiesa, 2016); Zika: do sertão nordestino à ameaça global (Diniz, 2016b); O Des-Aprendizado de si: transexualidades, interação e cuidado em saúde (Borba, 2016); Depressão na Infância: uma abordagem antropológica (Nakamura, 2016); Uma Sociedade para todas as idades: Centro Dia e Centro de Convivência para idosos em Campo Grande (Limoeiro, 2017); Doentes e parentes: composiçóes de governo na Estratégia Saúde da Família (Oliveira, 2018); Descontrolada: uma etnografia dos problemas de pressäo (Fleischer, 2018); Doença falciforme: da politização pelo movimento negro como doença étnico-racial às associaçôes representativas dos falcêmicos como doença especifica (Araújo, 2017); Compartilhando Genes e Identidades: orientação genética, raça e politicas de saúde para pessoas com doença e traço falciforme em Pernambuco (Silva, T. C., 2014); e Do espirito na saúde: oferta e uso de terapias alternativas/complementares nos serviços de saúde pública no Brasil (Toniol, 2018).

12 Das quais podem ser citadas: Gênero, saúde e aflição: abordagens antropológicas (organização de Maluf e Tornquist, 2010); Novas abordagens para casais sorodiferentes (organizaçāo de Franch et al., 2011); Trajetórias, sensibilidades, materialidades: experimentaçóes com a fenomenologia (organização de Rabelo, Souza e Alves, 2012); Para além da eficácia simbólica: estudos em ritual, religiāo e saúde (organizaçấo de Tavares e Bassi, 2013); Etnobiologia e saúde de povos indigenas (organização de Haverroth, 2013); Etnografias em serviços de saúde (organização de Fleischer e Ferreira, 2014); Saúde indígena em perspectiva: explorando suas matrizes históricas e ideológicas (organização de Teixeira e Garnelo, 2014); Corpo e saúde na mira da Antropologia: ontologia, práticas, traduçōes (organização de McCallum e Rohden, 2015); Saúde indígena: politicas comparadas na América Latina (organização de Langdon e Cardoso, 2015); O asilo e a cidade: histórias da Colônia Juliano Moreira (organização de Venâncio e Potengy, 2015); Saúde, mediação e mediadores (organização de Teixeira, Valle e Neves, 2017); Antropologia e saúde: diálogos indisciplinados (organização de Silva e Guimarães, 2017); Antropologia da Saúde: ensaios em políticas da vida e cidadania (organização de Neves, Longhi e Franch, 2018); Estado, politicas e agenciamentos sociais em saúde: etnografias comparadas (organização de Maluf e Quinaglia Silva, 2018); Antropologias, saúde e contextos de crise (organização de Castro, Engels e Martins, 2018); e Comunidades terapêuticas: temas para reflexão (organização de Santos, 2018). 
mente presentes nos congressos de antropologia, ciências sociais e saúde coletiva - muitos desses GTs resultando em publicaçóes. No caso dos livros monográficos, grande parte deles é resultado de teses e dissertaçóes.

Dos trabalhos levantados, há um número significativo de balanços do campo, alguns temáticos (sobre itinerários terapêuticos, saúde indígena, saúde mental, método qualitativo em saúde, entre outros temas mais gerais da antropologia da saúde). De certo modo, interpretamos isso como próprio a um programa de pesquisas que está em momento de consolidação, delimitação das fronteiras e afirmação diante do campo científico brasileiro, tanto na antropologia quanto na saúde coletiva. Também a relação entre a antropologia e as demais áreas que têm a saúde como objeto é tematizada em vários artigos sobre antropologia e saúde pública, antropologia e epidemiologia etc. ${ }^{13}$

\section{Novos contextos, novas questões para a antropologia}

$\mathrm{Na}$ última década, os estudos antropológicos no campo da saúde cresceram quantitativamente, diversificaram-se em termos temáticos e introduziram novas questôes teóricas, conceituais e metodológicas, a partir dos desafios colocados pelos novos contextos sociais, políticos e culturais da sociedade brasileira. Esses desafios não são exclusivos do campo da antropologia da saúde, mas é de dentro dele e da especificidade das pesquisas que a contribuição da antropologia para uma compreensão dos processos de saúde e doença, adoecimento e cura revela sua importância.

\section{Entre práticas, saberes}

locais e politicas públicas

Uma característica importante da antropologia da saúde nesta segunda década do século XXI, ao lado das pesquisas etnográficas voltadas às práticas e aos saberes de comunidades, grupos sociais e sujeitos, é o aprofundamento de um diálogo mais direto com as políticas públicas voltadas às populações e aos sujeitos das pesquisas e, consequentemente, com o próprio Estado. A implantação mais sistemática, na primeira década, de políticas governamentais - previstas desde a Constituição de 1988 - despertou o interesse de antropólogos(as), que deram um passo além comparativamente a uma antropologia até então marcada pelo diálogo intercultural. Se antes os marginalizados pelo Estado e pelo sistema biomédico (Sarti, 2010) eram o foco das pesquisas, as novas políticas inclusivas desafiaram a antropologia da saúde na produção de trabalhos que pudessem contribuir para o fomento e a melhoria dessas políticas, sem, por isso, deixar de lado a dimensão reflexiva e crítica do trabalho etnográfico consistente. É essa dimensão que se constitui na principal contribuição que as pesquisas antropológicas podem trazer. A abordagem das políticas públicas em saúde tem se desdobrado em diversas vertentes de análise, entre as quais as que privilegiam uma etnografia dos serviços e atendimentos, tais como os trabalhos reunidos na coletânea de Fleischer

13 Não incluímos nesse balanço o mapeamento dos grupos de pesquisa do campo da antropologia da saúde ou que têm a antropologia da saúde entre suas linhas. Contudo, um breve levantamento no Diretório de Grupos de Pesquisa do Conselho Nacional de Desenvolvimento Científico e Tecnológico (CNPq), com algumas palavras-chave relacionadas ao tema (antropologia da saúde; saúde e corporalidade; etnografia da saúde; antropologia e saúde), evidenciaram-nos questôes, tais como a interdisciplinaridade e a interseccionalidade entre as temáticas trabalhadas e a diversidade regional e institucional desses grupos. 
e Ferreira (2014) e os livros de Limoeiro (2017) e Fleischer (2018); de instituiçóes de internação, tais como as pesquisas feitas em hospitais de custódia por Diniz (2013); da formação de profissionais (Bonet, 2014); e das políticas públicas, incluindo leis, documentos e protocolos (Maluf, 2010; 2015).

Nesse campo etnográfico, estimulado pela expansão das políticas públicas e dos serviços e pelo aumento no número de profissionais e agentes do Estado nas mais remotas regiōes, reflexóes sobre os impactos sociais da pesquisa antropológica ganham volume e densidade. Questôes como a participação de antropólogos(as) na elaboração, no acompanhamento ou na avaliação de políticas públicas em saúde, que já estấo na preocupação da antropologia desde os anos 1990 (Minayo, 1991), perpassam o conjunto das pesquisas e se desdobram em novas abordagens, entre elas o retorno e a devolução da pesquisa tanto para os sujeitos pesquisados quanto para os órgãos de gestão e o Estado (Knauth; Meinerz, 2015; Fleischer, 2015; Ferreira, 2015; Maluf; Andrade, 2017).

Diversos desses trabalhos estáo voltados à pesquisa do que se poderia considerar um novo terreno etnográfico, que é a zona de confluência entre práticas e agenciamentos sociais dos sujeitos, comunidades e populaçôes e açôes do Estado, seus agentes, serviços e rotinas institucionais. Esses estudos têm abordado a complexidade dessas relaçóes e os modos como valores, linguagens, práticas e compreensóes no campo da saúde e do adoecimento circulam, se friccionam e são ressignificados. Nessa abordagem, sujeitos, comunidades, Estado, políticas públicas e o campo biomédico se constituem, nas pesquisas, em diferentes planos etnográficos, dotados de consistência própria e, ao mesmo tempo, articulados, em relação e interpenetração, atravessados por diferentes linhas de força.
Entre os conceitos que buscam contemplar essa perspectiva e ao mesmo tempo reafirmar a força das pesquisas etnográficas focadas nas práticas e nos saberes dos sujeitos e das comunidades pesquisadas, destacamos o de "agenciamento" ou "agenciamentos sociais", tal como propõem Maluf (2013; 2018b), Tavares (2017) e Maluf e Quinaglia Silva (2018), que acrescenta aos clássicos trabalhos sobre trajetórias, itinerários, práticas e experiências terapêuticas a ideia de que práticas e saberes se produzem na malha das relaçóes de poder. Voltando suas lentes para os processos de subjetivaçáo e de agenciamentos junto ao Estado, a coletânea Estado, politicas e agenciamentos sociais em saúde: etnografias comparadas (Maluf; Quinaglia Silva, 2018), o título mais recente da Coleção "Brasil Plural", conta com 13 artigos que problematizam essas relações entre práticas e agenciamentos locais e políticas públicas.

Do mesmo modo, mostram-se potentes conceitos como o de "práticas de autoatenção", formulado por Eduardo Menéndez para descrever as práticas e as representaçóes locais no plano dos sujeitos ou grupos sociais (Langdon, 2014), e o de "cuidado" (care), para além do conceito normativo presente nas políticas de saúde, buscando abordar as subjetivaçóes produzidas nos processos de saúde e adoecimento (Bustamante; McCallum, 2014; Longhi, 2015; além de diversos trabalhos no campo da saúde coletiva).

A pesquisa etnográfica com os sujeitos, acompanhando suas trajetórias, experiências, práticas, saberes e representaçôes e observando suas escolhas e estratégias em situaçóes de adoecimento ou afliçáo e sofrimento, tem se mostrado potente tanto para dar visibilidade e propiciar a compreensão de modos diversos de lidar com os processos de saúde e adoecimento, quanto para confrontar com as respostas institucionais e 
governamentais, nem sempre voltadas para o cuidado e a garantia de direitos. Também pesquisadores(as) da saúde coletiva ${ }^{14}$ têm feito apropriaçóes da antropologia da saúde, partindo da "constatação de que o modelo biomédico de atenção à saúde é incapaz de lidar isoladamente com a complexidade dos problemas de saúde", como ressaltam Mello e Oliveira (2013). O foco em itinerários terapêuticos de diferentes populaçóes tem sido outro recurso para compreender a relação entre usuários e serviços e os agenciamentos sociais que não podem ser reduzidos às racionalidades biomédicas. Durante muito tempo, o tema restringiu-se à "percepção do paciente sobre a doença e tratamento" (Cabral et al., 2011), voltando-se nesta última década para o acesso dos usuários aos sistemas de saúde oficiais e a combinação destes com variadas terapêuticas. Um bom exemplo é a coletânea Itinerários Terapêuticos: integralidade no cuidado, avaliação e formação em saúde (Gerhardt et al., 2016), que conta com artigos de pesquisadores(as) da saúde coletiva, alguns(mas) dos(as) quais com formação antropológica. Segundo os organizadores, a necessidade de "entender os caminhos na busca por cuidado, em meio a desigualdades regionais, sociais e políticas e a diversidades culturais" (Gerhardt et al., 2016, p. 14) é uma forma de avaliação do próprio sistema de saúde.

Com a expansão dos serviços e das políticas de saúde nas últimas décadas, que ganhou impulso com o Programa Mais Médicos, é difícil identificar comunidades ou localidades que não disponham desses aparelhos ou de um profissional ou agente de saúde que atenda a população. Muitas ve- zes, é por meio desses serviços e instituições - como centros de atenção básica - que o Estado se faz presente nas localidades, tornando difícil uma abordagem das práticas locais que não sejam atravessadas, nos itinerários, linguagem e discursos, pela biomedicina. Entretanto, mesmo com essa presença forte das políticas públicas e da biomedicina nos trabalhos produzidos no período, a perspectiva radicalmente etnográfica permanece sendo uma característica central no campo da antropologia da saúde, tanto na abordagem das práticas, dos discursos e dos saberes locais quanto na abordagem das políticas públicas, como veremos a seguir. Um exemplo desse vigor da etnografia é o livro Descontrolada, de Soraya Fleischer (2018), sobre a pressão alta entre mulheres imigrantes nordestinas vivendo em um bairro popular da cidade de Ceilândia, no Distrito Federal. Em torno da pressão alta, a pesquisa aciona as trajetórias dessas mulheres para além da doença, suas vidas cotidianas, os modos de viver a experiência junto aos serviços públicos de saúde e os cuidados e modos de lidar com a doença na comunidade e em casa, levantando um conjunto de informaçóes e de questóes dificilmente observadas pelas lentes da biomedicina e trazendo uma contribuição importante tanto para a antropologia da saúde, a metodologia e a teoria da pesquisa etnográfica, quanto para os profissionais que atuam em serviços públicos de saúde e seus gestores.

\section{Temas emergentes e emergenciais}

Observa-se nos últimos anos uma grande diversificação dos temas no âmbito das doenças e das afecçóes pesquisadas, entre

14 Autoras como Knauth e Leal (2014) fazem uma reflexão crítica sobre o crescimento de dissertaçóes, teses e artigos científicos em revistas de saúde coletiva que se utilizam da metodologia qualitativa, com um privilégio de procedimentos caros à antropologia, como a etnografia, mas sem os instrumentos teóricos e conceituais da antropologia. 
os quais se destacam aqueles que trazem demandas emergenciais, como é o caso das epidemias ligadas ao Aedes aegypti, como o Zika vírus e seus efeitos relacionados à síndrome congênita do Zika (SCZ), que incluem a microcefalia em crianças. Como apontado, o Zika vírus é considerado emblemático em relação à rápida resposta dada pelas pesquisas antropológicas que cobriram o leque das dimensóes da antropologia da saúde desde as experiências e os itinerários de mulheres mães de crianças com SCZ às políticas públicas e pesquisas desenvolvidas no campo biomédico, definidas por Silva, Matos e Quadros (2017) como uma economia política da Zika, que abraça questóes tais como agentes e instituiçóes envolvidos, níveis de decisão, programas e orientaçóes, entre outras. No rastreamento de todas as dimensóes envolvidas, a antropologia tem importante papel ao se dedicar a uma perspectiva pouco levada em consideração, a das próprias mães das crianças com SCZ, que sofrem as contradiçóes e os paradoxos das políticas públicas, mas que também criam suas próprias formas de cuidado e produzem estratégias para se inserirem em redes de assistência e apoio (Diniz, 2016a, 2016b; Scott et al., 2018; Carneiro; Fleischer, 2018).

Uma abordagem emergente na última década foi a das doenças de longa duração, crônicas ou, conforme denominaram Fleischer e Franch (2015) e Fleischer (2018), apropriando-se de uma expressão popular, compridas. O tema foi objeto de um dossiê na revista Politica \& Trabalho (n. 42, 2015) e do livro organizado por Canesqui (2015a) sobre adoecimentos e sofrimentos de longa duração. Muitas das doenças classificadas sob essa grade de leitura, como o HIV/Aids, o diabetes ou a pressão alta já eram objeto de pesquisas antropológicas, mas a abordagem destas a partir da longa duração ou mesmo da cronicidade da experiência da doença fez emergir questóes comuns, tais como os aprendizados envolvidos no convívio com a doença e as relaçóes de longo prazo com profissionais de saúde, cuidadoras(es), medicamentos, exames e procedimentos, entre outras que esses trabalhos abordam.

Outro tema emergente que tem crescido é o das doenças genéticas, especificamente das doenças genéticas raras, que também englobam enfermidades que já eram objeto da pesquisa antropológica, como a anemia falciforme. Esses estudos fazem emergir diversas questóes, como impactos do diagnóstico, relaçóes entre doença e parentesco e trajetórias terapêuticas familiares, judicialização da saúde, questóes de risco genético e orientação genética - tal como discutem os trabalhos de Aureliano (2018), Diniz, Medeiros e Schwartz (2012), entre outros. Uma das dimensóes da abordagem das doenças genéticas está associada à discussão sobre cidadanias e identidades genéticas e os modos como diagnósticos biomédicos e tudo o que desencadeiam no que se refere a tratamentos, terapêuticas, higienes corporais e dietas alimentares podem ser analisados como regimes de subjetivação. A coletânea Identidades emergentes, genética e saúde: perspectivas antropológicas (Santos; Gibbon; Beltrão, 2012) é um dos exemplos de trabalhos que discutem os impactos do uso e da linguagem das tecnologias genéticas sobre questôes de eugenia, tecnologias de imagem, risco e saúde, etnicidade e identidades sociais e processos de saúde e doença, articulados com questôes biopolíticas contemporâneas.

O processo de expansão da biomedicina para a vida cotidiana e para esferas que não são tradicionais da área da saúde impulsionou pesquisas sobre processos de medicalização e medicamentalização do sofrimento e da experiência e a abordagem de questóes 
como a expansão do alcance da biomedicina, das novas tecnologias de exames, incluindo as de imagem, dos fármacos e dos psicofármacos (Rohden, 2018; Maluf, 2010; 2015; Fleischer, 2012; dossiê "Antropologia e Medicamentos", da R@u, v. 4, n. 1, 2012). A abordagem da medicalizaçáo conflui com a abordagem dos processos biopolíticos relacionados à saúde, ao adoecimento e às políticas públicas, tal como apresentam também os dossiês "Bioidentidades, biossocialidades e espaços sociais", publicado na revista $V i$ vência em $2013,{ }^{15}$ e "Health/Illness, biosocialities and culture", publicado na Vibrant em 2015, ${ }^{16}$ em que temas como biossocialidades, bioidentidades e produção de cidadania no campo das políticas de saúde, biopolíticas e biolegitimidades, entre outros, são abordados como dimensóes centrais dos processos de expansão dos domínios do discurso, das práticas, das técnicas e dos saberes biomédicos.

Saúde, politicas identitárias e da vida: gênero, sexualidade, raça e deficiência

Diferentes temáticas desafiadas pelos novos contextos se situam, ainda, na confluência da antropologia da saúde com as relaçóes de gênero e a sexualidade, tais como o impacto do aborto, da violência doméstica, do processo transexualizador e da cidadania LGBTI - lésbicas, gays, bissexuais, travestis, transexuais e intersexuais - para os serviços de saúde. Especificamente o tema do aborto aparece com força diante do acirramento do conservadorismo no país, bem como de discussóes promovidas pelos casos de anencefalia, Zika, microcefalia e violência sexual, que fizeram a questão chegar ao Supremo Tribunal Federal (STF). Os trabalhos publicados sugerem duas tendências: de um lado, o debate público e jurídico (Machado, 2017), com etnografias que vão das representaçóes midiáticas às sessóes do STF, em que se discutem o estatuto do feto e o conceito de vida (Luna, 2014; 2015; 2018; Quinaglia Silva; Codonho, 2013); de outro lado, os itinerários abortivos, que cobrem desde a realização de abortos clandestinos (Porto; Sousa, 2017; Diniz; Medeiros, 2012; Heilborn et al., 2012) até os serviços de saúde disponíveis para os casos previstos em lei - risco à vida da mulher e gravidez em decorrência de estupro - ou autorizado pelo STF - gestação de fetos anencéfalos (Porto; Costa, 2018). Ao ressaltar a ideia de itinerários abortivos, esses trabalhos mostram que as diferenças socioeconômicas levam a diferentes caminhos em relação ao aborto, com maior segurança para as pessoas de maior poder aquisitivo: "A ilegalidade do aborto no Brasil não impede a sua realização em condiçôes muito diversas que espelham um grave quadro de desigualdades sociais" (Heilborn et al., 2012, p. 1700). As etnografias colocam em relevo os saberes e as redes de relaçóes que sustentam o aborto clandestino, desde a combinação de chás e o uso do misoprostol até a finalização em hospitais com o apoio de parentes e outras mulheres (Diniz; Medeiros, 2012). Porto e Sousa (2017, p. 594) consideram que o aborto tem inspirado uma "preocupação [que] vem sendo materializada e engendrada em forma dos mais variados estudos acadêmicos envolvendo a vivência das mulheres enquanto sujeitas portadoras de diversos direitos concernentes à sua vivência e bem-estar reprodutivos".

As políticas públicas voltadas à população LGBTI também marcam o fim da

15 Organizado por Carlos Guilherme Octaviano do Valle, Ednalva Maciel Neves, Horacio Sívori e Soraya Fleischer.

16 Organizado por Carlos Guilherme Octaviano do Valle e Sahra Gibbon. 
primeira década e o início da segunda, mas parece flagrante a ausência de discussóes ligadas à saúde de homens e mulheres que se relacionam homoafetivamente, enquanto se destacam as pesquisas que se voltam aos itinerários terapêuticos de travestis (Carrara et al., 2019; Souza; Pereira, 2015), à medicalização da intersexualidade (Lima; Machado; Pereira, 2017; Pires, 2016), ao acesso de mulheres trans e travestis aos serviços de saúde (Monteiro; Brigeiro, 2019) e ao processo transexualizador do Sistema Único de Saúde (SUS) (Bento; Pelúcio, 2012; Borba, 2016; Braz, 2017) - ainda que esse destaque se dê mais no que se refere a teses e dissertaçóes, o que talvez indique maior visibilidade desses estudos na próxima década. O espaço temático "Saúde e direitos da população trans", ${ }^{17}$ publicado em 2019, na revista Cadernos de Saúde Pública, é uma das poucas coletâneas de artigos sobre o tema, o que revela o crescimento no número de pesquisas. A produção do período mostra uma ênfase também para as hormonioterapias, tanto para homens e mulheres trans (Lima; Cruz, 2016) quanto para pessoas cis (Rohden, 2018; Rohden; Alzuguir, 2016; Faro; Russo, 2017). Uma linha comum nesses trabalhos é a importância dada aos itinerários terapêuticos desses sujeitos e aos embates com os serviços de saúde, em uma clara crítica ao viés biomédico que incide na produção de subjetividades.

Adjacente a esses estudos, as pesquisas sobre HIV/Aids, que marcaram as décadas de 1990 e 2000, tiveram continuidade em diversos trabalhos com novos e velhos enfoques. A sorodiferença ou sorodiscordância na vida conjugal e reprodutiva dos sujeitos mobiliza uma série de trabalhos (Franch et al., 2011; Perrusi; Franch, 2012; Perrusi et al., 2013). Também Longhi (2015) traz a questão da sorodiferença entre casais do mesmo sexo. Com base em tais olhares sobre a Aids, talvez seja possível pensar em um deslocamento do foco anteriormente mais direcionado a questóes como o desenvolvimento social da epidemia para outros que buscam pensar nas possibilidades de vida com o vírus HIV, como nos estudos de Agostini, Maksud e Franco $(2017 ; 2018)$, que mostram a chegada à adolescência de crianças infectadas pelo HIV por "transmissão mãe-bebê" em seus agenciamentos afetivo-sexuais.

As políticas públicas voltadas à Aids continuaram tema comum na antropologia da saúde, como nos trabalhos de Lizandro Lui e Andrea Fachel Leal (2018) e Leal e Lui (2018), que discutem a criação e o funcionamento do primeiro Comitê de Mortalidade por Aids no Brasil, criado em Porto Alegre. O comitê investiga as mortes por Aids para elaborar medidas que possam impactar na melhoria do atendimento prestado. Os autores discutem o conceito de legibilidade, a fim de pensar como o Estado elabora estratégias para tornar legível o mundo social, estratégias que, muitas vezes, falham e criam apagamentos que impactam nas políticas públicas e nas doenças, como no caso de homens heterossexuais, que, diante das concepçóes hegemônicas de masculinidade, se tornam invisíveis e acabam sendo desconsiderados nos serviços e nas políticas públicas (Leal; Knauth; Couto, 2015), agravando sua condição de transmissores e vítimas da epidemia.

Enquanto o Estado tem falhado na leitura de alguns dos sujeitos-alvo das políticas públicas, lutas sociais dão-se com o intuito de melhorar o alcance dessa legibilidade, no reconhecimento de trajetórias e práticas de indivíduos. Isso nos permite pensar no quanto a antropologia da saúde tem se

17 Organizado por Simone Monteiro, Mauro Brigeiro e Regina Maria Barbosa. 
debruçado sobre arenas nas quais a legibilidade de sujeitos é um campo de disputas para a construçáo de legitimidade de sujeitos sociais, o que nos leva ao conceito de biolegitimidade (Maluf, 2015; 2018a; 2018b; Fassin, 2004), no qual temas como natureza, essência e biologia não dão a tônica apenas dos discursos oficiais, mas também da pauta dos movimentos sociais e políticas identitárias, deslocando o foco dos direitos sociais e econômicos para o direito à vida.

O caso das doenças falciformes é emblemático nesse sentido e desponta na última década como ponto privilegiado da discussão sobre as relaçôes entre raça e saúde. Ana Cláudia Rodrigues da Silva (2014; 2016), ao etnografar as políticas públicas para pessoas com traço e doença falciforme em Pernambuco, problematiza o conceito de "cidadania genética", questionando a "possibilidade desse termo ser considerado um exemplo de política ontológica para a saúde". Ela parte das performances da doença, construindo realidades distintas para pacientes, profissionais, cientistas e familiares. Preocupação semelhante está no livro de Reginaldo da Silva Araújo (2017), que se debruçou sobre as reivindicaçóes tecidas pelo movimento negro e pelo movimento de portadores da doença falciforme na cidade de São Paulo, apontando para estratégias de normatizaçáo e politização da doença, em ações até mesmo conflitantes entre os dois movimentos. Já Ariana Silva e Hilton Silva (2013) analisam a situação de vulnerabilidade social dos sujeitos portadores de anemia falciforme no Pará, suas percepçóes sobre o processo saúde-doença, as terapias alternativas às quais recorrem e as experiências de preconceito e racismo em suas dificuldades de acesso aos serviços de saúde.

Também tomando o racismo institucional como temática importante na antropo- logia da saúde, Rosamaria Carneiro (2017) trabalha na interseccionalidade entre raça, classe e gênero para etnografar os serviços públicos voltados à vida sexual e reprodutiva das mulheres. A autora descortina processos cotidianos discriminatórios nas diferentes leituras do corpo negro feminino por parte dos profissionais desses serviços, como formas de tratamento diferenciadas, em narrativas que falam de mulheres que não são examinadas ou tocadas, seja durante o pré-natal ou consultas médicas ordinárias, ou não recebem analgesia na hora do parto por serem consideradas mais fortes e resistentes. Os pressupostos racistas também se fazem presentes em serviços de saúde mental, como mostra a etnografia de Branco Pereira (2018) em um desses serviços voltados para imigrantes refugiados (africanos e haitianos, em sua maioria) na cidade de São Paulo. A categoria "trauma" é constantemente acionada pelos profissionais do serviço, mas não pelos sujeitos atendidos, que parecem estar mais impactados com questóes ligadas à língua, ao trabalho e ao racismo - se "descobrem" negros no Brasil - do que com supostos eventos traumáticos (políticos e naturais) que marcam seus deslocamentos forçados.

Ainda nessa seara que coloca tão em relevo as produçôes de saúde e de subjetividade, é preciso ressaltar as experiências de pessoas que convivem com deficiências de várias ordens. Na movimentaçáo política de sujeitos em uma diversidade de experiências com deficiências (Mello, 2010; 2014; 2016), na experiência de inclusão no mercado de trabalho de sujeitos com autismo e nos impactos dessas políticas na vida deles (Aydos, 2016), na problematização dos significados de "ser e se sentir diferente" na deficiência física (Martins; Barsaglini, 2011) ou ainda nas múltiplas possibilidades de cuidado (Fietz; Mello, 2018; Weid, 2018), esse campo de 
pesquisa colocou ainda mais em relevo as experiências subjetivadoras ou a constituição de sujeitos com base em suas corporalidades. São experiências que, ainda que possam ser vistas como individuais, revelam processos coletivos que podem iluminar não apenas os serviços de saúde, mas ampliar ainda mais as compreensóes antropológicas sobre corpo e corporalidade.

Uma última, mas não menos importante, temática interseccional está ligada ao recorte de saúde e geração, com ênfase na relação entre envelhecimento, saúde e adoecimento. Com o pano de fundo do processo crescente de envelhecimento da população brasileira (com a diminuição da natalidade e o aumento da expectativa de vida nas últimas décadas), o envelhecimento em si tem se tornado um "problema" do ponto de vista da gestão pública, tanto no que diz respeito aos serviços de saúde, à distribuição gratuita de medicamentos etc., quanto em relação às políticas de seguridade social. Assim, proliferam os discursos sobre o que seria o "envelhecimento saudável”, o cuidado com a própria saúde (Britto da Motta, 2012), em um processo que Guita Debert (1999) denominou de "reprivatização do envelhecimento". Entre os temas abordados, estâo as estratégias de saúde, presentes e futuras, voltadas para o processo de envelhecimento da população brasileira; questóes do cuidado voltado a pessoas idosas; sexualidade, saúde e envelhecimento; biotecnologias e vida saudável; medicinas e tecnologias antienvelhecimento; envelhecimento, saúde e espiritualidade; e mulheres idosas cuidadoras e curadoras. Entre os trabalhos sobre o tema, ressaltamos o dossiê "O final da vida no século XXI", com vários artigos sobre saúde e envelhecimento, entre eles Engel (2012), Andrade e Franch (2012), assim como os trabalhos de Bizerril (2010), Rohden (2011; 2017),
Leitão e Pedro (2014) e Longhi (2018a, 2018b). Também parte dos trabalhos sobre as doenças chamadas crônicas - tais como diabetes, hipertensão, problemas cardiovasculares, Alzheimer, entre outras - é feita com foco em sujeitos em processo de envelhecimento. Aproxima-se igualmente desse tema aquele da deficiência, uma vez que o corpo com impedimentos (físicos, sensoriais ou intelectuais) é uma condição de existência para quem experimenta os benefícios do progresso biotecnológico e envelhece (Diniz; Barbosa; Santos, 2010).

Contudo, apesar de grande quantidade dos estudos sobre geração e saúde estar concentrada na abordagem do envelhecimento, alguns estudos, notadamente no campo da saúde mental e psicossocial, têm se debruçado sobre a juventude, com ênfase na depressão na infância e na juventude (Nakamura, 2016; Moreira; Nunes de Torrenté; Jucá, 2018). Essa é uma temática emergente na antropologia da saúde, e a maior parcela dos estudos que encontramos sobre o tema estava na forma de teses ainda não publicadas, como é o caso de Pereira (2018).

\section{Saúde indigena}

Um tema que ficou ausente em balanços anteriores, apesar de se constituir em um verdadeiro subcampo da antropologia da saúde que cresceu quantitativa e qualitativamente na última década e meia, é o da saúde indígena. Sem abandonar os estudos voltados às práticas de cura, xamanismo e curandeiras tradicionais, a saúde dos povos indígenas já não se limita ao viés interpretativo - quase tradutor - das cosmologias ameríndias e seus sistemas de cura. Há uma ênfase nas relaçôes entre agentes comunitários e profissionais de saúde com as comunidades-alvo das políticas públicas. Em seu mapeamento dos estudos de saúde indígena, Teixeira e Silva (2013) 
apontam o que seriam duas tendências complementares nos estudos: os que abordam os processos de adoecimento, práticas e itinerários, e os focados nas relaçóes políticas e nos conflitos em torno da saúde indígena. Scopel, Dias-Scopel e Langdon (2015) ressaltam que o papel dos agentes indígenas de saúde "transcende atividades estritamente técnicas", no caso do povo Munduruku estudado por eles. Os agentes realizam uma articulação entre os saberes biomédicos e os saberes indígenas, emergindo como novos atores em contextos interétnicos e de intermedicalidade. O mesmo tom marca o trabalho de Pires, Neves e Fialho (2016), cujas pesquisas buscam compreender como as práticas de saúde tradicionais e biomédicas são vivenciadas no diálogo entre equipes de saúde e os Xukuru do Nordeste. O trabalho de Guimarães (2015) é outro exemplo que discute como os Sanumá de Roraima se relacionam com a política pública de atenção à saúde indígena, por meio de uma etnografia junto a missionários, a funcionários de organizaçôes não governamentais (ONGs) e ao Estado brasileiro. Já Garnelo (2011), em pesquisa sobre a vacinação na terra indígena dos Baniwa, mostra as reinterpretaçóes das açóes biomédicas na cosmologia local, mas ressalta as implicaçóes negativas que a diferença de perspectivas entre indígenas e profissionais de saúde gera ao processo de vacinação. Pereira (2012), por sua vez, volta suas lentes para os profissionais de saúde para investigar concepçóes diferenciadas de corpo, saúde e doença, com base em narrativas de médicos e enfermeiras e suas afetaçóes com as cosmologias ameríndias. Ainda, Teixeira (2012) aponta um viés higienista baseado na busca por mudanças comportamentais no trabalho de profissionais de saúde e de engenharia sanitária nas terras indígenas, produzindo novas hierarquias "cívicas e civi- lizatórias”. Um destaque entre as produçóes do período é a coleção Saúde dos Povos Indígenas, da Fiocruz, que começou a ser publicada ainda no início da década passada e teve quatro títulos lançados desde 2010. A coletânea Processos de Alcoolização Indígena no Brasil: perspectivas plurais, organizada por Maximiliano Loiola Ponte de Souza (2013), discute o alcoolismo em uma perspectiva intercultural, questionando a transculturalidade de padróes biomédicos sobre o tema. Já a coletânea organizada por Carla Costa Teixeira e Luiza Garnelo (2014), Saúde Indigena em Perspectiva: explorando suas matrizes históricas e ideológicas, traz uma discussão atualizada das políticas de saúde implantadas no SUS, especialmente o Subsistema de Saúde Indígena.

Um panorama geral da emergência das medicinas tradicionais indígenas no campo das políticas públicas de saúde é elaborado na obra Medicinas indigenas e as politicas da tradição: entre discursos oficiais e vozes indigenas, de Luciane Ouriques Ferreira (2013). Ademais, o livro de Raquel Dias-Scopel (2018), A cosmopolitica da gestaçâo, do parto e do pós-parto: autoatenção e medicalização entre os indios Munduruku, discute como os processos de medicalização colocam em questão não apenas o direito aos serviços de saúde, mas também a necessidade de se reconhecer a autonomia e a criatividade dos sujeitos indígenas, que nesse contexto articulam os diferentes modelos de atenção e cuidado em saúde. Outro destaque entre os livros publicados no período é a Coleção Brasil Plural, editada desde 2013 pela EdUFSC em parceria com o INCT Brasil Plural. Dos 11 títulos publicados, cinco deram especial destaque à antropologia da saúde, parcial ou integralmente.

A relação entre o Estado e os povos indígenas marca a coletânea Saúde Indígena: 
politicas comparadas na América Latina, organizada por Esther Jean Langdon e Marina Cardoso (2015), com a participação de antropólogos(as) brasileiros(as) e de países vizinhos que se dedicam a estudar a interculturalidade em variados contextos. Os textos têm origem em dois eventos realizados no início da década de 2010 pela ABA em parceria com o INCT Brasil Plural. Antropólogos(as) da Argentina, do Brasil, do Chile, da Colômbia, do México e da Venezuela apresentam as experiências da implantaçáo das políticas públicas para a saúde indígena em diferentes contextos nacionais, apontando contradiçóes e desafios que afetam as próprias formas de representação indígena com efeitos na inclusão dessas populaçôes (Langdon; Cardoso, 2015). ${ }^{18}$

Uma temática que tem sido emergente nos últimos anos no campo da saúde indígena é a questão do suicídio de jovens indígenas, que atinge níveis epidêmicos em algumas etnias. No entanto, os estudos alertam para o cuidado em se transpor categorias biomédicas para um fenômeno que envolve especificidades culturais, simbólicas e cosmológicas (Souza; Orellana, 2012; Souza, 2016; Souza; Ferreira, 2014). O tema foi objeto de diversas teses defendidas no período, ainda não publicadas, como a de Matos (2014), e de vários trabalhos no campo da psiquiatria e da psicologia, além de ter sido objeto de muitos artigos na imprensa enfa- tizando o nível epidêmico e as altas taxas de suicídio indígena no país.

\section{Campos psi, saude mental e politicas de álcool e drogas}

Outro campo de pesquisa que trilhou um caminho próprio são os estudos sobre aflição e sofrimento, cultura psi e doença dos nervos, saúde mental e redes psicossociais, psiquiatrização da vida e do sofrimento. Um olhar sobre a trajetória desses estudos a partir dos anos 1970/1980 mostra o quanto eles antecipam ou dramatizam algumas questóes que se tornaram centrais para a antropologia da saúde de modo geral. Uma dessas questóes é a relação entre representaçôes e práticas sociais, muitas vezes alocadas a diferentes vertentes teóricas na antropologia, dicotomização em muitos momentos redutora. Os estudos das representações e das configurações de valores definiram dois modos ou modelos diferenciados para representar a aflição e o sofrimento entre camadas sociais distintas. De um lado, as culturas chamadas $p s i$, predominantes nas classes médias urbanas brasileiras, e de outro, a configuraçáo dos nervos e da perturbação físico-moral, predominante nas camadas populares e nas classes trabalhadoras. Nessa abordagem, os modos em que questóes de sofrimento, afliçáo e/ou perturbação são vivenciadas estáo relacionados a valores e ideologias que predominam nas diferentes

18 Sem se situar exclusivamente no campo da saúde indígena, Umbigos enterrados: corpo, pessoa e identidade capuxu através da infância (Sousa, 2017) elabora uma discussão sobre pessoa e corporalidade na produção de parentescos e territorialidades. Com foco mais voltado às relações entre a antropologia e o Estado, a coletânea Políticas públicas: reflexóes antropológicas (Langdon; Grisotti, 2016) apresenta um balanço das pesquisas realizadas no âmbito do INCT Brasil Plural que contribuíram para subsidiar as políticas públicas, debater as controvérsias e estimular novas ideias. Dos 15 artigos, nove situam-se no campo da saúde em interface com a antropologia, a maioria deles se referindo a contextos indígenas, ribeirinhos e rurais. Ainda cabe uma menção a um outro título dessa coleção, Mulheres e o mar: pescadoras embarcadas no litoral de Santa Catarina (Gerber, 2015), que traz um mergulho etnográfico no cotidiano de mulheres que se constituem como sujeitos tendo a pesca por profissão, mas não possuem reconhecimento do Estado, o que impacta diretamente em seus processos de saúde e doença e na conquista de direitos como a previdência social. 
camadas ou classes sociais. No entanto, são os valores individualistas que demarcam as compreensóes e as respostas biomédicas à aflição e ao sofrimento, incluindo a psiquiatria e as psicologias, assim como as políticas de saúde delas advindas, o que indica a necessidade não apenas de uma relativização radical da perspectiva biomédica (Duarte, 1994), mas um compromisso da pesquisa antropológica em propor novos paradigmas para a elaboração de políticas públicas que contemplem essas diferentes realidades socioculturais.

A abordagem das práticas sociais engloba os estudos com foco na experiência da doença e do sofrimento, com ênfase nas narrativas de doença, nas práticas e nos itinerários terapêuticos, tomando a doença mental como experiência vivida e significada (Alves; Rabelo, 1999). A observação das práticas locais, dos caminhos percorridos nos processos de adoecimento, sofrimento e cura tornou-se um dispositivo etnográfico importante para compreender os modos como sujeitos agem diante de situaçóes críticas ou adversas (Silveira, 2000). Na última década, muitos estudos buscaram articular representaçóes e práticas sociais a partir da abordagem dos modos de subjetivação e da relevância no foco sobre o que fazem e como são produzidos sujeitos e subjetividades com base nesses saberes, representaçóes e práticas sociais, também levando em conta os regimes biopolíticos que atravessam essas práticas. Essas novas perspectivas teóricas e metodológicas têm sido fundamentais para uma compreensão de contextos contemporâneos de medicalização, biologização e psiquiatrização da vida e da experiência social e as múltiplas resistências e agenciamentos dos sujeitos, das comunidades e dos grupos sociais.
Nas últimas duas décadas, os estudos descrevem uma acelerada biologização do modo como questóes do campo psiquiátrico ou da saúde mental são concebidas e experienciadas, com ênfase na disseminação e na ambulatorização da psiquiatria, nos efeitos do processo da reforma psiquiátrica brasileira e na expansão do consumo de psicofármacos (Maluf, 2010; Azize, 2010), bem como no enorme impulso recebido pelas neurociências a partir da década de 1990 (Azize, 2008; Duarte, 2018), sobretudo em seu "programa forte", como define Ehrenberg (2009), de pretenderem ser um modelo explanatório que englobe as dimensóes sociais, culturais, psicológicas e históricas da experiência humana. Uma das questóes trazidas pelos trabalhos desenvolvidos no período é o dos limites de noçóes como saúde mental para dar conta de um campo vasto de experiências sociais, intervençóes biomédicas e açóes do Estado.

De certo modo, o crescimento e a expansão dos trabalhos antropológicos no campo da saúde mental correm paralelamente, de um lado, ao crescimento da especialização cada vez mais acentuada e da expansão dos diagnósticos e das doenças descritas no Manual Diagnóstico e Estatístico de Transtornos Mentais (Diagnostic and Statistical Manual of Mental Disorders - DSM) IV (publicado em 1994) e no DSM V (publicado em 2013), ${ }^{19}$ além da própria dimensão epidêmica da depressão, apontada em estudos acadêmicos e propagada na mídia; e, de outro lado, à ampliação e à consolidação das políticas públicas desencadeadas pela reforma psiquiátrica brasileira, com a criação e a expansão das redes de atenção psicossocial, tanto na atenção primária quanto nos Centros de Atenção Psicossocial (CAPS), assim como com o pro-

19 O DSM III já constituía um marco na virada biológica das definiçōes e dos diagnósticos no campo psiquiátrico e da saúde mental (Russo; Venâncio, 2006). 
cesso de encerramento gradativo dos leitos em hospitais psiquiátricos e a abertura de leitos em hospitais gerais. Assim, grande parte dos trabalhos na última década está focada na etnografia feita com pessoas que frequentam os serviços e são objeto dessas políticas públicas (Tornquist; Andrade; Monteiro, 2010; Quinaglia Silva; Brandi, 2014; Andrade; Maluf, 2016; 2017a; 2017b; 2017c; Quinaglia Silva, 2018); nos estudos voltados às políticas públicas e às práticas do Estado nos serviços e nas instituiçôes de saúde mental (Maluf, 2010; 2015; Andrade; Maluf, 2014; Quinaglia Silva; Moreira, 2017; Maluf; Andrade, 2017; Quinaglia Silva; Calegari, 2018; Quinaglia Silva; Santos; Cruz, 2018); e também na história dos saberes e das instituiçóes psiquiátricas (Duarte, 2010; Venâncio, 2010; 2011; Bittencourt; Caponi; Maluf, 2013; Venâncio; Potengy, 2015), dando seguimento a uma linha importante desenvolvida em anos anteriores.

Outra dimensão dessa temática diz respeito aos estudos sobre o consumo de drogas, principalmente voltados para os consumidores ou usuários de crack, nos quais a própria abordagem antropológica acompanha os deslocamentos e as ambiguidades entre questôes de moralidade, criminalidade e saúde-doença. Muitos são os trabalhos que abordam essa temática no campo dos estudos das violências e da segurança pública. No campo da saúde, as abordagens têm privilegiado focar nas experiências e nas representaçôes dos sujeitos usuários e nas respostas institucionais, ${ }^{20}$ pressionadas pelas disputas entre diferentes modelos de atenção em relação ao uso de drogas, em que se destacam questóes como as políticas de redução de danos, a internaçáo compulsória e o rea- tivamento recente das políticas de abstinência, que, com a Nota Técnica no 11/2019, passam, junto às Comunidades Terapêuticas (CT), a ganhar mais centralidade nas políticas de drogas. Em 2018, o Instituto de Pesquisa Econômica Aplicada (IPEA) publicou uma coletânea que pode ser considerada o mais extensivo e aprofundado estudo sobre as CT no Brasil, resultado de pesquisa feita em duas frentes, quantitativa (em $700 \mathrm{CT}$ em um universo de duas mil cadastradas) e qualitativa/etnográfica (com um estudo em profundidade em dez CT) (Santos, 2018).

As rápidas mudanças na política nacional de saúde mental, sintetizadas na nota técnica mencionada, mas que já vinham sendo aplicadas desde 2016, representam uma reviravolta no campo da saúde mental no país, com o retorno de uma política que estimula as internações hospitalares de longa duração e reinsere o hospital psiquiátrico na rede de atençáo psicossocial, sendo considerada pelos pesquisadores e ativistas da saúde pública uma verdadeira contrarreforma psiquiátrica. Como assinalado, os recuos e os retrocessos na política de saúde - incluindo mudanças que fragilizam o SUS, ameaças às políticas de atenção diferenciada na saúde indígena e mudanças de rumo na política de saúde mental - têm sido tema de diversos fóruns e encontros e já têm produzido impactos nas pesquisas sociais em saúde.

\section{Saúde, espiritualidade e práticas complementares/alternativas}

Ainda nessa relação com o Estado e as políticas públicas, a antropologia tem sido cada vez mais acionada pela importância do conceito de integralidade na constituição do SUS, em que medicinas complementares

20 Com foco mais dirigido para as questôes de experiências e políticas no campo da saúde (Medeiros, 2014; Labate et al., 2016; entre outros). 
podem ser (e têm sido) agregadas aos sistemas médicos hegemônicos (Andrade; Costa, 2010). Há um renovado interesse por itinerários terapêuticos ou terapias oriundas de diferentes sistemas médicos (Kleinman, 1978), não apenas por parte de antropólogos(as) da saúde, mas também por pesquisadores(as) da enfermagem, da nutrição e, principalmente, da saúde coletiva que encontram na antropologia um aporte privilegiado para o tema. Se antes a ideia era buscar saber "o que fazem os sujeitos" para fins de intervenção, geralmente biomédica, cabe agora pensar como o diálogo entre diferentes terapias pode ser favorável aos processos de cura.

Em relação à medicina complementar ou às práticas integrativas e complementares (PIC), elas começam a ganhar legitimidade em uma arena tomada por paradigmas biomédicos com o crescente interesse de organismos internacionais, tais como a Organização Mundial da Saúde (OMS), mediante a investigação e a validação de terapias de uso difundido por clínicas particulares, comunidades tradicionais, igrejas, movimentos sociais e entidades não governamentais (Andrade; Costa, 2010). Na sequência, o Ministério da Saúde (MS), no Brasil, passa a estimular essas práticas mediante sua regulamentação por meio da Portaria Interministerial no 971 , que, em 2006, instituiu a Política Nacional de Práticas Integrativas e Complementares. Essas práticas também ganham destaque em uma perspectiva de humanizaçáo, em que "medicinas vividas como alternativas são continuamente inventadas e reinventadas pelos profissionais de saúde que integram os mais diversos projetos, grupos e outras iniciativas correlatas" (Silva, 2011, p. 147). A autora fala de certo consenso entre esses profissionais de que a formação biomédica em enfermagem e medicina, principalmente - é marcada pela desconsideração da comple- xidade dos processos de saúde/doença, que precisariam reconhecer tratamentos e curas como processos comunicativos que suscitam experiências subjetivas. Em uma pesquisa etnográfica aprofundada sobre as práticas integrativas, Rodrigo Toniol (2018) articula questóes de espiritualidade e saúde abordando a implementação das PIC nas políticas de saúde pública. Esses trabalhos levantam questóes que vão desde os sentidos domesticadores dados pela regulamentação dessas práticas no espaço da complementaridade, que náo desafia o protagonismo da medicina, até a reflexáo de quanto o uso de terapias alternativas nos locais de atendimento e serviços públicos em saúde extrapola as políticas das PIC, para além de sua domesticação.

Intersecções já caras à disciplina, como entre religião e saúde, ganharam um novo destaque para mostrar suas possibilidades nos processos de tratamento e cura. É o caso da coletânea Para além da eficácia simbólica: estudos em ritual, religião e saúde (Tavares; Bassi, 2013), que reúne, em torno do debate sobre esse conceito clássico da antropologia, reflexóes e trabalhos feitos em diferentes campos etnográficos que articulam saúde, ritual e religião. Mercante (2013), por exemplo, explora as possibilidades do uso da ayahuas$c a$ em tratamentos de dependência química, com base em uma etnografia em centros religiosos do Brasil e do Peru. Ele ressalta que não se trata de uma "terapia de substituição", em que uma droga substituiria a outra, como os usos de antidepressivos em terapias de caráter biomédico, mas da produção de novos agenciamentos e da relação com as emoções que disparam a adicção (Mercante, 2013).

Já Serra, Pechine e Pechine (2010) mostram como os estudos antropológicos evidenciam situaçôes de intolerância religiosa em relação às práticas terapêuticas dos terreiros de candomblé de Salvador, que "não são so- 
mente templos, mas também agências de serviço de saúde populares importantes" (Serra; Pechine; Pechine, 2010, p. 163). Por fim, Oliveira (2010), em uma etnografia sobre o Vale do Amanhecer, dá valor à narrativa para pensar a construção performativa do self nos deslocamentos pelas várias terapêuticas que constituem esse "movimento místico-esotérico" sediado no Distrito Federal.

\section{Ética nas pesquisas sociais (em saúde)}

Finalmente, especificamente quanto à reflexão sobre a ética em pesquisa, embora se trate de uma temática que perpassa a antropologia como um todo, ela incide particularmente sobre a antropologia da saúde. Isso ocorre não somente porque nos últimos anos etnografias têm sido realizadas em instituiçôes de saúde, na interface desse campo com a biomedicina (Sarti, 2010), como também porque houve, no Brasil, a exemplo do que ocorreu nos Estados Unidos nas décadas de 1990 e 2000, uma "expansão sorrateira” para as áreas humanas do modelo regulatório biomédico de apreciação ética de estudos feita por comitês independentes (Langdon; Maluf; Tornquist, 2008; Fonseca, 2015). Desde a criação da primeira resolução nacional - Resolução no 1 , de 13 de junho de 1988, do Conselho Nacional de Saúde (CNS), do MS - até sua atualização por meio da aprovação das resoluçóes seguintes - Resolução no 196, de 10 de outubro de 1996 , e Resolução no 466, de 12 de dezembro de 2012, ambas do CNS, do MS, esta última em vigor -, o modelo biomédico, que não contempla as metodologias e as especificidades éticas das pesquisas em ciências humanas e sociais, manteve-se como base das diretrizes concernentes à avaliação de projetos de pesquisas que envolvem seres humanos (Brasil, 1988; 1996; 2012). Conforme apontam Sarti (2010), Guerriero e Minayo (2013),
Minayo e Guerriero (2014), Duarte (2015), Fonseca (2015), Schuch e Victora (2015), Quinaglia Silva e Pereira (2016), Quinaglia Silva e Portela (2017), Quinaglia Silva (2017) e Quinaglia Silva e Lionço (2018), além das coletâneas Ética e regulamentação na pesquisa antropológica (organização de Soraya Fleischer e Patrice Schuch, 2010), Antropologia e ética: desafios para a regulamentação (organização de Cynthia Sarti e Luiz Fernando Dias Duarte, 2013) e Ciclo de Estudos e Debates: Procedimentos Éticos e a Pesquisa em Antropologia (organização de Telma Camargo da Silva, 2014), prevalece a manutenção de uma hegemonia da epistemologia biomédica na inteligibilidade sobre o que é ética em pesquisa e, ainda, o que é ciência, o que compromete a realização de pesquisas nas áreas humanas. O Sistema CEP/Conep, criado pelas resoluçóes antepostas e formado pela Comissão Nacional de Ética em Pesquisa e pelos Comitês de Ética em Pesquisa, acaba por criar o próprio sentido de "ética" a ser por ele avaliado (Schuch; Victora, 2015).

Nesse cenário, os dossiês temáticos "Ética nas pesquisas em ciências humanas e sociais em saúde: identificando especificidades", da Ciência \& Saúde Coletiva; "A pesquisa e sua ética, o poder e sua norma”, da Revista Brasileira de Sociologia; "Avanços da Resolução 510/2016 e impasses do Sistema CEP/Conep", da Revista Mundaú; e "Bioética e ética na pesquisa social: dilemas e perspectivas", da Amazônica: Revista de Antropologia mostram o embate científico, ético e, ainda, político, motivado pelas ciências humanas e sociais, que culminou com a criação, em 2016, da Resolução no 510, de 7 de abril, também do CNS, do MS. Essa resolução passou a regulamentar as pesquisas nas áreas supracitadas quanto a seus aspectos éticos (Brasil, 2016). Tratou-se de um marco importante para o alcance das reivindica- 
çôes do GT de Ciências Humanas e Sociais (CHS), criado no âmbito da Conep e composto por 18 associaçóes nacionais de pesquisa e pós-graduação das ciências humanas e sociais e por representantes do CNS e do MS (Guerriero; Bosi, 2015). Essas diretrizes trouxeram avanços, tais como a obtenção e o registro do consentimento e do assentimento livre e esclarecido em diferentes formatos e momentos da pesquisa; a retirada do processo de avaliação pelo Sistema CEP/Conep das etapas preliminares das pesquisas; a exigência de composição equânime entre membros das ciências humanas e sociais e das demais áreas nos colegiados do Sistema CEP/Conep, seja na própria Conep, seja nos CEP; a criação de uma instância, no âmbito da Conep, dedicada à implementação da referida resolução com a participação de membros titulares das ciências humanas e sociais integrantes da Conep, representantes de associações científicas dessas áreas, membros dos CEP igualmente voltados para as pesquisas sociais e usuários (sendo incluída, como parte das incumbências dessa instância, a elaboração de um formulário de registro de protocolos que diferencie as pesquisas em ciências humanas e sociais das biomédicas e as encaminhe com a devida clareza e agilidade à Plataforma Brasil, sistema oficial de lançamento de pesquisas para análise de seus aspectos éticos); a prescindibilidade de registro e avaliaçáo pelo Sistema CEP/Conep de uma série de tipos de pesquisa (de opinião pública, censitária, decorrente da prática profissional); e a substituição de uma noçáo reificada de "vulnerabilidade" por uma ideia de "situação de vulnerabilidade", o que sinaliza para a necessidade de avançar em duas direções fundamentais: a ampliaçáo do rol de vulnerabilidades exaustivamente documentado nas resoluçôes anteriores e a observação das potencialidades dos participantes das pesquisas sociais, para além dos riscos, amiúde mínimos ou baixos, que poderiam correr nesses estudos (Brasil, 2016; Dias, 2016; Quinaglia Silva; Portela 2017; Quinaglia Silva, 2017; Quinaglia Silva; Lionço, 2018).

Há, contudo, um distanciamento entre a norma e sua atualização, como a dissolução do próprio GT CHS, que levaria a cabo as mudanças propostas. Apesar das conquistas trazidas nos últimos três anos pela referida Resolução no 510/2016, a falta de contrapartida real do que é preconizado mantém a divisão dos(as) pesquisadores(as) entre aqueles(as) que, de um lado, propõem uma "recusa reflexiva" ao Sistema CEP/Conep e suas orientaçôes metadisciplinares, e aqueles(as) que, de outro lado, sustentam um "engajamento crítico", uma resistência interna ao atual sistema de revisão ética por meio da participação em CEP (Duarte, 2004; Schuch; Victora, 2015).

No intento desse segundo grupo, apenas cinco CEP - o Comitê de Ética em Pesquisa em Ciências Humanas e Sociais da Universidade de Brasília (CEP/CHS-UnB), o Comitê de Ética em Pesquisa do Centro de Filosofia e Ciências Humanas da Universidade Federal do Rio de Janeiro (CEP/CFCH-UFRJ), o Comitê de Ética na Pesquisa em Ciências Sociais, Sociais Aplicadas, Humanas, Letras, Artes e Linguística (CEP/Humanas-UFF), o Comitê de Ética em Pesquisa em Ciências Humanas e Sociais da Universidade Estadual de Campinas (CEP/CHS-Unicamp) e o Comitê de Ética em Pesquisa com Seres Humanos da Área das Ciências Humanas e Sociais da Universidade Federal de Mato Grosso (CEP/Humanidades-UFMT) -, entre os 848 existentes no Brasil (Brasil, 2019), sobrevivem no interior do sistema de regulamentaçâo da ética em pesquisa vigente e buscam promover uma sensibilizaçáo para as particularidades das pesquisas sociais (Qui- 
naglia Silva; Lionço, 2018). Nesse sentido, muito embora em 2011, a ABA tenha aprovado, na assembleia geral do $35^{\circ}$ Encontro Nacional da Anpocs, uma moção de retirada da apreciação ética de projetos de pesquisas das ciências humanas e sociais do Sistema CEP/Conep (Sarti; Duarte, 2013), em 2018, essa mesma associaçáo aprovou, por unanimidade, na assembleia geral da $31^{\text {a }}$ RBA, uma nova moção de cobrança desse sistema de correspondência entre o que prevê a resolução própria das ciências humanas e sociais e o que é concretizado.

Guerriero e Minayo (2013), Minayo e Guerriero (2014), Duarte (2015), Fonseca (2015), Guerriero e Correa (2015), Schuch e Victora (2015), Minayo (2015), Quinaglia Silva e Pereira (2016), Quinaglia Silva e Portela (2017), Quinaglia Silva (2017) e Quinaglia Silva e Lionço (2018) defendem a necessidade de haver uma (re)apropriação e (re)politização da ética em pesquisa, que deve ser entendida para além de uma noção meramente técnica, sinônimo do protocolo a ser submetido ao Sistema CEP/Conep. Uma ética de responsabilidade (Minayo; Guerriero, 2014; Quinaglia Silva; Lionço, 2018), mediante a adoção de uma postura crítica e comprometida com os nossos sujeitos de pesquisa, significa até mesmo extrapolar os muros acadêmicos para a construção de fóruns de debates dos quais a população possa participar, a exemplo das "conferências de cidadãos" europeias (Fonseca, 2015; Schuch; Victora, 2015).

No último balanço feito por Sarti (2010), essa autora enfatizou a oposição entre os saberes e fazeres biomédicos e aqueles das ciências humanas e sociais. Para além de um embate entre esses campos, emerge uma perspectiva que aponta para a possibilidade de negociação entre eles e entre eles e a sociedade mais ampla. $\mathrm{O}$ enfrentamento des- ses desafios pode fortalecer a criaçâo de uma cultura de reflexão ética sobre a pesquisa científica que supere as críticas à burocratização do sistema de regulamentaçáo vigente rumo à produçáo de consensos na comunidade científica sobre o propósito político da existência dos CEP como instâncias deliberativas de controle social sobre a ciência (Quinaglia Silva; Lionço, 2018).

\section{Apontamentos finais}

A análise da trajetória dos estudos de antropologia da saúde no Brasil a partir da consulta a vários balanços anteriores e especificamente do levantamento da produção recente, com este balanço dos últimos dez anos, mostra-nos o quanto as mudanças teóricas, conceituais, metodológicas e mesmo institucionais no campo da antropologia são impulsionadas tanto por questóes e debates internos à própria disciplina quanto por contextos, conjunturas e demandas mais amplas. Do reconhecimento das dimensóes sociais e culturais dos processos de adoecimento e cura, dos estudos das práticas locais, das configuraçóes cosmológicas sobre corpo, adoecimento e cura e da abordagem dos diferentes sistemas médicos e processos de interculturalidade no campo da saúde à etnografia das políticas públicas e açôes do Estado, dos processos biopolíticos, das formas de governamentalidade e das políticas da vida, a pesquisa antropológica e etnográfica tem se mostrado um campo essencial para a compreensão das dimensôes sociais, das dinâmicas e experiências de adoecimento, sofrimento e aflição e dos processos de cura, alívio e cuidado. Além disso, tem proporcionado que se entendam a extensão e os limites de atuação da biomedicina e do Estado, suas linguagens, discursos, saberes, práticas e tecnologias para 
a compreensão de dimensôes da vida social que vão além dos processos de adoecimento e cura com base em uma perspectiva organicista - o que diversos(as) autores(as) têm denominado de processos de medicalização da vida.

Os trabalhos produzidos no período também mostram o processo inverso, aquilo que Russo e Carrara (2015) denominaram de "socialização" das questôes médicas, quando temas e questóes próprios à biomedicina se estendem para a esfera social e política. Esse conjunto de questóes recoloca ou ressitua no campo biomédico o que seriam os estudos sociais da saúde e, particularmente, a antropologia da saúde. A compreensão da dimensão social do campo do adoecimento/cura ou da doença/saúde se estende para além da relação de causalidade (as condiçóes sociais de produção da doença), chegando às formas como as doenças são compreendidas, aos agenciamentos sociais em torno da doença (e da saúde), às práticas e saberes locais, aos modos de relação dos sujeitos, comunidades, populaçóes com o campo biomédico e com os serviços, instituiçóes e práticas do Estado.

A seguir, buscamos sistematizar algumas questóes apontadas neste balanço da produção dos últimos dez anos e que ajudam a delinear o campo da antropologia da saúde hoje:

- Inicialmente, é necessário sublinhar o vigor da etnografia para a compreensão dos fenômenos ligados aos processos de adoecimento e cura ou doença e saúde de modo amplo, tanto a partir da continuidade das pesquisas clássicas voltadas às práticas, saberes e lógicas locais, quanto por meio do desenvolvimento de pesquisas que buscam abranger os diferentes agenciamentos em torno da doença, incluindo a biomedicina, o Estado e as políticas públicas no campo da investigação etnográfica. Compreende- mos a pesquisa etnográfica não apenas como um método utilizado no levantamento de dados, mas também como o aporte teórico e conceitual da antropologia - como uma "teoria em ação", segundo Peirano (2008; 2014) -, fundamental para uma compreensão crítica e reflexiva sobre esses dados;

- Outra questão já acentuada no início do artigo é a abertura do leque de temáticas abordadas pela antropologia da saúde e o desenvolvimento de uma sensibilidade aos problemas centrais de saúde da população. Alguns exemplos são as abordagens do HIV/Aids nos anos 1990 e 2000; de questóes psicossociais e de saúde mental já a partir dos anos 1970/1980, intensificadas a partir dos anos 2000; e do Zika vírus na década de 2010. Cabe acentuar que não necessariamente a percepção mais atenta às questóes e aos problemas mais evidentes de saúde da população significa uma submissão à agenda da pesquisa epidemiológica, das políticas públicas ou da biomedicina. Como vimos, em muitos momentos são as demandas dos próprios movimentos sociais e dos estudos interseccionais que têm trazido pautas na agenda de pesquisa no campo da antropologia da saúde;

- Outra dimensão que muitos desses trabalhos apresentam é a abordagem dos sujeitos pesquisados como sujeitos políticos, não apenas produzidos e afetados pelas experiências vividas, mas produtores de experiências, relaçóes, saberes e práticas, protagonistas na e da pesquisa, produzindo suas versóes (e mundos) na relação etnográfica. Existe um tom predominante nos estudos de evidenciar esses sujeitos de "carne e osso" e, a partir deles, construir os caminhos da pesquisa. É com base neles que a antropologia 
tem confrontado o discurso e as práticas hegemônicas da biomedicina e favorecido uma compreensão crítica e reflexiva das relações de poder estabelecidas no campo da saúde e da doença;

- A clivagem entre os trabalhos acadêmicos e os políticos apontada em narrativas que buscam historicizar a antropologia da saúde e os estudos sociais de saúde de modo geral parece não fazer mais tanto sentido ou produzir tantos efeitos no campo. Essa questão se articula com os impactos sociais da pesquisa antropológica, que podem ser tanto imediatos, como no caso de pesquisas aplicadas voltadas a produzir respostas para determinados problemas de saúde da população, avaliar políticas públicas e definir protocolos específicos de atendimento, quanto mediatizados por traduçôes e mediações culturais (e políticas). Talvez a diferença entre essas duas vertentes da pesquisa antropológica seja a temporalidade com que esses efeitos são produzidos. No período de expansão das políticas públicas, a antropologia foi requisitada de modo crescente a se manifestar e trazer os resultados de suas pesquisas. Pode ser cedo para determinar, no novo momento em que há redução e mesmo transformaçóes radicais nessas políticas, como as mencionadas anteriormente, qual será o papel da antropologia. Entretanto, alguns eventos, tais como a defesa diante do STF do direito ao aborto e a produçáo de pareceres sobre prováveis efeitos de uma mudança na política de saúde indígena, falam sobre um ativismo antropológico que faz convergir a pesquisa avançada com a compreensáo dos impactos sociais e dos efeitos políticos da pesquisa.

Todas essas temáticas conformam uma política da antropologia que acena para uma antropologia (da) política, em que a pesquisa antropológica se (pre)ocupa com os efeitos teórico-práticos da pesquisa em diversas esferas. $\mathrm{Se}$, em um momento anterior, a racionalização e a ideologia individualista que marcam os saberes e as práticas biomédicas foram centrais para delimitar as fronteiras da especificidade da pesquisa antropológica, o novo contexto de emergência de uma antropologia política da saúde, a partir de meados dos anos 2000 a 2019, remete aos estudos sobre políticas públicas, instituiçóes e serviços de saúde, além dos regimes de subjetivação, práticas e agenciamentos sociais. Nesse cenário, as fronteiras disciplinares deslocam-se para outro patamar, no qual a disputa de regimes de verdade entre biomedicina e antropologia dá lugar a pesquisas cooperativas, em rede, e de potencialização mútua - mesmo que crítica. Trata-se de um projeto em movimento, em construção, mas cujos efeitos científicos, éticos e políticos são inegáveis.

\section{BIBLIOGRAFIA}

AGOSTINI, Rafael.; MAKSUD, Ivia; FRANCO, Tulio. "Essa doença para mim é a mesma coisa que nada": reflexóes socioantropológicas sobre o descobrir-se soropositivo. Saúde e Sociedade, v. 26, n. 2, p. 496-509, 2017. http://dx.doi.org/10.1590/s0104-12902017170072

AGOSTINI, Rafael.; MAKSUD, Ivia.; FRANCO, Túlio. "Eu tenho que te contar um negócio”: gestão da 
soropositividade no contexto dos relacionamentos afetivo-sexuais de jovens vivendo com HIV. Sexualidad, Salud y Sociedad, n. 30, p. 201-223, 2018. http://dx.doi.org/10.1590/1984-6487.sess.2018.30.10.a

ALVES, Paulo C.; MINAYO, Maria Cecilia (orgs.). Saúde e doença: um olhar antropológico. Rio de Janeiro: Fiocruz, 1994.

ALVES, Paulo C.; RABELO, Miriam C. Tecendo selfe emoção nas narrativas de nervoso. In: RABELO, Miriam; ALVES, Paulo C.; SOUZA, Iara M. (orgs.). Experiência de doença e narrativa. Rio de Janeiro: Fiocruz , 1999. p. 187-204.

ANDRADE, Ana Paula Müller de; MALUF, Sônia Weidner. Cotidianos e trajetórias de sujeitos no contexto da reforma psiquiátrica brasileira. In: FERREIRA, J.; FLEISCHER, S. Etnografias em serviços de saúde. Rio de Janeiro: Garamond, 2014. p. 35-55.

ANDRADE, Ana Paula Müller de; MALUF, Sônia Weidner. Entre políticas públicas e experiências sociais: impactos da pesquisa etnográfica no campo da saúde mental e suas múltiplas devoluçōes. Saúde e Sociedade, v. 26, n. 1, p. 171-182, 2017a. http://dx.doi.org/10.1590/s0104-12902017168331

ANDRADE, Ana Paula Müller de; MALUF, Sônia Weidner. Experiências de desinstitucionalização na reforma psiquiátrica brasileira: uma abordagem de gênero. Interface, v. 21, n. 63, p. 811-821, 2017b. http://dx.doi. org/10.1590/1807-57622015.0760

ANDRADE, Ana Paula Müller de; MALUF, Sônia Weidner. Loucos/as, pacientes, usuários/as, experientes: o estatuto dos sujeitos no contexto da reforma psiquiátrica brasileira. Saúde em Debate, v. 41, n. 112, p. 273284, 2017c. http://dx.doi.org/10.1590/0103-1104201711222

ANDRADE, Ana Paula Müller de; MALUF, Sônia Weidner. Sujeitos e(m) experiências: estratégias micropolíticas no contexto da reforma psiquiátrica no Brasil. Physis - Revista de Saúde Coletiva, v. 26, n. 1, p. 251-270, 2016. http://dx.doi.org/10.1590/S0103-73312016000100014

ANDRADE, João Tadeu de; COSTA, Liduina Farias Almeida da. Medicina complementar no SUS: práticas integrativas sob a luz da Antropologia médica. Saúde e Sociedade, v. 19, n. 3, p. 497-508, 2010. http://dx.doi. org/10.1590/S0104-12902010000300003

ANDRADE, Márcia Andrea R.; FRANCH, Mónica. "Eles não estão mais pra nada": sexualidade e processos de envelhecimento na dinâmica do Programa Saúde da Família. Mediaçóes. Revista de Ciências Sociais, v. 7, n. 2, p. 41-56, 2012.

ARAÚJO, Reginaldo Silva de. Doença falciforme: da politização pelo movimento negro como doença étnico-racial às associaçóes representativas dos falcêmicos como doença específica. Curitiba: CRV, 2017.

AURELIANO, Waleska. Trajetórias Terapêuticas Familiares: doenças raras hereditárias como sofrimento de longa duração. Ciência \& Saúde Coletiva, v. 23, n. 2, p. 369-380, 2018. http://dx.doi.org/10.1590/141381232018232.21832017

AYDOS, Valéria. Agência e subjetivação na gestão de pessoas com deficiência: a inclusão no mercado de trabalho de um jovem diagnosticado com autismo. Horizontes Antropológicos, v. 22, n. 46, p. 329-358, 2016. http:// dx.doi.org/10.1590/S0104-71832016000200012

AZIZE, Rogério L. Notas de um "não-prescritor": uma etnografia entre estandes da indústria farmacêutica no Congresso Brasileiro de Psiquiatria. In: TORQUIST, Carmen S.; MALUF, Sônia W. (orgs.). Gênero, saúde e aflição: abordagens antropológicas. Florianópolis: Letras Contemporâneas, 2010.

AZIZE, Rogério L. Uma neuro-weltanschauung? Fisicalismo e subjetividade na divulgação de doenças e medicamentos do cérebro. Mana, v. 14, n. 1, p. 7-30, 2008. http://dx.doi.org/10.1590/S010493132008000100001 
BARSAGLINI, Reni A. As representaçóes sociais e a experiência com o diabetes: um enfoque socioantropológico. Rio de Janeiro: Fiocruz, 2011.

BENTO, Berenice; PELÚCIO, Larissa. Despatologização do gênero: a politização das identidades abjetas. Estudos Feministas, v. 20, n. 2, p. 559-568, 2012. http://dx.doi.org/10.1590/S0104-026X2012000200017

BITTENCOURT, Silvia Cardoso; CAPONI, Sandra.; MALUF, Sônia. Medicamentos antidepressivos: inserção na prática biomédica (1941 a 2006) a partir da divulgaçâo em um livro-texto de farmacologia. Mana, v. 19, n. 2, p. 219-247, 2013. http://dx.doi.org/10.1590/S0104-93132013000200001

BIZERRIL, André. O caminho do retorno: envelhecer à maneira taoísta. Horizontes Antropológicos, v. 16, n. 34, p. 287-313, 2010. http://dx.doi.org/10.1590/S0104-71832010000200013

BONET, Octavio. Os médicos da pessoa: um olhar antropológico sobre a medicina de família no Brasil e na Argentina. Rio de Janeiro: 7 Letras, 2014.

BORBA, Rodrigo. O Des-Aprendizado de si: transexualidades, interação e cuidado em saúde. Rio de Janeiro: Fiocruz, 2016.

BRANCO PEREIRA, Alexandre. O refúgio do trauma. Notas etnográficas sobre trauma, racismo e temporalidades do sofrimento em um serviço de saúde mental para refugiados. Revista Interdisciplinar da Mobilidade Humana, v. 26, n. 53, p. 79-97, 2018. http://dx.doi.org/10.1590/1980-85852503880005306

BRASIL. Ministério da Saúde. Comissão Nacional de Ética em Pesquisa. Mapa dos CEPs. 2019. Disponível em: <hDisponível em: ttp://conselho.saude.gov.br/comissoes-cns/93-comissoes/conep/comites-de-etica-empesquisa-conep/645-mapa-dos-ceps-conep>. Acesso em: 17 set. 2019.

BRASIL. Ministério da Saúde. Conselho Nacional de Saúde. Resolução no 1, de 13 de junho de 1988. Diário Oficial da Uniáo, 13 jun. 1988.

BRASIL. Ministério da Saúde. Conselho Nacional de Saúde. Resolução no 196, de 10 de outubro de 1996. Diário Oficial da Uniáo, 10 out. 1996.

BRASIL. Ministério da Saúde. Conselho Nacional de Saúde. Resoluçáo no 466, de 12 de dezembro de 2012. Diário Oficial da Uniáo, 12 dez. 2012.

BRASIL. Ministério da Saúde. Conselho Nacional de Saúde. Resoluçáo no 510, de 7 de abril de 2016. Diário Oficial da Uniáo, 7 abr. 2016.

BRAZ, Camilo Albuquerque. Transmasculinidades, salud y espera Antropología del tiempo y el acceso a la salud para hombres trans en Brasil. In: PECHENY, M. M.; PALUMBO, M. (orgs.). Esperar y hacer esperar: escenas y experiencias en salud, dinero y amor. Buenos Aires: Teseopress, 2017.

BRITTO DA MOTTA, Alda. O Final da Vida no Século XXI. Mediaçóes, v. 17, n. 2, p. 9-25, 2012. http://dx.doi. org/10.5433/2176-6665.2012v17n2p9

BUSTAMANTE, Vania; MCCALLUM, Cecilia. Cuidado e construção social da pessoa: contribuiçóes para uma teoria geral. Physis, v. 24, n. 3, p. 673-692, 2014. http://dx.doi.org/10.1590/S0103-73312014000300002

CABRAL, Ana Lucia Lobo Vianna et al. Itinerários terapêuticos: o estado da arte da produção científica no Brasil. Ciência \& Saúde Coletiva, v. 16, n. 11, p. 4433-4442, 2011. http://dx.doi.org/10.1590/S141381232011001200016

CAMPOS, Edemilson de. "Nosso Remédio É a Palavra": Uma etnografia sobre o modelo terapêutico de Alcoólicos Anônimos. Rio de Janeiro: Fiocruz, 2010. 
CANESQUI, Ana Maria. Notas sobre a produção acadêmica de antropologia e saúde na década de 80. In: ALVES, Paulo C.; MINAYO, Maria Cecilia (orgs.). Saúde e doença: um olhar antropológico. Rio de Janeiro: Fiocruz , 1994.

CANESQUI, Ana Maria. Os estudos de antropologia da saúde/doença no Brasil na década de 1990. Ciência \& Saúde Coletiva, v. 8, n. 1, p. 109-124, 2003. http://dx.doi.org/10.1590/S1413-81232003000100009

CANESQUI, Ana Maria (org.). Adoecimentos e Sofrimentos de Longa Duraçáo. 2. ed. São Paulo: Hucitec, 2015a.

CANESQUI, Ana Maria (org.). "Pressáo Alta” no cotidiano: representaçōes e experiências. Rio de Janeiro: Fiocruz, $2015 b$.

CARNEIRO, Rosamaria. O peso do corpo negro feminino no mercado da saúde: mulheres, profissionais e feministas em suas perspectivas. Mediaçóes, v. 22, n. 2, p. 394-424, 2017. http://dx.doi.org/10.5433/2176$6665.2017 \mathrm{v} 22 \mathrm{n} 2 \mathrm{p} 394$

CARNEIRO, Rosamaria; FLEISCHER, Soraya Resende. "Eu não esperava por isso, foi um susto": conceber, gestar e parir em tempos de zika à luz das mulheres de Recife, Pernambuco, Brasil. Interface, v. 22, n. 66, p. 709-719, 2018. http://dx.doi.org/10.1590/1807-57622017.0857

CARRARA, Sérgio. et al. A construção do corpo e itinerários de saúde: um estudo entre travestis e pessoas trans no Rio de Janeiro, Brasil. Cadernos de Saúde Pública, v. 35, n. 4, 2019. http://dx.doi.org/10.1590/0102$311 \times 00110618$

CASTRO, Rosana; ENGELS, Cíntia; MARTINS, Raysa (orgs.). Antropologias, saúde e contextos de crise. Brasília: Sobrescrita, 2018.

CHIESA, Gustavo Ruiz. Além do que se vê: magnetismos, ectoplasmas e paracirurgias. Porto Alegre: Multifoco, 2016.

DEBERT, Guita Grin. A reinvençáo da velhice: socializaçáo e processos de reprivatização do envelhecimento. São Paulo: Edusp, 1999.

DIAS, Bruno. Aprovada a resolução sobre ética em pesquisa nas Ciências Humanas e Sociais. Associaçáo Brasileira de Saúde Coletiva, 2016. Disponível em: <Disponível em: https://www.abrasco.org.br/site/outras-noticias/ formacao-e-educacao/aprovada-a-resolucao-sobre-etica-em-pesquisa-nas-chs/17194/>. Acesso em: 19 fev. 2019.

DIAS-SCOPEL, Raquel. A cosmopolítica da gestaçáo, do parto e do pós-parto: autoatenção e medicalização entre os índios Munduruku. 2. ed. Rio de Janeiro: Fiocruz , 2018.

DINIZ, Debora. A custódia e o tratamento psiquiátrico no Brasil: censo 2011. Brasília: LetrasLivres, Editora da UnB, 2013.

DINIZ, Debora. Vírus Zika e mulheres. Cadernos de Saúde Pública, v. 32, n. 5, p. 1-4, 2016a. http://dx.doi. org/10.1590/0102-311X00046316

DINIZ, Debora. Zika: do sertão nordestino à ameaça global. Rio de Janeiro: Civilização Brasileira, 2016b.

DINIZ, Debora; BARBOSA, Lívia; SANTOS, Wederson. Deficiência, direitos humanos e justiça. In: DINIZ, Debora; SANTOS, Wederson. (orgs.). Deficiência e discriminação. Brasília: Letras Livres, EdUnB, 2010.

DINIZ, Debora; MEDEIROS, Marcelo. Itinerários e métodos de aborto ilegal em cinco capitais brasileiras. Ciência \& Saúde Coletiva, v. 17, n. 7, p. 1671-1681, 2012. http://dx.doi.org/10.1590/S1413-81232012000700002

DINIZ, Debora; MEDEIROS, Marcelo.; SCHWARTZ, Ida Vanessa D. Consequências da judicialização das políticas de saúde: custos de medicamentos para as mucopolissacaridoses. Cadernos de Saúde Pública, v. 28, n. 3, p. 479-489, 2012. http://dx.doi.org/10.1590/S0102-311X2012000300008 
DUARTE, Luiz Fernando D. A ética em pesquisa nas Ciências Humanas e o imperialismo Bioético no Brasil. Revista Brasileira de Sociologia, v. 3, n. 5, p. 29-52, 2015. http://dx.doi.org/10.20336/rbs.90

DUARTE, Luiz Fernando D. A outra saúde: mental, psicosocial, físico-moral? In: ALVES, Paulo C.; MINAYO, Maria Cecilia (orgs.). Saúde e doença: um olhar antropológico. Rio de Janeiro: Fiocruz , 1994.

DUARTE, Luiz Fernando D. Ciências humanas e neurociências: análise de um caso crítico em contexto educacional. Revista Brasileira de Ciências Sociais, v. 33, n. 97, p. 1-19, 2018. http://dx.doi.org/10.1590/339702/2018

DUARTE, Luiz Fernando D. Ética de pesquisa e “correção política” em Antropologia. In: VICTORA, Ceres et al. (orgs.). Antropologia e ética: o debate atual no Brasil. Niterói: EdUFF-ABA, 2004.

DUARTE, Luiz Fernando D. Investigação antropológica sobre doença, sofrimento e perturbação: uma introdução. In: DUARTE, Luiz Fernando D.; LEAL, Ondina F. (orgs.). Doença, Sofrimento, Perturbaçáo: perspectivas etnográficas. Rio de Janeiro: Fiocruz , 1998.

DUARTE, Luiz Fernando D. O nervosismo como categoria nosográfica no começo do século XX. História, Ciências, Saúde - Manguinhos, v. 17, supl. 2, p. 313-326, 2010. http://dx.doi.org/10.1590/S010459702010000600003

DUMONT, Louis. O individualismo: uma perspectiva antropológica da ideologia moderna. Rio de Janeiro: Rocco, 1993.

EHRENBERG, Alain. O sujeito cerebral. Psicologia Clínica, v. 21, n. 1, p. 187-213, 2009.

ENGEL, Cíntia. Dependência e estratégias de cuidado no Brasil. Mediaçôes. Revista de Ciências Sociais, v. 17, n. 2, p. 166-180, 2012.

ESCOBAR, Arturo. Mas allá del tercer mundo: globalización y diferencia. Bogotá: ICAN, 2005.

ESCOBAR, Arturo. The Latin American Modernity/Coloniality Research Program: Worlds and Knowledges Otherwise. Cuadernos del CEDLA, v. 16, p. 31-67, 2004.

FARO, Liv; RUSSO, Jane A. Testosterona, desejo sexual e conflito de interesse: periódicos biomédicos como espaços privilegiados de expansão do mercado de medicamentos. Horizontes Antropológicos, v. 23, n. 47, p. 61-92, 2017. http://dx.doi.org/10.1590/s0104-71832017000100003

FASSIN, Didier. Entre las políticas de lo viviente y las políticas de la vida: Hacia una antropología de la salud. Revista Colombiana de Antropología, v. 40, p. 283-318, 2004.

FERREIRA, Jaqueline. Restituição dos dados na pesquisa etnográfica em saúde: questões para o debate a partir de experiências de pesquisas no Brasil e França. Ciência \& Saúde Coletiva, v. 20, n. 9, p. 2641-2648, 2015. http://dx.doi.org/10.1590/1413-81232015209.06672015

FERREIRA, Luciane O. Medicinas indígenas e as políticas da tradição: entre discursos oficiais e vozes indígenas. Rio de Janeiro: Ed. Fiocruz, 2013.

FIETZ, Helena M.; MELLO, Anahi Guedes. A multiplicidade do cuidado na experiência da deficiência. Anthropológicas, v. 29, n. 2, p. 114-141, 2018.

FLEISCHER, Soraya. Autoria, subjetividade e poder: devolução de dados em um centro de saúde na Guariroba (Ceilândia/DF). Ciência \& Saúde Coletiva, v. 20, n. 9, p. 2649-2658, 2015. http://dx.doi.org/10.1590/141381232015209.03312015

FLEISCHER, Soraya. Descontrolada: uma etnografia dos problemas de pressão. São Carlos: Ed. UFSCar, 2018. 
FLEISCHER, Soraya. Parteiras, buchudas e aperreios: uma etnografia do cuidado obstétrico não oficial na cidade de Melgaço, Pará. Santa Cruz do Sul/RS; Belém/PA: EDUNISC; Paka Tatu, 2011.

FLEISCHER, Soraya. Uso e circulação de medicamentos em um bairro popular urbano na Ceilândia, DF. Saúde e Sociedade, v. 21, n. 2, p. 410-423, 2012. http://dx.doi.org/10.1590/S0104-12902012000200014

FLEISCHER, Soraya; FERREIRA, Jaqueline (orgs.). Etnografias em Serviços de Saúde. Rio de Janeiro: Garamond, 2014.

FLEISCHER, Soraya; FRANCH, Mónica (orgs.). Uma dor que não passa: Aportes teórico-metodológicos de uma Antropologia das doenças compridas. Política \& Trabalho, n. 42, p. 13-28, 2015.

FLEISCHER, Soraya; SCHUCH, Patrice (orgs.). Ética e regulamentação na pesquisa antropológica. Brasília: Letras Livres, Editora UnB, 2010.

FONSECA, Claudia. Situando os comitês de ética em pesquisa: O sistema CEP (Brasil) em perspectiva. Horizontes Antropológicos, v. 21, n. 44, p. 333-369, 2015. http://dx.doi.org/10.1590/S010471832015000200014

FRANCH, Mónica et al. (orgs.). Novas abordagens para casais sorodiferentes. João Pessoa: Manufatura, 2011.

GARNELO, Luiza. Aspectos socioculturais de vacinação em área indígena. História, Ciências, Saúde Manguinhos, v. 18, n. 1, p. 175-190, 2011. http://dx.doi.org/10.1590/S0104-59702011000100011

GERBER, Rose Mary. Mulheres e o mar: Pescadoras embarcadas no litoral de Santa Catarina, sul do Brasil. Florianópolis: Ed. UFSC, 2015.

GERHARDT, Tatiana Engel et al. (orgs.). Itinerários terapêuticos: integralidade no cuidado, avaliação e formação em saúde. Rio de Janeiro: CEPESC/IMS/UERJ/ABRASCO, 2016.

GUERRIERO, Iara Coelho Z.; BOSI, Maria Lucia M. Ética em pesquisa na dinâmica do campo científico: desafios na construção de diretrizes para ciências humanas e sociais. Ciência \& Saúde Coletiva, v. 20, n. 9, p. 2615 2624, 2015. http://dx.doi.org/10.1590/1413-81232015209.06022015

GUERRIERO, Iara Coelho Z.; CORREA, Fernando P. Ethics, collective health, qualitative health research and social justice. Ciência \& Saúde Coletiva, v. 20, n. 9, p. 2631-2640, 2015. http://dx.doi.org/10.1590/141381232015209.05672015

GUERRIERO, Iara Coelho Zito; MINAYO, Maria Cecília de Souza. O desafio de revisar aspectos éticos das pesquisas em ciências sociais e humanas: a necessidade de diretrizes específicas. Physis, v. 23, n. 3, p. 763-782, 2013. http://dx.doi.org/10.1590/S0103-73312013000300006

GUIMARÃES, Sílvia Maria Ferreira. O sistema médico Sanumá-Yanomami e sua interação com as práticas biomédicas de atençáo à saúde. Cadernos de Saúde Pública, v. 31, n. 10, p. 2148-2156, 2015. http://dx.doi. org/10.1590/0102-311X00194414

HAVERROTH, Moacir (org.). Etnobiologia e Saúde de Povos Indígenas. Recife: NUPPEA, 2013. v. 7. (Série Estudos e Avanços.)

HEILBORN, Maria Luiza et al. Itinerários abortivos em contextos de clandestinidade na cidade do Rio de Janeiro — Brasil. Ciência \& Saúde Coletiva, v. 17, n. 7, p. 1699-1708, 2012. http://dx.doi.org/10.1590/S141381232012000700008

KLEINMAN, Arthur. Concepts and a Model for the comparison of Medical systems as cultural systems. Social Science and Medicine, v. 12, n. 2B, p. 85-95, 1978. https://doi.org/10.1016/0160-7987(78)90014-5 
KNAUTH, Daniela Riva; LEAL, Andrea Fachel. A expansão das Ciências Sociais na Saúde Coletiva: usos e abusos da pesquisa qualitativa. Interface, v. 18, n. 50, p. 457-467, 2014. http://dx.doi.org/10.1590/1807-57622014.0274

KNAUTH, Daniela Riva; MEINERZ, Nádia Elisa. Reflexôes acerca da devolução dos dados na pesquisa antropológica sobre saúde. Ciência \& Saúde Coletiva, v. 20, n. 9, p. 2659-2666, 2015. http://dx.doi. org/10.1590/1413-81232015209.04672015

LABATE, Beatriz C. et al. Drogas, Políticas Públicas e Consumidores. Campinas: Mercado de Letras, NEIP, 2016.

LANGDON, Esther J. Os diálogos da antropologia com a saúde: contribuiçōes para as políticas públicas. Ciência \& Saúde Coletiva, v. 19, n. 4, p. 1019-1029, 2014. http://dx.doi.org/10.1590/1413-81232014194.22302013

LANGDON, Esther J.; CARDOSO, Marina D. (orgs.). Saúde indígena: políticas comparadas na América Latina. Florianópolis: EdUFSC, 2015.

LANGDON, Esther J.; GRISOTTI, Márcia (orgs.). Políticas Públicas: reflexões antropológicas. Florianópolis: EdUFSC, 2016.

LANGDON, Esther J.; FOLLÉR, Maj-Lis; MALUF, Sônia W. Um balanço da antropologia da saúde no Brasil e seus diálogos com antropologias mundiais. Anuário Antropológico, p. 51-89, 2012. http://dx.doi. org/10.4000/aa.254

LANGDON, Esther J.; MALUF, Sônia Weidner; TORNQUIST, Carmen Susana. Ética e política na pesquisa: os métodos qualitativos e seus resultados. In: GUERRIERO, Iara; ZICKER, Fábio; SCHMIDT, Maria Luisa Sandoval (orgs.). Ética nas pesquisas em ciências humanas e sociais na saúde. São Paulo: Hucitec , 2008.

LEAL, Andréa Fachel.; KNAUTH, Daniela R.; COUTO, Márcia T. A invisibilidade da heterossexualidade na prevenção do HIV/Aids entre homens. Revista Brasileira de Epidemiologia, v. 18, supl. 1, p. 143-155, 2015. http://dx.doi.org/10.1590/1809-4503201500050011

LEAL, Andréa Fachel; LUI, Lizandro. Instituiçôes participativas e seus efeitos nas políticas públicas: estudo do Comitê de Mortalidade por Aids de Porto Alegre. Saúde e Sociedade, v. 27, n. 1, p. 94-105, 2018. http:// dx.doi.org/10.1590/s0104-12902018170425

LEITÃO, Antônio Nogueira; PEDRO, Rosa Maria Leite Ribeiro. Medicina antienvelhecimento: notas sobre uma controvérsia sociotécnica. História, Ciências, Saúde - Manguinhos, v. 21, n. 4, p. 1361-1378, 2014. http:// dx.doi.org/10.1590/S0104-59702014005000021

LIMA, Fátima; CRUZ, Kathleen T. Os processos de hormonização e a produção do cuidado em saúde na transexualidade masculina. Sexualidad, Salud y Sociedad, n. 23, p. 162-186, 2016. http://dx.doi. org/10.1590/1984-6487.sess.2016.23.07.a

LIMA, S.hirley Acioly Monteiro de; MACHADO, Paula Sandrine; PEREIRA, Pedro Paulo Gomes. (Des)encontros no hospital: itinerário terapêutico de uma experiência intersexo. Cadernos Pagu, n. 49, p. e174916, 2017. http://dx.doi.org/10.1590/18094449201700490016

LIMOEIRO, Beatrice Cavalcante. Uma Sociedade para todas as idades: Centro Dia e Centro de Convivência para idosos em Campo Grande. Rio de Janeiro: Gramma, 2017.

LONGHI, Marcia Reis. Cuidado, Velhice, Gênero e Deficiência Social: Algumas reflexôes. Anthropológicas, v. 29, n. 2, p. 28-48, 2018a.

LONGHI, Marcia Reis. Dependência, autonomia, cuidado e velhice: consideraçôes sob o prisma das políticas públicas. In: CASTRO, Rosana; ENGEL, Cíntia; MARTINS, Raysa (orgs.). Antropologia, saúde e contextos de crise. Brasília: Sobrescrita, 2018b. 
LONGHI, Marcia Reis. "Eu cuido e ela cuida de mim": reflexôes sobre o cuidado a partir de narrativas de casais homossexuais sorodiscordantes. Política e Trabalho, n. 42, p. 91-109, 2015.

LUI, Lizandro; LEAL, Andrea Fachel. Legibilidade e gestão da saúde: notas etnográficas sobre o Comitê Municipal de Mortalidade por AIDS de Porto Alegre. Mediaçóes, Londrina, v. 23, n. 3, p. 354-381, 2018. http://dx.doi. org/10.5433/2176-6665.2018v23n3p354

LUNA, Naara. Aborto e corporalidade: sofrimento e violência nas disputas morais através de imagens. Horizontes Antropológicos, v. 20, n. 42, p. 293-325, 2014. http://dx.doi.org/10.1590/S0104-71832014000200012

LUNA, Naara. From abortion to embryonic stem cell research: biossociality and the constitution of subjects in the debate over human rights. Vibrant, v. 12, n. 1, p. 167-203, 2015. http://dx.doi.org/10.1590/1809$43412015 \mathrm{v} 12 \mathrm{n} 1 \mathrm{p} 167$

LUNA, Naara. O julgamento no Supremo do aborto de anencéfalo - ADPF 54: uma etnografia da religião no espaço público. Horizontes Antropológicos, v. 24, n. 52, p. 165-197, 2018. http://dx.doi.org/10.1590/ s0104-71832018000300007

MACHADO, Lia Zanotta. O aborto como direito e o aborto como crime. Cadernos Pagu, n. 50, p. e175004, 2017. http://dx.doi.org/10.1590/18094449201700500004

MALUF, Sônia W. Antropologia e política em contextos de crise: saudades do futuro. In: CASTRO, Rosana; ENGEL, Cíntia; MARTINS, Raysa (orgs.). Antropologias, saúde e contextos de crise. Brasília: Sobrescrita, $2018 \mathrm{a}$.

MALUF, Sônia W. Biolegitimacy, rights and social policies: New biopolitical regimes in mental healthcare in Brazil. Vibrant, v. 12, n. 1, p. 321-350, 2015. http://dx.doi.org/10.1590/1809-43412015v12n1p321

MALUF, Sônia W. Biolegitimidade, direito e políticas sociais: novos regimes biopolíticos no campo da saúde mental no Brasil. In: MALUF, Sônia W.; QUINAGLIA SILVA, Érica. (orgs.). Estado, políticas e agenciamentos sociais em saúde: etnografias comparadas. Florianópolis: EdUFSC , 2018b.

MALUF, Sônia W. Gênero, saúde e aflição: políticas públicas, ativismo e experiências sociais. In: MALUF, Sônia W.; TORNQUIST, Carmen Susana. Gênero, saúde e aflição: abordagens antropológicas. Florianópolis, EDUFSC, 2010.

MALUF, Sônia W. Por uma antropologia do sujeito: da Pessoa aos modos de subjetivação. Campos, v. 14, n. 1-2, p. 131-158, 2013. http://dx.doi.org/10.5380/campos.v14i1/2.42463

MALUF, Sônia W.; ANDRADE, Ana Paula Müller de. Entre políticas públicas e experiências sociais: impacto das pesquisas etnográficas no campo da saúde mental e suas múltiplas devoluções. Saúde e Sociedade, v. 26, n. 1, p. 171-182, 2017. http://dx.doi.org/10.1590/s0104-12902017168331

MALUF, Sônia W.; QUINAGLIA SILVA, Érica. Estado, políticas e agenciamentos sociais em saúde. Florianópolis: EdUFSC, 2018.

MALUF, Sônia W.; TORNQUIST, Carmen Susana. Gênero, saúde e aflição: abordagens antropológicas. Florianópolis: EdUFSC, 2010.

MARTINS, José Alves; BARSAGLINI, Reni Aparecida. Aspectos da identidade na experiência da deficiência física: um olhar socioantropológico. Interface, v. 15, n. 36, p. 109-122, 2011.

MATOS, Beatriz A. A visita dos espíritos: ritual, história e transformaçáo entre os Matses da Amazônia brasileira. Tese (Doutorado em Antropologia Social) - Museu Nacional, Universidade Federal do Rio de Janeiro, Rio de Janeiro, 2014. 
MCCALLUM, Cecília; ROHDEN, Fabíola (orgs.). Corpo e saúde na mira da Antropologia: ontologia, práticas, traduçōes. Salvador: EdUFBA, ABA, 2015.

MEDEIROS, Regina. Construção social das drogas e do crack e as respostas institucionais e terapêuticas instituídas. Saúde e Sociedade, v. 23, n. 1, p. 105-117, 2014. http://dx.doi.org/10.1590/S0104-12902014000100008

MELLO, Anahi Guedes de. A Construção da Pessoa na Experiência da Deficiência: corpo, gênero, sexualidade, subjetividade e saúde mental. In: MALUF, Sônia W.; TORNQUIST, Carmen S. (orgs.). Gênero, Saúde e Afliçáa: abordagens antropológicas. Florianópolis: Letras Contemporâneas , 2010.

MELLO, Anahi Guedes de. A Deficiência, incapacidade e vulnerabilidade: do capacitismo ou a preeminência capacitista e biomédica do Comitê de Ética em Pesquisa da UFSC. Ciência \& Saúde Coletiva, v. 21, n. 10, p. 3265-3276, 2016. http://dx.doi.org/10.1590/1413-812320152110.07792016

MELLO, Anahi Guedes de. A “Ou todo mundo é louco ou ninguém é!": refletindo sobre possibilidades de articulação entre deficiência e loucura. Vivência: Revista de Antropologia, v. 1, n. 44, p. 37-52, 2014.

MELLO, Márcio Luiz; OLIVEIRA, Simone Santos. Saúde, religiáo e cultura: um diálogo a partir das práticas afro-brasileiras. Saúde e Sociedade, v. 22, n. 4, p. 1024-1035, 2013. http://dx.doi.org/10.1590/S010412902013000400006

MERCANTE, Marcelo. A ayahuasca e o tratamento da dependência. Mana, v. 19, n. 3, p. 529-558, 2013. http:// dx.doi.org/10.1590/S0104-93132013000300005

MERCANTE, Marcelo. Imagens de cura: ayahuasca, imaginação, saúde e doença na Barquinha. Rio de Janeiro: Fiocruz , 2012.

MINAYO, Maria Cecília de Souza. Abordagem antropológica para avaliação de políticas sociais. Revista de Saúde Pública, v. 25, n. 3, p. 233-238, 1991. http://dx.doi.org/10.1590/S0034-89101991000300012

MINAYO, Maria Cecília de Souza. A construção da identidade da antropologia na área da saúde. In: ALVES, Paulo César; RABELO, Miriam C. M. (orgs.). Antropologia e saúde: traçando identidade e explorando fronteira. Rio de Janeiro: Fiocruz -Relume Dumará, 1998. p. 29-46.

MINAYO, Maria Cecília de Souza. Disputas científicas que transbordam para o campo da ética em pesquisa: entrevista com Maria Cecília de Souza Minayo. Ciência \& Saúde Coletiva, v. 20, n. 9, p. 2693-2696, 2015. http://dx.doi.org/10.1590/1413-81232015209.11862015

MINAYO, Maria Cecília de Souza; GUERRIERO, Iara Coelho Zito. Reflexividade como éthos da pesquisa qualitativa. Ciência \& Saúde Coletiva, v. 19, n. 4, p. 1103-1112, 2014. http://dx.doi.org/10.1590/141381232014194.18912013

MONTEIRO, Simone; BRIGEIRO, Mauro. Experiências de acesso de mulheres trans/travestis aos serviços de saúde: avanços, limites e tensōes. Cadernos de Saúde Pública, v. 35, n. 4, 2019. http://dx.doi. org/10.1590/0102-311x00111318

MOREIRA, Carolina Pinheiro; NUNES DE TORRENTÉ, Mônica de Oliveira; JUCÁ, Vládia Jamile dos Santos. Análise do processo de acolhimento em um Centro de Atenção Psicossocial Infantojuvenil: consideraçôes de uma investigação etnográfica. Interface, v. 22, n. 67, p. 1123-1134, 2018. http://dx.doi.org/10.1590/180757622017.0500

NAKAMURA, Eunice. Depressão na infância: uma abordagem antropológica. São Paulo: Hucitec , Fapesp, 2016.

NEVES, Ednalva M.; LONGHI, Marcia R.; FRANCH, Mónica (orgs.). Antropologia da Saúde: Ensaios em Políticas da Vida e Cidadania. Brasília: ABA Publicaçôes; João Pessoa: Mídia Gráfica, 2018. 
OLIVEIRA, Amurabi Pereira. Percursos biográficos e eficácia simbólica: a dinâmica da cura no Vale do Amanhecer. Mediaçóes, v. 15, n. 2, p. 248-265, 2010. http://dx.doi.org/10.5433/2176-6665.2010v15n2p248

OLIVEIRA, Everton de. Doentes e parentes: composiçōes de governo na Estratégia Saúde da Família. São Paulo: Alameda, 2018.

PEIRANO, Mariza. Etnografia não é método. Horizontes Antropológicos, v. 20, n. 42, p. 377-391, 2014. http:// dx.doi.org/10.1590/S0104-71832014000200015

PEIRANO, Mariza. Etnografia, ou a teoria vivida. Ponto Urbe, v. 2, 2008. http://dx.doi.org/10.4000/ pontourbe. 1890

PEREIRA, Maria Fernanda Salvadori. Sensibilidade, risco e cuidado: trajetórias e tratamentos de jovens usuários de um CAPS. Tese (Doutorado) - Programa de Pós-Graduaçáo em Antropologia Social, Universidade Federal de Santa Catarina, Florianópolis, 2018.

PEREIRA, Pedro Paulo Gomes. Limites, traduções e afetos: profissionais de saúde em contextos indígenas. Mana, v. 18, n. 3, p. 511-538, 2012. http://dx.doi.org/10.1590/S0104-93132012000300004

PERRUSI, Artur F. A. et al. Viver é muito perigoso. Risco e sorodiscordância. In: PERRUSI, Artur F.; FRANCH, Mónica. (orgs.). Casais (im)possíveis: um estudo socioantropológico sobre sorodiscordância para o HIV/Aids. João Pessoa: EdUPFB, 2013.

PERRUSI, Artur F. A.; FRANCH, Mónica. Carne com carne: Gestâo do risco e HIV/Aids em casais sorodiscordantes do Estado da Paraíba. Política \&Trabalho, n. 37, p. 179-200, 2012.

PIRES, Barbara Gomes. As políticas de verificação de sexo/gênero no esporte: Intersexualidade, doping, protocolos e resoluçōes. Sexualidad, Salud y Sociedad, v. 24, p. 215-239, 2016. http://dx.doi.org/10.1590/1984-6487. sess.2016.24.09.a

PIRES, Maria Jaidene; NEVES, Rita de Cássia Maria; FIALHO, Vânia. Saberes Tradicionais e Biomedicina: reflexōes a partir da experiência dos Xukuru do Ororubá, PE. Anthropológicas, v. 27, n. 2, p. 240-262, 2016.

PORTO, Rozeli M.; COSTA, Maynara. Negociaçōes do corpo: reflexōes sobre o acesso ao aborto legal em uma maternidade potiguar. In: MALUF, Sônia W.; SILVA, Érica Q. (orgs.). Estado, políticas e agenciamentos sociais em saúde: etnografias comparadas. Florianópolis: Editora da UFSC, 2018.

PORTO, Rozeli M.; SOUSA, Cassia H. D. Percorrendo caminhos da angústia: Cytotec e os itinerários abortivos em uma capital do Nordeste brasileiro. Estudos Feministas, v. 25, n. 2, p. 593-616, 2017. http://dx.doi. org/10.1590/1806-9584.2017v25n2p593

QUINAGLIA SILVA, Érica. A política pública de saúde mental e a construção do indivíduo 'perigoso' no âmbito da medida de segurança no Distrito Federal. In: CASTRO, Rosana; ENGEL, Cíntia; MARTINS, Raysa (orgs.). Antropologias, saúde e contextos de crise. Brasília: Sobrescrita , 2018.

QUINAGLIA SILVA, Érica. O sistema de revisão ética do Brasil: apontamentos a partir de uma perspectiva das ciências humanas e sociais. In: TINANT, Eduardo Luis. (org.). Anuario de Bioética y Derechos Humanos. Ciudad Autónoma de Buenos Aires: Instituto Internacional de Derechos Humanos, Capítulo para las Américas, 2017.

QUINAGLIA SILVA, Érica; BRANDI, Caroline Quinaglia A. C. S. "Essa medida de segurança é infinita ou tem prazo de vencimento?": interlocuçôes e desafios entre o Direito e a Psicologia no contexto judiciário. Ciência \& Saúde Coletiva, v. 19, n. 9, p. 3947-3954, 2014. http://dx.doi.org/10.1590/1413-81232014199.13202013

QUINAGLIA SILVA, Érica; CALEGARI, Marília. Crime e loucura: estudo sobre a medida de segurança no Distrito Federal. Anthropológicas, v. 29, n. 2, p. 154-187, 2018. 
QUINAGLIA SILVA, Érica; CODONHO, Camila G. As tecnologias con(tra)ceptivas a partir de noçôes de pessoa: (des)construindo as significaçōes de morte e vida. Bagoas - estudos gays: gênero e sexualidades, v. 7, n. 9, p. 235-244, 2013.

QUINAGLIA SILVA, Érica; LIONÇO, Tatiana (orgs.). Bioética e ética na pesquisa social: dilemas e perspectivas. Amazônica: Revista de Antropologia, v. 10, n. 2, p. 385-390, 2018. http://dx.doi.org/10.18542/amazonica. v10i2.6507

QUINAGLIA SILVA, Érica; MOREIRA, Sthefânya Shabryny C. R. O grito silencioso de um louco infrator: estudo de caso sobre a medida de segurança no Distrito Federal. In: TEXEIRA, Carla Costa; VALLE, Carlos Guilherme; NEVES, Rita de Cássia (orgs.). Saúde, mediaçáo e mediadores. Brasília, Natal: ABA Publicaçôes, EDUFRN, 2017. p. 406-424.

QUINAGLIA SILVA, Érica; PEREIRA, Éverton Luís. Ética em pesquisa: os desafios das pesquisas em ciências humanas e sociais para o atual sistema de revisão ética. Anthropológicas, v. 27, n. 2, p. 120-147, 2016.

QUINAGLIA SILVA, Érica; PORTELA, Soraya Christina Oliveira. Ética em pesquisa: análise das (in)adequaçóes do atual sistema de revisão ética concernentes à pesquisa social. Mundaú, n. 2, p. 38-53, 2017.

QUINAGLIA SILVA, Érica; SANTOS, Josenaide Engracia dos; CRUZ, Mônica Oliveira da. Gênero, raça e loucura: o perfil das mulheres que cumprem medida de segurança no Distrito Federal. In: MALUF, Sônia W.; QUINAGLIA SILVA, Érica. (orgs.). Estado, políticas e agenciamentos sociais em saúde: etnografias comparadas. Florianópolis: Editora da UFSC, 2018. v. 1. p. 45-59.

RABELO, Miriam C. M.; SOUZA, Iara Maria A.; ALVES, Paulo C. (orgs.). Trajetórias, sensibilidades, materialidades: experimentaçôes com a fenomenologia. Salvador: EdUFBA, 2012.

ROHDEN, Fabiola. "O homem é mesmo a sua testosterona": promoção da andropausa e representações sobre sexualidade e envelhecimento no cenário brasileiro. Horizontes Antropológicos, v. 17, n. 35, p. 161-196, 2011. http://dx.doi.org/10.1590/S0104-71832011000100006

ROHDEN, Fabiola. "Os hormônios te salvam de tudo": produção de subjetividades e transformaçōes corporais com o uso de recursos biomédicos. Mana, v. 24, n. 1, p. 199-229, 2018. http://dx.doi.org/10.1590/1678$49442018 \mathrm{v} 24 \mathrm{n} 1 \mathrm{p} 199$

ROHDEN, Fabiola. Vida saudável versus vida aprimorada: tecnologias biomédicas, processos de subjetivação e aprimoramento. Horizontes Antropológicos, v. 23, n. 47, p. 29-60, 2017. http://dx.doi.org/10.1590/s010471832017000100002

ROHDEN, Fabíola; ALZUGUIR, Fernanda Vecchi. Desvendando sexos, produzindo gêneros e medicamentos: a promoção das descobertas científicas em torno da ocitocina. Cadernos Pagu, n. 48, p. e164802, 2016. http:// dx.doi.org/10.1590/18094449201600480002

RUSSO, Jane; CARRARA, Sergio L. Sobre as ciências sociais na Saúde Coletiva - com especial referência à Antropologia. Physis Revista de Saúde Coletiva, v. 25, n. 2, p. 467-484, 2015. http://dx.doi.org/10.1590/ S0103-73312015000200008

RUSSO, Jane; VENANCIO, Ana Teresa A. Classificando as pessoas e suas perturbaçóes: a "revolução terminológica" do DSM III. Revista Latinoamericana de Psicopatologia Fundamental, v. 9, n. 3, p. 460-483, 2006. http:// dx.doi.org/10.1590/1415-47142006003007

SANTOS, Maria Paula (org.). Comunidades terapêuticas: temas para reflexão. Rio de Janeiro: IPEA, 2018.

SANTOS, Ricardo Ventura; GIBBON, Sahra; BELTRÃO, Jane. Identidades emergentes, genética e saúde: perspectivas antropológicas. Rio de Janeiro: Garamond / Fiocruz, 2012. 
SARTI, Cynthia A. Saúde e sofrimento. In: MARTINS, Carlos B.; DUARTE, Luiz Fernando D. (coords.). Horizontes das Ciências Sociais brasileiras: antropologia. São Paulo: ANPOCS/Barcarolla/Discurso Editorial, 2010.

SARTI, Cynthia; DUARTE, Luiz Fernando D. (orgs.). Antropologia e ética: desafios para a regulamentação. Brasília: ABA, 2013.

SCHUCH, Patrice; VICTORA, Ceres. Pesquisas envolvendo seres humanos: reflexóes a partir da Antropologia Social. Physis, v. 25, n. 3, p. 779-796, 2015. http://dx.doi.org/10.1590/S0103-73312015000300006

SCOPEL, Daniel; DIAS-SCOPEL, Raquel P.; LANGDON, Esther J. Intermedicalidade e protagonismo: a atuação dos agentes indígenas de saúde Munduruku da Terra Indígena Kwatá-Laranjal, Amazonas, Brasil. Cadernos de Saúde Pública, v. 31, n. 12, p. 2559-2568, 2015. http://dx.doi.org/10.1590/0102-311X00139014

SCOTT, Parry et al. Itinerários terapêuticos, cuidados e atendimento na construçấo de ideias sobre maternidade e infância no contexto da Zika. Interface, v. 22, n. 66, p. 673-84, 2018. http://dx.doi.org/10.1590/180757622017.0425

SERRA, Ordep; PECHINE, Maria Cristina Santos; PECHINE, Serge. Candomblé e políticas públicas de saúde em Salvador, Bahia. Mediaçóes, v. 15, n. 1, p. 163-171, 2010. http://dx.doi.org/10.5433/2176$6665.2010 \mathrm{v} 15 \mathrm{n} 1 \mathrm{p} 163$

SILVA, Ana Cláudia R. da. Compartilhando Genes e Identidades: orientação genética, raça e políticas de saúde para pessoas com doença e traço falciforme em Pernambuco. Recife: Editora Universitária UFPE, 2014.

SILVA, Ana Cláudia R. da. Políticas Ontológicas e Realidades Múltiplas: a doença falciforme performada na prática. Anthropológicas, v. 27, n. 2, p. 169-195, 2016.

SILVA, Ana Cláudia Rodrigues da; MATOS, Silvana Sobreira de; QUADROS, Marion Teodósio de. Economia política do Zika: realçando relaçôes entre Estado e cidadão. Anthropológicas, v. 28, n. 1, p. 223-246, 2017.

SILVA, Ariana K.; SILVA, Hilton Pereira da. Anemia falciforme como experiência: relaçóes entre vulnerabilidade social e corpo doente enquanto fenômeno biocultural no estado do Pará. Amazônica, v. 5, n. 1, p. 10-36, 2013. http://dx.doi.org/10.18542/amazonica.v5i1.1295

SILVA, Cristina Dias da. Notas etnográficas sobre a humanização em saúde: corpo e mediação. Anthropológicas, v. 22, n. 2, p. 145-171, 2011.

SILVA, Cristina da S.; GUIMARÃES, Silvia Maria Ferreira. Antropologia e saúde: diálogos indisciplinados. Juiz de Fora: EdUFJF, 2017.

SILVA, Telma Camargo da (org.). Ciclo de Estudos e Debates: Procedimentos Éticos e a Pesquisa em Antropologia. Goiânia: FUNAPE/UFG, ABA, 2014.

SILVEIRA, Maria Lucia da. O Nervo Cala, O Nervo Fala: a linguagem da doença. Rio de Janeiro: Fiocruz , 2000.

SOUSA, Emilene Leite de. Umbigos enterrados: corpo, pessoa e identidade capuxu através da infância. Florianópolis: EdUFSC , 2017.

SOUZA, Maximiliano Loiola Ponte de. Narrativas indígenas sobre suicídio no Alto Rio Negro, Brasil: tecendo sentidos. Saúde e Sociedade, v. 25, n. 1, p. 145-159, 2016. http://dx.doi.org/10.1590/S0104-12902016145974

SOUZA, Maximiliano Loiola Ponte de. Processos de alcoolizaçáo indígena no Brasil: perspectivas plurais. Rio de Janeiro: Fiocruz, 2013.

SOUZA, Maximiliano Loiola Ponte de; FERREIRA, Luciane O. Jurupari se suicidou?: notas para investigação do suicídio no contexto indígena. Saúde e Sociedade, v. 23, n. 3, p. 1064-1076, 2014. http://dx.doi. org/10.1590/S0104-12902014000300026 
SOUZA, Maximiliano Loiola Ponte de; ORELLANA, Jesem Douglas Y. Suicide among indigenous people in Brazil: a hidden public health issue. Revista Brasileira de Psiquiatria, Rio de Janeiro, v. 34, n. 4, p. 489-490, 2012. http://dx.doi.org/10.1016/j.rbp.2012.04.008

TAVARES, Fátima. Rediscutindo conceitos na antropologia da saúde: notas sobre os agenciamentos terapêuticos. Mana, v. 23, n. 1, p. 201-228, 2017. http://dx.doi.org/10.1590/1678-49442017v23n1p201

TAVARES, Fátima; BASSI, Francesca. (orgs.) Para além da eficácia simbólica: estudos em ritual, religiâo e saúde. Salvador: EdUFBA, 2013.

TEIXEIRA, Carla Costa. A produçáo política da repulsa e os manejos da diversidade na saúde indígena brasileira. Revista de Antropologia, v. 55, n. 2, p. 567-608, 2012. https://doi.org/10.11606/2179-0892.ra.2012.59296

TEIXEIRA, Carla Costa, GARNELO, Luíza (orgs.). Saúde indígena em perspectiva: explorando suas matrizes históricas e ideológicas. Rio de Janeiro: Fiocruz , 2014.

TEIXEIRA, Carla Costa; SILVA, Cristina Dias da. Antropologia e saúde indígena: mapeando marcos de reflexão e interfaces de açáo. Anuário Antropológico, v. 38, n. 1, p. 35-57, 2013.

TEIXEIRA, Carla Costa; VALLE, Carlos Guilherme do; NEVES, Rita de Cássia. (orgs.). Saúde, mediaçáo e mediadores. Brasília: ABA Publicações , 2017.

TONIOL, Rodrigo. Do espírito na saúde: oferta e uso de terapias alternativas/complementares nos serviços de saúde pública no Brasil. São Paulo: LiberArs, 2018.

TORNQUIST, Carmen Susana; ANDRADE, Ana Paula Müller de; MONTEIRO, Marina. Velhas histórias, novas esperanças. In: MALUF, Sônia; TORNQUIST, Carmen S. (orgs.). Gênero, saúde e afliçóes: abordagens antropológicas. Florianópolis: Letras Contemporâneas , 2010.

VENÂNCIO, Ana Teresa. Classificando diferenças: as categorias demência precoce e esquizofrenia por psiquiatras brasileiros na década de 1920. História, Ciências Saúde - Manguinhos, v. 17, supl. 2, p. 327-343, 2010. http://dx.doi.org/10.1590/S0104-59702010000600004

VENÂNCIO, Ana Teresa. Da colônia agrícola ao hospital-colônia: configuraçóes para a assistência psiquiátrica no Brasil na primeira metade do século XX. História, Ciências, Saúde - Manguinhos, v. 18, supl. 1, p. 35-52, 2011. http://dx.doi.org/10.1590/S0104-59702011000500003

VENÂNCIO, Ana Teresa A.; POTENGY, Gisélia Franco. O asilo e a cidade: histórias da Colônia Juliano Moreira. Rio de Janeiro: Garamond, 2015.

WEID, Olivia V. D. Entre o cuidado e a autonomia: deficiência visual e relaçôes de ajuda. Revista AntHropologicas, ano 22, v. 29, n. 2, p. 49-82, 2018. 


\title{
A produção antropológica em gênero e sexualidades no Brasil na última década (2008-2018)*
}

\author{
Mónica Franch ${ }^{\mathrm{I}}$ \\ Silvana Nascimento ${ }^{\text {II }}$
}

\section{Introdução}

Este artigo tem como objetivo realizar um balanço da produção antropológica em gênero e sexualidades no Brasil na última década, de 2008 a 2018. Esse período pode ser caracterizado por mais uma expansão nessa produção, que abrange novos cenários e temáticas, ao evidenciar distintos contextos etnográficos, em variadas regióes do país, além de demonstrar um aprofundamento de abordagens teóricas previamente existentes. Podemos dizer que esse balanço, um tanto desafiador, não pôde dar conta da totalidade das produçôes existentes nem de suas autoras e autores, mas pretendeu mapear as principais linhas temáticas que se desenharam nos últimos dez anos, como se poderá demonstrar ao longo do texto.

Para começar, a rica e ampla produçáo sobre gênero e sexualidade na área de antropologia, a nosso ver, só pode ser apreendida pela longa trajetória desse campo de estudos no Brasil, que começou nos anos 1970. Desde o início, esse campo teve caráter multidisciplinar e, a partir dos anos 1990, e com mais força nos anos 2000, as pesquisas em antropologia passaram a ganhar mais visibilidade e ramificaram-se por diferentes eixos temáticos, como se poderá observar ao longo do texto.

Ressaltamos que a produção na última década precisa ser localizada no contexto político do país num período marcado pelo avanço de setores conservadores em áreas estratégicas de poder e pela consequente ameaça à ampliação e à manutenção das conquistas no campo democrático. Se foge do escopo deste artigo discutir o complexo cenário atual, escolhemos alguns eventos como marcos que enquadram o contexto político e acadêmico em volta da produção analisada. Do ponto de vista das conquistas, destacamos o lançamento do Programa Brasil sem Homofobia, em 2004, e a aprovação da Lei Maria da Penha, em 2006, medidas que vieram acompanhadas da implementação de políticas públicas para mulheres e LGBTQI+, promovidas pela Secretaria Especial da Mulher e pela Secretaria Especial dos Direitos Humanos, ambas ligadas ao Gabinete da Presidência da República na época. Tais medidas, implementadas no primeiro mandato de Lula, faziam parte de um am-

*Dedicamos este artigo a Mariza Corrêa (1945-2016), in memoriam.

\footnotetext{
IDepartamento de Ciências Sociais e Programa de Pós-Graduaçáo em Antropologia, Universidade Federal da Paraíba - João Pessoa (PB), Brasil. E-mail: monicafranchg@gmail.com

IIDepartamento de Antropologia e do Programa de Pós-Graduação em Antropologia Social da Universidade de São Paulo - São Paulo (SP), Brasil. E-mail: simples.humano@gmail.com
} 
biente favorável ao debate público e à produção de conhecimento em torno de gênero, sexualidade e direitos humanos, temáticas que foram objeto, também, de editais específicos de pesquisa e extensão. Nesse período, impulsionadas pelas políticas públicas federais, foram instaladas diversas coordenadorias, secretarias e serviços voltados à defesa da cidadania de mulheres e LGBTQI+ em diversos municípios e estados brasileiros. Já do ponto de vista da política acadêmica, ressaltamos o lançamento, em 2007, do Programa de Apoio a Planos de Reestruturaçáo e Expansão das Universidades Federais (Reuni), que resultou na abertura de novos campi universitários e cursos de graduação, e também dos primeiros cursos de bacharelado em antropologia, além da ampliação da oferta de vagas para contrataçáo de professores(as). Tal expansão foi acompanhada por um impulso à abertura de cursos de pós-graduação, também na área da antropologia, muitos deles em universidades consideradas periféricas ${ }^{1}$.

A década em análise também deve ser caracterizada com base no movimento de backlash empreendido por setores conservadores, muitos deles abertamente fundamentalistas. Entretanto, também é importante notar que assistimos a um rejuvenescimento das lutas feministas, do movimento negro e LGBTQI+, fenômeno que encontra um solo fértil também fora de nossas fronteiras. Assim, em contraste com um cenário de apoio à produçáo de conhecimento em gênero e sexualidade, passamos a assistir à articulaçáo e ao fortalecimento de setores que se apoiam nas teses da ideologia de gênero na tentativa de deslegitimar esse campo. Se os ataques começaram nos ensinos fundamental e médio, associados aos projetos de Escola sem Partido, nesse momento, voltam-se para o ensino superior, alvo, por um lado, de controle e escárnio e, por outro lado, da desidratação das fontes de financiamento. Além disso, a deriva autoritária no país tem gerado situaçôes de incerteza e até mesmo insegurança para as(os) pesquisadoras(es) e ativistas dos direitos humanos e das questôes de gênero, como ficou palpável com as perseguiçóes a Débora Diniz (UnB) e Sonia Maluf (UFSC). Cabe ainda salientar que esses retrocessos e ameaças vêm sendo monitorados de perto pelo Comitê de Gênero e Sexualidade da Associação Brasileira de Antropologia, sempre uma voz atenta na defesa dos direitos humanos e da democracia no Brasil. Resumindo, o cenário em que esse balanço vem a lume se apresenta como uma encruzilhada. Por um lado, a produção de 2008-2018 na área de gênero e sexualidade mantém sua vitalidade e reflete os esforços para a expansão e democratização do ensino superior; por outro, a área é alvo de ataques e ameaças, podendo comprometer a sobrevivência de um campo que é, atualmente, um dos mais profícuos na antropologia realizada no Brasil.

Pela impossibilidade de abraçar toda a atividade em torno de gênero e sexualidade na antropologia brasileira dos últimos dez anos, fizemos alguns recortes estratégicos. Em primeiro lugar, listamos os principais balanços ou retrospectivas da produção das ciências sociais, e da antropologia, em gênero e/ou sexualidade desde os anos 1980 para

1 O fortalecimento da Coordenação de Aperfeiçoamento de Pessoal de Nível Superior (Capes) e do Conselho Nacional de Desenvolvimento Científico e Tecnológico (CNPq), que receberam dotaçōes orçamentárias para a ampliação das bolsas e financiamento de projetos de pesquisa, marcaram o período até o ano de 2015, no segundo mandato de Dilma Rousseff, quando se deu o primeiro corte significativo dos recursos destinados às universidades federais, que concentram a maioria da produção acadêmica no país. 
compreender como esses balanços tinham sido realizados até agora. A leitura desse material (por volta de 30 artigos) foi um procedimento necessário para evidenciar as continuidades e descontinuidades na produção brasileira em gênero e sexualidade, permitindo situar de uma maneira mais precisa a produção do período em análise (2008 a 2018). Também foram analisados os grupos de trabalho (GT) que apresentavam temáticas de gênero e/ou sexualidade, nos anos de 2008 a 2018, dessa vez para conhecer a visibilidade das temáticas nos seguintes eventos: Reunião Brasileira de Antropologia, Reunião Equatorial de Antropologia (REA) e Reunião de Antropologia do Norte e do Nordeste (Abanne), Reunião da Associaçáo de Pós-Graduação em Ciências Sociais (Anpo$\mathrm{cs}^{2}$ ). Os balanços bibliográficos anteriores, seguidos de uma breve análise dos eventos, são a base da primeira parte deste artigo.
Em segundo lugar, fizemos uma seleção de periódicos especializados e/ou vinculados a programas de pós-graduação em antropologia ${ }^{3}$, nos quais procuramos os artigos publicados por antropólogas(os) ${ }^{4}$ e os catalogamos pelas temáticas estudadas, ano de publicação, local e instituição de origem das autoras e autores. Esses dados foram analisados e sáo discutidos na segunda parte deste artigo, intitulada "Eixos temáticos". Para evitar possíveis perdas e também para ter uma noçáo mais clara da composição dos volumes, a busca náo foi feita por palavras-chave: todos os números publicados entre 2008 e 2018 nos periódicos selecionados foram acessados e pesquisados, totalizando um quantitativo de 522 artigos consultados. Todos os artigos foram considerados na análise, mas, por limitaçôes de espaço e para evitar privilegiar algumas(alguns) autoras(es) em detrimento de outras(os), apenas os dos-

2 Não foi possível analisar os encontros temáticos (Fazendo Gênero, Desfazendo Gênero, Enlaçando Sexualidades e REDOR) pelo volume de dados ali contidos. Informamos que também foi feito levantamento de coletâneas e livros, mas não foi possível fazer análise e incorporar os dados para esse momento. Nossos agradecimentos à equipe de pesquisa que nos ajudou nesses levantamentos, composta de: Ana Carolina Azevedo, Luiza Arouca, Júlio Cesar Ferreira de Oliveira e Sabrina Damasceno, estudantes de graduação em Ciências Sociais da Universidade de São Paulo e integrantes do Laboratório do Núcleo de Antropologia Urbana (LabNAU/USP).

3 Periódicos da área da antropologia (em alguns casos, ciências sociais): Vibrant (Associação Brasileira de Antropologia/ABA), Anuário Antropológico (Universidade de Brasília/UnB), Mana (Museu Nacional/Universidade Federal do Rio de Janeiro/UFRJ), Revista de Antropologia (USP), Horizontes Antropológicos (Universidade Federal do Rio Grande do Sul/UFRGS), Ilha (Universidade Federal de Santa Cataarin/UFSC), Vivência (Universidade Federal do Rio Grande do Norte/UFRN), R@U (Universidade Federal de São Carlos/UFSCar), Antropológicas (Universidade Federal de Pernambuco/UFPE), Amazônica (Universidade Federal do Pará/UFPA), ACENO - Revista de Antropologia do Centro-Oeste (Universidade Federal do Mato Grosso/UFMT), Antropolitica (Universidade Federal Fluminense/UFF), Sociologia \& Antropologia (UFRJ), Áltera (Universidade Federal da Paraíba/UFPB), Revista Mundaú (Universidade Federal de Alagoas/UFAL), Politica \& Trabalho (UFPB), Sociologia \& Antropologia (UFRJ). Revistas especializadas: Cadernos Pagu (Universidade Estadual de Campinas/Unicamp), Bagoas (UFRN), Ártemis (UFPB), Gênero, Labrys - Estudos Feministas, Revista de Estudos Feministas (UFSC), Sexualidad, Salud y Sociedad (Centro Latino-americano em Sexualidade e Saúde/CLAM, Universidade Estadual do Rio de Janeiro/UERJ), Periódicus (Universidade Federal da Bahia/UFBA), Caderno Espaço Feminino (Universidade Federal de Uberlândia/UFU), Feminismos (UFBA), Cadernos de Gênero e Diversidade (UFBA).

4 Consideramos antropólogas(os) aquelas pessoas que têm formação na área e/ou que atuavam em departamentos/ programas de antropologia. Sabemos que essas fronteiras, de certo modo, não refletem o caráter interdisciplinar desse campo de estudos, mas optamos por esse critério ante o convite que nos foi feito para produzir um balanço na área de antropologia. 
siês e suas organizadoras(es) foram nomeados e incluídos na bibliografia.

\section{Uma mirada cronológica: o que dizem os balanços anteriores}

De 1985 até hoje, pudemos levantar mais de 30 artigos, algumas coletâneas e dossiês, que procuraram organizar e refletir sobre a produção em gênero e sexualidade nas ciências sociais no Brasil. Grande parte desse material foi produzido nos anos 2000 e dobrou de tamanho a partir de 2014, o que demonstra o aumento de pesquisas na área nos últimos 10 anos. Há textos voltados especificamente para a antropologia, outros mais abrangentes, alguns envolvendo determinadas regióes do Brasil e aqueles centrados em temas mais específicos.

Os primeiros balanços evidenciam que, até a década de 1990, os estudos de gênero eram pensados como uma área separada dos estudos sobre sexualidades. Aos poucos, suas fronteiras borraram-se e ganharam contornos menos definidos, com problemáticas transversais. Um dos primeiros levantamentos bibliográficos foi produzido por Albertina de Oliveira Costa, Carmem Barros e Cynthia Sarti (1985), como resultado de uma pesquisa realizada na Fundação Carlos Chagas (FCC). Nesse artigo, as autoras realizam uma reflexão ampla sobre o panorama das pesquisas sobre mulheres produzidas nas ciências humanas, de 1975 a 1984, e apontam as principais tendências temáticas, levando em conta seus contextos políticos e institucionais. Elas elegem 1975, o Ano Internacional da Mulher, para iniciar suas investigaçôes, quando se realiza a I Conferência Mundial da Mulher, da Organização das Naçóes Unidas (ONU), que institui a Década da Mulher. Naquele momento, no Brasil, os temas feministas, em um ambiente acadêmico demasiado masculino, terminaram por ficar, de certo modo, subsumidos à pauta política, em plena ditadura militar ${ }^{5}$.

Já no início dos anos 1980, surgiram os primeiros núcleos de pesquisa na área em diferentes regiôes, como Rio de Janeiro, Ceará, Bahia, Pernambuco, Rio Grande do Sul, Minas Gerais, Santa Catarina e São Paulo ${ }^{6}$. Costa, Barroso e Sarti (1985) elencam as principais temáticas das pesquisas naquele período, como a participação das mulheres no mercado de trabalho, as relaçóes entre produção e reprodução, organizaçóes familiares e, na área da antropologia, mencionam, rapidamente, uma perspectiva que lança luz sobre diferentes experiências femininas, como as mulheres indígenas, negras, prostitutas, idosas, religiosas, encarceradas etc. Parece haver naquele momento um olhar antropológico voltado para grupos minoritários e periféricos, acompanhando também a produção antropológica de modo mais amplo no Brasil.

Já no fim dos anos 1980, o conceito de gênero passou a ser utilizado como ferramenta teórico-metodológica em diferentes acepçôes. Como parte dessa reflexão, em 1990, organizou-se o Seminário Estudos sobre a

5 As autoras também destacam o ano de 1978 como um marco importante, quando ocorreram o Seminário A Mulher na Força de Trabalho, no Rio de Janeiro, e o primeiro concurso de pesquisas sobre a mulher brasileira na FCC. Nesse ano, também se criou o Grupo de Trabalho A Mulher na Força de Trabalho no 2o Encontro Anual da Anpocs. Segundo Costa, Barroso e Sarti (1985), a Sociedade Brasileira para o Progresso da Ciência (SBPC) foi a pioneira em incluir GT sobre mulheres em suas reunióes, já em 1972, e abriu também para a participação de movimentos sociais que não estavam inseridos nas universidades.

6 Em 1981, outros dois GT foram criados no 5º Encontro da Anpocs: Mulher e Política e Família e Sociedade. 
Mulher no Brasil: Avaliação e Perspectivas, pela FCC, em São Roque (SP), que resulta no livro Uma questão de gênero, organizado por Albertina de Oliveira Costa e Cristina Bruschini, em 1992, e que conta com a participação de três antropólogas, Lia Zanotta Machado, Maria Luiza Heilborn e Claudia Fonseca. Brevemente, Machado (1992) reflete sobre a passagem da categoria "mulher" para "gênero" e sugere uma perspectiva que assuma a existência de assimetrias de poder e de uma relação arbitrária (e não naturalizada) entre sexo e gênero. Heilborn (1992) produz um estado da arte da antropologia da mulher no Brasil, nas décadas de 1970 e 1980, e destaca os seguintes temas: violência de gênero, corpo, identidade e pessoa, papéis sexuais, família, maternidade e reprodução, matrifocalidade, domesticidade, individualismo e homossexualidades ${ }^{7}$. Fonseca (1992), por sua vez, apresenta uma pesquisa etnográfica sobre honra e humor em um bairro periférico de Porto Alegre, artigo que posteriormente será incorporado em seu livro Família, fofoca e honra (2000). De certo modo, a coletânea, que se tornou uma referência na produção bibliográfica da área naquele período, revela uma mirada de antropólogas preocupadas com direitos sexuais e reprodutivos e com dinâmicas familiares. Há o esforço de delimitar e compreender como se forma a categoria gênero, preocupação que se estende, $\mathrm{e}$ se transforma, até hoje.

Nesse momento, Sandra Azeredo (1994) publicou um artigo na Estudos Feministas de- nunciando a invisibilidade da questão racial na produçáo bibliográfica sobre gênero no Brasil. Inspirada na mobilização dos feminismos negros estadunidenses, a autora aponta a ausência da categoria raça para pensar as formas de opressão de gênero entre as intelectuais brancas brasileiras, como se a categoria gênero pudesse universalizar as desigualdades entre homens e mulheres, deixando de lado o racismo e o colonialismo. Kia Lilly Caldwell (2000), alguns anos depois, também publicou outro texto na mesma revista e corroborou os comentários de Sandra Azeredo (1994), demonstrando a importância da questão racial para pensar gênero. Naquele momento, intelectuais negras, como Lélia Gonzalez, focalizavam suas açōes no combate ao racismo, mas também estavam inseridas em espaços acadêmicos e de pesquisa, ainda que com muitos obstáculos e pouca visibilidade e reconhecimento nas universidades. Além disso, as questóes das mulheres negras envolviam problemas muito distantes do universo das feministas brancas (Carneiro, 2002), como relaçóes de trabalho e classe, associativismos, religiosidades afro-brasileiras, alimentação, moradia, maternidade etc. Assim, as intelectuais negras já apontavam, nos anos 1980 e 1990, para a necessidade de uma perspectiva que pudesse cruzar marcadores sociais da diferença (Bairros, 1995).

Continuando o mapeamento dos balanços, em 1999, a Anpocs lançou a coletânea $O$ que ler nas ciências sociais brasileiras (1975-1995), coordenada por Sergio Miceli,

7 Maria Luiza Heilborn reconhece que, apesar do crescimento de pesquisas na área, as principais linhas de financiamento, naquele momento lideradas pela FCC (com apoio da Fundação Ford), estavam concentradas em São Paulo e Rio de Janeiro. Além disso, ela aponta o GT Cultura Popular e Ideologia, da Anpocs, criado em 1981, coordenado por Ruth Cardoso e Gilberto Velho, como um espaço de apresentação de pesquisas na área de antropologia, mulheres e gênero. Também destaca algumas publicaçôes: as revistas Anuário Antropológico e Religiäo e Sociedade, a coleção "Perspectivas Antropológicas da Mulher", que teve cinco edições, de 1981 a 1985, e a coletânea "Espelho de Vênus: identidade sexual e social da mulher" (1981), editada pelo Grupo Ceres. 
que traz um artigo elaborado por Maria Luiza Heilborn e Bila Sorj (1999). Nesse texto, as autoras refletem sobre a institucionalização dos estudos de gênero na academia e apontam os desafios das pesquisadoras em enfrentar temáticas até então pouco reconhecidas nas universidades. Elas elencam os principais temas que emergem desses estudos (trabalho, violência, sexualidade e família) e destacam o grande peso da antropologia no conjunto de pesquisas nessa área. Na década de 1990, houve considerável ampliação dos estudos de gênero no país com a formação de núcleos de pesquisa em diferentes regióes (UERJ, UFSC, UFRN etc.) e a criação de dois importantes periódicos, a revista Estudos Feministas, em 1992, e a Cadernos Pagu, em $1993^{8}$.

Partindo de outra perspectiva, Parry Scott elaborou um balanço bibliográfico publicado pelo Boletim Informativo Bibliográfico da Anpocs, em 2004, em que busca compreender como a ideia de nação, no Brasil, incorpora as relaçóes entre homens e mulheres e como os modelos familiares vão sendo construídos em diferentes investigaçóes, dos anos 1970 até a década de 1990, em ambientes rurais e urbanos. Scott (2004) menciona, cuidadosamente, variadas pesquisas que pensam família, gênero e poder. Nos anos 1970 e 80, ele menciona a impor- tância dos estudos feministas para o questionamento do binômio trabalho produtivo e reprodutivo e a centralidade da domesticidade para compreender as relaçóes de poder entre os sexos tanto no meio rural quanto no meio urbano. Já na década de 1990, o autor mostra um enfoque nas questóes de gênero no tema família e, cada vez mais, o crescimento de uma multiplicidade de modelos familiares, acompanhando, de um lado, os desdobramentos políticos das conferências internacionais da ONU e, de outro, o período de redemocratização do país.

No que se refere à sexualidade, no início dos anos 2000, identificamos, provavelmente, o primeiro balanço bibliográfico que trata dessa temática na área das humanidades e da saúde coletiva no Brasil, elaborado por Maria Andréa Loyola (2000) e publicado na Physys. A autora apresenta uma retrospectiva histórica dos primeiros eventos e publicações que surgiram no início dos anos 1980 e relembra a organização dos primeiros GT na Associação Brasileira de Estudos Populacionais (ABEP), destacando um importante protagonismo de antropólogas(os) ${ }^{9}$.

Ainda ressaltamos a publicação de $\mathrm{Ma}-$ ria Teresa Citeli $A$ pesquisa sobre sexualidade e direitos sexuais no Brasil (1990-2002), lançada em 2005, que resulta de um vasto

8 Nesse período, com relação ao Nordeste, ressaltamos a organização dos encontros da Rede Feminista Norte e Nordeste de Estudos e Pesquisas sobre Mulher e Relaçôes de Gênero (REDOR). Criada em 1992 durante uma reunião organizada pelo NEIM/UFBA, a REDOR manteve caráter interdisciplinar, sendo a participaçáo de antropólogas mais fragmentada (Sardenberg, 2005).

9 O I Seminário do Grupo de Trabalho Sexualidade e Reprodução foi realizado em 1983, pela ABEP, no Rio de Janeiro, e contou com a participaçáo de Peter Fry, Aracky Martins Rodrigues, Lia Fukui e da própria autora. Nesse GT, eles reuniram trabalhos de pesquisadoras(es) das ciências sociais, da medicina, da história e da psicologia, que giravam em torno de cinco temas: relaçóes entre os sexos, constituição da sexualidade, identidade, casamento e afetividades e planejamento familiar. Já no II Seminário, um ano depois, organizado por Peter Fry e Maria Loyola, ocorrido em Águas de São Pedro (SP), os trabalhos apresentados ampliaram a reflexão sobre sexualidade, promovendo uma dissociação entre sexualidade e reprodução, sexo e afeto, e que também envolviam a desconstruçáo de outros binômios, como hierarquia e igualdade, individualidade e coletividade etc., problemáticas que, segundo a autora, são contemporâneas às preocupaçôes desse campo no início dos anos 2000. 
levantamento bibliográfico sobre sexualidade e saúde sexual nas ciências sociais, desenvolvido pelo Centro Latino-Americano em Sexualidade e Direitos Humanos (CLAM), no Instituto de Medicina Social/UERJ ${ }^{10}$. Segundo a autora, a partir da década de 1990, desenvolveram-se pesquisas sobre identidades de gênero e orientação sexual e, de forma mais reduzida, sobre mulheres negras e povos indígenas. Ela destaca inovaçôes no âmbito das homossexualidades, que associam conjugalidades e paternidades, e, ao mesmo tempo, aponta para uma escassez de trabalhos sobre a articulação entre sexualidades e gênero masculino, sobre prazer e erotismo e envelhecimento. Indica também a presença de poucos estudos acerca de travestis e ambiguidades das identidades sexuais.

No que se refere à antropologia, Sérgio Carrara e Júlio Simóes publicaram, em 2007, um artigo nos Cadernos Pagu que não faz propriamente um mapeamento da produção de forma exaustiva, mas ressalta a importância de algumas pesquisas, dos anos 1970 a 1990. Nele, problematizam a ideia de uma identidade homossexual homogênea e exotizada e a aplicação de teorias importadas para pensar as especificidades e diversidades da homossexualidade masculina no país. Os autores mostram como pesquisas antropológicas, dos anos 1980 aos 2000, antecipam os estudos de sexualidade contemporâneos ao enfatizarem a relação entre sexualidade e poder e problematizarem a ideia de uma fluidez das identidades de gênero (Fry, 1982; Perlongher, 1987; MacRae, 1990; Guimarães, 2004) ${ }^{11}$. De acordo com os auto- res, com o movimento de combate à aids, nos anos 1990, as configuraçóes do movimento homossexual produzem diferentes modos de construir sujeitos políticos e identidades, que revelam uma tradição específica no ativismo e nas pesquisas em sexualidade no Brasil.

Em 2010, lançou-se uma segunda coletânea organizada pela Anpocs, Horizontes das Ciências Sociais no Brasil: Antropologia, coordenada por Carlos Benedito Martins e Luís Fernando Dias Duarte, com um artigo de Miriam Grossi (2010), "Gênero, sexualidade e reprodução". Seu artigo focaliza as pesquisas em antropologia de 2000 a 2010 e mostra uma ampliaçáo dos estudos de gênero e de sexualidade em todo o país, nas universidades e fora delas, a criação de novas revistas ${ }^{12} \mathrm{e}$ a organização de grandes eventos, como o Seminário Internacional Fazendo Gênero, que teve sua primeira ediçấo em 1994 em Florianópolis (SC). No que se refere às temáticas, a autora descreve um leque de investigaçóes que se baseiam, de um lado, em teorias antropológicas e, de outro, nos estudos feministas e da teoria queer. Identifica e desenvolve os seguintes temas: violências de gênero, gênero e classe, masculinidades, geração, religiosidade, etnicidade, mulheres negras, direitos reprodutivos (maternidade, paternidade, parto, aborto, homoparentalidades), direitos sexuais, sexualidades, homossexualidades, travestilidades, prostituição e pornografia.

Alguns anos depois, em 2014, Adriana Piscitelli organizou o dossiê Antropologia, Gênero e Sexualidade no Brasil: Balanços e Perspectivas, na Cadernos Pagu, com ar-

10 O livro está organizado em capítulos que aglutinam áreas temáticas (identidade de gênero e orientação sexual; expressōes da sexualidade; instâncias reguladoras da sexualidade; sexualidade, DST e aids; saúde, direitos sexuais e reprodutivos) e, ao final de cada um deles, são apontadas tendências e lacunas.

11 Além dos pesquisadores no Rio de Janeiro e São Paulo, nos anos 1990, é importante ressaltar também as pesquisas de Luiz Mott, na Bahia, e Richard Parker, no Ceará.

12 Labrys (UnB), Bagoas (UFRN), Sexualidad, Saludy Sociedad (CLAM) e Ártemis (UFPB). 
tigos de diversas(os) antropólogas(os) sobre a produção recente feita no Brasil ${ }^{13}$. Piscitelli (2014) mostra, em sua apresentação, uma explosão de pesquisas antropológicas na área a partir dos anos 2000, com a diversificação de temáticas e a ampliação das perspectivas para além das oposiçôes binárias entre masculinidades e feminilidades e entre homossexualidades e heterossexualidades. Também aponta uma produção que focaliza corporalidades, famílias, direitos humanos, feminismos, direitos sexuais e reprodutivos, formas de violência, erotismos, sociabilidades e mercado. Essa coletânea reúne importantes balanços bibliográficos e debates recentes no campo dos estudos de gênero e sexualidade nos anos 2000 na área da antropologia pelo olhar de pesquisadoras(es) que já atuam como um grupo de interlocução há muitos anos e se organizam em torno do eixo Campinas-São Paulo-Rio de Janeiro. De forma muito resumida, Regina Facchini, Isadora Lins França e Camilo Braz (2014) apresentam uma revisão crítica das temáticas que relacionam sexualidade, sociabilidade e mercado em trabalhos antropológicos produzidos no Brasil desde os anos 1960. Maria Filomena Gregori (2014) analisa pesquisas antropológicas contemporâneas a respeito do tema do erotismo articulado a práticas sexuais, gênero e sexualidades. Por sua vez, Adriana Piscitelli (2014) faz um balanço da produção antropológica brasileira sobre trocas sexuais e econômicas na década de 2000, mostrando o aumento expressivo de pesquisas sobre o tema da prostituição e dos mercados do sexo. Júlio Simões e Sergio Carrara (2014) tomam como ponto de partida os debates resultantes das pesquisas apresen- tadas nos encontros anuais da Anpocs, desde 2004, nos GT sobre sexualidade e gênero. Eles mostram uma transformação das abordagens em torno da diversidade sexual, das sexualidades dissidentes, não normativas e não hegemônicas, e demonstram como os trabalhos refletem sobre essas categorias e práticas e fazem a crítica à homossexualidade como categoria englobante e universalizante, bem como apontam para um número reduzido de pesquisas que articulam raça e classe. Lia Zanotta Machado (2014) opta por realizar uma reflexão sobre como os saberes antropológicos e os movimentos sociais se entrecruzam e se confrontam no campo de gênero e sexualidade, analisando os desafios de pesquisas que pretendem conciliar a diversidade cultural, de um lado, e os direitos das mulheres, de outro. Paula Sandrine Machado (2014) faz um balanço da produção ainda tímida nas ciências humanas e sociais na América Latina sobre questão da intersexualidade e mostra como ela se articula a uma perspectiva feminista e a uma crítica aos protocolos médicos e aos binarismos sexuais. Por fim, Laura Moutinho (2014) faz uma valiosa reflexão sobre a diferença e a desigualdade por meio dos chamados marcadores sociais, evidenciando como pesquisas antropológicas clássicas e recentes articulam gênero, raça, sexualidade e nação.

Com relaçáo aos balanços, vale a pena mencionar, ainda, a pesquisa coordenada por Regina Facchini cujos resultados parciais foram publicados em "Estudos de Gênero no Brasil: 20 anos depois", em coautoria com Isadora Lins França, em coletânea organizada por Sergio Miceli e Carlos Benedito Martins (2017). Nesse artigo, as autoras fazem uma

13 O dossiê foi resultado de uma série de debates que ocorreram em um pré-evento da $28^{a}$ Reuniáo Brasileira de Antropologia, em 2013, por iniciativa do Comitê Gênero e Sexualidade da ABA e da realização do Simpósio Antropologia, Gênero e Sexualidade no Brasil: Balanços e Perspectivas. 
análise panorâmica dos estudos de gênero dos últimos 20 anos, em caráter interdisciplinar, sugerindo uma releitura do artigo de Maria Luiza Heilborn e Bila Sorj, publicado em 1999. No período analisado por Facchini e França (2017), a categoria gênero já não aparece autossuficiente, mas aliada a outras categorias, como sexualidade, e outros modelos também ganham força e destacam questôes mais estruturais de dominação.

Com relação à diversificação das temáticas, Facchini e França (2011) apresentam certa variaçáo em torno dos eixos que Heilborn e Sorj (1999) haviam sugerido, nos anos 1990 - trabalho, violência, sexualidade e família. Agora, nos anos 2000, adicionam o tema do poder, participação política e cidadania, um dos assuntos mais abordados, principalmente, nas revistas disciplinares das ciências sociais ${ }^{14}$. Em 51\% dos artigos de antropólogas(os) que foram mapeados, a questão dos marcadores sociais da diferença, da sexualidade e dos direitos reprodutivos estava presente. Já o tema das políticas sexuais surgiu em $45 \%$ das publicaçóes. As autoras demonstram que, a partir dos anos 2000, houve grande visibilidade das perspectivas interseccionais e notável influência, assim, das produçôes de intelectuais negras.

Para finalizar, há outros artigos que fizeram balanços bibliográficos que focalizaram regióes ou temas mais específicos, por exemplo, os artigos de Fabiano Gontijo (2015a; 2015b; 2017), alguns em coautoria (Gontijo; Erick, 2015; 2016; 2017), que apresentam as produçôes específicas realizadas no Piauí e no Pará e também na Amazônia e em áreas rurais, e a Coleção Bahianas, produzida pelo NEIM da UFBA. Esses artigos e compêndios voltados para o Norte e o Nordeste desvelam a necessidade de dar maior visibilidade à produção realizada para fora do eixo Sul-Sudeste, reflexão que não poderemos aprofundar neste texto.

Como podemos observar, os balanços mencionados aqui, de certo modo, revelam o caráter interdisciplinar dos estudos de gênero e sexualidade e a impossibilidade de limitá-los a um único campo disciplinar, como a antropologia. Contudo, é possível perceber algumas tendências que se direcionaram para certas miradas antropológicas que se revelaram com mais força a partir dos anos 2000, com o incrível crescimento de pesquisas na área, que acompanhou também a ampliação dos programas de pós-graduação em antropologia e sua ramificação por diferentes regióes do Brasil, muitas delas periféricas e que, aos poucos, conquistaram visibilidade e reconhecimento.

Aponta Piscitelli (2014) que as pesquisas recentes em antropologia, em diferentes contextos etnográficos, procuraram romper com as leituras binárias tanto do masculino/ feminino quanto da hetero e da homossexualidade. Além disso, os levantamentos e balanços analisados revelam preocupação com a promoção dos direitos sexuais e reprodutivos, acompanhando as pautas dos movimentos feministas e LGBTQI+, com alguns "vazios" que aos poucos foram sendo preenchidos, como é o caso das(dos) intelectuais negras e, mais recentemente, das(dos) intelectuais trans (que não são mencionadas(os) em nenhum dos artigos que pesquisamos) ${ }^{15}$.

14 Regina Facchini e Isadora Lins França fazem um levantamento nos seguintes periódicos: Revista Brasileira de Ciências Sociais (RBCS/Anpocs), Revista Brasileira de Ciência Politica (RBCP/ABCP), Viritual Anthropology (Vibrant/ABA) e Revista Brasileira de Sociologia (RBS).

15 Amara Moira, doutora em Teoria e História Literária pela Unicamp e ativista travesti, ao lado de outrxs pesquisadorxs trans, tem recentemente realizado esse levantamento no Brasil e no mundo. 


\section{Encontros acadêmicos: ampliação e diversificação}

Para ficarmos no período em análise, a partir de 2008, eventos acadêmicos nacionais e regionais da área de antropologia passaram a receber um maior número de GT, fóruns e mesas-redondas. Pudemos realizar um mapeamento, ainda que com limitaçóes, dos principais encontros acadêmicos da área de antropologia no âmbito nacional e regional, além do Encontro Nacional da Anpocs. Para este artigo, limitamo-nos a buscar títulos e temas que foram apresentados nesses encontros e náo nos detivemos, especificamente, nos trabalhos apresentados.

Com relação às Reuniōes da Associação Brasileira de Antropologia (RBA), na última década, mantiveram-se quatro ou cinco GTs a cada edição, sem contar mesas, fóruns, pré-eventos etc. Em 2008, no encontro realizado em Porto Seguro (BA), foram organizados cinco GTs cujas temáticas foram: gênero entre os povos indígenas; subjetividades; gênero, raça e classe; relaçóes étnico-raciais e sexualidades; transnacionalização e migraçôes. Também houve uma mesa-redonda sobre famílias, conjugalidades e parentalidades contemporâneas e dois fóruns de pesquisa: um sobre gênero, sexualidade e religião e outro sobre antropologia feminista. Em 2010, na edição realizada em Belém, houve a organização de cinco GTs que propuseram temáticas como prostituição, transnacionalização e afetividades, sexualidades, arranjos domésticos e familiares. Não foram organizadas mesas, tampouco fóruns, nesse evento.

Quando a RBA foi sediada em São Paulo, em 2012, foram sete grupos que discutiram temas como prostituição, sexualidades e moralidades; família e geração; gênero entre povos indígenas; arranjos familiares e militâncias. Além disso, houve a organização de um workshop e um simpósio cujos textos foram publicados, posteriormente, em dossiê organizado por Adriana Piscitelli (2014), como já foi mencionado anteriormente. Foram organizadas também uma mesa-redonda sobre aborto e outra sobre estudos de gênero e família negras.

Já em 2014, em Natal, foram montados quatro GTs, apresentando trabalhos sobre sexualidades, prostituição, parto e maternidade e parentesco. Além disso, ocorreram um simpósio especial, "Antropologia, direitos e fundamentalismos", e a mesa-redonda "Desafios e políticas da sexualidade". Em João Pessoa, em 2016, também quatro grupos apresentaram pesquisas sobre intersecionalidade e marcadores da diferença, prostituição, esporte e lazer, destacando este último tema como uma novidade. Houve três mesas e dois simpósios especiais debatendo temáticas como biomedicalização, aborto, gênero e sexualidade em áreas rurais e etnicamente diferenciadas, políticas, ativismos e violência e prostituição. Também aconteceu o pós-evento Jornadas Internacionais: Políticas Públicas, Diversidades em Gênero e Educação, reunindo pesquisadores que estavam coordenando cursos de extensão e de formação para professores(as) e outros profissionais.

No último encontro, realizado em Brasília em 2018, houve seis grupos que contaram com apresentaçóes de trabalhos sobre os seguintes temas articulados a gênero e sexualidades: saúde, educação, culturas populares e performances, povos indígenas e prostituição. Além disso, ocorreram três simpósios especiais, com temáticas semelhantes às do encontro anterior, como conservadorismos, violência e ativismos, gênero e sexualidade em contextos não metropolitanos, prostituiçáo e mercados do sexo, e mais duas mesas-redondas, também repetindo questóes apresentadas em 2016, como a biomedicali- 
zação e gênero e diversidade sexual em contextos interioranos.

Quanto aos encontros da Anpocs, que são considerados eventos de abrangência nacional, aglutinam, de forma mais permanente, pesquisadores(as) das regiốes Sudeste e Sul. Segundo pesquisa realizada por Arlene Ricoldi (2017), em 1990, no momento de consolidação das pesquisas em gênero no Brasil, na Anpocs criou-se o Seminário Temático (ST) "A Transversalidade do Gênero nas Ciências Sociais", por iniciativa de Lena Lavinas e Lourdes Bandeira, e um ano depois o GT "Relaçôes Sociais de Gênero", que passou a reunir pesquisas com temas que já estavam sendo gestados na década anterior (mulheres no mercado de trabalho, família e participação política). Esse GT manteve-se até 1996, e depois se criou outro grupo, apenas em 2005, "Estudos de Gênero na Contemporaneidade", coordenado por Lucila Scavone, Maria Lygia Quartim de Moraes e Luzinete Minella, no qual foram incluídos também os temas da sexualidade e da violência. Esse GT, de certo modo, teve continuidade em 2007 e 2008 e depois não houve ediçóes subsequentes. Com relação aos direitos sexuais e reprodutivos especificamente, em 2001, um ST foi criado por Adriana Piscitelli e Miriam Grossi, "Sexualidade, reprodução, parentesco: novas questôes, novos desafios?”, que não se repetiu nos próximos anos. Em 2004, organizou-se o ST "Corpo, Sexualidade e Identidade", por Sergio Carrara, Maria Filomena Gregori e Julio Simóes, que prosseguiu como o GT "Sexualidade, Corpo e Gênero" no ano seguinte e, de certo modo, houve reediçóes sucessivas, com poucas alterações do título, alterando entre ST e GT até os dias de hoje.

Afora os eventos de abrangência nacional, a Abanne tem sido um espaço importante para a divulgação de pesquisas no âmbito regional ${ }^{16}$. Observamos que, a partir de 2011, os temas dos GTs se diversificaram e alguns receberam maior destaque, como sexualidades (com maior número de trabalhos), intersecionalidade, violências e políticas. Outros temas emergiram pontualmente, como migraçôes, direitos reprodutivos e ativismos. Se até 2011 a participação na REA/Abanne estava mais voltada para pesquisadoras(es) do Norte e Nordeste, de 2013 em diante houve maior diversificação de pesquisadoras(es) de outras regiōes do país e aumento de apresentaçóes de trabalhos na área ${ }^{17}$.

Além disso, não podemos deixar de mencionar o congresso Fazendo Gênero, em Florianópolis, que reúne milhares de pesquisadoras(es) de diferentes formaçóes disciplinares no âmbito nacional e internacional, mas que náo pudemos mapear aqui. Mais recentemente, há seminários menores

16 Com relação ao Norte e ao Nordeste, a partir do início dos anos 1980, os encontros de Ciências Sociais do Norte e Nordeste (CISO), as Abanne e as REA foram os principais espaços em que as pesquisas em gênero e sexualidade na área puderam ser compartilhadas. A primeira Abanne ocorreu em 1985, na UFPE, no Recife e, em 2007, com expressivo aumento de participação e ampliação de temas, o evento agregou uma nova denominação, abarcando a REA. Já o CISO ocorreu pela primeira vez em 1986, em João Pessoa.

17 Sem entrar em detalhes, em 2011, na III REA e XIII Abanne, realizada em Boa Vista (RR), houve a organização de dois GT, um sobre migrações, fronteiras e gênero e outro sobre intersecçōes de gênero, raça e movimentos sociais. Já em 2013, em Fortaleza, ocorreram três GT, repetindo-se o GT de intersecçôes, um de culturas corporais, sexualidade e reconhecimentos e outro sobre partos, maternidades e políticas do corpo. Também foram organizados uma mesa-redonda e um fórum. Em 2015, a Abanne/REA ocorreu em Maceió e contou com quatro GT, um sobre "a vida social dos direitos", outro sobre sexualidades, moralidades e direitos, um sobre violência de gênero e o GT sobre intersecçōes, além de três fóruns. 
realizados no Nordeste, como Enlaçando Sexualidades, que ocorreu pela primeira vez em 2009, coordenado pelo Grupo de Pesquisa Enlace da UNEB e pelo Grupo de Atuação em Defesa das Mulheres (Gedem), vinculado ao Ministério Público do Estado da Bahia, e o Seminário Desfazendo Gênero, que tem ocorrido em diferentes universidades públicas da Região Nordeste desde $2013^{18}$.

Destacamos, ainda, a celebração de quatro ediçôes do Seminário Internacional Homens, Sexualidade e Reprodução, em 2003, 2005, 2006 e 2017, coordenados pelo Instituto de Apoio ao Pai Adolescente (Instituto PAPAI) e pelo Grupo de Estudos de Masculinidades (Gema), vinculado à pós-graduação em psicologia da UFPE, tendo contado com a participação do Núcleo de Família, Gênero e Sexualidade (Fages) na organização das três primeiras ediçóes.

Como tentamos mostrar, rapidamente, houve não somente a ampliação das temáticas que envolvem gênero e sexualidades nos encontros específicos da antropologia, bem como dos encontros voltados para esse campo interdisciplinar, de forma abrangente. Alguns temas permaneceram ao longo dos anos, como o da prostituiçáo e dos mercados do sexo, os de família e dos direitos sexuais e reprodutivos, os de parentesco e os de violência, outros foram surgindo, como contextos não metropolitanos e etnicamente diferenciados, esportes, intersecionalidade e políticas e ativismos.

\section{Eixos temáticos}

Com relação aos eixos temáticos, nesta seção apresentamos uma classificação dos artigos publicados por antropólogas(os) em periódicos especializados e da área de antropologia na última década. A divisão dos artigos por tema não é tarefa fácil, uma vez que, em muitos casos, ocorrem cruzamentos ou ainda recortes de difícil classificação. Embora a proposta dialogue com aquelas de balanços anteriores, uma classificação possível foi elaborada pelas autoras, na tentativa de dar visibilidade às articulaçôes que mais se destacaram nas produçóes do período analisado. Optamos por citar somente as autorias de organização de dossiês e não citar autorias de artigos, em particular para não personalizar os debates nem reforçar certas hierarquias que, geralmente, se impóem à produção acadêmica.

\section{Família, conjugalidade e reprodução}

Este é um dos eixos fortes do período analisado, embora com desigual presença. Família e conjugalidade tiveram uma participação comparativamente modesta, com um único dossiê, Parentalidades, Conjugalidades e Gênero, na revista $A C E N O$, organizado por Ana Paula Vencato e Flávio Luiz Tarnovski (2018). Situando-se na renovação dos estudos de parentesco, o dossiê buscou dar foco à dimensão prática das relaçôes afetivas e sexuais contemporâneas, bem como visibilizar a diversidade de arranjos existentes. Ainda sobre esse tema, foram encontrados artigos sobre poliamor, swing, festas de casamento, casamentos invertidos (mulheres mais velhas e homens mais jovens), entre outros. A homoparentalidade e as famílias LGBTQI+, que foram destaque em balanços anteriores (Grossi, 2010), parecem não ter

18 Na década de 2010, diversas ediçóes do Congresso Internacional de Estudos sobre a Diversidade Sexual e de Gênero da Associaçáo Brasileira de Estudos de Homocultura (chamados inicialmente de Congressos da ABEH) foram realizadas na Região Nordeste (nenhuma edição foi ainda realizada no Norte). 
tido tanta importância nesse momento, apesar de perpassarem muitos artigos, mas não como foco principal da reflexão.

Já uma área de forte investimento nesse eixo foi o parto, mais especificamente questóes ligadas ao parto humanizado e, em menor medida, à gravidez ${ }^{19}$. $\mathrm{O}$ interesse que esse tema suscitou reflete a mobilização que ele tem tido, sobretudo entre mulheres de classe média e, especificamente, entre acadêmicas, como fica claro no movimento Parent in Science, uma iniciativa surgida em 2017 com o intuito de trazer a público o debate da maternidade no âmbito da produção científica. É possível aventar certo efeito geração, no sentido de que algumas das pesquisadoras que adentraram na área de gênero nas últimas duas décadas estão experimentando, elas próprias, processos de gestação e parto num contexto de mobilização pública em torno desses temas. Pesquisas sobre a maternidade e a adoção também foram tema de alguns artigos. Destaque para o dossiê Antropologia dos Úteros, organizado por Giovana Acacia Tempesta, Rosamaria Giatti Carneiro e Soraya Fleischer (2018), na revista Amazônica. Com base em abordagens não essencialistas nem fisicalistas dos úteros, os textos desse dossiê giram em torno de questóes como controle dos úteros, ativismo materno e deficiência, prestando especial atenção às questôes raciais.

$\mathrm{Na}$ trilha dos direitos reprodutivos, destacamos os artigos sobre aborto, tema que esteve no centro do debate público em mais de uma ocasiāo no período em análise e que continua sendo um desafio tanto em termos de autonomia das mulheres quanto pelos efeitos deletérios da criminalização. $\mathrm{O}$ dossiê Aborto, organizado por Carmen Susana Tornquist, Cristiani Bereta da Silva e Mara Coelho Lago (2008), para a Estudos Feministas, inclui artigos de diversos contextos nacionais (França, Portugal, Uruguai e Brasil) que refletem embates entre o movimento feminista e a construção das leis, bem como trazem experiências de pessoas envolvidas com o tema. Um segundo dossiê, organizado por Maria Luiza Heilborn (2012) para a revista Sexualidad, Saludy Sociedad, sob o título Heterossexualidade, Contracepção e Aborto, traz os resultados de pesquisa desenvolvida em Bogotá, Buenos Aires, Rio de Janeiro e Montevidéu a respeito de experiências de aborto em distintas faixas etárias e segmentos sociais e tem como principal contribuição a reflexão sobre o aborto no âmbito da heterossexualidade e o manejo contraceptivo. Cabe notar que, com exceção desse dossiê e de alguns artigos sobre contracepção de emergência, contracepção hormonal e esterilização feminina, a contracepção é a grande esquecida neste eixo temático. É urgente, a nosso ver, dar mais visibilidade às trajetórias reprodutivas e às peregrinaçóes contraceptivas, bem como trazer de volta as redes familiares e conjugais ao cenário de nossas pesquisas.

\section{Feminismo, participação política e políticas públicas}

Eixo clássico nos estudos de gênero e das sexualidades, a produçáo em torno dos feminismos e da participação política das mulheres parece ter arrefecido ligeiramente na década em análise, embora tenha

19 Entre outros temas, os artigos abordaram: dor de parto e humanizaçáo do parto; subjetividade da gestante e redes de apoio; partos entre mulheres de classe média; doulas; parto, gênero e emoçóes; direitos reprodutivos e violência obstétrica; hormônios e o movimento pela humanização do parto; gravidez e parto entre os mundukuru, entre outros. 
se mantido como um tema importante. Várias(os) pesquisadoras(es) debruçaram-se sobre a chamada hifenização do feminismo. $\mathrm{Na}$ tentativa de compreender a renovação do movimento e a pluralidade de posicionamentos possíveis, diversos artigos abordaram questóes como: feminismo e trabalhadoras sexuais; feminismo na web; feminismo e antropologia; feminismo e Estado; conflito pela terra e mulheres; feminismo cosmopolita; movimento feminista e democracia; feminismo e movimento queer; iconografias e corporalidades no feminismo contemporâneo; Marcha das Vadias; feminismo indígena; fortalecimento político de mulheres e conhecimentos tradicionais. Quando nos interrogamos especificamente sobre as mobilizaçóes empreendidas por mulheres das novas geraçôes, como o Fora Cunha e o movimento secundarista (com exceção da Marcha das Vadias), observamos, entretanto, que apareceram pouco refletidas nos artigos analisados, apesar de sua importância no período analisado. Essa lacuna foi percebida por Regina Facchini e Isadora França (2011), que, em seu dossiê Feminismos Jovens pela Cadernos Pagu, pautaram a questão geracional, focando as "jovens feministas" ou as "feministas jovens".

Já em relação a mulheres e política partidária, encontramos aqui outra ausência na literatura, com apenas dois artigos identificados, mais especificamente sobre mulheres e eleiçôes. Também é digno de nota o número 4, volume 4, da revista Cadernos de Gênero e Diversidade, que é dedicado ao tema e inclui uma seção de entrevistas a mulheres que estão na política, algumas delas feitas por antropólogas(os).
Ampliando esse eixo para incluir questóes sobre Estado e políticas públicas, o Programa Bolsa Família e seus possíveis impactos de gênero emergiram como uma questão importante. Em funcionamento há mais de uma década, o Bolsa Família centra o repasse de recursos nas mulheres e desperta questionamentos que podem ser resumidos na dicotomia entre política como reprodutora de papéis de gênero versus política empoderadora e promotora de autonomia.

Ainda sobre a relaçáo com o Estado, o dossiê "Desenvolvimento, poder, gênero e feminismo", organizado por Parry Scott e Marion Quadros (2018), problematiza os impactos que grandes obras como a Copa de Mundo têm acarretado para as populaçôes afetadas, sobretudo para as mulheres, numa perspectiva feminista.

Por fim, embora tenha aumentado a atenção às questóes raciais em sua relação com a política e os feminismos, esse ainda é um recorte sub-representado, conforme já destacavam Sandra Azeredo (1994), Luiza Bairros (1995) e Sueli Carneiro (2002), entre outras intelectuais.

\section{Violência de gênero e outras violências}

A temática da violência de gênero, que foi central nos estudos de gênero nas décadas de 1980 e 1990 , teve participação menor nas revistas em análise. Continuaram os artigos que refletem sobre dinâmicas de violência, sobretudo sobre violência sexual ${ }^{20}$, desapareceram aqueles sobre as delegacias da mulher, mas, em compensação, apareceu um novo problema de pesquisa em torno da Lei Maria da Penha (Lei no 11.340/06), que tem

\footnotetext{
20 Artigos sobre estupro e abuso sexual, violência e produção da vítima, violência sexual e justiça criminal, bem como sobre denúncias de estupro contra a mulher indígena.
} 
sido um dos mais importantes avanços em termos de visibilidade e combate à violência de gênero. Destacamos, nesse sentido, o dossiê organizado por Cecília Sardenberg e Miriam Grossi (2015) na Estudos Feministas, "Balanço sobre a Lei Maria da Penha", que aglutina artigos sobre pesquisas em torno da aplicabilidade da lei em contextos específicos, pondo em evidência as dificuldades para sua implementaçâo efetiva.

Já a questão da violência que podemos denominar de urbana e que inclui aspectos como narcotráfico, violência policial e encarceramento das mulheres parece ter crescido nessa década. Esse aumento reflete, por um lado, mudanças nas dinâmicas da violência e, por outro, também no modo de compreender a atuação das mulheres, pondo em destaque sua agência na esfera ligada à criminalidade e no enfrentamento político à questáo $0^{21}$.

\section{Prostituição e mercados do sexo}

Os temas trabalho sexual, prostituição, mercados do sexo e, em menor medida, tráfico de pessoas mobilizam a atençâo de diversas(os) autoras(es), muitas(os) das(dos) quais fazem parte da rede articulada pelo Núcleo Pagu, na Unicamp, sendo Adriana Piscitelli uma das principais representantes desses esforços, mas há também investimentos externos a essa rede. Remetemo-nos, nesse sentido, ao balanço realizado pela referida autora para Cadernos Pagu (Piscitelli, 2014). Salientamos, igualmente, o dossiê "Pesquisando prostituição e mercados do sexo: contribui- çôes, debates e novos desdobramentos", na revista Ártemis, organizado por José Miguel Nieto Olivar (2014), que representa a vitalidade e importância desse tema para as(os) pesquisadoras(es) de gênero e sexualidades ${ }^{22}$. Além de dar visibilidade a uma pluralidade de contextos etnográficos e de sujeitos envolvidos na prostituição, a produção sobre o tema joga luz nas questôes transnacionais, quer seja pelos deslocamentos das trabalhadoras, enredadas em trocas que envolvem sexo, dinheiro e afeto, quer seja pelo entrelaçamento entre prostituição e turismo e os espaços fronteiriços. Apesar de existirem diferenças entre as abordagens, dominaram perspectivas que evidenciam a agência das mulheres e uma noção ampliada das trocas que envolvem sexo, dinheiro e afeto, acompanhando a discussão política hoje liderada pela Rede Brasileira de Prostitutas, que defende o reconhecimento legal da profissão.

\section{Gênero, trabalho e educação}

A questão do trabalho das mulheres, que apareceu no primeiro balanço pesquisado (Costa; Barros; Sarti, 1985), permaneceu pouco explorada nesta última década. Foi possível identificar artigos sobre cooperativismo e gênero, empreendedorismo, mulheres e economia solidária, trabalho e mulheres solteiras, entre outros. $\mathrm{O}$ trabalho doméstico, que foi foco importante das discussôes sobre público/privado, produção/ reprodução, aparece em alguns artigos sobre diaristas e empregadas domésticas. A relação entre público e privado também retorna sob

21 Exemplos desse novo interesse são os artigos sobre o papel das mães no Rio de Janeiro na luta por justiça e visibilidade para as mortes violentas de que seus filhos são vítimas, mulheres e crime, mulheres e famílias na prisão.

22 Os artigos pesquisados cobrem recortes como: feminismos e trabalhadoras sexuais; Estado, prostituição e violência; turismo sexual; tráfico de pessoas; exploração sexual; prostituição travesti; prostituição feminina; prostituição transnacional; prostituição em contexto indígena, entre vários outros. 
o tema emergente do cuidado, destacando-se o dossiê de Helena Hirata e Guita Grin Debert (2016) Gênero e Cuidado, nos Cadernos Pagu. Alinhada a discussóes do feminismo internacional (em torno do care), a temática do cuidado tem potencial para reaquecer as discussóes sobre público e privado, num momento de aprofundamento da precarização no mundo do trabalho, que afeta especialmente as mulheres e as relaçóes de cuidado, sejam essas mercantilizadas ou não.

Em compensação à pouca presença do trabalho como tema (que talvez possa ser creditada à especialização disciplinar, sendo o trabalho uma área muito mais apropriada pela sociologia), artigos sobre educação fizeram-se visíveis, marcando um diferencial com relação aos períodos anteriores. A temática da educação tem sido central no debate público, nomeadamente depois dos ataques contra a chamada ideologia de gênero nas escolas, que galvanizaram as eleiçóes presidenciais em 2018. O avanço conservador no campo educacional não passou despercebido nos artigos, mas também houve forte investimento na descrição e na análise dos resultados de mais de uma década de políticas voltadas à capacitação dos professores da rede básica de ensino em questóes de gênero e sexualidade, nos governos Lula e Dilma. Mencionamos, como exemplo, o dossiê organizado por Felipe Bruno Martins Fernandes e Bruna Andrade Irineu (2015), publicado na Revista Feminismos, Extensão Universitária em Gênero e Sexualidades. Embora as opçóes para a realização desse balanço, conforme explicitado anteriormente, tenham deixado de fora um amplo contingente da produção sobre o tema, que se fez visível em encontros específicos, livros e publicaçóes em revistas da área da educação, os artigos analisados já nos permitem observar o impacto das políticas de gênero na educação em forma de um novo campo de intervenção e pesquisa.

\section{Religião, gênero e sexualidade}

Além dos artigos sobre ideologia de gênero, o avanço dos conservadorismos fez-se presente em vários artigos que problematizaram questóes relativas à religião, em sua interface com gênero e sexualidade. Parte dessa produção é oriunda de pesquisas etnográficas ${ }^{23}$, mas também foram publicados artigos de análise sobre polêmicas nacionais e internacionais em meio televisivo e nas redes sociais. Pela sua notável influência no debate público, as atençóes têm se voltado, sobremaneira, às igrejas evangélicas, evidenciando tanto as práticas excludentes como as inclusivas. Resta uma janela aberta para estudos que abordam as reaçóes (adesões e resistências) de outras religióes ao referido avanço conservador, como as religióes de matriz africana, que têm sido alvo constante de ataques.

Por fim, destacamos neste item a contribuição de Horácio Sívori, Emerson Giumbelli, Fabíola Rohden e Sergio Carrara (2017), em dossiê organizado na revista Sexualidad, Salud y Sociedad, "Fundamentalismos", Sexualidade e Direitos Humanos: Interrogando Termos, Expandindo Horizontes, no qual problematizam a ampliação do uso político do termo fundamentalismo, incluindo também esferas seculares em que ocorrem controvérsias em torno dos

23 Os artigos trouxeram recortes como: evangélicos, homossexualidade e igrejas inclusivas; Assembleia de Deus, jovens e sexualidade; homossexualidade no judaísmo e entre católicos; Igreja Universal do Reino de Deus e mulheres; umbanda, feminino e sagrado; religião e homofobia. 
direitos sexuais e reprodutivos e dos avanços de gênero.

\section{Saúde, gênero e sexualidade}

Além das questôes ligadas a parto já mencionadas, é possível encontrar diversos artigos que enfatizam a relação entre o campo da saúde e o de gênero e/ou sexualidade $^{24}$ e ao menos um dossiê específico sobre o assunto (Saúde e Gênero), na revista Vivência, da UFRN, organizado por Rozeli Porto, Ana Paula Vencato e Ana Flavia Lucas D’Oliveira (2016). Também organizado por Rozeli Porto, dessa vez em parceria com Patrícia Rosalba Salvador Costa (2017), dossiê na Cadernos de Gênero e Diversidade aborda o Zika vírus e as síndromes neurológicas congênitas com base nas suas contribuiçóes para o campo de estudos de gênero.

Importante tópico mobilizador de pesquisas nos anos 1990, a questão do HIV/aids retorna em artigos sobre diversos contextos nacionais e internacionais e sobre temáticas como homossexualidade, ativismo, mulheres, travestis, jovens, entre outras. A maior parte da produção no período concentra-se em dois dossiês publicados no ano de 2018 na revista do CLAM, Sexualidad, Salud y Sociedad, organizados respectivamente por Regina Facchini, Thiago Pinheiro e Gabriela Calazans (Prevenção de HIV/Aids, Produção de Diferenças e Processos de Mudança Social) e por Claudia Mora, Mónica Franch, Ivia Maksud e Felipe Rios (2018) (HIV/Aids: Sexualidades, Subjetividades e Políticas).

Destacamos, por fim, artigos que se situam no diálogo entre saúde e sexualidade, renovando, com base nas novas intervenções disponíveis, questôes que estão presentes nas primeiras abordagens sobre sexualidade, principalmente aquelas baseadas no pensamento de Michel Foucault. São objeto de atenção questóes como tecnologias de intervenção na sexualidade e políticas sexuais; medicalizaçáo, sexualidade e gênero; circuncisão, HIV, cirurgias corretivas e intersex; adiçáo sexual; ciência da sexualidade e crianças; vagina pós-orgânica, sexualidade e medicalização; BDSM e psiquiatrização, entre outros temas. Uma amostra desse tipo de abordagem é constituída do dossiê organizado por Fabíola Rohden, Jane Russo e Alejandra Roca (2017) na revista Horizontes Antropológicos, Gênero e Sexualidade, Saberes e Intervenções.

Como observamos em relação à questão da educação, o recorte metodológico impede que entrem nessa análise artigos publicados em revistas na saúde coletiva e em áreas correlatas, mas se pode afirmar que essa é uma área de crescente atividade, com autoras(es) trabalhando nas interfaces entre gênero, sexualidade e antropologia da saúde e antropologia da ciência.

\section{Sexualidades: práticas, saberes e direitos}

Ora em diálogo com os estudos de gênero, ora de forma independente, uma grande parcela da produçáo desse período se insere no campo de estudos da sexualidade. São artigos que tratam de diferentes práticas ligadas a expressôes da sexualidade, sua relação com instâncias reguladoras da sexualidade, questóes ligadas aos direitos sexuais, à socia-

24 Alguns temas identificados foram: diabetes e cuidado de si; hanseníase, gênero e afeto; Mulheres que Amam Demais (MADA); transtornos alimentares; depressão, mulheres e etnografia; medicalização da sexualidade; saúde do homem; testosterona, mulheres e medicina; gerontologia e homossexualidade; hormônios; processo transexualizador; despatologização e identidade trans; intersexualidade; mulheres com endometriose, entre outros. 
bilidade e aos mercados do sexo. Entre as expressóes da sexualidade, destacam-se práticas dissidentes, incluindo artigos sobre sexo animal e sexo bizarro, erotismo e pornô, swing, fetichismo e BDSM. Atençáo para o dossiê Pornôs, organizado por Bibia Gregori e Maria Elvira Díaz-Benítez (2012), com artigos de cunho etnográfico que dão visibilidade a representaçóes e redes em torno da pornografia náo mainstream: etnografias de sex shops em São Paulo; representaçóes raciais na pornografia gay; altporn; sexo com animais etc. Expressóes ou práticas que poderiam ser enquadradas como mainstream têm presença quase nula entre os artigos pesquisados.

Já a relação entre sexualidade e instâncias reguladoras está presente nos artigos mencionados na interface entre gênero, sexualidade, saúde e ciência, problematizando tecnologias de intervenção na sexualidade e políticas sexuais. A biomedicina, especialmente a psiquiatria, mas não apenas ela, assume papel de destaque no disciplinamento e na patologização das expressóes menos normativas da sexualidade. Outra instância reguladora em evidência é a justiça, que aparece sobretudo nos artigos sobre pedofilia e pornografia infantil.

Tema clássico nos estudos sobre sexualidades, a sociabilidade está presente em diversos artigos tanto em espaços físicos (bailes de forró e outros circuitos de lazer) como em espaços virtuais (Facebook e outras redes sociais) - embora estes últimos tenham menor presença do que poderia se esperar ante a popularizaçáo de aplicativos de paquera e sexo nos últimos anos. Diversos artigos fazem cruzamento da questáo da sociabilidade com o mercado, trazendo temas como homossexualidade e mercados, turistas estrangeiros, internet e mulheres heterossexuais, sex shops, rádio e mercado LGBTQI+. Sobre esse assunto, remetemo-nos ao balanço já mencionado de Regina Facchini, Isadora Lins França e Camilo Braz (2014) para a Cadernos Pagu, em que o tema é discutido em detalhe.

Destacamos, por fim, a presença de artigos voltados para a temática da sexualidade entre povos indígenas. Nesses contextos, póem-se em questão a universalidade e o rendimento analítico que as abordagens sobre gênero e sexualidade podem trazer, conforme refletido por Cecilia McCallum (2013), Patrícia Rosa (2013) e Vanessa Lea (2013), em debate promovido pela revista Cadernos Pagu em Alteridade, Gênero, Sexualidade, Afeto.

\section{Diversidade sexual e de gênero}

Seguindo tendência apontada nos balanços anteriores, o eixo em torno da diversidade sexual e de gênero explodiu nessa década. São artigos que se apropriam de diferentes terminologias relativas aos sujeitos com base em sua orientação sexual, nas práticas sexuais ou nas identidades/performances de gênero - homossexuais, gays, travestis, transexuais, bichas, viados, LGBTQI+, lésbicas, sapatão, trans, homens trans, crossdressers, intersex, não binários. Em meio a uma riqueza de cenários etnográficos e à proliferação dos olhares, é possível destacar algumas tendências mais marcantes.

Em primeiro lugar, percebe-se a multiplicação de estudos etnográficos que retiram sua singularidade de espaços, até então, pouco explorados na literatura sobre o tema, historicamente concentrada nas grandes cidades do eixo Sul-Sudeste. Nas produçóes pesquisadas nos anos de 2008 a 2018, passaram a aparecer estados como Pará, Piauí, Goiás, Paraíba, Ceará etc. Essas ênfases refletem, por um lado, maior visibilidade da produçãa de núcleos e grupos de estudos existentes há algum tempo fora do eixo Sul-Sudeste, mas também os efeitos da ex- 
pansão universitária (Reuni), acompanhando a trajetória de pesquisadoras(es) que se formaram em centros metropolitanos ou em universidades com grupos de pesquisa em gênero e sexualidades, passaram em concursos públicos nos novos campi interiorizados e ali começaram a desenvolver estudos sobre os temas de sua formação.

Os títulos dos artigos enfatizam essa dimensão local das pesquisas: travestis no Pará e no Piauí, bichas de Goiás, gays no Pantanal, homossexualidade em Belém, LGBTQI+ Cuiabá, transfeminilidades na Paraíba, políticas LGBTQI+ em Goiás, concursos de Miss Gay, transexuais em Belém, saunas em Campina Grande, pegação em João Pessoa, envelhecimento entre homossexuais no Pantanal, etnografia noturna em Bragança, movimento LGBTQI+ em Cuiabá e Mato Grosso, redes de sociabilidade gay e lésbica em Teresina, entre outras. Não que os centros metropolitanos como Rio e Sáo Paulo tenham desaparecido das pesquisas, mas essa diversificação dos cenários merece ser salientada. Destacamos, nesse sentido, os três dossiês organizados por Estêvão Fernandes, Fabiano Gontijo, Martinho Tota e Moisés Lopes nas revistas ACENO e Amazônica, em torno das questóes da diversidade sexual e de gênero em áreas rurais, contextos interioranos e/ou situaçóes etnicamente diferenciadas, mapeando o que os autores denominam de "descentramentos" e "novas axialidades" (Fernandes et al., 2016a; 2016b; Gontijo et al., 2016).

Entre os novos contextos, destacamos a emergência de pesquisas com grupos indígenas. Embora não propriamente uma novidade dessa década, foi no período analisado que o tema adquiriu visibilidade no campo de estudos sobre sexualidades, trazendo um potencial para renovaçóes no estudo das etnicidades.

Quanto à questão das identidades de gênero e/ou orientação sexual, é notável o predomínio dos estudos sobre gays ou homossexualidades masculinas, seguidos dos estudos sobre travestis e transexuais. Em relação a estes, destacamos dossiê organizado por Berenice Bento e Larissa Pelúcio (2012) para a revista Estudos Feministas: Vivências Trans: Desafios, Dissidências e Conformações. Comparando com a produção de décadas anteriores, apareceram alguns deslocamentos na temática trans: menor ênfase na prostituição; uma mudança nas questóes ligadas às intervençóes corporais com enfoques mais voltados à indústria farmacológica e menos às tradicionais aplicaçóes de silicone pelas conhecidas bombadeiras; atenção especial voltada para o processo transexualizador no Sistema Único de Saúde (SUS) e a relação entre o Estado e as políticas públicas de saúde; ampliação na consideração das vivências trans, incorporando questóes ligadas à experiência, como as memórias de infância e o sofrimento. Além disso, homens trans constituem, igualmente, um campo de crescente interesse nas pesquisas, refletindo sua maior visibilidade na década em questão.

Já a temática lésbica continuou menos presente na literatura sobre gênero e diversidade sexual, o que mais uma vez corrobora a invisibilidade das experiências homoafetivas femininas que a militância vem denunciando há tempos. Encontramos artigos sobre as aproximaçóes e diferenças entre a categoria lésbica e homem trans, experiências homoafetivas de mulheres em contextos comparativos internacionais, o envelhecimento entre mulheres lésbicas ou, ainda, expressões de gênero entre mulheres que gostam de mulher. Um único dossiê foi identificado, organizado por Ana Carla da Silva Lemos e Nathalia Cristina Cordeiro (2018) para a revista $C a$ dernos de Gênero e Diversidade, contendo artigos apresentados no marco da I Jornada sobre o Pensamento Lésbico realizada em 2017 em 
Salvador. Cabe salientar que iniciativas como a I Jornada e o desenvolvimento do Projeto Lésbicas que Pesquisam apontam para uma mudança nesse cenário, que, esperamos, possa ser verificada em futuros balanços.

Houve, por fim, poucas contribuiçóes sobre intersexualidade (Machado, 2014) e menos ainda sobre expressóes de gênero minoritárias, como os crossdressers. Destacamos, também, que não encontramos nada específico sobre bissexualidade. Essa distribuição, com predomínio do $\mathrm{G}$ ante as demais "letrinhas" (parafraseando Regina Facchini, 2005), confirma tendências anteriormente observadas e permanece como um desafio para os estudos sobre diversidade sexual.

Em relação aos temas, a questão do movimento LGBTQI+, que foi objeto de muito interesse na década de 2000, teve aparição modesta quando comparada à sociabilidade do tipo espontânea ou regulada pelo mercado - festas, saunas, pegações, putaria, circuitos de lazer, concursos de beleza gay etc. Mobilização política e movimento LGBTQI+ apareceram em artigos a respeito da cidadania homossexual, direitos trans, movimento de travestis e transexuais e movimento LGBTQI+ nos novos cenários anteriormente mencionados. Também é possível encontrar diversos artigos cujo foco de interesse recai nas políticas públicas voltadas para a população trans ou outros coletivos, bem como sobre questóes jurídicas. Uma temática surpreendentemente inexpressiva nos trabalhos é a da violência, sobretudo a violência letal contra a população trans, o que é algo a se refletir, ante a dimensão desse fenômeno no Brasil, que é o campeão mundial em transfeminícídio.

\section{Masculinidades}

Temática emergente décadas atrás (Grossi, 2010), as masculinidades apareceram em franca recessão, o que contrasta com o vívido interesse nas questóes de sexualidade, nomeadamente no campo das sexualidades dissidentes, sugerindo uma migração do interesse de um campo para outro. Há um dossiê sobre o assunto organizado por Rolf Malungo de Souza (2013) na revista Antropoliticas, contando com artigos sobre questóes raciais e masculinidade, além do único artigo identificado na pesquisa sobre masculinidades entre mulheres que gostam de mulher ${ }^{25}$. Afora os artigos do mencionado dossiê, outros recortes encontrados foram: masculinidades na internet; masculinidade e polícia militar; masculinidades, sujeito e gênero; esportes; masculinidade e raça; masculinidade e ciganos; masculinidade e futebol; medicalização e masculinidade; masculinidade e homossexualidade, além de artigos de caráter mais genérico.

\section{Outros temas}

Dossiê publicado na revista Caderno Espaço Feminista é responsável pela aparição do tema da alimentação no conjunto de temáticas discutidas (Abdala; Menasche, 2008). Artigos avulsos e um dossiê na revista Estudos Feministas (Camargo, 2018) trazem o tema do esporte também para o conjunto de temáticas.

Foram encontrados poucos artigos voltados exclusiva ou prioritariamente a compreender gênero e ruralidade. Duas exceçóes aparecem em revistas do Nordeste. Uma delas é o dossiê Mulheres em Contextos Rurais, pu-

25 Mara Coelho de Souza Lago e Cristina Scheibe Wolff (2013) também organizaram o dossiê Masculinidades, Diferenças, Hegemonias, na Estudos Feministas, mas ele não teve contribuiçôes de antropólogas(os). 
blicado na revista Vivência (UFRN), organizado por Elisete Schwade e Ellen Woortman (2014), incluindo artigos sobre migração e conhecimentos tradicionais, trabalhadoras rurais e movimentos sociais, mulheres jovens em assentamentos rurais e saberes práticos. O outro dossiê é organizado por Parry Scott, Rosineide Cordeiro e Fernanda Sardelich Nascimento Gomes (2012) na revista AntHropológicas, contando com artigos sobre mulheres rurais e financiamento, juventude rural e sexualidade, mulheres rurais e violência.

Por fim, em contraste com a proliferaçáo de estudos sobre diversidade sexual, a heterossexualidade raramente aparece como tema de pesquisa em si mesmo. Pouquíssimos artigos fazendo referência explícita ao tema foram localizados, abordando recortes como internet e mulheres heterossexuais; representaçóes de jovens heterossexuais sobre a homossexualidade; festas e heterossexualidade, além do dossiê anteriormente mencionado sobre heterossexualidades, contracepção e aborto na revista Sexualidad, Salud y Sociedad (Heilborn, 2012). Esse é um vazio a ser urgentemente preenchido.

\section{Marcadores sociais da diferença e a questão das gerações}

Por fim, uma característica marcante na produçáo desse período tem a ver com o impacto crescente das teorias sobre intersecionalidade. Essa influência expressa-se numa grande quantidade de artigos que tem no título ou nas palavras-chave o descritor "marcadores sociais da diferença", incluindo temas sobre raça, gênero e nação; raça, gênero e sexualidade; gênero, raça e jovens; gênero, raça e classe; cotas raciais; corpo; baianas, identidade racial e gênero; branquitude e homossexualidade; masculinidade e raça; raça, gênero e políticas culturais; relaçóes de pes- quisa e o lugar da cor da pele; gênero, raça e classe na universidade, entre outros recortes. É possível perceber o predomínio da tematizaçáo da raça em cruzamento com gênero e, em menor medida, com classe social.

Numa abordagem comparativa transnacional, destacamos os artigos resultantes da pesquisa Relations among "race", sexuality and gender in different local and national context, voltada a discutir o impacto do racismo, dos preconceitos e estereótipos sobre gênero e sexualidade, bem como das condiçóes materiais de vida, nos cuidados de saúde (especificamente, mas não apenas, com doenças sexualmente transmissíveis - DST/HIV/ aids) em cidades do Brasil, da África do Sul e dos Estados Unidos, com resultados parcialmente apresentados em dossiê organizado por Laura Moutinho e Sergio Carrara (2010), Raça e Sexualidade em Diferentes Contextos Nacionais, na Cadernos Pagu. Outro conjunto de reflexôes interessante é compilado no dossiê Retrato das Desigualdades de Gênero e Raça, organizado por Aline Bonetti e Ana Carolina Querino (2009) para a revista Estudos Feministas.

Se as questóes raciais usualmente se articulam com a temática da desigualdade, a temática indígena, quando aparece nos estudos sobre gênero e sexualidade, não está tematizada pelas desigualdades, e sim majoritariamente pelos contextos específicos de experiências de gênero e de diversidade sexual.

Embora ainda com uma presença limitada, é importante destacar a aparição da temática da deficiência, em sua interface com gênero e, em menor medida, com sexualidade, entre o leque de novidades trazidas nas publicaçóes da última década. Destacamos o dossiê organizado por Alfonsina Faya Robles e Ana Cláudia Rodrigues (2018) na revista AntHropológicas, da UFPE, sobre deficiência, gênero e cuidado. A temática vem ga- 
nhando força pela maior visibilidade e ativismo de coletivos, como o das pessoas surdas, mas também é possível perceber o interesse de pesquisadoras(es) que chegam ao tema a reboque de outras questóes, principalmente da síndrome congênita pelo Zika.

A questão geracional, no entanto, foi pouco incorporada. Embora a idade seja um elemento importante, raramente ela é trazida como elemento de análise em cruzamento com as dimensóes de classe, raça, gênero e sexualidade ou compreendida como um marcador de desigualdade. Uma exceção é o dossiê sobre gênero e geraçôes organizado por Márcio Souza e Monica Franch (2012), na revista Caderno Espaço Feminino. Quando pensamos o recorte específico a cada "idade da vida", observamos que a infância é a grande ausente na produção deste período. Há alguns artigos que versam sobre pedofilia e pornografia infantil, mas não são estudos com crianças, e sim em torno de aspectos jurídicos e representacionais. Carecem estudos que mostrem como as dimensóes de gênero e sexualidade operam na infância, o que pode ser especialmente difícil na atual conjuntura. Comparativamente, a presença de jovens e adolescentes nos artigos é bem mais evidente ${ }^{26}$. Destacamos o dossiê já mencionado sobre feminismos jovens (Facchini; França,
2011), em que as autoras adotam uma compreensão de geração com base no contexto e nos termos mobilizados pelas protagonistas de cada movimento. Já em relação à velhice, é possível encontrar um número razoável de artigos que problematizam, sobretudo, questôes voltadas à homossexualidade e ao envelhecimento, principalmente masculino, mas também sobre homossexualidade feminina. A idade adulta, problematizada como uma idade da vida, foi encontrada em apenas um artigo sobre mulheres maduras.

\section{Considerações finais}

Enfim, encerramos esse balanço, que náo pôde abarcar todo o projeto de levantamento que tínhamos quando iniciamos essa jornada, com a percepção de que houve, na última década, notável proliferação de pesquisas antropológicas realizadas no Brasil, em todas as regiōes de um país continental, no campo dos estudos de gênero e sexualidades.

Somente na área de antropologia, pudemos levantar a existência, atualmente, de pelo menos 25 grupos e núcleos de pesquisa centrados no tema de gênero e sexualidade, sendo três da Regiāo Sul, sete do Sudeste, seis do Centro-Oeste, cinco do Nordeste e quatro do $\mathrm{Norte}^{27}$. Ou seja, na última dé-

26 Encontramos artigos sobre jovens, sexualidade e sociabilidade; feminismos jovens; travestis adolescentes; religião, jovens e sexualidade; gênero, raça e jovens; iniciação sexual; jovens homossexuais e famílias; amizade, sexualidade, gênero e juventude; juventude, masculinidade e pobreza; juventude rural e sexualidade, entre outros temas.

27 UFRGS: Núcleo de Pesquisa em Antropologia do Corpo e da Saúde (Nupacs); UFSC: Núcleo de Identidades de Gênero e Subjetividades (NIGS); UFSCar: Quereres; Unesp/Bauru: Transgressōes: corpos, gêneros, sexualidades e mídias; USP: NUMCAS; Unicamp: Pagu; Museu Nacional/UFRJ: Nusex; UFRJ/IFCS: Núcleo de Estudos de Sexualidade e Gênero (NESEG); UERJ: Núcleo de Estudos em Desigualdades Contemporâneas e Relaçôes de Gênero (NUDERG); UFG: Ser-Tão - Núcleo de Estudos e Pesquisas em Gênero e Sexualidade; UFMT: Grupo de Pesquisas Gênero, Sexualidade e Família; UFMS: Núcleo de Estudos Néstor Perlongher; UFPE: Núcleo de Família, Gênero e Sexualidade (FAGES); UFBA: ENLACE; UFRN: Grupo de Pesquisa Gênero Corpo Sexualidade; UFPB: Grupo de Pesquisas em Saúde, Sociedade e Cultura (GRUPESSC) e Grupo de Etnografias Urbanas (Guetu); UFAL: Mandacaru; UFPA: SEXGEN; UFAM: Azulilás, GERSECS e Observatório da Violência de Gênero do Amazonas; UNILAB: Núcleo de Políticas de Gênero e Sexualidade (NPGS); UFBA: CUS; UNIPAMPA: Tuna - Gênero, Educação e Diferença; UnB: NEPEM. 
cada, houve maior distribuição de pesquisadoras(es) por diferentes universidades, em regióes distintas, que também revelam os desdobramentos das políticas do Reuni.

A ampliação, o fortalecimento e a capilaridade de investigaçóes que possibilitam compreender e complexificar relaçóes de gênero, práticas sexuais, sexualidades, normatividades, socialidades, territorialidades e corporeidades têm colaborado para uma resistência acadêmica à reprodução de formas de desigualdade estruturais e arcaicas na sociedade brasileira. Contudo observamos que essa diversidade nem sempre é refletida nos balanços existentes, que tendem a privilegiar algumas redes em detrimento de outras.

O panorama da década analisada traz como destaque o predomínio de pesquisas etnográficas. Mais do que assistirmos a uma renovação das teorias, o que vemos é a proliferaçáo dos estudos em campos cada vez mais diversificados, o que, por sua vez, termina por renovar as temáticas. Essa diversidade é, do nosso ponto de vista, a maior contribuição do período, que também vem acompanhada da construção de uma antropologia mais implicada, acompanhando as pautas e reivindicaçôes dos feminismos e dos movimentos LGBTQI+. Muitas(os) jovens antropólogas(os), do campo de gênero e sexualidades no Brasil, também são ativistas e têm construído suas pesquisas com base em perspectivas políticas e que também pretendem transformar as realidades das quais fazem parte. Ainda que negras(os) e trans não possuam grande visibilidade no campo da antropologia, de modo geral já se pode notar grande crescimento pelo interesse das temáticas que envolvem os feminismos negros e latino-americanos e dos transfeminismos, crescimento que, esperamos, se fará notar ainda mais nos próximos anos, com a formação de novas(os) antropólogas(os).
Importante ressaltar que ainda há problemáticas que não foram enfrentadas e que devem merecer nossa atenção nos próximos anos, acreditando (sonhando?) na construção de um processo democrático no Brasil. Depois de uma abertura para a descrição e compreensão de práticas, identidades e saberes que vão na contramão da heterocisnormatividade hegemônica, há a necessidade urgente de compreensão densa de modelos de heterossexualidade mais tradicionais, ou conservadores, que acompanham também uma força contrária à autonomia das mulheres, como a legalização do aborto, e que também tapam os olhos ao genocídio das pessoas trans (e negras). Ainda, é necessária uma presença mais representativa de intelectuais antropólogas negras, que possam tornar suas escritas visíveis e que se movimentem contra o racismo e o sexismo estruturais nos sistemas hierárquicos universitários.

Refletindo o pouco interesse pela heterossexualidade, a contracepção permanece uma questão pouco representada, o que significa fechar os olhos para uma experiência compartilhada, e muitas vezes problemática, na vida de uma parcela importante das mulheres brasileiras em suas diversas parcerias afetivo-sexuais. Do mesmo modo, vemos com preocupação o menor interesse nas questôes de masculinidades. Será preciso um esforço da nossa parte para compreender o modo como setores conservadores têm conseguido angariar adesóes pela manipulação de símbolos associados a certos modelos de masculinidades, como a promessa de facilitar o acesso a armas de fogo. Chamamos, igualmente, a atenção para temas que continuam pouco representados, embora apresentando sinais de mudança, como a temática lésbica. Por fim, pensamos que as ferramentas intelectuais e metodológicas da antropologia podem nos ajudar a lançar novos olhares 
para temas e questóes que hoje concentram a atenção de outros cientistas sociais, como o trabalho, a política partidária e a questão ambiental, pouco representada.

Nesse sentido, é bom lembrar que o nosso trabalho - como antropólogas(os), docentes de instituiçóes públicas de ensino e pesquisadoras(es) — está cada vez mais precarizado e ameaçado. Ante um cenário de cortes do Ministério da Educação no orçamento das federais, de risco iminente de fechamento de cursos e de perda de autonomia universitária, de poucas(os) professoras(es), servidoras(es) (sem chance de contrataçôes novas), bolsas e financiamento de pesquisas na área, afora a perseguição ideológica ao tema de gênero que vem sendo encampada nacional e internacionalmente pelo governo atual, quais são as perspectivas para nossos estudos? Pensamos que é com base na radicalidade do pensar e do fazer, na busca do diálogo interno e para fora das nossas fronteiras, na permeabilidade com os movimentos sociais que, nesse momento, resistem ao desmonte e ao retrocesso que pesquisadoras(es) em gênero e sexualidade continuarão (continuaremos) produzindo conhecimento e práticas transformadoras.

\section{Bibliografia}

ABDALA, Mônica Chaves; MENASCHE, Renata. Comida e gênero: repensando teorias e práticas. Caderno Espaço Feminino, v. 19, n. 1, 2008.

AZEREDO, Sandra. Teorizando sobre gênero e relaçóes raciais. Estudos Feministas, Florianópolis, v. 2, n. esp., 1994.

BAIRROS, Luiza. Nossos feminismos revisitados. Estudos Feministas, Florianópolis, v. 3, n. 2, 1995.

BENTO, Berenice; PELÚCIO, Larissa. Vivências trans: desafios, dissidências e conformaçōes. Estudos Feministas, v. 20 , n. 2, p. 485-488, 2012. https://doi.org/10.1590/S0104-026X2012000200009

BONETTI, Aline; QUERINO, Ana Carolina. Retrato das desigualdades de gênero e raça: apresentação. Estudos Feministas, v. 17, n. 3, 2009.

CALDWELL, Kia Lilly. Fronteiras da diferença: raça e mulher no Brasil. Estudos Feministas, Florianópolis, v. 8, n. 2, 2000.

CAMARGO, Wagner Xavier. O universo dos gêneros nos esportes: descortinando relaçóes. Estudos Feministas, v. 26, n. 1, p. 1-3, 2018.

CARNEIRO, Sueli. Gênero e raça na sociedade brasileira. In: BRUSCHNI, Cristina; UNBEHAUM, Sandra G. (orgs.). Gênero, democracia e sociedade brasileira. São Paulo: Fundação Carlos Chagas/34, 2002. p. 153-185.

CARRARA, Sérgio; SIMÓES, Júlio. Sexualidade, cultura e política: a trajetória da identidade homossexual masculina na antropologia brasileira. Cadernos Pagu, n. 28, p. 65-99, 2007. https://doi.org/10.1590/S010483332007000100005

CITELI, Maria Teresa. A pesquisa sobre sexualidade e direitos sexuais no Brasil (1990-2002). Rio de Janeiro: Cepesc, 2005.

COSTA, Albertina de Oliveira; BARROSO, Carmem; SARTI, Cynthia. Pesquisa sobre mulher no Brasil - do limbo ao gueto? Cadernos de Pesquisa, São Paulo, n. 54, p. 5-15, 1985. 
COSTA, Albertina de Oliveira; BRUSCHINI, Cristina (org.). Uma questão de gênero. São Paulo: Fundação Carlos Chagas, 1992.

FACCHINI, Regina; FRANÇA, Isadora Lins. Os feminismos jovens. Cadernos Pagu, n. 36, p. 9-24, 2011.

FACCHINI, Regina; FRANÇA, Isadora. Estudos de Gênero no Brasil. 20 anos depois. In: MICELI, Sergio; MARTINS, Carlos Benedito (org.). Sociologia Brasileira Hoje. Cotia: Ateliê Editorial, 2017. p. 283-357.

FACCHINI, Regina; FRANÇA, Isadora Lins; BRAZ, Camilo. Estudos sobre sexualidade, sociabilidade e mercado: olhares antropológicos contemporâneos. Cadernos Pagu, Campinas, n. 42, p. 99-104, 2014. https://doi. org/10.1590/0104-8333201400420099

FACCHINI, Regina; PINHEIRO, Thiago Félix; CALAZANS, Gabriela. Prevençáo do HIV/aids, produção de diferenças e processos de mudança social. Sexualidad, Salud y Sociedad, n. 29, p. 253-262, 2018. https://doi. org/10.1590/1984-6487.sess.2018.29.12.a

FACCHINI, Regina. Sopa de letrinhas? Movimento homossexual e produção de identidades coletivas nos anos 90. Rio de Janeiro: Garamond, 2005.

FERNANDES, Estêvão et al. Diversidade sexual e de gênero em áreas rurais, contextos interioranos e/ou situaçôes etnicamente diferenciadas: novos descentramentos em outras axialidades: apresentação. ACENO, v. 3, n. 5 , p. 10-13, 2016a.

FERNANDES, Estêvão et al. Diversidade sexual e de gênero em áreas rurais, contextos interioranos e/ou situaçóes etnicamente diferenciadas: novos descentramentos em outras axialidades: apresentaçáo. Amazônica, v. 8, n. 1, p. 9-12, 2016b. https://doi.org/10.18542/amazonica.v8i1.4721

FERNANDES, Felipe Bruno Martins; IRINEU, Bruna Andrade. Extensão Universitária em Gênero e Sexualidades. Revista Feminismos, v. 3, n. 1, p. 100-107, 2015.

FONSECA, Claudia. Família, fofoca e honra. Porto Alegre: Editora da UFRGS, 2000.

FONSECA, Claudia. Honra, humor e relaçôes de gênero: um estudo de caso. In: COSTA, Albertina de Oliveira; BRUSCHINI, Cristina. Uma questão de gênero. Rio de Janeiro: Rosa dos Tempos; São Paulo: Fundação Carlos Chagas, 1992. p.310-333.

FRY, Peter. Para inglês ver: identidade e política na cultura brasileira. Rio de Janeiro: Zahar, 1982.

GONTIJO, Fabiano. Antropologia fora dos eixos? Algumas considerações sobre as particularidades da formação de um campo de pesquisas no Piauí, Brasil, Revista FSA, v. 12, n. 5, p. 49-62, 2015a. http://dx.doi. org/10.12819/2015.12.5.3

GONTIJO, Fabiano. As experiências da diversidade sexual e de Gênero no interior da Amazônia: apontamentos para estudos nas ciências sociais. Ciência e Cultura, v. 69, n. 1, 2017. http://dx.doi.org/10.21800/231766602017000100017

GONTIJO, Fabiano. Sexualidade e ruralidade no Brasil: o que os estudos rurais e os estudos de gênero e sexualidade (não) dizem sobre essa relação? Vivências, Natal, v. 1, n. 45, 2015b.

GONTIJO, Fabiano; ERICK, Igor. A experiência da diversidade sexual e de gênero no Pará: espaço público, representaçōes e discursividades. Revista FSA, Teresina, v. 13, n. 4, p. 40-59, 2016. http://dx.doi. org/10.12819/2016.13.4.\%203

GONTIJO, Fabiano; ERICK, Igor. Diversidade sexual e de gênero, ruralidade, interioridade e etnicidade no Brasil: ausências, silenciamentos e... exortaçōes. ACENO, v. 2, n. 4, p. 24-40, 2015. 
GONTIJO, Fabiano; ERICK, Igor. Experiências da diversidade sexual e de gênero e sociabilidades na Amazônia. ACENO, v. 4, n. 7, p. 249-272, 2017.

GONTIJO, Fabiano et al. Apresentação: ainda sobre novos descentramentos em outras axialidades da diversidade sexual e de gênero. Amazônica, v. 8, n. 2, p. 261-262, 2016. http://dx.doi.org/10.18542/amazonica.v8i2.5038

GREGORI, Bibia. Práticas eróticas e limites da sexualidade: contribuiçōes de estudos recentes. Cadernos Pagu, Campinas, n. 42, p. 47-74, 2014. https://doi.org/10.1590/0104-8333201400420047

GREGORI, Bibia; DÍAZ-BENÍTEZ, María Elvira. Pornôs. Cadernos Pagu, n. 38, p. 7-12, 2012.

GROSSI, Miriam. Gênero, sexualidade e reprodução. In: MARTINS, C. B.; DUARTE, L. D. (orgs.). Horizontes das Ciências Sociais no Brasil: Antropologia. São Paulo: Anpocs, 2010. p. 293-340.

GUIMARÃES, Carmen Dora. O homossexual visto por entendidos. Rio de Janeiro: Garamond, 2004.

HEILBORN, Maria Luiza. Fazendo gênero? A antropologia da mulher no Brasil. In: COSTA, Albertina de Oliveira; BRUSCHINI, Cristina (orgs). Uma questão de gênero. São Paulo: Fundação Carlos Chagas, 1992. p. 93-128.

HEILBORN, Maria Luiza. Heterossexualidades, contracepção e aborto: uma pesquisa em quatro capitais latinoamericanas. Sexualidad, Salud y Sociedad, n. 12, p. 127-134, 2012. https://doi.org/10.1590/S198464872012000600006

HEILBORN, Maria Luiza; SORJ, Bila. Estudos de gênero no Brasil. In: MICELI, Sérgio (org.). O que ler nas ciências sociais brasileiras (1975-1995). São Paulo: Sumaré/Anpocs, 1999. p. 183-222.

HIRATA, Helena; DEBERT, Guita Grin. Gênero e cuidado. Cadernos Pagu, n. 46, p. 7-15, 2016.

LAGO, Mara Coelho de Souza; WOLFF, Cristina Scheibe. Masculinidades, diferenças, hegemonias. Estudos Feministas, n. 21, v. 1, p. 233-240, 2013. https://doi.org/10.1590/S0104-026X2013000100013

LEA, Vanessa. O som do silêncio (Paul Simon). Cadernos Pagu, n. 41, p. 87-93, 2013.

LEMOS, Ana Carla da Silva; CORDEIRO, Nathalia Cristina. Pensamentos e resistências lésbicas feministas, dialogando com teóricas clássicas, contemporâneas e movimentos lésbicos. Cadernos de Gênero e Diversidade, v. 4, n. 2, 2018. http://dx.doi.org/10.9771/cgd.v4i2.26703

LOYOLA, Maria Andréa. A antropologia da sexualidade no Brasil. Physys, Rio de Janeiro, v. 10, n. 1, p. 143-167, 2000. https://doi.org/10.1590/S0103-73312000000100007

MACHADO, Lia. Feminismo, academia e interdisciplinaridade. In: COSTA, Albertina de Oliveira; BRUSCHINI, Cristina (orgs.). Uma questão de gênero. São Paulo: Fundação Carlos Chagas, 1992. p. 24-38.

MACHADO, Lia. Interfaces e deslocamentos: feminismos, direitos, sexualidades e antropologia. Cadernos Pagu, Campinas, n. 42, p. 13-46, 2014. https://doi.org/10.1590/0104-8333201400420013

MACHADO, Paula Sandrine. (Des)fazer corpo, (re)fazer teoria: um balanço da produção acadêmica nas ciências humanas e sociais sobre intersexualidade e sua articulação com a produção latino-americana. Cadernos Pagu, Campinas, n. 42, p. 141-158, 2014. https://doi.org/10.1590/0104-8333201400420141

MACRAE, Edward. A construção da igualdade: identidade sexual e política no Brasil da "abertura". Campinas: Ed. da Unicamp, 1990.

MARTINS, Carlos Benedito; DUARTE, Luiz Fernando Dias (org.). Horizontes das Ciências Sociais: Antropologia. São Paulo: ANPOCS, Instituto Ciência Hoje, Editora Barcarolla, Discurso Editorial, 2010. 
MCCALLUM, Cecilia. Nota sobre as categorias "gênero" e "sexualidade" e os povos indígenas. Cadernos Pagu, n. 41, p. 53-61, 2013. https://doi.org/10.1590/S0104-83332013000200006

MICELI, Sergio; MARTINS, Carlos Benedito (org.). Sociologia Brasileira Hoje. Cotia: Ateliê Editorial, 2017.

MORA, Claudia et al. HIV/Aids: sexualidades, subjetividades e políticas. Sexualidad, Salud y Sociedad, n. 30, p. 141-152, 2018. https://doi.org/10.1590/1984-6487.sess.2018.30.07.a

MOUTINHO, Laura. Diferenças e desigualdades negociadas: raça, sexualidade e gênero em produçóes acadêmicas recentes. Cadernos Pagu, Campinas, n. 42, p. 201-248, 2014. https://doi.org/10.1590/01048333201400420201

MOUTINHO, Laura; CARRARA, Sergio. Dossiê: Raça e sexualidade em diferentes contextos nacionais. Cadernos Pagu, n. 35, p. 9-35, 2010. https://doi.org/10.1590/S0104-83332010000200002

OLIVAR, José Miguel Nieto. Pesquisando prostituição e marcadores do sexo: contribuiçōes, debates e novos desdobramentos. Ártemis, v. 18, n. 1, p. 3-11, 2014. https://doi.org/10.15668/1807-8214/artemis.v18n1p3-11

PERLONGHER, Nestor. O negócio do michê: a prostituiçâo viril. São Paulo: Brasiliense, 1987.

PISCITELLI, Adriana. Violências e afetos: intercâmbios sexuais e econômicos na (recente) produçáo antropológica realizada no Brasil. Cadernos Pagu, Campinas, n. 42, p. 159-199, 2014. https://doi.org/10.1590/01048333201400420159

PORTO, Rozeli; COSTA, Patricia Rosalba Salvador. Zika vírus e síndromes neurológicas congênitas: contribuiçóes para o campo dos estudos de gênero. Cadernos de Gênero e Diversidade, v. 3, n. 2, p. 70-72, 2017. http:// dx.doi.org/10.9771/cgd.v3i2.23320

PORTO, Rozeli; VENCATO, Anna Paula; D’OLIVEIRA, Ana Flavia Lucas. Apresentação. Vivência, v. I, n. 48, p. 7-10, 2016.

RICOLDI, Arlene. Trabalho, família e política: os estudos de gênero e os grupos de trabalho da Anpocs". In: ENCONTRO ANUAL DA ANPOCS, 41., 2017. Anais [...]. Caxambu: ANPOCS, 2017.

ROBLES, Alfonsina Faya; RODRIGUES, Ana Cláudia. Deficiências, gênero e cuidados. AntHropológicas, v. 29, n. 2, p. 1-5, 2018.

ROHDEN, Fabíola; RUSSO, Jane; ROCA, Alejandra. Gênero e sexualidade, saberes e intervençôes. Horizontes Antropológicos, ano 23, n. 47, p. 9-26, 2017.

ROSA, Patrícia. Romance de primas com primas e o problema dos afetos: parentesco e micropolítica de relacionamentos entre interlocutores tikuna, sudoeste amazônico. Cadernos Pagu, n. 41, 2013. https://doi.org/10.1590/S010483332013000200008

SARDENBERG, Cecília M. B. Para re-tecer a rede: reflexôes sobre a trajetória da REDOR. In: SEMINÁRIO INTERNACIONAL ENFOQUES FEMINISTAS E O SÉCULO XXI: FEMINISMO E UNIVERSIDADE NA AMÉRICA LATINA, 1., 2005. Anais [...]. Salvador: NEIM/UFBA, 2005.

SARDENBERG, Cecília M. B.; GROSSI, Miriam Pillar. Balanço sobre a Lei Maria da Penha. Estudos Feministas, v. 23, n. 2, p. 497-500, 2015. https://doi.org/10.1590/0104-026X2015v23n2p497

SCHWADE, Elisete; WOORTMANN, Ellen F. Mulheres em contextos rurais. Vivências, v. 1, n. 43, 2014.

SCOTT, Russell Rarry. Família, gênero e poder no Brasil no século XX. Boletim Informativo Bibliográfico, n. 58, p. 29-78, 2004. 
SCOTT, Parry; CORDEIRO, Rosineide Moura; GOMES, Fernanda Sardelich Nascimento. Políticas e práticas entre mulheres rurais na busca de autonomia e igualdade. AntHropológicas, v. 23, n. 1, p. 9-11, 2012.

SCOTT, Parry; QUADROS, Marion. Desenvolvimento, poder, gênero e feminismo. Cadernos Pagu, n. 52, 2018. https://doi.org/10.1590/18094449201800520000

SIMÓES, Júlio Assis; CARRARA, Sergio. O campo de estudos socioantropológicos sobre diversidade sexual e de gênero no Brasil: ensaio sobre sujeitos, temas e abordagens. Cadernos Pagu, Campinas, n. 42, p. 75-98, 2014. https://doi.org/10.1590/0104-8333201400420075

SÍVORI, Horácio et al. "Fundamentalismos", sexualidade e direitos humanos: interrogando temas, expandindo horizontes. Sexualidad, Salud y Sociedad, n. 26, p. 171-180, 2017. https://doi.org/10.1590/1984-6487. sess.2017.26.09.a

SOUZA, Márcio; FRANCH, Monica. Condição e trânsito? Articulando as categorias gênero e geração. Caderno Espaço Feminino, v. 25, n. 2, 2012.

SOUZA, Rolf Malungo de. Um panorama sobre as discussōes sobre gênero, masculinidade e poder. Antropolítica, n. 34, p. 11-15, 2013.

TEMPESTA, Giovana A.; CARNEIRO, Rosamaria G.; FLEISCHER, Soraya. Das múltiplas faces da fertilidade: Pensando uma antropologia dos úteros. Amazônica, v. 10, n. 1, 2018. http://dx.doi.org/10.18542/amazonica. v10i1.5851

TORNQUIST, Carmen Susana; SILVA, Cristiane Bereta da; LAGO, Mara Coelho. Dossiê Aborto. Estudos Feministas, v. 16, n. 2, p. 631-637, 2008. https://doi.org/10.1590/S0104-026X2008000200017

VENCATO, Ana Paula; TARNOVSKI, Flávio Luiz. Parentalidades, conjugalidades e gênero. ACENO, v. 5, n. 9, p. 11-14, 2018. 


\title{
Balanços bibliográficos e ciclos randômicos: o caso dos futebóis na antropologia brasileira
}

\author{
Luiz Henrique de Toledo
}

\section{Preâmbulo}

em ciências sociais, de tempos em tempos, publicam-se textos cujo propósito é apresentar paradigmas conceituais e estratégias metodológicas adensados pela constante prospecção de fenômenos empíricos. São os chamados balanços bibliográficos, textos que invocam a ideia de um cenário, ou que remetem a outra alegoria, a do pano de fundo do qual se destacam algumas "imagens" e ocultam-se outras. $\mathrm{O}$ corpus que alimenta tal empreitada decorre das pesquisas que se espraiam pelos inscritores canônicos textualizados, genericamente denominados de trabalhos acadêmicos.

Há tempos, autores como Latour e Woolgar (1997) definiram inscritores como parte dos procedimentos que levam aos registros dos experimentos científicos na elaboração de enunciados, fazendo com que as inscriçôes (os argumentos em suas formas literárias de apresentação) apareçam como procedimentos finais de um processo racional de descoberta. Inscritores acomodam aquilo que, de modo geral, crê-se como sendo o desvelar de porçóes de uma dada realidade externa, objetiva, portanto, investigativa. Mas a natureza externalizada na forma de fenômenos já se constitui, advertem os autores, como produto dos procedimentos de máquinas inscritoras, que objetivam tais fenômenos ou a eles conferem existência própria sob condiçóes específicas.

Dito de outro modo, as coisas não estão simplesmente dispostas na natureza à espera da descoberta pelos cientistas, são dela extraídas nos processos de depuração realizados pelas ciências. Há um duplo movimento de invenção, tanto dos procedimentos (técnicas, máquinas, textos etc.) quanto da natureza ou "real" a ser investigado. Tais observaçôes, feitas a partir das ciências da natureza, valem, em boa medida, para a prospecção daquilo que vulgarmente, nas humanidades e de modo geral, chamamos de "realidade social".

Interessa a este texto especular sobre um recorte, o futebol pensado por um conjunto representativo de intelectuais brasileiros, engendrado pela bibliografia tanto como uma "realidade social", fazendo dele um assunto sério, quanto metáfora que se estendeu aquém e além da perspectiva científica. Ambos os modos pelos quais o futebol é simbolizado amparam continuadamente as abordagens a ele destinadas, implementadas por seus motivadores, incluindo aí todos nós, os antropólogos esportistas.

IUniversidade Federal de São Carlos - São Carlos (SP), Brasil. E-mail: kikeppgas@gmail.com 
Dispersos e muito condicionados por esforços individuais, ${ }^{1}$ dissertaçôes, teses ou artigos mais avulsos estimulam as interlocuçóes entre pares diretos (não raramente diletos), laterais ou potenciais que, quando cotejados nesses conhecidos balanços bibliográficos, são expostos às sínteses de fatura exegética que orientam a fortuna crítica e os "estados da arte" de temas específicos, indicando o grau de maturidade e formaçáo dos emaranhados e das frentes de expansão investigativas.

Balanços bibliográficos circunscrevem ou tentam sintetizar um conjunto de textos e autores tornando-os de algum modo "aparentados", servindo de averiguação de uma produção que se pretende reconhecida. $\mathrm{E}$ a despeito da aleatoriedade na escolha de objetos aqui e acolá, intenta-se fortalecer o surgimento de temáticas, áreas e subáreas inteiras de pesquisa no esforço de direcionar, divisar e visibilizar essas investigaçôes potencialmente correlatas.

Pari passu segue a lógica da oferta de descritores institucionais que passam a con- centrar tais emaranhados de "objetos" (antropologia do Estado, da saúde, da alimentação, dos esportes, da ciência, entre muitas outras), bem como promover a circulaçâo de expressōes geoanalíticas que alcançam o poder de sínteses (perspectivismo, pós-estruturalismo, pós-social etc.). De modo que se configuram movimentos que seguem um vetor na direção da dispersão ao adensamento (de inscritores, de pesquisadores, de conceitos, de temas etc.).

Balanços servem de guias bibliográficos e cumprem evidenciar formas de abordagem que levam a prospectar lacunas empíricas e teóricas, identificar inserçôes institucionais, elencar relevâncias e hierarquias de centros de pesquisa, avaliar contribuiçóes e limites teórico-metodológicos e acomodar ou desacomodar os pesquisadores autores no interior dessas redes parciais.

Quando promovido à temática, o fenômeno passa a acolher seguidos balanços bibliográficos e textos exegéticos. Tal movimento implica em mais adensamento,

1 Processos de produção científica geram protocolos específicos de divulgação, nesse sentido vale notar como outras áreas vêm as ciências sociais no tocante ao tema da autoria: "O International Committee of Medical Journal Editors, criado em janeiro de 1978, em Vancouver, tem por objetivo o estabelecimento de critérios comuns para a publicação de artigos científicos na área da saúde [...] Alguns alunos, especialmente em nível de doutorado, necessitam de tão pouco auxílio, que podem ser considerados autores únicos de seus trabalhos. Esta situação ocorre mais frequentemente na área de Ciências Humanas, onde a produção é mais pessoal e depende menos do trabalho realizado por uma equipe de pesquisa. Na área da pesquisa em Ciências Biológicas e da Saúde, por exemplo, esta situação é mais difícil de ocorrer [...]”. (Goldim, 2007, grifo meu). José Roberto Goldim (2007), Aspectos éticos, legais e morais relacionados à autoria na produção científica. Disponível em: <https://www.ufrgs.br/bioetica/autor. htm>. Acesso em: 19 fev. 2020. Modelos de colaboração coletiva tais como Creative Commons, Science Commons, autoria coletiva progressiva (cc) ainda se mostram tímidos nas ciências humanas em geral, que seguem modelos que primam pela autoria individual na produção das carreiras universitárias. Um exercício interessante na antropologia brasileira foi a Rede Abaeté: "No final de 2004, dois professores do Programa de Pós-Graduação em Antropologia Social do Museu Nacional (Universidade Federal do Rio de Janeiro - UFRJ), Marcio Goldman e Eduardo Viveiros de Castro, idealizaram a Rede Abaeté de Antropologia Simétrica [...]" onde se deu a "[...] criação de uma página wiki, na qual é possível desenrolar discussões e produzir textos coletivos, (no sistema wiki, toda pessoa que acessa a página pode mudar o conteúdo do que lê, e todas as outras pessoas que acessam podem ver essas modicaçōes)'”. Aristóleles Barcelos Neto, Danilo Ramos, Maíra Santi Bühler, Renato Sztutman, Stélio Marras e Valéria Macedo. "Entrevista com Eduardo Viveiros de Castro e Marcio Goldman", Carbono - Natureza, Ciência e Arte. Disponível em: <http://revistacarbono.com/artigos/02abaete-rede-de-antropologia-simetrica/>. Acesso em: 20 fev. 2020. Originalmente publicada em Cadernos de Campo, São Paulo, n. 14/15, p. 1-382, 2006. 
diagnosticado como um bom sinal de que as disputas por narrativas já podem ser visibilizadas menos como "estados da arte" sobre determinado tema e apontar para dinâmicas mais relacionais. Nesse sentido, balanços bibliográficos servem tanto para expor e correlacionar substantivamente os trabalhos quanto para prospectar e mover de quando em quando as fronteiras que abrigarão o conjunto de pesquisas e pesquisadores para além dos marcadores formais das instâncias acadêmicas.

"Estados da arte", e que se tenha em mente algumas das extensões metafóricas do próprio termo "estado" como condição de instanciação classificatória visando essencializaçóes de toda ordem (Herzfeld, 2014), se prestam a conter o aparente caos que se instaura na miudeza ou no varejo da produção científica, que inevitavelmente se dispersa e se entrechoca ao tentar se perpetuar institucionalmente.

Partimos da ideia de que balanços bibliográficos, expressóes mais técnicas para "estado da arte", nos servem como inscritores inventados para auxiliar na descoberta de pontos nodais da produção de redes concorrentes, tais como novos recortes empíricos, escopos e escalas temáticas, inflexóes teóricas, questóes epistemológicas. Em que pesem os desafios impostos a qualquer ciência, é óbvio também que os rumos que as abordagens tomam no interior do debate acadêmico são motivados por demandas vindas de fora, ou de muitos foras inventados, redes discursivas e contextos sócio-históricos que comprometem (e turvam, redirecionam) os olhares dos pesquisadores.

Somada a tudo coroa-se a rotina laboral nas universidades, onde, por intermédio das disciplinas ofertadas em cursos de graduaçáo e pós-graduação, núcleos e laboratórios, os temas convertidos em temáticas povoarão salas de aula, dossiês em revistas, coletâneas, reunióes, encontros científicos e, por fim, balanços ou ensaios bibliográficos que testam as conjunturas e a relevância deste ou daquele tratamento ou abordagem, mobilizando os emaranhados acadêmicos para muito além de seus objetos.

Reticentes em relação à dispersão etnográfica, e impondo uma visão sociológica mais estrita, muitos balanços bibliográficos cumprem corrigir tais dinâmicas aleatórias enunciando a produção em torno de algum tema como produto histórico de ações conscientes, inconscientes e ideológicas, desferidas por seus próprios atores e seus interesses. E diante do "real", última instância a ser desvelada e ou detida, impóem-se, nesse caso, constructos objetivistas e tipológicos de classificação, reagrupando e ordenando pesquisas em grupos de estudo, tipologizando contextos de produção, familiarizando ou desfamiliarizando autores e aportes conceituais.

Alguns balanços podem ser concebidos como mais cartográficos, rearranjando ou arrumando os temas, recortes e autores em inscritores quantitativos e bibliométricos, chamando a atenção para a importância, a diversidade e a qualidade da produção em tela, tomando o tema como coisa externa ou real. Outros propóem sínteses críticas reflexivas, "escavaçôes" profundas (Souza; Marchi Júnior, 2017), externalizando o próprio conhecimento como sendo uma espécie de última fronteira do esforço intelectual na prospecçáo do mesmo real. A despeito de ao menos inquirir sobre a possibilidade de tomar qualquer cultura acadêmica como desdobramento do processo inventivo cultural, concentram esforços sobre essa produção acumulada, constituindo sociologias, histórias e antropologias dos intelectuais e "seus" temas. 
Partindo da concepção de que a cultura não é tăo somente algo (um sistema, um conjunto de artefatos, amálgama de ideias e representaçóes), mas o próprio movimento ou conjunto de relaçóes inventadas permanentemente por qualquer um (de intelectuais a torcedores de futebol), talvez outro deslocamento possa ser sugerido a partir das recomendaçóes mais gerais feitas por Roy Wagner (2010), autor praticamente retido na seara antropológica, mas ignorado como inspiração teórica e metodológica nos estudos sobre futebol. Wagner chama a atenção para as motivaçôes de natureza simbólica e de controle em torno do objetivismo que clama pela descoberta dos chamados interesses ocultos na presunçáo de um real colocado como estado ontológico universal.

No caso das ciências sociais, inventamos a sociedade, nossa realidade, como sendo essa entidade imanente e ao mesmo tempo externa passível de objetivação (Pinheiro, 2004), coisa tangível e instância última suportada pelas noçôes de "social", "cultural", promovendo correlatos conceituais de grande persuasão narrativa como "estrutura", "campo", "sistema".

Não há espaço, obviamente, para retomar aqui essas implicações "pós-sociais", mas nos inspirar em algumas de suas proposições que podem servir para problematizar uma perspectiva hierarquizante inerente à ideia sobre esses balanços. Só ressalto que há pouco rendimento em tomar uns como sendo balanços "superficiais", porque são mais cartográficos, e outros mais "profundos", porque são "epistemológicos". O interesse aqui é outro, até mesmo porque não pretendo replicar, para os balanços, novas tipologias. Partimos, então, da singela alegoria de que balanços bibliográficos balançam, se movimentam, e, ao contrário de evocar adensamentos, fluidificam o conhecimento acumulado sobre determinado assunto. Tomo-os menos como pano de fundo fixo para assumi-los como figuras agentivas em nosso metiér.

De uma perspectiva mais etnográfica, tendo a ver os balanços bibliográficos, assim como as pesquisas e os textos que os alimentam, como portadores de uma irredutibilidade criativa infinitesimal e espécie de alteridade diante dos modelos sociológicos sistematizadores, conservando das pesquisas um certo frescor randômico que abre e não encerra ou cerca os debates.

Por isso mesmo realizar um balanço bibliográfico sobre alguns balanços da produção sobre futebol não induz a replicar mais um reducionismo ou mero atalho. Em antropologia, há um bom tempo recomenda-se aos pesquisadores que se encontram no momento de redação de suas dissertaçóes e teses a evitarem as revisóes ou apanhados bibliográficos apartados da produção dos dados etnográficos.

Faço agora a mesma recomendação na leitura dos balanços bibliográficos que, não inertes ou pairando sobre as bibliografias que reúnem, a elas devem ser incorporados como inscritores que se póem em relaçáo com o conteúdo que expõem e tentam circunscrever, sem com isso deixar de perceber que, ao organizar e reconstituir campos de saber, também os tornam elementos de um ciclo sempre randômico de novas possibilidades investigativas no interior da produção científica.

2 Para uma síntese sobre a operacionalidade do conceito de sociedade em antropologia, consultar vários textos reunidos em Strathern (2014). 


\section{O futebol e a identidade nacional}

As muitas práticas dos futebóis ${ }^{3}$ que se formalizaram em experiências continuadas Brasil afora tornaram-se, nas últimas cinco décadas, objetos dessa dinâmica acadêmica, bastante desigual, é bem verdade, de prospecção, captura, reprodução e estabilização de uma área temática que, pode-se dizer, fez sua aparição no cenário intelectual universitário nacional no final dos anos 1970.

Balanços cartográficos mais cuidadosos dáo conta de textos pouco ou nada conhecidos da maioria dos intelectuais esportistas, como segue: "[...] as primeiras contribuiçôes dentro das ciências humanas para o estudo do futebol datam da década de 1940: o ensaio 'O papel da magia no futebol', de Mário Miranda Rosa (1944), e a resenha do sociólogo Luiz Aguiar Costa (1947) do livro de Mário Filho, 'O negro no futebol brasileiro’, então recém-lançado” (Giglio; Spaggiari, 2010, p. 295). ${ }^{4}$

Intelectuais de carreira acadêmica em ciências sociais ensaiaram, nos anos 1970, suas primeiras provocaçôes a respeito do futebol pela imprensa escrita, exemplos mais notórios podem ser consultados em Baeta Neves (1979) ou Miceli (1977a; 1977b;1978). Mas a aparição acadêmica destacada, uma raridade nas narrativas das ciências estatais ou normais, foi justamente feminina, identificada nas pesquisas de mestrado de Simoni Lahud Guedes e que redundaram em sua dissertação intitulada $O$ futebol brasileiro: instituição zero, defendida no
Museu Nacional e orientada pelo professor Castro Farias, em 1977.

Deslocar o eixo Rio-São Paulo, tanto da produção intelectual específica quanto das narrativas sócio-históricas pretensamente hegemônicas que pautaram parte do discurso socioantropológico sobre futebol, foi um esforço espraiado que atingiu excelentes resultados, implementado por muitos pesquisadores solitários ou centros, grupos e laboratórios de pesquisa que desvelaram a ocorrência empírica dessa prática, multiplicando narrativas e problematizando os reducionismos de uma sociologia e antropologia regional domiciliada no Sudeste. Essa é uma advertência e um incômodo explicitado em alguns dos balanços bibliográficos mais recentes, que problematizam questóes factuais pontuais, essencializadas e difusionistas, tais como onde surgiu o futebol, quem escreveu a primeira tese etc.

Essa pequena nebulosa de intelectuais em torno do futebol firmou-se nas ciências humanas, destacando-se, entre elas, a contribuição da antropologia, que paulatinamente passou a abrigar a sociologia dos esportes (Da Matta et al., 1982), a antropologia do esporte (cf. Guedes, 2011), os etnoesportes (Toledo, 2001); etnodesportos (Fassheber; Rocha Ferreira, 2006; Freitag; Fassheber, 2011), os estudos sociais do esporte (cf. Gastaldo, 2010; Spaggiari; Machado; Giglio, 2016), a antropologia do futebol (cf. Guedes, 2010), a antropologia das práticas esportivas (cf. Toledo, 2001; Costa; Toledo, 2009; Guedes, 2010).

3 O termo "futebóis" ganhou uma revisão e apuro crítico em Damo (2018). O autor indicará, pelo menos, dois amplos contextos, epistemológico e político, em que esse descritor passou a problematizar algumas guinadas e a expansão dos estudos em ciências sociais.

4 Vale apenas mencionar que Mário Miranda Rosa, embora um educador acadêmico, não era exatamente um cientista social. 
Esses jogos de descritores e nomeaçôes de subáreas têm obviamente relações de contiguidade e afinidades entre si e dizem respeito às linhagens acadêmicas, aos enfoques teórico-metodológicos que ostentam e que acabam produzindo um certo esgarçamento conceitual sobre os esportes e o futebol em específico. Circulam também, nesse meio, termos que poderiam ser tomados por alegóricos ou divertidos, portanto não sérios, e que, por isso mesmo, são curiosamente considerados menos técnicos e curiosamente distantes do "real", tais como a provocativa "antropologia do óbvio" (Da Matta, 1994), "antropologia do avesso" (Guedes, 2010)5 ou ainda a "socioantropologia da bola" (Morais; Ratton; Barreto, 2008).

A despeito da carga um tanto jocosa que tais expressóes oferecem, tornam-se exemplos da tensão que os trabalhos de fatura acadêmica não deveriam negligenciar, ou seja, algo que tem a ver com as dimensóes da "coetaneidade" (Fabian, 2013) entre narradores diversos, alguns mais "objetivistas", outros mais alegóricos, não obstante todos, na verdade, metafóricos porque próximos aos níveis das "experiências" (Goldman, 2006) que os motivam diante de um assunto tão ubíquo.

Já adiantando uma discussão, metáforas são compreendidas aqui não apenas como figuras de linguagem a se colocar no lugar de outras coisas, conservando essas "outras coisas" em uma representação inerte ou estável, preservadas das relações que possam estabelecer com elas, mas implicando, sobretudo, um senso dialético entre a linguagem de conhecimento comum e a científica, transformando metáforas da vida em cultura acadêmica e vice-versa. Ou, dito de outra maneira, levando-se também em consideração que "[...] a característica fundamental da antropologia seria o estudo das experiências humanas a partir de uma experiência pessoal" (Goldman, 2006, p. 167).

Inicialmente uma prática corporal tomada pelos juízos higienistas, eugenistas, lúdicos e políticos, obviamente que não necessariamente nessa ordem linear temporal, o jogar futebol ganhou atenção e olhares provenientes de muitos lugares, gestando um campo espraiado de sociabilidades organizadas em associaçôes, clubes e organizações, tal como uma historiografia (Meihy; Witter, 1982; Franco Júnior, 2007; Pereira, 2000; Melo, 2001; Santos, 2010; Silva, 2016; Streapco, 2016; Souza, D. A., 2018; Souza, J., 2018; Burlamaqui, 2019) ou trabalhos de fatura histórica em outras áreas (Caldas, 1990; Melo; Genovez, 1998; Giglio, 2013) seguiram e seguem mapeando.

Mobilizo aqui um conceito basilar para compreender o processo de espraiamento e potência gregária assumida pelo futebol, condição para que valores políticos, econômicos e estéticos fossem a ele agregados, e que diz respeito aos modelos de sociabilidade que redundaram em essencializaçóes de toda ordem: das práticas mais erráticas entre convivas reunidos nos contextos ou horas de lazer às formalizações, associações recreativas de variados segmentos sociais (Pereira, 2000; Santos, 2010; Silva, 2016; Favero, 2018), culminando com o espraiamento das fronteiras clubísticas que paulatinamente concentraram em torno de si dezenas, centenas e milhôes de seguidores. Isso porque o exame das "estruturas de sociabilidade", seguindo

5 Antropologia do avesso, a bem da verdade, é um termo que a autora atribui a toda produção damattiana, o que inclui os textos sobre futebol. 
uma orientaçấo historiográfica que estreitou diálogos com a antropologia, produziu seus métodos que delinearam "[...] em filigranas as mudanças de uma sensibilidade coletiva, talvez mais que a evolução de uma problemática histórica" (Vovelle, 1987, p. 238).

Nascente com os esportes, foi a atenção jornalística quem primeiro textualizou a novidade corporal futebolística, adestrando os olhares correlacionados ao jogar e às percepçóes sensoriais que formatariam o alastramento de práticas (masculinas e femininas, diga-se) nas nascentes metrópoles na passagem do século XIX para o XX (Sevcenko, 1992; Pereira, 2000; Santos, 2010; Del Priore; Melo, 2009; Bonfim, 2019).

As ciências sociais praticadas no Brasil, mais jovens que ambos os fenômenos - $\mathrm{o}$ advento dos esportes e a tateante imprensa esportiva -, começariam a polir conceitualmente, mas também ideologicamente, segundo algumas abordagens que promoveram balanços críticos à produção sociológica do futebol (Souza, 2014; Souza; Marqui Júnior, 2017; Souza, J., 2018), o lugar dessa prática corporal na sociedade brasileira. Aparecem destacados neste momento alguns ensaios ecléticos presentes em autores, digamos, que usufruíram de métodos mais híbridos, tais como Gilberto Freyre, Mario Rodrigues Filho e Anatol Rosenfeld, comumente tomados como aqueles que metamorfosearam uma prática em discurso (estético, filosófico, sociológico e antropológico).

Essa protogeraçáo, se assim pudermos reuni-los, germinaria a temática do futebol que seria acomodada, mais sistematicamente, por uma outra camada de intelectuais mais estabelecidos, na rotina das carreiras universitárias, tal como se conhece hoje e que passaram a dar atenção a esse esporte, seja como metáfora e/ou realidade social.

Coube, no contexto da antropologia, pela primazia de etnólogos como Roberto $\mathrm{Da}$ Matta e um seleto grupo de pesquisadores, ${ }^{7}$ a tarefa de incorporar o futebol no rol de objetos que compuseram um primeiro agregado temático. É comum identificar rapidamente em Da Matta uma correlação estreita da sua obra com os autores seminais que inauguraram a protogeração dos estudos sobre futebol. Aliás, é o próprio autor que se coloca na posiçáo de continuador de um pensamento social brasileiro (Da Matta, 1979). ${ }^{8}$

6 Não caberá aqui tecer uma discussão mais detida sobre essas duas instâncias gerativas e da ordem dos sentidos que amparam, na minha concepção, as noçóes de jogo e esporte, quais sejam, o olhar e o jogar, esforço analítico que ofereci na minha tese de titularidade, renomeando tais sentidos pelas expressóes dialéticas olhar jogado e jogar olhado. A referida tese foi defendida no final de 2019 e até o momento encontra-se inédita.

7 Excetuando Simoni Lahud Guedes, os outros autores que constam de Universo do Futebol, para além de Roberto Da Matta, que no ano de publicação (Da Matta et al., 1982) já era uma autoridade reconhecida em etnologia Jê, Luiz Felipe Baeta Neves e Arno Vogel mobilizavam, à época e posteriormente, interesses de pesquisa muito distintos. Apenas por uma rápida consulta aos currículos lattes de ambos constatamos alguns temas e linhas de pesquisa as quais se debruçaram ao longo de suas carreiras: o primeiro desenvolveu pesquisas sobre instituiçóes jesuíticas, arqueologia histórica e memória, e o segundo, antropologia urbana, meio ambiente, movimentos sociais, antropologia das populaçóes afro-brasileiras. Há de se mencionar um quinto incluído autor ausente em Universo do Futebol, Ricardo Benzaquen de Araújo, que talvez tenha produzido o segundo trabalho acadêmico em antropologia sobre futebol, sua dissertação de mestrado Os gênios da pelota, autor que logo se enveredaria pelo pensamento social brasileiro, destacando trabalhos sobre Joaquim Nabuco e Gilberto Freyre (tese de doutorado) (Araújo, 1980).

8 Porém, há de se levar em alta conta sua formaçăo propriamente etnológica que resultou em seus estudos sobre os Apinajés em $O$ mundo dividido (Da Matta, 1976), para que se complete uma crítica mais razoável e menos intempestiva à sua visão dual sobre a relação que estabelece e projeta para a díade futebol e sociedade. 
Para além da problemática relacionada ao imbricamento entre cultura, sociedade e futebol, também presente na protogeração, esses primeiros trabalhos em antropologia ofereceram alguns aportes conceituais que devem ser lidos como uma marca inalienável desses antropólogos esportistas, que pautaram e formaram seguidas geraçóes dentro dessa específica área do conhecimento e alhures.

Damo, em um criativo e sintético balanço bibliográfico, aponta com muita acurácia para essa questáo dos usos literalizados do termo esporte pela sociologia eliaseana comparado às mediaçôes que o termo jogo impôs ao conceito de esporte no Brasil: "mesmo estando na Inglaterra, onde o futebol sobressai em relação às demais modalidades esportivas, nota-se que na publicação conjunta de Elias e Dunning (1992) fala-se seguidamente em esporte - mesmo que a partir do futebol [...] ao passo que na produção brasileira da primeira geraçáo, sobretudo, o futebol aparece como descolado, a tal ponto de $\mathrm{Da}$ Matta [...] sugerir até mesmo uma oposição entre sport e game, situando o futebol brasileiro no registro deste, ou seja: como jogo" (Damo, 2016, p. 328).

Vista sobretudo de "fora" das ciências sociais, mas em parte também a partir do seu interior, a produção antropológica sobre futebol, às vezes, é reduzida a um "culturalismo" espectral, evocando um descritor anacrônico do ponto de vista do desenvolvimento das teorias ditas sociais.

Todavia, sem desconsiderar os usos e abusos conceituais que o termo culturalismo possa evocar, tais reificaçôes, que pesam desmedidamente no concerto da crítica, impôem ao termo culturalismo um plano meramente representacional de algo mais determinante e "real", se esquivando do debate sobre o estatuto epistemológico da etnografia, presumida, não raramente, como mera técnica de pesquisa subsidiária. Essa crítica também investe na ideia de que há, ao cabo de tudo, continuidades e aproximações um tanto perniciosas entre o senso comum, com suas metáforas, e o objetivismo amparado nas teorias sociológicas bem estabelecidas.

Ao contrário dessa visão, a intenção aqui é tratar metáforas e teorias como domínios "igualmente diferentes" (Goldman; Viveiros de Castro, 2006), o que não implica em obliterar relaçóes de poder que possam tensionar os domínios do senso comum e da ciência. De todo modo, problematizar tais fronteiras objetivistas é todo esforço que as etnografias podem explicitar.

A crítica, embora seja pontualmente atenta em relação aos aspectos que tematizam as relaçóes entre um determinado futebol hegemônico e outra noção problemática, identidade nacional, no interior de parte dessa produção antropológica, peca por um reducionismo e objetivismo já há muito problematizado na antropologia. Negligenciar o alcance epistemológico das etnografias em muitos desses trabalhos e desconhecer a crítica ao estatuto de cientificidade que se definiu pela conhecida virada ontológica na disciplina há algumas décadas (Holbraad; Pedersen, 2017; Viveiros de Castro, 2018) é tratar seletivamente toda uma área de pesquisa.

\section{De balanços e futebóis}

como este não é um texto de mapeamento da produção antropológica sobre a temática do futebol, coextensivamente dos esportes, venho entremeando e destacando uma diminuta bibliografia formada por balanços bibliográficos, que, de dentro e fora dos muros mais cerrados da antropologia, cumprem estabelecer algumas diretrizes de leitura para quem se inicia nos estudos so- 
bre futebol ao mesmo tempo em que pautam itinerários bibliográficos de pesquisas em andamento.

Alcançar uma produção representativa pela via de um único balanço bibliográfico sobre a categoria genérica e problemática futebol, pretensão hoje descartada por quase todos aqueles que se voltam à tarefa dos balanços, certamente é empreendimento intelectual descabido, ou viável somente se levar em consideração, tal como esboçado no tópico seguinte, a importante segmentação temática que essa bibliografia alcançou, multiplicando cada vez mais as demandas políticas e, por consequência, acadêmicas na abordagem de outros futebóis para além do futebol dito espetacularizado (Damo, 2007).

Por isso, uma ampla bibliografia híbrida e conexa sobre futebol como fenômeno pervasivo só poderia merecer uma atenção sistemática desde que tomada por parcial e segmentada, ou seja, tratada por balanços bibliográficos que recortem aquilo que defino por temáticas-demandas que vão além da contenção estimulada pelas searas acadêmicas.

São inúmeros trabalhos que circulam e que tematizam Copas do Mundo, sociabilidade torcedora, mídia esportiva e recepção, ${ }^{9}$ futebol e estética popular, futebol de várzea, futebol de mulheres etc (Goellner; Kessler, 2018). Alguns exemplos de balanços mais circunscritos já foram oferecidos: futebol e gênero, ${ }^{10}$ futebol e marcadores raciais, ${ }^{11}$ futebol e urbanizaçáa ${ }^{12}$, futebol na literatura ensaística, ${ }^{13}$ e há outros ainda por realizar, como comportamentos de coletivos torcedores, ${ }^{14}$ futebol e justiça, futebol no contexto ameríndio, Copas do Mundo na perspectiva das ciências sociais, etnografias sobre megaeventos, enfim, algumas poucas sugestóes que podem ser seguidas.

Alguns balanços bibliográficos (Toledo, 2001; Alabarces, 2004; Guedes, 2010;

9 Conforme Soares (1994); Gastaldo (2002); Andrade (2013).

10 Atestando o impacto da temática de gênero, o enfoque na relação com os esportes já foi objeto de balanços bibliográficos de caráter mais historiográfico presentes em Goellner (2013).

11 Por exemplo, Leite Lopes (1994; 1997); Gordon Junior (1995); Moura (1998); Soares (1997); Silva (2006); Silva (2008).

12 A bibliografia sobre esportes e futebol em específico realça ou superdimensiona, segundo Dias (2013), a relação estreita entre a emergência dos grandes centros metropolitanos que despontaram no Brasil na virada do século XIX para o XX e a popularização das práticas esportivas. Em um sucinto e instigante balanço bibliográfico, aponta como algumas regiốes mais periféricas igualmente colaboraram para a difusão dos esportes em território brasileiro. Um bom exemplo pode ser consultado em Rigo (2004). Nessa chave podem ser acolhidos os muitos futebóis metropolitanos denominados de "pequenos" ou varzianos, abordados, por exemplo, em Guedes (1977); Magnani e Morgado, (1996); Santos (2001); Hirata, (2005); Favero (2018).

13 Conforme Buarque de Hollanda (2017).

14 O viés "torcedores" contribuiu para que os acadêmicos esportistas nacionais (antropólogos(as), sociólogos(as), historiadores(as), geógrafos, pesquisadores e pesquisadoras em educaçáo física, produzissem colaboraçôes pontuais em coletâneas, mas também redes internacionais e colaborativas de pesquisas. E, dentro dessa paisagem, nomes importantes como Pablo Alabarces, Eduardo Archetti, Eric Dunning, Martin Curi Spörl, José Garriga Zucal, Matías Godio, Verónica Moreira, Santiago Uliana, Gastón Gil, Anastassia Tsoukala, Richard Giulianoti, Patrick Mignon, Nicolas Houcarde, entre muitos outros, passaram a colaborar e ou frequentar a bibliografia nacional contribuindo de uma perspectiva comparativa para elencar e problematizar um conjunto de temas como relaçóes raciais no futebol, feminismo, política e poder, judicialismo e violência, Estado e, no geral, comportamento torcedor. Por exemplo, ver Armstrong e Giulianotti (1997); Alabarces, Conde e Dodaro (2005); Godio e Uliana (2011), Zucal (2013), Buarque de Hollanda e Reis (2014); Spörl (2014); Buarque de Hollanda e Aguilar (2017). 
Spaggiari; Machado; Giglio, 2016) registram que a rotinização dos debates acadêmicos em ciências sociais sobre esportes iniciou seus primeiros movimentos gregários nas reuniōes da Associação Brasileira de Antropologia (ABA) em 2000. ${ }^{15}$ Por ocasião da edição ocorrida em 2004, Guedes e Toledo (2004), que coordenavam àquela época o grupo de trabalho, lançavam algumas hipóteses em relação ao lugar da antropologia naquele contexto:

Se, como hipótese geral, a subárea Antropologia do Esporte tem sido marcada por uma certa multidisciplinaridade em relaçáo às contribuições recebidas nos encontros científicos, sobretudo quando coordena tais eventos (RAM ou RBA), o que a distingue de outras áreas mais consolidadas, cujas especializações as tornam fortemente endogâmicas, tais como os grupos de etnologia, a antropologia do esporte ocupa, ao menos até o presente, um papel de receptora de pesquisadores, temáticas e novas abordagens. $\mathrm{O}$ que, em princípio, poderia confirmar definitivamente o sucesso da abordagem antropológica sobre os esportes desde sua maior sistematização em Da Matta et al. (1982). Mas esta acolhida ou "troca" intensa tem revelado seus próprios limites e impasses. Se, por um lado, a contribuição de historiadores, psicólogos, educadores, geógrafos é fundamental para consolidar a legitimidade temática diante de temas e pares no campo científico, por outro lado, essa "troca" revela-se menos evidente no que diz respeito às demandas específicas dos próprios antropólogos, que assumem na "troca" uma postura menos simétrica, em parte sustentada pela centrali- dade e um certo pioneirismo ostentado pela disciplina na investigação dos esportes no Brasil, posicionando-se como doadora de recortes empíricos, conceitos e métodos, bem como assumindo para si mesma, num certo sentido, uma postura menos multidisciplinar (Guedes; Toledo, 2004).

Nos anos subsequentes, esse panorama enunciado por Guedes e Toledo náo se confirmou porque o deslocamento de outros "acadêmicos esportistas", notadamente sociólogos, historiadores, geógrafos, educadores, comunicólogos, conferiu várias direçôes e intensidade à produção, com agendas investigativas para além dos temas canônicos que balizaram os estudos em antropologia social (ritual e drama, identidade nacional, futebol e representaçôes coletivas), diluindo sua área de influência que àquela altura, 2004, parecia uma forte tendência.

Em outro texto mais recente (2020), estendi essas observaçóes para o interior da própria disciplina: "É sabido que outras sociologias e antropologias (inclusive trabalhos de fatura etnológica) alimentaram e seguem contribuindo com os estudos sobre esportes e fenômenos lúdicos da perspectiva antropológica [...] O que faltaria a esse movimento antropológico em torno dos esportes inverter um pouco a direção e passar a contribuir metodologicamente e/ou conceitualmente com outras subáreas dentro da própria Antropologia? Ao menos, [...] as relaçóes com uma Antropologia urbana [...] parecem evidentes [...]", porém saindo da seara antropológica e "[...] quando folheamos as bibliografias de trabalhos oriundos de algumas outras áreas [...]" nota-se “[...] pouca contribuição nas

15 O ano de 2020 é a efeméride marcada por uma publicação da ABA a respeito dessas duas décadas de atividade de pesquisas apresentadas nas reunióes anuais, tais como se verifica no volume organizado por Camargo, Pisani e Rojo (2020). 
abordagens em Psicologia, pouco mais nas áreas da Economia e Administração, bem mais em subáreas da Educação física e contribuições que vão se adensando na medida em que se aproximam da História e outras Ciências sociais, em menor escala na Geografia e sobretudo Ciências políticas" (Costa; Toledo, 2020).

Destaco, para encerrar esta sessão e para efeitos de rápida visualização, uma pequena cronologia de textos que podem ser classificados como balanços bibliográficos ou textos mais exegéticos que circulam amparando e pautando teses, dissertaçôes e artigos que enfocam o futebol, seja na antropologia ou em outras áreas que tematizam esportes.

Importante notar que, paulatinamente, se váo somando a essa cronologia autores de outras áreas, embora a tendência a uma socioantropologização das análises se mantenha como argumento que instiga, ao se aproximar ou ao se distanciar dos temas prevalecentes em ciências sociais.

Como se nota, trata-se de uma listagem que deveria incorporar muitos outros trabalhos que resvalam as características dos balanços bibliográficos. ${ }^{16}$ Percebe-se também um esforço inicial da parte de antropólogos que tentaram produzir e orientar essas primeiras narrativas visibilizando a própria produção em contextos comparativos com outras searas acadêmicas, como a sociologia, a história e a educação física.

\section{1}

Luiz Henrique de Toledo. Futebol e teoria social: aspectos da produção acadêmica brasileira (1982-2002).

\section{3}

Simoni Lahud Guedes. Esporte e modernidade. Apresentação de dossiê.

\section{4}

Simoni Lahud Guedes e Luiz Henrique de Toledo. Antropologia do esporte: traçados interdisciplinares através das trajetórias.

Pablo Alabarces. Veinte años de ciencias sociales y deporte em América Latina: un balance, una agenda.

José Sérgio Leite Lopes. O estilo brasileiro de futebol, seus dilemas e seus intérpretes.

\section{9}

Ana Letícia Pedeski Ferreira. O estado da arte da sociologia do esporte no Brasil: um mapeamento da produção bibliográfica de 1997-2007.

\section{0}

Edison Luis Gastaldo. Estudos sociais do esporte: vicissitudes e possiblidades de um campo em formação.

Sergio Settoni Giglio e Enrico Spaggiari. A produçáo das ciências humanas sobre futebol no Brasil (1990-2009).

16 Alguns ensaios bibliográficos adquirem a densidade de muitos balanços bibliográficos, tais como Leite Lopes (1997) ou Franco Júnior (2010). Dossiês em revistas ou coletâneas de estudos também recebem para efeitos de apresentação dos trabalhos reunidos algum texto cujo tratamento guarda muito do estilo narrativo dos balanços bibliográficos, é o caso do já citado dossiê na revista Estudos de Sociologia do Programa de Pós-Graduação da Universidade Federal de Pernambuco (UFPE), denominado "Futebol, cultura e sociedade: contribuiçōes para uma socioantropologia da bola" (Morais; Ratton; Barreto, 2008), ou o texto de título lacônico, mas que esconde sua acuidade denominado de "Apresentação" (Alfonsi e Campos, 2014), que introduz o volume Futebol objeto das ciências humanas, fruto do I Simpósio de Estudos sobre futebol organizado pelo Núcleo Interdisciplinar de Pesquisas sobre Futebol e Modalidades Lúdicas (LUDENS-USP), Departamento de Antropologia da Pontifícia Universidade Católica de São Paulo (PUC-SP) e Museu do Futebol. 
Simoni Lahud Guedes. Esporte, lazer e sociabilidade.

\section{1}

Pablo Alabarces. Veinte años de ciencias sociales y deportes, diez años después.

Simoni Lahud Guedes. Os estudos antropológicos dos esportes no Brasil: perspectivas comparativas com a América Latina.

\section{4}

Juliano de Souza. O "esporte das multidóes" no Brasil: entre o contexto de ação futebolístico e a negociação mimética dos conflitos sociais.

\section{6}

Enrico Spaggiari, Giancarlo Marques Carraro Machado e Sergio Settoni Giglio. Apresentação da obra Por uma (nova) agenda de pesquisa sobre práticas esportivas.

Arlei Damo. Posfácio da obra Novas abordagens sobre o esporte em ciências humanas no Brasil.

\section{7}

Juliano de Souza e Wanderley Marchi Júnior. As linhagens da sociologia do futebol brasileiro - um programa de análise.

Arlei Damo. Romantismo e futebol nas ciências humanas brasileiras.

\section{8}

Juliano de Souza. A linhagem culturalista da sociologia do futebol brasileiro.

Arlei Sander Damo. Futebóis - da horizontalidade epistemológica à diversidade política

2020

Édison Gastaldo. Esporte, antropologia e comunicaçáo no Brasil: explorando encruzilhadas de um campo indisciplinar.

\section{Antropologias}

No balanço bibliográfico sobre futebol (Toledo, 2001) publicado na Revista Brasileira de Informaçóes Bibliográficas, conhecida no meio acadêmico nacional pelo acrônimo $\mathrm{BIB},{ }^{17}$ elenquei aquilo que à época ousava considerar como sendo a face da produção acadêmica mais visibilizada sobre a difusão do fenômeno futebol dentro das ciências sociais brasileira em um período curto e denso (1982-2002). ${ }^{18}$

Esse balanço, como se nota pela diversidade de referências diretas e colaterais, seguiu um amplo espectro de acomodaçáo do tema, aproximando-o à teoria antropológica clássica, distanciando-o de algum marxismo que já vinha acossado por releituras na antropologia (Da Matta et al., 1982), abrigando-o no interior da antropologia urbana e sociologia histórica, ${ }^{19}$ elencando

17 Publicação da Associação Nacional de Pós-graduação e Pesquisa em Ciências Sociais (Anpocs).

18 Anos que compreenderam importante ebulição política no país dado o ocaso do regime militar instalado em 1964, fortalecimento de movimentos sindicais, acirramentos de demandas vindas de fraçóes da sociedade civil em torno da Constituinte, redemocratização e movimentos de rua em prol das Diretas Já para presidente, crises como o impeachment do primeiro presidente eleito pós ditadura, seguidos planos econômicos implementados pelos governos federais de reajuste da pressão inflacionária cujos impactos incidiam diretamente no cotidiano. No âmbito fugidio do futebol masculino profissional, a seleção voltaria a vencer mais duas Copas do Mundo, 1994 e 2002, reaquecendo os temas da identidade nacional e futebol.

19 Aspecto bem retomado por Guedes (2010). 
alguns dos aportes conceituais até entâo em voga, sempre daquele meu ponto de vista, em um sobrevoo que indicava também um ou outro aspecto da institucionalização formal que despontava a partir daqueles estudos, acentuada ao longo da década de 1990. ${ }^{20}$ Depurava algumas poucas, mas persistentes, referências nacionais ou estrangeiras recorrentes nos trabalhos em ciências sociais daquele momento, não sem cometer importantes ausências que iniciativas posteriores couberam apontar. ${ }^{21}$

E assim, autores como Marcel Mauss (para as abordagens sobre representaçóes, corpo e técnicas corporais), Huizinga (para se pensar a extensão do conceito de jogo), Norbert Elias e sua abordagem sociogenética dos esportes (autor que na educação física ganharia uma projeção importante), ${ }^{22}$ algum Bourdieu (da teoria da prática), somados aos ensaios e insights propriamente damattianos e de autores de sua preferência, pautaram toda uma agenda de pesquisa e se dispersaram em contribuições em uma bibliografia que ganhou cada vez mais espaço nas variadas publicaçôes acadêmicas.

Em um amálgama de autores, destacadamente Geertz, Turner, Dumont, Roberto Da Matta ofereceu seu modelo pendular de "estrutura social", espécie de mandala que se desdobra em uma dialética com síntese a desvendar a lógica de uma virtude estética e moral brasileira que estaria no meio (Geiger; Velho, 2000), conjurando os chamados dilemas da nacionalidade, sendo o futebol, igualmente expressão da cultura, um deles.

De lá pra cá, outros textos ao estilo dos balanços bibliográficos focaram mais detidamente esses e outros tantos matizes da produção já suficientemente espraiada em artigos, resenhas, dissertações, teses, arguições em bancas, ${ }^{23}$ ora mapeando e indicando aspectos quantitativos dessa produção (Giglio; Spaggiari, 2010; Campos et al., 2017), ora reagrupando e reclassificando a bibliografia de uma perspectiva geracional e comparativa (Spaggiari; Machado; Giglio, 2016; Damo, 2016), ora aprofundando a análise sobre al-

20 Destacava à época a novidade e importante iniciativa vinda da sociologia implementada pelo professor Mauricio Murad: "O próprio futebol passou a ser tema de curso na grade curricular de ensino de graduação na Universidade do Estado do Rio de Janeiro a partir de 1994. Antes, em maio de 1990, foi fundado o Núcleo de Sociologia do Futebol, no departamento de Ciências Sociais, que procura veicular trabalhos e contribuiçóes através de um periódico" (Toledo, 2001, p. 135). Mais tarde, Murad reconstitui sucintamente aquele panorama de colaboração em que contextualiza o papel da Universidade do Estado do Rio de Janeiro (UERJ) e os esforços coletivos em acolher tais iniciativas a partir de 1994, conforme Murad (2017).

21 Outros balanços bibliográficos chamariam a atenção para autores como Thorstein Venblen, Eric Hobsbawn, ou ainda nomes mais contemporâneos diretamente relacionados às pesquisas sobre futebol, como Christian Bromberger, Richard Giulianoti, Eduardo Archetti, entre outros.

22 Damo fará uma importante observação a esse respeito: "Diferentemente dos antropólogos, os sociólogos e historiadores dedicados ao estudo do esporte no Brasil apropriaram-se muito mais da obra de Elias, e não sem motivos. O conjunto da sua produção tem implicaçóes epistemológicas mais próximas a essas disciplinas do que da Antropologia [...]" (Damo, 2016, p. 332). Só acrescentaria que algumas áreas da educação física voltadas para uma abordagem mais sociológica também se beneficiaram amplamente desse autor. Para a verificação dessa relação colaborativa entre sociologia e educação física, consultar, por exemplo, o apanhado feito por Murad (2009).

23 No livro Remexer anotaçôes: o trabalho de um arguidor antropólogo (Toledo, 2019a), no qual discuto o estatuto das arguiçôes como peça importante de interlocução acadêmica, selecionei vinte arguiçôes em que participei em bancas de mestrado e doutorado em alguns programas de pós-graduação, das quais uma trata do skate e sete tematizam o futebol. 
guns temas negligenciados, tais como política, Estado, poder e futebol (Alabarces, 2004; 2011; Guedes, 2010; Spaggiari, Machado; Giglio, 2016; Damo, 2016), ora reivindicando maior sinergia entre áreas contíguas de abrangência temática, particularmente a educação física e a comunicação (Gastaldo, $2010 ; 2020$ ), ora visibilizando a possibilidade de um pensamento social esportivo propriamente dito naquilo que ele se comprometeu em suas implicaçóes epistemológicas para a reflexão mais crítica sobre esse conhecimento (Souza; Marchi Júnior, 2017).

Para efeitos didáticos e extrapolando, um pouco, as consideraçóes de Damo, que somente a leitura integral do seu texto dirimirá essa falsa sensação tipológica ao revelar uma maior sofisticação e entrecruzamento de autores, conceitos e abordagens, faço uso da sua proposta em dividir em três geraçóes a produção brasileira sobre futebol (esportes).

A primeira o vincula à noção de nação:

o que se passa é que na divisão social do trabalho intelectual sobre o Estado-nação, essa instituição tão cara ao Ocidente, nota-se no espectro das Ciências Sociais uma tendência de se imputar à Antropologia (e poderíamos incluir a História nesse registro) a autoridade sobre a temática da nação [...] ao passo que sociólogos e cientistas políticos se ocupam sobretudo do tratamento das questôes envolvendo o Estado (Damo, 2016, p. 328).

Nessa primeira geração encontram-se as contribuições do e ao redor do antropólogo Roberto Da Matta, indicadas amiúde em praticamente todos os balanços bibliográficos.

Uma segunda geração despontaria sob a égide de outros conceitos menos abrangentes em seus propósitos epistemológicos, digamos mais tecnicizados pelas rotinas de pesquisa, tais como sociabilidade (Simmel, 2006; Waizbort, 2013; Maia, 2001; Magnani; Souza, 2007; Toledo, 2020) e lazer (Magnani, 2012; Guedes, 1977, entre muitos outros), mas que se ajustariam à prova etnográfica, imprimindo um afastamento da perspectiva ensaística que pode ser creditada, em boa parte, à primeira geração, sabidamente de composição mais heteróclita, congregando ensaístas (que poderiam definir, como já aludi, uma protogeração) e profissionais das ciências sociais.

Uma terceira geração traria questóes deixadas mais à margem pela segunda geração, tais como as relaçóes políticas e econômicas e o papel do Estado em sua multiplicidade de aproximaçóes (tensóes, conflitos) com demandas populares. ${ }^{24} \mathrm{E}$ no que diz respeito especificamente aos antropólogos nela inclusos, o corte se deu em relação à geração anterior, sem abrir mão do recurso oferecido pela etnografia e do controle das categorias nativas advindas dos contextos locais pesquisados.

Como bem salientam autores signatários dessa terceira geração, possivelmente em diálogo com outras antropologias, como a da política, a dos deslocamentos e a do Estado: "[...] a problematização desse caráter multifacetado e dinâmico do Estado mostra-se essencial para analisar os agenciamentos político-esportivos, pois a atuação dos seus

24 Mas essas divisões, se tomadas por rígidas, fracassam desde que confrontadas com as biografias de tantos pesquisadores. Por exemplo, os trabalhos de Florenzano (1998; 2009), antropólogo da PUC-SP e que, em tese, poderia se acomodar na segunda geração, dela se afasta ao tratar temas políticos concernentes menos às metaforizações em torno da ideia de nação, focando da perspectiva foucaltiana as relaçôes entre futebol e Estado. 
diversos segmentos e as relações construídas com os agentes do universo esportivo produzem diferentes configuraçôes do Estado" (Spaggiari; Machado; Giglio, 2016, p. 21).

Geração que acredito em expansão, daí a dificuldade em definir de chofre os seus contornos, porque parece antever ou divisar ainda uma quarta, mais comprometida com demandas pela subjetividade que se politizam em redes de afetos, dentro e fora dos muros universitários, nas ruas e nos domínios da sociabilidade, e que talvez guarde suas características próprias, abrigando temáticas relacionadas às hierarquias de gênero, aos corpos generificados, ao feminismo, à sexualidade e aos modos de existência, aos marcadores sociais da diferença e às teorias da interseccionalidade (Pisani, 2018; Bonfim, 2019; Camargo, 2018).

É como se pudéssemos dizer que o futebol que quase sempre se apresentou hegemônico e portador de identidades monolíticas relacionadas geralmente à noção de Estado-Nação, ao menos nas suas características mais decisivas, também pode ser desconcebido a partir dos mil futebóis dissonantes, que mais ou menos silenciosamente o integralizaram (Toledo; Camargo, 2018, p. 96).

Nessa linha, acrescentaria e defendo que a contribuição antropológica ao tema (afinal, por que destoaria das demais subáreas da disciplina?) se acomoda na potência da perspectiva etnográfica e o que ela pode oferecer também como teoria etnográfica, isso porque "[...] entre um saber científico sobre os outros e um diálogo com os saberes desses mesmos outros, entre as teorias científicas e as representaçóes ou teorias nativas, nesse espaço se desenrola a história da antropologia" (Goldman, 2006, p. 163).
Para além das dissertaçóes, das teses e dos artigos, o acúmulo crescente de coletâneas e dossiês em revistas acadêmicas nas duas últimas décadas, boa alternativa editorial que auxilia a acelerar a visibilidade das pesquisas realizadas no âmbito mais solitário e artesanal da relação orientador e orientando, tem ampliado as estratégias cuja tônica contemporânea empenha-se na fragmentação de abordagens, consolidando a crítica ao futebol genérico essencializado como produto dos processos históricos metropolitanos, nacionalizante em seus aspectos representacionais, masculino e masculinizante na sua feição existencial e subjetiva, bem como profissionalizado e/ou espetacularizado em sua hegemonia política e econômica.

Tais constructos sócio-históricos e imagens perpetuadas pelas mídias têm se dissolvido em uma miríade de futebóis e demandas capturadas pelas pesquisas que, grosso modo, passam a aclarar e reivindicar práticas mais localistas, regionais, generificadas, dissonantes, insurgentes, periféricas e que, de modo geral, descortinam uma economia simbólica da emoção assentada na noção de diversidade, muitas vezes aproximada à categoria do empoderamento, outro modo de correlacionar a dimensão política com as demandas pelo esporte.

Essa multiplicidade de abordagens, que também contrariamente recebem a pecha de identitaristas, acompanha os contextos mais recentes de crise das representaçóes em vários sentidos e direçóes e que alcançaram os domínios das universidades por intermédio das acertadas políticas de cotas que pressionaram, até onde puderam, as rotinas conservadoras de produção do conhecimento. Em que medida as análises sobre o futebol ou os esportes puderam se reinventar a partir dessas demandas ainda é uma pergunta prospectiva, mas já existem bons indícios sugeridos 
nessa produção renovada, ao menos, em seus aspectos temáticos.

Impossível elencar aqui essa produção antropológica recente, então cito, obviamente de maneira muito enviesada, trabalhos que, descobertos pelas oportunidades profissionais, indicaçóes pessoais e visibilidade de redes de pesquisa, me chegaram às mãos $\mathrm{e}$ que atestam novos impulsionamentos na direção de outros temas com desdobramentos conceituais importantes. Destacaria, entre esses: Spaggiari (2014); Chiquetto (2014); Bocchi (2016); Machado (2017); Alfonsi (2018); Favero (2018); Thomaz (2019); e Pires (2020), só para ficar em uma lista muito impressionista e próxima. ${ }^{25}$

Vale dizer que se esses trabalhos citados foram defendidos em programas de pós-graduação em antropologia, nem todos se autoatribuem ou são reconhecidos como herdeiros diretos de uma antropologia esportiva, tal como alguns balanços bibliográficos desenharam, pensando em fronteiras mais delimitáveis entre subáreas. Não obstante, os conjuntos que tematizam os esportes e o futebol tendem a ganhar, mesmo no interior da antropologia, esse direcionamento mais randômico de suas produçôes, que não podem ser disciplinarmente contidas, apontando para o fato da diversidade como força motriz e pressuposto metodológico no acolhimento de novos interlocutores de pesquisa. Movimento que hoje parece mais constante, mas que ao longo dessas últimas décadas já ofereceu exemplos pontuais, tal como é o caso da relação com a etnologia ameríndia, alcançada pelas práticas esportivas em pesquisas etnográficas (Vianna, 2008; Costa, 2013).
Mas, para além das evidências da diversidade, mais contemporaneamente tem-se colocado a questão da diferença como matriz epistemológica, vislumbrada a partir de toda uma bibliografia que, pontualmente, começa a aparecer nos estudos sobre futebol, e penso particularmente em autores seminais, sobretudo Marilyn Strathern e Roy Wagner, ou mesmo outros clássicos paulatinamente mobilizados para além de suas searas de origem, como Gabriel Tarde e Gregory Bateson, que têm estimulado outras perspectivas, retirando o futebol de suas seguras esferas mais morfológicas amparadas em noçôes como nação, sociedade, instituição e outras categorias holísticas, passando a ambientá-lo no torvelinho de noçóes como relaçóes, redes, invenção, metaforização, cismogenia.

$\mathrm{Na}$ última parte deste texto ofereço uma breve discussão sobre as possibilidades de que a intrincada noção wagneriana de metáfora pode auxiliar na prospecção de novas abordagens sobre "velhos" temas, e assim encerro este balanço bibliográfico com uma digressão conceitual que sempre tensionou e esteve mesmo no cerne desses estudos. Retornarei para a relação entre "realidade social" e metaforização como controles epistemológicos na produção de saberes sobre o futebol, tensão persistente que parece amparar as classificaçóes presentes em muitos balanços bibliográficos, na constituição de tipologias e famílias conceituais.

Porque os usos e abusos desse recurso estilístico da metáfora variam, se tomarmos o rendimento que tiveram nos trabalhos de cada geração de estudiosos, dos mais ensaísticos aos mais sociológicos, mas o que parece um consenso silencioso é o modo como tal

25 Mas incluiria nessa terceira geração trabalhos anteriores que focaram outros aspectos importantes e menos observados pela segunda geração, tais como a circulação de jogadores (Rial, 2008; Palmieri, 2009). 
máxima, qual seja, tomar o futebol a partir de algum paradigma metafórico, foi apenas parcialmente explorada em um sentido propriamente metodológico.

Passo a indicar a contribuição que alguma antropologia muito menos exposta ao tema do futebol pode oferecer aos estudos mais contemporâneos, levando em consideração as advertências feitas por Damo de que "de um ponto de vista teórico nossa produção precisa avançar, desvencilhando-se do uso instrumental de certos autores consagrados, que não raras vezes aparecem mais para emprestar autoridade aos argumentos do que para suscitar interpretaçóes arrojadas" (Damo, 2016, p. 334).

Mas, dito de outra maneira, para se levar a sério as conceituaçóes, é preciso obviá-las como se fossem metáforas, quer dizer, torná-las evidentes para que possam, ao mesmo tempo, ser desmobilizadas da função de meras artífices de narrativas representacionais explicativas, práticas que as fazem perder a fulgurante dinâmica ou capacidade relacional de metaforização. A presunção unívoca analítica que as teorias retêm só as fazem aumentar o fosso objetivista entre as fronteiras do senso comum e as perspectivas científicas.

\section{Balanço bibliográfico como metáfora?}

Não existe metáfora em si, literalidade em si, significante em si, significado em si. Não são distinçóes essenciais, absolutas. É provável que algo próximo se dê na oposição entre o dado e o construido na semiótica de Roy Wagner: o dado é o que é pressuposto em função do que se usa como controle. Isso não quer dizer que, em outra circunstância, não se possa tomar o que se tomava como construido como dado e vice-versa. Ou que seja necessário dispor primeiro de um dado para que depois se tenha um construido: eles são simultâneos, estão em implicação ou pressuposição recíprocas. ${ }^{26}$

Metáforas são mais que boas figuras de linguagem para alcançar significados. Quero entender com isso que usar uma metáfora para definir algo e estender seu significado é expressar um movimento que não necessariamente leva à representação solidária com o objeto ou a coisa metaforizada (coisa, de um lado, e ideia, a metáfora, o conceito, de outro). Metáfora não apenas auxilia a "representar" algo ou tornar a coisa mais "próxima" porque também pode colocar a coisa representada sob o risco de outras significaçóes, a depender do contexto relacional em que pode ser enunciada, exprimindo também distanciamento, diferença ou indiferença em relação à coisa metaforizada. E que nas relaçóes entre os atores náo se tem garantia de alcançar o significado somente no reino da convenção semântica.

Classificações simbólicas (codificações referenciais que medeiam a percepção e o mundo) são, para autores como Roy Wagner, apenas parte dos fundamentos que levam à simbolização humana, uma vez que as ações, as motivaçóes (inputs individuais) e as experiências sensórias (imagens) também participam desse constructo da significação em que percepçôes, signos e sentidos não se plasmam tão somente em representaçóes (uma coisa representando outra mediada por signos e metáforas), mas em relaçóes que re-

26 "Entrevista com Eduardo Viveiros de Castro e Marcio Goldman". Entrevistadores: Aristóleles Barcelos Neto, Danilo Ramos, Maíra Santi Bühler, Renato Sztutman, Stélio Marras e Valéria Macedo. Carbono - Natureza, Ciência e Arte. Disponível em: <http://revistacarbono.com/artigos/02abaete-rede-de-antropologia-simetrica/>. Acesso em: 20 fev. 2020. Originalmente publicada em Cadernos de Campo, São Paulo, n. 14/15, p. 1-382, 2006. 
têm, tanto a potência da condição de significado, quanto de significante. Uma representação tem sempre o potencial de inovar sobre algo a que se refere. Nessa direção, Gonçalves e Head (2009, p. 78) socorrem-nos ao esclarecer esse ponto:

Os significados lexicais, gramaticais, contêm uma arbitrariedade, portanto, são sempre tautológicos, podendo ser expressos em fórmulas do tipo: isso é um cachorro porque é um cachorro em oposição a um gato. Para Wagner é assim que construímos um sistema classificatório, sempre buscando significados tautológicos. Entretanto, são os significados não tautológicos os mais interessantes para se pensar o modo de representaçáo e apresentação de um sistema cultural, visto que são produzidos através da inovação dos significados justamente pelos processos de metaforização. Para Wagner, a significação metafórica envolve uma não-arbitrariedade e uma indeterminação da relação entre significante e significado.

Invenção não é apanágio dos cientistas e de mulheres e homens iluminados, portanto não opóe atos criativos dos atos estabelecidos habitualmente, afastando-se da ideia de acidente e novidade, mas também não se presta necessariamente a sinonimizar com inovação em sua acepção instrumental. Nessa direção, tudo seria inventivo no sentido da realização criativa da cultura e qualquer ato tomado por simbólico, desde que passível de produzir alguma comunicação, manifesta-se potencialmente como ato diferenciante.

Toda expressão dotada de significado, e, portanto, toda experiência e todo entendimento é uma espécie de invenção e a invenção requer uma base de comunicação em convençóes compartilhadas para que faça sentido, isto é, para que possamos referir a outros e ao mundo de significados que compartilhamos com eles (Wagner, 2010, p. 76).

Se invenção se refere às ações que estabelecemos no, e com, o mundo, a convenção vai definir a perspectiva do ator (Wagner, 2010, p. 95). No contexto ameríndio, o perspectivismo colocado por Viveiros de Castro parece bem próximo disso e o reconhecimento ou a negação, o encontro, a descoberta, em síntese, relação e percepção de novas humanidades, mexe com todos os outros mundos: "vendo-nos como não humanos, é a si mesmos que os animais e espíritos veem como humanos" (Viveiros de Castro, 2015, p. 44).

Nesse contexto simbólico, a pressuposição de uma humanidade generalizada (acento da condição inata na cultura e não na natureza) não leva à semelhança entre esses seres porque tal humanidade só se efetua de fato na perspectiva de cada ator (individual e coletivo). No contexto ocidental, o que operam são as visóes diversas de mundo (a visão do cientista, a visão do religioso, a visão de senso comum etc.) alocadas dentro de um mesmo mundo humano onde tudo que é externo constitui-se como natureza (o inato, ou seja, aquilo que se quer descobrir, domesticar, quantificar, sistematizar). Esse afastamento progressivo e o domínio do que se concebe por natureza (aquilo que passa a ser real, o objeto do controle) produzem o princípio da objetivação convencional que inventa essa cultura.

Convenção, portanto, é definida para Wagner como sendo a distinção interpretativa entre inato e artificial (adquirido) presente em qualquer sociedade (mas também em segmentos e fraçóes sociais quaisquer), sendo que o que muda são os pontos de vista entre o que se convencionaliza como objeto de ação humana. $\mathrm{O}$ desenvolvimento do 
pensamento sociológico pela legitimação de um objeto próprio náo deixou de replicar esse grande passo, assumindo o conceito de sociedade, e a despeito dos "interesses" que a fazem mover pelas formaçóes históricas, como um reino próprio dotada de realidade em si mesmo.

Dentro desse constructo simbólico, "esse mecanismo de extensão do significado é o que Wagner denomina metáfora, alegoria ou, mais usualmente, analogia, e corresponde, também, à "diferenciação" (Goldman, 2011).

Wagner oferece outras imagens do que compreende por metáfora:

O grande erro é imaginar que a metáfora (imagens verbais) é de alguma forma adventícia, uma coisa em si mesma e, portanto, coadjuvante na linguagem. Não é! É linguagem. Não é "sobre" algo chamado "imaginação", mas antes, a imaginação, seja lá o que for, é sobre isso. O que isso significa, à luz dessa discussão é que o que chamamos de "linguagem" é ferramenta e usuário ao mesmo tempo, mais ou menos como a mão humana, e que a coisa que chamamos de "metáfora" é o reflexo automático de sua reinversão fora de si. Isso significa que a metáfora, em última análise, "nasce da tentativa de livrar-se da metáfora e sobreviver como condição limite de nossa incapacidade de fazer isso" (Wagner, 2001, p. 20). Significa que a metáfora é a base auto-sustentável, recíproca de perspectivas, na medida em que define a transposição final de fins e meios, pois "funciona da maneira que significa e significa como funciona” (Wagner, 2001, p. 34) (Wagner, 2017, p. XVI).

Metáforas são mais do que propriamente representaçóes de algo porque, antes de tudo, agem sobre as coisas, assim como fazem as coisas agirem sobre elas. E, se ganham essa impressão de fixação tautológica nas classificaçóes é porque, muitas vezes, escondemos o fluxo de suas movimentaçóes.

Foi inspirado nessa perspectiva que a oferta de um balanço bibliográfico sobre outros balanços bibliográficos se colocou como exigência neste texto, ou seja, ativá-los em um fluxo. Menos como "estado da arte", todo balanço não deixa de ser uma apropriação ou um controle metafórico de contextos convencionais. Bloquear, por fim, a ideia da figura que emerge do fundo, selecionada de maneira que seus elementos (textos, autores, teorias, conceitos) ganhem uma imagem de estabilização decalcada em representaçóes sobre o tema ao qual se debruçou.

Colocar as revisóes em movimento, em uma espécie de revisão das revisóes, foi uma tentativa de chamar a atenção para os excessos classificatórios que toda revisão pode induzir. Portanto, não se tratou de metarrevisão, mas unicamente, e por que não dizer, alegoricamente, de tomar as revisóes como um conjunto de metáforas autorreferenciadas em que este texto (uma revisão das revisóes) se destaca tão somente como mais uma imagem ou figura de um tema, o futebol, que também se renova e pode ser inventado pela bibliografia.

Porque metáforas podem ser tomadas também como recursos que inovam sobre si mesmos, fazendo avançar sobre os acontecimentos ditos factuais, um tipo de entendimento que se propaga ou se extenua nas relaçóes. Segui-las, então, pode ser uma boa estratégia de encurtar as narrativas factuais e etnográficas ou compactá-las, não exatamente em "sistemas", campos ou estruturas, ou posteriormente em balanços bibliográficos que se prestarão às sínteses de relaçôes dispersas em inscritores dos quais nos valemos. 
Metáforas são recursivas não somente porque remetem a um significante, mas ao próprio movimento das metáforas que impregnam ou conferem camadas de significados contextuais (estéticos, políticos) a esse significante. E, confrontando-nos com esse movimento, nada escaparia ao recurso das metáforas, nem os conceitos que acreditamos exprimir o que quer que tomemos ou nomeemos por "realidade" ou estado da arte. Afinal, por que sonegar esse mesmo processo, condição de simbolização ou invenção de culturas, às nossas disciplinas pomposamente denominadas de científicas, se também são, igualmente, máquinas inscritoras de produção de metáforas e analogias?

\section{A relatividade do futebol}

Para terminar este longo percurso, volto-me para um caso mais próximo desse tipo de exegese metafórica que associa cultura e futebol, que pode ser lida em muitos lugares, exemplifico-o com Franco Júnior: "Como toda metáfora, uma coisa no lugar de outra, o futebol é sentido antes de ser compreendido, e no entanto, como toda metáfora, ele pode, e deve, ser também analítica e criticamente examinado" (Franco Júnior, 2007, p. 166).

Muito antes, e com maior impacto inovador sobre a bibliografia, Da Matta et al. (1982) já havia tomado a figura da metáfora como estratégia representacional do futebol:

Talvez agora possamos juntar os episódios que abrem esse texto com a metáfora do jogo como a própria vida [...] Nós choramos vendo o nosso time seguir à risca as regras do jogo, estabelecendo honestamente um novo padrão de excelência, padrão que atualiza claramente um estilo nosso, que em outras esferas da vida não podíamos distinguir com tanta precisão e facilidade. O futebol, portanto, permite também descobrir a nossa "alma" e o nosso "coração" de modo positivo, como uma coletividade que pode, sabe e faz muito bem as coisas. Somente isso justifica a imensa popularidade deste jogo entre nós (Da Matta et al., 1982, p. 15).

Da Matta esclarece o sentido ou o princípio organizador da metáfora, porém sua análise, como outras, fica retida na estrutura e no conjunto de categorias que definiriam uma cultura, ou seja, suas formas mais convencionais de elicitaçôes metafóricas, dissociando ou subordinando signos e sentidos (algo no lugar de outra coisa), fazendo com que os últimos se tornassem intangiveis $f$ lutuantes (significantes flutuantes) e efeitos de estruturas permanentes.

Antes, se seguirmos as sugestóes de Wagner para contornar alguns fatalismos ou curto-circuitos entre metáfora e vida, não bastaria apenas explicitar ou nomear os sentidos ao categorizá-los, pois "tal abordagem tende a restringir o sentido de nomear as coisas à nomeação dos sentidos, ou seja, a refletir, de forma inadvertida, o convencionalismo e a racionalidade do procedimento acadêmico dentro de seu objeto de estudo" (Wagner, 2017, p. X).

Alternativamente, é preciso observar que a eliciação interpretativa de sentidos, o que Wagner denomina de invenção, pode ser considerada como tendo vida própria e "modelar o uso de convençôes culturais para seus próprios fins" (Wagner, 2017, p. X) em uma dialética com a convenção cultural. A metáfora não estaria somente no lugar de outra coisa, na verdade ela pode se assumir como a própria coisa, ou ainda que coisa e metáfora se estranham ou se entranham mutuamente.

E se futebol pode ser tomado como metáfora da "vida", a "vida" pode ser tomada 
como metáfora do futebol, abandonando a presunçáo de um real exterior, "coisa" metodológica e instância última das determinações simbólicas. E, em uma dialética sem síntese, em que figura e fundo se alternam na produção de sentidos, a metáfora "equivale ao germe de uma disseminada tendência processual. Uma espécie de involuçáo da autorreferência [...]" (Wagner, 2017, p. IX).

Etnografei, alhures, um "encontro" inusitado entre acadêmicos ligados a um simpósio internacional de estudos sobre o futebol ${ }^{27}$ e militantes políticos mobilizados pela campanha presidencial de 2018. Fortuito, tudo, rapidamente, ocorreu na Praça Charles Miller, em São Paulo, onde se localiza o Estádio Paulo Machado de Carvalho, o Pacaembu.

Temos aqui um exemplo pontual de como metáforas, menos como representaçôes de algo fixo e de fundo, podem se posicionar como figuras no centro de produçáo ou invenção de controvérsias simbólicas traduzidas em uma economia política da diferença ou em uma diferença de economias políticas. O mote estético se deu em torno de um item caro à memorabilia futebolística, camisas de futebol.

Embora os dois lados potencialmente contendores não tivessem produzido qualquer sociabilidade, não se pode afirmar que se estava ali diante de um não diálogo a estabelecer apenas uma paisagem morfológica composta por duas formas contrastivas e distanciadas nas expressões de suas identidades ideológicas, estéticas e existenciais. Muito menos fazer a suposição de um exercício fugidio de algum relativismo cultural em que dois coletivos coloridos apenas se ignoravam ou se entreolhavam a intuir algo a respei- to de "realidades relativas" consumadas em que, de um lado, acadêmicos encerravam os trabalhos do referido simpósio, sabidamente críticos à plataforma do entâo candidato que estimulava, do outro lado, aquela reunião política que se adensava em torno de ruidosos militantes.

Historiadores, sociólogos e antropólogos esportistas constituíam maioria naquele simpósio e ostentavam muitas camisas, mimetizando seus "objetos" e externando uma moda esportiva que passava por valores diversos. Tais vestimentas não faziam coincidir, necessariamente, com preferências clubísticas pessoais e os usos de camisas outras se colocavam como projeção política em um simpósio em que, justamente, se discutiu a multiplicidade dos futebóis e a crise epistemológica em torno da primazia analítica sobre um determinado futebol, o masculino e de espetáculo.

Camisas de outros selecionados também se faziam presentes, perfeitamente cabíveis em um encontro internacional de estudiosos no qual muitos abertamente explicitavam suas posiçóes políticas de esquerda e ou seu distanciamento ideológico com o que ocorria na praça. A ausência no simpósio ficava por conta da camisa da seleçáo brasileira. Ninguém, ao menos naquele dia, ousou trajá-la.

Já do lado de fora das dependências do estádio, portanto um pouco mais distante de onde ocorria a sessão final do simpósio, via-se um mar amarelo integralizado por camisas que aludiam à seleçáo brasileira a exibir o patriotismo contrainventado que alimentava o que, posteriormente, se definiu como campanha exitosa do entáo candidato Jair Bolso-

27 Tratou-se do quadrienal Simpósio Internacional de Estudos sobre o Futebol em sua terceira edição (1918). A etnografia mais circunstanciada encontra-se em Toledo (2019b). 
naro (à época filiado ao Partido Social Liberal - PSL) pleiteando a Presidência da República. Usos dessa camisa e suas versóes já haviam sido estimulados desde as manifestaçóes conhecidas por "Jornadas de Junho", em 2013, amplificadas como vestuário entre aqueles que foram favoráveis ao impeachment da presidenta Dilma Rousseff, no ano de 2016.

Para muitos ali no simpósio, tratava-se de um sequestro semiótico da camisa da seleção, interpretação que se mantinha na chave do relativismo (e não da relatividade) porque levava em conta, até como um golpe sentido, a associação entre identidade nacional e futebol, deslocada, naquele momento, em função das posiçôes ideológicas em jogo. Ainda que o simpósio tematizasse a multiplicidade de demandas legítimas por outros futebóis, aquele pequeno drama mantinha latente a relação entre o futebol e o Brasil na chave da identidade nacional. Bastariam outros momentos e lutas políticas para novamente repatriar a camisa para o lado de cá. ${ }^{28}$

Escrevi a respeito que

Do lado externo ao evento, com as ruas mobilizadas de verde e amarelo pelos militantes bolsonaristas erigia-se o grande futebol pátrio como signo de uma mudança política restauradora, uma "história retrospectiva", como salientou Lévi-Strauss na discussão sobre a morte ou enfraquecimento dos mitos. Curiosa mudança que ao mesmo tempo negava a história e seus fatos, esquentando um futebol idealizado numa bricolagem e fabulação de fatos históricos reivindicando um país que fora grande, mas que se perdeu pelo caminho, e que agora precisaria retomar sua vocação [...] (Toledo, 2019b, p. 276).

Bolsonaristas reivindicavam a volta da velha camisa da seleção revelada em um revival histórico, já os acadêmicos fingiam ignorá-la para, na verdade, demonstrar o tamanho valor que ela, historicamente, já havia representado como símbolo dominante. ${ }^{29}$ Ambos, por vias adversas, acabavam por glamourizar as mesmas memórias de um Brasil esportivo sintetizado pela camisa do selecionado. Podemos dizer que as metaforizaçóes eram mais que desdobradas sobre si mesmas a permitir um fluxo de dissonâncias cognitivas, inclusive entre os próprios acadêmicos, em relação ao mito original da camisa como síntese de uma cultura.

Essa tridimensionalidade ou holografia de significados em torno da camisa da seleçâo revelava-se em atos inventivos, em que ambos os ajuntamentos pareciam contrainventar a camisa da seleçâo do outro, na tentativa de corroer as inovaçôes dos sentidos atribuídos por um ou outro, em uma competição semiótica relacional estendida ao plano da política.

A camisa deveria ser invisibilizada, ao menos momentaneamente, porque virou indumentária de coxinhas e bolsonaristas, tal como propugnavam os acadêmicos esportistas diante das circunstâncias ou, na visão dos bolsonaristas, a camisa seria agora tomada como signo retroativo a reivindicar um Brasil recuperado da performance de sucessivos

28 Um artigo do jornalista João Carlos Assumpção, divulgado no blog do jornalista Juca Kfouri, exorta pela mudança das cores da camisa da seleção por reconhecer que o verde e amarelo "nesse momento não nos representam". Disponível em: <https://blogdojuca.uol.com.br/2020/05/campanha-para-mudar-a-camisa-da-selecao/?utm_ source=facebook\&utm_medium $=$ social-media\&utm_campaign=esporte\&utm_content=jkfouri $>$. Acesso em: 18 maio 2020 .

29 Turner (2005, p. 58) irá definir símbolo dominante como sendo aquele que agrega significados díspares. 
governos de "esquerda" que, estando no poder, a corromperam?

De qualquer modo e à revelia dos sujeitos, a camisa deixava ali de exibir suas qualidades tautológicas de classificação simbólica para se colocar como um devir-camisa no emaranhado das metaforizaçóes. O que precisaria voltar a ser um símbolo pátrio para uns, revelava-se "desnecessário" ou mascarado para outros porque fora apropriado ou sequestrado pelos opositores políticos.

$\mathrm{O}$ que mais essas movimentaçóes puderam revelar, para além da busca por um Brasil bolsonarista conservador ou intelectual e progressista, esteve associado à possibilidade de que esse Brasil de representação monotemática talvez tivesse se esgotado em seus movimentos de metaforização e significação, escancarando muitos brasis igualmente diferentes a clamar por novas conceituaçóes.

No cerne de uma disputa política de seguidas metaforizaçôes, a camisa, para uns, seria expressão de uma história que seria restaurada com a eleição, em um movimento retroativo metafórico, tal como se acreditou entre os bolsonaristas; já para os acadêmicos esportistas, a sintomática recusa no uso da camisa da seleção prenunciava, impunha ou contrainventava novas movimentaçôes em torno de futebóis que já há tempos seguem desacomodando o caráter hegemônico do futebol masculino e profissional com ressonâncias importantes sobre o caráter nacional.

Os usos e as ausências da camisa naquele contexto passaram a operar como uma espécie de revisão simbólica em ato das representaçôes reprimidas, porém ainda calcadas na relação tautológica entre futebol e identidade nacional para ambos os coletivos. Aquilo que se teorizava e experenciava no simpósio como sinal de crise representacional de um futebol hegemônico, que não mais cobria os corpos ou vestia as demandas e subjetivida- des em curso, era posto à prova na relaçáo com os bolsonaristas na praça. Até onde se podia ir com a crítica ao futebol hegemônico masculino acabou mais bem explicitado metaforicamente pela ausência sentida da camisa da seleção entre os intelectuais, que a escondendo também a revelavam.

Tal como tentamos posicionar aqui, o conjunto de revisóes bibliográficas sobre o tema futebol, esse exemplo etnográfico novamente coloca a questão da reversão entre figura e fundo. Muitos futebóis parecem dispersar ou borrar a figura de fundo que por muito tempo se manteve ativa na elaboraçáo das alegorias sobre um país e sobre um único futebol de sucesso. O futebol masculino profissional, que figurou como pano de fundo de vários brasis, não ostenta mais sozinho o estado da arte em um cenário esportivo multiplicado por outras demandas.

Se camisas de futebol, correntemente tomadas como signos culturais de uma localidade ou de um país, produzem inovaçóes contextuais, é porque são continuadamente metaforizadas. O custo simbólico (porque também afetivo, existencial, noutras palavras, subjetivo) em desfocar essa imagem impressa na camisa síntese da seleção, em que fulgura a representação de algum Brasil de fundo, recarregava as crises epistemológicas e interpretativas suscitadas no simpósio.

Os bolsonaristas, imersos em um discurso essencialista sobre Brasil, serviram aos intelectuais como mecanismo de controle de seus próprios limites, colocando à prova os arcabouços teóricos e metodológicos ao estenderem, metaforicamente, os usos de outras camisas para além da noção de identidade nacional, firmando localismos e novas identidades. A camisa da seleção brasileira em corpos bolsonaristas passou a exprimir posicionamentos ideológicos marcados, identitaristas e a contragosto dos intelec- 
tuais. Todavia, identitaristas à sua maneira, bolsonaristas inovaram sobre a camisa mesmo a colocando a serviço de um discurso conservador extravagante. Já os intelectuais, com sua recusa em usar a camisa da seleção brasileira, acusaram o golpe corroborando, a contrapelo, a permanência da ideia de que a camisa, mesmo na atitude sintomática em desvesti-la, persistia como um incômodo símbolo dominante.

\section{Poucas palavras finais}

Seguir o movimento ruidoso das metáforas em uma conjuntura simbólica crítica fez perceber neste texto como os balanços bibliográficos podem, para além de guias e estados da arte, revolver camadas mais acomodadas de significaçóes tomadas por conceituaçôes seguras. Na vida, as metáforas já fazem isso à nossa revelia, e o (des) encontro inusitado com os bolsonaristas corroborou esse argumento. Por isso, pode ser proveitoso reapresentá-las como mais uma via de inspiração metodológica para reavaliar continuamente o modo como encaramos a realidade social em nossas próprias pesquisas.
Balanços bibliográficos, que em princípio enunciam identidades temáticas e disciplinares, são, primeiro, inscritores em um sentido atribuído por Latour, porque essencializam processos tomados como estados da arte, mas também podem se prestar às aproximaçóes analógicas de contextos díspares no sentido wagneriano porque permitem capturar fluxos de transformaçóes a partir das imagens formuladas como metáforas, não importando que estejam manipulando expressóes de senso comum (antropologia do óbvio) ou conceituações estabelecidas no discurso sociológico.

Nossos balanços bibliográficos, continentes textuais que cercam a dispersão sobre um determinado tema, devem participar desse mesmo movimento, que, a cada tentativa de restabelecer a coesão bibliográfica, termina por transformar o próprio tema e suas implicações na produção de novos aportes conceituais e metodológicos, continuadamente expostos às movimentaçóes inventivas nas e das etnografias. O que fica desta lição é que se faz necessário, não somente apontar para a diversidade dos futebóis, mas também para as diferenças que engendram paradigmas teóricos distintos.

\section{Bibliografia}

ALABARCES, P. Veinte años de ciencias sociales y deporte em América Latina: un balance, una agenda. Revista Brasileira de Informaçáo Bibliográfica em Ciências Sociais, v. 1, n. 58, p. 159-179, 2004.

ALABARCES, P.; CONDE, M.; DODARO, C. (orgs.). Hinchadas. Buenos Aires: Prometeo Libros, 2005.

ALABARCES, P. Veinte años de ciencias sociales y deportes, diez años después. Revista da ALESDE, v. 1, n. 1, p. $11-22,2011$.

ALFONSI, D.; CAMPOS, F. Apresentação. In: ALFONSI, D.; CAMPOS, F. Futebol objeto das ciências humanas. São Paulo: Leya, 2014. p. 7-20.

ALFONSI, D. Réplicas originais. Um estudo sobre futebol nos museus. Doutorado (Antropologia Social) Programa de Pós-Graduaçáo em Antropologia Social, Universidade de São Paulo, São Paulo, 2018. 
ANDRADE, A. G. R. Mídia, futebol e sociedade: controvérsias públicas midiatizadas em torno da escolha do Brasil como sede da Copa do mundo FIFA 2014. Tese (Doutorado) — Programa de Pós-Graduação em Antropologia, Universidade Federal Fluminense, Niterói, 2013.

ARAÚJO, R. B. Os gênios da pelota: um estudo do futebol como profissão. Mestrado (Antropologia Social) Universidade Federal do Rio de Janeiro, Rio de Janeiro, 1980.

ARMSTRONG, G.; GIULIANOTTI, R. (orgs.). Entering the field: perspectives in world football. Oxford: Berg Publishers, 1997.

BAETA NEVES, L. F. O paradoxo do coringa e o jogo do poder \& saber. Rio de Janeiro: Editora Achimaé, 1979.

BOCCHI, G. M. M. Do Estádio do Pacaembu para a Arena Corinthians: etnografia de um processo de "atualização". Dissertação (Mestrado) — Programa de Pós-Graduação em Antropologia Social, Universidade de São Paulo, São Paulo, 2016.

BONFIM, A. F. Football feminino entre festas esportivas, circos e campos suburbanos: uma história social do futebol praticado por mulheres da introdução à proibição (1915-1941). Dissertaçáo (Mestrado) — Programa de Pós-graduação em História, Política e Bens Culturais, Escola de Ciências Sociais, Fundação Getúlio Vargas, Rio de Janeiro, 2019.

BUARQUE DE HOLLANDA, B. O ensaio como gênero e a produção ensaística sobre futebol no Brasil: um balanço. In: CORNELSEN, E. L.; SILVA, S. R.; CAMPOS, P. A. F. (orgs.). Futebol, linguagem, artes, cultura e lazer. Produção acadêmica sobre futebol - análises e perpectivas. Rio de Janeiro: Jaguatirica, 2017. p. 31-58.

BUARQUE DE HOLLANDA, B.; BURLAMARQUI, L. G. (orgs.). Desvendando o jogo. Nova luz sobre o futebol. Niterói: Editora da UFF; Faperj, 2014.

BUARQUE DE HOLLANDA, B.; REIS, H. B. (orgs.). Hooliganismo e Copa de 2014. Rio de Janeiro: 7 Letras, 2014.

BUARQUE DE HOLLANDA, B.; AGUILAR, O. R. (orgs.). Torcidas organizadas na América Latina. Rio de Janeiro: 7 Letras, 2017. (Estudos Contemporâneos).

BURLAMAQUI, L. G. A dança das cadeiras: a eleição de João Havelange à presidência da FIFA (1950-1974). Tese (Doutorado em História Social) — Faculdade de Filosofia, Letras e Ciências Humanas, Universidade de São Paulo, São Paulo, 2019.

CALDAS, W. O Pontapé Inicial. Memória do Futebol Brasileiro (1893-1933). São Paulo: Ibrasa, 1990.

CAMARGO, W. X. A Champions LiGay e a colonização do futebol. Ludopédio, v. 113, n. 12, p. 1-6, 2018.

CAMARGO, W.; PISANI, M.; ROJO, L. (orgs.). Vinte anos de diálogos. Os esportes na antropologia brasileira. Brasília, DF: Associação Brasileira de Antropologia, 2020.

CHIQUETTO, R. V. A cidade do futebol: etnografia sobre a prática futebolística manauara. Dissertação (Mestrado) — Programa de Pós-Graduação em Antropologia Social, Universidade de São Paulo, São Paulo, 2014.

COSTA, C. E. Ikindene hekugu: uma etnografia da luta e dos lutadores no Alto Xingu. Tese (Doutorado em Antropologia Social) - Programa de Pós-Graduação em Antropologia Social, Universidade Federal de São Carlos, São Carlos, 2013.

COSTA, C. E.; TOLEDO, L. H. Visão de jogo. Antropologia das práticas esportivas. São Paulo: Editora Terceiro NomeFapesp, 2009.

COSTA, C. E.; TOLEDO, L. H. Cenas e encenaçôes: a antropologia intersticial de Simoni Guedes. In: HELAL, R.; 
COSTA; L. M. (orgs.). A Antropologia de Simoni Guedes. Rio de Janeiro: LEME, 2020.

CAMPOS, P. A. F. et al. Pesquisas sobre futebol nas ciências humanas e sociais. Um mapa a ser analisado. In: CORNELSEN, E. L.; SILVA, S. R.; CAMPOS, P. A. F. (orgs.). Futebol, linguagem, artes, cultura e lazer. Produção acadêmica sobre futebol - análises e perspectivas. Rio de Janeiro: Jaguatirica, 2017. p. 167-184.

DA MATTA, R. O mundo dividido: a estrutura social dos Apinayé. Petrópolis: Vozes, 1976. DA MATTA, R. Carnavais, malandros e heróis: para uma sociologia do dilema brasileiro. Rio de Janeiro: Zahar, 1979.

DA MATTA, R.; BAETA NEVES, L. F.; GUEDES, S. L.; VOGEL, A. Universo do Futebol. Rio de Janeiro: Editora Pinakotheke, 1982.

DA MATTA, R. Antropologia do óbvio - Notas em torno do significado social do futebol brasileiro. Revista USP, $\mathrm{n}$. 22, p. 10-17, 1994. https://doi.org/10.11606/issn.2316-9036.v0i22p10-17

DAMO, A. Do dom à profissão. A formação de futebolistas no Brasil e na França. São Paulo: Hucitec; Anpocs, 2007.

DAMO, A. Posfácio. Novas abordagens sobre o esporte em ciências humanas no Brasil. In: SPAGGIARI, E.; MACHADO, G. M. C.; GIGLIO, S. S. (orgs.). Entre jogos e copas. Reflexôes de uma década esportiva. São Paulo: Intermeios; Fapesp, 2016. p. 325-353.

DAMO, A. Romantismo e futebol nas ciências humanas brasileiras. In: CORNELSEN, E. L.; SILVA, S. R.; CAMPOS, P. A. F. (orgs.). Futebol, linguagem, artes, cultura e lazer. Produção acadêmica sobre futebol análises e perspectivas. Rio de Janeiro: Jaguatirica, 2017. p. 9-29.

DAMO, A. Futebóis - da horizontalidade epistemológica à diversidade política. FuLiA UFMG, v. 3, n. 3, p. 37-66, 2018. https://doi.org/10.17851/2526-4494.3.3.37-66

DEL PRIORE, M.; MELO, V. A. (orgs.). História do esporte no Brasil. São Paulo: Editora da Unesp, 2009.

DIAS, C. Esportes e cidades: balanços e perspectivas. Revista Tempo, v. 17, n. 34, p. 33-44, 2013. Dossiê "Uma história do esporte para um país esportivo". https://doi.org/10.5533/TEM-1980-542X-2013173404

ELIAS, N.; DUNNNG, E. Em busca da excitaçáo. Lisboa: Difel, 1992.

FABIAN, J. O tempo e o outro. Como a Antropologia estabelece seu objeto. Petrópolis: Editora Vozes, 2013.

FAVERO, R. P. F. A várzea é imortal: abnegação, memória, disputas e sentidos em uma prática esportiva urbana. Dissertação (Mestrado) — Programa de Pós-Graduação em Antropologia Social, Universidade de São Paulo, São Paulo 2018.

FASSHEBER, J. R. M.; ROCHA FERREIRA, M. B. Etno-desporto Kaigang. In: REUNIÃO DE ANTROPOLOGIA DO MERCOSUL, 7., 2007, Porto Alegre. Anais [...]. Porto Alegre: UFRGS, 2007.

FERREIRA, A. L. P. O estado da arte da sociologia do esporte no Brasil: um mapeamento da produção bibliográfica de 1997-2007. Dissertação (Mestrado em Sociologia) — Departamento de Ciências Sociais, Universidade Federal do Paraná, Curitiba, 2009.

FLORENZANO, J. P. Afonsinho e Edmundo: a rebeldia no futebol brasileiro. São Paulo: Musa, 1998.

FlorenZano, J. P. A democracia corinthiana. Práticas de liberdade no futebol brasileiro. São Paulo: Educ; Fapesp, 2009.

FRANCO JÚNIOR, H. A dança dos deuses. Futebol, sociedade, cultura. São Paulo: Companhia das Letras, 2007. 
FRANCO JÚNIOR, H. WISNIK, J. M.: Veneno remédio. O futebol e o Brasil. Revista de História, n. 163, p. 369389, jul./dez. 2010. Ensaio Bibliográfico.

FREITAG, L. C.; FASSHEBER, J. R. Um estranho no ninho? O futebol nas identidades indígenas. In: CAMARGO, V. T. C.; FERREIRA, M. B. F.; VON SIMSON, O. R. M. (orgs.). Jogo, celebraçáo, memória e identidade: reconstrução da trajetória de criação, implementação e difusão dos Jogos Indígenas no Brasil (1996-2009). Campinas, SP: Curt Nimuendajú, 2011. p. 127-139.

GASTALDO, É. L. Pátria, chuterias e propaganda. O brasileiro na publicidade da Copa do Mundo. São Leopoldo: Editora Unisinos; Annablume, 2002.

GASTALDO, É. L. Estudos sociais do esporte: vicissitudes e possibilidades de um campo em formação. Logos, v. 17, n. 2, p. 7-15, 2010. https://doi.org/10.12957/logos.2010.853

GASTALDO, É. L. Esporte, antropologia e comunicação no Brasil: explorando encruzilhadas de um campo indisciplinar. In: CAMARGO, W.; PISANI, M.; ROJO, L. (orgs.). Vinte anos de diálogos. Os esportes na antropologia brasileira. Brasília, DF: Associação Brasileira de Antropologia, 2020.

GEIGER, A.; VELHO, O. A liminaridade antropofágica de Roberto Da Matta ou Tupi or not Tupi? A virtude está no meio. In: GOMES, L. G.; BARBOSA, L.; DRUMMOND, J. A. (orgs.). O Brasil não é para principiantes: carnavais, malandros e heróis 20 anos depois. Rio de Janeiro: Editora FGV, 2000.

GIGLIO, S. S.; SPAGGIARI, E. A produção das ciências humanas sobre futebol no Brasil (1990-2009). Revista de História, n. 163, p. 293-322, 2010. Dossiê "História e Futebol".

GIGLIO, S. COI X FIFA: a história política do futebol nos Jogos Olímpicos. Tese (Doutorado) — Escola de Educação Física e Esporte, Universidade de São Paulo, São Paulo, 2013.

GOELLNER, S. V. Gênero e esporte na historiografia brasileira: balanços e potencialidades. Revista Tempo, v. 17, n. 34, p. 45-52, 2013. Dossiê "Uma história do esporte para um país esportivo". https://doi.org/10.5533/tem$1980-542 x-2013173405$

GOELLNER, S. V.; KESSLER, C. S. A sub-representação do futebol praticado por mulheres no Brasil. Ressaltar o protagonismo para visibilizar a modalidade. Revista USP, n. 117, 2018, p. 31-38, 2018. Dossiê "Copas do Mundo". https://doi.org/10.11606/issn.2316-9036.v0i117p31-38. [Publicado anteriormente em Francisco Pinheiro e Victor Andrade Melo, A bola ao ritmo de fado e samba: 100 anos de relaçóes luso-brasileiras no futebol. Lisboa: Ediçōes Afrontamento, 2013].

GODIO, M.; ULIANA, S. Fútbol y sociedad: prácticas locales e imaginarios globales. Buenos Aires: Universidad Nacional de Tres de Febereo, 2011.

GONÇALVES, M. A.; HEAD, S. (orgs.). Devires imagéticos: a etnografia, o outro e suas imagens. Rio de Janeiro: 7 Letras, 2009.

GOLDMAN, M. Alteridade e experiência: antropologia e teoria etnográfica. Etnográfica, v. 10, n. 1, p. 161-171, maio 2006.

GOLDMAN, M.; VIVEIROS DE CASTRO. Abaeté, Rede de Antropologia Simétrica Entrevista com Márcio Goldman e Eduardo Viveiros de Castro. Entrevistadores: Barcelos Neto et al. Cadernos de Campo, n. 14/15, p. 1-382, 2006.

GOLDMAN, M. O fim da antropologia. Novos estudos - CEBRAP, n. 89, p. 195-211, 2011. https://doi. org/10.1590/S0101-33002011000100012

GORDON JUNIOR, C. História social dos negros no futebol brasileiro: primeiro tempo. Pesquisa de Campo, n. 2, p. 71-90, 1995. 
GUEDES, S. L. O futebol brasileiro: instituição zero. Dissertação (Mestrado) — Programa de Pós-Graduação em Antropologia Social, Universidade Federal do Rio de Janeiro, Rio de Janeiro, 1977.

GUEDES, S. L. Apresentação. Antropolítica, n. 14, p. 11-16, 2003. Dossiê "Esporte e Modernidade”.

GUEDES, S. L. Esporte, lazer e sociabilidade. In: DUARTE, L. F. D.; MARTINS, C. B. Horizontes das ciências sociais no Brasil: antropologia. São Paulo: Anpocs, 2010. p. 431-456.

GUEDES, S. L. Os estudos antropológicos dos esportes no Brasil: perspectivas comparativas com a América Latina. Antropolítica, n. 31, p. 31-43, 2011.

GUEDES, S.; TOLEDO, L. H. Antropologia do esporte: traçados interdisciplinares através das trajetórias. In: REUNIÃO BRASILEIRA DE ANTROPOLOGIA, 24., 2004, Recife. Anais [...]. Recife: RBA, 12 a 15 jun. 2004. Mimeografado.

GUEDES, S.; SILVA, E. M. A. O segundo sequestro do verde e amarelo: futebol, política e símbolos nacionais. Cuadernos de Aletheia, n. 3, p. 73-89, mar. 2019.

HERZFELD, M. Antropologia. Prática teórica na cultura e na sociedade. Petrópolis: Editora Vozes, 2014.

HIRATA, D. V. O futebol varzeano: práticas sociais e disputas pelo espaço em São Paulo. Dissertaçâo (Mestrado) —Programa de Pós-Graduação em Sociologia, Universidade de Sáo Paulo, São Paulo, 2005.

HOLBRAAD, M.; PEDERSEN, M. A. Analogic anthropology: wagner's inventions and obviations. In: HOLBRAAD, M.; PEDERSEN, M. A. The ontological turn: an anthropological exposition. Cambridge: Cambridge University Press, 2017. p. IX-XIX.

LATOUR, B.; WOOLGAR, S. A vida de laboratório. A produção dos fatos científicos. Rio de Janeiro: RelumeDumará, 1997.

LEITE LOPES, J. S. A vitória do futebol que incorporou a pelada. A invenção do jornalismo esportivo e a entrada dos negros no futebol brasileiro. Revista USP, n. 22, p. 64-83, 1994. Dossiê "Futebol". https://doi.org/10.11606/ issn.2316-9036.v0i22p64-83

MACHADO, G. M. C. A cidade dos picos: a prática do skate e os desafios da citadinidade. Tese (Doutorado) Programa de Pós-Graduação em Antropologia Social, Universidade de São Paulo, São Paulo, 2017.

MAGNANI, J. G. C. MORGADO, N. Futebol de várzea também é patrimônio. Revista do Patrimônio Histórico e Artístico Nacional, n. 24, p. 175-184, 1996.

MAGNANI, J. G. C. Da periferia ao centro: trajetórias de pesquisa em antropologia urbana. São Paulo: Terceiro Nome, 2012.

MAGNANI, J. G.; SOUZA, B. M. Jovens na metrópole. Etnografias de circuitos de lazer, encontro e sociabilidade. São Paulo: Terceiro Nome, 2007.

MAIA, R. C. M. Sociabilidade: apenas um conceito? Geraes - Revista de Comunicaçáo Social, n. 53, p. 4-15, 2001. Disponível em: <https://www.researchgate.net/profile/Rousiley_Maia/publication/317051024_Sociabilidade_ apenas_um_conceito/links/5923241caca27295a8a7e774/Sociabilidade-apenas-um-conceito.pdf $>$. Acesso em: 5 jul. 2019.

MELO, V. A. Cidade esportiva: primórdios do esporte na cidade do Rio de Janeiro. Rio de Janeiro: Relume Dumará; Faperj, 2001.

MELO, V. A.; GENOVEZ, P. F. Bibliografia brasileira de história da educaçáo física e do esporte. 1. ed. Rio de Janeiro: Editora da Universidade Gama Filho, 1998. v. 1. 
MEIHY, J. C. S.; WITTER, J. S. (orgs). Futebol e Cultura. Coletânea de estudos. São Paulo: Imprensa Oficial do Estado, 1982.

MICELI, S. A força política que vem das arquibancadas. Isto É, n. 38, p. 48-50, 14 set. 1977a.

MICELI, S. Corinthians, e o pão?. Isto É, n. 42, p. 12-16, 12 out. 1977 b.

MICELI, S. Os Gavióes da Fiel: torcida organizada do Corinthians. Revista de Administraçáa de Empresas, v. 18, n. 2, p. 43-46, 1978. https://doi.org/10.1590/S0034-75901978000200007

MORAIS, J. V.; RATTON, J. L.; BARRETO, T. V. Futebol, cultura e sociedade. Contribuiçôes para uma socioantropologia da bola. Estudos de Sociologia - Revista do Programa de Pós-Graduaçáo em Sociologia da UFPE, v. 2, n. 14, p. 11-16, 2008.

MOURA, G. A. O Rio corre para o Maracanã. Rio de Janeiro: Editora Fundação Getulio Vargas, 1998.

MURAD, M. Sociologia e educaçáo física: diálogos, linguagens do corpo, esportes. Rio de Janeiro: Fundaçáo Getulio Vargas, 2009.

MURAD, M. Para uma sociologia da sociologia do futebol no Brasil: memória. In: CORNELSEN, E. L.; SILVA, S. R.; CAMPOS, P. A. F. (orgs.). Futebol, linguagem, artes, cultura e lazer. Produçấo acadêmica sobre futebol análises e perspectivas. Rio de Janeiro: Jaguatirica, 2017. p. 151-165.

PALMIERI, J. C. J. Quanto vale um talento? Uma análise antropológica sobre a valorização e circulação dos jogadores de futebol profissional no mercado esportivo. Dissertação (Mestrado) — Programa de Pós-Graduação em Antropologia Social, Universidade Federal de São Carlos, São Carlos, 2009.

PEREIRA, L. A. M. Football Mania: história social do futebol carioca (1902-1938). Rio de Janeiro: Nova Fronteira, 2000.

PINHEIRO FILHO, F. A noção de representação em Durkheim. Lua Nova, n. 61, p. 139-155, 2004. http://dx.doi. org/10.1590/S0102-64452004000100008

PIRES, B. G. A gestão da integridade. Corpo, sujeição e regulação das variaçōes intersexuais no esporte de alto rendimento. Tese (Doutorado) - Programa de Pós-Graduação em Antropologia Social, Universidade Federal do Rio de Janeiro, Rio de Janeiro, 2020.

PISANI, M. S. "Sou feita de chuva, sol e barro": o futebol de mulheres praticado na cidade de São Paulo. Tese (Doutorado) - Programa de Pós-Graduação em Antropologia Social, Universidade de São Paulo, São Paulo, 2018.

RIAL, C. S. M. Rodar: a circulaçâo dos jogadores de futebol brasileiros no exterior. Horizontes Antropológicos, v. 4, n. 30, p. 21-65, dez. 2008. https://doi.org/10.1590/S0104-71832008000200002

RIGO, L. C. Memórias de um futebol de fronteira. Pelotas: Editora da UFPel, 2004.

SANTOS, M. A. S. Futebol de várzea como espaço de sociabilidade. Dissertação (Mestrado) - Pontifícia Universidade Católica de São Paulo, São Paulo, 2001.

SANTOS, J. M. C. M. Revoluçáo vascaína: a profissionalização do futebol e a inserção sócio-econômica de negros e portugueses na cidade do Rio de Janeiro (1915-1934). Tese (Doutorado) — Programa de Pós-Graduação em História Econômica, Universidade de São Paulo, São Paulo, 2010.

SEVCENKO, N. Orfeu extático na metrópole. São Paulo, sociedade e cultura nos frementes anos 20. São Paulo: Companhia das Letras, 1992. 
SILVA, M. R. Mil e uma noites de futebol. O Brasil moderno de Mário Filho. Belo Horizonte: Editora da UFMG, 2006.

SILVA, A. P. Pelé e o complexo de vira-latas: discurso sobre raça e modernidade no Brasil. Tese (Doutorado) Universidade Federal de Roraima, Boa Vista, 2008.

SILVA, D. M. M. Futebol de várzea em Sáo Paulo. A Associação Atlética Anhanguera (1928-1940). São Paulo: Alameda; Fapesp, 2016.

SIMMEL, G. Questóes fundamentais de sociologia. Rio de Janeiro: Zahar Editor, 2006.

SOARES, E. A bola no ar. O rádio esportivo em São Paulo. São Paulo: Summus, 1994.

SOARES, A. J. G. Mário Filho: a "inesgotável fonte" da repetida história do futebol brasileiro e seus crentes bebedores. In: V Encontro de História do Esporte, Lazer e Educação Física, 5., 1997, Maceió. Anais [...]. Maceió: CHELEF, 1997.

SOUZA, D. A. Pra frente, Brasil! Do Maracanazzo aos mitos de Pelé e Garrincha, a dialética da ordem e da desordem (1950-1983). São Paulo: Intermeios, 2018.

SOUZA, J. O "esporte das multidóes" no Brasil: entre o contexto de açâo futebolístico e a negociação mimética dos conflitos sociais. Tese (Doutorado em Educação Física) — Universidade Federal do Paraná, Curitiba, 2014.

SOUZA, J.; MARCHI JÚNIOR, W. As linhagens da sociologia do futebol brasileiro - um programa de análise. Movimento - Revista e Educaçáo Física da UFRGS, v. 23, n. 1, p. 101-118, 2017. https://doi. org/10.22456/1982-8918.55428

SOUZA, J. A linhagem culturalista da sociologia do futebol brasileiro. Lua Nova, n. 103, p. 103-134, 2018. http:// dx.doi.org/10.1590/0102-103134/103

SPAGGIARI, E. Família joga bola. Constituição de jovens futebolistas na várzea paulistana. Tese (Doutorado) Programa de Pós-Graduaçáo em Antropologia Social, Universidade de São Paulo, São Paulo, 2014.

SPAGGIARI, E.; MACHADO, G. M. C.; GIGLIO, S. S. Apresentação. Por uma (nova) agenda de pesquisa sobre práticas esportivas. In: SPAGGIARI, E.; MACHADO, G. M. C.; GIGLIO, S. S. (orgs.). Entre jogos e copas. Reflexôes de uma década esportiva. São Paulo: Intermeios; Fapesp, 2016. p. 9-31.

SPÖRL, M. C. C. (org.). Soccer in Brazil. Sport in the global society. contemporary perspectives. Abigton: Routledge, 2014.

STRATHERN, M. O efeito etnográfico. São Paulo: Cosac Naify, 2014.

STREAPCO, J. P. F. Cego é aquele que só vê a bola. O futebol paulistano e a formaçâo de Corinthians, Palmeiras e São Paulo. São Paulo: Edusp, 2016.

TOLEDO, L. H. Futebol e teoria social: aspectos da produção acadêmica brasileira (1982-2002). Revista Brasileira de Informação Bibliográfica em Ciências Sociais, v. 52, p. 133-165, 2001.

TOLEDO, L. H. Remexer anotaçóes: o trabalho de um arguidor antropólogo. São Carlos: EdUFScar, 2019a. (Coleçáo Aracy Lopes da Silva).

TOLEDO, L. H. Mortes esportivas e alegorias políticas: etnografando temores em torno dos esportes-nação. Anuário Antropológico, v. 44, n. 1, p. 253-284, 2019b. https://doi.org/10.4000/aa.3519

TOLEDO, L. H. Antijogo: consideraçôes em torno de uma categoria da diferença. Horizontes Antropológicos, ano 26, n. 56, p. 255-291, 2020. https://doi.org/10.1590/s0104-71832020000100011 
TOLEDO, L. H.; CAMARGO, W. X. Futebol dos futebóis: dissolvendo valências simbólicas de gênero e sexualidade por dentro do futebol. Revista FULIA/UFMG, v. 3, n. 3, p. 93-107, 2018. http://dx.doi.org/10.17851/25264494.3.3.93-107

THOMAZ, D. W. Medalha e continência: uma etnografia de atletas militares no esporte de representação nacional. Dissertação (Mestrado) - Programa de Pós-Graduação em Antropologia Social, Universidade Federal de São Carlos, São Carlos, 2019.

TURNER, V. Floresta de símbolos. Aspectos do ritual Ndembu. Niterói: EdUFF, 2005.

VIANNA, F. Boleiros do cerrado: índios Xavantes e o futebol. São Paulo: Annablume Editora; Fapesp; ISA, 2008.

VOVELLE, M. Ideologias e mentalidades. São Paulo: Brasiliense, 1987.

WAIZBORT, L. As aventuras de Georg Simmel. 3. ed. São Paulo: Editora 34, 2013.

WAGNER, R. A invençáo da cultura. São Paulo: Cosac Naify, 2010.

WAGNER, R. The logic of invention. Chicago: Hau Books, 2017.

VIVEIROS DE CASTRO, E. Metafísicas canibais. São Paulo: Cosac Naify, 2015.

VIVEIROS DE CASTRO, E. A antropologia perspectiva e o método da equivocação controlada. ACENO - Revista de Antropologia do Centro-Oeste, v. 5, n. 10, p. 247-264, 2018.

ZUCAL, J. G. (comp.). Violencia en el fútbol. Investigaciones sociales y fracasos políticos. Buenos Aires: Ediciones Godot, 2013. 


\title{
Das áreas culturais às redes de relações: os sistemas regionais ameríndios em análise ${ }^{*}$
}

\author{
Felipe Vander Velden ${ }^{\mathrm{I}}$ \\ Pedro Lolli ${ }^{\mathrm{I}}$
}

\section{Introdução}

Desde o final dos anos $1970^{1}$, um dos desafios da etnologia americanista tem sido pensar as sociedades indígenas nas (ou nativas das) terras baixas da América do Sul ${ }^{2}$ num contexto de multiplicidade de comunidades fluidas, dinâmicas e dispersas, as quais se relacionam como sistemas abertos e nas quais não se verificam delimitaçóes claras sobre o que se define como fronteiras étnicas. Esses contextos de multiplicidade de comunidades resistiam à aplicaçáo de outro relacionado à unidade social, marcado pelo estrutural-funcionalismo. A corrente teórica ainda estava em voga no pensamento antropológico mainstream, em que as unidades sociais eram concebidas como totalidades internamente articuladas, cujas funçôes visavam, principalmente, à "autopreservação" do grupo. Desse modo, noçôes como as de sociedades "tribais" ou "étnicas" e de "gru- pos (sociais)" vinham sendo questionadas, pois pressupunham coletivos como unidades de análise isoladas, fixadas em torno de um território, mônadas cosmológicas que compartilhavam língua, cultura e identidade comuns e perseveravam ao longo do tempo. Além disso, essas categorias podiam, em tese, ser acompanhadas desde seus vestígios arqueológicos até tempos históricos e, em alguns casos, até o momento presente (Leach, 2014 [1954]; Barth, 1969).

Os desdobramentos dessas críticas foram muitos e variados, tanto no que diz respeito às áreas etnográficas quanto aos temas e às abordagens das pesquisas. Portanto, não seria possível aqui, nos limites deste artigo, esgotar essa riquíssima produçãa ${ }^{3}$. Vale seguir com mais cuidado os impactos que essas críticas produziram nas pesquisas sobre os chamados sistemas regionais ameríndios ou as redes de relaçôes que conectam comunidades distintas, por meio de circulação de

1 Os marcos importantes foram as publicaçóes das Actes du XLII Congrès International des Américanistes, organizadas por Overing Kaplan (1977), e do conhecido artigo seminal de Seeger, DaMatta e Viveiros de Castro (1979).

2 Também denominadas, por alguns, ameríndias, ainda que este termo cubra todos os povos nativos das três Américas e só tenha ganhado tração para agregar os povos sul-americanos na década seguinte

3 Ver, entre outros, a discussão crítica de Viveiros de Castro (1999).

${ }^{*}$ Os autores agradecem aos dois pareceristas anônimos da BIB pela criteriosa leitura e sugestôes muito pertinentes, e a Luisa Fanaro, pela gentileza de revisar o manuscrito.

'Universidade Federal de São Carlos (UFSCar). E-mails: fvander@ufscar.br, pelolli@ufscar.br 
pessoas, alimentos e palavras, questóes discutidas por Lévi-Strauss (1976 [1949]) e Clastres (1974). Igualmente, bem no espírito da formulação Maussiana dos "sistemas de prestaçôes totais", ou seja, de recursos naturais, artefatos, animais e plantas, mitos, rituais, conhecimentos, guerras, partes de corpos e muito mais. Nosso ponto, nesta recensão bibliográfica, é demonstrar que as investigaçóes cada vez mais detalhadas dos sistemas regionais ou das redes de intercâmbio têm deslocado o foco das unidades étnicas para conjuntos multicomunitários, driblando a "ilusão presentista" que enxerga a polinésia de "ilhas indígenas" (Viveiros de Castro, 2019) atuais como um retrato aproximado fiel do passado, apostando nas descontinuidades étnico-territoriais (Lévi-Strauss, 1952 [1975], Viveiros de Castro, 1993a). Ainda, a ênfase na análise de regióes ou redes mais ou menos interligadas tem permitido não apenas adensar o conhecimento interno a esses sistemas, mas, sobretudo, a "abri-los" para a compreensão das relaçóes entre regióes, redes ou sistemas - de relaçóes entre relaçóes, por assim dizer — , de modo a produzir um cenário de conexóes de alcance continental, um tecido contínuo de contatos, orquestrados por um "sistema de pensamento". Esta parece a muitos autores uma imagem mais precisa das comunidades humanas nativas das terras baixas da América do Sul antes da conquista europeia iniciada em 1972 — a tal "Idade Média à qual teria faltado sua Roma" (Lévi-Strauss, 2004 [1964], p. 27) ${ }^{4}$.

Neste balanço bibliográfico, propomos reconstituir parte das abordagens teórico-metodológicas que abandonaram paulati- namente o "fechamento" ou "isolamento" monádico das unidades sociais nas terras baixas da América do Sul, rumo a análises que passaram a privilegiar sua "abertura", "conexão" ou "interdependência” em relação umas às outras. Tal reconstituição concentra-se na história intelectual, no interior da etnologia americanista, dos conceitos de "áreas cultural ou etnográfica", de "sistemas regionais" e, mais recentemente, de "redes (de relaçôes)". Não estamos, por esta razão, tão interessados nas propostas que postulam filosofias sociais indígenas da abertura do socius para o exterior ou à alteridade, tal como se configura com força na disciplina a partir dos anos 1990 (Viveiros de Castro, 1996). Na prática, isso é dissolvido na própria oposição entre exterior e interior, ainda que o impacto dessas abordagens para a investigação dos sistemas regionais nativos seja inegável e certamente produtivo, quiçá revolucionário. De todo modo, nossa ideia central é, justamente, apostar no rendimento de um novo debate sobre as complexas interaçóes entre os postulados (por nativos e etnólogos) "exterior" e "interior" — pela via privilegiada de estudos em escalas regionais ampliadas, de caráter multiétnico ou multicomunitário.

Para tanto, e de modo a enfatizar nossa adesão a estudos dessa natureza ampliada, pretendemos comparar dois sistemas regionais: um deles já consagrado por ampla etnografia e pela literatura, o Alto do Rio Negro (ARN), e o outro, proposto de forma alternativa ao modo usual de tratar a região e o tema, a chamada Grande Rondônia, ou Alto Madeira. Nesse sentido, apresentamos uma reflexão sobre um sistema e uma refle-

4 Note-se que, como a produção etnológica (mesmo no Brasil) é imensa (ainda mais quando nos lançamos às discussóes pancontinentais), optamos por concentrar nossas referências em trabalhos publicados (livros, capítulos, artigos, teses e dissertações), infelizmente deixando de lado uma produção substancial de relatórios e laudos e a documentação primária que ainda aguarda exploraçóes mais detalhadas. 
xão-proposta sobre o outro, com a intenção de testar a proficuidade da noção de sistema regional e de outras noçóes correlatas, tanto no interior de uma área amplamente investigada etnograficamente como sistema regional clássico quanto no interior de outra regiāo apresentando elementos que, como sustentado aqui, autorizam pensá-la também como sistema regional. Para isso, bastam ajustes ao conceito, que constituem, precisamente, parte de nossa contribuição neste texto. Esta seleção não pretende sugerir que outras áreas geográficas, etnográficas ou culturais (ou outras redes) não possam ser definidas e analisadas da mesma forma que fizemos aqui com apenas duas delas. De fato, os recortes são, e não poderiam deixar de sê-lo, sempre arbitrários, dada a abertura das redes de relaçóes. Se o leitor, ou leitora, precisar de um esforço semelhante para outras áreas ou redes, não é porque estas são tangentes às redes tratadas ou às franjas nos sistemas regionais tomados em primeiro plano; mas, sim, porque orientamos nossos recortes em função de nossas especialidades (o ARN e Rondônia/Sudoeste amazônico).

Não obstante, acreditamos que esta estratégia comparativa rende frutos, como se verá, especialmente pelo fato de compararmos regióes com históricos de abordagens muito distintos, conforme mencionamos. O resultado é demonstrar que, guardadas todas as especificidades regionais, as dinâmicas que se caracterizam pela abertura e pelos intercâmbios generalizados entre "unidades sociais" - relações que orquestram a própria definição, sempre dinâmica e contextual, dessas mesmas unidades perpassam diferentes áreas etnográficas ou culturais, tão somente recortes analíticos, conectando virtualmente todo o tecido social sul-americano, tanto física quanto metafisicamente.

\section{Das áreas culturais às redes de relações}

A noção de sistema regional é bastante antiga e largamente aplicada em estudos sobre os povos nas Américas, embora não de maneira uniforme. Na Mesoamérica e no Altiplano Andino, não houveram muitas dificuldades em afirmar que as sociedades ("civilizaçôes") encontradas, as quais apresentavam formas de centralizaçáo hierárquica $e$ estratificação social, compunham extensos sistemas regionais conectados por estruturas políticas de tipo estatal e instituiçóes de naturezas militar e comercial (Kirchhoff, 1943; Steward, 1946; Oberg, 1955; Service, 1975). No entanto, nas chamadas Terras Baixas Sul-Americanas, sempre houve muitas dificuldades, visto que a imagem cristalizada das sociedades encontradas era a de unidades sociais de pequena escala, atomizadas, igualitárias, endogâmicas, fluidas e dispersas, separadas por largos vazios demográficos, amplos domínios da "natureza", e largamente desprovidas de contatos com vizinhos um pouco distantes, as famosas mônadas.

O contraste entre terras altas e baixas se consolidou com a publicação do Handbook of South American Indians, doravante HSAI, em sete volumes, sob a organização de Julian Steward no final da década de 1940 e início dos anos 1950. Este foi um trabalho de enorme fôlego no sentido de estabelecer uma classificação geral de áreas culturais para a América do Sul (Steward; Faron, 1959). Isso não se referia apenas à macrodivisão do mapa etnológico do continente, orientada, como se sabe, por critérios ecológico-materialistas, em quatro grandes divisões correspondentes aos volumes dois a cinco da coleção, mas, igualmente, na percepção de que, para algumas regiôes, a análise se mostrava muito mais profícua quando abordados conjuntos pluriétnicos, como foi o caso, entre 
vários outros, das Guianas (Gillin, 1948), do Gran Chaco (Métraux, 1946) e do Valle del Cauca colombiano (Hernández de Alba, 1948). Esse é apenas um exemplo de cada volume dos três concernentes às Terras Baixas, e não de sociedades ou povos isolados. Porém, talvez (mais pesquisa se faz necessária aqui) esta organização dos volumes tenha seguido critérios relacionados tanto à quantidade de informação disponível para distintas zonas ou populaçóes, quanto por uma seleção, entre organizadores e autores, de quais grupos mereceriam ser abordados por capítulos separados e quais seriam subsumidos em panoramas regionais mais amplos (cf. Fausto, 2000; Faulhaber, 2012). Apenas pesquisas adicionais em torno do processo de organização e edição do HSAI poderão esclarecer a escolha dos autores e as decisóes quanto aos recortes étnicos, linguísticos e/ou históricos adotados na versão final da coleção de volumes, incluindo as definiçóes de certos conjuntos regionais e suas fronteiras.

Outro esforço de se estabelecerem sistemas regionais, por meio da noção aproximada, mas não exatamente coincidente, de áreas culturais, na América do Sul, foi o de Eduardo Galvão (1979) e Silva (2007). Segundo Melatti (2019), a contribuição de Galvão em relação ao HSAI foi incluir, nos critérios de definição das áreas, um limite temporal de validade (1900 a 1959), além dos contatos intertribais e com as sociedades coloniais e nacionais. $\mathrm{O}$ autor aprofundou, desse modo, a ênfase nas relaçóes sociais em detrimento dos traços culturais para se pensar a constituiçấo de sistemas regionais, algo em certa medida iniciado pelo HSAI, a "validade" temporal das áreas definidas por Galvão, reconhecendo implicitamente as transformaçóes permanentes dos grupos indígenas, em um contexto intelectual marcado pelas ideias de "aculturação" e profecias de acelerada mudança, integração e extinção dos povos nativos do Brasil (Ribeiro, 1996 [1970]). Sem dúvida, essa mudança permitiu que se abrisse um campo extenso de pesquisas mais focadas nos intercasamentos, nas trocas comerciais, nos convites para festas e rituais, na procura dos serviços de médicos-pajé, no contato com a sociedade não indígena; em suma, nas relaçôes sociais entre grupos culturais, ainda que a interação entre distintos sistemas regionais fosse pouco marcada e a noção sistêmica de "rede", inexistente.

Tanto os autores do HSAI como Eduardo Galvão incorporaram algumas propostas antigas de certos sistemas regionais, tais como o Alto Xingu, o ARN e a região das Guianas, que puderam ser observados etnograficamente ainda em funcionamento relativamente estável (Von den Steinen, 1942; Koch-Grünberg, 1979), mas propuseram, em larga medida, quais seriam as regiōes marcadas pelo adensamento de suas conexões internas, em detrimento das relaçóes com o exterior. Com isso, abriram portas para pesquisas que investiram nessas regióes, incrementando sua caracterização sistêmica segundo eixos não só étnicos e socio-históricos, mas também linguísticos e socioculturais (Rivière, 1984). Além disso, mais trabalhos buscaram caracterizar as conexões internas a outras regióes, embora a percepção destas como sistemas regionais em sentido estrito não fosse aventada; é o caso, por exemplo, do Brasil central (Maybury-Lewis, 1979), do litoral atlântico brasileiro (Fausto, 1992) e da imensa zona ocupada pelos grupos Guarani no Sul do continente (Monteiro, 1992; Soares, 1997).

Contudo, permaneceu, como problema metodológico, as questôes referentes a como delimitar os sistemas regionais. Onde termina, ou onde começa, um sistema regional? 
Quais os limites das redes de intercâmbios de distintas naturezas, e em quais direçóes se espraiam a partir de diferentes centros de origem? O que qualifica, afinal, cada uma das noçôes correlatas discutidas aqui: sistema regional, rede de trocas, áreas etnográficas, geográficas ou culturais? As dificuldades de se enfrentar essas questôes são homólogas àquelas enfrentadas por estudos monográficos sobre um determinado grupo nas Terras Baixas Sul-americanas, na medida que aqui, também, as fronteiras sociológicas não se deixam definir facilmente: a definição dos limites de uma "sociedade" pode ser táo problemática, e mesmo tấo arbitrária, quanto a definição dos limites de um sistema regional, ou seja, um "sistema de sociedades". Ainda, são muitos os casos em que nem todos os grupos de um sistema regional apresentam as características sociais e culturais "típicas" do conjunto, o que solicita aprofundamento constante das investigaçôes internas aos sistemas em questão.

Durante a década de 1980, houve uma profusão de excelentes monografias etnográficas clássicas realizadas junto a grupos étnicos específicos, que trouxeram importantes contribuiçóes para o entendimento da organizaçáo social ameríndia e para uma superação de suas várias definiçôes por ausências, ecoando, desde tempos coloniais, a famosa expressão de Pero de Magalháes Gândavo que se referia aos nativos americanos: "sem rei, sem lei e sem fé". Trabalhos mais gerais sobre os sistemas regionais ameríndios não tiveram a mesma atenção das pesquisas, embora já despontassem trazendo conclusóes interessantíssimas, só retomadas, a rigor, no início dos anos 2000 (Lathrap, 1970; Lyon, 1974; 1981; Myers, 1981; DeBoer, 1981; Bodley, 1981; Renard-Casevitz; Saignes; Taylor, 1986; Dreyfus, 1993). Portanto, as etnografias localizadas e em profundidade não significaram um abandono das questôes regionais, sobretudo em relação às pesquisas realizadas em áreas classicamente definidas como sistemas regionais, por exemplo, os mencionados ARN e o Alto Xingu. Além disso, muitas dessas monografias ofereceram descrições etnográficas riquíssimas sobre as relaçôes de troca inter e multiétnica e outras formas de conexão (guerra, casamentos ou rapto de mulheres e crianças, corpora mitológicos, comércio de objetos e outras).

Essa desproporçáo entre as monografias sobre povos específicos e as sínteses de caráter regional talvez tenha sido necessária, ou mesmo inevitável, e representou um certo momento da produçáo etnográfica. Parecia, então, muito temeroso conjecturar explicaçôes mais gerais sobre os sistemas regionais na América do Sul, pois ainda existiam muitas lacunas a serem preenchidas no mapa do etnologicamente "menos conhecido dos continentes" (Lyon, 1974). No entanto, a despeito das dificuldades, isso não impediu a consolidação de questóes teóricas comuns, de amplo alcance, que contribuíssem para a produção de uma etnologia indígena sul-americana propriamente dita, constituída como campo disciplinar autônomo e às voltas com seu conjunto de problemas específicos de natureza regional. Já haviam sido plenamente digeridas tanto as contribuiçóes de Lévi-Strauss, para pensar as Américas como um conjunto coerente no quadro das regiōes etnográficas do planeta, quanto as elaboraçôes dos anos 1970, que seguem no mesmo rumo, com destaque para o projeto "Harvard Central-Brazil", distanciando a etnologia americanista das preocupaçóes gestadas sobretudo em solo africano.

Vale destacar também as profundas diferenças linguístico-culturais, de localização geográfica, ou de história e situação de contato, ou seja, um mesmo conjunto temático 
que parecia ocupar muitos etnólogos (Overing Kaplan, 1983-1984; 1984; 1986; 1989; Menget, 1985; 1993a; 1993b; Carneiro da Cunha; Viveiros de Castro, 1985; Henley, 1996). Esses trabalhos pioneiros, mais à frente de suas contribuiçóes de cunho etnográfico, apostavam mais fortemente em reflexôes comparativas, identificando questóes comuns a grupos e conjuntos multiétnicos para além dos sistemas regionais clássicos (Rio Negro, Xingu, Guianas) e ultrapassando, desse modo, as fronteiras étnicas, linguísticas, históricas e culturais que marcam a multiplicidade de povos indígenas no continente. Além disso, os autores buscavam eixos analíticos e comparativos que os afastassem do viés culturalista que até então pensava os povos indígenas como mônadas suspensas e dispersas pelo continente, agrupadas tão somente por caracteres geográficos ou culturais mais ou menos "naturais" (que constituíam as tais "áreas culturais" até então em voga). Esses trabalhos, que abrem novas estratégias analíticas e comparativas, acabam por encontrar no termo "ameríndio" um substituto menos controverso do que os termos "indígena" ou "índio sul-americano", carregados pela história colonial e dispersos por outras disciplinas. Ademais, de certo modo, tais autores e autoras começaram a demonstrar que os estudos não deveriam se limitar ao interior dos conjuntos étnico-cultural-regionais consagrados, mas deveriam se abrir para interseçôes entre tais conjuntos, ou seja, relaçóes entre sistemas de relaçóes.

Desse modo, ao final dos anos 1980 e início dos anos 1990, um grande e valioso número de estudos monográficos minuciosos e localizados tinha se acumulado que acabou fornecendo um consistente solo etnográfico para que as pesquisas sobre os sistemas regionais pudessem avançar. Muitos desses trabalhos deixaram de se centrar ape- nas no nível do grupo ou tribo e passaram a abarcar relaçóes mais amplas, enfatizando-se mais e mais as interaçóes socio-históricas e os sistemas regionais. No início da década de 1990, verificou-se uma certa relativização das abordagens monográficas e a-históricas que marcaram a etnografia da América do Sul até aquele momento (Descola; Taylor, 1993, p. 21). Dentre os trabalhos etnográficos que obrigatoriamente estavam relacionados com o problema das interaçóes regionais, como aqueles realizados no Alto Xingu e no ARN, começam a tomar forma e força os estudos sobre os povos da família linguística Aruak e a emergir sua caracterizaçáo como os grandes artífices intelectuais e materiais da integração das terras baixas sul-americanas em grandes sistemas regionais articulados. Como se sabe, a família linguística Aruak (Arawak) tem se espalhado amplamente por diversas partes da América do Sul (Urban, 1992; Campbell, 1997; Ramirez, 2001; Hill; Santos-Granero, 2002; Hornborg, 2005). Além das duas regióes supracitadas, também encontramos grupos nas regióes do Purus, do Orinoco, do Caribe, das savanas da Bolívia e do sudoeste do Brasil; talvez, também fossem Aruak a maioria das populaçóes encontradas na calha do Amazonas desde a conquista. Essa enorme dispersão Aruak levou, desde muito cedo, pesquisadores a se questionarem sobre a possibilidade de sustentarem extensas redes de troca e circulação entre vários sistemas regionais da América e algumas propostas explicativas a avançarem (Schmidt, 1917; Lathrap, 1970; Hill; Santos-Granero, 2002; Eriksen, 2011).

Hipóteses mais robustas começaram a ganhar consistência ao longo da década de 1990, quando houve o desenvolvimento de muitos trabalhos antropológicos, históricos, linguísticos e arqueológicos, que, reunidos de maneira sistemática pela primeira vez 
em volumes dedicados ao tema das relaçóes regionais, deram força às investigaçóes que dirigiram seus olhares não apenas às unidades sociais ou "tribais" singulares, mas para regiōes ou sistemas regionais. Datam desta década duas coletâneas fundamentais e de grande impacto para a subárea da História Indígena, que tomam diferentes partes das Terras Baixas da América do Sul como contextos pluriétnicos e multilinguísticos necessários para o entendimento dos povos nesta regiāo (Carneiro da Cunha, 1992; Salomon; Schwartz, 1999a; 1999b).

Vale ressaltar que, se esses trabalham colocam na ordem do dia o campo da História Indígena, na interface entre Antropologia e História, focando-se nas complexas relaçóes entre povos ameríndios e atores coloniais ou nacionais diversos, ou seja, de caráter eminentemente relacional (Monteiro, 1994; Celestino de Almeida, 2010), as pesquisas também sofrem um acrimonioso ataque por parte daqueles que sustentam o privilégio das elaborações internas aos grupos sociais às expensas de reflexóes sobre suas relaçóes com o que lhes é exterior. Lévi-Strauss (2001), um dos primeiros críticos da ambiciosa proposta de Salomon e Schwatrz, argumenta, entre outras coisas, que a obra não passava de uma coleção de histórias escritas "de fora", ou seja, pelos historiadores que escamoteavam a relação entre história e mito e ignoravam o aporte estruturalista na análise dos fenômenos. Junto às bem-humoradas respostas dos dois autores norte-americanos (Schwartz, 2002; Schwartz; Salomon, 2003), o debate deixa entrever, de certa forma, a questão buscada aqui: como articular esta ênfase lévi-straussiana na autonomia das estruturas com as novas abordagens, oriundas não apenas $\mathrm{da}$ etnografia mas também, em larga medida, da etno-história indígena, perspectivas que sustentavam cada vez mais a tese da centralida- de dos intercâmbios na própria constituição da socialidade ameríndia? É plausível supor que a leitura bastante crítica do mestre francês tenha constituído tão somente um breve desvio na trajetória relativamente retilínea na direção de investigaçóes que privilegiavam a abertura e as conexóes sistêmicas ao invés de mecanismos interiores, haja vista a boa recepção da coletânea de Manuela Carneiro da Cunha no Brasil, expressa de forma contundente (Viveiros de Castro, 1993a) por um dos grandes entusiastas dos modelos de abertura dos universos sociais ameríndios para o exterior, abertura tal que a própria dicotomia interno/externo acaba por perder muito de seu sentido (Viveiros de Castro, 1986b).

As pesquisas etno-históricas e arqueológicas - ou, neste último caso, leitura paralela de achados arqueológicos e etnologia indígena - também avançam, sobretudo na várzea amazônica (Porro, 1992; 1993; 1996; 2007; Roosevelt, 1991; 1992; 1994; McEwan; Barreto; Neves, 2001). Nesse cenário, começam a tomar corpo as hipóteses concernentes à centralidade dos povos de língua Aruak na história de formação dos conjuntos regionais e das redes de intercâmbio que percorriam o continente sul-americano. Em 2002, como reação às sínteses disponíveis para os povos de língua Jê (Maybury-Lewis, 1979), Tupi (Laraia, 1986; Viveiros de Castro, 1986b) e Karib (Basso, 1977; Rivière, 1984), mas ainda ligadas, portanto, a uma relação talvez pouco problematizada entre língua e etnia/cultura, publicou-se a coletânea Comparative Arawakan Histories. Rethinking language family and culture are in Amazonia (Hill; Santos-Granero, 2002). Esta reunia uma parte desse mosaico de pesquisas e propunha desenvolver uma síntese das principais questóes e hipóteses encontradas nos estudos dos grupos da família Aruak. A discussão sobre a interação entre 
os sistemas regionais é colocada em primeiro plano na coletânea na medida em que uma das questôes centrais é entender, justamente, a diáspora do que se costuma chamar de matriz Aruak, que sedimentou, por séculos, os circuitos de trocas transcontinentais.

Segundo Hill e Granero (2002), a dispersão dos Aruak por extensas áreas do continente - muitas onde, atualmente, não se encontram redes de comunicação e intercâmbio em pleno funcionamento - torna praticamente impossível a distinção entre traços culturais, que são o produto da filiaçáo linguística, e aqueles resultantes da convivência histórica entre grupos. Por isso, os autores da coletânea se propuseram a levar o exercício comparativo adiante sem se orientar tanto por uma noçáo de "traços culturais". A ideia de unidade Aruak permaneceu, mas com o objetivo de examiná-la a partir da comparação entre distintos processos históricos e práticas culturais produzidas historicamente, a qual vários trabalhos etnográficos, históricos, linguísticos e arqueológicos tinham descrito e analisado. Com isso, a noção de migração como simples movimento de grupos Aruak sobre uma terra vazia perdeu força e passou a ser questionada como explicação da excepcional diáspora Aruak. Tampouco pressupóe-se que os grupos Aruak, quando avançaram sobre novos territórios, expulsaram ou aniquilaram os outros que encontraram ao longo do caminho. Em vez disso, propõe-se que a dispersão Aruak esteve ligada à integraçáo de uma extensa rede regional de comércio que se estendia ao longo da Bacia Amazônica, conectando-a tanto aos Andes quanto ao Caribe (cf. Hornborg, 2005). As pesquisas arqueológicas realizadas na Amazônia, sobretudo a partir da década de 1990 , foram fundamentais para corroborar essa hipótese, na medida em que começaram a encontrar indícios da existência de grandes concentraçôes populacionais após a formação de grandes centros regionais que mantinham contato, diferentemente da imagem tradicional de que na Amazônia somente teriam existido sociedades fragmentadas, fechadas e de pequena escala (Porro, 1992; 1993; 1996; Balée, 1998; Neves, 2012a). $\mathrm{Na}$ própria coletânea, temos a contribuiçâo de arqueólogos cujas pesquisas defendem essa nova imagem da regiáo (Heckenberger, 2002; Zucchi, 2002).

A partir daí, a ênfase das pesquisas passou a ser mais nos processos sociais envolvidos na manutenção e na construção de fronteiras étnicas. Ganhou destaque o conceito de "etnogênese", que procura superar o essencialismo de conceitos como identidade e destacar as dinâmicas das interaçóes e a produção historicamente contextual e multicêntrica de "etnias" e "grupos" (Hornborg, 2005). Portanto, aproxima-se, ainda, do conceito de "transculturação", também aplicado na relativização das unidades étnicas ou socioculturais e na aposta de sua contingência e fluidez (Uzendoski, 2004). A crítica à tese da migração, postulada nessa coletânea de 2002, foi aprofundada quase uma década depois com o lançamento de outra coletânea que também concentra estudos sobre os grupos Aruak: Ethnicity in ancient Amazonia: reconstructing past identities from archaeology, linguistics, and ethnohistory (2011), também organizada por Hill, mas agora em parceria com Alf Hornborg.

A partir de tal abordagem, as duas coletâneas sintetizaram o que foi denominado de "matriz Arawak", que reúne as características que podem ser atribuídas aos grupos desta família linguística: integram sistemas regionais multilinguísticos, multiétnicos e centralizados, organizados por uma hierarquia que se define por uma complexa rede de trocas cerimoniais; toponímia é muito importan- 
te, pois é carregada de sentido histórico por meio de "escritas topográficas" (Santos-Granero, 1998). Em ligação com tais características, constata-se forte ênfase nas noçôes de descendência, genealogia, consanguinidade e ancestralidade. Além disso, as formaçôes sociopolíticas dos grupos Aruak são marcadas por ênfase na conexão, abertura e expansão dos sistemas regionais em seus diferentes níveis de abrangência, o que levou à caracterização dessas formaçóes como pacíficas, ao menos internamente, por meio de "supressão da endo-guerra" - como no conhecido caso dos Aruak subandinos (Renard-Casevitz, 1992; Santos-Granero, 1993; Hill; Santos-Granero, 2002; Eriksen, 2011, p. 269-278).

No mesmo período, durante o início da década de 2000, um outro conjunto de trabalhos etnográficos, que também se propuseram a superar os modelos identitaristas e substancialistas, mas concentrados na Amazônia, também procurava consolidar algumas sínteses sobre as sociedades ameríndias seguindo a vasta produçáo das duas décadas anteriores. A partir de um exame etnográfico minucioso das ligações e transformaçôes que atravessam os múltiplos planos sociopolíticos, cosmológicos e ontológicos, esses autores também deram ênfase à rede de relaçóes supralocais. Inspirados numa Amazônia lévi-straussiana - a partir da leitura das $\mathrm{Mi}$ tológicas - esses trabalhos procuraram levar adiante a ideia da "abertura para os outros" e, por isso, foram reunidos sob a rubrica de "economia simbólica da alteridade" (Viveiros de Castro, 2002). Assim, a relaçấo com a exterioridade deixa de ser uma dimensão do antissocial para se transformar não só em parte da engrenagem da reprodução social, mas o próprio cerne de seu funcionamento. Com isso, ganham destaque a noção de afinidade potencial e os temas que em alguma medida tratam das relaçóes com a alteridade: guerra, xamanismo, caça, canibalismo, ritos funerais e comércio. Especial destaque é a guerra, que, nessas abordagens, não é mais entendida como um signo de destruiçáo dos vínculos sociais ou do fracasso de uma negociaçáo, mas como uma relaçáo positiva e produtiva socialmente - e que tem impacto na formação (e na análise) das redes de relaçóes ou sistemas regionais em funcionamento na Amazônia: trocam-se não somente bens, pessoas (via casamento) e visitas, mas também agressóes, butins de guerra e partes de corpos.

Desse modo, ainda que também fundamentada na ideia de abertura, essa abordagem se desenvolve a partir e através da guerra e da predação, contrastando com a proposta dos estudos Aruak mencionados, que trabalham a abertura a partir dos idiomas da generosidade e confiança. Essa foi (ou é) uma divergência importante, que acabou por produzir um denso e intenso debate entre os autores dessas respectivas abordagens e cujas controvérsias produziram momentos de tensão no campo disciplinar, que, inclusive, remetem à discussão sobre certa definição de história evocada anteriormente e ao embate entre trabalhos alinhados ao estruturalismo de Lévi-Strauss e trabalhos críticos a esta linha. Não reproduziremos as minúcias desse debate, pois isso desviaria o foco de nossa proposta, mas tratamos de evidenciá-lo para afirmarmos que as controvérsias foram um importante combustível para impulsionar ainda mais as pesquisas sobre os sistemas regionais. Uma das interessantes consequências desses debates mais recentes parece ter sido a emergência dos Aruak como oponentes centrais, na compreensão das sociocosmologias ameríndias, dos Tupi já alçados a protagonistas de certo modelo teórico desde Clastres e, depois, Viveiros de Castro; e 
isso às expensas, sobretudo, dos Jê-Bororo, que perderam algo de sua proeminência nos debates - mesmo após a extensa síntese de materiais disponíveis efetuada por Coelho de Souza (2002).

Houve um grupo de pesquisadores ${ }^{5}$ em torno do projeto “Transformaçóes indígenas: os regimes de subjetivação ameríndios à prova da história”, coordenado por Viveiros de Castro em 2003, que se dedicou a pensar a formação dos sistemas regionais a partir e através da abordagem que privilegiava o idioma da guerra e da predação e desenvolveu os conceitos (entre outros) de perspectivismo e afinidade potencial. Em vez de buscar os contornos nítidos de onde se encontram as fronteiras dos sistemas sociais regionais, esse grupo procurou focar nas transformações possíveis entre os limites a partir da noção de afinidade, tornando-a um operador cosmológico central e fundante do socius. Como Hugh-Jones (2013) postula, a noção adquire "um valor transcendental de afinidade sem afins" que regula as relações sociais com as alteridades distantes, incluídas aí as relações com os muitos seres não humanos (Århem, 1996; Descola, 1994; Viveiros de Castro, 1992; Fausto, 2001; Lima, 2005). Com isso, a predação, a guerra e a afinidade deixam de ser uma ameaça para a sociedade e adquirem um valor positivo na constituição do socius ameríndio.

Desse modo, os sistemas sociais regionais passam a ser definidos como redes policêntricas transitórias que se organizam por um regime contrátil de alianças, que ora se expande, ora se contrai em alternância e que funciona predominantemente por meio do idioma da predação e da afinidade. Esses avanços teóricos foram fundamentais na crítica às abordagens cujo modelo de sociedade ameríndia era o de sociedades atomistas, fragmentadas, para as quais o exterior (a alteridade) era uma ameaça ao socius, sempre independentes e fechadas sobre si mesmas, em luta perpétua contra as forças antissociais do cosmos.

Nessa mesma direção crítica, outro grupo de pesquisa se formou na mesma época num projeto no Núcleo de História Indígena e do Indigenismo (NHII) da Universidade de São Paulo (USP), sob a coordenação de Dominique Gallois e Lux Vidal. O projeto, intitulado "Sociedades indígenas e suas Fronteiras na regiáo Sudeste das Guianas", resultou na publicação, em 2005, da coletânea "Redes de relaçóes nas Guianas", organizada por Gallois. Resultaram num estudo comparativo robusto de uma determinada região sem, no entanto, delimitá-la a prio$r i$ - conforme estabelecido nas discussões sobre a clássica "área cultural guianesa” ou "Circum-Roraima” (Rivière, 1984; Howard, 1993; 2001; Farage, 1991; Farage; Santilli, 1992), mas já incluindo seus extremos, por assim dizer, o conjunto Yanomami, a Oeste, e os Wajāpi e povos do Uaçá (Amapá), a Leste. $\mathrm{O}$ resultado foi uma imagem das sociedades guianenses, segundo os autores, distinta daquela que havia se consolidado até então: a de microssociedades atomizadas, retraídas e xenófobas, cultivando, em alto grau, a endogamia, a autonomia e a recusa do exterior (cf. Rivière, 1984).

As pesquisas reunidas na coletânea (Gallois, 2005) demonstraram que, para além

5 O projeto foi desenvolvido pelo Núcleo de Transformaçóes Indígenas (NuTI) no Museu Nacional da Universidade Federal do Rio de Janeiro (UFRJ), sob a coordenaçáo de Viveiros de Castro, e tinha como membros Tânia Stolze Lima, Oscar Calávia, Carlos Fausto, Aparecida Vilaça, Marcela Coelho, Bruna Franchetto, Geraldo Andrello, Márnio Teixeira-Pinto, César Gordon e Cristiane Lasmar. 
das relaçôes de trocas mais localizáveis, esse conjunto de sociedades possuía uma intensa rede de relaçóes que se estendia para além desses agrupamentos parciais. Abordada desse ponto de vista, a regiáo aparece, então, como um sistema regional formado por conjuntos multiétnicos e linguísticos que se relacionam por trocas matrimoniais, rituais e de bens, e não como um sistema de "fechamento ao outro".

Uma das contribuições desses pesquisadores foi insistir na importância da investigação e da reflexão sobre as interaçóes regionais na América do Sul para se lograr compreender os princípios das organizaçôes sociais. O que se verifica, também, é a extrema dificuldade de operar com categorias como as de etnia e tribo para se pensar a tessitura social nas Guianas. Com isso, mesmo contextos sociais regionais que classicamente se mostraram, a princípio, mais fechados e centrípetos, acabaram se revelando também movidos por forças centrífugas e tendentes à abertura, o que pode caracterizar os (macro) sistemas regionais. Como alternativa aos critérios rígidos de unidade, foi proposta a noção de rede como um valor heurístico para designar um agregado de relaçôes sociais que se transforma à medida que se atualiza, historicamente contraindo-se ou expandindo-se. Esta noção de rede, cuja cotação cresceu, nos últimos anos, devido a várias novas propostas teórico-metodológicas nas ciências sociais em geral, tendo, como seu grande expoente contemporâneo, Bruno Latour, deve ser tomada como a grande contribuiçáo do trabalho deste grupo da USP, uma vez que sua caracterização do sistema regional guianense, que se levanta contra Peter Rivière, foi duramente criticada por ele. Rivière (re) afirma que "a Guiana é uma entidade puramente artificial, isolada para propósitos analíticos, e que é clara e distintamente reconhe- cível como parte de uma cultura mais vasta das Terras Baixas Sul-Americanas" (Rivière et al., 2007, p. 252). O mesmo autor, resenhando a coletânea e recusando a imagem que esta veicula de suas pesquisas, insurge-se contra a ideia de um "tipo ideal guianense", asseverando que, se ele existe, "é a imagem ideal que os próprios povos da Guiana mantêm" (Rivière et al., 2007, p. 252). Com isso, Rivière coloca um ponto importante que, de certo modo, traz à tona preocupaçôes correntes na discussão sobre os sistemas sociais ameríndios: onde buscar e situar a definição desses sistemas? Dentro ou fora deles? Em certo sentido, ele faz, aqui, eco à crítica de Lévi-Strauss aos trabalhos da História Indígena aludidos anteriormente, porém a questão ainda não nos parece resolvida, ainda que a natureza das articulaçóes entre "interior" e "exterior", ou entre as noçóes indígenas e as ferramentas antropológicas, venha se tornando cada vez mais complexa.

Outro importante debate sobre sistemas regionais advém de trabalhos realizados na região do Alto Xingu, talvez o sistema regional mais bem conhecido nas Terras Baixas, desde o trabalho pioneiro do etnólogo alemão Karl von den Steinen (Lévi-Strauss, 1948c; Coelho, 1993). O Alto Xingu se configura como uma regiâo de intercâmbio estreito entre povos de quatro famílias linguísticas e de uma língua isolada, incluindo cerimonial, comércio de produtos especializados e casamentos (Agostinho, 1974; Bastos, 1995; Franchetto; Heckenberger, 2001). Mais recentemente, mostrou-se que o Alto Xingu foi formado a partir de uma matriz inicial Aruak, seguida dos povos Karib e de conexốes com grupos periféricos chegados posteriormente, como os Tupi e Gê (Heckenberger, 2005), mas que o sistema também esteve aberto a relações — sobretudo conflitivas, mas não só - com grupos mais distantes ou periféricos, como, 
por exemplo, os Ikpeng (Menget, 2001). Estudos recentes também sugerem a existência de "redes de relaçóes sociais, econômicas, identitárias, cerimoniais, visuais e políticas" no Brasil central, formadas, majoritariamente, por povos de língua Macro-Jê (Demarchi; Morais, 2016), e sepultando de uma vez as tradicionais teses do fechamento centrípeto dos grupos Jê (Coelho de Souza, 2002), que produziriam suas socialidades por meio da proliferação de diferenças internas, ou seja, sem nenhuma dependência do mundo exterior.

Além disso, vários autores têm sustentado a existência de um extenso bloco de povos Aruak meridionais que conectava, rumo ao Oeste, o Alto Xingu com os Paresi e com os Llanos de Mojos (na Bolívia), e mesmo com os grupos Aruak mais ao Sul, como os Guaná e Chané, e ao Norte com os Apurinã (Heckenberger, 2002, 2005; Eriksen, 2011). Esta conexáo deve ter sido histórica, porém se verificou também uma associação referente a práticas sociais e culturais, como a dependência da pesca e dos peixes (Nahum-Claudel, 2018), o que pode vincular a região também ao ARN e aos povos que ocupavam, no passado, a calha do Amazonas, todos mais focados na utilização de recursos aquáticos e das formas de organização política. Neste último caso, os trabalhos de Heckenberger (2005) e Guerreiro Jr. (2011, 2015, 2016), entre outros, vêm produzindo uma imagem mais precisa da natureza interna do sistema regional alto-xinguano, na qual as hierarquias e a centralizaçáo políticas estáo em alta, o que produz certo impacto no modo como outros sistemas de trocas têm sido analisados.

Diversos intercâmbios espalhados pelo continente são mais restritos, por assim dizer, provavelmente porque foram menos investigados e conhecidos, embora existam estudos detalhados de alguns deles. Este é o caso, por exemplo, dos grupos no chamado Piemonte andino, ou Montańa peruana, que se espalham pelos contrafortes dos Andes até o Sudoeste da Amazônia brasileira. Este sistema regional é muito bem caracterizado na sua porção ocidental (Lathrap, 1970; Taylor, 1992; Santos-Granero, 1992), incluindo o mencionado conjunto Aruak subandino. Porém, pesquisas exploram cada vez mais as conexôes entre um conjunto diverso de coletivos plurilinguísticos, embora dominado pelas famílias Pano e Aruak, que desenvolvia e, em certos casos, ainda desenvolve relaçôes estreitas, muitas delas entre povos de filiações linguísticas distintas (Gonçalves, 1991; Erikson, 1992; 1993; Gow, 1991; 1993; Calavia Sáez, 2000) nas bacias dos rios Ucayali, Juruá e Purus. Mais recentemente, ao complexo Pano-Aruak desta região vêm sendo adicionados, no lado brasileiro da fronteira, os povos de língua Katukina, os quais possuem antigos contatos com os grupos Pano e Arawa, conformando um "sistema regional do Juruá" (Costa, 2017, p. 201-210). Ainda, esses grupos de língua Arawá, cuja morfologia social, cosmologia, redes de relaçôes e percursos históricos comuns autorizam, a nosso ver, a constituição de um sistema regional no rio Purus, o das "redes Arawa" (Santos, 2011; Santos; Aparício, 2016). Para o Norte, este sistema se conecta com os povos no Alto Solimôes, marcado por relaçôes intensas e antigas entre grupos de várias famílias linguísticas, como Tikuna, Pano e Peba-Yagua (Chaumeil, 1985; Santos-Granero; Barclay, 1994), mas bastante dinamizado pela presença de povos Tupi, como os Omágua (Eriksen, 2011). Ainda mais ao Norte, ele se conecta com os povos Bora-Miraña e Witoto na região do Caquetá, extremamente conectados entre si (Faulhaber, 1987a; 1987b; 1998; Whiffen, 2019), e às 
outras gentes de centro (Micarelli, 2009; Londoño-Sulkin, 2012), e chegando, finalmente, ao sistema regional altorionegrino, com falantes de línguas Tukano oriental, Aruak e Naduhup, ocupando a zona noroeste amazônica nas fronteiras entre o Brasil, a Colômbia e a Venezuela.

Pode-se notar que, por definição, os estudos apontam para sistemas regionais abertos e profusamente conectados em todas as direções: poderíamos continuar a cadeia de contatos indefinidamente - comerciais, matrimoniais, cerimoniais, militares - entre as regióes até abarcar todo o continente, nunca sendo ocupados, ao que parece, por unidades sociais isoladas e fechadas. Mas os leitores certamente não deixaram de notar a ausência, aqui, de outro dos mais conhecidos e bem estudados sistemas regionais nas Terras Baixas: o ARN. Ele será objeto da seção seguinte, porque nosso objetivo é compará-lo com outro sistema regional "emergente”, por assim dizer: o Alto Madeira/ Guaporé ou Grande Rondônia. O sistema regional altorionegrino constitui, como se sabe, um locus classicus da discussão acerca dos sistemas regionais ameríndios tanto no que tange às suas dimensóes internas, quanto no que se refere às suas amplas conexóes com regióes vizinhas e povos fronteiriços, formando redes cuja extensão parece-nos cada vez maior e mais notável. Além disso, as redes de troca no ARN são constituídas por grupos Aruak, e sua importância neste cenário pluriétnico e multilinguístico vem sendo notada há tempos.

Ademais, o rendimento das análises comparativas entre sistemas tem sido desenvolvido no que toca ao ARN e o Alto Xingu (Andrello; Guerreiro Jr.; Hugh-Jones, 2015). O outro sistema regional, que sugerimos denominar de sistema regional do Alto Madeira, ou Grande Rondônia (Vander
Velden, 2010), ainda carece de estudos mais aprofundados que sustentem a integração de suas unidades socioculturais nos moldes do que foi proposto para os sistemas regionais discutidos. Conforme sugere Melatti (2019, p. 7), as áreas etnográficas propostas "não são todas igualmente convincentes", e apenas "[a]lgumas como que se impóem imediatamente". Além disso, ali não há grupos de língua Aruak, no coração da área, embora existam em suas margens, e tudo indica que devem ter se vinculado a ela no passado. Esperamos demonstrar, entretanto, que possam ser detectados contatos e influências mútuas, formando uma área cultural com características sistêmicas e, claro, aberta em múltiplas direções.

Essa distinção tem impacto no estilo de debate que cada sistema regional suscita. Enquanto no ARN a questão dos limites do sistema regional é bem assentada e o debate se concentra na discussão em torno do parentesco e da definição das unidades sociais, na região do Alto Madeira/Guaporé ou Grande Rondônia, a discussão gira em torno da definição dos limites do sistema regional - ou, dito de outra forma, de sua própria definiçãa - , ainda que o problema das unidades sociais permeie o debate, assim como a imagem de uma integração contínua entre conjuntos populacionais e (sub)sistemas regionais simultaneamente adjacentes. Não obstante, a hipótese é que mesmo sistemas regionais aparentemente tão distintos podem ser comparados se adotarmos uma forma mais aberta de olhar e descrever sistemas regionais que não seja tão restritiva quanto à necessidade de definir fronteiras étnicas e linguísticas (como no caso do ARN ou Alto Xingu). As redes de trocas e intercâmbios de diversas naturezas (como nas Guianas) sustentam a ideia expandida e abrangente de sistemas regionais. 
Este é um ponto importante aqui, pois esse deslocamento de foco possibilita, por um lado, que o sistema regional do ARN (assim como todos os demais) possa ser comparável a outros sistemas, já que não é mais necessário tratar a comparação somente da perspectiva da estrutura do parentesco - a existência de hierarquia, ancestralidade, clãs e fratrias. Por outro lado, a região do Alto Madeira-Guaporé pode ser abordada como um sistema regional, na medida em que é possível traçar uma rede de intercâmbios ao longo dessa área que não necessariamente se estabeleça pela troca matrimonial, como se observará em detalhes mais adiante.

\section{Alto Rio Negro}

Começamos por um dos mais conhecidos e bem estudados sistemas regionais nas terras baixas sul-americanas, o assim chamado ARN. Ainda que desde muito cedo, pelo menos a partir do trabalho de Koch-Grünberg (2005) no início do século XX, tenha sido possível isolar as unidades sociais que compóem esse sistema - noções de tribo, fratria, clã, sib e linhagem não tiveram tanta dificuldade de serem aplicadas e, efetivamente, o foram, à revelia da forte crítica americanista empreendida aos modelos africanistas —, a questão dos seus limites nunca deixou de ser colocada, a ponto de Christine Hugh-Jones afirmar que se tratava de uma rede aberta e ilimitada formada por grupos, cuja característica principal é a falta de delimitação (Hugh-Jones, 1979, p. 15). É esse caráter de sistema aberto que nos interessa destacar e que corrobora com a proposta deste artigo de enfatizar as conexóes entre sistemas, muito mais do que o arcabouço interno dos mesmos - ainda que, obviamente, numa rediscussão dos termos da dualidade entre interior e exterior, ambos só possam ser separados por razóes analíticas.

O sistema de integração multiétnica e multilinguística geralmente inclui a região dos formadores e afluentes do rio Negro, importante tributário do Amazonas, na divisa entre o extremo Noroeste do Brasil (estado do Amazonas), a Colômbia e o Sul da Venezuela. Tradicionalmente, a área é ocupada por grupos de língua Tukano Oriental e Aruak, que se distribuem pelas calhas dos grandes rios e pelas comunidades de línguas Naduhup e Kakua-Nukak, nas zonas de interflúvio, embora existam registros de grupos falantes de línguas de outras famílias na região ou de contatos entre os povos rio-negrinos e conjuntos étnicos vizinhos, como Karib (Halbmayer, 2013, p. 67-72; Schindler, 2019), Bora e Witoto (Whiffen, 2019), Yanomami (Nimuendajú, 1955; Ramos, 1980; Albert, 1985; Gallois, 2005; Sarmento, 2018; Goulart, 2020), entre outros. Atualmente, existem 29 etnias na região (Sarmento, 2019), mas é difícil precisar esse número no passado, dada a proliferação de etnônimos e os problemas relacionados à definição das unidades étnico-sociais relevantes (Brüzzi, 1962; Wright, 2005).

A literatura etnográfica sobre o sistema regional ao longo do tempo acabou por consolidar, não sem discordâncias, a partir do critério linguístico, três grandes conjuntos de povos: Tukano Oriental, Aruak e Maku. A família linguística Tukano oriental é a mais numerosa e diversa, sendo composta (no lado brasileiro) por Cubeo, Desana, Tukano, Miriti-Tapuia, Tuyuka, Wanano, Bará, Arapasso, Karapaná, Pira-Tapuia, Siriano e Makuna. Essas populaçóes se concentram principalmente nos rios Uaupés e Tiquié. A família Maku, atualmente designada Naduhup, é composta por Hupdah, Yuhupdeh, Nadöb e Dow. Os dois primeiros se 
concentram na calha do Tiquié, os Nadöb no médio Rio Negro, e os Dow ficam defronte à sede do município de São Gabriel da Cachoeira. A família Aruak, por sua vez, é formada por Baniwa, Warekena, Tariano, Kuripako e Baré e se concentra nas bacias dos rios Negro, Içana e Xié. A distribuição delineada corresponde às áreas de concentração de cada povo, porém, devido ao trânsito constante de pessoas ao longo da drenagem do rio Negro, é possível encontrar membros desses povos espalhados por toda a região (ISA; FOIRN, 1998; Wright, 2005; Epps; Stenzel, 2013). Essa circulação de pessoas e sua diversidade cultural são características fundamentais desta área.

Ainda que a região do ARN seja classicamente caracterizada como um sistema social integrado composto por redes de trocas matrimoniais, rituais e de bens, a questão dos limites das unidades sociais sempre se mostrou espinhosa e causou dificuldades para os estudiosos da região. Como veremos, a definição das fronteiras da unidade social tem grande variaçáo de acordo com o trabalho e a época. Não será o caso, aqui, de estabelecer algum critério seguro quanto aos contornos do sistema - na verdade, uma das intenções desta recensão é, justamente, mostrar como os limites são arbitrários. $\mathrm{O}$ ponto que aparece como inconteste, entretanto, diz respeito à existência de um vasto circuito de trocas que envolvem diversidades multiétnica e multilinguística de grupos que vão para além das fronteiras geralmente atribuídas ao sistema regional altorionegrino.

Desde os primeiros registros sobre a regiấo, ainda no século XVI, nota-se a existência de uma expressiva diversidade cultural e linguística (Acuña, 1994; Carvajal, 2011), aspecto que continuou sendo destacado ao longo dos séculos seguintes, com a paulatina ocupação colonial, que começou a se inten- sificar a partir do século XVIII, período em que se realizaram as expediçôes de Sampaio (1985) e Ferreira (1983). Em 1786, Barcelos tornou-se o centro da província amazônica e chegou a contar com 3.000 habitantes e a desenvolver as indústrias de têxteis, algodão, café, cacau e outras. A demanda por mão de obra indígena e produtos da floresta levou ao estabelecimento de descimentos e uma crescente onda de aldeamentos (Hemming, 1978; Moreira Neto, 1988; Farage, 1991; Santos, 1999; Wright, 2005; Carvalho Jr., 2017, e muitos outros). Enquanto muitos grupos evadiram-se para as cabeceiras dos rios, outros estreitaram suas alianças com os agentes coloniais.

No início do século XIX, contudo, Barcelos deixou de ser a capital da província e sofreu um forte êxodo populacional. Com a diminuição da pressão por mão de obra e o rareamento populacional, os povos indígenas que haviam se deslocado para as cabeceiras dos rios voltaram, pouco a pouco, a ocupar as margens dos grandes cursos d'água. Porém, engana-se pensar que esse retorno significou um período de tranquilidade para os índios na zona, já que a área continuou sendo explorada por comerciantes que se abasteciam de produtos como piaçaba, farinha de mandioca, salsaparrilha, peixe seco e peles de onça, em troca de roupas, machados, facas, espingardas, dentre outras mercadorias (Andrello, 2016; Wright, 1992; 2005; Meira, 2005; 2018; Sarmento, 2019).

Até o século XIX, a maior parte dos registros sobre a região eram realizados por agentes coloniais e comerciantes que procuravam controlá-la econômica e politicamente. Embora contenham informaçôes sobre a diversidade de grupos que ocupavam este amplo território, os dados não trazem grandes detalhes etnográficos sobre o modo de vida desses mesmos grupos. Em 
meados do século XIX, começa a se esboçar a caracterizaçáo da regiáo como um sistema social integrado, com os escritos de vários viajantes que passaram por ali (Humboldt, 1852; Coudreau, 1886; Spruce, 1908; Wallace, 1979; Stradelli, 2009) e que tinham interesse de catalogar não só a fauna e a flora, mas também as línguas e os costumes dos povos.

É a partir do trabalho de Koch-Grünberg, realizado na virada para o século XX, que o sistema regional adquire contornos mais definidos. Durante mais de uma década, o etnógrafo alemão percorreu não só uma vasta área da bacia do Rio Negro, como também da bacia do Orinoco, o que o levou a conjecturar que os grupos indígenas no Orinoco, no Rio Negro, no Japurá e no sopé dos Andes mantinham relaçôes de troca antes mesmo da chegada dos agentes coloniais (Koch-Grünberg, 2005). Além disso, as festas de Jurupari, que envolvem o uso de flautas e trompetes, era uma prática muito difundida pela região do ARN (cf. Hill, 2002; 2011; Chaumeil, 1997). Do mesmo modo, foram descritos a cultura material e o quanto objetos análogos eram encontrados em uma vasta área. Ficou consolidado ainda que o sistema regional era formado por três grandes famílias linguísticas: Aruak, Tukano Oriental e Maku. Koch-Grünberg aventou a hipótese de que os primeiros habitantes da regiáo seriam os grupos Maku, povos nômades, caçadores e coletores, seguidos por grupos Aruak e, posteriormente, Tukano Orientais, esses últimos povos sedentários, pescadores e horticultores. O etnógrafo alemão foi seguido por Nimuendajú (1955), quando este fez sua viagem de reconhecimento pela regiáo em 1927. Entretanto, essa questáo nunca alcançou o consenso, e outras hipóteses foram aventadas, como veremos mais adiante.
Ao longo da primeira metade do século XX, seguiu-se uma série de trabalhos de cunho mais etnográfico que ajudaram a consolidar a regiáo como uma subárea da floresta tropical, como se pode constatar no HSAI (Goldman, 1948). Como postulado por Sorensen (1967), o ARN passou a ser bem caracterizado como área cultural homogênea a partir dos trabalhos de Steward (1946; 1959), Nimuendajú (1955), Goldman (1948), Steward e Faron (1959) e, por fim, Galvão (1979).

Entre esses trabalhos destacamos o de Goldman (1963), pois é aquele que não se preocupou somente em entender a formação histórica do sistema regional, mas também passou a ter a investigação da dinâmica das relaçôes sociais que integram o sistema como um de seus focos. Com isso, a partir dessa época e até meados da década de 1980, a maior parte da produção sobre a regiāo dedicou-se ao debate em torno do parentesco como a chave para entender a dinâmica do sistema (Sorensen, 1967; Reichel-Dolmatoff, 1968; Bidou, 1976; Hugh-Jones, C., 1979; Hugh-Jones, S., 1979; Reid, 1979; Silverwood-Cope, 1990; Wright, 1981; Århem, 1981; Chernela, 1983; Jackson, 1983; Hill, 1983; Pozzobon, 1983); mais especificamente, procurou-se definir quais são as unidades sociais que o integram. Ganha relevância, nesse contexto, a noçấo de descendência, que passa a ser diferenciada conforme suas dimensóes de abrangência e definida a partir de categorias como sib/clã, fratria e tribo. A aplicação dessas categorias para definir os segmentos de grupos sempre gerou grandes dificuldades e diferentes concepçóes, assim como a definição das fronteiras geográficas do sistema. Um breve, mas minucioso, excurso analítico será necessário, na sequência, para iluminar os problemas dos limites e das definiçôes ét- 
nicas e sociológicas no ARN — questão relevante neste artigo.

No ARN, o termo "tribo" foi usado para designar as unidades de maior inclusão no sistema. Por exemplo, para Goldman (1963), em seu estudo sobre os Cubeo, a tribo é formada por três fratrias que trocam cônjuges entre si e falam a mesma língua; já para Sorensen (1967), a tribo é formada por uma única fratria, no seio da qual não se trocam cônjuges e falam a mesma língua. Essas duas definiçóes têm desdobramentos distintos quanto ao entendimento da relação com outros segmentos de descendência - linhagem, sib ou fratria. Embora ambas afirmem que a fratria se constitui a partir de um conjunto de sibs que se relacionam agnaticamente e que, portanto, não se casam, há divergências significativas em relação à questão dos limites dos agrupamentos. Sorensen (1967) estabeleceu uma equivalência entre tribo, fratria e língua, a qual conjuga a exogamia sociológica com a unidade linguística, além de afirmar que são categorias nominadas e hierarquizadas entre si. Goldman (1963), por outro lado, não observou uma correspondência entre unidades frátrica e linguística, e afirma que não são categorias nominadas e hierarquizadas entre si. A divergência entre os autores é minimizada em trabalho posterior de Goldman (2004), que reconsidera parte de seu entendimento em relação à fratria e afirma que são categorias nominadas e internamente hierarquizadas. Segundo este autor, a mudança se deveu ao fato de que, em seu primeiro estudo, a etnografia foi realizada junto a grupos de baixa hierarquia, os quais procuravam minimizar as assimetrias, ao passo que, no segundo estudo, esteve junto a grupos de alta hierarquia, que procuravam afirmar as assimetrias. Entre um estudo e outro, o que se mantém é a não correspondência entre os limites tribais e linguísticos devido ao fato de os Cubeo se casarem com grupos que falam a mesma língua. Podemos inferir que a tribo Cubeo é definida como uma federação de fratrias que se ligam por uma história de origem comum, mas cujas relaçôes se desdobram em relaçôes de germanidade ou cunhadismo. As federaçôes são constituídas por conjuntos frátricos que se formam pela história do surgimento de uma geraçáo de irmãos em determinado território, os quais se diferenciam segundo um princípio de senioridade, estabelecendo-se, então, uma ordem hierárquica.

$\mathrm{O}$ ambiente de exogamia linguística detectado por Sorensen em seu trabalho etnográfico conduz a um entendimento um pouco distinto da relação entre as ordens tribal e frátrica. $\mathrm{O}$ autor restringe a definiçấo de fratria somente àqueles grupos que se reconhecem pela história de surgimento de uma geração de irmãos em determinado território e que falam a mesma língua. Com isso, faz coincidir a unidade tribal e a frátrica e coloca um problema para a funcionalidade dessas categorias de abrangência. Um dos efeitos disso é que se produzem perspectivas diferentes do que parece estar se replicando em diversos níveis. Enquanto Goldman observa conjuntos que se relacionam tanto agnaticamente quanto por afinidade desde o nível das relações interfrátricas, Sorensen afirma que essa composição se dá somente no nível das relações intertribais. Neste nível, o conjunto de tribos que se relacionam por agnatismo não se reúnem em torno de um nome, ao contrário do nível frátrico, no qual o conjunto é nominado. Jackson (1983), embora siga Sorensen quanto ao critério linguístico, propóe outra diferenciação em relação às categorias de abrangência: ao invés da ordem tribo, fratria e sib, prefere a ordem fratria, agregado-linguístico e sib. Embora náo entenda a fratria como Goldman, já que 
a supôe sendo formada por diferentes grupos linguísticos, também afirma que é não nominada e a ordenação hierárquica é mais variável na medida em que é mais passível de contestação. Christine Hugh-Jones (1979, p. 21) também entende que a fratria não é nominada e que, nesse nível, encontramos uma hierarquia enfraquecida entre os grupos que a compóem. No entanto, diferentemente de Jackson, no lugar de agregado linguístico, a autora propóe dois outros termos: "grupo exogâmico composto" e "grupo exogâmico simples" (Hugh-Jones C., 1979, p. 15). Neste modelo, a fratria equivale ao grupo exogâmico composto. $\mathrm{O}$ enfraquecimento da hierarquia e a ausência de nominação no nível frátrico são observados também por muitos outros autores, tais como Chernela (1983), Århem (1981), Bidou (1976) e Journet (1988).

Se, por um lado, a maior parte dos trabalhos afirmam uma distensão da hierarquia no nível frátrico, por outro, mostram que o princípio de senioridade ordenando o seriamento hierárquico continua não só operante nesses níveis, como também apresenta desdobramentos. O trabalho de Chernela (1983), que segue a distinção de Jackson, traz uma contribuição importante a esse respeito, pois é o primeiro a evidenciar com clareza um desdobramento do princípio de senioridade no nível frátrico, o qual não se limita à relação irmão maior/irmão menor e chefe/escravo. A autora observou que, entre essas unidades de descendência, são usados três termos de parentesco masculinos que indicam uma gradação, do maior ao menor: neto, tio, avô (cf. Andrello, 2006). Esses termos são definidos como classes de geração e servem para marcar uma posiçáo na armação hierárquica tanto no nível interfrátrico como no intrafrátrico. Christine Hugh-Jones (1979) também estabelece outro des- dobramento do seriamento hierárquico que opera na relaçáo entre os sib, que compóe um grupo exogâmico simples e diz respeito à atribuição de especialidades a essas unidades. Idealmente, um grupo exogâmico simples é composto por cinco sibs especializados (chefes, xamãs, cantores, guerreiros e servidores), cujo eixo é orientado pelo princípio de senioridade (Hugh-Jones C., 1979, p. 19-20). Dado o caráter complementar das especialidades, elas conformam, em seu conjunto, uma unidade funcional: um grupo exogâmico composto é formado por, pelo menos, duas dessas unidades. Embora a especialização dos sibs seja algo destacado por vários autores, nem mesmo Christine Hugh-Jones pôde observar a existência de um grupo exogâmico simples completo ocupando um mesmo território. O que parece inconteste são a fama de alguns sibs/clãs como especialistas de uma dessas cinco funçôes e a posição hierárquica atribuída a cada especialidade.

De maneira homóloga à fratria, os sibs são segmentos que se reconhecem a partir e pela história da origem de um ancestral da linha de descendência patri - em determinado território e que fazem parte de um grupo de germanos que se distinguem pelo princípio de senioridade. $\mathrm{O}$ nome do ancestral não só confere o nome do sib, como, concomitantemente, expressa a posição no seriamento hierárquico em seus diversos desdobramentos: chefe/escravo, primogênito/ caçula, neto/tio/avô, chefes/xamãs/cantores/ guerreiros/servidores. O seriamento hierárquico se mostra mais rígido neste nível, pois a linha genealógica que conecta os descendentes a um ancestral comum por meio de um conjunto de nomes é mais detalhada. É nesse sentido que sib/clã é tomado como a unidade de descendência que apresenta os contornos mais bem definidos e, por conse- 
guinte, é entendido como o segmento básico da estrutura social no ARN.

A maior estabilidade do sib/clã em relação às outras unidades de descendência não se resume somente à maior correspondência entre a linha genealógica "biológica" e aquela traçada pelas pessoas em relação a um ancestral comum, mas também aí reside um efeito pragmático quanto às posiçóes hierárquicas. Portanto, a diferenciação entre as posições tem um impacto concreto, por exemplo, na relação que se estabelece entre os sib/clã e o território. As histórias das geraçóes ancestrais que compóem o estoque de um sib/clã são de trajetórias de movimentos no tempo e espaço que estabelecem um vínculo inextricável com o ambiente em que se sucederam tais histórias. Alguns autores, como Chernela (1983), afirmam que áreas à jusante dos grandes rios são ocupadas por sibs/clãs tidos como irmão maiores e aquelas à montante por sib são tidas como irmãos menores. Também é argumentado que os sib/clãs de maior prestígio ocupam áreas em que se encontram recursos naturais mais abundantes e, portanto, teriam uma vantagem em relação aos sib/clãs de menor prestígio, que enfrentariam maior escassez.

Conquanto seja inegável que, nesse nível dos sibs/clãs, os limites de uma possível unidade social se mostrem mais definidos do que em outros níveis de abrangência ou inclusividade, isso não significa que sejam completamente estáveis e nem que os maiores estão, necessariamente, à jusante e nas áreas de maior riqueza de recursos. Há muitos casos relatados de sibs/clãs que se separaram ou se juntaram ou, ainda, desapareceram e que complicam o esquema, sugerindo a necessidade de investigaçóes mais detalhadas sobre a estrutura interna das organizaçóes sociais regionais, nos modos como estas se articulam na extensa rede de "grupos" em contato, tanto "dentro" como "fora" - estas distinções são sempre precárias — do sistema regional do ARN.

A análise desses casos, a nosso ver, vem corroborar com a definição de que os grupos na região do ARN são marcados por constantes processos de fissão, fusão e desaparecimento, como pontuam vários trabalhos dos mais antigos até os atuais (Goldman, 1963; Bidou, 1972; 1976; Hugh-Jones, C., 1979; Reid, 1979; Århem, 1981; Jackson, 1983; Pozzobon, 1983; Athias, 1995; Hugh-Jones, 1995; Wright, 1998; Lasmar, 2005; Andrello, 2006; 2015; 2016; Cabalzar, 2008; Maia, 2009; Lolli, 2010; Ramos, 2013; Chacon; Cayón, 2013; Marques, 2015). Talvez resida, nisso, a mencionada proliferação de etnônimos que se registra nesta porção da Amazônia, assim como a abertura do sistema regional rio-negrino para regióes, grupos ou conjuntos étnicos vizinhos.

Esses movimentos conferem uma característica recorrentemente presente em praticamente todas as etnografias disponíveis sobre os povos do ARN, que acabou por consolidar dois modelos de estruturas sociais (um fechado, rígido, hierárquico e outro aberto e igualitário, fluido), que se relacionam de forma complementar no sistema regional e cuja polarização se expressa respectivamente em dois grandes rituais: o ritual de iniciação masculina, conhecido em língua geral (Nheengatu) como Jurupari (Tí, He, Miria Porã, Kwai e outros, nos vernáculos locais), e os rituais de trocas de alimentos e objetos, conhecidos regionalmente como dabucuri.

Como se pode entrever a partir desse modelo sociológico, baseado predominantemente em etnografias de grupos Tukano, mas não só, o sistema regional do ARN apresenta uma série das características atribuídas também aos grupos Aruak (à “matriz Aruak”), 
conforme exposto. Ainda que estudos etno-históricos e arqueológicos mais recentes sobre os Aruak tenham defendido a tese de que esses grupos têm sua origem nessa regiáo ou nas proximidades e sejam seus moradores mais antigos (Vidal; Zucchi, 1999; Wright, 2005; Neves, 2005; 2011), o que justificaria essas características do sistema altorionegrino, o ponto não é pacífico quanto ao que é próprio dos Aruak e de grupos Tukano e Naduhup. Por outro lado, o que parece não despertar divergência é a anterioridade do sistema regional ao tempo da colonização. Neves $(2005,2012 \mathrm{a})$ defende que os povos Naduhup, Aruak e Tukano ocupam a região há mais de dois mil anos e que é possível aventar a hipótese de que o sistema regional do ARN é estruturalmente homólogo àquele que existia antes da colonização da América. $\mathrm{Na}$ mesma direção, os trabalhos de Vidal e Zucchi (1999) e Vidal (1999), baseados em pesquisas com grupos Aruak, indicam que o sistema regional do ARN não é apenas mais antigo do que a empresa colonial, como também era muito mais pungente e vasto, estendendo suas relaçóes à bacia do Orinoco, de um lado, e à bacia do Japurá, de outro. Seriam, nos termos das autoras, "macrossistemas políticos indígenas", cuja densidade demográfica era consideravelmente superior àquela dos tempos atuais, o que é corroborado por outros trabalhos como o de Wright (1991), Meira (2018) e Sarmento (2018). Hill e outros (Hill, 2002; 2011; Wright, 2005; Zucchi, 2010), em vários trabalhos, também defendem que, por meio de um conjunto de narrativas e músicas rituais que descrevem longas viagens por toda a região ao norte do Amazonas —, é possível supor as conexóes do ARN por uma vasta área que cobre todo o escudo das Guianas, desde a foz do Amazonas aos contrafortes andinos, bem como o vale do Orinoco e até mesmo as ilhas de Trinidad e Tobago (Arvelo-Jiménez, 1982; Arvelo-Jiménez; Morales Méndez; Castillo, 1989; Vidal, 1987; 1999; Heinen; García-Castro, 2000; Vidal; Zucchi, 2000; Koch-Grünberg, 2006; Whitehead; Alemán, 2009; Eriksen, 2011, p. 197-198). Os nexos entre o ARN com os trechos médio e baixo do mesmo rio (Herrero; Fernandes, 2015) e com a Amazônia central mais além também estão claros na História Indígena regional (Sweet, 1974; Farage, 1991; Neves, 2001).

Tenha ou não origem Aruak, as características do sistema regional do ARN se estendem pelos outros grupos que o compóem, até mesmo os grupos Naduhup, geralmente excluídos do sistema. Além disso, se admitirmos, como fazem os poucos estudos arqueológicos realizados na região (Neves, 1998; 1999; 2012b; Zucchi, 2002), que esses grupos se relacionam há mais de dois mil anos e que sua característica principal seja a abertura aos outros, fica difícil estabelecer o que é próprio de quem. É também essa longevidade interacional entre grupos que oferece uma impressão de certo fechamento do sistema regional e de limites mais nítidos de suas fronteiras - imagem reforçada ao longo da colonização, na medida em que as trocas realizadas com grupos da bacia do Orinoco praticamente cessaram, sobretudo com a definição das fronteiras dos estados nacionais (no caso, entre Brasil e Venezuela), por conta de o trânsito entre as regiōes ter ficado mais restrito e sujeito ao controle estatal.

Hugh-Jones, Andrello e Guerreiro Jr. (2015, p. 701) chamaram a atenção para a necessidade de não reduzir as especificidades do ARN a uma suposta "especificidade ontológica" dos "sistemas Aruak". Hugh-Jones (2013) propõe seguir Gow (1991, p. 279) em sua proposta de abordar os sistemas regionais da Amazônia por meio de suas transformaçóes topológicas em seu âmbito his- 
tórico. A noção de etnogênese aplicada aos estudos em Arqueologia e História Indígena, como vimos, também complica o cenário que busca definiçôes rigidamente estabelecidas de relaçôes entre etnia, língua, unidade sociológica e traços culturais (Hornborg, 2005; Hill, 1996). De todo modo, conforme afirma Lolli (2011, p. 170):

Pensar as coletividades indígenas no rio Negro a partir de uma noçáo de rede aberta e ilimitada demonstrou ser uma abordagem interessante para enfrentar o problema da formação dos grupos. A ênfase passa a incidir nos processos de formaçáo desses grupos, nos quais conexóes estão sendo refeitas, desfeitas e feitas.

Comparativamente, o sistema regional do ARN se coloca a meio caminho dos sociais encontrados nas Terras Altas e Baixas da América do Sul, na medida em que estes apresentam, concomitantemente, estruturas sociais hierárquicas, segmentadas, exogâmicas e complexas, mas não a ponto de se estabelecer o mesmo nível de estratificação e centralização dos Andes ou da Mesoamérica, e outras sociais igualitárias, fluidas e dispersas, também náo na mesma intensidade daquelas encontradas na região das Guianas (Viveiros de Castro, 1986a, 1993b). Esses sistemas estariam, nesse sentido, mais próximos aos modelos classicamente chamados de cacicados, chiefdoms ou ainda chefaturas (Perrone-Moisés, 2015). No tocante à cosmologia (sobretudo no que se refere à definição da humanidade), o ARN estaria, assim como o Alto Xingu, distante do "modelo amazônico" (Viveiros de Castro, 1993b; 2002), centrado na predaçáo e alteridade, o que sugere seu relativo "fechamento" quando comparado às sociedades guerreiras do restante da Amazônia.
Assim, o estilo de análise que privilegia a teoria da predação e enfatiza as trocas externas, por meio de canibalismo, guerra, rituais funerários, xamanismo e caça, não parece se aplicar bem à região do ARN (Hugh-Jones, 2013; Andrello, 2017), já que, ali, as trocas se dáo por valores como generosidade, paz e respeito mútuo. Nesse sentido, também se distinguem do estilo que restringe esses valores somente às relações intracomunitárias. $\mathrm{Na}$ regiáo, operaria tanto uma troca predatória quanto uma produção pacífica, que se estendem não só às relaçóes intracomunitárias, mas também às intercomunitárias. Isso também é encontrado em outras regiôes, como a do Alto Xingu (Hugh-Jones, 2013; Andrello; Guerreiro Jr.; Hugh-Jones, 2015).

A abertura do sistema para o exterior, táo notada nos estudos Aruak, está intimamente ligada à amplificação das relações interétnicas, que ocorre pela realização de reuniôes festivas envolvendo dois ou mais grupos o dabucuri sendo o protótipo. Em tais ocasiôes, não só se efetuam trocas matrimoniais, de objetos e de alimentos, mas, sobretudo, são exibidas performances de danças, cantos, discursos retóricos e instrumentos sonoros; em suma, trocas rituais que engendram um campo intelectual compartilhado sobre o universo. É nesses contextos, ainda, que o doméstico, a comensalidade e as falas cotidianas se juntam e trazem o cotidiano para dentro do evento ritual (Hugh-Jones, 2013).

Nas últimas duas décadas, cada vez mais os trabalhos têm se dedicado a investigar sobretudo os intercâmbios rituais e de bens, em detrimento das trocas matrimoniais, para discutir o funcionamento da dinâmica social que integra essa vasta rede de relaçóes. Isso permitiu dois deslocamentos importantes: as unidades sociais deixaram de ser concebidas como algo dado e suas definiçôes náo são mais determinadas, em última instância, 
pelas relaçôes de parentesco. O que a discussão tem demonstrado é que as trocas rituais e de bens são táo ou mais importantes para a integração do sistema regional. Com isso, e este constitui o segundo deslocamento, a relação entre anfitrião e convidado, estabelecida como ethos de todas as festas e reunióes realizadas no ARN, adquire grande relevância para o entendimento da dinâmica social. É difícil restringir o compartilhamento desse ethos somente a essa região ou, menos ainda, aos grupos Aruak (cf. Perrone-Moisés, 2015).

Além do complexo do Alto Xingu, Hugh-Jones (2013) chama atenção, por exemplo, para o fato do festival sari ou warime piaroa também se enquadrar nesse ethos. Dada a extensão desse complexo, parece difícil sustentar que ele tenha sua origem em grupos Aruak, o que, de certa maneira, reificaria uma ideia de essência identitária: como Andrello, Guerreiro Jr. e Hugh-Jones (2015) propóem, é não pensar os sistemas regionais, no caso o do ARN e do Xingu, como resultados de uma "mera coleçâo" de povos que existiam antes de estabelecerem relações, mas como o campo interacional por meio do qual as diferenças entre os grupos se constituem - algo semelhante ao assinalado por Hornborg (2005, p. 607), o qual sustenta que as características atuais dos grupos Aruak são antes produtos do que causas de sua expansáo. Campos interacionais, como se sabe, expandem-se e contraem-se ao sabor da história e das contingências; suas fronteiras são porosas, e seus limites não são estanques.

É nesse sentido que os trabalhos mais recentes sobre o ARN têm se preocupado muito mais com os processos de formação dos grupos e visado especialmente às transformaçôes dos sistemas regionais (Andrello, 2012). Mais recentemente, esse caminho analítico tem sido levado a cabo por um conjunto de pesquisas realizadas na Universidade Federal de São Carlos (UFSCar). O problema central é investigar e analisar as dinâmicas de constituiçấo e atualização das unidades sociais que conformam o sistema regional a partir da produção de diferenças entre os grupos. Os trabalhos se dedicaram a revisar a noção de estrutura social e as categorias sociológicas elaboradas por sucessivas geraçóes de pesquisadores. Um dos principais resultados desse esforço foi a produção de um conjunto de trabalhos que fizeram despontar novos caminhos de investigação e novas questóes para o sistema regional do ARN (Andrello, 2015; Scolfaro, 2012; Toledo, 2013; Ferreira, 2014; Junio Felipe, 2018; Rodrigues, 2019).

\section{Alto Madeira, ou Grande Rondônia}

À primeira vista, o ARN, definido por extensa bibliografia como um sistema regional que podemos denominar "clássico", contrasta fortemente com a proposta emergente de descrição do Alto Madeira, ou Grande Rondônia, também como uma rede articulada de relaçóes de escala regional. Isso é, certamente, um efeito do modo como ambas as regiōes (assim como as demais áreas do continente) vêm sendo interpretadas pela etnografia e história indígenas. Nosso objetivo é avançar a proposição, fundamentada em ampla literatura, de que o foco em relaçóes multidimensionais e multitemporais encontra intensas e extensas conexóes entre unidades sociais que podem ser delimitadas, ao menos para fins analíticos ou políticos, somente por meio de suas interaçóes. $\mathrm{Na}$ região do Alto Madeira/Grande Rondônia, fica patente que a quantidade e a qualidade dos estudos (inclusive comparativos) das organizaçóes sociais em suas dinâmicas "inter- 
nas" contrastam fortemente com o panorama do ARN, descrito na seção anterior. Não obstante, tencionamos demonstrar o que a ênfase nas conexóes "externas" pode produzir em termos da análise de redes de relaçôes de escopo regional - mesmo que, com o tempo e novas investigaçóes etnográficas, este cenário tenda a alterar-se, talvez sensivelmente. A região do Sudoeste da Amazônia brasileira, território compreendido entre os formadores dos rios Tapajós (a Leste) e Madre de Dios (a Oeste), o Médio e Alto Madeira (ao Norte) e o Guaporé (ao Sul), constitui a zona que poderíamos denominar "Grande Rondônia" (Vander Velden, 2010). Esta área engloba o estado de Rondônia, o Noroeste do Mato Grosso, o Sudeste de Amazonas e ainda o Nordeste do assim chamado Oriente boliviano — ou seja, grosso modo, a área drenada pela bacia do Alto Rio Madeira e seus principais formadores - Mamoré, Guaporé e Beni - e afluentes. Esta delimitação "emergente", por assim dizer, contrasta com outras propostas de definição das áreas etnográficas ou culturais nesta região do Brasil (Lévi-Strauss, 1948a; Galvão, 1979; Schettino, 2003; ISA, 2006; Melatti, 2019), porém a informação disponível e o deslocamento nos modos de sua análise que orienta este texto sugerem fortes conexóes histórico-culturais entre os grupos nesta zona - isto é, se levarmos em conta, na investigação das redes de relaçóes ameríndias, não apenas o passado, mas também os fluxos e percursos que têm origem no período colonial e chegam até os dias de hoje. Trata-se de uma área com "[e]xtraordinária diversidade de línguas, com uma concentração de pequenas famílias linguísticas e de línguas isoladas" (Eriksen, 2011, p. 70, tradução nossa; ver também Crevels; Van der Voort, 2008), tendo línguas pertencentes aos troncos Tupi (Tupi-Guarani, Arikém, Rama-ra- ma, Puruborá, Mondé, Munduruku, Tupari e Mawé) e Macro-Jê (família Jabuti e língua Rikbatsa), e às famílias Txapakura, Nambikwara, Aruak, Pano, Takana e Mura, além de pelo menos 11 línguas isoladas ou não classificadas, como o Kanoê (Kapixana), o Iranxe-Myky e o Kwaza, além de outras sete na Bolívia. Sua alta sociodiversidade pode ser visualmente conferida no famoso Mapa Etno-histórico de Curt Nimuendajú (1981a), e esta mesma riqueza sociolinguística pode ser fruto de processos identitários contrastivos, gerados, precisamente, pela intensidade de interaçôes entre coletivos (Eriksen, 2011, p. 276).

$\mathrm{O}$ reconhecimento das conexóes entre os povos desta área da Bacia do Alto Rio Madeira é corroborado, em parte, por estudos linguísticos e arqueológicos. Da perspectiva destes últimos, Miller (2009) delimitou uma região designada como "Mesopotâmia Guaporé-Madeira-Aripuanâ” e que corresponde, em linhas gerais, à porção oriental desta Grande Rondônia. Já os linguistas Crevels e Van der Voort (2008) definem - a partir de extensa recensão das fontes linguísticas, históricas e etnográficas - a região do Guaporé-Mamoré como "área linguística" (linguistic area), considerando a zona drenada pelos rios Mamoré, Guaporé, Beni e Madre de Dios (e seus tributários), nos limites entre Bolívia, Brasil e (em menor medida) Peru. Esta corresponde, em larga medida, à proposta da Grande Rondônia defendida (exceto pela porção situada ao Norte do rio Madeira). Ramirez (2006; 2010), por fim, argumenta por uma análise ampliada da Etno-história e Linguística histórica de “o grande Madeira”, que corresponde exatamente aos limites geográficos das "áreas cultural" ou "etnográfica" — ou do "sistema regional” — defendida aqui. Esta área, onde se localizam os formadores dos rios Madeira e 
Tapajós, vem sendo apontada, por exemplo, como centro de origem das línguas e culturas Tupi (Rodrigues, 1964; 1986; 2007; Heckenberger; Neves; Peterson, 1998; Cruz, 2008; Zimpel Neto, 2009), o que igualmente indica a pertinência das abordagens históricas e etnográficas de seus povos e línguas como um conjunto em relação.

Se agrupados os estudos etno-históricos clássicos sobre certos territórios, povos ou conjuntos multiétnicos nesta região (Nordenskiöld, 2001 [1924]; 2002 [1912]; 2003 [1922]; Rondon, 1916; Roquette-Pinto, 1935; Caspar, 1953; Lévi-Strauss, 1948a; 1948b; 1996 [1955]; Leigue Castedo, 1957; Hugo, 1959; Meireles, 1984; 1989; 1991; Snethlage, 2015; Menéndez, 1981-1982; 1984-1985; 1992; Sampaio; Silva, 1997; CIMI, 2002; 2015; Cypriano, 2007; Miller, 2007; Pessoa da Silva; Costa, 2014; Costa, 2013), é possível costurar as articulaçóes culturais e históricas entre as diferentes sociedades que ali vivem ou viviam, demonstrando uma unidade em função das relaçóes mais ou menos permanentes, das trajetórias histórico-culturais comuns e dos alinhamentos políticos recentes - todos afetados por macroprocessos históricos, sociais e políticos semelhantes. Da mesma forma, verifica-se, com base nos estudos mais recentes, que uma rede de intercâmbios conecta na forma reminiscente de um "arquipélago horizontal” (Uzendoski, 2004) — a área a regióes vizinhas um pouco distantes, por meio, especialmente, de contatos belicosos. Sabe-se, desde há algum tempo, que a guerra constitui também circuitos de trocas - de agressóes, partes de corpos, mulheres e crianças cativas - fundamentais para a constituição do socius em várias partes da Amazônia, conforme se observou anteriormente (Albert, 1985; Viveiros de Castro, 1986b; 2002; Fausto, 2001; Santos-Granero, 2009).
A prática de tomar cabeças dos inimigos mortos como troféus de guerra e a produtividade destas em variados contextos cerimoniais, conectam, por exemplo, os Karitiana e os Kagwahiva (Peggion, 2011b) nesta região (Vander Velden, 2011) a populaçóes vizinhas ao Norte, como Munduruku (Menget, 1993c; Leopoldi, 2016), Xipaya (Nimuendajú, 1981b) e Juruna (Lima, 1995), e, mais a Leste, aos Arara (Teixeira-Pinto, 1997), o que demanda investigação comparativa e assinala potenciais conexóes ao longo da zona limítrofe entre a floresta amazônica e os cerrados do Brasil central.

A rigor, este sistema regional vem sendo pensado como uma fronteira que separaria dois conjuntos étnico-culturais distintos ao longo do sistema fluvial Guaporé-Madeira. Lévi-Strauss (1948a, p. 371, tradução nossa), em seu artigo sobre o vale do Guaporé no HSAI, defendeu que "[d]iferente da maioria dos rios da América do Sul, o rio Guaporé não constitui o eixo de uma área cultural homogênea; ele é uma fronteira, mais do que uma ligação". Com isso, o grande antropólogo francês divide a zona em duas áreas culturais marcadamente distintas: a Oeste, o complexo cultural Mojo-Chiquito (Denevan, 1966), e, a Leste, o complexo cultural do Guaporé (Galvão, 1979). Da mesma forma, estudos arqueológicos e linguísticos sustentam diferenças marcantes entre as margens Norte e Sul do Madeira, as quais Eriksen distribui como partes, respectivamente, de sua "Western Amazonia" e "Southern Amazonia" (Eriksen, 2011, p. 17-89). Contudo, tanto as redes de relaçóes historicamente documentadas quanto aquelas interaçóes políticas contemporâneas apontam para um cenário de movimentação e intercâmbios pelas duas regióes: "Ainda que as áreas culturais do Guaporé e de Moxo-Chiquito sejam muito distintas, existem evidências arqueológicas 
e históricas de intercâmbios entre ambas ao longo do rio Guaporé" (Crevels; Van der Voort, 2008, p. 154, tradução nossa). Rios, afinal, têm um duplo caráter: unem e dividem populaçóes, regiốes e culturas (Harris, 2018, p. 638-639).

O Guaporé (chamado de Itenez na Bolívia), portanto, náo parece ter sido uma fronteira estanque, senão terreno de intensa circulação de grupos entre seus lados espanhol (boliviano) e português (brasileiro), como mostra, por exemplo, a provável circulação de pequenos grupos Sirionó (Pereira, 2018) e de outros por ambas as margens do rio (Leigue Castedo, 1957; Meireles, 1991; Miller, 2007; Snethlage, 2015; Dietrich, 2016), incluindo os povos da família linguística Txapakura (Angenot-de Lima; Angenot, 2000), como os Wari' (Pakaa Nova), cuja detalhada etno-história (Vilaça, 1992; 2006; também Von Graeve, 1991; Conklin, 2001) merece ser emulada para todos os povos na região e os "recém-redescobertos" Gwarasu'gwe ou Guarasugwe (Warazukwe) na margem direita do rio, lado brasileiro (Ramirez; Vegini; França, 2017). De fato, o rio Guaporé parece ter sido a rota preferencial da ampla rede de contatos de natureza histórica e estrutural que ligava os Llanos de Mojos ao alto Xingu via grupos de língua Aruak (Heckenberger, 2002; 2005; Heckenberger; Neves, 2009; Eriksen, 2011; Nahum-Claudel, 2018); especialmente os Paresi (Campos, 1862 [1720]; Roquette-Pinto, 1935; Costa, 1985; Canova, 2019), que se espalhavam pelas periferias meridionais da Amazônia, o que vincula os estudos desta zona do Alto Madeira/Grande Rondônia às discussóes sobre os processos de expansão dos povos Aruak e das significativas inovaçôes tecnoculturais trazidas por eles, cuja análise ainda está concentrada, largamente, na porção Norte do continente (ARN, Ori- noco e escudo das Guianas). O Guaporé e seus afluentes também vinculavam esta zona de transição Amazônia-cerrado ao conjunto Nambikwara mais ao Sul em sua complexa divisão em (sub)grupos nomeados que alguns autores defendem ser povos distintos, agrupados em certos conjuntos regionais (Price, 1978; 1983; 1987; 1989; Costa, 2002; Reesink, 2007; 2010; 2015; Miller, 2009, 2018; Fiorini, 2000), além de outros povos no atual Sul de Rondônia e Oeste do Mato Grosso (Reesink, 2010).

Galvão (1979) inclui os Nambikwara, Paresi e Iranxe nesta área do complexo do Guaporé, em função dos contatos destes com os grupos do "complexo do marico". Evidências míticas e de outras naturezas (Jakubaszko, 2003; Moi et al., 2009; Lisbôa, 2010) suportam relaçôes próximas - o mútuo reconhecimento como "parentes distantes" - entre os Paresí e os Enawenê-Nawê (Salumã), grupo de filiação Aruak também no Oeste mato-grossense. O mesmo pode-se afirmar dos contatos destes com os Iranxe e Myky na mesma regiáo (Lisbôa, 2018) e com os Apiaká, Rikbatsa e outros povos na bacia do Juruena (Tempesta, 2009; Arruda, 2019) - muitos deles atraídos pela Missão de Utiariti, no rio Papagaio (Silva, 1999). Reesink (2010) postulou a existência de processos de convivência entre grupos Paresí e Nambikwara no vale do Guaporé, além de apontar para os contatos - ora de conflitos, ora de coesão - permanentes entre estes últimos e seus vizinhos do Norte, os Rikbatsa e os Cinta Larga.

No caso do rio Madeira, "[e]lo entre a Amazônia, a região pantaneira e os Andes" (Almeida; Kater, 2017, p. 44), ainda que seu mapa étnico pré-contato (século XVIII) seja pouco conhecido (Hugo, 1959; Pessoa da Silva; Costa, 2014), é certo que transaçôes também ocorriam ali. Num passado distan- 
te (por volta do ano 1.000 d.C.), o Madeira pode ter funcionado como um dos corredores de comunicação do sistema regional de intercâmbios formado pelos povos falantes de Aruak (Eriksen, 2011, p. 219) que não existem mais naquela areação. Crevels e Van der Voort (2008, p. 154), por exemplo, incluem a área cultural Tapajós-Madeira de Galvão (1979) na região Guaporé-Mamoré. O caso dos grupos Tupi-Kagwahiwa, em especial o dos Parintintim, ilustra esta rede de intercâmbios: empurrados do Norte pelos movimentos belicosos dos Mura, dos Munduruku e dos colonizadores não indígenas (Menéndez, 1981-1982; 1984-1985; 1992; Kracke, 2007; Peggion, 2011a; 2011b; Sampaio, 2001), espalharam-se pelo Norte e Centro de Rondônia, englobando grupos nativos, como os Karitiana, que têm memórias detalhadas de conflitos com os Uru-Eu-Wau-Wau (Vander Velden, 2014; 2018) e conectando o Sul do Amazonas ao conjunto multiétnico nos vales dos rios Branco e Guaporé (Leonel, 1995; Peggion, 2011b). A expansão dos Kawahiwa chegou a alcançar as redes Arawa bem mais a Oeste. Maizza (2012, p. 35-37) menciona complexas relaçóes entre os Juma e Jarawara no Purus (cf. Peggion, 2000; Cornwall, 2003). Isso ilumina o que poderíamos entender como resíduos de redes mais amplas que comunicavam os vales do Madeira e do Tapajós com o baixo Amazonas (Harris, 2018).

Da mesma forma, a regiáo do Alto Madeira estava vinculada ao conjunto Pano por meio dos grupos Pano meridionais, que se espalhavam pela região Noroeste de Rondônia, os assim chamados "Caripunas" antes da chegada dos Kawahiwa, os Karipuna que ocupam a regiâo hoje. Esses Pano meridionais constituíam, segundo Córdoba e Villar (2009), um antigo sistema regional ou multiétnico, integrado também por povos de língua Aruak e Tacana, entre outras, que os autores denominam "continuo transversal de sociedades pano-hablantes", que conectava toda a zona entre o vale do Madeira e o Ucayali, no Peru (Erikson, 1992; Villar; Córdoba; Combès, 2009; Córdoba; Villar, 2011; Córdoba; Valenzuela; Villar, 2012; Córdoba, 2015). Com efeito, as análises produtivas destas redes de intercâmbios Pano meridional mostram-se em consonância com o que defendemos aqui a respeito da abertura dos sistemas regionais em múltiplas direçôes e da recusa em naturalizar unidades étnicas fechadas e com fronteiras étnicas definidas, levando-se em conta, nas investigaçóes, a história de contatos intensos não apenas em tempos pré-hispânicos como com distintos atores da colonização:

[...] la historia de los pano meridionales es, fundamentalmente, una historia de relaciones interetnicas. No hay, ni hubo nunca, "etnias" aisladas que luego entran en contacto entre si: el mestizaje, la circulación, el multilingüismo, los intercambios constituyen la condición originaria (Córdoba; Villar, 2009, p. 23).

Um grupo Pano, os Kaxarari, ainda ocupa a regiấo na divisa entre os estados de Rondônia e Amazonas, porém informaçóes sobre eles ainda são fragmentárias (Santos, 2002; Charles; Silva; 2019; Pereira; Silva; Kaxarari, 2019). Há sugestôes, inclusive, de que os Karitiana (cf. Moser, 1993; 1997; Vander Velden, 2012; 2017; 2018; Araújo, 2015; Castro, 2018) mantinham contato com os vizinhos Karipuna (Hugo, 1959), belicosos, com grupos bem mais a Leste, como os $\mathrm{Su}$ ruí e Zoró, e a Oeste, como os Wari' (Vander Velden, 2014). É provável que estejam de alguma forma relacionados aos Omagua-Kambeba no alto Solimóes (Cabral, 2007, p. 376-377) ou mesmo aos Andes (Mendon- 
ça de Souza, 1994), em função da modificaçáo craniana artificial similar praticada pelos dois grupos, o que aponta para uma conexão de longa distância entre a bacia do Madeira e o Alto Amazonas e mais além (Pessoa da Silva; Costa, 2014). Outras práticas Karitiana e dos extintos Arikém, da mesma família linguística, também parecem relacioná-los a grupos na Bolívia (Cavalcante, 2015), como os pilóes feitos de pedra, encontrados também entre os Jabuti (Van der Voort, 2006; Crevels; Van der Voort, 2008, p. 154). A distribuição dos povos Kawahiwa até o centro de Rondônia e suas relaçóes com grupos Tupi-Guarani em outras regióes têm sido objeto de várias pesquisas recentes (Sampaio; Silva; Miotello, 2004; França, 2012; Almeida Silva, 2015a, 2015b), assim como os nexos políticos contemporâneos entre o Sul do Amazonas e as estruturas da política indigenista situadas em Rondônia (Araújo, 2019). Adicione-se que, ainda recentemente, pequenos grupos Tupi-Kagwahiwa isolados perambulam pelo Noroeste mato-grossense e Centro-norte de Rondônia (Cartagenes; Lobato, 1991; Shiratori, 2019).

Quanto aos povos da família linguística Mura, composta por duas línguas, o Mura, provavelmente extinto, e o Pirahã, anteriormente chamado de Mura-Pirahã, eles estáo localizados um pouco ao Norte, na zona do médio Madeira e afluentes, embora grupos familiares Mura, às vezes identificados como Moura, possam ser encontrados em várias cidades rondonienses. Pouco se produziu antropologicamente acerca dos Mura, a despeito de sua longa história e do impacto que tiveram na expansão colonial portuguesa pela Amazônia (Amoroso, 1992; 1998; Amoroso; Farage, 1994), inclusive com reflexos significativos na região do Alto Madeira e Norte de Rondônia, como vimos com as movimentaçóes Kawahiwa (Gondim, 1925). Já os Pirahá nos rios Marmelos e Maici (AM), que são cada vez mais atraídos pela estrutura de assistência indigenista no Norte de Rondônia, foram objeto de duas excelentes monografias de Marco Antonio Gonçalves (1993; 2001). Nimuendajú (1948; 1982) já relacionava os Mura e Pirahã com outros povos no Alto Madeira, tratando conjuntamente suas trajetórias históricas.

Entretanto, notemos que, nesta região em análise, existe um complexo sistema de intercâmbios linguísticos, rituais, xamânicos e matrimoniais, calcados sobre uma organização política multiétnica e um conhecimento amplamente distribuído entre povos de diferentes famílias linguísticas; em suma, um sistema regional no sentido "clássico" está bem documentado para a área de médio e baixo Guaporé. Meireles (1991) chamou esse sistema de complexo cultural do marico. Esse conjunto multiétnico e multilinguístico, que foi nomeado a partir de um tipo de bolsa de linha de tucum fabricada e utilizada pelos povos na regiáo (Mezacasa, 2018b), abrange 18 etnias de pelo menos sete famílias linguísticas e está concentrado em duas terras indígenas: T. I. Rio Guaporé e T. I. Rio Branco 6 (Meireles, 1989; Braga et al., 2011; CIMI, 2015). Não existem, todavia, estudos que abarquem o sistema como um todo, embora investigaçóes de longa data demonstrem os contatos intensos entre os muitos povos nesta área (Snethlage, 2015;

6 Além dos maricos, bolsas produzidas com a linha do tucum, "que não são só característicos como exclusivos dos grupos indígenas que habitam hoje a área Indígena do Rio Guaporé e Rio Branco” (Meireles, 1991, p. 211), estes povos também compartilha(va)m a ausência do cultivo de mandioca brava e da farinha na alimentação e o consumo da chicha de milho na alimentação regular e da chicha fermentada em ocasióes cerimoniais. 
Caspar, 1952; 1953; 1955; 1975; Becker-Donner, 1955), bem como a partilha de conhecimentos, como ocorre com narrativas míticas amplamente disseminadas (Mindlin, 1993; 1995; 1997; 1999, 2006). As pesquisas que abordam tal sistema, tendo como via de acesso, por assim dizer, povos específicos (Galúcio, 2006), Soares Pinto (2009; 2012; 2015; 2014; 2017), Pesovento (2012), Soares Pinto e Nogueira (2014), Sanchez (2019a; 2019b), Mezacasa (2018a), entre outros), vêm crescendo nos últimos anos e sugerem que a análise do conjunto ainda é muito lacunar e deve nos reservar surpresas para o futuro. No que toca à presença de grupos de língua Macro-Jê na região (Djeoromitxi e Arikapu), Ribeiro e Van der Voort (2010) citam antigas conexóes da região do Guaporé com grupos mais a Leste, como os Bororo e Otuki (Wüst, 1994; Ramirez, 2010; Martínez, 2018) e com a Chiquitania (Costa, 2006; Silva, 2008a, 2008b) e, mais além, com Pantanal, Paraguai e Chaco (Costa, 1999; Martínez, 2018). O monumental diário de Emil Heinrich Snethlage, publicado recentemente (2015) em alemáo, traz informaçôes detalhadas e preciosas sobre as redes de contato por todo o vale do Guaporé indígena, complementando trabalho anteriormente publicado por Snethlage (1937), e espera-se em breve uma edição em língua portuguesa (Mere, 2013).

Entre os grupos no rio Branco estão os Aruá e Salamãi, povos Tupi-Mondé separados do principal conjunto destes Tupi-Guarani no chamado Corredor Etnoambiental Tupi-Mondé (Cinta Larga, Suruí Páiter, Zoró e Gavião-Ikolen), que se espalha entre Rondônia e Noroeste do Mato Grosso (Brunelli, 1985; 1987; 1988; 1989; 1990; Mindlin, 1985; 1996; 2001; Dal Poz, 1991; 1998; 2004; Suruí, 2008; Bento, 2013; Ribeiro, 2015; Cardozo, 2016; Pappiani; La- cerda, 2016; Felzke, 2017, 2018; Almeida Silva, 2019). Esta localização algo anômala dos Aruá e Salamãi, a respeito dos quais, virtualmente, quase nada sabemos (Ferreira de Melo; Vegini, 2013), ainda merece consideraçáo, o que deve nos fornecer um esclarecimento sobre a movimentação dos grupos indígenas nesta etnicamente complexa zona do centro das terras rondonienses. Meireles (1991) já discutia as conexóes entre os "povos do marico" e a regiâo dos rios Roosevelt/ Ji-Paraná (onde se situa o conjunto Mondé). O mesmo vale para as relaçôes entre os Mondé e seus vizinhos, como os Arara-Karo (Gabas Jr., 2002; 2009; Nóbrega, 2008; Cardozo; Vale Jr., 2012; Otero dos Santos, 2015; 2019; Keppi; Gomide, 2016; Keppi; Pruiksma, 2018) e, do lado mato-grossense, os Nambikwara e demais povos já na bacia do Tapajós, como os Rikbatsa (Arruda, 2019) e os Arara do rio Branco (Dal Poz, 1995; Christ, 2009). Evidências recentes sugerem que os Tupi-Mondé, em suas andanças, podem ter frequentado as margens do rio Madeira, mais de mil quilômetros ao Norte de sua atual localização (Felzke, 2017, p. 20-22). Ademais, se as famílias linguísticas Ramarama (Arara Karo) e Puruborá estão, de fato, relacionadas em uma putativa família Pururama (Galúcio; Gabas Jr., 2002), então faz-se também necessário investigar a relação dos Arara-Karo com os povos no vale do Guaporé, como os Puruborá (Snethlage, 1937; Catheu, 2001; Monserrat, 2005; 2018; Galúcio, 2005; Galúcio; Puruborá; Aporete Filho, 2013; Montanha; Barboza; Oliveira, 2014; Menezes, 2016; Vander Velden, 2017) e Migueleno (Nascimento, 2018a; 2018b), entre outros. Caso interessantíssimo é o dos Palmella (ou Paumelenhos), falantes da única língua Karib na região (a mais meridional da família) e cuja presença nesta zona constitui um enigma 
(Severiano da Fonseca, 1986 [1880-1881], p. 190-207; Becker-Donner, 1956), com notícias de que este povo, considerado extinto, ainda resiste no vale do rio Sáo Miguel (Crevels; Van der Voort, 2008, p. 162).

Devemos levar em conta também as amplas movimentaçóes de povos indígenas nesta regiáo, provocadas, desde o final do século XIX e primeira metade do século XX, pelo ciclo da borracha e pelas açóes do Serviço de Proteção ao Índio (SPI) e que exerceram impacto determinante na atual configuração étnica do Alto Madeira e nas experiências de contatos e intercâmbios entre distintas populaçôes e conjuntos multiétnicos. De fato, a Grande Rondônia pode ter se constituído como "área de refúgio" a partir do século XVII, em função da presença massiva da empresa colonizadora nas suas bordas (Leonel, 1995; Crevels; Van der Voort, 2008, p. 172; Trubiliano, 2017). Esses movimentos podem ser analisados, por exemplo, pela presença de um grupo Apurinã (Aruak) em Rondônia, os Karitiana, que inclusive, mencionam conflitos com este povo (Vander Velden, 2011), talvez em sua rota migratória do vale do médio e baixo Purus para a Terra Indígena Roosevelt (CIMI, 2002, p. 14), e pela existência de expressivo número de indígenas em cidades como Porto Velho, capital rondoniense (Pereira, 2010), em que há povos quase inteiros para lá deslocados pelas políticas indigenistas, como os Kassupá (Maciel, 2000; Timóteo da Cunha, 2016; 2017; Andrade; Fernandes, 2018). De todo modo, alguns registros mais antigos assinalam a existência, por toda a região, de aldeias compósitas, nas quais conviviam representantes de diferentes povos (Zack, 1943). É possível, deste modo, pensar as redes de trocas e relaçóes nesta região como fenômeno de uma longa profundidade histórica que se desdobra, de muitas e variadas maneiras, até o momento presente.
Ao mesmo tempo, seria um movimento recente, incluindo, atualmente, as cidades em que os povos na região se encontram, em função das dinâmicas da assistência (saúde, educação, política indigenista), e forjam novas alianças e modalidades de intercâmbios. Se as culturas ameríndias são pensadas por boa parte da literatura como historicamente paradas no tempo (em spatial stasis), o que há, na verdade, é movimento, e este movimento permanente serviu e serve para tramar contatos e correspondências entre povos até hoje (Alexiades, 2009).

\section{Considerações finais}

É evidente, ao fim e ao cabo, que esta demarcação de limites da área cultural ou sistema regional da Grande Rondônia é arbitrária, posto que as relaçôes entre as populaçóes na região não parecem estar completamente ou majoritariamente voltadas ao seu interior, como parece acontecer em certas áreas etnográficas nas Terras Baixas, como o Alto Xingu ou, como mostramos, o ARN. Náo obstante, por um lado, mesmo para estas áreas relativamente bem delimitadas, há algum grau de arbitrariedade na definição de limites - como bem perceberam, nas suas variações, os próprios autores que se dedicaram à definição de "áreas culturais" (Galvão, 1979) ou "etnográficas" (Melatti, 2019). Além disso, tal arbitrariedade constitui, justamente, uma das premissas desta nossa retomada da discussão dos sistemas regionais no último meio século: a ideia de que suas fronteiras são abertas e seus limites não podem ser, assim, facilmente demarcados, estendendo-se ou contraindo-se ao sabor da história. Por outro lado, as informaçôes ainda incipientes disponíveis sobre as populaçôes indígenas no Sudoeste da Amazônia 
parecem indicar que partilham de certas experiências históricas pré e pós-coloniais comuns, algo apontado pelos estudos realizados na região. Com isso, exibimos outra das premissas deste texto: a de que os sistemas regionais ou redes de intercâmbio são, para além de configuraçóes socioespaciais mais ou menos antigas, também resultado de políticas e de abordagens analíticas recentes ou contemporâneas, para além de envolverem, sempre, meios multimodais de interação (Whitehead, 2001; Neves et al., 2019).

Em suma, esses sistemas se organizam não em função das putativas semelhanças entre as sociedades, mas de acordo com a vida social compartilhada por diferentes povos (Melatti, 2019, p. 4-5). Qualquer visitante de Porto Velho reconhecerá que, como maior centro urbano regional, a cidade polariza grande parte das demandas das populaçôes nativas desta grande área, incluindo aquelas originadas ou vivendo fora do estado de Rondônia. A cidade forma, assim, uma espécie de centro, ou vértice, deste enorme sistema que abarca as populaçôes indígenas de Rondônia, Sul do Amazonas, Oeste e Noroeste do Mato Grosso e, mesmo, das regiōes limítrofes do lado boliviano da fronteira internacional.

De maneira homóloga, Manaus também pode ser vista como um vértice de atração de uma ampla diversidade de grupos indígenas que se conectam e estabelecem relaçóes de troca envolvendo a bacia do médio e alto Amazonas. Em relaçáo aos grupos oriundos do ARN, há registros muito antigos de migração, fenômeno que tem se intensificado nas últimas quatro décadas, mesmo com uma distância considerável entre essas áreas (Bernal, 2009). De maneira mais intensa, o município de São Gabriel da Cachoeira também tem sido ponto de reuniâo dos diversos grupos do ARN, com a expansão da contratação de professores, agentes de saúde indígena e outros profissionais e da distribuição de benefícios como aposentadorias, Bolsa Família e licenças-maternidade (Andrello, 2006; Iubel, 2015).

O ponto a se destacar é que se, por um lado, as interaçóes entre os sistemas regionais ameríndios e os sistemas coloniais e estatais produziram, como é amplamente sabido, muita destruição, por outro, aqueles povos que não foram exterminados conseguiram se movimentar pelos sistemas colonial e estatal de forma a manter e/ou ampliar o escopo de interaçóes com grupos indígenas de outros sistemas regionais, reconfigurando os muitos "polos de articulação indígena” (Melatti, 1979). Sem dúvida, os impactos dessas interaçóes obrigaram os arranjos das interaçóes regionais pré-coloniais a se modificarem e conferiram especificidades conforme o histórico da interação. Nesse sentido, o sistema regional do ARN aparenta ter se mantido mais estável do que o do Alto Madeira-Guaporé quanto às transformaçóes impostas pelas empresas coloniais e, posteriormente, pelos governos nacionais, o que levou muitos estudiosos a ressaltarem a homogeneidade cultural do ARN e outros a destacarem a heterogeneidade da regiáo da Grande Rondônia, colocando-a como uma zona fronteiriça.

Entretanto, conforme as novas abordagens sobre os sistemas regionais que apresentamos, é necessário nuançar o contraste entre as regióes do ARN e da Grande Rondônia, de modo a trazer matizes para a nossa investigação sobre os sistemas regionais ameríndios em geral. Dessa forma, quando focado numa escala mais aproximada, o sistema do ARN náo se mostra tão homogêneo, e as diferenças entre os grupos não 
param de saltar à vista, ao mesmo tempo que, se observarmos numa escala histórica e arqueológica mais ampla, também há muitos indícios de que o sistema do ARN tinha conexóes mais extensas e com maiores heterogeneidades linguística e cultural de grupos. De maneira homóloga, a heterogeneidade do sistema da Grande Rondônia também não se mostra muito expressiva quando fazemos uma aproximação da lente, e, numa escala histórica e arqueológica, a heterogeneidade se mostra tão antiga, podendo-se afirmar que há certa estabilidade do sistema. De todo modo, em ambos os casos, e como se verifica em outras porçôes das Terras Baixas Sul-Americanas, as análises devem privilegiar a longa duração, mas não se encerrarem com a conquista: a noção de "etnogênese", conforme aplicada por recentes estudos etno-históricos e arqueológicos, é útil para estender a reflexão até o momento presente, uma vez que os contextos interétnicos amazônicos parecem trazer à tona novamente as agendas políticas e culturais contemporâneas dos povos indígenas (Conklin; Graham, 1995).

O que se depreende do debate das últimas três décadas é uma forte ênfase nas conexôes entre sistemas, que se dão em múltiplos eixos — inclusive entre sistemas que tradicionalmente não eram ou são pensados como estando conectados —, de modo a abri-los de seu putativo isolamento e a pensar o continente como um tecido contínuo de conexóes, movimento para o qual a contribuição mais recente da noção de "rede" parece-nos fundamental. Neil Whitehead (1994, 1999), Eduardo Neves (2001), entre outros, argumentam que muitos estudos subestimaram a escala regional e o caráter supraétnico das organizaçóes sociais ameríndias pré-coloniais e há de se dizer o mesmo, como pensamos ter feito neste artigo, para as organizaçóes sociais pós-conquista ou para aquelas dos dias correntes.

Com isso, não é mais possível sustentar uma imagem das culturas ameríndias como estáticas no espaço em que vivem, entre enormes vazios geográficos ocupados apenas pela floresta. Em vez disso, ganhou força, nos estudos aqui recenseados, a partir, sobretudo, da década de 1980, uma imagem dinâmica de intenso movimento entre as diversas regióes, possivelmente de dimensôes continentais. Portanto, no passado, as migraçóes eram possivelmente ainda mais severas do que nos dias atuais. Estamos mais próximos a uma imagem dos sistemas regionais, em que estes se desenvolvem como uma nebulosa, no sentido de que Lévi-Strauss confere essa noção em sua magistral série de estudos sobre a mitologia ameríndia. Ora a nebulosa se expande, ora se contrai "sem jamais reunir de modo durável ou sistemático a soma total dos elementos", engendrando um corpo multidimensional a partir do qual não é possível definir, a não ser arbitrariamente, um ponto de origem e outro de chegada (Lévi-Strauss, 2004 [1964], p. 20-24).

Este movimento não é trivial e foi seguido por uma profunda crítica à aplicação de noçóes totalizantes e identitárias para se definir as unidades sociais que compóem os sistemas regionais. Isso tem levado a uma revisão da importância do papel do que se convencionou chamar de parentesco na definição dessas unidades sociais, pelo menos no que diz respeito ao parentesco ser a instância privilegiada na constituição da organização social (Hugh-Jones, 2013). A investigação dos sistemas regionais também permitiu ampliar a complexidade das redes de relaçôes ameríndias e evidenciar que é muito difícil atribuir certas características sistêmicas a determinado grupo, como se 
fosse possível mapear as dinâmicas a partir de uma origem, como, por vezes, os estudos sobre grupos da família linguística Aruak aparentaram fazer. Parece-nos um caminho mais interessante não tomar os grupos como constituídos anteriormente às redes de relaçôes, mas formados a partir e através das interaçóes sociais regionais de escalas mais ou menos ampliadas. As relaçóes precedem os termos.

Além disso, a complexidade e variedade das redes de relaçôes mostram que o idioma da predaçáo não tem o mesmo rendimento ao longo das diversas regióes que conformam o tecido social do continente, mesmo que a troca de agressóes (a guerra) seja um dos componentes críticos das redes de relaçôes em várias partes do continente. Para além da relação aliado/inimigo, há contextos nos quais as relaçóes anfitriáo/ convidado sáo tão ou mais centrais para a constituição das redes de relaçôes regionais (Sztutman, 2012). Nesses contextos, as reunióes festivas adquirem proeminência. Segundo Perrone-Moisés (2015) propôs recentemente, guerra e festa aparecem como um par indissociável nas interaçóes sociais ameríndias. Vale dizer, portanto, que não enxergamos a oposição analítica como crucial - que poderia ser resumida na dualidade Aruak versus Tupi (mas também, em menor medida, Jê, Pano, Karib e outras) - entre os modelos do ideal de independência e dispersão sociocosmológica continental, anárquicos, monádicos ou autárquicos, e aqueles centrados nas múltiplas conexốes via redes, hierárquicas, ou não, de relações mais ou menos inclusivas. Nossa sugestão é que ambas as imagens podem caracterizar os povos ameríndios, ora se aproximando, ora se afastando de seus vizinhos, mas sempre em relaçáo com eles - seja de convivialidade, comércio e mistura, seja de predação e guerra. Nosso ponto, que obviamente náo é novo, mas, talvez, necessite ser reforçado, é que as relaçóes se sobrepóem aos termos: sejam republicanas ou monárquicas, são sempre as mesmas. A sugestão de se pensar as conexốes entre os povos indígenas nas Terras Baixas como sistemas de prestaçóes totais sintetiza o argumento, e qualquer que seja a dimensão dos modos de articulação indígena (local ou regional) ou a forma de definição daquilo que lhes é "externo", o estatuto maior é o da abertura. "Relações entre relações" é o que, em três palavras, define as paisagens indígenas na América do Sul.

Por fim, o avanço da compreensão dos sistemas regionais ameríndios nos últimos 30 anos foi possível somente por um esforço coletivo, que excede os limites de uma única disciplina e que reuniu pesquisadores das áreas da Antropologia, História, Arqueologia e Linguística e, ainda, da genética, cuja contribuição infelizmente, não pudemos apreciar aqui (cf. Salzano, 2019). Dada a dimensão do continente americano e da sua diversidade de contextos, muito ainda há que se fazer para compreender a densidade $\mathrm{da}$ textura do tecido social ameríndio. Isso exige, sem dúvidas, que essas disciplinas, e outras que a elas venham se juntar, continuem em seus esforços sistêmicos e em rede de dialogarem e contribuírem com o debate.

7 Ou seja, se aquilo que está "fora" ou "difere" da sociedade deve ser predado/familiarizado e incorporado, convertendo o outro externo em si mesmo, ou continuamente combatido e afastado para a preservaçáo de um si mesmo "interior". 


\section{BIBLIOGRAFIA}

ACUÑA, C. Novo descobrimento do grande rio das Amazonas. Rio de Janeiro Agir, 1994.

AGOSTINHO, P. Kwarip, mito e ritual no Alto Xingu. São Paulo: EPU, 1974.

ALBERT, B. Temps du sang, temps des cendres: représentation de la maladie, système rituel et espace politique chez les Yanomami du Sud-Est (Amazonie brésilienne). Thèse (Doctorat) — Université de Paris X, Paris, 1985.

ALEXIADES, M. (ed.). Mobility and migration in Indigenous Amazonia: contemporary ethnoecological perspectives. New York: Berghahn Books, 2009.

ALMEIDA, F. O.; KATER, T. As cachoeiras como bolsões de histórias dos grupos indígenas das terras baixas sulamericanas. Revista Brasileira de História, v. 37, n. 75, p. 39-67, maio/ago. 2017. https://doi.org/10.1590/180693472017v37n75-02a

ALMEIDA SILVA, A. Territorialidades, identidades e marcadores territoriais: Kawahib da Terra Indígena Uru-EuWau-Wau em Rondônia. Jundiaí: Paco Editorial, 2015a.

ALMEIDA SILVA, A. Entre a floresta e o concreto: os impactos socioculturais no povo indígena Jupaú em Rondônia. Jundiaí: Paco Editorial, 2015b.

ALMEIDA SILVA, A. (org.). Representaçôes e marcadores territoriais dos povos indígenas do corredor etnoambiental Tupi Mondé. Jundiaí: Paco Editorial, 2019.

AMOROSO, M. Corsários no caminho fluvial: os Mura do rio Madeira. In: CUNHA, M. C. C. (org.). História dos índios no Brasil. Sáo Paulo: Companhia das Letras, 1992. p. 297-310.

AMOROSO, M. Território do medo. Notas sobre a utilização da crônica setecentista como fonte da etnografia Mura. In: NIEMEYER, M. A.; GODOY, E. P. (orgs.). Além dos territórios. Para um diálogo entre a tecnologia indígena, os estudos rurais e os estudos urbanos. Campinas: Mercado de Letras, 1998. p. 251-269.

AMOROSO, M.; FARAGE, N. (orgs.). Relatos da fronteira amazônica no século XVIII: Alexandre Rodrigues Ferreira e Henrique João Wilckens. São Paulo: Núcleo de História Indígena e do Indigenismo/Universidade de São Paulo, 1994.

ANDRADE, R.; FERNANDES, E. Etnicidade e identidade em contexto urbano: os Cassupá de Porto Velho (RO). Revista Mosaico, v. 11, p. 101-106, 2018. http://dx.doi.org/10.18224/mos.v11i1.6111

ANDRELLO, G. Cidade do índio: transformaçōes e cotidiano em Iauaretê. São Paulo: Editora Unesp: Instituto Socioambiental; Rio de Janeiro: NuTI, 2006.

ANDRELLO, G. Escravos, descidos e civilizados: índios e brancos na história do rio Negro. Revista Estudos Amazônicos, v. 5, n. 1, p. 107-144, 2010.

ANDRELLO, G. (org.). Rotas de criaçáo e transformaçáo: narrativas de origem dos povos indígenas do rio Negro. São Paulo: Instituto Socioambiental; São Gabriel da Cachoeira: Federação das Organizaçōes Indígenas do Rio Negro, 2012.

ANDRELLO, G. Cultura ou parentesco? Reflexóes sobre a história recente do Alto Rio Negro. R@U - Revista de Antropologia da UFSCar, v. 6, n. 1, p. 175-189, 2015.

ANDRELLO, G. Nomes, posiçôes e (contra) hierarquia: coletivos em transformação no Alto Rio Negro. Ilha Revista de Antropologia, v. 18, n. 2, p. 57-97, 2016. https://doi.org/10.5007/2175-8034.2016v18n2p57

ANDRELLO, G. "Aún mi cuerpo aloja una lanza de los peces": troca e predação no noroeste amazônico. Anuário Antropológico, v. 42, n. 1, p. 229-248, 2017. https://doi.org/10.26512/anuarioantropologico.v42i1.2017/6322 
ANDRELLO, G.; GUERREIRO JR., A.; HUGH-JONES, S. Space-time transformations in the Upper Xingu and Upper Rio Negro. Sociologia \& Antropologia, v. 5, n. 3, p. 699-724, 2015. https://doi.org/10.1590/2238$38752015 \mathrm{v} 533$

ANGENOT-DE LIMA, G.; ANGENOT, J.-P. O sistema prosódico Panchapakura de demarcação lexical (com uma bibliografia das línguas Chapakura). In: VAN DER VOORT, H.; VAN DER KERKE, S. (eds.). Indigenous languages of lowland South America - Indigenous Languages of Latin America. Leiden: Research School of Asian, African and Amerindian Studies, 2000. v. 1, p. 149-164.

ARAÚJO, Í. Osikirip: os “especiais" Karitiana e a noçẫo de pessoa ameríndia. Tese (Doutorado) — Universidade de São Paulo, São Paulo, 2015.

ARAÚJO, J. O fenômeno da liderança Tupi Kagwahiva: trajetórias sociais, resistências e movimento indígena no sul do Amazonas. Tese (Doutorado) — Universidade Estadual Paulista “Júlio de Mesquita Filho”, Araraquara, 2019.

ÅRHEM, K. Makuna social organization. Stockholm: Almqvist \& Wiksell, 1981.

ÅRHEM, K. The cosmic food web: human-nature relatedness in the Northwest Amazon. In: DESCOLA, P.; PÁLSSON, G. (eds.). Nature and society: anthropological perspectives. London: Routledge, 1996. p. 185-204.

ARRUDA, R. Os Rikbaktsa: mudança e tradiçấo. Embu das Artes: Alexa Cultural; Manaus: Edua, 2019.

ARVELO-JIMÉNEZ, N. The political struggle of the Guayana region's indigenous peoples. Journal of International Affairs, v. 36, n. 1, p. 43-54, 1982.

ARVELO-JIMÉNEZ, N.; MORALES MÉNDEZ, F; CASTILLO, H. Repensando la historia del Orinoco. Revista de Antropología, v. 5, n. 1-2, p. 155-174, 1989.

ATHIAS, R. Hupdë-Maku et Tukano: relations inégales entre deux sociétés du Uaupés, amazonien (Brésil). Thèse (Doctorat) - Université de Paris X, Paris, 1995.

BALÉE, W. (ed.). Advances in historical ecology. New York: Columbia University Press, 1998.

BARTH, F. (ed.). Ethnic groups and boundaries. Boston: Little, Brown \& Company, 1969.

BASSO, E. B. (ed.). Carib-speaking Indians: culture, society and language. Tucson: The University of Arizona Press, 1977.

BASTOS, R. J. M. Indagação sobre os Kamayurá, o Alto-Xingu e outros nomes e coisas: uma etnologia da sociedade Xinguara. Anuário Antropológico, n. 94, p. 227-269, 1995.

BECKER-DONNER, E. Notizen über einige Stämme an den rechten Zuflüssen des Rio Guaporé. Archiv für Völkerkunde, v. X, p. 275-343, 1955.

BECKER-DONNER, E. Archäologische Funde am mittleren Guaporé (Brasilien). Archiv für Völkerkunde, v. XI, p. 202-249, 1956.

BENTO, R. C. A flecha mata porque tem vida: um estudo etnográfico sobre os artefatos de caça dos Gavião Ikólóéhj. Dissertação (Mestrado) — Programa de Pós-Graduação em Antropologia Social, Universidade Federal de São Carlos, São Carlos, 2013.

BERNAL, R. J. Índios urbanos: processo de reconformação das identidades étnicas indígenas em Manaus. Manaus: Edua, 2009.

BIDOU, P. Les Fils de l'Anaconda céleste (les Tatuyo): étude de la structure socio-politique. Thèse (Doctorat) Université de Paris, Paris, 1976. 
BIDOU, P. Representations de l'Espace dans Mytologie Tatuyo (Indiens Tucano). Journal de la Société des Americaniste, n. 61, p. 92-105, 1972.

BODLEY, J. H. Deferred exchange among the Campa: a reconsideration. In: FRANCIS, P. D.; KENSE, F. J.; DUKE, P. J. (eds.). Networks of the past: regional interaction in archaeology. Proceedings of the Twelfth Annual Conference, the Archaeological Association of the University of Calgary. Calgary: Archaeology Association of the University of Calgary, 1981. p. 49-60.

BRAGA, A.; CABRAL, A. S. A. C.; RODRIGUES, A. D.; MINDLIN, B. Línguas entrelaçadas: uma situação sui generis de línguas em contato. Papia, v. 21, n. 2, p. 221-230, 2011.

BRUNELLI, G. Bebe! Bebe!... Jikkoi! Les Zorós vont à la chasse. Recherches Amérindiennes au Québec, v. 15, n. 3, p. 45-57, 1985 .

BRUNELLI, G. Migrations, guerres et identités: faits ethno-historiques zoró. Anthropologie et Sociétés, v. 11, n. 3, p. 149-172, 1987. https://doi.org/10.7202/006443ar

BRUNELLI, G. Maîtres de l'invisible. Notes et réflexions sur le chamanisme tupi-mondé. Recherches Amérindiennes au Québec, v. 18, n. 1-2: 127-143, 1988.

BRUNELLI, G. De los espiritus a los micróbios. Salud y cambio social entre los Zoró de la Amazonía brasileña. Quito: Abya-Yala; Roma: MLAL, 1989.

BRUNELLI, G. Crossing worlds in quest for answers: Zoró indians explain illness. In: POSEY, D. A.; OVERAL, W. L. (eds.). Ethnobiology: implications and applications. 2 v. Belém: Museu Paraense Emílio Goeldi, 1990. p. $141-146$.

BRÜZZI, A. A civilizaçáo indígena do Uaupés: observaçôes antropológicas, etnográficas e sociológicas. São Paulo: Centro de Pesquisas de Iauaretés; Amazonas: Missão Salesiana do Rio Negro, 1962.

CABALZAR, A. Filhos da cobra de pedra: organização social e trajetórias Tuyuka no rio Tiquié (Nororeste Amazônico). São Paulo: Editora Unesp: Instituto Socioambiental; Rio de Janeiro: NuTI, 2008.

CABRAL, A. S. A. C. New observations on the structure of Kokáma/Omágwa. In: WETZELS, L. (ed.). Language endangerment and endangered languages. Leiden: CNWS Publications, 2007. p. 365-379.

CALAVIA SÁEZ, O. O inca pano: mito, história e modelos etnológicos. Mana, v. 6, n. 2, p. 7-35, 2000. http:// dx.doi.org/10.1590/S0104-93132000000200001

CAMPBELL, L. American Indian languages: the historical linguistics of Native America. Oxford: Oxford University Press, 1997.

CAMPOS, A. P. Breve noticia que dá o capitão Antonio Pires de Campos do gentio barbaro que ha na derrota da viagem das minas de Cuyabá e seu reconcavo. Revista Trimestral do Instituto Historico, Geographico e Ethnographico do Brasil, tomo XXV, 3. trim., p. 437-449, 1862 [1720].

CANOVA, L. Os Paresi na conquista portuguesa de Mato Grosso (1719-1757). Cuiabá: EdUFMT, 2019.

CARDOZO, I. (org.). Diagnóstico etnoambiental participativo. Etnozoneamento e plano de gestâo em terras indígenas: Terra Indígena Roosevelt. Porto Velho: Ecam: Kanindé, 2016.

CARDOZO, I.; VALE JR., I. C. (orgs.). Diagnóstico etnoambiental participativo. Etnozoneamento e plano de gestão em terras indígenas: Terra Indígena Igarapé Lourdes. Porto Velho: Edufro: Kanindé, 2012.

CARNEIRO DA CUNHA, M. (org.). História dos índios no Brasil. São Paulo: Companhia das Letras, 1992. 
CARNEIRO DA CUNHA, M.; VIVEIROS DE CASTRO, E. Vingança e temporalidade: os Tupinambás. Anuário Antropológico, v. 10, n. 1, p. 57-78, 1985.

CARTAGenes, R.; LOBATO, J. C. À espera do desastre. In: RICARDO, C. A. Povos indígenas no Brasil, 1987/88/89/90. São Paulo: Centro Ecumênico de Documentação e Informação, 1991. p. 445-446.

CARVAJAL, G. Descubrimiento del río de las Amazonas por el capitán Francisco de Orellana. Madri: Babelia. DOC, 2011.

CARVALHO JR., A. D. Índios cristâos: poder, magia e religiâo na Amazônia colonial. Curitiba: Editora CRV, 2017.

CASPAR, F. Tupari: Unter Indios im Urwald Brasiliens. Deutschland: Friedrich Vieweg \& Sohn Braunschweig, 1952.

CASPAR, F. Tupari: entre os índios, nas florestas brasileiras. São Paulo: Melhoramentos, 1953.

CASPAR, F. A expedição de P. H. Fawcett a tribo dos Maxubi em 1914. In: CONGRESSO INTERNACIONAL DE AMERICANISTAS, 21., 1955, São Paulo. Anais [...]. São Paulo: Editora Anhembi, 1955. v. 1, p. 113-120.

CASPAR, F. Die Tuparí Indianerstamm in Westbrasilien. Berlin: Walter de Gruyter, 1975.

CASTRO, A. C. M. O. Koro'op: e-moçôes, sociabilidade, paisagem e temporalidade entre os Karitiana. Tese (Doutorado) — Universidade Federal de Juiz de Fora, Juiz de Fora, 2018.

CATHEU, G. Puruborá: mais um povo ressurgido em Rondônia. Porantim, v. 23, n. 241, p. 7, 2001.

CAVALCANTE, W. Os Arikêmes e o SPI: o desafio da reelaboração cultural indígena sob poder tutelar do Estado brasileiro. Dissertação (Mestrado) — Universidade Federal de Rondônia, Porto Velho, 2015.

CELESTINO DE ALMEIDA, M. R. Os índios na história do Brasil. Rio de Janeiro: Editora FGV, 2010.

CHACON, T.; CAYÓN, L. Consideraçóes sobre a exogamia linguística no Noroeste Amazônico. Revista de Letras, v. 6, n. 1/2, p. 6-20, 2013.

CHARLES, C.; SILVA, J. C. Viver Kaxarari! Uma abertura para o outro. In: XIMENES, C.; PICANÇO, F.; CARVALHO, R.; SILVA, R. (orgs.). Educaçáo e modo de vida das populaçóes indígenas amazônicas. Curitiba: Editora CRV, 2019. p. 109-119.

CHAUMEIL, J.-P. Échange d'énergie: guerre, identité et reproduction sociale chez les Yagua de l'Amazonie péruvienne. Journal de la Société des Américanistes, n. 71, p. 143-157, 1985. https://doi.org/10.3406/jsa.1985.2259

CHAUMEIL, J.-P. Les os, les flûtes, les morts. Mémoire et traitement funéraire en Amazonie. Journal de la Société des Américanistes, n. 83, p. 83-110, 1997. https://doi.org/10.3406/jsa.1997.1672

CHERNELA, J. Hierarchy and economy among the Uanano (Kotiria): speaking people of the middle Uaupés basin. Tesis (Doctorado) — Columbia University, New York, 1983.

CHRIST, C. L. Mutiráo de solidariedade: retomada da Terra Indígena Arara. Campinas: Curt Nimuendajú, 2009.

CLASTRES, P. A sociedade contra o Estado. Rio de Janeiro: Fracisco Alves, 1974.

COELHO, V. P. (org.). Karl von den Steinen: um século de antropologia no Xingu. São Paulo: Edusp, 1993.

COELHO DE SOUZA, M. O traço e o círculo: o conceito de parentesco entre os Jê seus antropólogos. Tese (Doutorado) - Universidade Federal do Rio de Janeiro, Rio de Janeiro, 2002.

CONKLIN, B. A. Consuming grief: compassionate cannibalism in an Amazonian society. Austin: University of Texas Press, 2001. 
CONKLIN, B. A.; GRAHAM, L. The shifting middle ground: Amazonian Indians and eco-politics. American Anthropologists, v. 97, n. 4, p. 695-710, 1995. https://doi.org/10.1525/aa.1995.97.4.02a00120

CONSELHO INDIGENISTA MISSIONÁRIO (CIMI). Panewa especial. Porto Velho: Conselho Indigenista Missionário, Regional Rondônia, 2002.

CONSELHO INDIGENISTA MISSIONÁRIO (CIMI). Panewa especial. Porto Velho: Conselho Indigenista Missionário, Regional Rondônia, 2015.

CÓRDOBA, L.; VAlENZUElA, P.; VILlaR, D. Pano meridional. In: CREVELS, M.; MUYSKEN, P. (eds.). Lenguas de Bolivia. Tomo II: Amazonia. La Paz: Plural Editores, 2012. p. 27-69, 2012.

CÓRDOBA, L.; VILLAR, D. Etnonimia y relaciones interétnicas entre los panos meridionales (siglos XVIII-XX). Revista Andina, n. 49, p. 211-244, 2009.

CÓRDOBA, L.; VILLAR, D. As estruturas de nominação étnica na história dos panos meridionais. In: LIMA, E. C.; CÓRDOBA, L. (orgs.). Os outros dos outros: relaçóes de alteridade na etnologia sul-americana. Curitiba: Editora UFPR, 2011. p. 109-118.

CÓRDOBA, L. Barbarie en plural: percepciones del indígena en el auge cauchero boliviano. Journal de la Société des Américanistes, v. 101, n. 1-2, p. 173-202, 2015. https://doi.org/10.4000/jsa.14384

CORNWALL, R. Os Jumas: a continuação da violenta reduçâo dos Tupi. Madalena: R. Cornwall, 2003.

COSTA, A. Entre artefatos e narrativas: a história indígena do Alto Rio Madeira a partir dos relatos dos viajantes do século XVIII. Monografia (Conclusão de Curso) \Universidade Federal de Rondônia, Porto Velho, 2013.

COSTA, A. M. R. F. M. Senhores da memória: uma história Nambiquara do cerrado. Cuiabá: Unicen, 2002.

COSTA, J. E. F. M. A coroa do mundo: religiâa, território e territorialidade Chiquitano. Cuiabá: Editora UFMT, 2006.

COSTA, L. The owners of kinship: asymmetrical relations in Indigenous Amazonia. Chicago: HAU Books, 2017.

COSTA, M. F. G. História de um país inexistente: o Pantanal entre os séculos XVI e XVIII. São Paulo: Estação Liberdade, 1999.

COSTA, R. R. Cultura e contato: um estudo da sociedade Paresi no contexto das relaçôes interétnicas. Dissertação (Mestrado) - Universidade Federal do Rio de Janeiro, Rio de Janeiro, 1985.

COUDREAU, H. La france équinoxiale. Tomo II: Voyages à travers les Guyanes et l'Amazonie. Paris: Challamel Ainé, 1886.

CREVELS, M.; VAN DER VOORT, H. The Guaporé-Mamoré region as a linguistic area. In: MUYSKEN, P. (ed.). From linguistic areas to areal linguistics. Amsterdam: John Benjamins Publishing Company, 2008. p. 151-179.

CRUZ, D. G. Lar, doce lar? Arqueologia Tupi na bacia do Ji-Paraná (RO). Dissertação (Mestrado) — Universidade de São Paulo, São Paulo, 2008.

CYPRIANO, D. C. C. A. Almas, corpos e especiarias: a expansão colonial nos rios Tapajós e Madeira. Pesquisas Antropologia, n. 65, p. 5-170, 2007.

DAL POZ, J. No país dos Cinta Larga: uma etnologia do ritual. Dissertação (Mestrado) — Universidade de São Paulo, São Paulo, 1991.

DAL POZ, J. A etnia e a terra: notas para uma etnologia dos índios Arara (Aripuanā-MT). Cuiabá: EdUFMT, 1995. (Série Antropologia, 4). 
DAL POZ, J. Os ritos da identidade: um estudo das relaçôes étnicas nos Cinta Larga. In: BARROS, E. P. (org.). Modelos e processos: ensaios de etnologia indígena. Cuiabá: EdUFMT, 1998. p. 149-226.

DAL POZ, J. Dádivas e dívidas entre os Cinta-Larga. Tese (Doutorado) — Universidade Estadual de Campinas, Campinas, 2004.

DEBOER, W. The machete and the cross: Conibo trade in the late seventeenth century. In: FRANCIS, P. D.; KENSE, F. J.; DUKE, P. J. (eds.). Networks of the past: Regional interaction in archaeology. Proceedings of the Twelfth Annual Conference, the Archaeological Association of the University of Calgary. Calgary: Archaeology Association of the University of Calgary, 1981. p. 31-48.

DEMARCHI, A.; MORAIS, O. Redes de relaçōes indígenas no Brasil Central: um programa de pesquisa. Espaço Ameríndio, v. 10, n. 2, p. 96-117, 2016. https://doi.org/10.22456/1982-6524.64124

DENEVAN, W. The aboriginal cultural geography of the Llanos de Mojos of Bolivia. Berkeley: University of California Press, 1966.

DESCOLA, P. In the society of nature: a native ecology in Amazonia. Cambridge: Cambridge University Press, 1994.

DESCOLA, P.; TAYLOR, A.-C. Introduction. L'Homme, t. 33, n. 126-128, p. 13-24, 1993. [La remontée de l'Amazone].

DIETRICH, W. As línguas tupi-guarani bolivianas e as de Rondônia: novas hipóteses sobre as origens. In: CABRAL, A. S. A. C.; ISIDORO, E. A.; LOPES, J. D. (orgs.). Línguas e culturas tupí. Brasília, DF: Laboratório de Línguas e Literatura Indígenas; Universidade de Brasília, 2016. v. 4, p. 43-68.

DREYFUS, S. Os empreendimentos coloniais e os espaços políticos indígenas no interior da Guiana Ocidental (entre Orinoco e Corentino) de 1613 a 1796. In: VIVEIROS DE CASTRO, E.; CUNHA, M. C. (orgs.). Amazônia: etnologia e história indígena. São Paulo: Universidade de São Paulo, 1993. p. 19-42.

EPPS, P.; STENZEL, K. (eds.). Upper Rio Negro: cultural and linguistic interaction in Northwestern Amazonia. Rio de Janeiro: Museu Nacional, 2013.

ERIKSEN, L. Nature and culture in prehistoric Amazonia: using GIS to reconstruct ancient ethnogenetic processes from archaeology, linguistics, geography, and ethnohistory. Thesis (Doctorate) — Lund University, Lund, 2011.

ERIKSON, P. Uma singular pluralidade: a etno-história Pano. In: CUNHA, M. C. (org.). História dos índios no Brasil. São Paulo: Companhia das Letras, 1992. p. 239-252.

ERIKSON, P. Une nébuleuse compacte: le macro-ensemble pano. L’Homme, t. 33, 126-128, p. 45-58, 1993. [La remontée de l'Amazone]. https://doi.org/10.3406/hom.1993.369628

FARAGE, N. As muralhas dos sertóes: os povos indígenas no Rio Branco e a colonização. Rio de Janeiro: Paz \& Terra, 1991.

FARAGE, N.; SANTILLI, P. Estado de sítio: territórios e identidades no Vale do Rio Branco. In: CUNHA, M. C. (org.). História dos índios no Brasil. São Paulo: Companhia das Letras, 1992. p. 267-278.

FAULHABER, P. O navio encantado: etnia e alianças em Tefé. Belém: Museu Paraense Emílio Goeldi, 1987a.

FAULHABER, P. (org.). Entrosando: questôes indígenas em Tefé. Belém: Museu Paraense Emílio Goeldi, 1987b.

FAULHABER, P. O lago dos espelhos: etnografia do saber sobre a fronteira em Tefé/Amazonas. Belém: Museu Paraense Emílio Goeldi, 1998. 
FAULHABER, P. The production of the Handbook of South American Indians Vol 3 (1936-1948). Vibrant: Virtual Brazilian Anthropology, v. 9, n. 1, p. 82-111, 2012. https://doi.org/10.1590/S1809-43412012000100003

FAUSTO, C. Fragmentos de história e cultura tupinambá: da etnologia como instrumento crítico de conhecimento etno-histórico. In: CUNHA, M. C. (org.). História dos índios no Brasil. São Paulo: Companhia das Letras, p. 381-396, 1992.

FAUSTO, C. Os índios antes do Brasil. Rio de Janeiro: Jorge Zahar Editor, 2000.

FAUSTO, C. Inimigos fiéis: história, guerra e xamanismo na Amazônia. São Paulo: Edusp, 2001.

FELZKE, L. Dança e imortalidade: igreja, festa e xamanismo entre os Ikólóéhj Gavião de Rondônia. Tese (Doutorado) — Universidade de Brasília, Brasília, 2017.

FELZKE, L. Os Ikólóéhj Gaviáo: a terra e os outros. São Leopoldo: Oikos, 2018.

FERREIRA, A. R. Viagem filosófica ao Rio Negro. Belém: Museu Paraense Emílio Goeldi, 1983.

FERREIRA, T. A. S. Política e "cultura” no Alto Rio Negro: o caso de Iauaretê. Dissertação (Mestrado) — Programa de Pós-Graduação em Antropologia Social, Universidade Federal de São Carlos, São Carlos, 2014.

FERREIRA DE MELO, L.; VEGINI, V. Notas sobre os Aruá de Rondônia. Revista Língua Viva, v. 3, n. 1, p. 1-14, 2013.

FIORINI, M. O. The silencing of the names: identity and alterity in an Amazonian Society. Dissertation (Anthropology) — New York University, New York, 2000.

FRANÇA, L. B. C. Caminhos cruzados: parentesco, diferença e movimento entre os Kagwahiva. Tese (Doutorado) - Programa de Pós-Graduação em Antropologia Social, Universidade Federal do Rio de Janeiro, Rio de Janeiro, 2012.

FRANCHETTO, B.; HECKENBERGER, M. J. (orgs.). Os povos do Alto Xingu: história e cultura. Rio de Janeiro: Editora UFRJ, 2001.

GABAS JR., N. (com narradores Arara, orgs.). Mây yamât Kanã xet pég xawero ma’i kanãy 'mãm — história dos Arara no tempo do contato com os brancos. Belém: Museu Paraense Emílio Goeldi, 2002.

GABAS JR., N. (com Sebastião Kara’yã Péw Arara, orgs.). Mitos Arara. Belém: Museu Paraense Emílio Goeldi, 2009.

GALLOIS, D. (org.). Redes de relaçóes nas Guianas. São Paulo: Humanitas, 2005.

GALÚCIO, A. V. (org.). Narrativas tradicionais Sakurabiat Mayãp Ebó. Belém: Museu Paraense Emílio Goeldi, 2006.

GALÚCIO, A. V. Puruborá: notas etnográficas e linguísticas recentes. Boletim do Museu Paraense Emílio Goeldi, v. 1, n. 2, p. 159-192, maio/ago. 2005. Série Ciências Humanas.

GALÚCIO, A. V.; GABAS JR., N. Evidências de agrupamento genético Karo-Puruborá, tronco Tupi. In: XVII ENCONTRO NACIONAL DA ANPOLL, 17., 2002, Gramado. Boletim informativo n. 31. Porto Alegre: Universidade Federal do Rio Grande do Sul, 2002.

GALÚCIO, A. V.; PURUBORÁ, J. E.; APORETE FILHO, P. Vocabulário ilustrado: animais na língua Puruborá. Belém: Museu Paraense Emílio Goeldi, 2013.

GALVÃO, E. Áreas culturais indígenas do Brasil: 1900-1959. In: GALVÃO, E. Encontro de sociedades: índios e brancos no Brasil. Rio de Janeiro: Paz \& Terra, 1979. p. 193-228. 
GILLIN, J. Tribes of the Guianas. In: STEWARD, J. H. (ed.). Handbook of South American Indians — volume 3: The tropical forest tribes. Washington: Smithsonian Institution Press, 1948. p. 799-860.

GOLDMAN, I. Tribes of the Uaupés-Caquetá Region. In: STEWARD, J. H. (ed.). Handbook of South American Indians - volume 3: The tropical forest tribes. Washington: Smithsonian Institution Press, 1948. p. 763-798.

GOLDMAN, I. The Cubeo: indians of the Northwest Amazon. Urbana: University of Illinois Press, 1963.

GOLDMAN, I. Cubeo Hehénewa religious thought: metaphysics of a northwestern Amazonian People. New York: Columbia University Press, 2004.

GONÇALVES, M. A. (org.). Acre: história e etnologia. Rio de Janeiro: Editora UFRJ 1991.

GONÇALVES, M. A. O significado do nome: cosmologia e nominação entre os Pirahă. Rio de Janeiro: 7 Letras, 1993.

GONÇALVES, M. A. O mundo inacabado: ação e criação em uma cosmologia amazônica. Rio de Janeiro: Editora UFRJ, 2001.

GONDIM, J. A Pacificaçáo dos Parintintins: Koró de iuirap. Manaus: Commissão de Linhas Telegraphicas Estrategicas de Matto Grosso ao Amazonas, 1925.

GOULART, L. T. Os Yanomami e o Projeto Yaripo: transformaçôes e turismo em Maturacá. Dissertaçāo (Mestrado) — Programa de Pós-Graduação em Antropologia Social, Universidade Federal de São Carlos, São Carlos, 2020.

GOW, P. Of mixed blood: kinship and history in Peruvian Amazonia. Oxfor: Clarendon Press, 1991.

GOW, P. Gringos and wild Indians: images of history in western Amazonian cultures. L'Homme, t. 33, 126-128, p. 327-347, 1993. [La remontée de l'Amazone]. https://doi.org/10.3406/hom.1993.369643

GUERREIRO JR., A. Aliança, chefia e regionalismo no Alto Xingu. Journal de la Société des Américanistes, n. $97-$ 2, p. 99-133, 2011. https://doi.org/10.4000/jsa.11902

GUERREIRO JR., A. Ancestrais e suas sombras: uma etnografia da chefia Kalapalo e seu ritual mortuário. Campinas: Editora Unicamp, 2015.

GUERREIRO JR., A. Do que é feita uma sociedade regional? Lugares, donos e nomes no Alto Xingu. Ilha - Revista de Antropologia, v. 18, n. 2, p. 23-55, 2016. https://doi.org/10.5007/2175-8034.2016v18n2p23

HALBMAYER, E. Contemporary Carib-Speaking Amerindians: a bibliography of social anthropological and linguistic resources. Marburg: Curupira Workshop, 2013.

HARRIS, M. The making of regional systems: the Tapajós/Madeira and Trombetas/Nhamundá regions in the Lower Brazilian Amazon, seventeenth and eighteenth centuries. Ethnohistory, v. 65, n. 4, p. 621-645, 2018. https:// doi.org/10.1215/00141801-6991274

HECKENBERGER, M. J. Rethinking the Arawakan diaspora: hierarchy, regionality, and the Amazonian Formative. In: HILL, J.; SANTOS-GRANERO, F. (eds.). Comparative Arawakan histories: rethinking language family and culture area in Amazonia. Urbana: University of Illinois Press, 2002. p. 99-122.

HECKENBERGER, M. J. The ecology of power: culture, place, and personhood in the Southern Amazon AD 1000-2000. New York: Routledge, 2005.

HECKENBERGER, M. J.; NEVES, E. G. Amazonian Archaeology. Annual Review of Anthropology, v. 38, p. 251 266, 2009. https://doi.org/10.1146/annurev-anthro-091908-164310 
HECKENBERGER, M. J.; NEVES, E. G.; PETERSON, J. B. De onde surgem os modelos? As origens e expansóes Tupi na Amazônia Central. Revista de Antropologia, 41, p. 69-96, 1998. https://doi.org/10.1590/S003477011998000100003

HEINEN, H. D.; GARCÍA-CASTRO, A. The multiethnic network of the Lower Orinoco in early colonial times. Ethnohistory, v. 47, n. 3-4, p. 561-579, 2000. https://doi.org/10.1215/00141801-47-3-4-561

HEMMING, J. Red Gold: the conquest of the Brazilian Indians. Cambridge: Harvard University Press, 1978.

HENLEY, P. Recent themes in the Anthropology of Amazonia: history, exchange, alterity. Bulletin of Latin American Research, v. 15, n. 2, p. 231-245, 1996. https://doi.org/10.1111/j.1470-9856.1996.tb00032.x

HERNÁNDEZ DE ALBA, G. Sub-Andean tribes of the Cauca Valley. In: STEWARD, J. H. (ed.). Handbook of South American Indians - volume 4: The Circum-Caribbean tribes. Washington: Smithsonian Institution Press, 1948. p. 297-328.

HERRERO, M.; FERNANDES, U. Baré: povo do rio. São Paulo: Edições Sesc, 2015.

HILL, J. Wakuenai Society: a processual-structural analysis of indigenous cultural life in the Upper Rio Negro region of Venezuela. Thesis (Doctorate) — University of Indiana, Bloomington, 1983.

HILL, J. (ed.). History, power, and identity: ethnogenesis in the Americas, 1492-1992. Iowa City: University of Iowa Press, 1996.

HILL, J. Musicalizando o outro: ironia ritual e resistência étnica Wakuénai (Venezuela). In: ALBERT, B.; RAMOS, A. R. (orgs.). Pacificando o branco: cosmologias do contato no norte-amazônico. Sáo Paulo: Imprensa Oficial: Editora Unesp, 2002. p. 347-374.

HILL, J. Sacred landscapes as environmental histories in Lowland South America. In: HORNBORG, A.; HILL, J. (eds.). Ethnicity in Ancient Amazonia: reconstructing past identities from archaeology, linguistics, and ethnohistory. Boulder: University of Colorado Press, 2011. p. 259-277.

HILL, J.; SANTOS-GRANERO, F. (eds.). Comparative Arawakan histories: rethinking language family and culture area in Amazonia. Urbana: University of Illinois Press, 2002.

HORNBORG, A. Ethnogenesis, regional integration, and ecology in prehistoric Amazonia. Current Anthropology, v. 46, n. 4, p. 589-620, 2005. https://doi.org/10.1086/431530

HORNBORG, A.; HILL, J. (eds.). Ethnicity in Ancient Amazonia: reconstructing past identities from archaeology, linguistics, and ethnohistory. Boulder: University of Colorado Press, 2011.

HOWARD, C. Pawana: a farsa dos "visitantes" entre os Waiwai da Amazônia setentrional. In: VIVEIROS DE CASTRO, E.; CUNHA, M. C. (orgs.). Amazônia: etnologia e história indígena. São Paulo: Núcleo de História Indígena e do Indigenismo/ Universidade de São Paulo, 1993. p. 229-264.

HOWARD, C. Wrought identities: the Waiwai expeditions in search of the "unseen tribes" of Northern Amazonia. Thesis (Doctorate) — University of Chicago, Chicago, 2001.

HUGH-JONES, C. From the Milk River. Cambridge: Cambridge University Press, 1979.

HUGH-JONES, S. The palm and the pleiades: initiation and cosmology in Northwest Amazonia. London: Cambridge University Press, 1979.

HUGH-JONES, S. Historia del Vaupés. Maguaré, v. 1, p. 29-51, 1981.

HUGH-JONES, S. Inside-out and back-to-front: the androgynous house in Northwest Amazonia. In: CARSTEN, J.; HUGH-JONES, S. (eds.). About the house: Lévi-Strauss and beyond. Cambridge: Cambridge University Press, 1995. p. 226-252. 
HUGH-JONES, S. Bride-service and the absent gift. Journal of the Royal Anthropological Institute, v. 19, n. 2, p. 356-377, 2013. https://doi.org/10.1111/1467-9655.12037

HUGO, V. Desbravadores. 2v. Humaitá: Missão Salesiana, 1959.

HUMBOLDT, A. Personal narrative of travels to the equinoctial regions of America. 2v. London: Nabu Press, 1852.

INSTITUTO SOCIOAMBIENTAL (ISA); FEDERAÇÃO DAS ORGANIZAÇÓES INDÍGENAS DO ALTO RIO NEGRO (FORIN). Mapa-Livro povos indígenas do Alto e Médio Rio Negro: uma introdução à diversidade cultural e ambiental do Noroeste da Amazônia brasileira. São Paulo: — Instituto Socioambiental: Federação das Organizaçōes Indígenas do Alto Rio Negro; Brasília, DF: Ministério da Educação, 1998.

INSTITUTO SOCIOAMBIENTAL (ISA). Povos indígenas no Brasil - 2001/2005. São Paulo: Instituto Socioambiental, 2006.

IUBEL, A. Transformaçóes políticas e indígenas: movimento e prefeitura no Alto Rio Negro. Tese (Doutorado) Programa de Pós-Graduação em Antropologia Social, Universidade Federal de São Carlos, São Carlos, 2015.

JACKSON, J. The fish people: linguistic exogamy and Tukanoan identity in Northwest Amazonia. Cambridge: Cambridge University Press, 1983.

JAKUBASZKO, A. Imagens da alteridade: um estudo da experiência histórica dos Enawene Nawe. Dissertação (Mestrado) - Pontifícia Universidade Católica de São Paulo, São Paulo, 2003.

JOURNET, N. Les jardins de paix: étude des structures sociales chez les Curripaco du haut Rio Negro (Colombie). Thèse (Doctorat em Ethnologie) — École des Hautes Études en Sciences Sociales, Paris, 1988.

JUNIO FELIPE, H. Falas, lugares e transformaçáo: os Yuhupdeh do Baixo Rio Tiquié. Tese (Doutorado) Programa de Pós-Graduação em Antropologia Social, Universidade Federal de São Carlos, São Carlos, 2018.

KEPPI, J.; GOMIDE, M. L. (orgs.). Alimentaçáo Karo Arara: saberes e práticas. São Leopoldo: Oikos, 2016.

KEPPI, J.; PRUIKSMA, N. (orgs.). Nossas vidas: histórias de mulheres Karo Arara. São Leopoldo: Oikos, 2018.

KIRCHHOFF, P. Mesoamérica: sus límites geográficos, composición étnica y caracteres culturales. Acta Americana, v. 1, n. 1, p. 92-107, 1943.

KOCH-GRÜNBERG, T. Del Roraima al Orinoco. 3t. Caracas: Talleres de Gráfica Armitano, 1979.

KOCH-GRÜNBERG, T. Dois anos entre os indígenas: viagens no Noroeste do Brasil (1903-1905). Manaus: Edua: Faculdade Salesiana Dom Bosco, 2005.

KOCH-GRÜNBERG, T. A distribuiçáo dos povos entre rio Branco, Orinoco, rio Negro e Yapurá. Manaus: Edua, 2006.

KRACKE, W. A posição histórica dos Parintintin na evolução das culturas Tupí-Guarani. In: RODRIGUES, A. D.; CABRAL, A. S. C. (orgs.). Línguas e culturas Tupí. Campinas: Curt Nimuendajú; Brasília, DF: Laboratório de Línguas e Literatura Indígenas; Universidade de Brasília, 2007. p. 23-35.

LARAIA, R. B. Tupi: índios do Brasil atual. São Paulo: Universidade de São Paulo, 1986.

LASMAR, C. De volta ao lago de leite. São Paulo: Editora Unesp: Instituto Socioambiental; Rio de Janeiro: NuTI, 2005.

LATHRAP, D. The upper Amazon. London: Thames and Hudson, 1970. 
LEACH, E. Sistemas políticos da Alta Birmânia. São Paulo: Edusp, 2014 [1954].

LEIGUE CASTEDO, L. El Itenez salvaje. La Paz: Ministerio de Educación; Departamiento de Arqueologia, Etnología y Folklore, 1957.

LEONEL, M. Etnodicéia Uruéu-Au-Au. São Paulo: Edusp, 1995.

LEOPOLDI, J. S. De caçadores de cabeças a índios urbanos: a saga dos índios Munduruku. São Paulo: Chiado, 2016.

LÉVI-STRAUSS, C. The tribes of the right bank of the Guaporé river. In: STEWARD, J. H. (ed.). Handbook of South American Indians - volume 3: The tropical forest tribes. Washington: Smithsonian Institution Press, 1948a. p. 370-379.

LÉVI-STRAUSS, C. The Tupí Cawahib. In: STEWARD, J. H. (ed.). Handbook of South American Indians volume 3: The tropical forest tribes. Washington: Smithsonian Institution Press, 1948b. p. 299-305.

LÉVI-STRAUSS, C. The tribes of the Upper Xingú River. In: STEWARD, J. H. (ed.). Handbook of South American Indians - volume 3: The tropical forest tribes. Washington: Smithsonian Institution Press, 1948c. p. 321-348.

LÉVI-STRAUSS, C. A noção de arcaísmo em etnologia. In: LÉVI-STRAUSS, C. Antropologia estrutural. Rio de Janeiro: Tempo Brasileiro, 1952 [1975].

LÉVI-STRAUSS, C. As estruturas elementares do parentesco. Petrópolis: Vozes, 1976 [1949].

LÉVI-STRAUSS, C. Tristes trópicos. São Paulo: Companhia das Letras, 1996 [1955].

LÉVI-STRAUSS, C. Compte rendu. Frank Salomon \& Stuart B. Schwartz, eds. The Cambridge history of the native peoples of the Americas - volume 3: South America. L'Homme, 158-159, p. 439-442, 2004 [1964].

LÉVI-STRAUSS, C. O cru e o cozido. São Paulo: Cosac Naify, 2004 [1964].

LIMA, T. S. A parte do cauim: etnografia Juruna. Tese (Doutorado) — Programa de Pós-Graduação em Antropologia Social, Universidade Federal do Rio de Janeiro, Rio de Janeiro, 1995.

LIMA, T. S. Um peixe olhou para mim. O povo Yudjá e a perspectiva. São Paulo: Editora Unesp: Instituto Socioambiental; Rio de Janeiro: NuTI, 2005.

LISBÔA, T. A. Enawenê-Nawê: primeiros contatos. Cuiabá: Carlini \& Caniato, 2010.

LISBÔA, T. A. Entre os índios Myky: a resistência de um povo. Cuiabá: Carlini \& Caniato, 2018.

LOLLI, P. A. As redes de trocas rituais dos Yuhupdeh no igarapé Castanha, através dos benzimentos (mihdiid) e das flautas Jurupari (Tí). Tese (Doutorado) — Universidade de São Paulo, São Paulo, 2010.

LOLLI, P. Os Yuhupdeh vistos de outro lugar. In: LIMA, E. C.; CÓRDOBA, L. (orgs.). Os outros dos outros: relaçôes de alteridade na etnologia sul-americana. Curitiba: Editora UFPR, 2011. p. 169-181.

LONDOÑO-SULKIN, C. People of substance: an ethnography of morality in the Colombian Amazon. Toronto: University of Toronto Press, 2012.

LYON, P. (ed.). Native south-Americans: ethnology of the least known continent. Long Grove: Waveland Press, 1974.

LYON, P. An imaginary frontier: prehistoric highland-lowland interchange in the Southern Peruvian Andes. In: FRANCIS, P. D.; KENSE, F. J.; DUKE, P. J. (eds.). Networks of the past: regional interaction in archaeology. Proceedings of the Twelfth Annual Conference, the Archaeological Association of the University of Calgary. Calgary: Archaeology Association of the University of Calgary, 1981. p. 3-18. 
MACIEL, M. N. A construçáo de uma identidade: história oral com os Cassupá. Monografia (Conclusão de curso) — Universidade Federal de Rondônia, Porto Velho, 2000.

MAIA, P. Desequilibrando o convencional. Estética e ritual com os Baré do Alto Rio Negro (Amazonas). Tese (Doutorado) — Universidade Federal do Rio de Janeiro, Rio de Janeiro, 2009.

MAIZZA, F. Cosmografia de um mundo perigoso: espaço e relaçóes de afinidade entre os Jarawara da Amazônia. São Paulo: Nankin: Edusp, 2012.

MARQUES, B. R. Os Hupd'äh e seus mundos possíveis: transformaçóes espaço-temporais do Alto Rio Negro. Tese (Doutorado) - Universidade Federal do Rio de Janeiro, Rio de Janeiro, 2015.

MARTÍNEZ, C. Una etnohistoria de Chiquitos: más allá del horizonte jesuítico. Cochabamba: Instituto de Misionologia: Itinerarios Editorial, 2018.

MAYBURY-LEWIS, D. (ed.). Dialectical societies: the Gê and Bororo of Central Brazil. Harvard: Harvard University Press, 1979.

MCEWAN, C.; BARRETO, C.; NEVES, E. (eds.). Unknown Amazon: culture in nature in ancient Brazil. London: British Museum Press, 2001.

MEIRA, M. Índios e brancos nas Águas Pretas: histórias do rio Negro. In: FORLINE, L.; MURRIETA, R. S.; VIEIRA, I. C. (orgs.). Amazônia além dos 500 anos. Belém: Museu Paraense Emílio Goeldi, 2005. p. 183-226.

MEIRA, M. A persistência do aviamento: colonialismo e história indígena no Noroeste Amazônico. São Carlos: EDUFScar, 2018.

MEIRELES, D. M. Populaçóes indígenas e a ocupaçáo histórica de Rondônia. Monografia (Conclusão de Curso) — Universidade Federal de Mato Grosso, Cuiabá, 1984.

MEIRELES, D. M. Guardiães da fronteira. Rio Guaporé, século XVIII. Petrópolis: Vozes, 1989.

MEIRELES, D. M. O complexo cultural do marico: sociedades indígenas dos rios Branco, Colorado e Mequens, afluentes do Médio Guaporé. Boletim do Museu Paraense Emílio Goeldi, v. 7, n. 2, p. 209-269, 1991. Série Antropologia.

MELATTI, J. C. Pólos de articulação indígena. Revista de Atualidade Indígena, n. 16, p. 17-28, 1979.

MELATTI, J. C. América do Sul - por que áreas etnográficas? Brasília, DF: Universidade de Brasília, 2019. Disponível em: <http://www.juliomelatti.pro.br/areas/alamersul.pdf $>$. Acesso em: 22 fev. 2020.

MENDONÇA DE SOUZA, S. Deformação craniana entre os índios Karitiana: análise de fotos de arquivo. Boletim do Museu Paraense Emílio Goeldi, v. 10, n. 1, p. 43-56, 1994. Série Antropologia.

MENÉNDEZ, M. Uma contribuiçâo para a etno-história da área Tapajós-Madeira. Revista do Museu Paulista, n. s., XXVIII, p. 289-388, 1981-1982.

MENÉNDEZ, M. Contribuição ao estudo das relaçōes tribais na área Tapajós-Madeira. Revista de Antropologia, v. 27-28, p. 271-286, 1984-1985.

MENÉNDEZ, M. A presença do branco na mitologia Kawahiwa: história e identidade de um povo Tupi. Studi e Materiali di Storia delle Religioni, v. 53, n. 1, p. 75-97, 1987.

MENÉNDEZ, M. Os Kawahiva: uma contribuição ao estudo dos Tupi Centrais. Tese (Doutorado) — Universidade de São Paulo, São Paulo, 1989.

MENÉNDEZ, M. A área Madeira-Tapajós: situação de contato e relação entre colonizador e indígenas. In: CUNHA, 
M. C. (org.). História dos índios no Brasil. São Paulo: Companhia das Letras, 1992. p. 281-296.

MENEZES, T. O passado, o presente e o futuro nas plantas Puruborá (Rondônia). Dissertação (Mestrado) Programa de Pós-Graduação em Antropologia Social, Universidade Federal de São Carlos, São Carlos, 2016.

MENGET, P. Jalons pour une étude comparative. Journal de la Societé des Américanistes, v. 71, n. 1, p. 131-141, 1985. https://doi.org/10.3406/jsa.1985.2258

MENGET, P. Le propre du nom. Remarques sur l'onosmatique Txicao. Journal de la Societé des Américanistes, v. 79, n. 1, p. 21-31, 1993a. https://doi.org/10.3406/jsa.1993.1467

MENGET, P. Les frontières de la chefferie: remarques sur le système politique du Haut Xingu (Brésil). L'Homme, t. 33, 126-128, p. 59-76, 1993b. [La remontée de l'Amazone]. https://doi.org/10.3406/hom.1993.369629

MENGET, P. Notas sobre as cabeças mundurucu. In: VIVEIROS DE CASTRO, E.; CUNHA, M. C. (orgs.). Amazônia: etnologia e história indígena. São Paulo: Núcleo de História Indígena e do Indigenismo: Universidade de São Paulo, 1993c. p. 311-321.

MENGET, P. Em nome dos outros: classificação das relações sociais entre os Txicão do alto Xingu. Lisboa: Museu Nacional de Etnologia: Assírio \& Alvim, 2001.

MERE, G. Emil-Heinrich Snethlage (1897-1939): nota biográfica, expedições e legado de uma carreira interrompida. Boletim do Museu Paraense Emílio Goeldi, v. 8, n. 3, p. 773-804, 2013. Série Ciências Humanas.

MÉTRAUX, A. Ethnography of the Chaco. In: STEWARD, J. H. (ed.). Handbook of South American Indians volume 1: The marginal tribes. Washington: Smithsonian Institution Press, 1946. p. 197-370.

MEZACASA, R. [...] Deu tempo de demarcar e eles tomarem conta do resto [...]: História(s) indígena(s) sobre territórios e territorialidades em Rondônia. In: TRUBILIANO, C. A. B. (org.). Debates indígenas na contemporaneidade. Ji-Paraná: Edinter, 2018a. p. 56-76.

MEZACASA, R. As mulheres Makuráp e o saber-fazer do marico. Revista Brasileira de Linguística Antropológica, v. 10, n. 1, p. 23-45, 2018b. https://doi.org/10.26512/rbla.v10i1.19050

MICARELLI, G. Ordenar el pensamiento: place-making and the moral management of resources in a multi-ethnic territory, Amazonas, Colombia. In: ALEXIADES, M. (ed.). Mobility and migration in Indigenous Amazonia: contemporary ethnoecological perspectives. New York: Berghahn Books, 2009. p. 195-219.

MILLER, E. T. História da cultura indígena do Alto Médio-Guaporé: Rondônia e Mato Grosso. Porto Velho: Edufro, 2007.

MILLER, J. Les Mamaindê: changement et continuité. Ethnies, v. XIX, p. 44-59, 2009.

MILLER, J. As coisas: os enfeites corporais e a noção de pessoa entre os Mamaindê (Nambiquara). Rio de Janeiro: Mauad X, 2018.

MINDLIN, B. Nós Paiter: os Suruí de Rondônia. Petrópolis: Vozes, 1985.

MINDLIN, B. Tuparis e Tarupás: narrativas dos índios Tuparis de Rondônia. São Paulo: Brasiliense: Edusp/Instituto de Antropologia e Meio Ambiente, 1993.

MINDLIN, B. Antologia de mitos dos povos Ajuru, Arara, Arikapu, Aruá, Kanoe, Jabuti e Makurap. São Paulo: Instituto de Antropologia e Meio Ambiente, 1995.

MINDLIN, B. Vozes da origem, estórias sem escrita: narrativas dos índios Suruí de Rondônia. São Paulo: Ática: Instituto de Antropologia e Meio Ambiente, 1996. 
MINDLIN, B. Moqueca de maridos: mitos eróticos. Rio de Janeiro: Record: Rosa dos Ventos, 1997.

MINDLIN, B. Terra grávida. Rio de Janeiro: Record: Rosa dos Ventos, 1999.

MINDLIN, B. O couro dos espíritos: namoro, pajés e cura entre os índios Gavião-Ikolen de Rondônia. São Paulo: Senac: Terceiro Nome, 2001.

MINDLIN, B. Mitos indígenas. São Paulo: Ática, 2006.

MOI, F.; SOUZA, E. R.; MORALES, W. F.; AZOINAYCE PARESI, R. W. Memória e oralidade: interpretaçáo de grafismos rupestres entre os Aruak do Noroeste do Estado do Mato Grosso, Brasil. In: MORALES, W. F; MOI, F. (orgs.). Cenários regionais em arqueologia brasileira. São Paulo: Annablume; Porto Seguro: Acervo Centro de Referência em Patrimônio e Pesquisa, 2009. p. 205-238.

MONSERRAT, R. M. F. Notícia sobre a língua Puruborá. In: CABRAL, A. S. A. C.; RODRIGUES, A. D. (orgs.). Novos estudos sobre línguas indígenas. Brasília: Editora UnB, 2005. p. 9-22.

MONSERRAT, R. M. F. Memória das atividades realizadas junto aos povos Puruborá e Kujubim, Rondônia, constantes em dois relatórios de viagem do Regional do CIMI/RO, de 2015 e 2017. Revista Brasileira de Linguística Antropológica, v. 10, n. 1, p. 87-95, 2018. https://doi.org/10.26512/rbla.v10i1.19057

MONTANHA, G. O.; BARBOZA, J. J.; OLIVEIRA, A. D. Puruborá: mitos de um povo indígena ressurgido na Amazônia. Tellus, ano 14, n. 27, p. 151-174, 2014. https://doi.org/10.20435/tellus.v0i27.326

MONTEIRO, J. Os Guarani e a história do Brasil meridional: séculos XVI-XVII. In: CUNHA, M. C. (org.). História dos índios no Brasil. São Paulo: Companhia das Letras, 1992. p. 475-498.

MONTEIRO, J. Negros da terra: índios e bandeirantes nas origens de São Paulo. São Paulo: Companhia das Letras, 1994.

MOREIRA NETO, C. A. Índios da Amazônia: de maioria a minoria (1750-1850). Petrópolis: Vozes, 1988.

MOSER, L. Os Karitiana e a colonizaçáo recente em Rondônia. Monografia (Bacharelado) — Universidade Federal de Rondônia, Porto Velho, 1993.

MOSER, L. Os Karitiana no processo de desenvolvimento de Rondônia nas décadas de 1950 a 1990 . Dissertação (Mestrado) — Universidade Federal de Pernambuco, Recife, 1997.

MYERS, T. Aboriginal trade networks in Amazonia. In: FRANCIS, P. D.; KENSE, F. J.; DUKE, P. J. (eds.). Networks of the past: regional interaction in archaeology. Proceedings of the Twelfth Annual Conference, the Archaeological Association of the University of Calgary. Calgary: Archaeology Association of the University of Calgary, 1981. p. 19-30.

NAHUM-CLAUDEL, C. Vital diplomacy: the ritual everyday on a dammed river in Amazonia. New York: Berghanh Books, 2018.

NASCIMENTO, L. A. Da maloca ao assentamento: territorialidades e trajetórias dos Migueleno no contexto da sobreposição da REBIO Guaporé. Odeere, v. 3, n. 5, p. 104-119, 2018a. https://doi.org/10.22481/odeere. v3i5.2720

NASCIMENTO, L. A. Dispersão e etnicidade de um grupo amazônico: a sobreposição da REBIO Guaporé e a transformaçáo dos Migueleno em colonos. Aceno - Revista de Antropologia do Centro-Oeste, v. 5, n. 9, p. $155-169,2018 b$.

NEVES, E. Paths in the dark waters: archaeology as indigenous history in the upper Rio Negro Basin, Northwest Amazon. Thesis (Doctorate) — Indiana University, Bloomington, 1998. 
NEVES, E. Arqueologia, história indígena e o registro etnográfico: exemplos do Alto Rio Negro. Revista do Museu de Arqueologia e Etnologia, suplemento 3, p. 319-330, 1999. https://doi.org/10.11606/issn.2594-5939. revmaesupl.1999.113476

NEVES, E. Indigenous historical trajectories in the Upper Rio Negro Basin. In: MCEWAN, C.; BARRETO, C.; NEVES, E. (eds.). Unknown Amazon: culture in nature in ancient Brazil. London: British Museum Press, 2001. p. 266-285.

NEVES, E. Tradição oral e arqueologia na história indígena no Alto Rio Negro. In: FORLINE, L. C.; MURRIETA, R. S.; VIEIRA, I. C. (orgs.). Amazônia além dos 500 anos. Belém: Museu Paraense Emílio Goeldi, 2005. p. 71-108.

NEVES, E. El nacimiento del "presente etnográfico": la emergencia del patron de distribución de sociedades indígenas y familias lingüísticas en las tierras bajas suramericanas, durante el primer milenio d. C. In: CHAUMEIL, J.-P.; ESPINOSA DE RIVERO, O.; CORNEJO CHAPARRO, M. (orgs.). Por donde hay soplo. Estudios amazónicos en los países andinos. Lima: Instituto Francés de Estudios Andinos, 2011. p. 39-65.

NEVES, E. Sob os tempos do equinócio: 8.000 anos de história na Amazônia Central (6.500 a.C. - 1.500 d.C.). Tese (Livre-Docência) — Museu de Arqueologia e Etnologia, Universidade de São Paulo, São Paulo, 2012a.

NEVES, E. A história dos Tariano vista pela oralidade e pela arqueologia. In: ANDRELLO, G. (org.). Rotas de criaçáo e transformaçáo: narrativas de origem e povos indígenas do Rio Negro. São Paulo: Instituto Socioambiental; São Gabriel da Cachoeira: Federação das Organizaçóes Indígenas do Rio Negro, 2012b. p. 223-245.

NEVES, E.; MUNITA, C.; HAZENFRATZ, R.; MONGELÓ, G. Ancient exchange networks in the Central Amazon. In: GLASCOCK, M.; NEFF, H.; VAUGHN, K. (eds.). Ceramics of the indigenous cultures of South America: studies of production and exchange through compositional analysis. Albuquerque: University of New Mexico Press, 2019. p. 231-239.

NIMUENDAJÚ, C. The Mura and Piraha. In: STEWARD, J. H. (ed.). Handbook of South American Indians volume 1: The tropical forest tribes. Washington: Smithsonian Institution Press, 1948. p. 255-269.

NIMUENDAJÚ, C. Reconhecimento dos rios Içána, Ayarí e Uaupés, março a julho de 1927. Apontamentos linguísticos. Journal de la Société des Américanistes, v. 44, p. 149-178, 1955. https://doi.org/10.3406/ jsa.1955.2598

NIMUENDAJÚ, C. Mapa etno-histórico do Brasil e regióes adjacentes. Rio de Janeiro: Instituto Brasileiro de Geografia e Estatística, 1981a.

NIMUENDAJÚ, C. Fragmentos de religião e tradição dos índios Shipáia. Religiáo e Sociedade, v. 7, p. 6-47, 1981 b.

NIMUENDAJÚ, C. As tribos do Alto Madeira. In: NIMUENDAJÚ, C. Textos indigenistas. São Paulo: Loyola, 1982. p. 111-22.

NÓBREGA, R. S. Contra as invasóes bárbaras, a humanidade: a luta dos Arara (Karo) e dos Gavião (Ikólóehj) contra os projetos hidrelétricos do rio Machado, em Rondônia. Dissertação (Mestrado) — Universidade de Campinas, Campinas, 2008.

NORDENSKIÖLD, E. Exploraciones y aventuras en Sudamérica. La Paz: Apoyo para el Campesino-Indígena del Oriente Boliviano/Plural, 2001 [1924]).

NORDENSKIÖLD, E. La vida de los índios: el Gran Chaco (Sudamérica). La Paz: Apoyo para el CampesinoIndígena del Oriente Boliviano, 2002 [1912].

NORDENSKIÖLD, E. Índios y blancos en el Nordeste de Bolivia. La Paz: Apoyo para el Campesino-Indígena del Oriente Boliviano/Plural, 2003 [1922]. 
OBERG, K. Types of social structure among lowland tribes of South and Central America. American Anthropologist, v. 57, n. 3, part. 1, p. 472-487, 1955. https://doi.org/10.1525/aa.1955.57.3.02a00060

OTERO DOS SANTOS, J. Sobre mulheres brabas, parentes inconstantes e a vida entre outros: a Festa do Jacaré entre os Arara de Rondônia. Tese (Doutorado) - Programa de Pós-Graduação em Antropologia Social, Universidade de Brasília, Brasília, 2015.

OTERO DOS SANTOS, J. Andar sobre a terra: constituição de lugares, coletivos e espaços-tempos Karo-Arara. Ilha - Revista de Antropologia, v. 21, n. 1, p. 139-169, 2019. https://doi.org/10.5007/2175-8034.2019v21n1p139

OVERING KAPLAN, J. (ed.). Social time and social space in Lowland South American Societies. In: CONGRÈS INTERNATIONAL DES AMÉRICANISTES, 42., 1977, Paris. Actes [...]. Paris: Société des Américanistes, 1977. v. 2, p. 259-275.

OVERING KAPLAN, J. Elementary structures of reciprocity: a comparative note on Guianese, Central Brazilian, and North-West Amazon socio-political thought. Antropológica, n. 59-62, p. 331-348, 1983-1984. [Themes in political organization: the Caribs and their Neighbours].

OVERING KAPLAN, J. Dualism as an expression of difference and danger marriage exchange and reciprocity among of Piaroa of Venezuela. In: KENSINGER, K. (ed.). Marriage Practices in Lowland South America. Chicago: University of Illinois Press, 1984. p. 127-155. (Illinois Studies in Anthropology, 14).

OVERING KAPLAN, J. Images of cannibalism, death and domination in a "non-violent" society. Journal de la Societé des Américanistes, t. 72, n. 1, p. 133-156, 1986.

OVERING KAPLAN, J. Styles of manhood: an Amazonian contrast in tranquility and violence. In: HOWELL, S.; WILLIS, R. (eds.). Societies at peace: anthropological perspectives. London: Routledge, 1989. p. 79-99.

PAPPIANI, A.; LACERDA, I. (orgs.). Histórias do começo e do fim do mundo: o contato do povo Paiter Suruí. São Paulo: Ikore, 2016.

PEGGION, E. Juma: a tragédia de um povo. In: RICARDO, C. A. (org.). Povos indígenas no Brasil 1996/2000. São Paulo: Instituto Socioambiental, 2000. p. 449-450.

PEGGION, E. Relaçóes em perpétuo desequilíbrio: a organização dualista dos povos Kagwahiva da Amazônia. São Paulo: Annablume: Instituto Socioambiental, 2011a.

PEGGION, E. Conflitos e alianças indígenas no sul do estado do Amazonas. O caso dos Tenharim do rio Marmelos (Tupi-Kagwahiva). In: LIMA, E. C.; CÓRDOBA, L. (orgs.). Os outros dos outros: relaçôes de alteridade na etnologia sul-americana. Curitiba: Editora UFPR, 2011b. p. 71-81.

PEREIRA, A. V. Demarcando vestígios: definindo (o território de) indígenas em isolamento voluntário na Terra Indígena Massaco. Dissertação (Mestrado) — Programa de Pós-Graduação em Antropologia Social, Universidade Federal de São Carlos, São Carlos, 2018.

PEREIRA, C. Situação social dos índios urbanos no município de Porto Velho, Rondônia. Monografia (Conclusão de Curso) - Universidade Federal de Rondônia, Porto Velho, 2010.

PEREIRA, P. C.; SILVA, M. L.; KAXARARI, C. Povos indígenas Kaxarari: a educação indígena e a luta no processo de resgate cultural diante dos novos aparatos tecnológicos. In: XIMENES, C.; PICANÇO, F.; CARVALHO, R.; SILVA, R. (orgs.). Educaçáo e modo de vida das populaçóes indígenas amazônicas. Curitiba: Editora CRV, 2019. p. 121-131.

PESOVENTO, A. Micro-história indígena em Rondônia: abusos contra meninas-moças-mulheres a partir de registros documentais do Serviço de Proteção aos Índios - SPI. Revista Labirinto, ano XII, n. 16, p. 5-15, 2012. 
PERRONE-MOISÉS, B. Festa e guerra. Tese (Livre-Docência) — Universidade de São Paulo, São Paulo, 2015.

PESSOA DA SILVA, C.; COSTA, A. Um quadro histórico das populaçōes indígenas no alto rio Madeira durante o século XVIII. Amazônica, v. 6, n. 1, p. 110-139, 2014. https://doi.org/10.18542/amazonica.v6i1.1751

PORRO, A. História indígena do alto e médio Amazonas: séculos XVI a XVIII. In: CUNHA, M. C. (org.). História dos índios no Brasil. São Paulo: Companhia das Letras, 1992. p. 175-196.

PORRO, A. As crônicas do Rio Amazonas: traduçẫo, introdução e notas etno-históricas sobre as antigas populaçôes indígenas da Amazônia. Manaus: Edua, 1993.

PORRO, A. O povo das águas. Ensaios de etno-história amazônica. Petrópolis: Vozes, 1996.

PORRO, A. Dicionário etno-histórico da Amazônia colonial. São Paulo: Instituto de Estudos Brasileiros: Universidade de São Paulo, 2007.

POZZOBON, J. Isolamento e endogamia: observaçôes sobre a organização social dos índios Maku. Dissertação (Mestrado) - Universidade Federal do Rio Grande do Sul, Porto Alegre, 1983.

PRICE, D. The Nambiquara linguistic family. Anthropological Linguistics, v. 20, n. 1, p. 14-37, 1978.

PRICE, D. Nambiquara geopolitical organization. Man: The Journal of the Royal Anthropological Institute, n. s. 22, p. 1-24, 1987.

PRICE, D. Before the bulldozer: the Nambiquara indians and the World Bank. Cabin John: Seven Locks Press, 1989.

PRICE, D. Pareci, Cabixi, Nambiquara: a case study in the western classification of native peoples. Journal de la Société des Américanistes, 69, p. 129-148, 1983. https://doi.org/10.3406/jsa.1983.2228

RAMIREZ, H. Línguas Arawak da Amazônia setentrional: comparação e descrição. Manaus: Edua, 2001.

RAMIREZ, H. As línguas indígenas do Alto Madeira: estatuto atual e bibliografia básica. Língua Viva, v. 1, n. 1, p. 1-16, 2006.

RAMIREZ, H. Etnônimos e topônimos no Madeira (séculos XVI-XX): um sem-número de equívocos. Revista Brasileira de Linguística Antropológica, v. 2, n. 2, p. 13-58, 2010. https://doi.org/10.26512/rbla.v2i2.16223

RAMIREZ, H.; VEGINI, V.; FRANÇA, M. C. V. O warázu do Guaporé (tupi-guarani): primeira descrição linguística. LIAMES: Línguas Indígenas Americanas, v. 17, n. 2, p. 411-506, 2017. https://doi.org/10.20396/liames. v17i 0.8647468

RAMOS, A. Hierarquia e simbiose: relaçôes intertribais no Brasil. São Paulo: Hucitec, 1980.

RAMOS, D. P. Círculos de coca e fumaça: encontros noturnos e caminhos vividos pelos Hupd'äh (Maku). Tese (Doutorado) - Universidade de São Paulo, São Paulo, 2013.

RENARD-CASEVITZ, F.-M. História Kampa, memória Ashaninka. In: CUNHA, M. C. (org.). História dos índios no Brasil. São Paulo: Companhia das Letras, 1992. p. 197-212.

RENARD-CASEVITZ, F.-M.; SAIGNES, T.; TAYLOR, A.-C. L'Inca, l'Espagnol et les sauvages: rapports entre sociétés amazoniennes et andines du XVe au XVIIe siècle. Paris: Éditions Recherche sur les Civilisations, 1986.

REESINK, E. Who are the Nambikwara? On names, partialities and peoples. In: WETZELS, L. (ed.). Language endangerment and endangered languages. Linguistic and anthropological studies with special emphasis on the languages and cultures of the Andean-Amazonian border area. Leiden: CNWS Publications, 2007, p. 249-268. 
REESINK, E. Allegories of wildness: three Nambikwara ethnohistories of sociocultural and linguistic change and continuity. Amsterdam: Rozenberg Publishers, 2010.

REESINK, E. Os Sabanê e os povos do Nambikwara do Norte: etno-histórias das ruínas da história e de recriaçôes tardias. Tellus, ano 15, n. 29, p. 113-133, 2015. https://doi.org/10.20435/tellus.v0i29.341

REID, H. Some aspects of movement, growth and change among the Hupdu Maku Indians of Brazil. Thesis (Doctorate) - University of Cambridge, Cambridge, 1979.

REICHEL-DOLMATOFF, G. Desana: simbolismo de los índios tukano del Uapés. Bogotá: Ediciones Universidad de los Andes, 1968.

RIBEIRO, D. Os índios e a civilizaçáo: a integração das populaçôes indígenas no Brasil moderno. Săo Paulo: Companhia das Letras, 1996 [1970].

RIBEIRO, E. R.; VAN DER VOORT, H. Nimuendajú was right: the inclusion of the Jabutí language family in the Macro-Jê stock. International Journal of American Linguistics, v. 76, n. 4, p. 517-570, 2010. https://doi. org/10.1086/658056

RIBEIRO, T. (org.). Diagnóstico etnoambiental participativo. Etnozoneamento e plano de gestão em terras indígenas: Terra Indígena Zoró. Porto Velho: Edufro: Kanindé, 2015.

RIVIÈRE, P. Individual and society in Guiana: a comparative study of Amerindian social organization. Cambridge: Cambridge University Press, 1984.

RIVIÈRE, P.; GRUPIONI, D.; GALLOIS, D.; BARBOSA, G.; SZTUTMAN, R.; DO PATEO, R. A propósito de Redes de relaçôes nas Guianas. Mana, v. 13, n. 1, p. 251-273, 2007. https://doi.org/10.1590/S010493132007000100010

RODRIGUES, A. D. A classificação do tronco linguístico Tupí. Revista de Antropologia, v. 12, n. 1/2, p. 99-104, 1964.

RODRIGUES, A. D. Línguas brasileiras: para o conhecimento das línguas indígenas. São Paulo: Ediçôes Loyola, 1986.

RODRIGUES, A. D. Tupí languages in Rondônia and in eastern Bolivia. In: WETZELS, L. (ed.). Language endangerment and endangered languages. Leiden: CNWS Publications, 2007. p. 355-363.

RODRIGUES, R. Descendo o rio: memórias, trajetórias e nomes no baixo Uaupés (AM). Tese de Doutorado. UFSCar, São Carlos, 2019.

RONDON, C. M. S. Missáo Rondon: apontamentos sobre os trabalhos realizados pela Commissão de Linhas Telegraphicas Estrategicas de Matto-Grosso ao Amazonas. Rio de Janeiro: Typographia do Jornal do Commercio, 1916.

ROOSEVELT, A. Moundbuilders of the Amazon: geophysical archaeology on Marajo Island, Brazil. San Diego: Academic Press, 1991.

ROOSEVELT, A. Arqueologia amazônica. In: CUNHA, M. C. (org.). História dos índios no Brasil. São Paulo: Companhia das Letras, 1992. p. 53-86.

ROOSEVELT, A. Amazonian anthropology: strategy for a new synthesis. In: ROOSEVELT, A. (ed.). Amazonian Indians from prehistory to the present: anthropological perspectives. Tucson: University of Arizona Press, 1994. p. 1-29.

ROQUETTE-PINTO, E. Rondônia. São Paulo: Companhia Editora Nacional, 1935. 
SALOMON, F.; SCHWARTZ, S. (eds.). The Cambridge history of the native peoples of the Americas - volume 3: South America, part 1. Cambridge: Cambridge University Press, 1999a.

SALOMON, F.; SCHWARTZ, S. (eds.). The Cambridge history of the native peoples of the Americas - volume 3: South America, part 2. Cambridge: Cambridge University Press, $1999 \mathrm{~b}$.

SALZANO, F. The Amerindian microcosm: anthropology, comparative history, ecology, genetics and evolution. Cambridge: Cambridge Scholars Publishing, 2019.

SAMPAIO, F. X. R. As viagens do ouvidor Sampaio (1774-1775). Manaus: Fundo Editorial: Associação Comercial do Amazonas, 1985.

SAMPAIO, W. As línguas tupi-kawahib: um estudo sistemático filogenético. Tese (Doutorado) — Universidade Federal de Rondônia, 2001.

SAMPAIO, W.; SILVA, V. Os povos indígenas de Rondônia: contribuiçóes para a compreensão de sua cultura e de sua história. Porto Velho: Universidade Federal de Rondônia, 1997.

SAMPAIO, W.; SILVA, V.; MIOTELlO, V. (orgs.). Mitos Amondawa. Porto Velho: Edufro, 2004.

SANCHEZ, G. Plantações de queixadas, peixes-mandioca e corujinhas-boiaderas: as relaçôes entre humanos, animais e maestria na Terra Indígena do Rio Guaporé (Rondônia). Mediaçóes, v. 24, n. 3, p. 28-41, 2019a. http://dx.doi. org/10.5433/2176-6665.2019v24n3p28

SANCHEZ, G. Os Kujubim e os bichos de pena: uma etnografia multiespecífica das relaçōes entre humanos e não humanos no Vale do Guaporé, Rondônia. Dissertação (Mestrado) - Programa de Pós-Graduação em Antropologia Social, Universidade Federal de São Carlos, São Carlos, 2019 b.

SANTOS, E. D. Os Kaxarari. In: FUNDAÇÃO DE CULTURA E COMUNICAÇÃO ELIAS MANSOUR; CONSELHO INDIGENISTA MISSIONÁRIO (orgs.). Povos do Acre: história indígena da Amazônia Ocidental. Rio Branco: Fundação de Cultura e Comunicação Elias Mansour; Porto Velho: Conselho Indigenista Missionário, 2002.

SANTOS, F. J. Além da conquista: guerras e rebeliōes indígenas na Amazônia Pombalina. Manaus: Edua, 1999.

SANTOS, G. M. (org.). Álbum Purus. Manaus: Edua, 2011.

SANTOS, G. M.; APARÍCIO, M. (orgs.). Redes Arawa: ensaios de etnologia do Médio Purus. Manaus: Edua, 2016.

SANTOS-GRANERO, F. Etnohistoria de la Alta Amazonia: siglos XV-XVIII. Quito: Abya-Yala, 1992.

SANTOS-GRANERO, F. Templos e ferrarias: utopia e re-invenção cultural no oriente peruano. In: VIVEIROS DE CASTRO, E.; CUNHA, M. C. (orgs.). Amazônia: etnologia e história indígena. São Paulo: Núcleo de História Indígena e do Indigenismo/Universidade de São Paulo, 1993. p. 67-93.

SANTOS-GRANERO, F. Writing history into the landscape: space, myth, and ritual in contemporary Amazonia. American Ethnologist, n. 25, p. 128-148, 1998. https://doi.org/10.1525/ae.1998.25.2.128

SANTOS-GRANERO, F. Vital enemies: slavery, predation, and the Amerindian political economy of life. Austin: University of Texas Press, 2009.

SANTOS-GRANERO, F; BARCLAY, F. Guía etnográfica de la Alta Amazonía. Quito: FLACSO; Lima: Instituto Francés de Estudios Andinos, 1994. v. 1.

SARMENTO, F. O médio rio Negro indígena: aspectos históricos, socioculturais e panorama antropológico contemporâneo. Dissertação (Mestrado) — Universidade de Brasília, Brasília, 2018. 
SARMENTO, F. O Alto Rio Negro indígena em mais de dois mil anos de história. Revista Brasileira de Linguística Antropológica, v. 11, n. 2, p. 41-72, 2019. https://doi.org/10.26512/rbla.v11i02.26900

SCHETTINO, M. P. F. Áreas etnográficas: proposta de reestruturação do Departamento de Identificação e Delimitação com base na atuação em áreas etnográficas. Terra dos Îndios: Revista Eletrônica sobre Questáo Fundiária Indígena no Brasil, v. 6, n. 2, p. 1-23, 2003. Disponível em: <www.funai.gov.br/ultimas/e_revista/ index.htm>. Acesso em: 15 mar. 2005. https://doi.org/10.26512/interethnica.v6i2.12336

SCHINDLER, H. Die Karihona: Eine Caribgruppe Nordwest-Amazoniens. Munique: Utzverlag GmbH, 2019.

SCHMIDT, M. Die Aruaken. Ein Beitrag zum Problem der Kulturverbreitung. Studien zur Ethnologie und Soziologie, herausgegeben von A. Vierkandt. Leipzig: Veit \& Comp, 1917. Heft 1.

SCHWARTZ, S. Denounced by Lévi-Strauss CLAH Luncheon Address. The Americas, v. 59, n. 1, p. 1-8, 2002. https://doi.org/10.1353/tam.2002.0090

SCHWARTZ, S.; SALOMON, F. Réponse à Claude Lévi-Strauss. L'Homme, 167-168, p. 315-318, 2003. https:// doi.org/10.4000/lhomme.21568

SEEGER, A.; DAMATTA, R.; VIVEIROS DE CASTRO, E. A construção da pessoa nas sociedades indígenas brasileiras. Boletim do Museu Nacional, n. 32, p. 2-19, 1979. Série Antropologia.

SERVICE, E. Origins of the State and Civilization. The process of cultural evolution. New York: W. W. Norton, 1975.

SEVERIANO DA FONSECA, J. Viagem ao redor do Brasil 1875-1878. Rio de Janeiro: Biblioteca do Exército Editora, 1986 [1880-1881]. v. 2.

SHIRATORI, K. O homem que falava cantando: um panorama da presença de povos indígena Kagwahiva em isolamento na bacia do rio Madeira. In: RICARDO, F.; GONGORA, M. (orgs.). Cercos e resistências: povos indígenas isolados na Amazônia brasileira. São Paulo: Instituto Socioambiental, 2019. p. 196-204.

SCOLFARO, A. Falas Waikhana: conhecimento e transformaçôes no Alto Rio Negro (rio Papuri). Dissertação (Mestrado) - Programa de Pós-Graduação em Antropologia Social, Universidade Federal de São Carlos, São Carlos, 2012.

SILVA, J. F. Utiariti - a última tarefa. In: WRIGTH, R. (org.). Transformando os deuses: os múltiplos sentidos da conversão entre os povos indígenas no Brasil. Campinas: Editora Unicamp, 1999. p. 399-424.

SILVA, J. F. (org.). Estudos sobre os Chiquitanos no Brasil e na Bolívia: história, língua, cultura e territorialidade. Goiânia: Editora UCG, 2008a.

SILVA, J. F. Identidades e conflitos na fronteira: poderes locais e os Chiquitanos. Memoria Americana, v. 16, n. 2, p. 119-148, 2008b.

SILVA, O. S. Eduardo Galvão: índios e caboclos. São Paulo: Annablume, 2007.

SILVERWOOD-COPE, P. Os Maku: povo caçador do Noroeste da Amazônia. Brasília, DF: Editora UnB, 1990.

SNETHLAGE, E. H. Atiko Y: meine Erlebnisse bei den Indianern des Guaporé. Berlin: Klinkhardt \& Biermann Verlag, 1937.

SNETHLAGE, E. H. Die Guaporé-Expedition (1933-1935): Ein Forschungstagebuch. Köln: Böhlau, 2015.

SOARES, A. L. Guarani: organização social e arqueologia. Porto Alegre: EdiPUCRS, 1997.

SOARES PINTO, N. Do poder do sangue e da chicha: os Wajuru do Guaporé (Rondônia). Dissertaçấo (Mestrado)

— Universidade Federal do Paraná, Curitiba, 2009. 
SOARES PINTO, N. Nós somos todos misturados?: histórias e parentesco Wajuru (Rondônia). In: PIMENTA, J.; SMILJANIC, M. I. (orgs.). Etnologia indígena e indigenismo. Brasília, DF: Positiva, 2012. p. 159-184.

SOARES PINTO, N. Entre as teias do marico: parentes e pajés djeoromitxi. Tese (Doutorado) — Programa de PósGraduação em Antropologia Social, Universidade de Brasília, Brasília, 2014.

SOARES PINTO, N. Percursos indígenas no rio Guaporé (Rondônia), sec. XX: a biografia de Kubähi Djeoromitxi e uma possível lógica mito-prática. In: MARTÍNEZ, C.; VILLAR, D. (orgs.). En el corazón de América del Sur: antropología, arqueología, historia. Santa Cruz de la Sierra: Biblioteca del Museo de Historia: UAGRM, 2015. v. 2 , p. $187-212$.

SOARES PINTO, N. De coexistências: sobre a constituição de lugares djeoromitxi. R@U - Revista de Antropologia da UFSCar, v. 9, n. 1, p. 61-82, 2017.

SOARES PINTO, N.; NOGUEIRA, A. F. S. A cosmologia lexical: etnografia e estudos linguísticos entre os Wajuru. Ilha-Revista de Antropologia, v. 16, n. 1, p. 41-68, 2017. https://doi.org/10.5007/2175-8034.2014v16n1p41

SORENSEN, A. P. Multilingualism in the Northwest Amazon. American Anthropologist, v. 69, n. 6, p. 670-682, 1967.

SPRUCE, R. Notes of a botanist on the Amazon and Andes. London: MacMillan and Co, 1908.

STEWARD, J. H. (ed.). Handbook of South American Indians - volume 2: The Andean civilizations. Washington: Smithsonian Institution Press, 1946.

STEWARD, J. H.; FARON, L. Native peoples of South America. New York: McGraw-Hill, 1959.

STRADELLI, E. Lendas e notas de viagem: a Amazônia de Ermano Stradelli. São Paulo: Martins Fontes, 2009.

SURUÍ, A. (org.). Plano de gestão etnoambiental da Terra Indígena Sete de Setembro. Brasília, DF: ACT Brasil, 2008.

SWEET, D. G. A rich realm of nature destroyed: the middle Amazon valley, 1640-1750. Thesis ( $\mathrm{PhD})$ - University of Wisconsin, Madison, 1974.

SZTUTMAN, R. O profeta e o principal. São Paulo: Edusp, 2012.

TAYLOR, A.-C. História pós-colombiana da alta Amazônia. In: CUNHA, M. C. (org.). História dos índios no Brasil. Sáo Paulo: Companhia das Letras, 1992. p. 213-238.

TEIXEIRA-PINTO, M. Ieipari: sacrifício e vida social entre os índios Arara. São Paulo: Hucitec: Anpocs; Curitiba: Editora UFPR, 1997.

TEMPESTA, G. Travessia de banzeiros: historicidade e organização sociopolítica Apiaká. Tese (Doutorado) Programa de Pós-Graduaçáo em Antropologia Social, Universidade de Brasília, Brasília, 2009.

TIMÓTEO DA CUNHA, E. Quando esse tal de SPI chegou: o Serviço de Proteçáo aos Índios na formação de Rondônia. Dissertação (Mestrado) — Universidade Federal do Amazonas, Manaus, 2016.

TIMÓTEO DA CUNHA, E. Da tutela ao protagonismo: a trajetória Cassupá em Rondônia. Mediaçóes, v. 22, n. 2, p. 223-276, 2017. http://dx.doi.org/10.5433/2176-6665.2017v22n2p223

TOLEDO, O. Profetismo entre os povos indígenas do rio Uaupés: escatologia e hierarquia. Dissertação (Mestrado) — Programa de Pós-Graduação em Antropologia Social, Universidade Federal de São Carlos, São Carlos, 2013.

TRUBILIANO, C. Apontamentos sobre a economia da borracha e a exploraçáo da mão de obra indígena em Rondônia. Nanduty, v. 5, n. 7, p. 45-63, 2017. https://doi.org/10.30612/nty.v5i7.7789 
URBAN, G. A história da cultura brasileira segundo as línguas nativas. In: CUNHA, M. C. (org.). História dos índios no Brasil. São Paulo: Companhia das Letras, 1992. p. 87-102.

UZENDOSKI, M. A. The horizontal archipelago: the Quijos/Upper Napo regional system. Ethnohistory, v. 51, n. 2, p. 317-357, 2004. https://doi.org/10.1215/00141801-51-2-317

VANDER VELDEN, F. Os Tupí em Rondônia: diversidade, estado do conhecimento e propostas de investigação. Revista Brasileira de Linguística Antropológica, v. 2, n. 1, p. 115-143, 2010. https://doi.org/10.26512/rbla. v2i1.16217

VANDER VELDEN, F. Banhos de sangue: relatos Karitiána de guerras, canibalismo e troféus humanos. In: CABRAL, A. S. A. C.; RODRIGUES, A. D.; LOPES, J. D.; JULIÁO, M. R. S. (orgs.). Línguas e culturas Tupí. Campinas: Editora Curt Nimuendajú; Brasília, DF: Laboratório de Línguas e Literatura Indígenas; Universidade de Brasília, 2011. p. 27-58.

VANDER VELDEN, F. Inquietas companhias: sobre os animais de criação entre os Karitiana. São Paulo: Alameda, 2012.

VANDER VELDEN, F. Entre o Ji-Paraná e o Amazonas: notas (e hipóteses) sobre o tempo antigamente dos Karitiana. In: COSTA, F. V. F.; FRANCO NETO, J. V. (orgs.). Multiverso indígena: abordagens transdisciplinares. Salvador: Empresa Gráfica da Bahia, 2014. p. 19-52.

VANDER VELDEN, F. O retorno das onças: os Puruborás e os desdobramentos da diversidade étnica e cultural recente em Rondônia. In: CABRAL, A. S. A. C.; ISIDORO, E.; LOPES. J. D. (orgs.). Línguas e culturas Tupí. Brasília, DF: Laboratório de Línguas e Literatura Indígenas; Universidade de Brasília, 2017. v. 4, p. 19-32.

VANDER VELDEN, F. Sobre crânios achatados e pilóes de pedra: algumas notas sobre a origem dos Karitiana. In: TRUBILIANO, C. A. B. (org.). Debates indígenas na contemporaneidade. Ji-Paraná: Edinter, 2018. p. 29-55.

VIDAL, S. M. El modelo del proceso migratorio prehispanico de los Piapoco: hipotesis e evidencias. Tesis (Maestría) — Instituto Venezolano de Investigaciones Científicas, Caracas, 1987.

VIDAL, S. M. Reconstrucción de los procesos de etnogénesis y de reproducción social entre los Baré de río Negro (siglos XVI-XVIII). Tesis (Doctorado) - Centro de Estudios Avançados, Instituto Venezoelano de Investigaciones Científicas, Caracas, 1993.

VIDAL, S. M. Amerindian Groups of Northwest Amazonia: their regional system of political-religious hierarchies. Anthropos, v. 94, n. 4/6, p. 515-528, 1999.

VIDAL, S. M.; ZUCCHI, A. Efectos de las expansiones coloniales en las poblaciones indígenas del Noroeste Amazonico (1798-1830). Colonial Latin American Review, v. 8, n. 1, p. 113-132, 1999. https://doi. org/10.1080/10609169984782

VIDAL, S. M.; ZUCCHI, A. Los caminos del Kúwai: evidencias del conocimiento geopolítico de las expansiones y migraciones de los grupos Arawakos. In: HERRERA, L.; CARDALE DE SCHRIP, M. (eds.). Caminos precolombinos: las vías, los ingenieros y los viajeros. Bogotá: Instituto Colombiano de Antropología y História, 2000. p. $87-113$.

VILAÇA, A. Comendo como gente: formas do canibalismo wari' (Pakaa Nova). Rio de Janeiro: Editora UFRJ; São Paulo: Anpocs, 1992.

VILAÇA, A. Quem somos nós: os Wari' encontram os brancos. Rio de Janeiro: Editora UFRJ, 2006.

VILLAR, D.; CÓRDOBA, L.; COMBÈS, I. La reducción imposible: las expediciones del padre Negrete a los Pacaguaras (1795-1800). Cochabamba: Editores Nómadas: Universidad Catolica de Cochabamba, 2009. 
VIVEIROS DE CASTRO, E. Sociedades minimalistas: a propósito de um livro de Peter Rivière. Anuário Antropológico, v. 10, n. 1, p. 265-282, 1986 .

VIVEIROS DE CASTRO, E. Araweté: os deuses canibais. Rio de Janeiro: Jorge Zahar Editor, 1986b.

VIVEIROS DE CASTRO, E. From the enemy's point of view: humanity and divinity in an Amazonian society. Chicago: University of Chicago Press, 1992.

VIVEIROS DE CASTRO, E. Histórias ameríndias. Novos Estudos, n. 36, p. 22-33, 1993 a.

VIVEIROS DE CASTRO, E. Alguns aspectos da afinidade no dravidianato amazônico. In: VIVEIROS DE CASTRO, E.; CUNHA, M. C. (orgs.). Amazônia: etnologia e história indígena. São Paulo: Núcleo de História Indígena e do Indigenismo/ Universidade de São Paulo, 1993b. p. 150-210.

VIVEIROS DE CASTRO, E. Images of nature and society in Amazonian Ethnology. Annual Review of Anthropology, 25, p. 179-200, 1996. https://doi.org/10.1146/annurev.anthro.25.1.179

VIVEIROS DE CASTRO, E. Etnologia brasileira. In: MICELI, S. (org.). O que ler na ciência social brasileira volume I: Antropologia. São Paulo: Sumaré: Anpocs, 1999, p. 109-223.

VIVEIROS DE CASTRO, E. Imagens da natureza e da sociedade. In: VIVEIROS DE CASTRO, E. A inconstância da alma selvagem e outros ensaios de antropologia. São Paulo: Cosac Naify, 2002. p. 317-344.

VIVEIROS DE CASTRO, E. Nenhum povo é uma ilha. In: RICARDO, F.; GONGORA, M. (orgs.). Cercos e resistências: povos indígenas isolados na Amazônia brasileira. São Paulo: Instituto Socioambiental, 2019. p. 8-14.

VON DEN STEINEN, K. O Brasil Central. São Paulo: Companhia Editora Nacional, 1942.

VAN DER VOORT, H. Djeoromitxi. In: ISA - Instituto Socioambiental. Povos indígenas. Lista de povos. São Paulo: Instituto Socioambiental, 2006. Disponível em: <https://pib.socioambiental.org/pt/ Povo:Djeoromitx\%C3\%AD>. Acesso em: 3 mar. 2020.

VON GRAEVE, B. The Pacaa nova: clash of cultures on the Brazilian frontier. Toronto: University of Toronto Press, 1991.

WALLACE, A. R. Viagens pelos rios Amazonas e Negro. São Paulo: Edusp, 1979.

WHIFFEN, T. O Noroeste Amazônico: notas de alguns meses que passei entre tribos canibais. Rio Branco: Nepan Editora, 2019.

WHITEHEAD, N. The ancient Amerindian polities of the Amazon, the Orinoco, and the Atlantic coast: a preliminary analysis of their passage from antiquity to extinction. In: ROOSEVELT, A. (ed.). Amazonian Indians from prehistory to present: anthropological perspectives. Tucson: The University of Arizona Press, 1994. p. 33-53.

WHITEHEAD, N. Native peoples confront colonial regimes in Northeastern South America (c. 1500-1900). In: SALOMON, F.; SCHWARTZ, S. (eds.). The Cambridge history of the native peoples of the Americas volume III: South America, part 2. Cambridge: Cambridge University Press, 1999. p. 382-442.

WHITEHEAD, N. Tribes make states and states make tribes: warfare and the creation of colonial tribes and states in Northeast South America. In: FERGUSON, B.; WHITEHEAD, N. (eds.). War in the tribal zone: expanding states and indigenous warfare. Santa Fe: School of American Research Press, 2001. p. 127-150.

WHITEHEAD, N.; ALEMÁN, S. W. (eds.). Anthropologies of Guayana: cultural spaces in northeastern Amazonia. Tucson: The University of Arizona Press, 2009. 
WRIGHT, R. The history and religion of the Baniwa peoples of the upper Rio Negro valley. Thesis (Doctorate) — University Micro lms, Ann Arbor, 1981.

WRIGHT, R. Indian slavery in the Northwest Amazon. Boletim do Museu Paraense Emílio Goeldi, v. 7, n. 2, p. 149-179, 1991.

WRIGHT, R. História indígena do Noroeste da Amazônia: hipóteses, questóes, e perspectivas. In: CUNHA, M. C. (org.). História dos índios no Brasil. São Paulo: Companhia das Letras, 1992. p. 253-266.

WRIGHT, R. Cosmos, self and history in Baniwa Religion: for those unborn. Austin: University of Texas Press, 1998.

WRIGHT, R. História indígena e do indigenismo no Alto Rio Negro. Campinas: Mercado de Letras; São Paulo: Instituto Socioambiental, 2005.

WÜST, I. The Eastern Bororo from an archaeological perspective. In: ROOSEVELT, A. (ed.). Amazonian Indians: from prehistory to the present. Tucson: The University of Arizona Press, 1994. p. 315-342.

ZACK, E. (Stanislav Zach). Relatório: vocabulário das tribus Massacá, Salamãin, Coaiá e Canoê. Manuscrito [microfilme n. 308: 328-343; 344-351, posto 333, planilha 3. Rio de Janeiro: Arquivo do Museu do Índio, 1943.

ZIMPEL NETO, C. Na direçáo das periferias extremas da Amazônia: arqueologia na bacia do rio Jiparana, Rondônia. Dissertação (Mestrado) — Museu de Arqueologia e Etnologia, Universidade de São Paulo, São Paulo, 2009.

ZUCCHI, A. A new model of the northern Arawakan expansion. In: HILL, J.; SANTOS-GRANERO, F. (orgs.). Comparative Arawakan histories: rethinking language family and culture are in Amazonia. Chicago: University of Illinois Press, 2002. p. 199- 222.

ZUCCHI, A. Antiguas migraciones Maipures y Caribes: dos areas ancestrales y diferentes rutas. In: PEREIRA, E.; GUAPINDAIA, V. (orgs.). Arqueologia Amazônica. Belém: Museu Paraense Emílio Goeldi, 2010. v. 1, p. $113-135$ 


\section{Introdução}

Neste artigo pesquisamos a literatura antropológica que trata mais diretamente do tema das drogas, assunto presente desde os primórdios da antropologia no Brasil. Essa investigação se faz necessária dado o crescente interesse sobre o tema, dentro e fora da antropologia. Há ainda a necessidade de proporcionar ao(à) pesquisador(a) um estudo conciso, capaz de expor parte significativa da grande variedade de contribuiçôes da disciplina sobre o uso de drogas e sobre as principais implicaçóes desse hábito. Trata-se, portanto, de descrever os temas e os autores basilares, no sentido geralmente do mais antigo para o atual, no interior de cada tema. Para tanto, além dos 20 anos dedicados à pesquisa e ao estudo do tema, realizamos uma pesquisa bibliográfica e análise sistemática da biblioteca digital Scientific Electronic Library Online (SciELO) e da ferramenta de pesquisa Google Scholar. Os assuntos que compóe este artigo foram pesquisados a partir de certos intervalos temporais sucessivos e variáveis de acordo com o assunto.

Cabe alertar o(a) leitor(a) para algo de que pudemos manter certa cronologia nos primeiros cinco subtítulos, desde os primórdios da antropologia até os estudos sobre o consumo do crack. O que não foi mais possível fazer a partir das pesquisas sobre a maconha, em que tivemos de retornar no tempo. Assim, acabamos por apresentar o amadurecimento teórico dos estudos em consonância com os temas que a realidade foi impondo. Com isso, esperamos fornecer ao(à) leitor(a) um panorama, uma profícua discussão que se estende por décadas, com seus conceitos-chave que, igualmente, buscamos analisar.

É comum trabalhos antropológicos sobre drogas trazerem, em sua introdução, um levantamento bibliográfico a respeito da produção da disciplina no âmbito do objeto a ser tratado em cada pesquisa. Mesmo textos mais dedicados à análise da produção sobre drogas (Rui; Labate, 2016) podem conter ênfase maior em determinado aspecto dessa produção que em outros. Portanto, buscamos realizar algo original e acreditamos que, nos oito subtítulos utilizados para organizar o artigo, pudemos cumprir nosso objetivo de elucidar, com alguma sistematizaçáo, o que há de mais significativo da contribuição antropológica brasileira para a questão das drogas.

\footnotetext{
'Programa de Pós-Graduação em Saúde Coletiva, Universidade Federal de São Paulo - São Paulo (SP), Brasil. E-mails: antropologiaygor@yahoo.com.br; pedropaulopereira@hotmail.com
} 
Nosso intuito foi verificar como as mudanças sofridas pela sociedade brasileira nos últimos cem anos impactaram a produção antropológica sobre o tema. Transformaçóes não apenas na relação do país com as drogas, mas também com a própria população, com a urbanização e com a política. Quais foram as alteraçóes provocadas, nessa parcela da antropologia dedicada à pesquisa sobre drogas, por novas substâncias, doenças e religiosidades? Quais os recursos teóricos e metodológicos mobilizados?

\section{Esforços iniciais}

As referências ao consumo de substâncias inebriantes remontam aos primórdios da antropologia brasileira. Vêm desde o início do século $\mathrm{XX}$, com as festas indígenas regadas à bebida alcoólica, passando pela descrição do consumo da maconha pelos negros recém-libertos. Esses pesquisadores pioneiros estabeleceram um importante ponto de partida para todo desenvolvimento ulterior da disciplina, pois formularam desde questionamentos sobre se as substâncias podem ser usadas de modo terapêutico até as consequências políticas de seu consumo. Manifestaram, até mesmo, a intenção de descrever o ambiente social em que são utilizadas e a parafernália de uso, afora a influência de ambos sobre os efeitos observados. Já no início do século XX, verificaram como as substâncias podem demarcar espaços culturais diferenciados.

Parece ser o caso das "festas de cachaça", com todos seus excessos, que são mencionadas em Nimuendaju (1987, p. 14). As festas eram dedicadas, entre os Apapokuva, aos santos cristáos e se diferenciavam da $o p y$, uma cerimônia religiosa em que não se consumia a pinga. Schaden (1974, p. 179) referiu-se ao "consumo de bebida alcoólica pelos Kaiowá em folguedos que varavam a noite".
Não havia muitas dúvidas quanto à origem da aguardente de cana-de-açúcar, tampouco quanto aos efeitos esperados. $\mathrm{O}$ mesmo náo se pode dizer com relação à maconha.

A pretensa origem africana da maconha existente no Brasil, seus rituais de consumo, efeitos, propriedades terapêuticas e caráter sagrado foram objeto de consideraçóes por parte de Freyre $(1937 ; 1973)$. Freyre também procurou localizar o hábito de plantar e fumar a erva no interior da sociedade formada em torno da lavoura de cana-de-açúcar, nas relaçôes entre senhores e escravos. Os escravos tinham permissão de se entregar à ociosidade na curtição do fumo de Angola, o que, pretensamente, diminuiria suas propensóes à revolta, levando tranquilidade a seus proprietários.

Bastide (1971), no esforço por compreender a adesão do descendente africano ao catimbó indígena, localizou, na possibilidade da incorporação de entidades pelo catimbozeiro, a razão eficiente para a adoção, por parte do negro, da mitologia e ritualística ameríndia. A descida dos santos só seria possível, segundo Bastide (1971), pela introdução da diamba em substituiçáo ao fumo, tradicionalmente utilizado no catimbó. $\mathrm{Na}$ ausência do batuque e da dança, a maconha, ao lado da jurema, forneceria, pelas suas características narcóticas, as condições necessárias para que os espíritos fossem incorporados.

Inversamente ao proposto por Bastide (1971), de que o candomblé dispensaria a necessidade da maconha para o iniciado obter a incorporação, que se torna possível pelo batuque e pela dança, Arthur Ramos observou, em Girão (1970), ser esta planta largamente conhecida nos cultos, por produzir alucinaçóes e por sua contribuição para o desempenho nas danças. Efeitos oníricos da liamba são, para Carneiro (1958, p. 48), o real motivo de sua utilizaçáo pelos negros 
africanos em busca de "sonhos maravilhosos". O autor se ocupou em descrever a parafernália de consumo da planta composta de cachimbo de barro, com um canudo de taquari inserido em uma cabaça com água. $\mathrm{O}$ conjunto tinha por objetivo esfriar a fumaça do fumo de Angola e possibilitar sua aspiraçáo confortável para aplacar os "momentos de tristeza, de banzo, de saudade da África" (Carneiro, 1958, p. 48).

Da descrição da parafernália para a roda de fumo, esse é o caminho percorrido por Pierson (1972, p. 95) ao delinear os contornos da marica utilizada no Vale do São Francisco e seu fornilho de barro, canudo e garrafa contendo algum líquido. Utilizada para consumir o fumo de Angola em grupo, mais precisamente em círculo, passando o instrumento de mão em mão e dizendo "Ajoie, Marica!", enquanto se canta uma lôa.

As preocupaçóes desses pioneiros, na abordagem do consumo de drogas no Brasil, estão voltadas, além de buscar a origem africana da erva, para:

- o propósito de uso, que pode variar entre o desfrute da ociosidade, o embevecimento onírico, a fuga de uma realidade melancólica e a incorporação espiritual;

- a descrição da parafernália e de técnicas de consumo;

- a descrição dos efeitos;

- traçar o contexto social caracterizado pela roda de fumo ou pelo ritual religioso;

- investigar a possibilidade de um uso quase que político-ideológico por parte dos senhores, para aplacar o ímpeto de revolta dos negros escravizados.

Essas preocupaçóes estariam, de certo modo, presentes na obra que abriria o estudo sistemático voltado ao consumo de drogas, por parte dos antropólogos, nas décadas que viriam: Nobres e Anjos: um estudo de tóxicos e hierarquia, tese de doutoramento de Gilberto Velho, defendida em 1975, na Universidade de São Paulo (USP), sob orientação de Ruth Cardoso.

\section{Gilberto Velho entre nobres e anjos}

Em plena ditadura militar e ainda sob a vigência do Ato Institucional Número Cinco, mais conhecido pela sigla AI-5, que, entre outras medidas, suspendia as garantias constitucionais, Gilberto Velho defendeu sua tese de doutoramento em antropologia social com um tema espinhoso para a época: o consumo de drogas pela classe média carioca, estrato social em que vivia o autor. Com esse quadro sociopolítico, a tese não foi publicada e ficou restrita à biblioteca da universidade, até ser finalmente publicada em forma de livro décadas depois. A maior preocupação era quanto ao anonimato das pessoas com quem Velho conviveu durante o trabalho de campo, pertencentes ao meio social do investigador. À época, o temor quanto a investidas e perseguiçóes policiais não era exagerado, mesmo entre a classe média alta carioca.

São dois grupos distintos, alvos de comparação no final do livro: vanguardistas-aristocratas e jovens surfistas, nobres e anjos, respectivamente, ambos oriundos de uma burguesia empresarial e de famílias de profissionais liberais com projeto de ascender socialmente. O consumo de substâncias, principalmente maconha e cocaína, entrou em um jogo mais amplo do que a obtençâo dos efeitos desejados e passou a demarcar hierarquias em situaçóes específicas, dentro de certo estilo de vida. O consumo de drogas, considerado apropriado pelas pessoas pesquisadas, sem maiores exageros e em oca- 
sióes sociais específicas, inseriu-se em uma gama muito maior de outras atividades de consumo. Atividades estas ligadas ao lazer, à vestimenta, às viagens e, também, à ingestão de bebidas alcoólicas; descreveu-se ali todo um modo de diferenciação social com marcadores ligados a bens e mercadorias, mas que carregaram, no entanto, traços de comportamento desviante.

O conceito de desvio retirado da obra de Becker (1973), principalmente de seu estudo seminal sobre usuários de maconha, serviu para localizar seus interlocutores na categoria de desviantes em relação à cultura abrangente. Os desviantes não podem consumir drogas sem certa apreensão em serem denunciados, de se tornarem desviantes puros, desmascarados e desqualificados ante aqueles cujas opinióes lhes são de significativa importância, algo mais grave que pessoas que tão somente fazem uma leitura divergente de sua cultura (Velho, 2003). Velho (2003) chegou a escrever que seus nobres e anjos, diante da cultura dominante, seriam oprimidos, malgrado a posição superior ocupada na hierarquia social.

Originalmente publicado em 1963, o livro Becoming a marihuana user: outsiders associou a problemática do desvio à teoria da rotulação; mais de meio século depois, constituiu-se em um clássico. Velho manteve profícuo intercâmbio com Becker desde, pelo menos, o ano de 1976, quando Becker foi professor visitante no Museu Nacional do Rio de Janeiro. Além de Becker, outro autor fundamental para a antropologia brasileira, segundo Velho, foi Erwing Goffman: "Becker e Goffman são hoje autores fundamentais dentro da antropologia que se faz no Brasil, particularmente nos trabalhos voltados para os estudos urbanos e para a temática ampla de individuo e sociedade"
(Velho, 2002, p. 13, grifo do original). Essa influência marcou uma grande diversidade de trabalhos acadêmicos daí por diante.

A perspectiva adotada por Velho rendeu frutos e alargou-se. Ao menos duas obras do mesmo autor merecem ser brevemente tratadas aqui. A primeira delas é Duas Categorias de Acusação na Cultura Brasileira Contemporânea (Velho, 1981). Trabalho em que o autor extrapolou a descrição e a análise de pequenos grupos de usuários de drogas para se valer desta questão, tal qual se apresentava na sociedade brasileira no momento da abertura política, no intuito de pensar duas importantes categorias de acusação: o drogado e o subversivo. Ambos, implícita ou abertamente, acusados de doença ao questionarem e criticarem certos domínios e papéis, colocando em dúvida determinada ordem, dada concepção de mundo, que deveria ser vista como acomodada e irrefutável (Velho, 1981).

Em $A$ dimensáo cultural e politica dos mundos das drogas (Velho, 1994) existe, como marca da produção do autor sobre o tema, novo esforço para complexificar o que comumente se designava na época como sendo o mundo das drogas. A essa generalização grosseira, Velho opôs um olhar sobre as drogas que levou em conta "a observação de redes sociais que organizam sua produção, distribuição e consumo, bem como conjunto de crenças, valores, estilos de vida e visóes de mundo" (Velho, 1994, p. 84). Quanto ao consumo de substâncias, especificamente, deveria ser observado que grupos diferentes consomem drogas em modos variados, além de que uma mesma substância poder apresentar padróes de consumo diversos.

As contribuiçóes de Velho estão presentes em grande número de pesquisas antropológicas sobre o tema das drogas, que deverão, inclusive, extrapolar os limites da disciplina, 
tornando sua perspectiva uma maneira fundamental com que iremos nos deter sobre este objeto, nas décadas seguintes.

\section{A abordagem sociocultural}

O estigma de ser considerado usuário de drogas ilícitas e suas consequências deletérias para a pessoa é tratado em Velho (1981). Essa ideia exerceu importante influência sobre outro autor que dedicou a maior parte de suas pesquisas à valorização heurística do ambiente cultural do consumo de drogas. Edward MacRae iniciou suas pesquisas no Brasil publicando trabalhos sobre sexualidade, juntamente com Peter Fry, que esteve na banca de doutoramento de Velho. Mas, precocemente, em 1986, publicou "A antropologia e o uso de drogas: a questão da maconha”, pela revista paulistana Temas Imesc, uma publicação do Instituto de Medicina Social e Criminologia de São Paulo (Imesc), em que MacRae havia sido diretor.

No Brasil da abertura política, às vésperas da Constituinte de 1988, pensar o consumo de drogas de uma perspectiva que fosse além da droga em si, que pudesse abarcar o meio físico e social, possuía algo de revolucionário. MacRae (1986) amparou sua perspectiva nos trabalhos de dois norte-americanos: Becker (1973) e Zinberg (1984). O primeiro, com presença pregressa no Brasil por meio do Museu Nacional do Rio de Janeiro; o segundo, um psiquiatra e professor de Harvard, autor do clássico Drug, set and setting. Há, no texto de MacRae (1986), constante determinação em sofisticar o debate de então. De droga como termo genérico se passa a falar das drogas como tema complexo. Tal mudança abriu caminho para se considerar distintas modalidades de uso, em uma "abordagem antropológica, que en- fatiza o até agora pouco estudado aspecto sociocultural no uso de drogas" (MacRae, 1986, p. 196). Essa abordagem iria levar em conta os aspectos rituais em torno do consumo das substâncias:

- padróes estilizados de comportamento prescrito;

- métodos de aquisição;

- técnicas de consumo;

- $\quad$ escolha do meio físico e social;

- $\quad$ atividades após o uso;

- maneiras de lidar com efeitos negativos.

Tudo isso iria acompanhar valores e regras de conduta, verdadeiras sançóes sociais a compor controles sociais informais que - e aí se encontra o grande salto político da nova proposta - poderiam suplantar os controles sociais formais, representados pela letra fria da lei e pelo punitivismo.

Ao invés da repressão pura e simples da guerra às drogas, o investimento deveria estar no próprio consumidor, no maconheiro, como detentor do conhecimento necessário para usar maconha com relativa segurança, por prazer, tal qual alertara antes Becker (1973) em Tornando-se um usuário de maconha. O consumo de drogas deixou de ser uma relação simples entre dois termos, substância e corpo, e passou a considerar outros elementos da cultura, como a aprendizagem entre pares. Dessa forma, sequer os efeitos esperados ao se fazer uso de maconha derivariam integralmente de uma díade. $\mathrm{O}$ maconheiro, muitas vezes, iniciava sua carreira como usuário com seguidas experiências negativas com a planta e precisava, então, ser instruído, guiado, por pessoas de confiança, nas técnicas de consumo, até aprender a fumar. Teria, igualmente, de ser orientado a perceber os efeitos e, uma vez identificados, não se desesperar (uma possibilidade sempre 
presente nos neófitos), mas apreciar, deixar fluir as sensaçóes que passariam a interpretar positivamente como sendo agradáveis.

$\mathrm{O}$ que se convencionou designar, a partir de então, como os determinantes (fatores, aspectos, contextos ou mesmo momento sociocultural), passou a ser considerado nas pesquisas e até mesmo nas políticas direcionadas às pessoas que usavam drogas. Tal procedimento teórico fez com que a observação de conotaçóes socioculturais viesse a extrapolar os limites da antropologia. Por toda a década de 1990, pesquisas sobre drogas e juventude (Paulilo; Jeolás, 2000); ambiente escolar (Aquino, 1998); violência (Minayo; Deslandes, 1998); tratamento (Rezende, 1999); e prevenção da Acquired Immunodeficiency Syndrome (Aids) (Fernandez, 1997; MacRae, 1994a; Pechansky et al., 2000) levariam em conta o contexto social em que as drogas são consumidas.

No novo século que se abria, os temas e os campos de pesquisa em que uma abordagem sociocultural se fez presente foram ainda mais diversificados, abrangendo novos e antigos temas, tais como redução de danos (MacRae; Gorgulho, 2003; Santos; Soares; Campos, 2010); riscos da Aids (Paulilo; Jeolás, 2005); educação (Ribeiro, 2005; Soldera et al., 2004); gênero (Bernal Roldán; Frari Galera; O’Brien, 2005; Marangoni; Félix de Oliveira, 2013; Oliveira; Paiva; Valente, 2006); implicações dos modelos de dependência nos serviços de saúde básica (Schneider; De Lima, 2011); e projetos de prevenção (Buchele; Cruz, 2011).

Em grande parte desses trabalhos, vemos, no intuito de se incluir aspectos socioculturais na análise do consumo de drogas, uma tentativa de complexificar o estudo. Como nesta conclusão de Schenker e Minayo (2005, p. 715): "O uso de drogas é uma questão com- plexa que perpassa inúmeros subsistemas da vida individual e social. As representaçóes sociais que levam à adesão ou à condenação dependem do contexto sociocultural". As autoras ampararam suas observaçóes em Nobres e anjos, de Velho (1998), e prosseguiram enfatizando a variabilidade cultural dos constrangimentos impostos ao consumo de drogas, além da necessidade de se levar em consideração os códigos e os significados de cada contexto sociocultural envolvido.

\section{Pesquisas sobre a relação entre o consumo de cocaína injetada e Aids}

A propagação da Aids atingiu duramente as pessoas que se utilizavam de cocaína por via intravenosa. A doença também poderia ser transmitida sexualmente para não usuários de drogas injetáveis. Talvez essas características tenham dado legitimidade a políticas de redução de danos e pesquisas epidemiológicas sobre essas pessoas. Investigaçóes qualitativas, particularmente as de cunho etnográfico, não costumavam fazer parte do arsenal metodológico utilizado na área da saúde. Então, fazia-se necessário demonstrar a necessidade e a validade do tipo de conhecimento, possibilitado pela antropologia, assim como explicitar e esclarecer seu objeto nesse campo específico, o uso de drogas.

Estava, mais uma vez, com MacRae (1994a) a responsabilidade por abrir esse novo campo investigativo. Porém, cabe um parênteses dedicado à obra de Lima (1990) sobre os usuários de Algafan, um poderoso anestésico, por via intravenosa, na cidade do Recife, Pernambuco. Sob importante influência das obras de Becker e Goffman, a autora empreendeu uma etnografia no interior da Divisão de Serviços Técnicos da Secretaria da Segurança Pública de Pernam- 
buco. Ali, acompanhou a produçáo da identidade desviante do dependente, a partir das relações estabelecidas entre acusados (dependentes de Algafan) e acusadores (lei, família, agentes policiais e equipe terapêutica).

O antropólogo Edward MacRae precisou esclarecer, primeiramente, a pequena dimensão do conhecimento existente sobre uma população, estigmatizada e incógnita, que, para continuar com seu hábito, necessitava se esconder. A verdade é que muito pouco se sabia sobre os usuários de drogas injetáveis (UDIs). Métodos qualitativos, como a etnografia, se prestariam muito bem a estudos sobre uma população oculta, no intuito de desvendar as conotaçóes socioculturais do consumo da cocaína injetável, tais como:

- as motivaçóes para se consumir a droga;

- as práticas de aquisição e uso (e quais podem ser consideradas de risco);

- os diferentes padróes de uso (que poderia variar de ocasional a pesado);

- as circunstâncias físicas e sociais em que ocorre.

O que se buscava desenhar seria um verdadeiro estilo de vida que poderia acompanhar a prática de se injetar com cocaína.

Por toda a década de 1990, pesquisas etnográficas sobre UDIs e Aids foram levadas à frente em diversas cidades brasileiras. Osvaldo Fernandez investigava o tema desde a virada da década e, em 1993, defendeu uma dissertaçấo de mestrado sobre $A$ epidemia clandestina: Aids e uso de drogas endovenosas em São Paulo. Oriundo do Instituto de Medicina Social e de Criminologia de Sáo Paulo (Imesc), a influência de MacRae foi imensa em seu trabalho. Andrade (1996) reconheceu os UDIs de Salvador, local de sua etnografia, como uma populaçáo de pouca visibilidade, o que tornava imperativo o conhecimento de aspectos socioculturais do uso de drogas injetáveis em uma comunidade marginalizada. Só assim, acreditava o autor, medidas de prevenção da infecção pelo human immunodeficiency virus (HIV) poderiam ter sucesso.

A questáo de gênero também será explorada em etnografias sobre a relação entre o uso de drogas e a Aids. Quatro etnografias podem ser destacadas. Mulheres e Aids: uma abordagem antropológica, de Denise Martin, publicada no Dossiê Aids da Revista da USP, de 1997. A autora procurou chamar a atenção para a complexidade da questáo e para a importância de se compreender o contexto cultural em que ocorre a contaminaçáo de mulheres pelo HIV. Assim, a autora procurou entender, por exemplo, os interditos existentes na dinâmica de casais heterossexuais em que a mulher, sem crer ser uma possível vítima de contaminação, acabava por ser contaminada com o vírus pelo marido. Preocupação semelhante à de Barroso, Miranda e Pinheiro (1998), para quem, em sua pesquisa realizada no estado do Ceará, fatores culturais situam a mulher como mãe e dona de casa e em certo estilo de vida que as pesquisadoras pretenderam descrever a partir da observação.

Sob uma perspectiva da mulher, os homens portadores do vírus que, por vezes, contaminavam suas companheiras, seriam por natureza livres e mais voltados a gostar de drogas e sexo fora do casamento. Knauth (1998), em seu estudo com casais em que o marido contaminou a esposa, percebeu uma inversáo, causada pela doença, nos termos que comumente qualificam o masculino e o feminino. A mulher acabou sendo mais resiliente que o homem no enfrentamento da doença, cujo aspecto moral pesa mais sobre os companheiros.

$\mathrm{O}$ aspecto moral apareceu, no caso das mulheres que se prostituem na região 
da Luz, centro da cidade de Sáo Paulo, em Silva (2000), vinculado à rotulaçáo de comportamentos desviantes, sexualidade e prazer. Nesse caso, prazer proporcionado pelo sexo e pelas diversas maneiras de se utilizar substâncias, fruto de variaçóes culturais que complexificam a análise meramente bioquímica. Nesse momento, a autora recorreu a Velho (1994). O trabalho de Silva (2000) pode ser considerado um marco na mudança de foco dos UDIs para consumidores de cocaína por outra via, a fumada a partir da pedra de crack.

\section{Cocaína - crack}

A mencionada pesquisa de Silva (2000), intitulada Mulheres da Luz: uma etnografia dos usos e preservação no uso do crack, foi orientada pelo antropólogo Rubens Adorno, ex-diretor do Imesc e dedicado a pesquisas no campo da saúde. A defesa de Mestrado teve a presença de Edward MacRae na banca. Selma da Silva havia sido estagiária do Imesc no início dos anos 1990. Após esse trabalho, temos a etnografia de Pelúcio (2005), que também versou sobre territórios de prostituição. Porém, a pesquisadora descreveu a construção do ser travesti, na cidade de São Carlos, em que apareceu o uso do crack entre outras substâncias disponíveis para "se 'colocar' - usar drogas” (Pelúcio, 2005, p. 231).

Entre os anos de 2002 e 2005 foram realizados, no Brasil, cinco projetos piloto de redução de danos entre usuários de crack; todos enfrentaram, de modo mais ou menos acentuado, grandes dificuldades. A pesquisadora Domanico (2006, p. 9) atribuiu as dificuldades à forma dos financiamentos, marcada pela "ditadura dos projetos", e ao elevado grau de exclusão dos usuários que viviam sob a égide do "pânico moral" em torno do crack. Domanico (2006) analisou o processo de popularização do crack e da decadência do uso da cocaína injetável - em seus efeitos sobre as ações das equipes de redução de danos, acostumadas a trabalhar com usuários de drogas por via intravenosa efetuando troca de seringas. A autora observou: "Todos iniciaram suas intervençốes com usuários de drogas injetáveis que tinham como prioridade a prevenção das DST/Aids e hepatites virais através do incentivo do não compartilhamento dos apetrechos para o uso de drogas injetáveis" (Domanico, 2006, p. 177).

Relatos etnográficos sobre o uso do crack foram produzidos por Rui (2006) na cidade de Campinas, próxima à capital paulista, entre os adolescentes em situação de rua, na forma do "pitilho", cigarro misturado com crack. O consumo da droga por crianças de Fortaleza, Ceará, também em condição de vulnerabilidade, foi referido na etnografia de Valentim (2007). No ano seguinte, Frúgoli Jr. (2008, p. 2) citou a existência de "tráfico e consumo de crack em vários espaços públicos" do bairro da Luz, centro da cidade de São Paulo. Esse artigo deu início, sob orientação de Frúgoli Jr., a uma larga produção, por diversos autores, sobre a Cracolândia. São pesquisas que continuam se renovando até hoje, juntamente com os trabalhos orientados por Adorno.

As pesquisas sobre o uso do crack na primeira década do século XXI não se limitam à cidade de São Paulo. Melotto (2009), em sua investigação sobre trajetórias de usuários de crack no contexto de bairros populares de Sáo Leopoldo, Rio Grande do Sul, introduziu um novo ponto de vista sobre a pessoa que fuma crack. Com base na obra de Pierre Bourdieu, a autora buscou relacionar sujeito e estrutura social, estrutura esta geradora de práticas e representaçóes. Seu esforço foi no sentido de apreender os processos nos quais 
fossem gestadas as "mudanças e mobilidades sociais como passagens de status, de situação econômica e de atividades profissionais" (Melotto, 2009, p. 45).

Raupp e Adorno (2010) realizaram uma etnografia voltada, especificamente, à descrição das relaçóes entre o contexto social vivido na Cracolândia e o padrão de uso compulsivo do crack. Introduziram, em Raupp (2011), o conceito de circuito, retirado de Magnani (2007) e utilizado, anteriormente, na pesquisa de Fernandez (2007, p. 159) sobre os "circuitos do pó". Buscavam descrever o exercício da prática de fumar crack e os equipamentos, estabelecimentos e espaços relacionados a essa prática - assim como a observação da sociabilidade e do manejo de códigos em um território psicotrópico (Fernandes; Pinto, 2004): local reconhecido pela função desempenhada em que se vive em torno da venda e do consumo de substâncias ilícitas. Conceito também presente em Gomes e Adorno (2011), que procuraram compreender a trajetória do usuário até "tornar-se noia", aqui percebido "como aquele que desrespeita as normas sociais e os parâmetros éticos em busca da pedra de crack, é visto com desconfiança e não consegue estabelecer relaçôes de outra forma com as pessoas" (Gomes; Adorno, 2011, p. 584). Frúgoli Jr. e Cavalcanti (2013), por sua vez, trataram das dinâmicas espaciais urbanas, presentes nas chamadas cracolândias das cidades do Rio de Janeiro e de São Paulo. Para tanto, valeram-se da ideia de itinerância, imposta pela disputa entre territorialidades, marcadas por grandes intervençôes urbanas em um contexto de repressão policial.

Do noia ao abjeto, Rui (2012) falou de como a relaçáo com o crack, sob certa circunstância, considerada pela autora como extrema e radical, pode ser produto e pro- dutora de uma corporalidade abjeta, que radicaliza a alteridade. Tal produção justificaria intervençóes de caráter tanto repressivo quanto assistencial, respectivamente, a eliminação e a recuperação. $\mathrm{Na}$ coletânea Crack: contextos, padróes e propósitos de uso, a etnografia de Malheiro (2013), orientada por MacRae e fortemente influenciada por Becker (1973), Zinberg (1984) e Grund (1993), complexificaram-se os termos atribuídos aos consumidores da droga que, na região do centro histórico da cidade de Salvador, apresentavam-se sob a forma de três tipos distintos: o sacizeiro, o usuário e o patrão. $\mathrm{O}$ primeiro corresponderia ao neófito, que fumava compulsivamente e deixava transparecer estar sob efeito da droga; o segundo, teria maior experiência e autocontrole sobre seu padrão de uso, recusando-se, no mais das vezes, estar na companhia dos sacizeiros; o último tipo, o patrão, era dedicado ao comércio da substância e muito dificilmente dela faria uso compulsivo.

Mais uma etnografia com olhar voltado para o contexto de uso do crack e sua influência sobre as práticas de uso, o trabalho de Vallim, Zaluar e Sampaio (2015) percorreu as seguintes cenas de uso no Rio de Janeiro: o bairro da Glória, as favelas de Manguinhos e de Jacarezinho e a estação Central do Brasil. Novamente, sob forte influência dos trabalhos de Zinberg e Grund, o estudo se dedicou à:

- descrição das cenas;

- sua influência sobre os efeitos da droga;

- descrição dos rituais, dos símbolos e das sançôes sociais que viessem a constranger o consumo do crack a padrôes aceitáveis pelos pares.

O contexto do consumo do crack também foi objeto de exposição na pesquisa de 
Alves (2016). O autor se dedicou a delinear a parafernália, as técnicas e os rituais de uso e os efeitos percebidos. Silva (2017), que no ano de 2000 havia realizado estudo pioneiro relacionando prostituição e consumo do crack no bairro da Luz, em São Paulo, expôs os diferentes padróes de controles informais e de autocuidado, a partir de narrativas obtidas nas cidades de Lisboa e, novamente, na capital paulista. Autocuidado este que pode ser impulsionado ou obstaculizado por certas políticas públicas, como são os programas a atuar na Cracolândia. Em Medeiros (2014), podemos verificar como as respostas institucionais costumam se prender a imagens negativas, construídas socialmente, e o quanto essas imagens contribuem negativamente no processo terapêutico levado à frente por equipes profissionais na cidade de Belo Horizonte.

Fromm (2017), em sua pesquisa etnográfica, entrou na cena de uso do bairro da Luz, em Sáo Paulo, por meio do acompanhamento dos percursos de três personagens, pelos programas Cristolândia, De Braços Abertos (DBA) e Recomeço. A autora buscou chamar atenção para as estratégias de sobrevivência no cotidiano, frente ao que acreditava serem tentativas de pôr fim à Cracolândia. O DBA também será objeto da análise de Nasser (2018), a partir dos percursos de uma jovem que não foi aceita no programa. Souza (2015), por sua vez, teve contato com o pessoal de ponta da saúde e assistência e, principalmente, com guardas municipais. Dessa forma, fez uma etnografia do trabalho dos agentes de segurança, a partir da implantaçáo do DBA, com um olhar para o drama diário vivido pelos agentes públicos e para as consequências advindas dos procedimentos adotados na diferenciaçáo entre usuários de traficantes. Uma descrição do DBA pode ser encontrada em Alves (2017), desde as articulaçôes entre secretarias municipais, para dar início ao programa, até uma descrição do seu modo de funcionamento. É, também, do mesmo autor, uma crítica ao conceito biomédico de dependência a partir do que designa como uma antropologia do "fluxo", como são chamados os movimentos e percursos em torno do consumo do crack, na Cracolândia (Alves; Pereira, 2019). Aos percursos em torno do consumo da droga se soma, na etnografia de Malheiro (2019), que já participava da Rede Nacional de Feministas Antiproibicionistas (Renfa), a descrição da violência racial, de classe e de gênero. A autora apontou, em seu trabalho com as mulheres que fumavam crack no centro velho de Salvador, como a construçáo de um campo feminista e antiproibicionista vem organizando politicamente as mulheres vítimas da guerra às drogas.

\section{Estudos sobre a maconha}

Neste ponto, como alertamos no início deste artigo, temos de fazer uma retrospectiva. Citaçóes ao consumo da maconha remontam aos antropólogos pioneiros como Gilberto Freyre, Arthur Ramos, Donald Pierson, Roger Bastide e Edison Carneiro. O estudo mais detido sobre os padróes e propósitos de uso, efeitos e influência do contexto social se faz presente a partir de Gilberto Velho, que também percebeu a influência dos "puxadores de maconha" em demarcar espaços mais e menos degradados da cidade (Velho, 1989, p. 33-34). Em sociedades complexas e heterogêneas, o chamado mundo das drogas é mais bem compreendido se levarmos em conta "a liberdade existencial dos indivíduos que transitam entre diferentes domínios e mundos de significado" (Velho, 1999, p. 89). 
Essa demarcação de espaços na cidade, proporcionada pelo consumo de drogas, poderia derivar de uma separação ainda mais ampla e profunda no interior da sociedade brasileira. Em Adiala (1986), temos um estudo pioneiro, calcado na análise de discurso e nos conceitos foucaultianos de poder, sobre as relaçôes entre o saber médico, construído em torno da diamba (maconha), sua vinculação com a populaçáo negra e com a repressão do plantio, comércio e consumo da erva. $\mathrm{O}$ artigo $A$ criminalização dos entorpecentes permanece um estudo influente que vem inspirando pesquisas por três décadas.

Complexificar o debate sobre a cannabis no país é o objetivo que podemos atribuir a MacRae e Simóes (2000), ao buscarem a valorização do setting de consumo da planta, em uma pesquisa realizada no ano de 1987, nas cidades de São Paulo e Salvador. Os autores se dedicaram, também, a contextualizar o consumo da maconha no interior das outras práticas dedicadas a alterar a consciência ordinária de vigília: o devaneio, o transe místico, a meditação ou mesmo a sensação provocada em crianças ao rodopiarem até caírem tontas. As expectativas dos maconheiros e o ambiente que encontram para fumar parecem ter influência decisiva nos efeitos percebidos. A descrição dos controles informais sobre o consumo de maconha entre as pessoas das camadas médias urbanas pesquisadas, integradas ao mercado de trabalho e de consumo, aparece, em Rodas de fumo (MACRAE; SIMÓES, 2000), como uma espécie de contraponto ao, então, chamado problema das drogas.

Porém, não é apenas em Copacabana ou nos centros urbanos, tais como São Paulo e Salvador, que a maconha delimitaria fronteiras culturais. Diniz e Cardia (1979, p. 82) observaram como no ritual xamanístico dos
Tenetehara-Guajajara, "conservantismo e mudança cultural" podem ser percebidos em sua dualidade - enquanto "o espírito do Kaipora masca e fuma maconha, o espírito do Karaiú (civilizado) bebe cachaça". Em Henman (1986), o caráter etnocida da guerra às drogas é denunciado a partir do caso de um índio tenetehara torturado durante operação da Polícia Federal, na segunda metade dos anos 1970, contra o plantio e o uso da cannabis pelo grupo indígena. No relatório apresentado em 1989, ao Imesc, o antropólogo Domingues (2016) relatou o embate repressivo em torno do uso da maconha por grupos indígenas do norte do estado do Tocantins. Os krahô-mankraré decidiram abandonar o cultivo e o uso da maconha para evitar as investidas punitivas da polícia em suas terras. Já em Assunção (1999, p. 28-9), temos um questionamento a respeito da resiliência apresentada pelo costume de se fumar maconha entre indígenas do estado do Maranhão em detrimento de outros costumes, como ingerir cauim. Tal opção se dá apesar da origem autóctone da beberagem em detrimento da, provável, ascendência africana do costume de se fumar cannabis.

A crítica ao proibicionismo foi a tônica de alguns trabalhos antropológicos publicados na segunda década do século XXI. Vidal (2009), ainda na primeira década, abriu o debate com seu texto sobre a regulamentação do cultivo da maconha como proposta de reduçâo de danos, tecendo um histórico da perseguição da planta no país. O autor percorreu, analiticamente, leis e convençốes sobre drogas até a emergência das políticas de redução de danos, que considerou ser um paradigma alternativo à proibição. Souza e De Moraes (2018) propuseram uma genealogia da proibiçáo da maconha no Brasil e descreveram a articulaçáo do proibicionismo com a atual 
política de drogas. Entre os efeitos deletérios da atual legislaçáo, um dos mais dramáticos é a dificuldade do uso de derivados da planta pela medicina oficial. $\mathrm{O}$ ativismo político das famílias com crianças portadoras de epilepsia de difícil controle foi objeto de análise em Oliveira (2016). A autora descreveu a organização e a atuação dessas famílias frente à Agência Nacional de Vigilância Sanitária (Anvisa), a construção da solidariedade e de uma verdadeira rede terapêutica.

O ativismo político em torno da descriminalização da cannabis incorpora, também, seu uso não medicinal, o uso recreativo. Como é o caso da atividade militante em torno da Marcha da Maconha, que pode assumir, por vezes, ares carnavalescos (Veríssimo, 2013). Em outras oportunidades, como em Brandáo (2017), pode se assemelhar mais a uma verdadeira cruzada simbólica contra o estigma em torno da planta, que não prescinde em possuir certo caráter performático nas manifestaçôes públicas da militância canábica. Pode apresentar-se, também, como um movimento social com marcante aspecto ritualístico, expressão, em Corteletti (2015), de uma possível nova noção de cidadania. Ou um problema público, com debate aberto acerca dos efeitos da droga e do proibicionismo - mais que se esconder, as pessoas parecem ter "vontade de se mostrar" (Brandão, 2016, p. 127). São esses consumidores que, dadas condiçôes propícias, poderiam, como desejou Policarpo (2013, p. 199, grifos do original), "modular seus conhecimentos produzidos a partir da experiência em discursos normativos sobre a experiência de consumo de drogas".

A ilicitude contida no ato de portar ou usar a droga não impediria o surgimento de um consumo sofisticado, que em Veríssimo (2016, p. 276) apareceu personificado no $c a-$ nabier, "termo cunhado em função da aproximação significativa entre os círculos de apreciadores de canabis oriundas de autocultivos domésticos e os círculos de apreciadores de vinhos finos (sommeliers)" (Veríssimo, 2016, p. 276). O proibicionismo tampouco impediria sua incorporação como substância terapêutica, recreativa ou mesmo religiosa, como a Santa Maria, nome pelo qual a maconha é conhecida nos cultos de Santo Daime (MacRae, 2005; Rocha, 2016), o que nos leva ao uso da ayahuasca.

\section{$\mathrm{O}$ uso ritual religioso da ayahuasca}

Na primeira metade dos anos 1990, não foi só a maconha que foi vítima de perseguição por parte das autoridades sanitárias e policiais. $\mathrm{O}$ chá ayahuasca também corria risco de ter seu uso ritual proscrito pelo Conselho Federal de Entorpecentes (Confen), o então órgáo responsável por regulamentar o consumo de substâncias no país. Embora Groisman (1991) tenha apontado, em trabalho pioneiro, algumas características da cosmovisão e dos rituais do Santo Daime, apenas em MacRae (1994b) que veremos uma defesa não só da legalidade do uso ritual do chá, mas da importância de se levar em consideraçấo os fatores socioculturais nas decisóes oficiais a respeito de políticas sobre drogas. $\mathrm{O}$ autor enfatizou que náo se deve deixar de levar em conta que a chamada medicina popular era, em diversos locais do Brasil, o único recurso de cura disponível, além de ser praticada por líderes espirituais, que também exercem "importantes funções civilizadoras e normativas entre populaçôes marginalizadas e carentes" (MacRae, 1994b, p. 33).

A religião conhecida como Santo Daime, seus mitos fundadores, as funçôes normativas como as desempenhadas por seu 
criador (o maranhense Raimundo Irineu Serra) foram objeto do estudo desenvolvido por Goulart (1996) durante a primeira metade dos anos 1990. O aspecto ritual do uso religioso da ayahuasca, com seus controles informais, valores e regras de conduta, permite a atualização dos mitos sob um estado alterado de consciência. Tal estado é tornado possível por certas características ritualísticas presentes nos cultos, tais como:

- prescriçóes dietéticas e comportamentais;

- organização hierárquica;

- controle da dosagem;

- organização espacial do culto com divisóes por sexo, estado civil e faixa etária (MacRae, 1992; 1999).

O consumo da ayahuasca também seria fundamental para a habilidade dos xamãs do alto Juruá em acessar diversos planos cosmológicos, múltiplos pontos de vista e se colocar em perspectiva, assumindo o olhar do outro como um tradutor (Cunha, 1998). Entre os Kaxinawá, a ayahuasca é a bebida dunuan isun que, ao ser consumida ritualmente, dá aos homens o poder de entrar em contato com o lado invisível da realidade (Lagrou, 1996).

O consumo ritual da bebida extrapolou, desde, pelo menos, a primeira metade do século XX, os agrupamentos indígenas amazônicos, dividindo-se em três correntes principais: Santo Daime, União do Vegetal e Barquinha. Essas três diferentes denominaçóes religiosas contrastam quanto à tradição, por meio de oposiçóes e acusaçóes recíprocas (Goulart, 2004). Tais características levaram, possivelmente, a uma intensa dinâmica de conversóes e mobilidade entre as distintas denominaçóes e no interior delas (Greganich, 2010).

As três denominaçóes possuem uma dimensão de cura com o uso de um chá en- teógeno (Ricciardi, 2009), e na Uniāo do Vegetal, por exemplo, problemas físicos e psíquicos, tais como a dependência de drogas, são tratados a partir de uma experiência de transformação. De Rose (2006), que pesquisou uma comunidade ayahuasqueira localizada no sul do estado de Minas Gerais, expôs como no Santo Daime o processo de cura enfatiza a relação entre as dimensões terapêutica e espiritual, a partir de diferentes procedimentos de tratamento. Mercante (2009) descreveu as sessóes promovidas por uma associação beneficente, em que moradores de rua poderiam superar o abuso de drogas, por meio do consumo de ayahuasca e da produção de imagens mentais espontâneas ou miraçóes. Para esse autor, além das imagens, as experiências vivenciadas no ritual com o chá também teriam papel fundamental na recuperação da dependência (Mercante, 2013).

A observação experiencial, como a que procurou realizar Mercante (2013) em sua pesquisa sobre a Barquinha, vem se constituir em um método específico de pesquisa dos estados alterados de consciência, produzidos por psicoativos. $\mathrm{O}$ investigador deixou de ser somente acadêmico para se tornar, também, um discípulo iniciado na tradição cultural que pretendeu estudar, capaz de ser participante e introspectivo, de observar e se auto-observar, ao mesmo tempo em que convivia e dialogava com outros usuários da substância, que aceitaram compartilhar experiências e confidências, como são as descrições das miraçôes vivenciadas.

$\mathrm{O}$ universo imagético provocado pela ingestão ritual do chá de ayahuasca, agora associado ao rapé indígena e ao Kampô, é composto de visóes que possibilitam a ordenação de equívocos e recriação de narrativas individuais com efeito terapêutico. Kampô, 
segundo Coutinho (2013b, p. 2), seria "uma secreção extraída de um sapo amazônico de hábitos noturnos, coletada por povos da etnia pano e utilizada como medicina alternativa em terapias encontradas na cidade de São Paulo". Em certo sentido, para Mercante (2016), as imagens mentais experienciadas no contexto ritual do uso da ayahuasca poderiam ser consideradas como base de uma realidade ancorada no poder da mente. As implicaçôes terapêuticas do consumo ritual da ayahuasca provocaram, entre outros motivos, sua disseminação por grandes centros urbanos.

A União do Vegetal teve uma expansão que data dos anos 1970, enquanto o Santo Daime se espalhou somente a partir dos anos 1980. Labate (2004), que havia, em 2001, participado da fundação do Núcleo de Estudos Interdisciplinares sobre Psicoativos (Neip), descreveu, no estudo do caso do centro terapêutico Caminho do Coraçáa, o surgimento das modalidades ayahuasqueiras urbanas com integrantes organizados em pequenos grupos, que denominou neo-ayahuasqueiros. Esse consumo urbano da ayahuasca e seu uso terapêutico fora da floresta foram precedidos por um largo processo de expansão do vegetalismo peruano, em que estrangeiros naquele país se tornaram curandeiros para um público de classe média dos Estados Unidos e da Europa (Labate, 2011). À expansão global do Santo Daime e da União do Vegetal correspondeu um processo regulatório internacional (Labate; Feeney, 2011), acompanhado de iniciativas voltadas à patrimonialização, permeadas por disputas entre os grupos religiosos (Barros, 2016). No entanto, malgrado os esforços regulatórios, a popularização do uso recreativo, terapêutico e espiritual da bebida levou, na atualidade, a maior questionamento quanto à legitimidade e à legalidade das novas práticas que envolvem seu consumo (Coutinho, 2013a). Além disso, desde Chaves (2003), houve um questionamento quanto a certa interpretação do culto a Maria, mãe de Jesus, no universo ayahuasqueiro, que pode cobrar das fiéis uma atitude passiva ao sofrerem violências e abusos por parte dos homens.

\section{Tráfico de drogas}

A liberdade de transitar entre diversos mundos de significados, apontada por Velho (1999) como parte das possibilidades oferecidas pelas sociedades complexas, levou, não poucas vezes, à experimentaçấo e mesmo ao hábito de se utilizar substâncias proscritas pela lei. Essa proibição possibilitou a criação de todo um comércio ilegal de drogas, geralmente conectado às redes internacionais do tráfico e, por vezes, um verdadeiro poder paralelo, capaz de colocar em xeque a existência de estados nacionais. De modo, talvez, premonitório, Velho (1999), pensando na realidade brasileira, alertou para os riscos que a imensa concentração de recursos nas mãos das quadrilhas de traficantes poderia significar para a democracia.

Zaluar (1996) advertiu para as múltiplas consequências da existência de um tráfico de drogas organizado internacionalmente:

- instalaçáo de pontos de venda nos bairros pobres;

- fomento de conflitos sangrentos nessas vizinhanças;

- corrupção das instituiçóes repressoras;

- demonizaçáo do usuário.

A desqualificação de quem usa drogas acaba facilitando o isolamento e dificultando o tratamento do dependente, que fica à mercê do traficante e do policial corrupto. Vargas (2000) abordou os corpos mutilados, 
vítimas da intervenção estatal, inclusive bélicas e em nível internacional no circuito das drogas. Rafael (2001) entendeu esse circuito como um fluxo gerenciado com algum grau de institucionalização, um agenciamento expresso em certo regime de signos e sistema de açóes. Esse agenciamento poderia ser observado no controle territorial, nas hierarquias e nos modos de interação e produção de códigos e palavras de ordem.

Seguindo essa trilha, Barbosa (2006) destacou a positividade do encontro nos bailes frequentados por membros do tráfico de drogas no Rio de Janeiro. Complementares às conexóes estabelecidas na prisão, os vínculos produzidos a partir dos bailes se dão no encontro de homens livres, por meio do riso e da alegria, celebrando a vida, o sexo, a vaidade e o dinheiro. Malvasi (2012) também se referiu a códigos, presentes no dialeto das chamadas quebradas de Sáo Paulo, em que a ideia de se viver na vida loka unifica a diversidade de experiências pelas quais passam os jovens sob o poder do tráfico de drogas.

Já as mulheres envolvidas no tráfico podem vislumbrar, a começar do ingresso na atividade criminosa, uma possibilidade de elevação na condição econômica, ao alcançarem, conforme relatou Helpes (2014), postos de trabalho elevados no interior da ilegalidade. Bernardi (2013), em sua pesquisa sobre o envolvimento de mulheres no tráfico de drogas, na cidade de Bagé, Rio Grande do Sul, revelou como o cárcere é o destino de muitas delas que, separadas do contato com o mundo exterior, vivem longe de família e filhos. Como é para os filhos que justificam sua entrada no universo do negócio das drogas, o tráfico apresenta aqui uma de suas faces mais deletérias: no binômio criminalidade e gênero, uma sobrepena é imposta às mulheres.

\section{Notas finais}

Desde a primeira metade do século XX que o tema das drogas trouxe à antropologia no Brasil preocupaçóes de cunho sociocultural, abordando questóes, tais como o propósito de uso, a descrição da parafernália e de técnicas de consumo e a descrição dos efeitos em determinado contexto social. Essas abordagens foram capazes de impor constrangimentos contra exageros e de circunscrever o uso de substâncias a ocasióes sociais específicas, marcadas por certa ritualidade, entendida como padróes estilizados de comportamento prescrito.

Esse arcabouço teórico precisou ser desenvolvido no país, primeiramente, para dar conta da repressão legal e política ao usuário de substâncias tornadas ilícitas. Em um segundo momento, a emergência provocada pelo advento da Aids tornou ainda mais necessária uma metodologia de pesquisa que pudesse ser eficiente em estudos sobre uma população oculta, usuária de cocaína injetável.

Com a mudança na forma de utilização da cocaína, de injetada para fumada, grandes cenas abertas de uso de crack surgiram pelo país, com destaque para a Cracolândia, em Sáo Paulo. O contexto social alargou-se, da roda de fumo, com seu pequeno número de participantes, para aglomeraçóes de centenas e até milhares de pessoas. Conceitos próprios da antropologia urbana que buscam dar conta do movimento na cidade, tais como o de circuito, são agregados a outros voltados diretamente a interpretar cenas de uso e comércio de drogas, os territórios psicotrópicos. Os territórios psicotrópicos, pelo jogo de interesses que rondam as metrópoles, são também postos em movimento como territorialidades itinerantes.

Gilberto Velho, desde os anos 1970, havia percebido que o consumo de drogas 
tornadas proibidas era utilizado nas cidades como demarcador de áreas degradadas. A proibição estaria na origem dos problemas enfrentados pelos usuários de substâncias, segregados em territórios estigmatizados. Um ativismo político iria surgir como resposta à violência impetrada pelos agentes do Estado e do tráfico de drogas. Tais mobilizaçôes e respostas sociais não passaram despercebidas das análises antropológicas.

Direitos também foram reivindicados pelos consumidores de substâncias psicoativas em contexto religioso, por meio da defesa de que os fatores socioculturais sejam considerados nas decisóes oficiais a respeito de políticas sobre drogas. A pesquisa etnográfica sobre esse tema, que necessariamente deveria incluir a participação em rituais, impele os antropólogos envolvidos a justificar, teórica e metodologicamente, a experiência do consumo da substância e sua importância na pesquisa de estados alterados de consciência. A incorporação do chá de Santa Daime no mercado de serviços religiosos oferecidos na cidade, quando seu consumo se internacionalizou, acarretou disputas, questionamentos e esforços no sentido da regulamentaçáo para evitar a ilegalidade. Essa mesma ilegalidade que concentrou recursos nas mãos das quadrilhas de traficantes, que instalaram pontos de venda nos bairros pobres, fomentando conflitos san- grentos, corrupção e demonização do usuário, como analisado por diversos(as) autores(as) mencionados(das).

Finalmente, consideramos importante observar que este artigo buscou somente elaborar uma revisão sobre o campo de estudos de drogas na antropologia. Trata-se, pois, de um trabalho que procurou retratar as mais diversas contribuiçôes e que, estamos conscientes disso, sempre será limitado pela economia de espaço de um artigo, mas também, e, principalmente, pelas limitaçóes e escolhas dos autores. Construímos um panorama inicial que destaca autores e movimentos teóricos importantes, mas que ainda deixa lacunas por preencher. Por exemplo, neste artigo optamos por não analisar os trabalhos que se voltam para as drogas (medicamentos) comercializadas sob prescrição médica e de consumo largamente incentivado, tais como moderadoras de apetite, antipsicóticas, entre outras, apesar de já contar com uma bibliografia rica que merece atenção especial (que pretendemos elaborar em outro espaço). Outra lacuna: falta, ainda, aprofundar a discussáo do uso político da guerra às drogas e sua relaçáo com o autoritarismo. Optamos por esse caminho, não porque haja somente uma direção a percorrer com proveito, mas porque, como lembrou Geertz (1989, p. 15), "há muitas: é necessário escolher".

\section{Bibliografia}

ADIALA, J. C. A Criminalização dos Entorpecentes. In: SEMINÁRIO CRIME E CASTIGO, 1., Rio de Janeiro. Papéis Avulsos. Casa de Rui Barbosa, n. 1, p. 58-87, 1986.

ALVES, Y. D. D. Jamais fomos zumbis: contexto social e craqueiros na cidade de São Paulo. Salvador: Edufba/Cetad, 2017.

ALVES, Y. D. D. O uso do crack como ele é: o cachimbo, o “bloco" e o usuário". Etnográfica, v. 20, n. 3, p. 495-515, 2016.

ALVES, Y. D. D.; PEREIRA, P. P. G. Uma antropologia do "fluxo": reflexôes sobre dependência no contexto do crack. Revista Internacional Interdisciplinar INTERthesis, v. 16, n. 1, p. 121-142, 2019. https://doi. org/10.5007/1807-1384.2019v16n1p121 
ANDRADE, T. M. de. Condiçóes psicossociais e exposiçáo ao risco de infecçáo pelo HIV entre usuários de drogas infetáveis, em uma comunidade marginalizada de Salvador-Bahia. Tese (Doutorado) - Faculdade de Medicina, Universidade Federal da Bahia, Salvador, 1996.

AQUINO, J. G. Drogas na escola. São Paulo: Summus, 1998.

ASSUNÇÃO, M. R. A formação da cultura popular maranhense: algumas reflexões preliminares. Boletim da Comissáo Maranhense de Folclore, v. 14, n. 1, 1999.

BARBOSA, A. R. O baile e a prisão: onde se juntam as pontas dos segmentos locais que respondem pela dinâmica do tráfico de drogas no Rio de Janeiro. Cadernos de Ciências Humanas, v. 9, n. 15, p. 119-135, 2006.

BARROS, G. C. Tradiçáo e modernidade no Campo Ayhuasqueiro: uma análise a partir dos processos de regulamentaçáo e patrimonializaçáo da ayahuasca no Brasil no período de 1985/2016. Tese (Doutorado) Programa de Pós-Graduação em Ciências Sociais, Universidade Federal de Campina Grande, Campina Grande, 2016.

BARroso, M. G. T.; MIRANDA, C. C. L.; PINHEIRO, P. N. da C. A AIDS sob o olhar da companheira contaminada. Revista Brasileira de Enfermagem, v. 51, n. 3, p. 393-402, 1998. http://dx.doi.org/10.1590/ S0034-71671998000300005

BASTIDE, R. As religiōes africanas no Brasil. São Paulo: EDUSP, 1971.

BECKER, H. Becoming a marihuana user: outsiders. Nova York: Free Press, 1973. p. 41-58.

BERNAL ROLDÁN, M. C.; FRARI GALERA, S. A.; O’BRIEN, B. Percepção do papel materno de mulheres que vivem em um contexto de drogas e violência. Revista Latino-Americana de Enfermagem, v. 13, n. esp. 2, p. 1118-1126, 2005. http://dx.doi.org/10.1590/S0104-11692005000800004

BERNARDI, M. L. Gênero, cárcere e família: estudo etnográfico sobre a experiência das mulheres no tráfico de drogas. Dissertação (Mestrado) - Programa de Pós-Graduação em Ciências Sociais, Universidade Federal de Pelotas, Pelotas, 2013.

BRANDÃO, M. D. Em Marcha: maconha e a reversão de um estigma. Praça, Recife, v. 1, n. 1, 2017.

BRANDÃO, M. D. Os ciclos de atenção à maconha e a emergência de um "problema público" no Brasil. In: MACRAE, E.; ALVES, W. C. Fumo de Angola: canabis, racismo, resistência cultural e espiritualidade. Salvador: Edufba, 2016.

BUCHELE, F.; CRUZ, D. D. de O. Aspectos socioculturais do uso de álcool e outras drogas e exemplos de projetos de prevenção. Brasília: Secretaria Nacional de Políticas sobre Drogas, 2011.

CARNEIRO, E. O quilombo dos Palmares. São Paulo: Brasiliana, 1958.

CHAVES, L. A mulher urbana no Santo Daime: entre o modelo arcaico e o moderno de feminino. Dissertaçáo (Mestrado) - Universidade Federal do Rio de Janeiro, Rio de Janeiro, 2003.

CORTELETTI, Y. B. F. Da rua ao Congresso: uma análise etnográfica da Marcha da Maconha DF e da política sobre o tema no Congresso Nacional. Monografia (Bacharelado em Ciências Sociais) - Universidade de Brasília, Brasília, 2015.

COUTINHO, T. A questão da legitimidade e da legalidade dos usos contemporâneos da ayahuasca: Um estudo de caso. Dilemas, v. 6, n. 2, p. 331-355, 2013a.

COUTINHO, T. Curando através de imagens. Ponto Urbe, v. 13, 2013 b.

CUNHA, M. C. da. Pontos de vista sobre a floresta amazônica: xamanismo e tradução. Mana, Rio de Janeiro, v. 4, n. 1, p. 7-22, 1998. http://dx.doi.org/10.1590/S0104-93131998000100001 
DE ROSE, I. S. Repensando as Fronteiras entre Espiritualidade e Terapia: Reflexóes sobre a cura no Santo Daime. Campos, v. 7, n. 1, 2006. http://dx.doi.org/10.5380/cam.v7i1.5450

DINIZ, E. S.; CARDIA, L. A situação atual dos índios Tenetehara. Revista de Antropologia, São Paulo, v. 22, p. 79-85, 1979. https://doi.org/10.11606/2179-0892.ra.1979.110805

DOMANICO, A. Craqueiros e cracados: bem vindo ao mundo dos nóias! Estudo sobre a implementaçáo de estratégias de reduçáo de danos para usuários de crack nos cinco projetos-piloto do Brasil. Tese (Doutorado) -Universidade Federal da Bahia, Salvador, 2006.

DOMINGUES, S. Maconha e Xamanismo numa Tribo Timbira. In: MACRAE, E.; ALVES, W. C. Fumo de Angola: canabis, racismo, resistência cultural e espiritualidade. Salvador: Edufba, 2016.

FERNANDES, L.; PINTO, M. El espacio como dispositivo de control social: territórios psicotrópicos y politicas de la ciudad. Monografias Humanitas, Fundación Medicina y Humanidades, n. 5, p. 147-162, 2004.

FERNANDEZ, O. F. R. L. A epidemia clandestina: AIDS e uso de drogas endovenosas em Sáo Paulo. Dissertação (Mestrado em Ciências Sociais) - Pontifícia Universidade Católica, São Paulo, 1993.

FERNANDEZ, O. F. R. L. Redes juvenis, droga injetável e o HIV/Aids. Revista USP, São Paulo, n. 33, p. 102-115, 1997. https://doi.org/10.11606/issn.2316-9036.v0i33p102-115

FERNANDEZ, O. F. R. L. Coca light?: usos do corpo, rituais de consumo e carreiras de "cheiradores" de cocaína em Sáo Paulo. Tese (Doutorado) - Faculdade de Filosofia e Ciência Humanas, Universidade Federal da Bahia, Salvador, 2007.

FREYRE, G. Casa-Grande e senzala: formação da família brasileira sob o regime da economia patriarcal. Rio de Janeiro: Livraria José Olympio, 1973.

FREYRE, G. Nordeste. Rio de Janeiro: Livraria José Olympio, 1937.

FROMM, D. Percursos e refúgios urbanos. Notas sobre a circulação de usuários de crack pela trama institucional da Cracolândia de São Paulo. Ponto Urbe, v. 21, 2017.

FRÚGOLI JR., H. Roteiro pelo bairro da Luz, São Paulo. Ponto Urbe, v. 2, n. 1, 2008.

FRÚGOLI JR., H.; CAVALCANTI, M. Territorialidades da(s) cracolândia(s) em São Paulo e no Rio de Janeiro. Anuário Antropológico, v. 38, n. 2, p. 73-97, 2013.

GEERTZ, C. A interpretaçáo das culturas. Rio de Janeiro: ETC, 1989.

GIRÃO, V. C. A coleção Arthur Ramos. Revista de Ciências Sociais, Fortaleza, v. 1, n. 1, p. 95-113, 1970.

GOMES, B. R.; ADORNO, R. de C. F. Tornar-se "noia": trajetória e sofrimento social nos "usos de crack" no centro de São Paulo. Etnográfica, v. 15, n. 3, p. 569-586, 2011.

GOULART, S. L. Contrastes e continuidades em uma tradiçáo Amazônica: as regióes da Ayahuasca. Tese (Doutorado) -Instituto de Filosofia e Ciências Humanas, Universidade Estadual de Campinas, Campinas, 2004.

GOULART, S. L. Raízes culturais do Santo Daime. Dissertação (Mestrado) -Universidade de São Paulo, São Paulo, 1996.

GREGANICH, J. Entre a rosa e o beija-flor: um estudo antropológico de trajetórias na Uniâo Vegetal (UDV) e no Santo Daime. Dissertação (Mestrado) - Universidade Federal do Rio Grande do Sul, Porto Alegre, 2010.

GROISMAN, A. Eu Venho da Floresta: ecletismo e práxis xamânica daimista no Céu do Mapiá. Dissertação (Mestrado) - Universidade Federal de Santa Catarina, Florianópolis, 1991. 
GRUND, J.-P. C. Drug use as a social Ritual: Functionality, symbolism and determinants of self-regulation. Roterdã: Institute Voor Verslavingsondersoek, Erasmus Universities, 1993.

HELPES, S. S. Vidas em jogos: um estudo sobre mulheres envolvidas com o tráfico de drogas. Dissertação (Mestrado) - Programa de Pós-Graduação em Ciências Sociais, Universidade Federal de Juiz de Fora, Juiz de Fora, 2014.

HENMAN, A. R. A guerra às drogas é uma guerra etnocida. In: HENMAN, A. R.; PESSOA JR., O. (orgs.). Diamba Sarabamba. São Paulo: Ground, 1986.

KNAUTH, D. R. Morte masculina: homens portadores do vírus da AIDS sob a perspectiva feminina. In: DUARTE, L. F.; LEAL, O. F. (orgs.). Doença, sofrimento, perturbaçáo: perspectivas etnográficas. Rio de Janeiro: Fiocruz, 1998. p. 183-198.

LABATE, B. C. A reinvençáo do uso da ayahuasca nos centros urbanos. Campinas: Mercado de Letras/Fapesp, 2004.

LABATE, B. C. Ayahuasca Mamancuma merci beaucoup: internacionalizaçáo e diversificaçáo do vegetalismo ayahuasqueiro peruano. Tese (Doutorado) -Instituto de Filosofia e Ciências Humanas, Universidade Estadual de Campinas, Campinas, 2011.

LABATE, B. C.; FEENEY, K. O processo de regulamentação da ayahuasca no Brasil e na esfera internacional: desafios e implicaçôes. Periferia, v. 3, n. 2, 2011. https://doi.org/10.12957/periferia.2011.4054

LAGROU, E. M. Poder criativo e domesticação produtiva na estética piaroa e kaxinawá. Cadernos de Campo, v. 5 , n. 5-6, p. 47-62, 1996. https://doi.org/10.11606/issn.2316-9133.v5i5-6p47-62

LIMA, J. C. da R. Passageiros da fantasia. Recife: Fundaj, 1990.

MACRAE, E. A abordagem etnográfica do uso de drogas. Drogas e Aids: estratégias de redução de danos. São Paulo: Hucitec, 1994a.

MACRAE, E. A antropologia e o uso de drogas: a questão da maconha. Temas Imesc, v. 3, n. 2, p. 195-202, 1986.

MACRAE, E. A importância dos fatores socioculturais na determinação da política oficial sobre o uso ritual de ayahuasca. In: ZALUAR, A. Drogas e cidadania: repressão ou redução de riscos. São Paulo: Brasiliense, $1994 \mathrm{~b}$.

MACRAE, E. Guiado pela lua: xamanismo e uso ritual da ayahuasca no culto do Santo Daime. São Paulo: Brasiliense, 1992.

MACRAE, E. Ritual and Religious Use of Ayahuasca in Contemporary Brazil. In: 12th INTERNATIONAL CONFERENCE ON DRUG POLICY REFORM, 12., 1999. Anais [...]. Washington, D.C., 1999.

MACRAE, E. Santo Daime e Santa Maria: usos religiosos de substâncias psicoativas lícitas e ilícitas. In: LABATE, B. C.; GOULART, S. L. (orgs.). O uso ritual das plantas de poder. Campinas: Mercado das Letras, 2005.

MACRAE, E.; GORGULHO, M. Redução de danos e tratamento de substituição: posicionamento da Rede Brasileira de Redução de Danos. Jornal Brasileiro de Psiquiatria, São Paulo, v. 52, n. 5, p. 371-374, 2003.

MACRAE, E.; SIMÓES, J. A. Rodas de fumo: o uso da maconha entre camadas médias. Salvador: Edufba, 2000.

MAGNANI, J. G. C. Vai ter música?: para uma antropologia das festas juninas de surdos na cidade de São Paulo. Ponto Urbe, v. 1, 2007.

MALHEIRO, L. S. B. Entre sacizeiro, usuário e patrão: Um estudo etnográfico sobre consumidores de crack no Centro Histórico de Salvador. In: TAVARES, L. A. (org.). Crack: contextos, padrōes e propósitos de uso. Salvador: Editora UFBA, Centro de Estudos e Terapia do Abuso de Drogas, 2013. 
MALHEIRO, L. S. B. Tornar-se mulher usuária de crack: trajetória de vida, cultura de uso e políticas sobre drogas no centro de Salvador-BA. Dissertação (Mestrado) - Faculdade de Filosofia e Ciências Humanas, Universidade Federal da Bahia, Salvador, 2019.

MALVASI, P. A. Interfaces da vida loka: um estudo sobre jovens, tráfico de drogas e violência em Sáo Paulo. Tese (Doutorado) - Faculdade de Saúde Pública, Universidade de São Paulo, São Paulo, 2012.

MARANGONI, S. R.; FÉLIX DE OLIVEIRA, M. L. Fatores desencadeantes do uso de drogas de abuso em mulheres. Texto \& Contexto Enfermagem, v. 22, n. 3, 2013. http://dx.doi.org/10.1590/S0104-07072013000300012

MARTIN, D. Mulheres e Aids: uma abordagem antropológica. Revista USP, n. 33, p. 88-101, 1997. https://doi. org/10.11606/issn.2316-9036.v0i33p88-101

MEDEIROS, R. Construção social das drogas e do crack e as respostas institucionais e terapêuticas instituídas. Saúde e Sociedade, v. 23, n. 1, p. 105-117, 2014. http://dx.doi.org/10.1590/S0104-12902014000100008

MELOTTO, P. Trajetórias e usos de crack: estudo antropológico sobre trajetórias de usuários de crack no contexto de bairros populares de Sáo Leopoldo-RS. Dissertação (Mestrado) - Universidade Federal do Rio Grande do Sul, Porto Alegre, 2009.

MERCANTE, M. S. Ayahuasca, dependência química e alcoolismo. Ponto Urbe, v. 5, 2009.

MERCANTE, M. S. A ayahuasca e o tratamento da dependência. Mana, Rio de Janeiro, v. 19, n. 3, p. 529-558, 2013. http://dx.doi.org/10.1590/S0104-93132013000300005

MERCANTE, M. S. Imagens mentais espontâneas: mente, alma, corpo e processos visionários durante o uso ritual de ayahuasca. Revista Interdisciplinar Internacional de Artes Visuais Art\&Sensorium, v. 3, n. 1, p. 74-86, 2016.

MINAYO, M. C. de S.; DESLANDES, S. F. A complexidade das relaçóes entre drogas, álcool e violência. Cadernos de Saúde Pública, v. 14, n. 1, p. 35-42, 1998. http://dx.doi.org/10.1590/S0102-311X1998000100011

NASSER, M. M. S. Entre a ameaça e a proteção: categorias, práticas e efeitos de uma política de inclusão na Cracolândia de Sáo Paulo. Horizontes Antropológicos, v. 24, n. 50, p. 243-270, 2018. http://dx.doi.org/10.1590/s010471832018000100009

NIMUENDAJU, C. As lendas da criaçáo e destruiçáo do mundo como fundamento da religiáo dos ApapocúvaGuarani. Sáo Paulo: Hucitec/Edusp, 1987.

OLIVEIRA, F. S. R. de. Maconheirinhos: cuidado, solidariedade, e ativismo de pacientes e seus familiares, em torno do óleo de maconha rico em canabidiol (CBD). Dissertaçáo (Mestrado em Antropologia Social) Universidade de Brasília, Brasília, 2016.

OLIVEIRA, J. F. de; PAIVA, M. S.; VALENTE, C. L. M. Representaçốes sociais de profissionais de saúde sobre o consumo de drogas: um olhar numa perspectiva de gênero. Ciência \& Saúde Coletiva, v. 11, n. 2, p. 473-481, 2006. http://dx.doi.org/10.1590/S1413-81232006000200024

PAULILO, M. A. S.; JEOLÁS, L. S. Aids, drogas, riscos e significados: uma construção sociocultural. Ciência \& Saúde Coletiva, v. 10, n. 1, p. 175-184, 2005. http://dx.doi.org/10.1590/S1413-81232005000100024

PAULILO, M. A. S.; JEOLÁS, L. S. Jovens, drogas, risco e vulnerabilidade: aproximaçôes teóricas". Serviço Social em Revista, v. 3, n. 1, p. 39-60, 2000.

PECHANSKY, F. et al. Estudo sobre as características de usuários de drogas injetáveis que buscam atendimento em Porto Alegre, RS. Revista Brasileira de Psiquiatria, Sáo Paulo, v. 22, n. 4, p. 164-171, 2000. http://doi. org/10.1590/S1516-44462000000400005 
PELÚCIO, L. Na noite nem todos os gatos são pardos. Cadernos Pagu, n. 25, p. 217-248, 2005. http://dx.doi. org/10.1590/S0104-83332005000200009

PIERSON, D. Homem no Vale do Sáo Francisco. Rio de Janeiro: Suvale, 1972.

POLICARPO, F. O consumo de drogas e seus controles: uma perspectiva comparada entre as cidades do Rio de Janeiro, Brasil, e de San Francisco, EUA. Tese (Doutorado em Antropologia) - Instituto de Filosofia e Ciências Humanas, Universidade Federal Fluminense, Niterói, 2013.

RAFAEL, A. As armas do crime Reflexōes sobre o tráfico de drogas no Rio de Janeiro. Civitas, v. 1, n. 2, p. 165-180, 2001. http://dx.doi.org/10.15448/1984-7289.2001.2.82

RAUPP, L. M. Circuitos de uso de crack nas cidades de Sáo Paulo e Porto Alegre: cotidiano, práticas e cuidado. Tese (Doutorado) - Universidade de São Paulo, São Paulo, 2011.

RAUPP, L. M.; ADORNO, R. de C. F. Uso de crack na cidade de São Paulo/Brasil. Toxicodependências, v. 16, n. 2, p. 29-37, 2010.

REZENDE, M. M. Tratamento de dependentes de drogas: diálogos com profissionais da área de saúde mental. Tese (Doutorado) - Faculdade de Ciências Médicas, Universidade Estadual de Campinas, Campinas, 1999.

RIBEIRO, W. Drogas na escola: Prevenir educando. São Paulo: Annablume, 2005.

RICCIARDI, G. S. O uso da Ayahuasca e a experiência de alívio, transformação e cura na União Vegetal (UDV). In: NERY FILHO, A. et al. (orgs.). Toxicomanias: incidências clínicas e socioantropológicas. Salvador: Edufba; Cetad, 2009.

ROCHA, J. De maconha à Santa Maria: Apontamentos para uma cartografia de um processo de subjetivação acerca do uso religioso de substâncias psicoativas lícitas e ilícitas (1970-2010). Diversidade Religiosa, v. 6, n. 1, p. 183-209, 2016.

RUI, T. Corpos abjetos: etnografia em cenários de uso e comércio de crack. Tese (Doutorado) - Programa de Pósgraduação em Antropologia Social, Universidade Estadual de Campinas, Campinas, 2012.

RUI, T. Só se vive uma vez: uma reflexão acerca de distintas concepçôes e práticas do uso de "drogas". Mediaçóes, v. 11, n. 2, p. 187-202, 2006. http://dx.doi.org/10.5433/2176-6665.2006v11n2p187

RUI, T.; LABATE, B. C. Psicoativos, cultura e controles: contribuições da antropologia ao debate público no Brasil. In: LABATE, B. C. et al. (orgs.). Drogas, Políticas Públicas e Consumidores. Campinas: Mercado de Letras/ Neip, 2016.

SANTOS, V. E. dos; SOARES, C. B.; CAMPOS, C. M. S. Redução de danos: análise das concepçóes que orientam as práticas no Brasil. Physis: Revista de Saúde Coletiva, v. 20, n. 3, p. 995-1015, 2010. http://dx.doi.org/10.1590/ S0103-73312010000300016

SCHADEN, E. Aspectos fundamentais da cultura guarani. São Paulo: Edusp, 1974.

SCHENKER, M.; MINAYO, M. C. de S. Fatores de risco e de proteção para o uso de drogas na adolescência. Ciência \& Saúde Coletiva, v. 10, n. 3, p. 707-717, 2005. http://dx.doi.org/10.1590/S1413-81232005000300027

SCHNEIDER, D. R.; DE LIMA, D. S. Implicaçôes dos modelos de atenção à dependência de álcool e outras drogas na rede básica em saúde. Psico, v. 42, n. 2, p. 168-178, 2011.

SILVA, S. L. da. Mulheres da luz: uma etnografia dos usos e preservaçáo no uso do crack. Dissertaçáo (Mestrado) Faculdade de Saúde Pública, Universidade de São Paulo, São Paulo, 2000. 
SILVA, S. L. da. A exposiçáo e a invisibilidade: percursos e percalços por Lisboa e Sáo Paulo. As narrativas dos usos e dos controles do uso de crack. Tese (Doutorado) - Universidade de São Paulo, São Paulo, 2017.

SOLDERA, M. et al. Uso de drogas psicotrópicas por estudantes: prevalência e fatores sociais associados. Revista de Saúde Pública, v. 38, n. 2, p. 277-283, 2004. http://dx.doi.org/10.1590/S0034-89102004000200018

SOUZA, A. T.; DE MORAES, P. R. B. O evolucionismo na proibição da maconha. Geographia Opportuno Tempore, v. 4, n. 1, p. 133-148, 2018.

SOUZA, L. C. de. Notas sobre a distinção entre usuários e traficantes na "cracolândia": Apontamentos para uma crítica da política de drogas. Áskesis, v. 4, n. 1, p. 206-224, 2015.

VALENTIM, D. C. Entre brincadeiras e trocados: Fragmentos Etnográficos das experiências lúdicas de crianças em situação de rua em Fortaleza-CE. Três Pontos, v. 4, n. 2, 2007.

VALLIM, D.; ZALUAR, A.; SAMPAIO, C. Uma etnografia das cenas de uso de crack no Rio de Janeiro e seus efeitos nos usuários. In: TEIXEIRA, M.; FONSECA, Z. Saberes e práticas na atençáo primária à saúde: cuidado à população em situação de rua e usuários de álcool, crack e outras drogas. São Paulo: Hucitec, 2015.

VARGAS, E. V. Que guerra é essa? A propósito da partilha moral entre drogas e fármacos. Conjuntura Política, Belo Horizonte, v. 22, p. 1-4, 2000.

VELHO, G. A dimensão cultural e política dos mundos das drogas. In: ZALUAR, A. (org.). Drogas e cidadania: repressão ou redução de riscos. São Paulo: Brasiliense, 1994.

VELHO, G. A utopia urbana: um estudo de antropologia social. Rio de Janeiro: Zahar, 1989.

VELHO, G. Becker, Goffman e a antropologia no Brasil. Sociologia, Problemas e Práticas, v. 38, p. 9-17, 2002.

VELHO, G. Duas Categorias de Acusação na Cultura Brasileira Contemporânea. In: VELHO, G. Individualismo e Cultura. Rio de Janeiro: Zahar, 1981.

VELHO, G. Nobres e anjos: um estudo de tóxicos e hierarquia. Rio de Janeiro: Editora Fundação Getulio Vargas, 1998.

VELHO, G. O estudo do comportamento desviante: a contribuição da antropologia social. In: VELHO, G. Desvio e divergência: uma crítica da patologia social. Rio de Janeiro: Jorge Zahar, 2003.

VELHO, G. Projeto e metamorfose: antropologia das sociedades complexas. Rio de Janeiro: Zahar, 1999.

VERÍSSIMO, M. A marcha mundial da maconha no Rio de Janeiro. In: PEREIRA, I.; NUNES, N.; FLORES, I. City in Movement: Activism, Social Participation and Urban Reinventions. Lisboa: Instituto Universitário de Lisboa, 2013.

VERÍSSIMO, M. Do maconheiro ao canabier: os autocultivos domésticos e outras domesticaçôes. In: MACRAE, E.; ALVES, W. C. Fumo de Angola: canabis, racismo, resistência cultural e espiritualidade. Salvador: Edufba, 2016.

VIDAL, S. A regulamentação do cultivo de maconha para consumo próprio: uma proposta de redução de danos. MACRAE, E.; TAVARES, L. A.; RÊGO, M. (orgs.). Toxicomanias: incidências clínicas e socioantropológicas. Salvador: Edufba, Cetad, 2009.

ZALUAR, A. Da revolta ao crime SA. São Paulo: Moderna, 1996.

ZINBERG, N. Drug, set and setting. Nova Haven: Yale University Press, 1984. 
